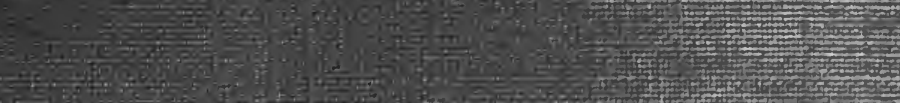

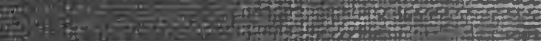
-

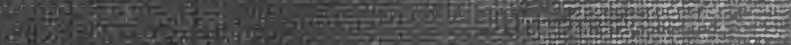
Fin:

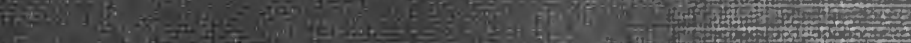
ink bit.

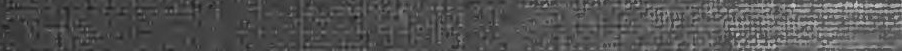

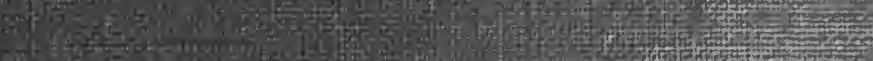

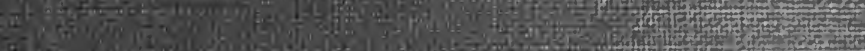
wit

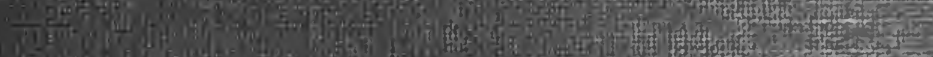

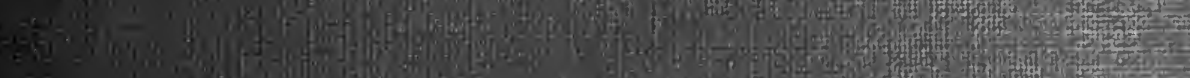
(5)

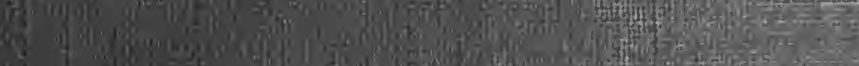
;

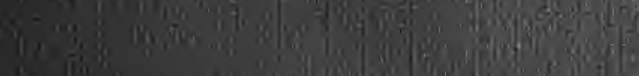

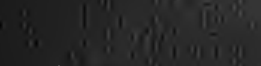

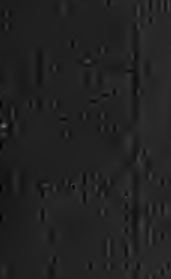
(1) 196.

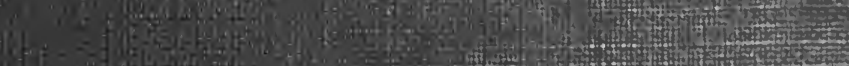

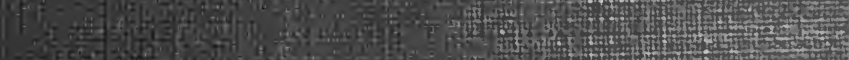
If Trom

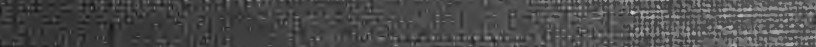

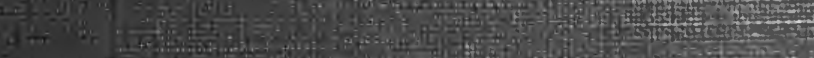

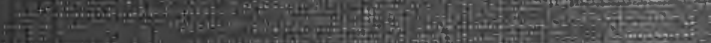
C4

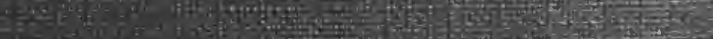

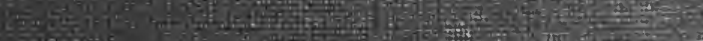
a T. Fit: Hon

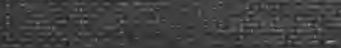



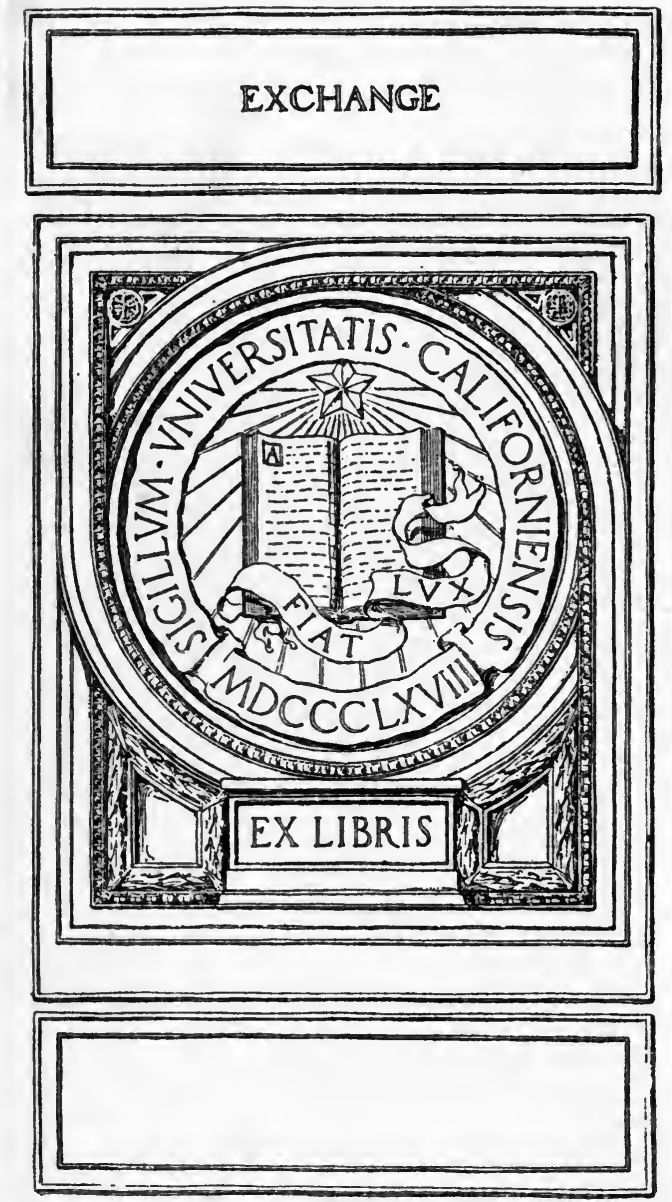

Digitized by the Internet Archive in 2007 with funding from Microsoft Corporation 
STUDIES IN ECONOMICS AND POLITICAL SCIENCE.

Edited by the Hon. W. Pember Regves, Ph.D., Director of the London School of Economics and Political Science.

No. 50 in the series of Monographs by writers connected with the London school of Economics and Political science.

\section{THE DEVELOPMENT OF} RATES OF POSTAGE 



\section{THE DEVELOPMENT OF RATES OF POSTAGE}

AN HISTORICAL AND ANALYTICAL STUDY

BY

A. D. SMITH, B.Sc. (Econ.)

OF THE SECRETARY'S OFFICE, GENERAL POST OFFICE, LONDON

WITH AN INTRODUCTION BY

THE RIGHT HON. HERBERT SAMUEL, M.P.

Postmaster-Grneral 1910-I4 AND 1915-16

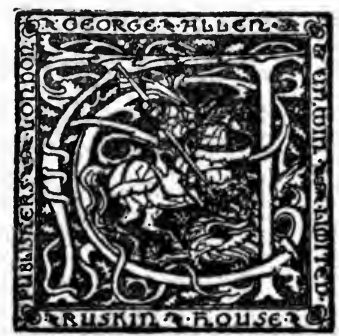

LONDON: GEORGE ALLEN \& UNWIN LTD. RUSKIN HOUSE 40 MUSEUM STREET, W.C. I 


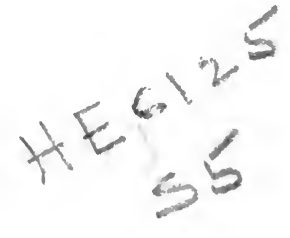

[Thesis approved for the Degree of Doctor of Science (Economics) in the University of London]

First published in 1917 


\section{PREFACE}

THIs study, which was prepared primarily as a Research Studentship Report for the University of London, is intended to be a contribution to the history of rates of postage, and an attempt to ascertain the principles, economic or otherwise, on which they are and have been based.

The Postmaster-General accorded me permission to consult the official records at the General Post Office, London, and through this courtesy I have been enabled to include a detailed examination of the economic aspect of the rates in the inland service in this country, and to place in the Appendix copies of some original documents which have not before been printed. Without this permission, which I desire here to acknowledge, it would, indeed, scarcely have been possible to undertake the inquiry. It must be made clear, however, that the work is of entirely private character, and cannot be taken as in any way expressing the views of the British Postal Administration.

- In 1912, as the holder of the Mitchell Studentship in Economics at the University of London, I visited Ottawa and Washington; in 1913 I visited Paris and the International Bureau at Berne; and in 1914, Berlin. I am much indebted to the various postal administrations visited, to whom, by the courtesy of the Postmaster-General, I carried official letters of introduction in addition to my letters from the University, for facilities to consult official papers relating to the subject of investigation, and for assistance from members of the staff with whom I was brought into contact.

The work was all but completed at the outbreak of war, but publication has been unavoidably delayed. The overpowering necessities created by the war have caused Governments again to look to postage for increased revenue. 
Penny postage itself has been in danger in the country of its origin. Various war increases of postage have already been made, both here and abroad, and brief particulars of the changes in the countries dealt with have been included. Further proposals for increasing the revenue from postage will possibly be made, and I am hopeful that these pages, in which the course of postage is traced, may then be found of service.

For the privilege of numerous facilities in connection with my work on the rates in this country I am indebted to Mr. W. G. Gates, Assistant-Secretary to the Post Office ; and for assistance in my inquiries abroad I am indebted to Dr. R. M. Coulter, C.M.G., Deputy Postmaster-General, Ottawa, and Mr. William Smith, I.S.O., at the time of my visit Secretary to the Canada Post Office; to Congressman the Hon. David Lewis, of Maryland, and Mr. Joseph Stewart, Second Assistant Postmaster-General, United States Post Oftice; to M. Vaillé, of the Secrétariat Administratif, Ministry of Posts and Telegraphs, Paris ; and to M. Ruffy, Director of the International Bureau, Universal Postal Union, Berne.

I am especially indebted to Professor Graham Wallas for valuable suggestions and advice.

A. D. SMITH.

London School of Economics, 1917. 


\section{CONTENTS}

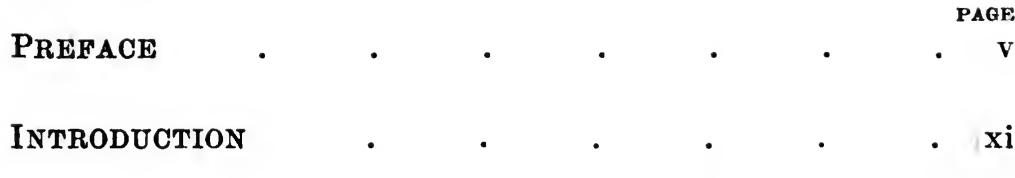

I. The RAte for Letters-

Letter Post in England • $\quad$. $\quad$. $\quad$ - 1

Letter Post in Canada $\quad$. $\quad$. $\quad$. 37

Letter Post in the United States of America . 59

Letter Post in France $\quad$. $\quad$. $\quad$ - 78

Letter Post in Germany $\quad$. $\quad$. $\quad$. $\quad$. 97

II. The RAte fOR Newspapers-

Newspaper Post in England . . . . 111

Newspaper Post in Canada $\quad . \quad$. 136

Newspaper Post (Secondnelass Mail) in the United

States of America $\quad . \quad$. 148

Newspaper Post in France . . . 164

Newspaper Post in Germany . . . 173

III. The Rate for Parcels-

Parcel Post in England . $\quad$. $\quad$. 183

Parcel Post in the United States of America . 191

Parcel Post in France . . . . . 204

Parcel Post in Germany . $\quad$. $\quad$. 209 
IV. MINOR RATES-
(i) Book Post
PAGE
(ii) Samples
. 220
(iii) Commercial Papers
. 229
. 238
(iv) Postcards
. 241
(v) Rate for Printed Matter for the Blind
. 244
(vi) Minor Rates in the United States and
$\begin{array}{llllll}\text { Canada } & \text {. } & \text {. } & & & \end{array}$

V. LOCAL Rates .

VI. International RATES-
(i) International Letter Post
.263
(ii) International Parcel Post
.277

VII. AN ANalysis of Cost-

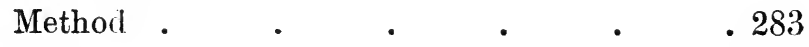

Cost . .

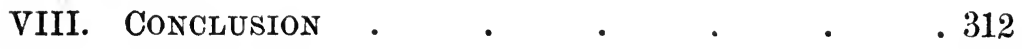

APPENDIX A-

I. RATES OF INLAND LETTER POSTAGE CHARged IN ENGLAND, 1635-1915 . 336

II. FOREIGN RATES IN THE BRITISH SERVICE 340

III. THE THURN AND TAXIS POSTS IN GERMANY 349

IV. PARCEL POST IN CANADA • . 355

V. THE SUPPLEMENTAL SERVICES . . 357

VI. POST OFFICE REVENUE $\quad$. $\quad .358$

VII. GRAPHS $\quad$. $\quad . \quad$. $\quad .368$ 


\section{APPENDIX B-}

DOCUMENTS AND EXTRACTS ILLUSTRATING ASPECTS

PAGE OF POSTAL HISTORY-

(i) Ancient Posts . $\quad$. $\quad$. $\quad$. 374

(ii) Nuncii and Cursores . $\quad . \quad$. $\quad 377$

(iii) Witherings' Scheme for the Reform of the Posts in England, 1635 . . . 378

(iv) The Monopoly and the General Farm of the Posts . $\quad . \quad$. $\quad . \quad 380$

(v) The English Post Office in $1681 \quad$. 384

(vi) The Cross Posts $\quad . \quad \ldots \quad$. $\quad . \quad 388$

(vii) The Early Posts in North America. . 391

(viii) The Clerks of the Road and the Transmission of Newspapers . . . 403

Appendix C-

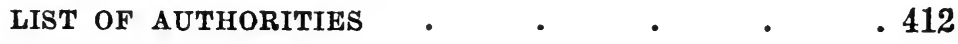

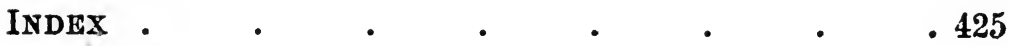





\section{INTRODUCTION}

THIs book contains a collection of facts and an examination of principles which will be of value to all students of the subject with which it deals. It is more comprehensive than any book on rates of postage yet published in the English language, or, I believe, in any other. It is careful and unbiased, and although here and there some of the author's conclusions may not meet with unanimous acceptance, they cannot fail to stimulate useful discussion on a matter which is far more important than is often realized.

The whole of our social organization has come to depend in large degree upon the post. Commerce, in all its departments, relies upon it. All the variety of associations which are, in their wide expansion, distinctive of modern civilization and necessary to its life and energy-employers' associations, trade unions, co-operative societies, friendly societies, religious bodies, political and propagandist organizations of every kind, local, national, and international-the whole nervous system of the modern State, depends upon the quick transmission of information and ideas; it would never have reached and could not maintain its present development without cheap, reliable, and speedy means of communication. The indirect effects of changes-even small changes-in the postal system are often extensive and almost incalculable.

Where the State itself conducts an industry there is always a risk that commercial considerations and fiscal considerations will not be sufficiently distinguished. Charges may be fixed at a higher point than is warranted by the cost of the services rendered. The surplus goes to the national revenue. It is a tax, but a concealed tax, and in the case of postal rates it is one of the worst kinds of tax, a tax on communications. 
On the other hand, charges may be fixed at a lower point than will cover the cost of the service. The deficit is a subsidy, but a concealed subsidy. The halfpenny postage rate for bulky newspapers, for example, or the extension of telegraph offices to rural districts, may be socially useful, but they are unremunerative. The loss that they involve to the Exchequer may be justifiable, but if so it should be deliberately incurred. It should not be hidden in the profit that is made on the letter post. Without a scientific examination into the actual cost of each part of the postal and telegraphic service, and into the precise relation of revenue to cost, the charges may include, haphazard, an excess which is nothing but pure taxation, the expenditure may include an addition which is nothing but pure subsidy, and neither the administrator nor the taxpayer may be aware of the fact.

It is therefore one of the essential duties of the Post Office to make such examinations, and of students or critics of postal affairs to check or to supplement them. Mr. A. D. Smith has made a useful contribution to the application, in this sphere, of the methods of science to the conduct of industry; and since the postal service is the most international of all forms of social activity, it may be expected that his contribution will be of value, and will have its influence, far beyond the limits of our own country.

HERBERT SAMUEL. 


\section{THE RATE FOR LETTERS}

\section{LETTIER POST IN ENGLAND}

In England the postal service, as an organized means for the carrying of the King's despatches, dates back some four hundred years, and as a recognized arrangement for the carrying of letters for the public, some three hundred years. Before the establishment of a regular system of posts, provision had been made for carrying the King's despatches by special messengers, called nuncii or cursores, attached to the royal household. ${ }^{I}$ Their function was naturally one of importance, and, from early times, large sums were spenced in their maintenance. They were employed on the private and confidential business of the Crown and of meriber if the royal household, and on affairs of State, both in England and abroad, although their function was primarily to serve the convenience of the King.

This was a system for the conveyance of official despatches only. ${ }^{2}$ No public provision was made for the conveyance of letters for private individuals. Such letters were conveyed by servants, by special messengers, or by the common carriers, 3 and there is evidence of the existence of a considerable private correspondence in the frequent issue of writs during the fourteenth and fifteenth centuries ordering supervision of the traffic in private letters, the uninterrupted transmission of

- Report from Secret Committee on the Pcst Office (Commonss), 1844, Appx., p. 21.

Ibid., p, 4. Annual Report of the Postmaster-General, 1854, p. 8.

3 Encyclopadia of the Laws of England, London, 1908, vol. xi. p. 344. J. W. Hyde, The Post in Grant and Farm, London, 1894, p. 131. 
which was a source of much anxiety to the Crown from fear of the fomenting of sinister and treasonable plots against itself. ${ }^{\text {I }}$

The establishment of the nuncii or cursores developed into a regular system. On certain lines of road relay stages were set up, at which the messengers might without delay obtain a change of horses, a system first set up by Edward IV in 1482, during the war with Scotland. ${ }^{2}$ Such relay messengers were called "posts," a word borrowed from the French.3 The term was also applied to the line of route, and the expression " post," or " line of posts," was used to denote a route along which, at certain stages, post-horses were kept in readiness for the use of the King's messengers. Travelling in this way the messengers were able to cover a hundred miles a day. The establishment of lines of regular posts became a feature of the administrative system, and a special officer of the royal household was appointed to control them.

The first recorded Master of the Posts was Brian Tuke, who held the office in 1512. The posts, like the establishment of special messengers, were maintained solely at the cost of the King. The master received a salary from the King (which in a patent issued in 1545 is given as $£ 6613 \mathrm{~s} .4 \mathrm{~d}$. a year), and also the amount of his expenses incurred in providing :for: the carrying of letters. The regular post-

Z Report from Secret Committee on the Past Office (Commons), 1844, Appx., p. 95. Iix 1324 a writ or latter was issued to the Constable of Dover and Warden of the Cinque Ports, to the Mayor and Sheriffs of London, the Bailiffs of Bristol, Southampton, and Portsmouth, and the Sheriffs of Hants, Somerset, Dorset, Devon, and Cornwall, reciting that previous orders de scrutinio faciendo had not been observed, in consequence of which many letters prejudicial to the Crown were brought into the kingdom; and commanding them to "make diligent scrutiny of all persons passing from parts beyond the seas to England, and to stop all letters concerning which sinister suspicions might arise, and their bearers, and to keep the bearers in custody until further directions, and to transmit the letters so intercepted to the King with the utmost speed."

" Richard III in 1484 "followed the practice which had been recently introduced by King Edward in the time of the last war with Scotland (1482) of appointing a single horseman for every 20 miles, by means of whom travelling with the utmost speed, and not passing their respective limits, news was always able to be carried by letter from hand to hand 200 miles within two days."Third Continuation of the Chronicle of Croyland, Oxford, 1684, p. 571. The system was identical with that of the posts of antiquity (vide Appendix B, pp. 374-7, infra).

3 Derived from posta, a contraction for posita, from ponere, to place. The general use of the word is to signify relays placed at intervals on the routes followed by messengers. 
masters received a daily wage from the King. On lines along which no regular post had been established, but along which it might on occasion be necessary to send special messengers, the townships were obliged to furnish horses for the service of the messengers. Remarks in contemporary papers suggest that no payment was made in such cases, but that horses were supplied gratis for the King's service. $x$ There is no record of the early days of Tuke's tenure of the office of Master of the Posts; but in 1533 Thomas Cromwell complained to Tuke concerning the condition of the posts, and the great default in the conveyance of letters. ${ }^{2}$

The posts were in many cases established on account of some special circumstance, and were of a temporary character. The first regular post-that established in 1482 during the war with Scotland-was, of course, temporary; but at much later dates, when "ordinarie," or permanent, posts had been established, such as the post from London to Berwick and that from London to Beaumaris, it was still usual to establish "extra ordinarie" posts "in divers places of the Realme" as occasion might from time to time require, as, for example, during the periods of the sovereign's progresses. 3

The early posts had a second function, not less in importance than that of providing for the conveyance of the sovereign's despatches, and despatches sent on affairs of State, viz. the provision of means by which persons actually travelling on the business of the sovereign, though not bearing despatches,

" "Ne men can kepe horses in redynes without som way to bere the charges." -Tuke to Cromwell, 17 August 1533 (Report from Secret Committee on the Post Office (Commons), 1844, Appx., p. 32).

2 “The King's pleasure is that postes be better appointed, and laide in al places most expedient; with commaundement to al townshippes in al places, on payn of lyfe, to be in such redynes, and to make such provision of horses at al tymes, as no tract or losse of tyme be had in that behalf."-Ibid., Appx., p. 32 .

3 "A.D. 1572. The Office of the Maister of the Postes. The Accompte of Thomas Randolphe esquier, Maister of the Postes. . . As also of the yssuyng and defrayment owte of the same, as well for the wages of the ordinarie postes laide betwene London and Barwicke and elles where within hir Mats Realme of Englande, As also for the wages of divers extra ordenarie postes laid in divers places of the Realme in the tyme of hir Mats severall progresses, and also to divers postes for cariage of packets of l'res from Sittingbourne, Dartforde, Rochester, Canterbury and Dover for hir Mats service and affayres, as occasion from tyme to tyme did requier."-Ibid., Appx., p. 34. 
might do so with facility. This second function, the travelling post, continued until the eighteenth century. It is a function which is essentially akin to the provision of a means of intercommunication by means of letters. In many parts of the United Kingdom, and also in other countries, the means provided for the conveyance of the mail are still largely used by persons desiring to travel. ${ }^{x}$

The use of the post-horses by ordinary travellers commenced at an early period. In 1553, when the posts had been in existence only some fifty or sixty years, a rate of a penny a mile for persons riding post was fixed by statute. ${ }^{2}$

Great abuses grew up round the travelling post, or " thorough post," as it was called.3 Riders in post frequently failed to pay a reasonable sum for the hire of horses; and since King's

I In the United Kingdom this system exists to a considerable extent, chiefly in the south and west of Ireland, and in many parts of Scotland, more especially among the Western Isles. In remote parts the means of communication are in general provided for the double purpose, and economy to the Post Office naturally results from the fact that the contractors for the mail service have a source of income in addition to the Post Office payment. Indeed, it is probable that since the days of the post-boys by far the greater portion of the mails has always been conveyed by means not exclusively provided for that purpose. The mail coaches carried passengers and goods, and it was from that traffic that the income of the proprietor was mainly derived. The payment in respect of the mails was very small, the real consideration inducing the proprietors to carry the mail being the fact that the mail coaches were exempt from tolls. The railway displaced the mail coach, and increased the dependence of the mail service on means of communication provided primarily for other purposes. The number of trains run solely for the conveyance of mails has always been extremely small. The weight of mails to be conveyed is usually insufficient to warrant the provision of a special train, and the Post Office is therefore compelled, as far as possible, to make use of such trains as may be run for other traffic, endeavouring to obtain such modification in the times and working as will make them of the greatest advantage to the mail service without destroying their utility for general traffic. The existence of extensive means of communication for general purposes therefore results advantageously to the Post Office.

22 and 3 Edward VI, cap. 3.

3 "The Lords of the Privie Counsell, endevouring heretofore the like furtherance of the service of the State, as well in horsing such as ride on their Prince's affaires, as the speedy despatch of packets in all places where Posts were erected and ordeined, considering that for the service of the one, a daily fee is allowed, and for the other, no certaino wages at all, but the hire of the horses let out, and that often ill paide, whereby they stand not so bound to the one, as to attend to the other; And that the townes and countreys besides became many wayes vexed and perplexed, by the over great libertie of riders in poste, specially by such as pretend publike service by speciall commission, contrary to tho King's 
messengers, although paying no fixed rates, obtained better accommodation than others, riders in post travelling on their own affairs made no scruple to represent themselves as travelling on public service. Orders directed against these abuses were issued in 1603. Riders in post on the King's affairs, with a special commission signed either by one of the Principal Secretaries of State, by six at least of the Privy Council, or by the Master of the Posts, were to pay at the rate of $2 \frac{1}{2} \mathrm{~d}$. a mile for a horse. All others riding post about their own affairs were to make their own terms with the postmaster, and to pay in advance. ${ }^{\mathrm{I}}$ The net result was that for all persons riding with the special commission a fixed rate was payable in place of uncertain rates as hitherto, and the postmasters were protected from being imposed upon by persons riding post on their private business. Without the special commission it was useless to pretend to be travelling on the King's affairs. By this proclamation the postmasters were also given the exclusive right of letting horses to travellers. ${ }^{2}$ The wages of the postmasters in respect of the "post for the pacquet" were a fixed sum per day, and a certain number of horses had to be kept in readiness, in proportion to the amount

meaning or their lordships' orders."-Orders for Thorough Posts and Couriers, riding Post on the King's Affairs, 1603 (Report from Secret Committee on the Post Office (Commons), 1844, Appx., p. 38).

The "Thorough Post" was the term applied to the travelling facilities provided by the posts, i.e. when the messenger travelled "through," in contradistinction to the "Post for the Pacquet" (or "Packet"), i.e. the post for the transmission of the mail, or "pacquet."

" "1. First it is ordered, That in all places where Posts are layde for the packet, they also, as persons most fit, shall have the benefit and preheminence of letting, furnishing, and appointing of horses to all riding in poste (that is to say) with horse and guide by commission or otherwise.

"2. And, like as in the orders for the carrying of the packets, the furtherance of our service and the State is only aymed at; so in this it is intended that none be holden to ride on publique affairs but with speciall commission, and the same signed either by one of our Principall Secretaries of State, . . . and of all such so riding in publike affaires, it shall be lawfull for the Posts, or the owners of the horses, to demand, for the hire of ich horse, after the rate of twopence halfe-peny the mile (besides the guides groats). But of all others riding poste with horse and guide, about their private businesses the hire and prices are left to the parties discretions, to agree and compound within them. selves." -Ibid., Appx., p. 39.

2 Contemporary papers show that this was largely a measure of police, intended to enable the Government to keep a watch on all persons travelling about the kingdom. 
of the wages paid. As regards the service for the State, the system of posts was therefore on a complete and definite financial basis. The rates for the thorough post, although not in any way rates of postage in the modern sense, were the first rates applied to the service of the posts (the pay of the postmasters for the packet post being merely wages per diem), and it was to them that the term "postage" was first applied. These rates were in fact the original " postage."

The number of regular posts was in early times quite small. ${ }^{x}$ In order to provide a means of reaching other parts of the kingdom with some degree of facility, the municipalities were required to maintain, or at least provide when required, post-horses for the use of the King's messengers. ${ }^{2}$ Some municipalities made definite provision of horses: Leicester, for example, maintained "certen poste-horses" (four in number) for the service of the Prince; but if horses were not provided voluntarily, the magistrates and constables were authorized to seize them for the King's service wherever they could be found.3 Many of the posts continued for a long period to be of a temporary nature. Even in the seventeenth century some which it might be thought would have been important at any time, were regarded as extraordinary posts, and were discontinued with the disappearance of the special circumstances on account of which they had been established.4

A third function became attached to the posts, viz. the transmission of private letters. As it is impossible to say at what date the posts began to be used by ordinary travellers, so it is impossible to say at what date they were first used for the conveyance of letters other than those on the affairs of the King or of the State. The universities and municipalities provided services for the carriage of their own letters; 5

x As late as 1620 there were only four, and they touched only a small portion of the kingdom. They were (1) The Courte to Barwicke, (2) The Courte to Beaumaris, (3) The Courte to Dover, and (4) The Courte to Plymouthe.

2 See supra, p. 3.

3 "The constables many times be fayn to take horses oute of plowes and cartes."-Brian Tuke, 1533 (Report from Secret Committee on the Post Office (Commons), 1844, Appx., p. 33).

4 The post from London serving the "Westerne part" of the kingdom was discontinued in 1610 as unnecessary except in time of war.-Ibid., Appx., p. 43.

5 "Universities and great towns had their own particular posts; and the same horse or foot post went through the journey, and returned with other 
but from a very early period the posts were also made use of for the conveyance of unofficial letters. The Master of the Posts received no direct profit from the carrying of such letters, ${ }^{I}$ but the price paid to him for the office of Deputy Postmaster was probably thereby increased.2

A Proclamation of 26th April 1591 prohibited the conveyance of letters to or from countries beyond the seas by any person other than the ordinary posts and messengers; and referred to previous similar prohibitions. The object of this prohibition, which foreshadowed the monopoly of the carriage of all letters, whether for places within the realm or to or from foreign countries, was alleged to be the redress of disorders among the posts in general, and particularly to prevent inconveniences both to the royal service and the lawful trade of honest merchants. 3 A Proclamation of 1609 repeated this prohibition. 4

In 1626 a legal struggle was in progress between Matthew de Quester and Lord Stanhope, both of whom claimed to hold a King's Patent conferring the right to carry foreign letters.5 This litigation led to laxity and omission in the conduct of the foreign service, so that merchants trading

letters, without having different stages as at present. It was thus practised later in Scotland as having less commerce than in England."-D. Macpherson, Annals of Commerce, London, 1805, vol. ii. p. 400.

- The Committee of Secrecy of the House of Commons were of opinion that the practice of carrying private letters probably began at an early period and became a perquisite of the postmasters (Report from Secret Committee on the Post Office (Commons), 1844, p. 4).

3 Ibid., Appx., p. 36 ; see p. 380, infra.

2 Ibid., Appx., p. 56.

4 Ibid., Appx., p. 41.

5 The business of carrying foreign letters had been conducted by the holder of the general patent for carrying letters, although that patent covered only inland posts and foreign posts within the King's dominions. In 1620 a patent was issued to Matthew de Quester and his son, conferring on them the office of Postmaster of England for Foreign Parts. The holder of the patent for the Inland Posts, who had hitherto been -conducting this service, attempted to resist this new grant, but without success; and for some time there was a sort of triple division of the posts, viz. the Inland Posts, the posts in parts beyond the seas within the King's dominions, and the posts for foreign parts out of the King's dominions. There was, nevertheless, no regular provision for the conveying of letters for places out of England. The foreign mails were conveyed by men who were engaged in other business, who bought their places in the posts, and were accused of delaying the mails through "more minding their own peddling traffic than the service of the State or merchants, omitting many passages, sometimes staying for the vending of their own commodities, many times through neglect by lying in tippling-houses." -See J. W. Hyde, The Post in Grant and Farm, London, 1894, p. 12. 
abroad were put to great inconvenience. In consequence, in November of that year, the King granted the Merchant Companies permission to arrange for the conveyance of their foreign letters by their own messengers. The high authorities were disturbed by the grant of this permission, ${ }^{\mathbf{I}}$ and in October 1627 it was revoked "upon weightie reasons of State." Only the Merchant Adventurers were still permitted to use their own messengers, and they and all other merchants were required in times of war and danger to the State to acquaint the Secretaries of State from time to time with what letters they forwarded abroad.

The foreign post continued in an unsatisfactory state, and a reorganization in accordance with a proposition submitted by the Master of the Foreign Posts, Thomas Witherings, was notified in orders issued on the 28th January 1633. In consequence of complaints, both of Ministers of State and merchants, it was decided to send no more letters by the carriers, who came and went at pleasure, but, in conformity with other nations, to erect "stafetti," or packet posts, at fit stages, to run day and night without ceasing. Under this new system the Foreign Postmaster of England undertook, with the consent of the foreign Governments, to provide "stafetti" for the conveyance of foreign letters on the Continent, e.g. he arranged the "stafetti" between Calais and Antwerp.

For the inland posts the financial arrangements of 1603 remained some thirty years undisturbed, and notwithstanding that the posts were used by travellers, and for the general conveyance of private letters, they remained a charge on the King's revenue. In 1633 the deficit was some $£ 3,400$, and in that year Witherings submitted a plan for the complete reorganization of the inland posts. ${ }^{2}$ The new

I "Nether can anie place in Christendom bee named wher merchants are allowed to send their letters by other body or posts, then by those only which are authorized by the State. . . . Your Lordship best knoweth what accompt wee shal bee hable to give in our places of that $w^{\text {ch }}$ passeth by letters in or out of the land, if everie man may convey lrs, under the covers of merchants, to whome and what place hee pleaseth." - 30th February 1627. John Coke to Lord Conway (Report from Secret Committee on the Post Office (Commons), 1844, Appx., p. 51).

$=$ A copy is given in Appendix B, infra, pp. 378-380. 
system, which applied only to the "post for the pacquet," was to be based on a definite scale of charges. Previously, there had been no regular system of charging letters carried for the public, and it is at this point that the modern Post Office emerges. Up to this time the conveyance of letters for private individuals, although it may have been a source of emolument to the postmasters and couriers, was not recognized by the State as part of the function of the service. Under the proposed system, a charge was to be made for every letter or packet, varying in accordance with the distance for which the letter or packet was conveyed, and its size. The latter was to be graduated for light letters according to the number of sheets, and for heavier letters and packets according to weight, starting from the ounce. Here, therefore, is to be seen at the inception of "postage" in the modern sense a definite distinction between the rate charged on the ordinary letter, the weight and bulk of which are in general insignificant, and that charged on the larger and heavier packets of deeds, or what not, which might be forwarded by post.

The reform of the posts on these lines was carried out by Witherings in October 1635, and constitutes a remarkable development of the Post Office system. The rates of charge were as follow:-

\begin{tabular}{|c|c|c|c|}
\hline Distance of Transmission. & Single Letter. & Double Letter. & Por Ounce. \\
\hline $\begin{array}{l}\text { Not exceeding } 80 \text { miles } . . \\
\text { Exceeding } 80 \text { miles, not exceeding }\end{array}$ & $2 \mathrm{~d}$. & $4 \mathrm{~d}$. & $6 \mathrm{~d}$. \\
\hline 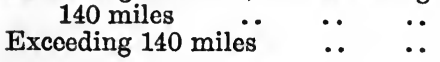 & 4d. & $\begin{array}{l}8 \mathrm{~d} . \\
12 \mathrm{~d} .\end{array}$ & $\begin{array}{l}9 \mathrm{~d} . \\
12 \mathrm{~d} .\end{array}$ \\
\hline
\end{tabular}

The great change of 1840 modified this system only at two points, viz. (1) uniformity of rate, that is, the elimination of the table of distances from the rate-table, and (2) the introduction of the method of charge according to weight for all letters and packets.

The monopoly of foreign letters was by this time well established, and the reason for its existence well defined. A further proclamation of the 11th February 1637-8 again declared this monopoly, and proceeded to declare a monopoly of letters between persons within the realm, the second 
monopoly being justified, not on the ground of necessity in order to guard the safety of the State, but on the ground that commerce and correspondence within the realm would benefit.x The real explanation of the new prohibition for inland letters was no doubt the fact that Witherings had been appointed Master of the Inland Letter Office for the purpose of bringing into operation his scheme for reorganizing the posts, and it was essential to the success of the scheme that he should have the sole right of carrying letters. There was, of course, the political reason of danger to the State from free and uncontrolled transmission of letters, but the feeling in that respect seems not to have been so strong regarding the inland letters as regarding the foreign letters. It developed later, however. ${ }^{2}$

In 1640 Witherings was displaced on some charge of maladministration, and the office was given to Philip Burlamachi, a merchant of the City of London. Witherings did not

" Now his Majesty . . . taking into his princely consideration how much it imports this State and this whole realm, that the secrets be not disclosed to foreign nations; which cannot be prevented if promiscuous use of transmitting or taking up of foreign letters by these private posts and carriers aforesaid should be suffered, which will be also no small prejudice to his merchants in their trading. . . . And his Majesty, taking further into his consideration that the mutual commerce and correspondency of his subjects within his Majesty's dominions will be as advantageous and beneficial as the trade with foreign nations, and that nothing will more increase and advance the same than the safe and speedy conveying, carrying, and re-carrying of letters from one place to another ... he doth hereby straightly charge and command, that no post or carrier whatsoever within his Majesty's dominions, other than such as shall be nominated and appointed by the said Thomas Witherings, shall presume to take up, carry, receive, and deliver any letter or letters, pacquet or pacquets whatsoever, to any such place or places where the said Thomas Witherings shall have settled posts, according to the said grant, except a particular messenger sent on purpose with letters by any man for his own occasions, or letters by a friend, or by common known carriers."-Proclamation of 11th February 1637-8 (Report from Secret Committee on the Post Office (Commons), 1844, Appx., p. 58).

2 "1650. June 29th. Council of State to (Serjeant Dendy and his assistants?) :-

"You are to repair to some post stage 20 miles from London on the road towards York; seize the letter mail going outward, and all other letters upon the mail rider, and present them by one of yourselves; the other shall then ride to the next stage, and seize the mail coming inwards, and bring the letters to Council, searching all persons that ride with the mail, or any other that ride post without warrant, and bring them before Council, or the Commissioners for Examinations. All officers civil and military to be assistants. With note of like orders for Chester Road and the western roads."-Calendar of State Papers Domestic Series), 1650, p. 223. 
give up the office without a struggle. For two years he strove to retain it, but without much success; and in 1642 he assigned his patent to the Earl of Warwick, who continued the struggle. Burlamachi was backed by Edmund Prideaux, afterwards Attorney-General. Into the merits or progress of the contest it is unnecessary to enter. It will be sufficient to record that the Lords espoused the cause of the 'Earl of Warwick and the Commons that of Burlamachi; that the contest continued some two years; and that in the end the Lords gave way, and Burlamachi continued Master of the Posts.

The office fell vacant in 1644, and Parliament appointed Prideaux to the charge of the posts.x This task he entered upon with some seriousness, and with considerable success. He extended the service, but raised the minimum postage to $6 \mathrm{~d}$. From a report submitted by him to the Council of State in 1649, it appears that he had established "a weekly conveyance of letters into all parts of the nation," and that with the moneys received as postage he had been able to defray the whole cost of the postmasters of England with the exception of those on the Dover Road. ${ }^{2}$ At the time of his appointment the posts involved a charge to the State of some $£ 7,000$ a year. 3 It might therefore be thought that for Prideaux to be able to carry on the system, to give a despatch of letters to all parts of the kingdom every week, and at the same time make the proceeds of postage cover the whole cost, except for the Dover Road, was a considerable achievement. The Commons were not, however, altogether satisfied. The long disputes between the various patentees, and their anxiety not to lose any part of the business of conveying letters, made it evident that there was a profit other than the salary paid by the King, notwithstanding that funds for the maintenance of the posts were drawn from the Exchequer year by year. The office of Master of the Posts was bought and sold. Witherings sold part of his wife's estate to the value of $£ 105$ a year in land to obtain the office. The deputy postmasters also bought their offices. And in 1642, by vote of both Houses, Burlamachi had been required to give an account of the profits of the Letter Office. The Letter Office was in

- Commons Journal, 7th September 1644, p. 621.

2 Ibid., 21st March 1650, p. 385.33 Ibid. 
fact not on the simple basis of payment by the messengers to the Master of Posts of all receipts, payment by the Master of Posts from the receipts of the ordinary fixed wages of the deputy postmasters (together with the cost of special expresses) and of his own salary, and payment from the Exchequer of the balance necessary to complete such payment. The deputy postmasters took, and retained for their own use, the postage received on private letters, paying a percentage to the Master of the Posts; and they had also the monopoly, which was very lucrative, of letting horses to travellers riding post. In view of these profits they were prepared to purchase from the Master of the Posts the office of deputy postmaster, and sums received from that source, together with the percentage of the postage of private letters, constituted the emoluments of the Master of the Posts, additional to his salary. The Commons, being no doubt aware of this, concluded that there ought to be a net revenue from the Office, and required Prideaux to pay the sum of $£ 5,000$ a year. ${ }^{x}$

Witherings, who by some strange chance seems never to have been altogether ousted from his offices, but to have retained that of Master of the Foreign Post, died in 1651, and there were numerous claimants for the succession to the office. The Council of State invited all persons with claims to submit them, and in reporting on the claims, suggested the farming of the Inland and Foreign Letter Offices. The question was put to the House of Commons that the whole business be "recommitted to the Council of State to take into consideration and present their opinions to the Parliament how the same may be managed for the best service of the State and ease of the people." The addition of the words "by contract or otherwise" was suggested, and accepted by the House. ${ }^{2}$ The question was considered by a Committee, who, having found much difficulty in dealing with the numerous claims in respect of the Foreign and Inland Letter Offices, decided on the 7th November 1651, probably as a way out of the difficulty, to recommend that the offices should be let to farm. The matter was not hurriedly disposed of. On

x H. Joyce, History of the Post Office, London, 1893, p. 25.

$=$ Commons Journal, 19th October, 1652, p. 192. 
the 7th May 1653, ${ }^{\mathrm{I}}$ resolutions were passed by the House of Commons asserting the State monopoly of the carriage of letters, and directing the Committee appointed to consider the posts to fix rates for private letters, to obtain tenders from persons for farming the carrying of letters, and to recommend what annual sum in their opinion the State should require in case it were thought well to let the posts to farm.

On the 30th June 1653 the Inland and Foreign Letter Offices were let to John Manley at a rent of $£ 10,000$ a year, ${ }^{2}$ and thus was instituted the system of farming, which continued until 1677 as regards the main posts, and until the late eighteenth century as regards the bye posts. The rent continuously increased. Shortly after the Restoration it was raised to $£ 21,500$ a year, and in 1667 to $£ 43,000$ a year.

The rate for a single letter, which had been raised by Prideaux to 6d., was in 1655 or 1656 reduced to $3 \mathrm{~d}$., owing to the efforts and competition of Clement Oxenbridge and others, who established and maintained rival services for the carriage of letters. These "interlopers" received scant consideration from Prideaux, and the services which they had established were suppressed.3 In 1657 an Ordinance of the Commonwealth Parliament further reduced the rate to $2 \mathrm{~d}$. for a single letter sent for distances under 80 miles, and 3d. for distances over 80 miles. The rates were not, however, as low

Register of Council of State, 7th May 1653, vol. xvi. pp. 34-6.

2 Calendar of State Papers (Domestic Series), 1652-3, p. 455.

3 "The case of the first undertakers for reducing letters to half the former rates, viz. Clem. Oxenbridge, Rich. Blackwell, Fra. Thompson, and Wm. Malyn. We observed that the postage of inland letters was long continued at $6 \mathrm{~d}$. a letter, and that the whole benefit went into one hand, to the grievance of many. Being encouraged by the votes of the last Parliament (made in the time of their primitive, free, and public actings, viz. 16 August 1642) that the taking of letters from and the restraints and imprisonments of Gower, Chapman, Cotton, and Mackedral were against the law and the liberty of the subject ... and that the said secretaries and Witherings were delinquents, being also encouraged by the opinion of the judges given in the House of Lords, that the clause in Witherings' patent for restraint of carrying letters was void and against law-we attempted to put the same in practice, but through the interest of Mr. Prideaux, who for many years had enjoyed excessive gains by the former high rates, we met with all the obstruction he could make against us, by stopping our mails, abusing our serviants, etc., though he always held forth that it was free for any to carry or send letters as they pleased." Calendar of State Papers (Domestic Series), 1653/1654, p. 22 . Cf. John Hill, A Penny Post, London, 1659. 
as would appear at first sight. There is the difference in the value of money to be allowed for; and there is the further consideration that postage was not charged according to the direct distance. 'All the post roads converged on London, and there were no cross posts. All letters from towns on one post road for towns on another post road must therefore pass through London, and all letters passing through London were subjected to an additional rate of postage; ${ }^{\mathbf{r}}$ that is to say, they ${ }^{\circ}$ were charged the appropriate rate in respect of the distance to London, and then, in addition, the appropriate rate in respect of the distance from London to destination.

The Ordinance of 1657 placed the Post Office system for the first time on a statutory basis. ${ }^{2}$ The objects for which such an Office was required were given as three in number: first, to maintain certain intercourse of trade and commerce; secondly, to convey public despatches; and thirdly, to discover and prevent many dangerous and wicked designs against the peace and welfare of the Commonwealth. In 1660 an Act of Parliament was passed, dealing with the Post Office. 3 Essentially it was the Ordinance of 1657, passed as an Act to give it legal validity under the changed order of things. The clauses relating to the use of the Post Office as a means of detecting plots against the State were included in a modified form, and this function was by no means lost sight of.4 During the excitement caused by the Popish Plot it was freely exercised.

I "Cross pests did not exist. Between two towns not being on the same post road, however near the towns might be, letters could circulate only through London; and the moment London was reached an additional rate was imposed. Hence the apparent charges, the charges as deduced from the table of rates, might be very different from the actual charges. Bristol and Exeter, for instance, are less than 80 miles apart; but in 1660, and for nearly forty years afterwards, letters from one to the other passed through London, and would be charged, if single, not $2 \mathrm{~d}$. but $6 \mathrm{~d}$., and if double, not $4 \mathrm{~d}$. but 1s. That is to say, the postage or portage, as it was then called, would consist of two rates, and each of these rates would be for a distance in excess of 80 miles." -H. Joyce, History of the Post Office, p. 29. Cf. infra, Appendix B, pp. 390-1.

This practice of charging according to the route traversed and not according to direct distance was also followed in other countries. It is perhaps comparable to the practice of computing railway charges on the basis of the distance by railway, and not as the crow flies.

- H. Scobell, Collection of Acts and Ordinances, London, 1658, p. 511.

312 Car. II, cap. 35.

4 See, e.g., Royal Proclamations, 16th January 1660-1 and 16th July 1667. 
The general farm of the posts was abolished in 1677, and the administration of the Office undertaken by the Government, except in the case of the smaller branch posts, in regard to which the practice of farming was even extended in the early years of the eighteenth century. ${ }^{x}$

The revenue yielded by the Office continued to expand. In 1694 it had reached $£ 60,000$; and when, for various reasons, but chiefly to provide for the control of the Post Office in Scotland, which had been brought under the English authorities by the Act of Union, a new Post Office Act became necessary, the Ministers, involved in a protracted war, seized the opportunity to obtain an increased revenue from the Office. Under William III this had been thought of. ${ }^{2}$

The Act of 1711,3 which remained for over fifty years the principal Act relating to the Post Office, was to be an instrument of taxation. For some fifty years the Post Office had been yielding a revenue, constant and increasing, but nevertheless more or less fortuitous. Its functions had always been defined as primarily to provide for the transmission of letters, for the benefit of commerce, and for the safety and security of the kingdom, by bringing all letters into "one Post Office settled and established in this Kingdom," and conducted immediately under the eye of the King's Government. The amount paid for the farm had increased with the passing of the years, in measure with the increase of the business of the Office-not by any change in the scale of charges, which remained as fixed in 1660 . Now, however, the Office was made a financial instrument, the proceeds of which were to be regulated by manipulation of the rates of charge. The results of the Act of 1711 did not fulfil the anticipations of its framers. Provision had been made for the disposal of that increase of revenue which was looked for: "the full, clear, and entire Weekly Sum of Seven Hundred Pounds of Lawful Money of Great Britain" was to be paid out of the revenues of the Post Office "towards

See Appendix, pp. 388-391.

" As early as William's reign they (the Postmasters-General) had been asked to estimate how much an additional penny of postage would produce; ... the necessities of the Civil List had prompted the inquiry."-H. Joyce, History of the Post Office, p. 119.

3 Anne, cap. 10. 
the Establishment of a good, sure, and lasting Fund, in order to raise a present Supply of Money for carrying on the War and other her Majesty's most necessary Occasions." x This $£ 700$ was to be paid entirely from the proceeds of the increase in the rates. The existing revenue of $£ 111,461$ a year was to be disposed of as theretofore. All pensions and charges on the revenue were to continue, and were to have preference over the payment of $£ 700$ a week. Of the surplus over and above the $£ 111,461$ a year and the $\mathfrak{L 7 0 0}$ a week, one-third part was to be at the disposal of Parliament, the rest to be paid into the Exchequer with the $£ 111,461$.

But the increase of revenue was so small that some of these provisions remained for many years inoperative. The increase of rate was found burdensome. Merchants resorted to every available means of avoiding the additional expense. ${ }^{2}$ A large clandestine traffic in letters grew up. The very postboys were found carrying letters outside the mail for what fees they could obtain. In 1710 the net revenue had been $£ 66,822$. In 1721 it was $\$ 99,784$, an increase of $£ 32,962$. After the deduction, therefore, of the $£ 700$ a week (or $£ 36,400$ a year), the payment of which had preference over all other payments chargeable on the Post Office revenue, excepting only the expenses of management, the actual net revenue of the Post Office available for the purposes prescribed by the Act was in $1721, \mathfrak{2} 63,384$, or less than the revenue of 1710 by $\mathfrak{E} 3,438$. The Act provided that one-third of the surplus of the yield of postage over and above the sum of $£ 147,861$ ( $£ 111,461$ plus the $£ 700$ a week) should be at the disposal of Parliament for the use of the public ; but although the gross revenue had exceeded that sum, there was no surplus for the use of the public, the explanation being

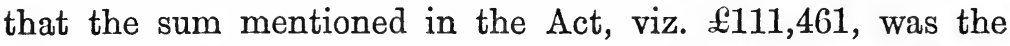
amount of gross revenue, which could only serve. as a basis provided the cost of management remained stationary. As a

I 9 Anne, cap. $10, \S 35$.

" "The additional tax has never answered in proportion to the produce of the revenue at the time it took place, the people having found private conveyances for their letters, which they are daily endeavouring to increase, notwithstanding all the endeavours that can be used to prevent them."-Statement by the Postmasters-General, 20th May 1718 (British Official Records). 
matter of fact, the cost so greatly increased that the net revenue was not sufficient to provide the sum of $£ 700$ a week and also a revenue equal to that obtained before 1711 . As Mr. Joyce has pointed out, the Treasury had confounded gross and net revenue. ${ }^{\mathrm{I}}$

The essentially fiscal character of the rates of 1711 is evidenced by a provision of the Act that from and after the 1st June 1743 the rates charged under the previous Acts were to be restored.2 But after 1743, although they were without legal sanction, the rates of 1711 continued in operation, and by an Act of 1763 they were made perpetual.3

The fifty years following the Act of the 9th of Anne were uneventful.4 The chief development was in connection with the cross posts; a development which, although not having direct reference to the question of the rates of postage, was yet of importance. At the commencement of the eighteenth century the main system of the Post Office still centred on London. All the main post routes radiated from London, and the great bulk of the letters passing by post were either for or from London, or passed through London. But there were, of course, numbers of letters which were not sent to London at all: letters between two towns on a post road, or letters between towns on different post roads, which could be sent direct and not by way of London. These letters were known as bye letters and cross post letters.5 Since they were not handled in London, the authorities had not the same

H. Joyce, History of the Post Office, p. 145.

29 Anne, cap. 10, $\$ 39$.

33 Geo. III, cap. 75 , 1 .

4 "An important legal decision, with which the Post Office had only the remotest concern, an improved system of expresses following as a natural consequence from circumstances over which the Post Office had no control, a simple contrivance to facilitate the posting of letters (i.e. the aperture), and an acceleration of the mail between London and Edinburgh-this as the record of forty or fifty years' progress is assuredly meagre enough; and yet we are not aware of any omission."-H. Joyce, ibid., p. 184.

5 "A letter between Bath and London would be a London letter, and a letter from one part of the country to another which in course of transit passed through London would be a country letter. A bye or way letter would be a letter passing between any two towns on the Bath Road and stopping short of London-as, for instance, between Bath and Hungerford, between Hungerford and Newbury, between Newbury and Reading, and so on; while a cross post letter would be a letter crossing from the Bath road to some other-as, for instance, a letter between Bath and Oxford."-Ibid., p. 147. 
means of checking their numbers, and the postmasters' accounts of postage in respect of them, as could be applied in London, and grave irregularities arose. The revenue was continually defrauded by the failure of the postmasters to bring to account the postage on such letters. No record was made in respect of many of them, and their transmission became so notoriously unsafe that illicit means of conveyance were constantly resorted to. The matter was already so serious that a special clause was included in the Act of the 9th of Anne, providing that for the suppression of the abuse any postmaster found guilty of embezzling the postage of bye or way letters should forfeit $£ 5$ for every letter and $£ 100$ for every week during which he continued the practice. ${ }^{1}$ Even this penal clause was insufficient to check the abuse, as owing to the unsatisfactory method of dealing with bye and way letters there was small risk of detection in fraud.

In 1719 Ralph Allen, then postmaster of Bath, proposed to the Postmasters-General that the management of the bye and cross post letters should be leased to him for a term of years, and offered a rent one and a half times as great as the revenue from the letters at that time. The offer was accepted, and the lease, which in the first instance was for seven years, was renewed from time to time. Allen, whose discovery was merely that of a method of check on the receipts of the postmasters from the bye and cross letters, was able to pay the rent agreed upon, largely to suppress the illicit transmission of the letters, and to make a handsome profit. ${ }^{2}$ The

9 Anne, cap. $10, \S 18$.

2 "To give a slight idea of the nature of this conveyance: The Bye and Way Letters were thrown promiscuously together into one large Bag, which was to be opened at every Stage by the Deputy, or any inferior Servant of the House, to pick out of the whole heap what might belong to his own delivery, and the rest put back again into this large Bag, with such Bye Letters as he should have to send to distant places from his own Stage. But what was still worse than all this, it was then the constant practice to demand and receive the postage on all such Letters before they were put into any of the Country Post Offices. Hence (from the general temptation of destroying these Letaters for the sake of the Postage) the joynt mischief of embezling the Revenue and interrupting and obstructing the commerce, fell naturally in, to support and inflame one another. Indeed, they were then risen to such a height, and consequently the discredit and disrepute of this conveyance grown so notorious, that many Traders and others in divers parts of the Kingdom had recourse to various contrivances of private and clandestine conveyance for their speedier and safer 
chief importance of Allen's work lies, however, not so much in the fact of his rendering the bye and cross post letters subject to effective check, as in the fact that in order to retain his lease he, on each occasion of renewal, undertook the provision of additional facilities. By this means a daily post was gradually extended to almost all the post routes. ${ }^{1}$

correspondence; whereby it became unavoidable but that other branches of the Post Office revenue should be greatly impair'd, as well as this. . . .

"Now whilst the Bye and Way Letters continued to be conveyed in so precarious and unsafe a way, as is shewn above, it was thought hard to punish such as undertook to convey them in a speedier and safer manner. But from a Time that this Branch of the Revenue was put under a just regulation, in consequence of the contract with Mr. Allen, all such Persons who were any way concerned in this illegal collection and conveyance of Letters, were by proper Officers employed by him, strictly enquired after, and when detected, the most notorious of them punished as a terror to the rest."-Ralph Allen's Narrative, 2nd December 1761 (Ralph Allen's Bye, Way and Cross Road Posts, London, 1897, pp. 6 and 18).

× Upon the next renewal of his Contract, which was in the Year 1741, the Postmasters-General, after largely expressing, as usual, their sense of the integrity of his conduct, and the services he had done to the Public, told him they judged it but reasonable to expect some addition to his rent of $£ 6,000$ a Year for the Bye, Way and Cross Road Letters, altho' he should still continue to support and inorease the produce of the Country Letters for the Benefit of the King. To which, Mr. Allen answered, that their expectations of additional rent appeared very reasonable to him, and which he should have made in his own way (a way he was going to open to them) had they not themselves proposed it. That there are two ways of giving this additional Rent: the one was by paying a further some of money yearly, such as he could afford to his Majesty's use without any advance to public commerce, the other was by paying his Majesty, and immediately too, a much larger sum than he could in the first way pretend to advance, in causing a considerable increase of the produce of the London and Country Letters by means of extending and quickening the correspondence of London and several of the most consider. able Trading Towns and Cities thro'out the Kingdom; a project that would be of infinite advantage to commerce. Which of these two ways the PostmastersGeneral would think fit to prefer, he left to themselves to consider; who on duly weighing all circumstances, did not in the least hesitate to prefer the latter method.

"Upon which Mr. Allen agreed to erect, at his own Expence, one every day post from London to Bath, Bristol, and Glocester towards the West; and from London to Cambridge, Lynn, Norwich, and Yarmouth towards the East; and to all intermediate places in both quarters: and that all the increase of the postage of Letters thus conveyed between London and the several places, East and West of it above-mentioned, should, without any charge or deduction, be paid in directly for his Majesty's use, as well as all the increase of the Country Letters within that District, that is, such Letters as pass between one Country Town and another thro' London.

"All this was accordingly done and executed conformable to the terms of the Contract."-Ibid., pp. 25-6.

Similar extensions were made at the renewals of the lease in 1748 and 1755. 
In 1765 the inland rates for short distances were reduced, and a new standard of charge was introduced. Hitherto, all charges had been regulated on a mileage basis. For short distances they were now based on the number of post stages. For one post stage the rate was made 1d. for a single letter, for a double letter $2 \mathrm{~d}$., for a treble letter $3 \mathrm{~d}$., and for every ounce $4 \mathrm{~d}$.; for two post stages, $2 \mathrm{~d}$., and in proportion for double, treble, and ounce letters. ${ }^{\mathbf{1}}$ The financial result of the change was unsatisfactory. ${ }^{2}$

Up to this period the mails were carried by postboys riding horse. Notwithstanding that on all the chief roads stage-coaches were running more expeditiously than the post-horses, the Post Office kept to the old way. The superiority of the stage-coaches as means for the conveyance of letters was noticed by Mr. John Palmer, proprietor of the theatre of Bath,3 who was so greatly impressed with the fact that he devised a complete and definite plan for the establishment of a system of mail conveyance by coach. The cost of the riding post (boy and horse) was $3 \mathrm{~d}$. a mile, and Palmer estimated that the change could be carried out without involving any increase of cost, especially if, as he proposed, the coaches carrying the mails should be exempted from toll. The proposal was severely criticized by the district surveyors of the Post Office, who reported on it.4 At the Treasury,

I 5 Geo. III, cap. $25, \S 5$.

2 "It is certain that the alteration of the rates of Postage in the year 1765 has not been attended with every good consequence then expccted from it and has been some loss to the Revenue."-Mr. Draper, District Surveyor, British Official Records, 1783.

3 " At a time when the mail leaving London on Monday night did not arrive at Bath until Wednesday afternoon, he (Palmer) had been in the habit of accomplishing the distance between the two cities in a single day. He had made journeys equally long and equally rapid in other directions; and, as the result of observation, he had come to the conclusion that of the horses kept at the post houses it was always the worst that were set aside to carry the mail, and that the post was the slowest mode of conveyance in the kingdom. He had also observed that, where security or despatch was required, his neighbours at Bath who might desire to correspond with London would make a letter up into a parcel and send it by stage-coach, although the cost by stage-coach was, porterage included, 2s. and by post 4d."-H. Joyce, History of the Post Office, pp. 208-9. Cf. D. Macpherson, op. cit., vol. iv. p. 54.

4 " If the present hours fixed at all the offices of the Kingdom with the greatest care and attention to that regular plan of correspondence which has been established after long experience were to be altered it would throw into the 
however, the proposal met with a more favourable reception. Pitt called a conference on the 21st June 1784, and after hearing the explanations of Palmer and the criticisms of the representatives of the Post Office, decided that the plan should be given a trial. Accordingly, on the 2nd August 1784 the first mail-coach ran. The experiment, which was conducted on the Bath Road, proved successful, and the plan was rapidly extended throughout the kingdom. The first coach cost $3 \mathrm{~d}$. a mile, the same rate as the riding post; but ultimately the coaches proved to be cheaper than the horse posts. In 1797 the rate was no more than a penny a mile. ${ }^{\mathrm{I}}$

Almost simultaneously with the introduction of mailcoaches there was an increase in the rates of postage, made solely with a view to increased revenue. ${ }^{2}$ The alteration was more or less fortuitous. In his Budget of 1784 Pitt had proposed a tax on coals which had not been well received, and the increased postage was substituted. Palmer is said to have claimed the credit of suggesting the substitution. 3 If so, his faith in his plan was abundantly justified. Notwithstanding the handicap of increased rates, it was an

greatest confusion for the present and would be many years before it could be restored to the degree of perfection it now has."-Observations on Mr. Palmer's Plan by Mr. Draper, District Surveyor (British Official Records, 1783).

"Indeed, it is a pity that the Author of the Plan should not first have been informed of the nature of the Business in question, to make him understand how very differently the Posts and Post Offices are conducted to what he apprehends, and that the constant Eye that has been long kept towards their improvement in all Situations and under all Circumstances has made them now almost as perfect as can be without exhausting the Revenue arising therefrom."-Observations on Mr. Palmer's Plan by Mr. Hodgson, District Surveyor. Ibid.

" Upon the whole it appears impracticable upon a general System to convey the Mails by Machine."-Observations on Mr. Palmer's Plan by Mr. Allen, District Surveyor. Ibid.

× "In 1797 there were forty-two mail-coach routes established, connecting sixty of the most important towns in the kingdom, as well as intermediate places. These coaches cost the Government $£ 12,416$ a year, only half the sum paid for post-horses and riders under the old system. The coaches made daily journeys over nearly two-thirds of the total distance traversed and tri-weekly journeys over something less than one-third the tatal distance. The remainder travelled one, two, four, and six times a week."-J. C. Hemmeon, History of the British Post Office, Cambridge, Mass., 1912, p. 40.

224 Geo. III, sess. 2, cap. 37.

3 H. Joyce, History of the Post Office, p. 215. 
unqualified success, and the effect on the revenue was immediate and considerable.

At about this time several horse and cross post mails had been molested, and it was desired, in response to a considerable public agitation, to establish mail-coaches on the minor posts. This would have involved heavy cost, and as an alternative Freeling (Secretary to the Post Office, afterwards Sir Francis) suggested that only responsible persons should be employed - at this time the post riders, in fact as well as name, were in many instances mere boys-and that the riders should be armed. In order to obtain funds to meet the cost of this scheme, the rates of postage were again increased in 1797. $\mathrm{A}$ A further increase was made in 1801 in order to provide an additional contribution of $£ 150,000$ a year to the Exchequer. ${ }^{2}$ The new rates were elaborate and complicated, comprising no less than thirteen rates for each class of letter, according to the distance of transmission. Another increase followed in 1805, when the Post Office was called upon to provide an additional $£ 230,000$ a year.3 This time the increase was made in a very simple manner, viz. by increasing the rates of 1801 in every case by $1 d$. for a single letter, $2 \mathrm{~d}$. for a double letter, $3 \mathrm{~d}$. for a treble letter, and 4d. per ounce.

All these increases, made with the avowed intention of increasing revenue, were successful in their main object. The net revenue, which in 1796 was $£ 466,457$, had risen in 1804 to $£ 956,212$, and in 1806 reached the sum of $£ 1,119,429$. The fiscal results seemed, therefore, to justify the Government in turning again and again to the Post Office when they were hard pushed to find revenue. This must be the justification of the further increase of 1812.4 The rates then established were the highest ever charged in England. The net revenue rose slightly after their establishment, but never increased materially. These rates continued in operation until 1839 , when they were completely swept away, and new rates based on principles fundamentally different were established.

I H. Joyce, History of the Post Office, pp. 317-18.

241 Geo. III, cap. 7.

345 Geo. III, cap. 11.

452 Geo. III, cap. 88. For details of the changes in the rates during this period see Appendix, pp. 338-9. 
This was the system, due to Sir Rowland Hill, of uniform rates, irrespective of distance of transmission, first introduced in the United Kingdom in 1839, and since adopted throughout the civilized world, not only for inland services, but for the international service. T The story of the conception, advocacy, and adoption of uniform postage is fully told by Sir Rowland Hill in his History of Penny Postage, ${ }^{2}$ and need be only briefly dealt with here. The plan itself is described in the famous pamphlet, Post Office Reform: Its Importance and Practicability, which was issued by Sir Rowland Hill in 1837.

The reform was directly related to the great reform movement in England of the second quarter of the nineteenth century, and is a brilliant example of the application of the deductive method in politics. Sir Rowland Hill was a member of a Radical family, remarkable even in those days for its zeal for reform. It was the ambition of all members of the family to aid as far as possible the great movement; and all the brothers interested themselves in the study of social and economic questions, with a view to reform and improvement.3 In the year 1835 there was a large surplus of revenue, and the brothers speculated on the direction in which reduction of taxation might best be made.4 Sir Rowland Hill examined

" "Von epochemachender Bedeutung war die berühmte von Rowland Hill angeregte Portoreform bei Briefen (sogenanntes Pennyporto) in GrossbritanNIEN 1839."-A. Wagner, Finanzwissenschaft, Leipzig, 1890, vol. ii. p. 152.

2 Sir Rowland Hill and G. Birkbeck Hill, Life of Sir Rowland Hill and History of Penny Postage, London, 1880.

3 "They were all full of high aims-all bent on 'the accomplishment of things permanently great and good.' There was no room in their minds for the petty thoughts of jealous spirits. Each had that breadth of view which enables a man to rise above all selfish considerations. Each had been brought up to consider the good of his family rather than his own peculiar good, and to look upon the good of mankind as still higher than the good of his family. Each was deeply convinced of the great truth which Priestly had discovered, and Bentham had advocated-that the object of all government, and of all social institutions, should be the greatest happiness of the greatest number for the greatest length of time. In their youth their aims were often visionary ; but they were always high and noble."-Ibid., vol. i. p. 193.

4 "Early in the 'thirties there had been some reduction in certain departments of taxation. It occurred to me that probably some ease might be given to the people by lowering the postal rate. . . Although occupied with other affairs, the reduction in the postal rate was not dismissed from my thoughts. The interest it had excited induced me to read Reports, etc., on postal administration."-Ibid., vol. i. p. 242. 
carefully the results of the financial reforms which had been introduced in recent years, and found that the effect on the revenue of reductions in the rate of tax showed very considerable variations. While in some cases, as, for example, leather and soap, a reduction of the duty by one-half had reduced the revenue by one-third, a similar reduction of the duty on coffee had increased the revenue by one-half. From this Sir Rowland Hill concluded that it was of the utmost importance to select carefully the taxes to be reduced, and he cast about for some guiding principle in the light of which the most suitable tax for reduction might be discovered. This principle he deduced to be as follows, viz. that the tax which most called for reduction was that which had failed most to keep pace with the increasing numbers and prosperity of the nation. ${ }^{\text {I }}$ Tested in this way, the tax on letters proved unsatisfactory. While in most other departments of the revenue the preceding twenty years had been years of expansion and progress - as might be anticipated during a period of peace following great and exhausting wars-in the case of the Post Office the period had been one of stagnation.

Attention had already been directed to this fact by Sir Henry Parnell.2 Between the years 1815 and 1835 the duty on stage-coaches had increased from $£ 218,000$ to nearly

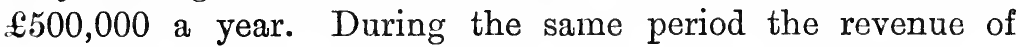
the Post Office, both gross and net, had not increased at all-in point of fact, it had slightly decreased. If it had kept pace with the increase of population, the annual net revenue would have increased by half a million. If it had

x "The best test to apply to the several existing taxes for the discovery of the one which may be reduced most extensively, with the least proportionate loss to the revenue, is probably this: excluding from the examination those taxes, the produce of which is greatly affected by changes in the habits of the people, as the taxes on spirits, tobacco, hair-powder, let each be examined as to whether its productiveness has kept pace with the increasing numbers and prosperity of the nation. And that tax which proves most defective under this test is, in all probability, the one we are in quest of."-Rowland Hill, Post Office Reform : Its Importance and Practicability, London, 1837, p. 2.

2 "The revenue of the Post Office has been stationary at about $£ 1,400,000$ a year since 1818. This can be accounted for only by the great duty charged on letters; for with a lower duty the correspondence of the country through the Post Office would have increased in proportion to the increase of population and national wealth."-Sir Henry Parnell, On Financial Reform, London, 1832, p. 41. 
increased in the same proportion as the duty on stagecoaches, the revenue of 1835 would have exceeded that of 1815 by no less than $£ 2,000,000$. These facts convinced Sir Rowland Hill that a reduction of the rates of postage was urgently necessary; and apart from financial considerations, the moral and intellectual results which would follow a facilitation of intercourse appealed powerfully to a reforming Radical. ${ }^{\mathrm{x}}$ Having arrived at the conviction that the Post Office offered most scope for his zeal, he found no lack of material to work upon. A Commission of Inquiry into the Revenue Departments had reported on the Post Office in 1829. A Commission of Inquiry on the Post Office had been sitting for some years, and had made numerous voluminous reports. Sir Rowland Hill set to work to make a careful study of the information contained in these reports, and as the result of this study evolved a complete plan for the reform and reorganization of the whole Post Office system, a plan involving the transformation both of the theory of Post Office finance, and of the methods of practical working. ${ }^{2}$

His inquiries led him to examine the cost of the Post Office service as a whole, and its relation to the work performed by the Post Office in respect of individual letters, or, as he termed it, "the natural cost of conveying a letter." 3 The investigations

$x$ "While thus confirmed in my belief that, even from a financial point of view, the postal rates were injuriously high, I also became more and more convinced, the more I considered the question, that the fiscal loss was not the most serious injury thus inflicted on the public; that yet more serious evil resulted from the obstruction thus raised to the moral and intellectual progress of the people; and that the Post Office, if put on a sound footing, would assume the now and important character of a powerful engine of civilization; that though now rendered fceble and inefficient by erroneous financial arrangements, it was capable of performing a distinguished part in the great work of national education." - Sir Rowland Hill in Life of Sir Rowland Hill and History of Penny Postage, London, 1880, vol. i. p. 245.

2 Post Office Reform : Its Importance and Practicability, by Rowland Hill, London, 1837.

3 "In order to ascertain, with as much accuracy as the circumstances of the case admit, the extent to which the rates of postage may be reduced, under the condition of a given reduction in the revenue, the best course appears to be, first to determine as nearly as possible the natural cost of conveying a letter under the varying circumstances of distance, etc., that is to say, the cost which would be incurred if the Post Office were conducted on the ordinary commercial principles, and postage relieved entirely from taxation; and then to add to the natural cost such amount of duty as may be necessary for producing the required revenue."-Ibid. p. 10. 
and calculations made in this connection elucidated a fact of first importance, viz. that the cost of the conveyance of a letter from one town to another was exceedingly small, being on the average no more than nine-hundredths of a penny-in the case of a mail from London to Edinburgh the cost of conveyance was no more than one-thirty-sixth of a penny. This fact was developed. It was shown that not only was the cost for conveyance for the average of distance exceedingly small, but that it did not vary with the distance. The variation was rather in the inverse proportion to the number of letters enclosed in a mail. ${ }^{x}$ Thus, while the average cost of the conveyance of a letter from London to Edinburgh was onethirty-sixth of a penny, the cost of the conveyance of a letter for a shorter distance was often greater, owing to the small number of letters included in the mail. On these facts rests the whole case for uniformity of rate irrespective of distance : ${ }^{2}$

I "I found, first, that the cost of conveying a letter between post town and post town was exceedingly small; secondly, that it had but little relation to distance; and thirdly, that it depended much upon the number of letters conveyed by the particular mail ; and as the cost per letter would diminish with every increase in such number, and as such increase would certainly follow reduction of postage, it followed that, if a great reduction could be effected, the cost of conveyance per letter, already so small, might be deemed absolutely insignificant.

"Hence, then, I came to the important conclusion that the existing practice of regulating the amount of postage by the distance over which an inland letter was conveyed, however plausible in appearance, had no foundation in principle, and that consequently the rates of postage should be irrespective of distance."-Sir Rowland Hill, Life of Sir Rowland Hill and History of Penny Postage, London, 1880, vol. i. p. 250.

2 "It appears, then, that the cost of mere transit incurred upon a letter sent from London to Edinburgh, a distance of 400 miles, is not more than one thirtysixth part of a penny. If therefore the proper charge (exclusive of tax) upon a letter received and delivered in London itself were twopence, then the proper charge (exclusive of tax) upon a letter received in London, but delivered in Edinburgh, would be twopence plus one-thirty-sixth part of a penny. Now, as the letters taken from London to Edinburgh are undoubtedly carried much more than an average distance, it follows, that when the charge for the receipt and delivery of the letter is determined, an additional charge of one-thirty-sixth part of a penny would amply repay the expense of transit. If, therefore, the charge for postage be made proportionate to the whole expense incurred in the receipt, transit, and delivery of the letter, and in the collection of its postage, it must be made uniformly the same from every post town to every other post town in the United Kingdom, unless it can be shown how we are to collect so small a sum as the thirty-sixth part of a penny."-Rowland Hill, Post Office Reform: Its Importance and Practicability, London, 1837, pp. 18-19. 
and they are sufficient to demonstrate that the principle is fundamentally sound.

The proposal for a uniform rate was the outstanding feature of the plan, but there were others of importance. It was a chief merit that the plan might be introduced without causing any serious diminution of net revenue, and the object of the further proposals was so to modify and simplify the working methods of the service as to enable the increased traffic which a low uniform rate would inevitably bring into the post to be dealt with without a proportionate increase in working expenses.

A vast increase in the number of letters must occur if the revenue was to be maintained, and this increase was confidently anticipated. With the existing rates there was a very large clandestine traffic in letters outside the Post Office, and it was calculated that a low uniform rate would effect the complete suppression of that traffic, and attract all letters into the post. But in order to maintain the net revenue, it was essential to simplify effectively the methods of working. This simplification was to be secured by the introduction of the system of prepayment, and the principle of charging by weight.

Covers and sheets of paper bearing the revenue stamp already impressed were to be sold at all post offices. The postage label, which has become so characteristic a feature of post oftice business throughout the civilized world, was proposed as an expedient to meet a certain exceptional case. If any person bringing a letter to the post should not be able to write the address on the stamped cover in which the letter was to be enclosed, Sir Rowland Hill suggested that "this difficulty might be obviated by using a bit of paper just large enough to bear the stamp, and covered at the back with a glutinous wash, which the bringer might, by applying a little moisture, attach to the back of the letter, so as to avoid the necessity for redirecting it." I

Letters prepaid in either of these ways were to pass through the post as franks, ${ }^{2}$ i.e. without charge or record. By this method a great reduction in the work of the Post Office

Ibid., p. 45.

"A "frank" was a letter or packet bearing on the outside the signature of a person entitled to send letters free of postage. 
would be effected. Under the existing system it was necessary to record and charge forward on the postmasters all letters the postage of which was to be collected on delivery, and these letters formed the vast majority. All such labour would be dispensed with. The increase of the number of letters was to be further encouraged by the provision of additional facilities, such as the establishment of day mails and increased frequency of deliveries in towns. ${ }^{x}$

It has sometimes been thought that Sir Rowland Hill's theory included the proposition that the increase of the number of letters varied in inverse proportion to the reduction of rate effected, that is to say, that if the rate were reduced by one-half, the number of letters posted would be doubled; if the rate were reduced by two-thirds, the number of letters posted would increase threefold. ${ }^{2}$ This is not the case. His estimate was that with the reduction of postage in the United Kingdom to the uniform rate of one penny, i.e. an average reduction of seven-eighths (from about eightpence), an immediate fourfold increase in the number of letters might be anticipated. This estimate was framed with regard to the circumstances existing in the United Kingdom at the time, and there is no other rule applicable to the relation between reduction of postage and resultant increase of postal traffic than that it is relative to the particular circumstances of time and place. Especially, it may be said, where postage is already low, further reduction is hardly likely to result in largely increased traftic.

In brief, Sir Rowland Hill calculated that by the adoption of his proposals for the modification of methods of working, the

I These proposals are not, howevor, necessarily related to the principle of uniformity, and, although interesting and important at the time, are now only of historical interest. They relate more particularly to the practicability of applying low and uniform rates to the postal service in the United Kingdom, having regard to the circumstances then obtaining and to the necessity for maintaining a large net revenue. Given that uniformity of rate was scientifically sound, it did not follow that it should be immediately adopted, and the financial effect was, to say the least, speculative. But since it was unlikely that the plan would be adopted if any large decrease in revenue were likely to result, Sir Rowland Hill was at great pains to explain methods by which his plan could be adopted without serious reduction of net revenue, and it was in this connection that the question of the increase in traffic which might be anticipated assumed such importance.

2 See, e.g., H. von Stephan, Geschichte der preussischen Post, Berlin, 1859, p. 615. 
letter postage in the United Kingdom might be reduced to the uniform rate of one penny irrespective of distance, without causing loss to the net revenue of more than $£ 300,000$ a year.

The pamphlet, Post Office Reform: Its Importance and Practicability, in which the plan was embodied, was first issued privately in January 1837 for circulation in political and official circles, to which Sir Rowland Hill had access, partly through the celebrity of his family on account of their school system, but chiefly through his brother Matthew Davenport Hill, then a member of Parliament. In February 1837 the author was invited to give evidence before the Commissioners for Post Office Inquiry.' The proposals were not, however, viewed favourably by the Government, and were resolutely opposed by the PostmasterGeneral and many of the high authorities of the Post Office. ${ }^{2}$

Finding it impossible to impress the official mind, Sir Rowland Hill issued the pamphlet to the public, 3 and it met with immediate, widespread, and influential support. The Press, Chambers of Commerce, and other bodies actively supported propaganda for the adoption of the scheme.4 Public meetings in support of it were held in all parts of the country, and numerous petitions in its favour were submitted to Parliament. So strong was the public feeling that in November 1837 the Government were constrained to appoint a Select Committee of the House of Commons for the express purpose

I Ninth Report of Commissioners for Inquiring into the Mode of Conducting the Business of the Post Office Department, 1837, Appendix, pp. 26-40.

2 "Of all the wild and visionary schemes he had ever heard or read of, it was the most extraordinary." -Lord Lichfield, Postmaster-General, 15 June 1837, Parl. Debates (Lords), vol. xxxviii, col. 1464.

" He considers the whole scheme of Mr. Hill as utterly fallacious; he thought so from the first moment he read the pamphlet of Mr. Hill; and his opinion of the plan was formed long before the evidence was given before the Committoe. The plan appears to him a most preposterous one, utterly unsupported by facts, and resting entirely on assumption. Every experiment in the way of reduction which has been made by the Post Office has shown its fallacy; for every reduction whatever leads to a Joss of revenue, in the first instance: if the reduction be small, the revenue recovers itself; but if the rates were to be reduced to a penny, revenue would not recover itself for forty or fifty years." Abstract of Evidence of Colonel Maberly, Secretary to the Post Office, Third Report from the Select Committee on Postage, 1838, p. 18.

3 Post Office Reform: Its Importance and Practicability, by Rowland Hill, second edition, London, 1837.

4 See Life of Sir Rowland Hill and History of Penny Postage, London, 1880 ; Sir Henry Cole, Fifty Years of Public Work, London, 1884. 
of considering Sir Rowland Hill's proposals. This Committee took a vast amount of evidence. The contentions of Sir Rowland Hill were in the main sustained by this evidence, and the Committee recommended (but only by the casting vote of its chairman) the adoption of a uniform rate. They were not, however, satisfied that the net revenue would be maintained if the uniform rate were made as low as one penny, and they therefore recommended the rate of twopence. ${ }^{x}$ The Committee reported in August, 1838, but no immediate steps were taken by the Government to carry out their recommendations. The condition of the national finances was not so healthy as in 1837, when the proposals were first broached, and they did not improve in the following years. ${ }^{2}$ The doubt as to the financial result of the scheme therefore made its early adoption in the normal course unlikely. The reform was, however, warmly taken up by the Radicals, 3 and in 1839 party exigencies enabled them to insist on the introduction of uniform penny postage as the price of their support in Parliament. 4

On the 10th January 1840, therefore, the reform was introduced.5 The new rate was one penny for each of the first two half ounces, and twopence for each additional

- Third Report of the Select Committee on Postage, 13th August 1838, $\$ 10$.

= In $1837-8$ the deficiency was $£ 1,428,000$; in $1838-9, £ 430,000$; in $1839-40$, $£ 1,457,000$; in $1840-1, £ 1,851,000$; and for $1841-2$ it was estimated at $£ 2,421,000$.

3 " Was the Committee ignorant-we think not-that the radicals in politics and the sectarians in religion, have been the warmest advocates-and indecd (except the mercantile body we have alluded to) the only very zealous advocates for this penny post?"-Quarterly Review, October 1839, p. 531. Cf. Edinburgh Review, January 1840; J. Morley, Life of Cobden, London, 1881, p. 411.

4 "On the 9th April 1839, Lord Melbourne's Government brought in what is generally known as the Jamaica Bill-a Bill for suspending for five years the constitution of that colony. This measure was strongly opposed by the Conservative party (led by Sir Robert Peel), and by many of the Radicals. On the second reading of the Bill, the Government only escaped defeat by the narrow majority of five votes. The Ministry thereupon resigned ; Sir Robert Peel was sent for by her Majesty, but owing to the 'Bedchamber Difficulty ' failed to form a Government. Lord Melbourne was recalled, and in the negotiations with the Radical members for future support to his Government, the bargain was struck that that support should be given, provided Penny Postage was conceded.

"Thus one of the greatest social reforms ever introduced was, to speak plainly, given as a bribe by a tottering Government to secure political support." - The Post Office of Fifty Years Ago, London, 1890, p. 24. Cf. Parl. Debates, 26th March 1855, vol. cxxxvii, col. 1136; Sir Stafford H. Northcote, Twenty Years of Financial Policy, London, 1862, pp. 8-9.

5 As a temporary measure, with the view of minimizing the practical difficulties of the Post Office, a uniform rate of $4 \mathrm{~d}$. a letter (1d. a letter for London local letters) was introduced on the 5th December 1839. 
ounce. The results were disappointing financially. The reduction in net revenue in the first year was one million pounds sterling (from $£ 1,500,000$ to $£ 500,000$ ), instead of $£ 300,000$ as forecasted. The number of letters, also, was doubled only, instead of quadrupled (in 1839, 82 millions, in 1840,169 millions). But the numbers continued to increase rapidly, in agreeable contrast to the stagnation under the old system. By 1847 they had quadrupled; by 1860 they had reached 564 millions; and the expansion has since been continuous. ${ }^{x}$ The gross revenue of 1839 was equalled in 1850 , and the net revenue of 1839 was reached in 1863. It has since gone on increasing. The plan was not an immediate financial success : neither was it a complete financial failure, as sometimes alleged. 2 The recovery of revenue was slow, but it was constant; and ultimately the plan has abundantly justified itself as a financial arrangement.

The changes in the British letter rates since 1840 have not been numerous or fundamental. The limit of weight for letters, viz. 16 ounces, fixed in 1840, was abolished in 1847 . In 1865 the progression of weight and charge above one ounce was made a penny the half-ounce. In 1871 the rates were reduced. Letters up to 1 ounce in weight became transmissible at the penny rate; for the second ounce, and for every succeeding 2 ounces up to 12 ounces, the rate was

- Estimate of number of chargeable letters delivered in the United Kingdom (in round numbers) :-

\begin{tabular}{|c|c|c|c|c|c|c|c|}
\hline 1839 & Letters & .. & $\cdots$ & $\cdots$ & .. & \multicolumn{2}{|c|}{76.0 millions } \\
\hline & Franks & .. & . & . & .. & $6 \cdot 6$ & ", \\
\hline 1840 & Letters & .. & . & . & . & $169 \cdot 0$ & ", \\
\hline 1841 & " & .. & .. & .. & .. & $197 \cdot 0$ & ", \\
\hline 1842 & , & .. & .. & .. & .. & $208 \cdot 0$ & $"$ \\
\hline 1843 & ", & .. & .. & .. & .. & $220^{\prime} 0$ & , \\
\hline 1844 & $"$ & .. & .. & -. & .. & $242 \cdot 0$ & $"$ \\
\hline 1845 & $"$ & .. & .. & .. & .. & $271 \cdot 0$ & $"$ \\
\hline 1846 & $"$ & .. & .. & .. & .. & $300 \cdot 0$ & , \\
\hline 1847 & " & .. & .. & .. & .. & $322 \cdot 0$ & " \\
\hline 1848 & ", & .. & .. & .. & .. & $329 \cdot 0$ & , \\
\hline 1849 & , & .. & .. & $\cdots$ & .. & $337 \cdot 0$ & $"$ \\
\hline 1860 & , & .. & .. & .. & .. & $564 \cdot 0$ & $"$ \\
\hline $1900-1$ & - " & .. & $\cdots$ & .. & .. & $2,323 \cdot 6$ & " \\
\hline $1913-1$ & 4, & .. & .. & .. & .. & $3,477 \cdot 8$ & ", \\
\hline
\end{tabular}

The total number of packets of all descriptions delivered in the United Kingdom in the year 1913-14 was about 6,000 millions.-Annual Reports of the Postmaster-General.

See J. R. McCulloch, Taxation and the Funding System, Edinburgh, 1863, p. 331 . 
made $\frac{1}{2} \mathrm{~d}$.; and for letters weighing more than 12 ounces, $1 \mathrm{~d}$. the ounce, including the first ounce. In 1885 the rate of $\frac{1}{2}$ d. for every 2 ounces after the second ounce was continued without limit; and in 1897, on the occasion of the Diamond Jubilee of Queen Victoria, a further reduction of the rate for heavier letters was made. The scale of $1 \mathrm{~d}$. for the first 4 ounces, and $\frac{1}{2} \mathrm{~d}$. for each succeeding 2 ounces, was then introduced. This method of effecting a reduction was dictated largely by a desire to simplify the rates of postage. It admitted of the abolition of the Sample Post, and of the Book Post (except as regards packets not exceeding 2 ounces in weight), and thus removed a source of confusion and loss of time both to the staff and the public.

In recent years postal traffic of all kinds has increased rapidly. The growth in numbers is shown by the following table:-

\begin{tabular}{c|c}
\hline Year. & $\begin{array}{c}\text { Total number of Postal } \\
\text { Packets dealt with in the } \\
\text { United Kingdom. }\end{array}$ \\
\hline $1880-1$ & $1,682,000,000$ \\
$1890-1$ & $2,623,988,000$ \\
$1900-1$ & $3,723,817,000$ \\
$1905-6$ & $4,686,182,000$ \\
$1910-11$ & $5,281,102,000$ \\
$1913-14$ & $5,920,821,000^{\mathrm{r}}$ \\
\hline
\end{tabular}

The ordinary letter, however, remains the characteristic of Post Office business and the sheet-anchor of postal finance. The vast proportion in point of numbers still consists of packets of small weight. ${ }^{2}$ In 1913-14, of a total traffic of

x The number of letters per head of population shows a continuous increase, as follows :-

\begin{tabular}{l|c|c|c|c}
\hline Year. & England. & Scotland. & Ireland. & $\begin{array}{c}\text { United } \\
\text { Kingdom. }\end{array}$ \\
\hline $1880-1$ & 38 & 29 & 15 & 34 \\
$1890-1$ & 50 & 36 & 21 & 45 \\
$1900-1$ & 61 & 47 & 32 & 57 \\
$1905-6$ & 68 & 51 & 36 & 62 \\
$1910-11$ & 73 & 56 & 40 & 68 \\
$1913-14$ & 81 & 63 & 45 & 75
\end{tabular}

$=$ As in other countries. It is contrary to the general principles upon which the post is conducted in the leading countries of Europe to throw a quantity of heavy matter upon the letter post, which exists primarily for the 
some six thousand million packets (including parcels), nearly three thousand five hundred millions passed at the letter rate of postage (less than 14 per cent. of which exceeded 1 ounce in weight), one thousand millions at the postcard rate, another thousand millions at the $\frac{1}{2} \mathrm{~d}$. packet rate (none exceeding 2 ounces in weight). The average weight of the two hundred million newspapers was just over 4 ounces, and of the hundred and thirty million parcels, some 2 to 3 pounds. Of the total traffic (including parcels), more than four thousand millions, consisting in general of ordinary letters and postcards, were under 1 ounce in weight; and of the remaining two thousand millions (including parcels) only some five hundred millions exceeded 4 ounces in weight.

The Post Office, in addition to its ordinary function of providing for the transmission of letters and packets, undertakes a number of subsidiary services. There are, of course, the telegraphs and telephones, the money order, postal order, and Savings Bank business, which have for many years been an integral part of the business of the Post Office. In recent years the Post Office has also undertaken the issue of certain local taxation licenses, and the payment of Old Age Pensions and Army Pensions. Now it has undertaken the sale of War Loan Stock, Exchequer Bonds, and War Savings Certificates. Apart from the telegraphs, telephones, and Savings Bank, however, these services form only a small part of the work of the Post Office. While the total cost of the ordinary postal services (i.e. excluding telegraphs, telephones, and Savings Bank) was in 1913-14 some $£ 17,000,000$, the cost of the subsidiary services was only about a million.

The staff of officers has increased as follows:-

\begin{tabular}{l|c|c|c}
\hline \multicolumn{1}{c|}{ Year. } & Male. & Female. & \multicolumn{1}{|c}{ Total. } \\
\hline $1880-1$ & - & - & 80,000 \\
$1890-1$ & 93,046 & 24,943 & 117,989 \\
$1900-1$ & 137,807 & 35,377 & 173,184 \\
$1905-6$ & 154,351 & 41,081 & 195,432 \\
$1910-11$ & 166,073 & 46,741 & 212,814 \\
$1913-14$ & 188,794 & 60,659 & $249,453^{1}$ \\
\hline
\end{tabular}

carriage of light letters, and would be seriously hampered by the transmission of large numbers of heavy packages."

Of these, 123,640 were established and 125,813 unestablished officers. 
Concurrently with the increase of the number of officers, the rate of wages has been revised on several occasions, as the result of the recommendations of Parliamentary and other Committees appointed to consider the question of Post Office wages. The cost of the increases of wages which have been granted as the result of these revisions, calculated on the basis of the staff at the dates of the respective revisions, without allowance for subsequent growth of force, is some

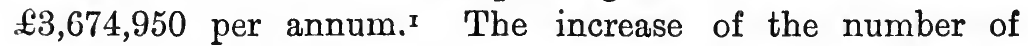
officers has, of course, increased the ultimate cost of each successive improvement in pay and conditions of service.

The increased wages of the staff have naturally counterbalanced to some extent the economies resulting from the large increase of business. Since the first of these revisions, the Fawcett of 1881-2, the wages of the staff have absorbed a larger percentage of the total revenue of the postal services, ${ }^{2}$ and the cost for staff per packet handled has increased from

I The following table shows the date and annual cost of the various revisions :-

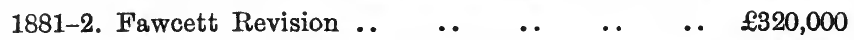

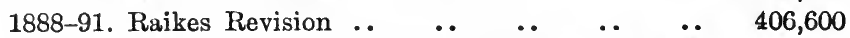

$$
\begin{aligned}
& \text { 1897-8. Tweedmouth Revision (including Norfolk- }
\end{aligned}
$$

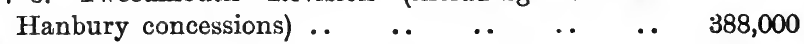

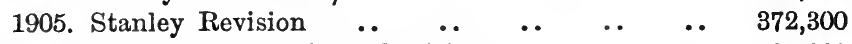

$$
\begin{aligned}
& \text { 1908. Hobhouse Committee Revision } \quad \text {. } \quad \text {.. } \quad \text {.. } \quad 707,900
\end{aligned}
$$

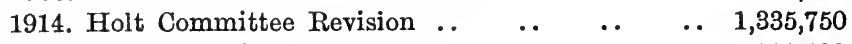

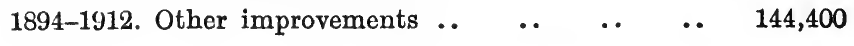

$$
\begin{aligned}
& \text { Total } \quad \ldots \quad \text {.. } \$ 3,674,950
\end{aligned}
$$

In addition, the annual cost of the War Bonus granted in 1915 is estimated at $£ 1,080,000$.

\begin{tabular}{l|c}
\hline & $\begin{array}{c}\text { Percentage of Salaries, } \\
\text { Wages, etc., to Total } \\
\text { Revenue. }\end{array}$ \\
\hline $1880-1$ & $28 \cdot 39$ \\
$1890-1$ & $35 \cdot 78$ \\
$1900-1$ & $45 \cdot 30$ \\
$1905-6$ & $45 \cdot 34$ \\
$1909-10$ & $49 \cdot 09$ \\
$1910-11$ & $47 \cdot 61$ \\
$1911-12$ & $49 \cdot 20$ \\
$1912-13$ & $47 \cdot 88$ \\
$1913-14$ & $47 \cdot 04$ \\
\hline
\end{tabular}


-288d. in $1880-1$ to 329 d. in $1890-1$, and 418 d. in $1913-14 .{ }^{x}$ During the same period the cost of conveyance of postal packets has decreased from 131d. per packet other than a parcel in 1880-1, to $119 \mathrm{~d}$. in 1890-1, and $080 \mathrm{~d}$. in 1913-14. ${ }^{2}$ The total cost of dealing with a postal packet other than a parcel has in recent years shown a small decrease. The cost in 1913-14 has been estimated at $\cdot 520 \mathrm{~d} .3$

The gross revenue of the postal services, i.e. excluding telegraphs and telephones, has increased from $£ 7,130,819$ in $1880-1$ to $£ 9,851,078$ in $1890-1$, and $£ 21,928,311$ in $1913-14$. The net revenue from postal services has increased from $£ 2,720,784$ in $1880-1$ to $£ 3,163,989$ in $1890-1$, and $£ 6,642,067$ in 1913-14. The expansion of net revenue has not kept pace with the increase in the total number of packets passing by post. Since 1880 the total numbers have increased some $3 \frac{1}{2}$-fold, and the net revenue some $2 \frac{1}{2}$-fold. 4 The relation

I The increase is partly accounted for by the fact that parcels are included in the later figures. Deducting the estimated cost of the parcel post (see infra, Chapter VII), the cost for staff for packets other than parcels was, in 1913-14, some $\cdot 340$ d. per packet.

2 Omitting the cost of conveyance of mails by sea, and omitting the cost of conveyance of parcels by railway, which is fixed by the Parcel Post Act of 1882. The following table shows the movement of the general cost of conveyance of mails :-

\begin{tabular}{l|c|c}
\hline Year. & $\begin{array}{c}\text { Cost of } \\
\text { Conveyance. }\end{array}$ & $\begin{array}{c}\text { Percentage of Cost of Conveysnce } \\
\text { of Mails by Road and Rail to Total } \\
\text { Revenue (excluding Cost of Con- } \\
\text { veysnce of Parcels by Railway). }\end{array}$ \\
\hline $1880-1$ & $£ 921,093$ & $16 \cdot 17$ \\
$1890-1$ & $1,273,894$ & $12 \cdot 62$ \\
$1900-1$ & $1,519,219$ & $11 \cdot 26$ \\
$1905-6$ & $1,710,891$ & $10 \cdot 68$ \\
$1910-11$ & $1,812,505$ & $9 \cdot 18$ \\
$1913-14$ & $1,940,735$ & $8 \cdot 85$ \\
\hline
\end{tabular}

3 Assuming there is no loss on the Parcel Post. If there is such loss, the cost per packet other than a parcel would be reduced (see infra, Chapter VII).

4 The general increase of wages partly accounts for this (see p. 34, opposite). The cost of working is, however, higher in the larger offices (where the bulk of postal work is done) than in the smaller offices, and tends to be highest in the largest offices. The matter is complicated by the fact that higher scales of pay are in force in the larger towns. 
between the gross revenue and the total expenditure on the postal services, which in recent years has not shown any large variation, fluctuates in the neighbourhood of 70 per cent. ${ }^{\mathrm{I}}$

Note.-On the 1st November 1915, in order to secure increased revenue for war purposes, the inland letter rate was increased to the following:-

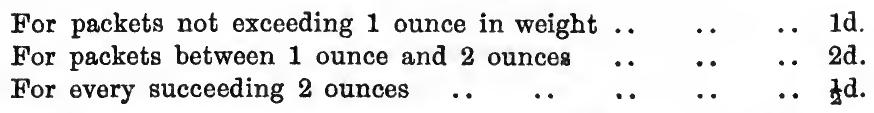

Under the existing abnormal circumstances it is difficult to form a satisfactory estimate of the result of this increase. Numerous contrary forces are in operation. The growth of the Army and the dislocation of private business resulting from the war have had important effects on the number of letters posted. Large numbers of letters are exchanged with men in the Army, but, on the other hand, all letters from troops on active service pass free of postage. It has been estimated that in the first five months the new rates yielded an increased revenue of nearly half a million.-See Postmaster-General's statement, 3rd July 1916 (Parl. Debates (Commons), vol. lxxxiii. cols. 1231-2).

\begin{tabular}{l|c|c}
\hline \multirow{2}{*}{ 1 Year. } & \multicolumn{2}{|c}{$\begin{array}{c}\text { Percentage of Total Expenditure to } \\
\text { Total Revenue. }\end{array}$} \\
\cline { 2 - 3 } & Postal Services. & All Services. \\
\hline $1839-40^{*} \dagger$ & $31 \cdot 66$ & - \\
$1840-41 \dagger$ & $63 \cdot 16$ & - \\
$1880-1$ & $61 \cdot 84$ & $68 \cdot 97$ \\
$1890-1$ & $65 \cdot 79$ & $74 \cdot 33$ \\
$1900-1$ & $71 \cdot 75$ & $80 \cdot 99$ \\
$1905-6$ & $69 \cdot 44$ & $80 \cdot 19$ \\
$1909-10$ & $73 \cdot 75$ & $84 \cdot 00$ \\
$1910-11$ & $72 \cdot 28$ & $82 \cdot 94$ \\
$1911-12$ & $72 \cdot 36$ & $82 \cdot 89$ \\
$1912-13$ & $71 \cdot 25$ & $82 \cdot 05$ \\
$1913-14+$ & $69 \cdot 71$ & $80 \cdot 02$ \\
\hline
\end{tabular}

* Penny Postage introduced, 10th January 1840.

+ Revenue does not include proceeds of Impressed Stamp on Newspapers.

Estimated. -Report of Postmaster-General, 1913-14, pp. 122-3. 


\section{LE'T'TER POST IN CANADA}

When Canada came into British hands after the capture of Quebec, no postal arrangements existed in the province. The population numbered only some 60,000 , excluding the Indians, and with so small a number spread over so vast a territory it was not to be expected that any Post Office establishment of the ordinary type could be maintained. ${ }^{x}$ Very soon, however, the English merchants interested in the Canadian trade urged upon the British Government the necessity for a regular service from New York to Quebec, and in this they were supported by the Governor of the province. The Government instructed the Deputy Postmasters-General in America to take steps for the establishment of the post, and they accordingly proceeded to Quebec. There they met a young Scotsman, Hugh Finlay, who offered to conduct a regular post between Quebec and Montreal, undertaking all risks, for a commission of 20 per cent. on all revenue collected on the post, ${ }^{2}$ and, in addition, a monopoly of licensing persons to provide horses and conveyances for the use of travellers-the old monopoly which had existed for so long in England as a source of emolument to the postmasters. Finlay contracted for the conveyance of the mail with a number of men, to whom he made over the exclusive right of furnishing travellers on the route. In addition to this privilege, these men, who were styled maittres de poste, were remunerated by payment at the rate of $6 \mathrm{~d}$. a league (2d. a mile) for providing horses and carriages for the couriers. Between Quebec and Montreal, a distance of 180 miles, there

2 "The inhabitants live so scattered and remote from each other in that vast country, that posts cannot be supported among them."--Benjamin Franklin, evidence before House of Commons, 28th January, 1766 (Parl. History, vol. xví. col. 138).

2. The usual rate of remuneration for deputy postmasters in North Ameriça. Cf. infra, pp. 49 and 66. 
were twenty-seven maîtres de poste and two post offices, viz., Three Rivers and Berthier. On the whole route, which was not of the easiest, there was not a single inn; there were six ferries to cross, that at Three Rivers being three miles wide, and one near Montreal nearly three-quarters of a mile. There was a service twice a week in each direction, and the journey occupied about forty hours, the courier who left Quebec at five o'clock on Monday afternoon arriving at Montreal on Wednesday morning, and the courier leaving Montreal on Thursday evening reaching Quebec on Saturday morning.

The statutory authority for the establishment of posts in Canada, as in other parts of North America, was section 4 of the Act of the 9th of Anne. This Act, however, failed to prescribe for North America rates of postage for letters passing greater distances than 100 miles. Hence, for the post from Quebec to Montreal no legal rate was ascertainable. The rate actually charged was $8 \mathrm{~d}$. for a single letter, and so in proportion for double, treble, and ounce letters, which was not an excessive charge, seeing that the legal charge for distances up to 100 miles was 6 d. for a single letter. It proved sufficient, however; the whole scheme was completely successful and greatly appreciated by the colonists. To link this local post with the service from England, the PostmastersGeneral at New York arranged a connecting post to run monthly in connection with the arrival and departure of the English packets. They realized that the number of letters likely to be carried by such a post would be small and would not yield a revenue nearly equal to the expenses, the more so as, in any case, a comparatively high rate of postage would be payable on account of the great distance, and in recommending its establishment, they suggested moderate rates of charge. ${ }^{\mathrm{I}}$

The Act of 1765 provided reduced rates of postage for North America. "The vast accession of territory gained by the late Treaty of Peace," and the establishment of new posts in America, for which rates of postage could not be ascertained

I "On account of the scarcity of money, people will forbear to correspond until they find occasions by friends, travellers, and the like, to send their letters, which makes it to be wished that the Legislature might enact that the rate of postage for the greatest distances on the Continent of America may not exceed 1s. 6d. for a single letter and so in proportion."-British Official Records, 1764. 
under the existing law, ${ }^{\mathbf{x}}$ made a new Act necessary, and the rates prescribed in that Act were fixed under the enlightened principle that moderate rates might yield increased revenue. ${ }^{2}$ The rate which would apply to Canada, for the greatest distances, was fixed at $8 \mathrm{~d}$. for a single letter for not more than 200 miles, and $2 \mathrm{~d}$. for each 100 miles beyond 200 milesdouble letters double rates, treble letters treble rates, ounce letter four times the single rate, in the usual way.

In January 1774 Finlay was appointed joint "DeputyGeneral for the Northern District of America" in the room of Dr. Franklin. He was allowed to retain, for the time being, the benefits of the Post Office at Quebec, which, in the words of the letter of appointment, he had been "so instrumental in bringing to a degree of perfection." 3 The disturbances of $\mathbf{1 7 7 5}$ in the coast colonies soon affected the post to Canada. In September of that year, the prospect of getting mails through from Canada to New York was so slight that Finlay was anticipating the suspension of all communication with the rest of the world during the whole of the winter, unless letters could be conveyed to Halifax. The couriers were frequently held up by armed men and robbed, and by November matters had become so serious that all postal arrangements in the province were stayed. Quebec was besieged throughout the winter and spring. After its relief Finlay tried to set up the posts again, but unsuccessfully, as the Governor refused to reestablish the monopoly of the maitres de poste, on the ground that travellers in Canada were very well accommodated in horses and conveyances and did not desire its re-establishment. Without it Finlay was unable to maintain a service, and no posts existed during the remaining period of the war.

After peace had been restored, Finlay represented the matter so strongly that the monopoly was re-established. The posts were again set up, and Finlay was appointed Deputy Postmaster-General of Canada, Nova Scotia, and

- Preamble of 5 Geo. III, cap. 25.

2 "The present rates may in some parts be reduced, and the Revenue nevertheless may heresfter be improved, by means of a more extensive circulation." -5 Geo. III, cap. $25, \S 1$.

3 British Official Records, 8th February 1774. 
New Brunswick. The mails for Canada were still sent by way of New York, as before the war, but for military reasons it was important that a mail route should be established from Halifax, the military headquarters, to run altogether within British territory. In 1787 a fortnightly post (monthly in winter) was accordingly established between Quebec and

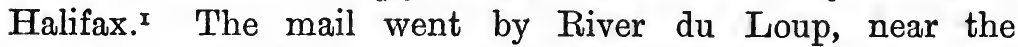
Grand Portage, where the courier from Quebec handed over his mail to the courier from Fredericton; by the Madawaska to the Grand Falls; thence by boat to Fredericton. A fresh courier went by boat from Fredericton to the mouth of the St. John's River. Here the mail was transferred to a sloop of about 34 tons burthen for conveyance across the Bay of Fundy to Digby, whence the route lay by Annapolis. The total distance from Quebec to Halifax was 633 miles, and the time required for the trip varied from twenty-one to thirty-one days.

A mail route from Montreal into Upper Canada was also established, but this was rather a military post, intended to serve the military stations and frontier settlements. The mail was despatched only once a year and was, in consequence, known as the "yearly express." The route followed was by the St. Lawrence from Montreal to Matilda, Augusta, and Kingston; across Lake Ontario to Niagara; thence to Detroit Fort, at the base of Lake St. Clair, and across Lake Huron to Michilimackinac, at the head of Lakes Huron and Michigan. After continuing some six years this post was curtailed and went no farther than Niagara. ${ }^{2}$

In 1800 Finlay was succeeded in the deputyship by John Heriot. The population had now increased to 450,000 , but there were only twenty post offices in the whole of the five provinces. Heriot's patent gave him authority to establish new routes and offices, but, in accordance with the general policy, only when in his opinion their establishment would be likely to benefit revenue. The rates at this time were, of course, nominally based on the Act of the 5th George III, but as the routes had never been properly measured, the distances on which the rates were actually based were

× British Official Records, 23rd September 1790.

? J. G. Hendy, Empire Review, London, 1902, vol. iv., p. 180. 
largely a matter of conjecture. The posts were said, however, to have paid their way and even to have yielded a surplus revenue, which was transmitted to England. ${ }^{x}$

The administration of the posts rested ultimately with the Postmasters-General in London. The service could be extended only by their authority, and the colonists found that the Deputy in the colonies, being bound by his instructions from the Postmasters-General, was unable to extend and improve the service in the manner which they themselves thought desirable. A large number of immigrants entered the provinces, especially Upper Canada, during this period, and settlements were springing up in remote districts far away from the post routes. Heriot was admonished from London that in considering the provision of new services he must look to the revenue to be anticipated as well as to the convenience of the public, and to adopt no scheme involving sacrifice of revenue. His instructions forbade the opening of any post office or post route unless the anticipated revenue was sufficient at least to pay the postmaster and courier. $\mathrm{He}$ found that these restrictions prevented him from providing a service in any degree adequate to the demands of the settlers, or indeed adequate to their real needs. It was essential that the settlers in the remote districts should be kept in touch with civilization. They could not be allowed to pass beyond the reach of the Government. They must be kept in contact with the means provided for the administration of the law.

I There is no doubt that the revenues of the provinces showed a nominal surplus, but it is not so clear that this surplus, which amounted to $£ 884$ in 1801 , and to $£ 2,514$ in 1811 , was a surplus on the provincial services. Many years later, when the administration of the Post Office in the colonies and the question of the disposal of the surplus revenue had become part of a political matter of the first magnitude, the provincial Legislatures alleged that the surplus amounted to a very considerable sum each year, and that the circumstances constituted a taxation of the colonies by the Mother Country; but the Deputy Postmaster-General asserted that this surplus was in fact composed of revenues to which the colonies had no claim, viz. the charges for British packet postage, that is, for transmission of letters across the ocean, and payments in respect of military postage, and that in point of fact the local service had never yielded a surplus-that, indeed, there was probably a deficit.

"This I feel myself bound to state as my firm conviction, that neither for the last ten years, nor for any previous period, has the postage of Lower Canada afforded one farthing of Net Revenue."-Mr. T. A. Stayner, Deputy PostmasterGeneral (Report of Special Cornmittee of the House of Assembly on the Post Office Department in the Province of Lower Canada, 11th February 1832, p. 12). 
For these reasons it was essential to provide post accommodation, although in the nature of the case it could not be expected that a revenue sufficient to cover the cost would be obtained. All these considerations were pressed on the Deputy, and he was so far persuaded as sometimes, in response to urgent local representations, to depart from his specific instructions. But such cases usually led to a reprimand. The natural result was that the province was driven itself to undertake by grants from the public funds the provision of many local services which it deemed essential.

Thus grew up the anomalous system under which the colonies made large grants in aid of the service, but were unable to exercise any substantial control over its administration. The more important routes were self-supporting and were controlled entirely from England. In order to obtain extensions of the service the colonists, through the Governor, requested the establishment of certain services, undertaking that, if the revenue derived from these services should prove insufficient to meet the expenditure, the balance should be made up by the colony. A regular post was established in 1801 between Quebec and York (Toronto) under a guarantee of this kind. The colonists naturally wished to have some controlling voice in the administration; but the Deputy, holding office under the Imperial authorities, was not bound to concede to them any rights over the administration of the service, however great sums they might pay towards its maintenance-a situation which was sure to lead to difficulties. Whether or not serious trouble occurred depended in large degree on the character of the Deputy. I In later years there was considerable friction and much irritation on the part of the colonists.

In Nova Scotia the system of grants in aid was developed to an even greater extent than in Upper Canada. When Sir George Provost became Governor in 1808, there were only five post offices in Nova Scotia-Halifax, Windsor, Horton, Annapolis, and Digby-and they were all on the line of the Quebec post. Sir George was anxious for an extension of the posts on military rather than general grounds, and he asked the postmaster of Halifax, John

- See, e.g., Report of Special Committee, House of Assembly, Lower Canada, 8th March 1836. 
Howe, to establish several new routes. Howe was inclined to favour the projected posts, but Heriot realized that they could not be expected to yield a revenue equal to their cost, and he informed the Governor that his instructions from England prevented compliance with the request. Sir George Provost thereupon induced the Legislature to appropriate a sufficient sum for the establishment of the posts. The Governors of New Brunswick and Prince Edward Island followed this example, with the result that a large part of the Post Office establishment in these provinces was outside the jurisdiction of the Imperial authorities.

This development is noteworthy. It has always been found in Canada that for a large part of the country the circumstances are such that a postal service adequate to the necessities of the inhabitants cannot be self-supporting, but the Legislature has never hesitated to make grants from general taxation in order to provide means of communication. In the early days the question of post office communication was intimately bound up with the question of general means of communication, and was usually treated in connection with the making or maintenance of roads. For a long period the posts in Canada were maintained not solely for the transmission of letters, but to a great extent on account of collateral advantages. They were largely military in character, and were identified with the military routes. ${ }^{\mathbf{1}}$

In 1816 Daniel Sutherland was appointed Deputy Postmaster-General for Canada, Nova Scotia, and New Brunswick. Under his administration the development of the service was pushed forward, and so far as was found consistent with the interests of revenue, new offices and routes were established. But in 1820 there were still no more than forty-nine post offices in the whole of British North America, distributed thus: in Lower Canada twenty offices, in Upper

I In 1790 Governor Carleton of New Brunswick manned the posts at St. John, Cumberland, Preguile, and Fredericton with a troop of soldiers, by which means "the route was kept in good order"; and in 1794 the Duke of Kent, then Commander-in-Chief of the forces in Nova Scotia, constructed a military post road from Halifax to Annapolis, and also other roads in the vicinity of Halifax.-British America (British Empire Series, vol. iii., London, 1900), p. 121. 
Canada nineteen, in Nova Scotia six, in New Brunswick three, and in Prince Edward Island one. The progress was from this time somewhat more rapid. By 1824 the number of offices in the Canadas alone had risen to sixtynine, and during the next ten or fifteen years the growth, both of Post Office accommodation and of Post Office revenue, was more rapid than the growth of population.

The settlers were not, however, completely satisfied. Their complaints were to some extent laid against the administration of the office-they claimed, for example, that gross overcharges of postage were being made, through incorrect computation of the distances on the post roads-but they became more and more dissatisfied that the control of the whole of the service and its officers should rest with the PostmasterGeneral in England. The question was, of course, to a large extent political, and one only among the several general grievances of the colonists at this period, which caused so much anxiety to the Home authorities.

As early as 1819 a movement began in Upper Canada to obtain the transference of the administration to the provincial authorities. A Committee of the House of Assembly considered the abuses of the existing Post Office system, and on presentation of their report, in March 1820, the House passed a resolution condemning the administration of the service. The question continued to receive a good deal of attention. The chief complaint of the colonists was that a net revenue was year by year transmitted to London. There is no doubt that a balance was paid over to the Imperial administration year by year, but it is questionable whether any of this balance was a net revenue on the local service. ${ }^{\text {I }}$ The colonists chose so to regard it. They advanced the contention that the legal right of the Imperial Government to levy postage rates in the colonies at all was doubtful, because postage was a tax; and the raising of money by authorities outside the colonies was a direct infringement of their own constitution, which provides that "no tax shall be levied on the people of this country except such as shall be appropriated for the public use and accounted for by the Legislature," 2 and of the Declaratory Act, in which Great Britain disclaimed the

\footnotetext{
Vide p. 41, note, supra.

$=31$ Geo. III, cap. 31.
} 
right to impose upon a colony any duty, tax, or assessment, except where necessary for the regulation of commerce. $x$ The Government were advised by the Law Officers that it would not be wise to contest the point, and proceeded to consider a measure for placing the establishment on a more satisfactory basis.

If the Home Government could have agreed to hand over the entire administration of the office in British North America to the local Legislatures, there would have been an end of the matter. But such a course would have left the interior provinces at the mercy of those on the seaboard as to the conveyance across those colonies of the mails to and from England. Although there was no desire to continue the appropriation to the Imperial revenue of any surplus which might arise on the service in North America, it was felt to be highly desirable that the Imperial Government should retain control over the administration of the office, particularly in the matter of fixing the rates of postage, since by that means excessive charges for transit across other provinces would be prevented. But in controlling the administration from London there was the difficulty that any alteration of the rates of postage by Act of the British Parliament might be an infringement of the rights of the colonists under the Declaratory Act of 1778. Accordingly, all intention of direct legislation by the British Parliament was abandoned, and in 1834 an Act was passed, ${ }^{2}$ repealing the Act of the 5th George III, on which the whole Post Office establishment of North America rested, conditionally on the passing by the Legislatures of all the provinces of a Bill for the regulation of the colonial Post Office service, which had been prepared in London. This Bill provided that the ultimate control of the whole service in British North America should remain in the hands of the PostmasterGeneral in London, but that the rates of postage should be fixed by the local Legislatures, and any surplus of revenue over expenditure should be divided between the provinces.

Nova Scotia was prepared to accept the Bill, but only with modifications which would have prevented its adoption as the basis of a general service throughout the five provinces. New

$$
\text { = } 18 \text { Goo. III, cap. } 12 .
$$$$
24 \text { Will. IV, cap. } 7 .
$$ 
Brunswick and both Upper and Lower Canada rejected the Bill. The Assembly of Lower Canada substituted a Bill of its own. ${ }^{x}$ The Legislative Council were indisposed to accept the substituted Bill,2 and in March 1836 adopted an Address to his Majesty, explaining that in their view it would be exceedingly difficult, if not impracticable, to secure the co-operation between the separate Post Office establishments of the several provinces essential for the attainment of the purpose of the original measure, and they pointed for illustration to the United States, a country where, notwithstanding a keen regard for State rights, the whole control and management of the Post Office department had been delegated to the Federal Government. Since the Post Office establishment was a most effective means for strengthening the ties connecting the several provinces, as well as an essential aid and convenience of commerce, they deemed the best course to be the retention by the Imperial Parliament of the exclusive power of legislating for the control and management of the Post Office in all parts of the Empire. In March of the following year, there being still no prospect of the adoption of the Bill by the provinces, the House of Assembly and Legislative Council of Upper Canada adopted a joint Address to his Majesty, substantially identical with that adopted a year earlier by the Legislative Council of Lower Canada. It was clear that little progress was to be anticipated.3

- Report of Special Committee, House of Assembly, Lower Canada, 8th March 1836.

2 Ibid., Legislative Council, Lower Canada, 15th March 1836. Cf. Report of Select Committee, Legislative Council, Upper Canada, 17th February 1837.

3 "We have failed to discover reasonable grounds for hoping that the several Colonial Legislatures will soon (if indeed they ever will) arrive at such uniformity in their enactments for the management of the Post Office within their respective localities as would ensure the establishment of a practicable system, more especially since it is admitted that the Bill of one Legislature, in order to become effective, must correspond in all its material provisions with the Bills of all the other Legislatures, and that after these Bills have been found to correspond with one another, and had in consequence thereof become Laws, no alterations in them, however expedient it might be deemed by one Legislature for the improvement of the system, could be carricd into effect, until agreed to by each separate Legislature."-Joint Address, Legislature of Upper Canada, March 1837, p. 11.

An example of the difficulties likely $\mathrm{c}$ be encountered, and some justification for the reluctance of the Imperial authorities to yield control of the service, is afforded by a dispute which occurred at about this time between Canada and 
In 1840 a Commission was appointed. Its attention was directed more especially to the faulty administration of the office and the excessive rates of postage. To remedy the former, and to make the administration more amenable to local control, they suggested placing the Deputy PostmasterGeneral under the control of the Governor-General in all matters which did not conflict with the authority of the Postmaster-General in England. As to postage, they were satisfied that the rates at that time in operation were too high. They considered that the rates should be such as would yield a revenue sufficient to meet the expenses of the department, and no more; and in their view, if the revenue improved after the establishment of such rates, which there should be no difficulty in calculating, the proper course would be either to grant further facilities or further to reduce the rates. There should not in any case be a net revenue of any magnitude. The Commissioners themselves made an estimate of the rate which should fulfil the requirements they had detailed. In so doing they proceeded on much the same lines as Sir Rowland Hill in his pamphlet Post Office Reform: Its Importance and Practicability. They had no difficulty in answering the demand for penny postage in British North America, a demand based on its successful inauguration in England. The circumstances in the two countries were not comparable. England, small and densely populated, the first industrial and commercial nation of the world, could not in such a matter be compared with a country of vast extent, sparsely peopled and almost entirely agricultural. While Sir Rowland Hill had been able to show that in the case of letters conveyed for comparatively long distances in England the actual cost of carriage was only one thirty-sixth part of a penny, the Commissioners found that in British North America the actual average cost of conveyance was no less than $3 \mathrm{~d}$., and the actual average total cost of dealing with letters no less than $5 \frac{1}{2} \mathrm{~d}$. Uniformity of rate at a penny, which had been justified in England on

Nova Scotia concerning the arrangements for the transmission of the British mails between Quebec and Halifax. Nova Scotia refused for the first time to make good the deficiency in the Post Office revenue. The authorities in London thereupon ordered the Deputy in the province to discontinue all unremunerative services, a course of action which proved effective. 
existing facts of the service, could therefore find no similar justification in North America.

There could, however, be no doubt that with a reduction of the rate, which then averaged $8 \frac{1}{2} \mathrm{~d}$. a letter, the number of letters would be very greatly increased and the cost per letter consequently reduced. The public were in the habit of making use of every available means other than the post for forwarding their letters. Steamboats which carried a mail would carry outside the mail many times the number of letters that were enclosed in the mail. Teamsters, stage drivers, and ordinary travellers all carried large numbers of letters, and in cases where no such opportunity offered, persons had been known to enclose the letter in a small package, which could be sent as freight at less charge than the rate of postage on the single letter. If, therefore, all these letters, and the many additional letters which would be written if transmission were cheap and easy, were sent in the mails, the cost of the service would not be by any means proportionately increased, and the average cost per letter would be very greatly reduced. It would still, however, have been considerably more than a penny. Their conclusions were less satisfactory in regard to the rates actually recommended. They proposed a graduation according to distance of no less than five stages, starting with as short a distance as 30 miles. For this the rate was 2 d., and the scale rose to $1 \mathrm{~s}$. for distances over 300 miles. The only virtues of the rates were that they were lower than those in operation in the United States and were to be charged by weight. ${ }^{x}$

The chief recommendations of this report were carried out under the authority of the Colonial Office. The weight basis for determining rates of postage was adopted, and the Deputy Postmaster-General's authority was restricted. His privilege of sending newspapers free of postage was also taken away, and in compensation he was given a salary of $£ 2,500$ a year-personal to himself, and high on account of his long enjoyment of the lucrative newspaper privilege. That for his successor was fixed at $£ 1,500$ a year. The agitation in the provinces in regard to the Post Office continued during

- Report of the Commissioners appointed to enquire into the affairs of tho Post Office in British North America, 31st December 1841. 
the succeeding years, but it was less vehement and concerned itself more with the question of rates than with questions of administration.

In 1842 a member of the headquarters staff of the British office (Mr. W. J. Page) was commissioned to examine and reorganize the service in the Maritime Provinces, with the object more especially of introducing such measures of reform as should bring the expenditures of the department in those provinces within the revenue. His reports throw a flood of light on the state and methods of the service. ${ }^{x} \mathrm{He}$ found extraordinary anomalies in the methods of charging postage, in the methods of remunerating the Deputy-Postmasters, the couriers, and the Way Office keepers, and in the relations subsisting between the Post Office and the local Legislatures. The financial arrangements of the office were in a condition which can only be described as chaotic. Postage was, of course, chargeable on the total journey of the letter. But in Nova Scotia letters were charged with a new rate at each office through which they passed, and postage became an excessive charge on all letters which passed through two or three offices. Deputy-Postmasters were paid a percentage, usually 20 per cent., on the amount of postage collected by them, but their chief remuneration in many cases arose from the right which they exercised of franking all their private and business correspondence, a consideration which they had principally, if not exclusively, in view in taking up their appointments. Many of the deputies were lawyers or other professional inen. The privilege was nominally subject to the limitation of four single letters, or two double letters, or one packet of an ounce by each mail; but this limitation was very generally disregarded. To such an extent was this the case that one-half of many mails consisted of free letters.

Couriers received fixed wages, which were either paid by the Deputy Postmaster-General out of the general funds of the department, or from grants in aid, given by the Legislature specifically for the support of the respective routes. Way Office keepers received no remuneration from the department: in many instances the existence of the Way

\section{- British Official Records, 1842-3.}


Offices was unknown at Halifax. This was explained in great part by the manner in which such offices were usually established. A courier travelling a particular line of road received from the despatching postmaster a number of "way letters," or letters for persons living on or near his route. Partly for his own convenience, and partly for the accommodation of the persons addressed, the courier would leave packets of the letters at some house on the route, and the occupant would collect the postage on behalf of the courier. In course of time the courier induced the postmaster to make up the letters for this particular place separately, and to open a private account with the householder, who thus became an agent for the postmaster, and the house became a Way Office. The keepers of these Way Offices usually charged a fee of $2 \mathrm{~d}$. on each letter received or sent. The Post Office was not in any way concerned in the transactions, except that in some cases, where it was not always possible for the Way Office keeper to obtain his fee in advance, the practice grew up, with the cooperation of the Deputy-Postmaster, of charging forward the unpaid Way Office keeper's fee as unpaid forward "postage." Some of the Way Office keepers also claimed and exercised the same rights of franking as the Deputy Postmasters. Others were paid on the basis of a percentage of 20 per cent. of the postage collected; and in such cases some of the keepers still collected their fee of $2 d$., and some did not.

When letters were sent from one Way Office to anotheras was frequently the case, since often there were several Way Offices in succession-a fresh fee was charged; and a letter might be charged four or five twopenny fees and no postage, the fees all being appropriated by the Way Office keepers and nothing finding its way to the Post Office revenue. Indeed, the Post Office department received scarcely any revenue from the Way Offices, and no sort of control over them was even attempted.

The House of Assembly was in the habit of establishing post routes, and of voting increases in the salaries of existing couriers, the resulting expense of which was to be paid by the Post Office. The action of the Legislature was often taken on the presentation of memorials from persons interested, or on the initiative of a member specially interested 
in Post Office matters with some axe to grind. The Legislature would vote, say, $£ 10$ or $£ 20$, for a courier to some remote place, for which the number of letters was negligible -perhaps a dozen in a year, perhaps two a week and a few newspapers. The resolution of the House would then be forwarded to the Postmaster-General, who by virtue of his delegated authority established the route, the cost over and above the amount voted by the House being drawn from Post Office funds. The whole system was permeated with jobbery, and the House used to become more than usually active in these matters as the elections approached. In Cape Breton, in 1841, the expenses of the couriers amounted to some $£ 604$, and the revenue, after deducting the commission of the three postmasters in the island, was some £308-the explanation being that the member for the island was one of the leaders in Post Office matters in the Legislature.

Internal correspondence was at this time literally nonexistent, many of the couriers conveying only newspapers (which in general went free), and fee letters (that is, letters charged only with the Way Office keeper's fee, and no postage). Except in five towns (Halifax, Yarmouth, and Picton in Nova Scotia ; and St. John and Fredericton in New Brunswick) there was no provision for the delivery of letters except at the post office window. In those towns, delivery was made in the first instance at the post office, but all letters which were not called for within a short time after the arrival of the mail, were sent out for delivery throughout the town by letter carrier. An additional charge of 1d. per letter was made by the carrier, and retained by him as his remuneration. In some cases 1d. was charged also for the delivery of newspapers ; in others this penny was charged only where the receivers could be induced to pay ; and in some cases newspapers were delivered free. At Halifax two letter carriers were employed, and their total weekly earnings were estimated at $£ 410$ s., indicating 1,080 as, approximately, the weekly number of letters and newspapers received. At Fredericton a charge of 1d. was made on letters and on newspapers, but the amount was taken by the postmaster, who paid a weekly wage to the carrier. The postmaster estimated his annual receipt at about $£ 1910$ s., corresponding with a weekly 
average of 90 letters and newspapers delivered in Fredericton. He paid the carrier $\$ 1410$ s. per annum.

Up to 1827 there were no internal posts in Prince Edward Island. The only post office in the province was at Charlottetown. In 1827 the Legislature resolved to establish an inland service, and appointed couriers to travel weekly for the conveyance of letters. Way Office keepers were also nominated at various places. A uniform rate of $2 d$. for single letters, and $\frac{1}{2} \mathrm{~d}$. for newspapers published in the island, was fixed for transmission within the island, and, in consideration of the whole expense being borne by the Provincial Treasury, the Deputy Postmaster-General of Nova Scotia and New Brunswick agreed to the retention by the province of the net revenue. The Way Office keepers received as their remuneration 20 per cent. on the postage collected, with the privilege of franking for transmission within the island. The province made a small grant, at first $£ 20$ per annum and later $£ 30$, in aid of the administration of the posts.

The first wish of the Home authorities was to bring the expenditure within the revenue, and after he had been in the colony some two months $\mathrm{Mr}$. Page submitted a scheme which should remove the deficit in Nova Scotia, then over $£ 1,000$ a year. ${ }^{x}$ This scheme, which was not lacking in boldness, proposed the discontinuance of no less than twentyfour couriers, and reduction of the frequency of the mail in two other cases, involving towns of some importance.

On the 6th July 1843 the Post Office of New Brunswick was separated from that of Nova Scotia and a large number of services abolished. Following on these drastic measures, the New Brunswick Legislature, in 1844, adopted a joint Address to his Majesty, praying for redress. They asked for a reduction of letter rates, for the abolition of newspaper rates, and for the application of all surplus revenue to the extension of facilities for inter-provincial communication, adding that in consideration of the introduction of these changes the Legislature would guarantee to provide such sums as might from time to time be necessary to defray the expenses of the department. The reply of the Colonial Office was that the prayer of the petition could not be granted, since other

3 W. J. Page, Report of 1st October 1842 (British Official Records). 
provinees were involved; but that, so long as the province guaranteed the charges, the proposal as regards newspapers, taken by itself, was unobjectionable.

The Home authorities, seeing that in Nova Scotia and New Brunswick the service still showed a deficit year by year, remained indisposed to introduce reduced rates; but when Lord Clanricarde was appointed Postmaster-General there was a change of policy. Lord Clanricarde came to the conclusion that the time was ripe for a reduction of rates in British North America, although he was convinced that such a reduction would entail heavy postal deficits in all the provinces. It would be for the provincial Legislatures to make good these deficits, and he concluded it was therefore expedient that the full control of the service should be handed over to the provincial authorities, subject to certain conditions imposed with the view of preventing friction between the provinces over the transit across the sea-board provinces of mails for or from the interior.

Lord Elgin, Secretary of State for the Colonies, suggested to the Governor-General ${ }^{x}$ that one or two members of the Executive Councils of Canada, Nova Scotia, New Brunswick, and Prince Edward Island should meet at Montreal to discuss the question and mature a plan, which could be submitted to the respective Legislatures, for the assumption by the provinces of the administration of the Post Office. A conference was arranged, and a plan for the establishment of a uniform system throughout the British North American Colonies elaborated.

The conference made clear that in the repeated remonstrances against the "transfer of assumed surplus receipts" to the revenue of the British office there was no desire on the part of the provinces to make the Post Office a source of revenue, or, indeed, to call into question the prudent management of the Imperial Government; but that the remonstrances were prompted by a growing conviction of the great importance of an efficient postal system as a factor in their social and commercial welfare, and as "a means in a new country of extending civilization." The provinces were impressed by the great social and moral benefits which

x Despatch of 28th August 1847. 
had followed the introduction of cheap postage in the Mother Country, and were anxious to extend to their own land the benefits of the system, which had already been introduced by their great neighbour. The delegates were satisfied that the most suitable rate would be $3 \mathrm{~d}$. the half ounce, uniform, irrespective of distance; but, thinking it likely that some of the provinces might be unwilling entirely to disregard distance, they recommended that an option be suggested for any province that wished so to do to charge double rates for distances greater than 300 miles. They recommended the establishment throughout British North America of a uniform system and rate of postage, with as little local modification as the circumstances of the various provinces might demand. But for two main reasons they were opposed to a common administration: (1) they considered that the control by each province of its postal establishment would be a powerful aid to economy in administration, would prevent imprudent extensions of postal accommodation, and would prevent also any feeling of jealousy between the provinces with regard to the application of the funds of the establishment to the extension of services in the respective provinces; (2) they thought the various provinces would be more likely to accept a system under local control, each province defraying the entire cost of its service, and retaining all postage collected within its limits, whether prepaid or post-paid. ${ }^{1}$

The Home authorities accepted the recommendations of the conference, subject to a few slight modifications in nonessentials, and an Act, passed in 1849, authorized provincial Legislatures to establish posts within their respective territories, but gave them no authority over the posts between the colonies and places abroad. ${ }^{2}$

The transfer of the Post Office systems to the provincial Governments was accomplished in 1851.

Delegates from all the colonies met to consider the arrangements to be made for conducting the office under the new conditions. With the example of England before them, as before the world, the delegates were anxious for a uniform rate, and for a low uniform rate. They realized, however,

' Report of a Committee of the Executive Council of Canada on the Post Office, 10th June 1848.

212 \& 13 Vict., cap. 66. 
that conditions vastly different from those prevailing in England prevailed in British North America. With their great distances and their thinly settled districts, with the rigours of the American climate and the generally poor state of the roads, it could not be anticipated that rates which had been found successful in England, with its comparatively small area and dense population, with its less difficult climate and its better facilities for intercommunication, would prove equally successful. In the end a compromise was adopted-uniformity of rate, but a rate moderately high, viz. 5 cents. ${ }^{\mathrm{I}}$

A period of great development ensued, especially in the Maritime Provinces. Under the stimulus of the reduction of the rate to the new uniform charge of 5 cents per $\frac{1}{2}$ ounce, in place of a charge graduated by distance which had averaged over $8 \mathrm{~d}$. a letter, the number of letters increased so rapidly that in four years the gross revenue had recovered its former level.2 But in both Nova Scotia and New Brunswick the account regularly showed a heavy deficit, in partial explanation of which there was the fact that both Governments carried newspapers in the mails free of charge. In Canada, with a larger number of commercial communities, the results were somewhat better. But even there the accounts showed a deficit until 1859. From that year there was an annual surplus until 1865, when the heavy charges for conveyance of the mails by railway began to tell.

These conditions continued until the confederation of the British North American Colonies in 1867. The control of the Post Office was within the powers assigned to the new Dominion Government. The Government was desirous of not falling behind other countries in the provision of Post Office services, and it was necessary for political reasons to take advantage of every available means for facilitating intercommunication between the different parts of the Dominion. Shortly after confederation, therefore, a Bill to establish and regulate a Federal Dominion Post Office was brought before the Dominion Parliament.

A reduction of the letter rate of postage from 5 cents to

- Correspondence on the Subject of the Establishment of a General Post Office System in British North America, Montreal, 27th February 1849.

$=$ In $1851, \$ 362,065$; in $1852, \$ 230,629$; in $1855, \$ 368,166$. 
3 cents per $\frac{1}{2}$ ounce was proposed, and a rate of postage on newspapers. In some of the provinces newspapers had previously been carried by the posts free of charge; and the establishment of a rate of postage for them was to some extent bound up with the reduction of the letter rate, since with the lower rate for letters the free transmission of newspapers would have proved so great a strain on the revenue, that either the Government would have been compelled to make larger grants in aid, or services would have to be withheld in districts where it was desirable they should be provided. Some members were disposed to think the better course would have been to retain the old rate for letters and to allow newspapers to pass free, as had long been the practice in the Lower Provinces; and the imposition of a rate on newspapers was characterized as a tax on the dissemination of public intelligence and a retrogressive step towards old and exploded abuses. ${ }^{\mathrm{I}}$

Other members desired to follow the English example and reduce the letter rate to 2 cents, the equivalent of a penny; but this was deemed impracticable on account of the different conditions under which the Post Office was conducted in Canada, where the mails were carried very long distances through a sparse population.2 In the United States, where the circumstances were more nearly comparable, the rate was still 3 cents. With a rate of 3 cents in Canada, as proposed, it was anticipated that there would be a considerable deficit, but that the deficit would soon disappear.3 It was alleged that there was no demand for a reduction and that everybody was willing to pay 5 cents; but the real objection was not to a reduction in the letter rate per se. The objection arose from the assumption, fairly well grounded, that the reduction was only possible if accompanied by the establishment of a postage on newspapers, to which a number of

s "He would, were it necessary for the revenue, prefer to retain the existing letter rate than to extend through the Dominion this newspaper impost, unknown in the Maritime Provinces before."-Hon. Dr. Tupper, Parl. Debates (Canada), House of Commons, 20th December 1867.

= Hon. Mr. Campbell, Ibid., Senate, 3rd December 1867.

3 "The Postal service should be expected to yield a revenue; but the service should be performed as low as possible, and if it paid its way that was all that need be desired."-Hon. Mr. Campbell, Ibid. 
members were strongly opposed. The rate of 3 cents for $\frac{1}{2}$-ounce letters was, however, adopted. In three years the yield of postage at 3 cents surpassed the former yield at 5 cents. ${ }^{x}$

In 1898 a Bill for modifying rates of postage was introduced. The main propositions of the Bill were (1) to reduce the letter rate to 2 cents per ounce, and (2) to impose a postage on newspapers. Since 1867 there had been several changes in newspaper postage, and for about nineteen years newspapers had been passing through the post in Canada free of any charge for postage. ${ }^{2}$ The postal service was at this time being carried on at some loss to the general Dominion revenue, and, as in 1867, the proposal to charge postage on newspapers was made to counterbalance any loss of revenue which might result from the reduction in the letter rate of postage. It was hoped that with this counterbalance any such loss would soon be made good, and that, indeed, the Post Office would become a self-sustaining department.3

The arguments in Parliament were almost identical with those of 1867, when the previous similar proposals as regards the letter and newspaper rates were before it. Stress was, however, now laid on the contention that letter-writing was the pursuit of the wealthy, and of business and commercial men, who were well able to pay for their correspondence, while the newspapers were sent mainly to the farmers of the country, who wrote few letters. The Government were proposing at this time to raise a million dollars by a tax on sugar, a course denounced as an imposition by the Government on the poorer classes, to whom sugar is a necessity, while the reduction of postage would present the wealthier classes with some $\$ 650,000$ a year. 4

The reduction was carried, and the 2-cent rate has proved successful. The gross revenue recovered within four years. 5 The number of letters has largely increased, especially in

The revenue in 1868 was $\$ 1,024,702$, and in $1871, \$ 1,079,768$. In 1889 the rate was made 3 cents per ounce.

2 See infra, p. 143.

3 Sir W. Mulock, Parl. Debates (Canada), House of Commons, 1st April 1898 (Official Reports, vol. xlvi.).

4 Sir Charles Tupper, Ibid., 13th May 1898.

5 In $1898, \$ 3,527,810$ : in $1902, \$ 3,888,126$. 
recent years, largely, no doubt, in consequence of the growing commercial prosperity. The total number, which in 1876 was some 41 millions, had in 1913 increased to 633 millions. The financial result has also proved satisfactory. The Post Office service in Canada as a whole in 1913 showed a profit of some $\$ 1,200,000$, and there is no doubt that the greater part of this profit was derived from letters.

Note.-In 1915 a war-tax of $\frac{1}{2} \mathrm{~d}$. was imposed on all letters and postcards. On the assumption that the numbers posted would not be appreciably diminished, the increase of revenue was estimated at $\$ 6,000,000$ a year, and this estimate has been realized. 


\section{LE'T'TER POS'T IN THE UNITED S'TATES OF AMERICA}

ThE New England colonies had not been long established when the public authorities first took cognizance of the arrangements for the distribution of letters. In 1639 the general court of the Massachusetts Bay colony made an order for the establishment of a service in respect of letters for or from places abroad. A house-to-house delivery of letters received from abroad at the low uniform rate of $1 \mathrm{~d}$. would seem to have been contemplated. ${ }^{\mathrm{I}}$ At various intervals during the latter half of the century, Post Offices were established in most of the other colonies-in Virginia in 1657, in New York in 1672, in Connecticut in 1674, in Philadelphia in 1683, and in New Hampshire in 1693.2 These Post Offices were set up in the various colonies by legal enactment, but they were in general local and municipal in character. In the circumstances of the case they could at that time hardly have been otherwise. The colonies were independent of 'each other in administrative matters, and seldom acted together for any purpose. The population relatively to the extent of the colonies was extremely small, the settlements were scattered, and the roads were mere trails. 3 In general there was very little intercourse between the various colonies. Such

" It is ordered that notice be given that Richard Fairbanks his house in Boston is the place appointed for all letters which are brought from beyond the seas or are to be sent thither to be left with him, and he is to take care that they are to be delivered or sent according to the directions; and he is allowed for every letter a penny, and must answer all miscarriages through his own negligence in this kind."

- Stanley I. Slack, A Brief History of the Postal Service, Omaha.

3 M. E. Woolley, Early History of the Colonial Post Office, Providence, R.I., 1894, p. 6. 
intercommunication as was carried on usually went by means of coastwise vessels or by occasional travellers. The one exception was a post route from New York to Boston, established in 1672 to go monthly. The system established in Virginia in 1657 was of a primitive character, being merely a requirement that every planter should furnish a messenger to convey the mail to the next plantation, under penalty of forfeiting a hogshead of tobacco in default.

In 1688, by an Order in Council, the establishment of a Post Office in Jamaica, and such other of his Majesty's plantations in America "as shall be found convenient," was authorized. On the 17th February 1692 the Crown granted a patent to Thomas Neale (then Master of the Mint) vesting in him the American post, with full power and authority to erect post offices in the chief parts of the American colonies "for the receiving and despatching of letters and pacquets, and to receive, send, and deliver the same under such rates and sums of money as the planters shall agree to give." It was no light matter to obtain the acquiescence of all the colonies in the exercise of general rights as regards the Post Office in North America, especially as they had previously been free to make their own arrangements in this respect. Neale was himself never in North America, but his deputy there, Andrew Hamilton, who was a very capable man, was able not only to secure the acceptance by the colonies of a general postal system under Neale's patent, but to obtain from some of them small grants in aid.

Most of the colonies passed Acts authorizing the establishment of Post Offices under the provisions of the patent; and the principle of postal monopoly was introduced in these enactments. ${ }^{x}$ The General Assembly of Virginia authorized a Post Office in the colony, believing such an office to be of "generall concernement and of great advantage for the increase and preservation of trade and commerce therein, for

- New York, in 1692, enacted that any persons or body politic or corporate other than the Postmaster-General presuming to " carry, re-carry, or deliver letters for hire, or to set up or imploy any foot-post, horse-post, or pacquet-boat whatsoever" for the carrying of letters or packets sbould forfeit $£ 100$; and the Act of New Hampshire, passed in 1693, provided that no person or persons whatsoever should carry letters for hire, "except letters sent by private friend or by any messenger for or concerning the private affaires of any person." 
thereby speedy and safe despatch may be had." I The rates of postage were as follows:-

$\begin{array}{lll}\begin{array}{l}\text { Every letter } \\ \text { not exceeding } \\ \text { one sheet }\end{array} & \begin{array}{l}\text { For distance not } \\ \text { excecding } 80 \\ \text { English miles }\end{array} & 3 \mathrm{~d} . \\ \begin{array}{l}\text { Ditto two sheets } \\ \begin{array}{l}\text { Every pacquet } \\ \text { of writs and } \\ \text { deeds }\end{array}\end{array} & , & 6 \mathrm{~d} . \\ \begin{array}{l}\text { Every letter } \\ \text { not exceeding } \\ \text { one sheet }\end{array} & \begin{array}{l}\text { Above distance } \\ \text { of } 80 \text { English } \\ \text { miles }\end{array} & \begin{array}{l}\text { 12d. per ounce } \\ \text { weight. }\end{array} \\ \begin{array}{l}\text { Ditto two sheets } \\ \begin{array}{l}\text { Every pacquet } \\ \text { of writs and } \\ \text { deeds }\end{array}\end{array} & , " & 4 \frac{1}{2} \mathrm{~d} . \\ \end{array}$

The rates established in the other colonies were similar but not identical.

The new postal service under the authority of the patent was commenced on the 1st May 1693. A post was set up from Portsmouth, New Hampshire, to Boston, Saybrook, New York, Philadelphia, Maryland, and Virginia. Five stages were fixed, and a rider was appointed to each stage. In summer the service was performed weekly, and in winter fortnightly. At the commencement, as may be readily understood, the conditions were somewhat difficult. ${ }^{2}$ But with the growth of population and commerce, conditions improved. The service to the South was for many years subject to general irregularity and temporary suspension, especially at times of flood.

The Post Office in America has from its first establishment as a general system, as distinguished from the merely local or municipal posts, had to reckon with two factors which have been of great importance in relation to all the main services-a vast extent of territory and a sparse population. The rates were higher than those in operation in England,

3 Preamble of Act (1st April 1693).

" "The mail carriers rode through the wilderness in this year of the beginning." - Stanley I. Slack, A Brief History of the Postal Service, Omaha, p. 11, 
but at first, and for many years, the revenue was insufficient to defray the expenses. The finance of the American Post Office consequently differed fundamentally from that of the English office.

Neale was required by the terms of his patent to render an account at the end of three years of the receipts and expenditures of the American post. His first account was not, however, rendered until 1698. It showed that the expenses up to May 1697 were $£ 3,817$, and the receipts $£ 1,457$, there being thus a loss of $£ 2,360$. The account was accompanied by a statement prepared by Hamilton, explaining the great advantages to the trade and commerce of the colonies, as well as to their security, which the Post Office provided; showing how necessary in consequence was the continuance of the office, and recommending that definite rates of postage for the whole territory be fixed by statute. Other regulations for the conduct of the system were also suggested, as the existing arrangement, involving such serious loss to the patentee, could not be continued indefinitely. Neale contented himself with a brief remark to the effect that whenever his Majesty should see fit to take the conduct of the posts into his own hands, he (Neale) would be glad to surrender his patent-of course, for a consideration. ${ }^{\mathrm{I}}$

The Postmasters-General opposed the suggested increase of rates on general grounds, their experience having taught them that " the easy and cheap corresponding doth encourage people to write letters, and that this revenue was but little in proportion to what it is now, till the postage of letters was reduced from sixpence to threepence."

Neale died shortly afterwards, and his rights in the patent were transferred to his creditors, who were Hamilton himself and an Englishman named West. Hamilton died in 1703, and his widow carried on the posts for some two or three years. In 1706 she and West endeavoured to obtain an extension of the term of the patent; so that, although the posts had been conducted for some years at heavy loss, both by Hamilton and by his widow, the conditions had improved, and there was now reasonable anticipation of a profit from the office. The view of the Postmasters-General, however, 
ultimately prevailed, and in 1707 the patent was bought back for the Crown for the sum of $£ 1,664$. When, a few years later, a general Act of Parliament was found necessary, the opportunity was taken to place the American posts on a definite statutory footing. ${ }^{\mathrm{I}}$

The preamble recites that posts had at great charges been established on the mainland of North America through most of her Majesty's plantations and colonies, and the PostmastersGeneral were authorized to establish a "Chief Letter Office" in New York, and other chief offices at some convenient place or places in each of the colonies in America, and to appoint deputies for the " better managing, ordering, collecting, and improving the Revenue" granted by the Act. Rates for the transmission of letters between England and America were fixed, and detailed rates for transmission between specific towns within the North American colonies. The rates between London and America were 1s. for a single letter, 2s. for a double letter, and so on. For transmission within the colonies the rates were, broadly, for distances under 60 miles, $4 \mathrm{~d}$. the single letter, $8 \mathrm{~d}$. the double letter, and so on; distances under 100 miles, for a single letter $6 \mathrm{~d}$., and so in proportion for double and treble and ounce letters.

These rates were, in general, higher than those which had been fixed by the colonies under the Neale patent, but for several years they did not produce sufficient revenue to meet expenses. In 1722 the Postmasters-General were for the first time able to say that in the future the Post Office in North America, even if it yielded no net revenue, would no longer involve a charge, and there was a good prospect of a profit. The Act of 1765 provided rates for the longer distances and made a general reduction of nearly 30 per cent. The rates now became, for a single letter, for conveyance for any distance not exceeding 60 miles, $4 \mathrm{~d}$.; from 60 to 100 miles, $6 \mathrm{~d}$.; from 100 to 200 miles, $8 \mathrm{~d}$.; for each additional 100 miles, $2 \mathrm{d.}^{2}$ In the intervening period the chief events had been the appointment of Benjamin Franklin, in 1737, to be Postmaster of Philadelphia, and in 1753, to be joint Postmaster-General for

"An Act for establishing a General Post Office for all her Majesty's Dominions" (9 Anne, cap. 10).

$=5$ Geo. III, cap. 25. See supra, pp. 38-9. 
British North America, and the acquisition of Canada in 1763. The latter event had, indeed, been one of the reasons assigned for the passing of the Act of $1765 .^{\mathrm{I}}$

Under Andrew Hamilton the posts had run only along the coast, the great main route extending from Portsmouth, N.H., through Boston and New York to Maryland and Virginia. Under his son, John Hamilton, who succeeded him in the office, the posts were pushed inland as occasion offered or circumstances demanded, and for these extensions John Hamilton adopted the principle of establishing routes in those cases where the postage was sufficient to maintain them. On such a basis the system could not, however, be very largely developed. The circumstances of the country made any great extension impossible, and in 1766 the posts still went mainly along the sea coasts. ${ }^{2}$

Franklin was dismissed in 1774 . The Crown Post Office was continued in North America, but about this time a competing system arose. For some years there had been friction in the colonies between the authorities and the publishers of newspapers. The anomalous English system of the distribution of newspapers free by post by certain favoured individuals had been introduced in America. The favoured officials were the American Postmasters-General, and for that reason the office was much sought after by publishers. Both Franklin and Hunter, who were joint Postmasters-General (Franklin from 1753 to 1774, and Hunter

Cf. supra, p. 38.

$=$ Evidence of Benjamin Franklin before House of Commons Committee, 28th January 1766. The Committee were, of course, most anxious on points having relation to the taxation of the colonies by the English Parliament, and Dr. Franklin was asked questions directed to discovering whether the colonists regarded postage, which was fixed by Act of the British Parliament, and had been newly fixed by such Act in the previous year (5 Geo. III, cap. 25), as a tax. On this point Dr. Franklin emphatically held that the postage paid on a letter was not of the nature of a tax, but that it was simply payment for service performed; and, moreover, the payment of postage was not compulsory, since a man might still, as before the passing of the Act, send his letter by a servant, a special messenger, or a friend, if he thought it cheaper or safer. Dr. Franklin said that every Assembly encouraged the Post Office in its infancy by grants of money; that they would not have done this if they had thought the postage charge a tax, and as a matter of fact the system was always regarded as supplying a great convenience (W. Cobbett, Parliamentary History of England, vol. xvi. cols. 137-160). 
from 1753 to his death in 1761), were printers, and Franklin's dismissal is sometimes attributed to a desire on the part of the British Government to hamper the distribution of his publications, and so restrict their influence. Great efforts were at this time made by the Crown authorities in America to prevent the dissemination of ideas contrary to the British ascendancy. As early as 1757 the Governor of Pennsylvania endeavoured to prevent the publication of improper intelligence in newspapers, and suggested that special instructions should be given to the Postmasters-General. The feeling against the newspapers grew with the developments of the years that followed, and by 1774 much trouble was being caused by the Crown Postmasters to the publishers of newspapers. Many were toning down their comments in order to retain the privilege of free transmission, but some began to look for other means of distributing their papers. William Goddard of Baltimore, publisher of the Maryland Journal, suggested the establishment of "an American Post Office on constitutional principles," and visited various colonies in the early part of the year 1774 with the object of enlisting support for his project. He received a good measure of approval, and on the 30th April 1774 subscriptions were invited from the public towards the establishment of an American Post Office. The scheme of this Post Office was that subscriptions should be invited for its establishment and maintenance, and "for the necessary defence of post officers and riders employed in the same" ; and that the subscribers in each colony should appoint a committee from among themselves, whose business should be to appoint postmasters at places where offices had hitherto been kept or might be judged necessary, "and to regulate the postage of letters and packets, with the terms on which newspapers are to be carried." I

Meantime the committees of safety and the Assemblies of the various colonies made certain provision for the transmission of mails, both within and between the colonies. In

- Manifesto to the American People, issued by Goddard, 2nd July 1774. Earlier in the manifesto it was remarked that " newspapers, those necessary and mportant alarms in time of public danger, may be rendered of little consequence ifor want of circulation." 
May 1775 the New York Committee appointed a sub-committee to inquire of the postmaster, Mr. Foxcroft, the reason for the recent discharge by him of the post riders. The postmaster's explanation was that the last four mails between New York and Boston had been held up and violated on the journey, and he had discharged the post riders on the ground that it was no longer safe to send them with mails. The committee thereupon themselves immediately arranged for the despatch of mails from New York, and a few days later issued a notice "to acquaint the publick that a constitutional Post Office is now rising on the ruins of the parliamentary one."

In the course of the next few months several provincial congresses passed resolutions establishing Post Offices in the respective colonies. Massachusetts fixed rates of postage at $5 \frac{1}{4} \mathrm{~d}$. for a single letter for not more than 60 miles, and increased rates for greater distances. The whole matter was at the same time under the consideration of the Continental Congress sitting at Philadelphia. Goddard had, from the first establishment of the constitutional Post Office, expected Congress to assume control. ${ }^{x}$ In May, Congress appointed a committee to consider the matter, and on the 26th July, having received the committee's report, agreed to resolutions providing for the establishment of a Post Office. Benjamin Franklin, who had been a member of the committee, was unanimously chosen to be the first Postmaster-General. It was provided that the remuneration of the deputies should, in general, be 20 per cent. on the sums they collected, the rate which had usually been paid under the parliamentary system. $^{2}$ Postage of letters was to be 20 per cent. less than those appointed by Act of Parliament. It was feared that such rates would prove too low, and the proceeds of the office be insufficient to support the necessary riders; and as people were in general well satisfied with the rates lately paid, or at least had made no complaints regarding them, the lowering of the rates was deferred. 3

" "It is not to be doubted but that the institution will be properly regulated by the Continental Congress."--Manifesto to the American People, 8th May 1774.

2 Journals of the Continental Congress, 1774-1789, pub. Washington, 1904, vol. ii. p. 208.

3 Resolution of 30th September 1775. Ibid., vol. iii. p. 267. 
The parliamentary post continued for some years, concurrently with the constitutional post, as the new independent Post Office was called. On the 7th October 1775 a debate arose in Congress as to the expediency of stopping the "parliamentáry or ministerial posts." The stopping of the post was desired chiefly as a means for hindering the correspondence of their enemies. Inaction in the matter was advocated by some who professed to find the royal post of great convenience; and by others who, although desirous of seeing the parliamentary post stopped, thought it unnecessary to take active measures against it, since it would soon cease in any case.

On Christmas Day, 1775, the Secretary to the Post Office in New York issued a notification to the public that, in consequence of the decision of a provincial convention at Annapolis not to permit the parliamentary post to travel through the province, that mail would be discontinued, and the letters held at New York at the disposal of the persons to whom they were addressed. The parliamentary post did not, however, altogether die. As late as 1779 the Secretary in London wrote to the Deputy-General at New York that the Postmasters-General were glad to find that a number of letters were being brought to the Post Office to be delivered, and as they hoped that method would be continued, the deputy would, no doubt, soon have sufficient funds to pay the expenses of the establishment. But in 1780 the Postmasters-General were concerned to find that the whole postage would not defray the cost of management, a circumstance attributed to the fact that the mails were often seized on arrival and carried first to the headquarters of the Army. In consequence of this, a great part of the letters were never delivered at all. Very little postage could be collected, and the PostmastersGeneral addressed strong representations to Lord George Germain, his Majesty's principal Secretary of State. ${ }^{\mathrm{I}}$

In 1776, in view of the great necessity, for the safety of the colonies, that means should be provided for the frequent and rapid transmission of intelligence, further dispositions with regard to the posts were made by the Congress. Riders were appointed for every twenty-five or thirty miles

s British Official Records, 6th December 1780. 
on the several post roads. They were required to proceed through their respective stages three times a week. They were to set out immediately on the receipt of the mail and were to travel " by night and by day, without stopping," until they had delivered the mail to the next rider. It was found that the revenue produced by the existing rates of postage fell far short of the expenses, and on the 17th October 1777 the rates were raised by 50 per cent. The difficulties of the administration continued, and various committees of inquiry were appointed. In April 1779 one of these committees recommended the doubling of the rates, a course which met with approval from patriotic Americans. ${ }^{\text {I }}$

Even this increase was not sufficient. In October of that year there was a balance of $£ 37518 \mathrm{~s}$. 6d. due to the Postmaster-General, and arrears of $\$ 17,666$ 1s. $3 \mathrm{~d}$. to the post riders. For the discharge of these liabilities and for the continuance of the functions of the office a draft on the Treasurer was authorized. In December 1779 a further grant was found to be absolutely necessary in order to maintain the service, and the sum of $\$ 30,000$ was voted. 2 The establishment of express riders which had been maintained in conjunction with the postal service was at the same time abolished, and the rates of postage raised 20 per cent. on those paid in 1775. But the cost still outran the revenue, and in May 1780 sums amounting to $\$ 100,000$ were voted in aid of the service. The finances of the posts became involved in further difficulties through the general depreciation of money, and Congress found it necessary in December 1780 to make good the depreciation on the pay of post riders, and to raise their nominal pay to double the sum received before the war. 3

2 "The officers of the American Army beg leave to inform their friends and correspondents that the postage of all letters to and from the Army is doubled: but as their pay is fully adequate to every expense, they therefore request them to send all letters by the public post, and not through any oconomical view by a private conveyance.

"Tis a pity that the Honourable Congress did not treble the postage for Officers' letters, as a large annual sum by this means would be put into the public Treasury.

"The several printers of newspapers on the Continent are requested to insert the above."-Pennsylvania Packet, 22nd June 1779.

2 In all, no less a sum than $\$ 111,967$ was advanced to the Post Office during the year 1779.--Journals of the Continental Congress, 1774-1789, pub. Washington, 1904, vol. xv. pp. 1412 and 1436.

3 Ibid., vol, xviii. p. 1142. 
Several minor changes of the rates of postage were made in this period. In December 1780 the Congress fixed the rates on letters at half the rates paid at the commencement of the war: and in October 1781 at the actual rates charged at the commencement of the war. But, whatever the rates, during the war they never produced. sufficient revenue to meet expenses, and the controlling factor in the administration of the service was the necessity for a means of circulating the earliest intelligence of the movements of the enemy, and of their ally, in order to make the best disposition of their own forces.

By the Articles of Confederation Congress was vested with the sole and exclusive rights and power of establishing a Post Office for the United States; and, deeming "the communication of intelligence with regularity and despatch from one part to another of the United States essentially requisite to the safety as well as the commercial interest thereof," in 1782 revised all the regulations made theretofore in respect of the Post Office, and reduced them to one Act. The Postmaster-General was required to cause the mail to be carried with all care and despatch at least once in every week to and from each of the stated post offices, and was given a monopoly of "letters, packets, or other despatches." Postmasters were to be paid such commission as the PostmasterGeneral might think their services merited, not exceeding 20 per cent. of the postage collected by them. Rates of postage on single letters were fixed as follows:-

\section{Distance.}

Rate. ${ }^{x}$

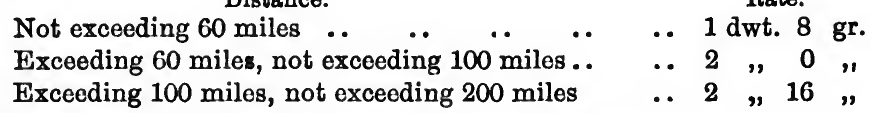
And so on, advancing 16 grains for every hundred miles.

For all letters for or from Europe by packet or despatch vessels, the charge was $4 \mathrm{dwt}$. The rates were doubled for double letters; trebled for treble letters; and a packet weighing an ounce was charged equal to four single letters, and in that proportion if a greater weight. In the event of a surplus of Post Office revenue over expenses, the Postmaster-

The rates were given in pennyweights and grains of silver, each pennyweight being estimated as equivalent to five-ninetieths of a dollar. 
General was required to pay the amount to the Treasurer of the United States " until the sums of money heretofore advanced by the United States for the support of the General Post Office, with the interest thereon at 6 per cent. per annum," should be repaid, after which any such surplus was to be devoted to the establishment of new post offices or other improvements of the service. If the necessary expenses were found to exceed the revenue, the excess was to be paid to the Postmaster-General by the Treasurer of the United States. ${ }^{I}$ Cross posts were farmed in much the same way as the cross posts and bye posts had been farmed in England, ${ }^{2}$ and the farmers were bound by contract not to charge rates in excess of those fixed by the ordinance. 3

After the adoption of the Constitution an Act of the Constitutional Congress became necessary. The President, in recommending to Congress the provision of the Post Office and post roads on a liberal and comprehensive scale, referred to the political importance of such a service as aiding the diffusion of a knowledge of the laws and proceedings of the Government, 4 a consideration which was paramount in determining the attitude of the United States Government towards the posts. It was held to be a first duty of the Government to afford every possible means for the dissemination of intelligence-general intelligence for the information and education of the people, and more especially political intelligence for the education of the people as citizens of the Republic. They were making, it was their legitimate boast, a tremendous experiment in politics. They were essaying to demonstrate to the world whether a people had the genius to govern itself, whether democracy and the republic were abstract political ideas only, or whether they could be made actual living things. The English Commonwealth had failed. The French Revolution had come after their own and was still in doubtful case. They could therefore neglect no means likely to strengthen the foundation of their own Republic, and in this view must consider seriously the question of providing effective means for the enlightenment

I Journals of Congress, Philadelphia, 1781-2, vol. vii. p. 509.

2 See pp. 12-14, supra.

3 Ibid., vol. xii. p. 11.

4 Message to Congress, 25th October 1791. 
of the sovereign people on all matters pertaining to the executive Government and the Legislature. ${ }^{\text {I }}$ In order to secure the dissemination of such intelligence members of Congress were given extensive powers of franking both letters and newspapers.

On the question of rates, opinion in Congress was divided. Although at the time the gross revenue of the Post Office was small, some members anticipated an increase sufficient to yield a net revenue, as in England and most other European countries; whilst others, with more wisdom, pointed out the vital difference in the case of America on account of "its great extent and uncultivated state, as well as from a thousand other causes." 2 The new rates were based on eight zones of distance. For distances under 30 miles the charge for single letters was 6 cents; for distances over 450 miles the charge was 25 cents; every double letter, double rates; every triple letter, triple rates; and every packet weighing 1 ounce avoirdupois, the rate of four single letters for each ounce.

The rates for letters fixed by the Act of 1792 continued some thirty years, except for slight modifications in $\mathbf{1 7 9 9}$ and 1816, and except for a brief period at the time of the war of 1812-14 with Great Britain. The Government then attempted to obtain an increased revenue from the Post Office, and the rates of postage were increased 50 per cent. The effect on the revenue and on the business of the country was, however, so disastrous that the increased rates were maintained only for about a year. 3

In 1825 the laws relating to the Post Office were codified. The codifying Act placed on the Postmaster-General the duty of establishing such post offices, and appointing such postmasters on the post roads as should appear to him expedient, and of providing for the carriage of the mail on all post roads that were or might be established by law, 4 with such frequency as he should think proper, "having

- See Debates and Proceedings in Congress, 20th December 1791. (Washington, 1849.)

2 Ibid., 6th December 1791.

3 See Congressional Record (House of Representatives), 21st February 1863.

4 Questions of the establishment and maintenance of the post roads were dealt with by Congress separately from questions of mail service. 
regard to the productiveness" of the routes, the means of the department, and other circumstances. Errors and irregularities crept into the service; but they were for the most part the result of "the representations and pressing solicitations of the citizens," sustained by members of Congress from almost every section of the country, of the extension of the franking privilege, of the desire of the head of the department "to extend the benefits of mail facilities and stage-coach accommodations to every portion of the community," and of legislation extending the transportation of the mail over unproductive routes. The deficits which resulted were not regarded altogether as an evil, because the public had greatly benefited by the measures which had produced them. ${ }^{I}$ Despite the solicitude of Congress the revenue failed to recover, and in 1837 and several succeeding years showed a deficit.

Sir Rowland Hill's pamphlet Post Office Reform: Its Importance and Practicability attracted attention in America, and as early as 1839 the question of applying the principle of uniformity of rate to the American service was under consideration. The rate proposed was not, however, 2 cents, the equivalent of a penny, but 5 cents. Sir Rowland Hill himself expressed the opinion that owing to the widely different circumstances penny postage might not be applicable to the United States, but that, as the American people did not look for a revenue from their Post Office, a low general rate might be feasible. ${ }^{2}$

Although a low and uniform rate was not immediately adopted, the example of Great Britain had great influence.3 There was considerable public agitation in favour of reduction of rates, and in many respects the circumstances resembled those obtaining in England before the reform. The high rates of postage led to constant and widespread evasion, advantage being taken of all available private means for the transmission of letters, and an association formed in New

- Reports of Senate Committee, 27th January 1835, p. 115.

$=$ Letter to Hon. Mr. Kennedy, Life of Sir Rowland Hill and History of Penny Postage, pp. 336-7.

3 See D. D. T. Leech, The Post Offioe Department of the United States of America; its History, Organization, and Working, Washington, D.C., 1879. 
York to work for the adoption of reduced postage held meetings in the large cities. In 1844 the finances of the department were in a more flourishing condition. For four years the service had been able to maintain itself. The state of the public Treasury had prevented any material change in previous years, but as difficulties under that head had ceased, the Government recommended the introduction of low ratesgradually, in order to prevent any serious dislocation of the finance of the department. ${ }^{x}$ A statute was accordingly passed which, while not introducing uniform postage, went a great way in that direction. There were to be only two distance charges, viz. for distances not exceeding 300 miles, or greater than 300 miles, respectively. The new rate for ordinary letters was 5 cents for distances not exceeding 300 miles, and 10 cents for any greater distance. This statute also introduced the principle of charge by weight instead of by sheets, the halfounce being taken as the unit weight. ${ }^{2}$

Message to Congress, 3rd December 1844.

2 Some notion of the spirit in which the question was approached may be gathered from the following extracts:-

"To content the man dwelling more remote from town with his homely lot, by giving him regular and frequent means of intercommunication : to assure to the emigrant, who plants his new home on the skirts of the distant wilderness or prairie, that he is not forever severed from the kindred and society that still share his interest and love: to prevent those whom the swelling tide of population is constantly pressing to the outer verge of civilization from being surrendered to surrounding influences and sinking into the hunter or savage state: to render the citizen, how far soever from the seat of his Government, worthy, by proper knowledge and intelligence, of his important privileges as a sovereign constituent of the Government : to diffuse, throughout all parts of the land, enlightenment, social improvement, and national affinities, elevating our people in the scale of civilization, and binding them together in patriotic affection."-Report of House Committee, 15th May 1844.

"It [the Post Office] was a most important element in the hand of civilization, especially of a republican people. There would be room to dilate in reference to the utility of the diffusion of sciences, the promotion of morals, and all these great benefits resulting from the intercourse of mind and mind. . . . Because it was so well understood by those who framed the Constitution, we find in that sacred instrument that the power of this department of the public service is exclusively vested in Congress. . . . Every nook and corner of this country should be visited by its operations, that it should shed light and information to the remote frontier settler as well as to the inhabitant of the populous city or densely populated districts."-Mr. Merrick in the Senate when introducing the Bill, 27th January 1815 (Congressional Globe).

"And what element but universal enlightenment of the people forms the chief corner-stone in the temple of our political hopes? and what instrument so 
The reduction resulted in so great a fall in the revenue that in the first year at the reduced rates there was a deficit of between one and two million dollars. In calling attention to this deficit, the President, in his Message to Congress, said that no principle had been more generally acquiesced in by the people than that the Post Office should sustain itself, but Congress had "never sought to make it a source of revenue except for a short period during the last war with Great Britain." At the same time the service should not become a charge on the general Treasury, and it would be necessary either to curtail the existing service or so to modify the Act of the previous March as to improve the revenue. As curtailment of service was out of the question, revision of the rates was recommended. ${ }^{\mathrm{I}}$

But the rates were not revised. Revision in an upward direction was, indeed, hardly feasible. The public agitation for low rates continued after the passing of the Act of 1845 . Many citizens were convinced that the system already adopted in England might be introduced in the United States. The benefits which had resulted in England in the way of commercial, social, and moral betterment were largely dwelt upon. The chief demand was for a uniform rate, which now meant simply the abolition of the increased charge for distances over 300 miles. There was, of course, Sir Rowland Hill's calculation in regard to cost of conveyance, which showed the futility of any attempt to make distance the basis of charge; and the further consideration that the actual cost of transit for each letter sent in a mail varies not in accordance with the distance travelled, but inversely as the number of letters contained in the mail. Moreover, it was not considered just that the letters of the people of the populous Eastern States should

calculated to awaken the ambition of the people to become educated as the cultivation of the taste for epistolatory correspondence, calling into action those energies of the mind so necessary to the intelligent discharge of the high and responsible duties of freemen, in a country where every man is equal, and the builder and maker of his Government."-Mr. Paterson in the House of Representatives, 1st March 1845 (Congressional Globe).

1 "The extension of the mail service and the additional facilities which will be demanded by the rapid extension and increase of population on our western frontier will not admit of such curtailment as will materially reduce the present expenditure."-Message to Congress, 2nd December 1815. 
be taxed in order to provide unremunerative mail services to the remote and newly settled Western States. ${ }^{x}$

Under the old high rates the revenue had not increased in proportion to the increase of population, but since the reduction of 1845 the increase was so much more rapid that even with the reduced rates the revenue was greater than ever before. The Government preferred rates of postage which were too low to rates which were too high, arguing that in the former case the great mass of the people would benefit, whilst in the latter case the benefits would extend only to a few. ${ }^{2}$ The need for some further reduction was well illustrated by the fact that the ordinary charge for transporting a barrel of flour from Detroit to Buffalo was at this time the same as the charge for carrying in the same conveyance a letter weighing half an ounce, viz. 10 cents.

In 1851 an Act reduced to 3 cents the rate of postage on letters not going over 300 miles, with a fourfold charge on Pacific mails, on account of the great expense incurred by the department. It was estimated that the expense of such mails was four times as great as in the case of ordinary mails, but the proposal met with opposition. 3

In 1863 mail matter was classified in three groups: (1) letters, (2) regular printed matter, (3) other miscellaneous matter. The charge for letters (first-class mail matter) was made 3 cents a half ounce irrespective of distance. The rate was reduced

" "The honour and interest of the nation required that as soon as the title to the country was settled, our citizens who were resident there, and those who shall go to settle there, should enjoy the benefits of the mail. And as it was the nation's business to establish the mail, it was equally the nation's business to pay the expense. No man can show how it is just and reasonable that the letters passing between Boston and New York should be taxed 150 per cent. to pay the expenses of a mail to Oregon on the pretext that the Post Office must support itself."-J. Leavitt, Cheap Postage, Boston, Mass., 1848, p. 27.

2 Mr. Root (Congressional Globe, House of Representatives, 18th December 1850).

3 "Sir, I am acquainted with the privations and hardships incident to the settlement of a new country : and I do not intend that my friends who are now combating the trials and hardships of California and Oregon shall be visited by their Government with such injustice. The men who are settling those countries are sacrificing their lives for a coming generation. I will not add to their hardships by taxing them four times as much as a citizen of the old States of the Union for a letter which shall give them intelligence of their friends left behind them, and shall chill that gush of feeling which will swell their bosoms, as they take possession of a letter that comes from their far-distant native land."Mr. Sweetser (Ibid., 4th January 1851). 
to 2 cents a half ounce in 1883 , in deference to the wish and determination of the public, supported by a very decided vote in Congress. It was anticipated that the revenue would not suffer severely, but that, as in the case of the earlier reductions, there would be an increase in the number of letters. It was also anticipated that many letters sent unsealed at 1 cent would be transferred to the sealed post, thus yielding an additional cent. The number of groups or classes of mail matter had been increased to four in 1879 , and the department was now asked to consider whether by rearranging the third and fourth class matter additional revenue could be obtained from such matter in order to diminish the deficiency resulting from the reduction of letter postage. The department was unable to suggest any method for achieving this object; but the contemplated reduction was not delayed. The condition of the Treasury was good, "there being money enough to meet any deficiency, even if it were as large as the maximum $(\$ 8,550,000)$," estimated on the basis of the number of letters then passing by post without allowance for any increase. ${ }^{\mathrm{I}}$ The actual loss of revenue consequent on the reduction was only $\$ 1,660,000$. A large stimulus was given to general correspondence, and, as anticipated, to the use of the sealed letter in place of postcards or unsealed circulars, whereby the department reaped considerable profit. In 1885 the allowance for weight was raised, and the rate became 2 cents for each ounce or fraction of an ounce.

Since that date the rate has not been changed, although from time to time proposals have been made for a reduction to 1 cent. The public and the department realize that the 2 -cent rate is immensely profitable. It not only sustains the service for letters: it enables the department to carry the heavy burden of both the second-class matter and the expensive rural delivery service, both of which involve heavy deficits, and still to show only a comparatively small, though fluctuating, deficit. ${ }^{2}$ As early as 1890 the question of 1 cent letter postage had attained considerable prominence.

- Congressional Record, Senate, 17th January 1883.

2 The cost of the provision and maintenance (lighting, heating, etc.) of Post Office buildings is charged directly on the Federal Treasury, and does not in any way figure in the Post Office deficit. 
Many newspapers were advocating the reduction, and numerous associations and conventions had declared for it. The Postmaster-General, Mr. Wanamaker, himself declared that great numbers of the people believed in 1 cent postage and wanted it, and that the existing rate yielded a large profit which would permit of a reduction of letter postage if it could be devoted to that purpose. ${ }^{\mathrm{I}}$ In $1891 \mathrm{Mr}$. Wanamaker expressed the view that in time not only would 1 cent postage be successfully demanded, but that the time was not far off; although he himself thought that many other improvements and extensions ought to be provided before such reduction was made, and that it would not be just and fair to the service, upon which much effort had been spent in order to make it self-supporting, to heap upon it a burden of millions from which it could not recover for years. ${ }^{2}$

The question was by no means lost sight of.3 With the department showing a deficit in most years, pressure could not be brought to bear for a reduction of postage which could only result in throwing a heavy charge on the public Treasury. Should, however, the department succeed in its efforts to obtain a higher rate of charge on second-class matter, and such higher charge results as satisfactorily to the revenue as the department anticipates, there can be little doubt that reduction of letter postage would soon follow.4

I "If the postal revenue arising from letter postage could be set aside for its proper uses, the millions of letter-writers of this country might quickly be permitted to enjoy a reduced taxation on letter-writing. In point of fact, there is a clear gain of nearly $\$ 30,000,000$ from letter postages."-Annual Report of the Postmaster-General, 1890, p. 53.

2 Ibid., 1891, p. 102.

3 "There is now, and has been for many years, an insistent demand for the reduction of letter postage. The advocates of that reduction argue that the volume of business naturally resulting therefrom would offset the temporary loss in revenue. They insist that the charge for first-class matter is out of all proportion to the cost of its handling and transportation."-Annual Report of the Postmaster-General, 1906, p. xlvi.

4 "As the profit on first-class matter is almost equal to the loss on second-class matter, it will readily be seen that an equalization of rates on the basis of the cost of service would permit a reduction in letter postage from 2 cents to 1 cent an ounce."-Mr. Hitohcock, Postmaster-General, evidence before Commission of 1911 , 


\section{LE'I'IER POS'T IN FRANCE}

THE Roman posts in France disappeared in the confusion which followed the incursions of the barbarians. Charlemagne repaired the roads to Germany, to Italy, and to Spain, in the early part of the ninth century, and established on them a system of relays; but with the passing of the Carlovingian Empire these arrangements fell into decay. The feudal system which arose after the break-up of the Empire was little adapted for the encouragement of posts. Its tendencies were rather towards disintegration and isolation. Although some of the services survived, there was for centuries no general system of posts in France. ${ }^{\mathrm{I}}$ During this period the chief means of communication were provided by the monasteries, which maintained regular intercourse between their various establishments scattered throughout France, Spain, Germany, and other countries; by travelling merchants, and by journeymen.

When a regular service of posts was again established in France, it was provided, not by the State, but by the University of Paris, which in the twelfth and thirteenth centuries increased in importance and renown, and attracted large numbers of students from all parts of France, and from foreign countries. In order to provide a means of communication between the students and their homes, the University obtained from the King authority to employ for the purpose messengers, to whom were accorded certain special privileges. Thus, in 1296, the messengers of the University were exempted from payment of tolls, or of fees for entry into towns. At first they travelled on foot, but at a later date on horseback or by carriage. The system developed regularity

× P. Jaccottey, Traité de Législation et d'Exploitation Postales, Paris, 1891, p. 5. E. Gallois, La Poste, etc., Paris, 1894, pp. 41 and 44. 
and rapidity, and in the fourteenth and fifteenth centuries was employed, although without authority, by the public generally. ${ }^{x}$

This service continued until 1720 , when the privileges of the University were suppressed, monetary compensation $\left(120,000\right.$ fr.) being paid from the revenue of the posts. ${ }^{2}$

An ordinary postal service was re-established by Louis XI in 1464.3 Relay stations were set up on the main routes, four leagues apart. At each station four or five horses were provided by the postmasters, who were required to convey the royal despatches without special remuneration. For conducting the royal couriers from stage to stage, however, payment was made at the rate of 10 sous for each stage for every horse.

In 1527 the postmasters were given the exclusive right of furnishing horses for the use of couriers. In order to provide accommodation for travellers, a system of relays was established in 1597, in addition to the ordinary posts. 4 The stages were fixed at distances varying from twelve to fifteen leagues, and the charge for a horse was 20 sous for each stage. This system was amalgamated with the posts in 1602 , and the functions for which the relays had been established were exercised by the posts until after the Revolution. They were definitely abandoned to private enterprise in 1797 .

The transmission of ordinary letters for private individuals was not at first contemplated, 5 but it became common for the royal messengers to carry letters for the public. The conveyance of private letters was first definitely provided for by the State in 1576. In that year a special system of messengers was established, whose function was to convey legal documents between the Parliament and the inferior courts, and was

s A. de Rothschild, Histoire de la Poste aux Lettres, Paris, 1879, p. 60.

2 P. Jaccottey, op. cit., p. 6.

3 Edict of 19th June 1464.

4 Edict of 8th May 1597: “Édit du Roy pour l'établissement des relais de chevaux de louage, de traite en traite, sur les grands chemins, traverses et le long des rivières, pour servir à voïager, porter malles et toutes sortes de bagages."

5 " Louis XI ne se préoccupait nullement de la correspondance des particuliers, ni du développement des relations commerciales et sociales: il poursuivait un but exclusivement politique.

"Engagé dans sa grande lutte contre la féodalité, il cherchait le moyen de transmettre avec célérité ses ordres dans les provinces et d'être rapidement informé des manœuvres de ses ennemis. . . . L'institution créée par Louis XI pour son usage exclusif était donc identique dans son but, sinon dans ses moyens, à la course publique des Romains."-P. Jaccottey, op. cit., p. 7. See also D. Macpherson, op. cit., vol. i. p. 695 , 
limited to the period during which Parliament was sitting. These messengers were required to carry letters for private individuals at the following rates:-

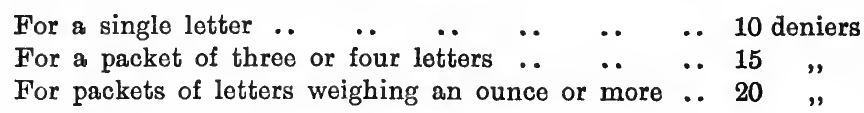

irrespective of distance. ${ }^{\mathbf{I}}$

Under Richelieu the ordinary posts were given a regular organization. Fixed days of departure and arrival were appointed; offices were established in the towns; and in 1627 the first general table of rates was issued.2 Previously the rate was fixed mutually between the couriers and the senders or receivers of letters. 3

For single letters the tariff of 1627 prescribed rates of 2 sous for transmission between Paris and Dijon, and 3 sous for transmission between Paris and Lyons, Paris and Bordeaux, Paris and Toulouse. For letters composed of more than one sheet, but less than $\frac{1}{2}$ ounce in weight, the rate varied from 3 to 5 sous; and for larger packets the rate was from 5 to 8 sous per ounce. In 1637 the posts were given the monopoly of the carriage of letters. 4

In the first years the posts had been a charge on the State, but at about this time they were let at farm, and proved a fruitful and growing source of revenue to the State. By 1672 the annual rent of the farm had risen to $1,700,000$ livres, and in 1791, the last year of the farm, the net revenue was about 12,000,000 fr.

A new tariff was established in 1676, as follows :-

\begin{tabular}{|c|c|c|c|c|c|c|}
\hline \multirow{2}{*}{\multicolumn{3}{|c|}{ Distance. }} & \multicolumn{3}{|c|}{ Letters } & \multirow{2}{*}{$\begin{array}{l}\text { Packets. } \\
\text { Per ounce. }\end{array}$} \\
\hline & & & Single. & $\begin{array}{c}\text { With } \\
\text { Envelope. }\end{array}$ & Double. & \\
\hline Less than 25 leagues & .. & . & 2 sous & 3 sous & 4 sous & 6 sous \\
\hline From 25 to 60 , & .. & .. & 3 " & 4 , & 5, & $9 "$ \\
\hline ", 60 to 80, & .. & .. & $4 "$ & $5 "$ & $6 "$ & $12 "$ \\
\hline Above 80 leagues & .. & .. & $5 "$ & 6 , & 9, & $15 "$ \\
\hline
\end{tabular}

A. Belloc, Les Postes françaises, Paris, 1886, pp. 43 and 46.

2 Regulation of 26th October 1627.

3 See Charles Bernede, Des Postes en Général, et particulièrement en France, Nantes, 1826.

${ }^{4}$ Léon Cazes, Le Monopole Postale, Paris, 1900. 
The progression for distance was in decreasing proportion.

In 1703 the rates were raised mainly in order to provide funds to meet the expenses of the wars of Louis XIV. Two reasons were assigned: the necessity for increased revenue, and the necessity for remedying certain defects in the existing rates, in regard to the distances and the progression of weight-the charges should be proportionate to the actual distance traversed by the couriers; and the existing rate of charge for ounce letters was therefore unjust, because it required at least six single letters to make up a weight of 1 ounce. ${ }^{x}$

As a matter of fact, the new rates fixed in 1703 did not vary exactly with distance. The number of zones was doubled, and the distances were reckoned according to the number of stages, and the routes actually followed by the couriers. The charge for a single letter varied from 3 to 10 sous.

These rates remained in force until 1759 , when a variety of causes led to a further increase of rates. The Seven Years' War had made an increase of taxation necessary; there had been a depreciation of money, and an increase in the cost of all commodities, which had resulted in an increase of the expenses of conducting the posts. Under the tariff of 1759 the eight zones of 1703 were maintained, and the rate for single letters varied from 4 to 14 sous, with an additional rate of 1 sou for all letters enclosed in an envelope. The principle of charge according to weight was introduced for letters weighing less than 1 ounce, which up to this time had been charged only according to the number of sheets. Double letters weighing more than $\frac{1}{4}$ ounce and less than $\frac{1}{2}$ ounce, were rated at 7 sous for the first zone, and for the other zones a "rate 2 sous less than the ordinary rate for double letters." Packets were charged by the ounce, and the rate per ounce was four times that for a single letter. As with the tariff of 1703 , distances were calculated according to the route actually followed by the couriers.

No further modification of the rates was made until after the Revolution. The lease of the posts was due to expire

I Edict of 8th December 1703. 
on the 31st December 1791, and it was decided that the Legislature should rectify the tariff before the date at which the posts would revert to the State. ${ }^{I}$ A rectification was accordingly announced by the decrees of the 17th-22nd August 1791. This revision slightly increased the rates of 1759. The initial rate of 4 sous for single letters circulating within the same departement was retained; the rate for letters circulating in the same arrondissement was fixed at 3 sous; between départements the rate was increased, and varied from 5 to 15 sous, according to distance of transmission; and the number of zones was increased to eleven. ${ }^{2}$

Distances were no longer to be reckoned according to the length of the route actually traversed, but from point to point as the crow flies. The points were not, however, the actual points of posting and of delivery. In each department a point was fixed upon, and the rate for all letters posted or delivered in the département was calculated as from that point; so that for a given weight the same rate was payable on all letters exchanged between the same two departements. This system, though comprising a very large number of rates, was much simpler than the earlier systems. Any one town or village now had only 82 rates for each step in the scale of rates, whereas under the previous system a special rate must be calculated for every other town or village in France. To assist the application of this tariff, a map showing the central point fixed upon for each of the 82 départements, and the distances from each central point to all others, was prepared and supplied to every post office in France.

The tariff of 1791 also abolished the method of charge according to the number of sheets, and substituted the simpler method of charge according to weight alone. The maximum weight for a single letter was fixed at $\frac{1}{4}$ ounce, and for heavier letters the rates were-

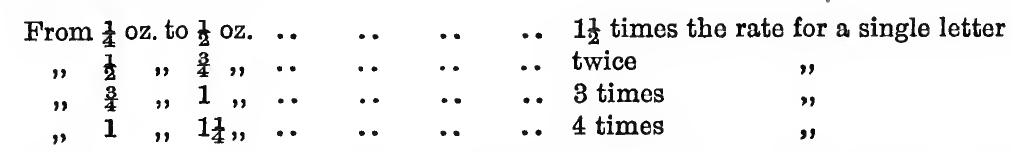

and so on, the increase being one single rate for each

× Decrees of 26th-29th August 1790.

\& P. Jaccottey, op. cit., p. 287. Cf. Le Moniteur Universel, 18 août 1791, p. 954. 
$\frac{1}{4}$ ounce increase of weight. The rate for letters circulating within the same town remained 2 sous an ounce.

This tariff continued in operation only for a short period. In these troubled times the public services fell into complete disorder, and the control of the posts by the Government did not prove a success. When in farm the rent had been comparatively large; but under State management, even with the increased rates of 1791 , the finances were altogether unsatisfactory. In 1791 there had been a profit of 12 millions. Soon there was a deficit: in 1793 it was found necessary to allow 4 millions in aid. Further increases in the rates followed. In $1795^{\mathrm{I}}$ they were made 2 livres 10 sous, 5 livres, 7 livres 10 sous, or 10 livres, according to distance, but, like most other very high postage rates, failed of their purpose. Instead of increasing revenue, they almost destroyed correspondence. Transmission by private means became widespread. ${ }^{2}$ Other circumstances-the general insecurity of the times, and the violation of the secrecy of letters by officers of the Government-contributed to this development. At the end of six months the rates were lowered to $3,5,7$, and 9 decimes, according to distance, but these rates were still high. The posts. were reconstituted under the Consulate and the Empire, and further minor changes introduced, the object held in view in all these changes being chiefly to secure a revenue sufficient to meet the expenditures of the service.

The last tariff under the old system of charge according to distance was introduced in 1827.3 The number of zones, which in 1810 had been increased to fourteen, in order to provide for the extended territory resulting from the French conquests, was reduced to eleven. The rates ranged from 20 centimes to 1 fr. 20 for single letters, and the weight limit for a single letter was fixed at 7 grammes. Distances were reckoned as the crow flies. In 1829 a postal service was established in the rural communes, and an additional rate of 1 decime imposed on all letters received or delivered in the communes.4 This surcharge was abolished in 1846. As in

L Law of 27th December 1795.

2 P. Leroy-Beaulieu, Traite de la Science des Finances, Paris, 1899, vol. i. p. 612.

3 Law of 15 th March 1827.

4 Law of 3rd June 1829. 
England, the charges imposed on letters sent for considerable distances were exceedingly heavy. The charge on a letter from Paris to Marseilles, weighing 15 grammes, was no less than 2 fr. 20.

Attention was soon directed to Sir Rowland Hill's proposals for the reform of the English system. Before the reform had been introduced in England, the French Government were urged to improve the French service on the lines proposed by Sir Rowland Hill. In July 1839 M. Lherbette, member of the Chamber of Deputies, suggested the introduction of a Government measure, and in this he met with considerable support. The Government, however, contented themselves with remarking that it would be better to await the result of the projected reform in England.

In the following years the question was frequently raised in the French Parliament, on the Budget, or on reports and petitions, and there was considerable public feeling in favour of the reform. In 1843, 65 conseils généraux presented petitions in favour of reduced postage. In $1844 \mathrm{M}$. de St. Priest made a proposal to reduce the number of zones to two, and to fix the rate of postage at 20 centimes for distances up to 40 kilometres, and 30 centimes for greater distances. A parliamentary Commission, appointed to examine this proposal, made an estimate of the actual cost to the Post Office of the transmission of letters, and found that while the cost of a letter going 40 kilometres (postage 20 centimes) was $9 \cdot 75$ centimes, the cost of a letter going 900 kilometres (postage $1 \mathrm{fr}$. 20) was 14.75 centimes. The Commission reported in favour of a uniform rate of 20 centimes, but the proposal was not adopted. Other proposals for the introduction of a reformed system were made in February 1846 and January 1848.

It was left to the Republican Government of 1848 to introduce the reform. ${ }^{x}$ The National Assembly had under

x “Citoyens représentants, puisque l'honorable défenseur de l'interêt du trésor a porté à cette tribune un mot, je ne le nie pas; il est vrai qu'au comité des finances j'ai dit que cette loi était une loi d'amour; je le répète, et j'adresse de sincère remerciements à la monarchie, pour avoir laissé à la République le soin de donner cette loi au pays."-Le Citoyen Goudchaux, Ministre des Finances, Assemblée Nationale, 24 aout 1848 (Le Moniteur Universel, Journal Officiel de la République Française). 
consideration at the same time two propositions for effecting the reform-that of $M$. de St. Priest, and that of the Government itself, both proposing a uniform rate of 25 centimes for single letters. These propositions were referred to a parliamentary Commission, of which $M$. de St. Priest was a member, and the report of the Commission, which recommended the reform, was adopted by the Assembly.

The Government Bill to give effect to the recommendation of the Commission was opposed in the National Assembly, mainly on the ground that the benefit of the reduction of rate would accrue almost entirely to the business and commercial interests and not to the general public; and on the ground that a letter was a parcel, and should be charged like any other parcel, according to its weight and according to the distance transmitted. The Government's justification for the proposal rested chiefly on the moral and social benefits which would result, $\mathbf{x}$ and they contended that if, as the opposers of the reduction had argued, commercial letters comprised seven-eighths of the total number of letters passing by post, such an extraordinary fact itself did not show that advantage from reduced rates would accrue only to business interests. It showed the injustice of the existing rates, and would never have existed if the postage on letters had not been higher in France than in any other country in the world. The Commission had, moreover, made a calculation of the actual cost of conveying and delivering letters, which showed that the average cost per letter was from 10 to 12 centimes.

The Government estimated that the number of letters would double in the first year (i.e. would increase from

× " La question que j'appelerai sociale est la première qui se presente à mon esprit. . . Je dis donc, que, au point de vue sociale, la diminution de la taxe des lettres, loin d'être favorable uniquement aux négociants, aux gros banquiers, comme on l'a supposé toute à l'heure, sera favorable aussi au plus grand nombre des citoyens. . .

"Quant à l'avantage moral qui résulterait de l'accroissement de ces correspondances, je crois inutile de m'appesantir sur ce côté de la question. Est-il douteux, en effet, que les enfants auront toujours à profiter des conseils d'un père, d'une mere? Est-il douteux que les liens de famille se resserreront davantage, lorsque les rélations seront plus fréquentes ?"-Le Citoyen Goudchaux, Assemblée Nationale, 24 aout 1848 (ibid.). 
55 millions ${ }^{1}$ to 110 millions), and the result would therefore be a diminution of $3,125,000 \mathrm{fr}$., or 6 per cent. of the total receipts. This would represent the total loss, since the Minister of Finance assured the Assembly that, after the most minute and persistent inquiries, he had received from the postal administration definite statements that no increase in expenses would be caused by the increase in the number of letters - a result explained by the fact that the increase of traffic would be appreciable only in certain large towns; in other places the result would simply be that the postmen would each have a few more letters to carry. Moreover, under the new system the manipulation of correspondence would be much simplified and facilitated.2

Frédéric Bastiat proposed to the Assembly, as an amendment, a postage of 5 centimes on letters up to 10 grammes, and $1 \mathrm{fr}$. for packets from 10 to 100 grammes. He said that the transmission of thought, of communications between men, was the very essence of society, from which arose wealth, business, civilization, and taxes themselves. Consequently, to him it appeared an anomaly to place a tax on such communication. 3

On the economic aspect of the question he contended that a rate of 5 centimes would provide sufficient revenue to meet the expenses of the service. 4

The total is made up thus:-

Local letters in towns of the departments $\quad$.

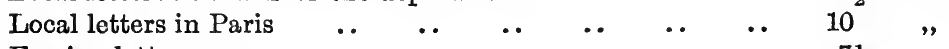

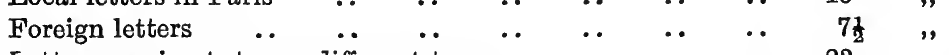

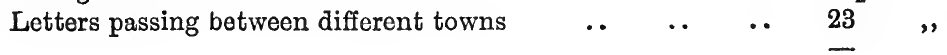

$\overline{55}$,

2 See Le Moniteur Universel, Journal Officiel de la République Française, août 1848.

3 "Je concevrais que le Gouvernement établit un impôt sur tout autre chose pour favoriser celle-là, mais qu'il établisse un impôt, sur celle-là, cela me parait contradictoire. Tous les jours nous votons des taxes pour faciliter la locomotion des hommes et des choses, nous construisons des routes, des canaux, des chemins de fer dont nous livrons gratuitement l'usage au public, et ensuite nous entravons par des taxes la transmission des idées! Je dis que le Gouvernement ne doit pas faire des profits sur ce service. C'est là un principe qui s'est étendu sur presque toute l'Europe. En Angleterre on est complètement entré dans cette voie. Aux Etats-Unis le Gouvernement fait des frais et des frais énormes pour en épargner à ceux qui veulent correspondre."-Le Citojen Frédéric Bastiat, Assemblée Nationale, 24 août 1848, ibid.

4 "Lues frais de la poste sont à peu près de 30 millions. Qu'est-ce que la poste nous porte? Qu'est-ce qu'elle distribue? Elle distribue trois natures 
The Government were not convinced, and maintained their original proposal, which was carried. The new rates were-

\begin{tabular}{|c|c|c|c|c|c|c|}
\hline Letters not exceed & ling $7 \frac{1}{2}$ & $\operatorname{ran}$ & & .. & .. & 20 centimes \\
\hline From $7 \frac{1}{2}$ grammos & to $15 \mathrm{~g}$ & & . & .. & .. & 40 \\
\hline & to 100 & & . & .. & .. & \\
\hline Over 100 grammes & .. & .. & . & .. & .. & $\begin{array}{l}1 \text { fr. for each } 100 \\
\text { grammes, or fraction } \\
\text { of } 100 \text { grammes }\end{array}$ \\
\hline
\end{tabular}

The special rates for local letters were continued, viz.-

Letters "de Paris pour Paris" not exceeding 15 grammes, 15 centimes;

Letters circulating in the limits of the same post office not exceeding 15 grammes, 10 centimes.

The reform, which took effect on the 1st January 1849, was much less sweeping than the reform of 1840 in England-the initial rate was 20 centimes, corresponding to a twopenny rate -and the results were naturally less striking in France. They were nevertheless quite considerable. The total number of letters posted increased from $113,500,000$ in 1848 to $148,600,000$ in 1849 , an increase of 31 per cent., compared with increase of 122 per cent. in the first year in England. The gross revenue from letters and other packets fell from $48,816,861 \mathrm{fr}$. in 1848 to $36,582,009$ fr. in 1849 , a decrease of $11,234,852 \mathrm{fr}$. The net revenue fell from $16,960,773$ to $6,862,920 \mathrm{fr}$. Thus there remained a substantial surplus.

Both the gross and net revenue recovered in much less time than in England, as might have been expected, since the falling off had not been nearly so great. Moreover, in

d'objets; d'abord une multitude de journaux, et remarquez-lo bien, ces journaux sont soumis à la même législation que je propose aujourd'hui pour les lettres; car, telle est la puissance de l'habitude, ce qui vous a paru fort extraordinaire se pratique sous nos yeux, tous les jours pour les journaux; et cependant aujourd'hui vous trouvez singulier qu'on lo propose pour les lettres. La poste transporte donc des journaux dont le poids, si je ne me trompe, est de 900 kilogrammes.

"Elle transporte ensuite toutes les dépêches administratives dont le poids dépasse 1,000 à 1,100 kilogrammes.

“Enfin elle transporte les lettres dont le poids n'est pas égal ni à celui des journaux, ni à celui des dépêches administratives.

" En conséquence, si vous répartissez les 30 millions ou 35 millions, si vous voulez, sur les trois services, vous verrez qu'il ne faut pas mettre au compte des lettres plus d'une douzaine de millions de francs.

“ Eh bien, si toutes les lettres étaient taxées à 5 centimes, il n'y a pas de doute que les 12 ou 15 millions de frais seraient parfaitement couverts."-Le Citoyen Frédéric Bastiat, ibid. 
1850, on account of financial stress, $^{1}$ the initial uniform rate was raised to 25 centimes, and the rate for letters of from $7 \frac{1}{2}$ grammes to 15 grammes, to 50 centimes. The result of this was a set-back to the total numbers, which were only $148,500,000$ in 1850 , but an improvement in the gross and net revenue. By 1853 the net revenue had reached 17,176,229 fr., and by 1854 the gross revenue had reached $50,019,801 \mathrm{fr}$.

In 1854 the initial rate for single letters was again reduced to 20 centimes, and the change was immediately reflected in the total number of letters. In 1852 the number was $167,100,000$, and in 1853,170,400,000, an increase of 2 per cent. In 1854 the number was 195,900,000, an increase of 15 per cent. over the number for 1853 .

Minor modifications were made in 1861 and 1862. The next important change followed the war of 1870 . It was necessary to increase existing taxes wherever possible, and to impose fresh taxes, in order to meet the heavy charges on the national exchequer resulting from the war. The possibility of obtaining an increased revenue from increased rates of postage was not overlooked. In 1871 the Government presented a Bill for the purpose, solely as a fiscal measure.2

New rates as follows were established:-

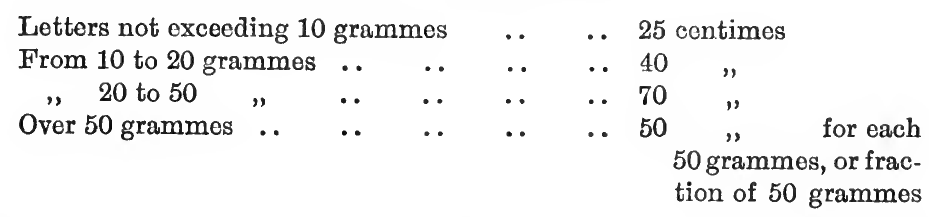

For local letters not exceeding 15 grammes the rate of 15 centimes was continued.

The results of this increase of rates are somewhat difficult to determine with any degree of precision. Other circumstances affected the number of letters, such as the loss of Alsace-Lorraine (an industrial province), the establishment of postcards in 1873, and the reduced means of the people by reason of increased taxation. The number of letters, which in 1869 was $313,360,723$, was in 1872 only $292,466,678$, and

- Edgar Bonnet, Importance des Postes et Télégraphes au point de vue social et économique, Paris, 1891.

2 M. Caillaux, Assemblée Nationale, 23 août 1871 (Journal Officiẹl de la République Française). 
the figures for 1869 were not regained until 1877. If the numbers are adjusted by reckoning the loss of Alsace-Lorraine to have resulted in a decrease in numbers proportionate to the numbers of its population, that is, one twenty-third of the total population of France, and adding the normal increase of 9 millions a year, the number in 1872 would have been 325 millions, whereas it was in point of fact 292 millions. The reduction was even greater in the following years. In 1873 the total number fell to $285,350,341$.

The financial result was no more satisfactory. The revenue in 1869 was $60,989,454$ fr. In 1872 it had risen to $72,615,276$ fr., an increase of 20 per cent. only, while the rates had been raised 25 per cent. for letters from office to office and 50 per cent. for local letters. In 1873 the yield was less. It was, indeed, little more than would have resulted from the old rates if the normal increase of numbers under those rates had continued, although it may be doubted whether this would have been the case in view of the heavy financial strain imposed by the war of 1870 . In any case, the financial result of the increase of rates, which pressed heavily on commercial and social intercourse, was extremely small. ${ }^{x}$

But. if the rates were higher in France than in other countries, there were yet some aspects in which the French service was in advance. ${ }^{2}$ Compared with England, for example, the uniform rate covered a much greater extent of territory, and a daily delivery of letters was afforded to every hamlet, and even to every isolated house, throughout that greater territory. 3 This service was provided by a body of 19,010 rural postmen, the number of rural postmen in England at this time being only 6,000. Facilities for the posting of letters were also more extended in France: the number of posting-boxes was 45,000 , as compared with some 22,000 in the United Kingdom.4

P. Jaccottey, op. cit., p. 298.

- See Rapport sur l'Administration des Postes, présenté au Ministre des Finances par M. Léon Riant, Directeur-Général, octobre 1877.

3 "Toute commune doit êtro desservic une fois par jour, au moins (loi $d u 21$ avril, 1832, art. 47) sauf exception temporaire en cas de force majeure, et dont il est rendu compte au directeur du département."-Instruction générale sur le service des Postes et des Télégraphes, Paris, 1905, vol. iv. p. 453, Instr. 5316.

4 It must further be borne in mind that France was less developed industrially. 
It was always desired to withdraw the increase of 1872 as soon as the financial situation would allow. This course was hastened by the establishment in 1874 of the Universal Postal Union, of which France became a member. The international rate for ordinary letters adopted by the Union was 25 centimes. As a result the internal rates of France were much higher than the rates for letters posted in France for places in other countries of the Union. Such a situation could not continue, and in August 1875 the internal rates were reduced. The new rates were:-

Letters not exceeding 15 grammes $\quad . \quad$.. 25 centimes

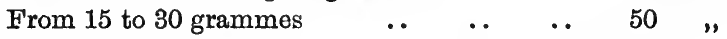

" 30 to $50 \quad$ " $\quad$.. $\quad$. $\quad$.

$\begin{array}{lllllll}\text { Over } 50 \text { grammes } & \text {. } & \ldots & \ldots & \ldots & 50 \quad \text {, } & \text { for } \text { each }\end{array}$

50 grammes, or frac-

tion of 50 grammes

The special local rates were retained.

The letter rate still remained comparatively high, and in the following year numerous proposals were put forward in Parliament for a reduction. In November 1876 the Government proposed the reduction of postage on ordinary letters to 20 centimes, and on postcards to 10 centimes, the special rates for local letters being continued. These proposals were referred to the Budget Commission, who expressed the opinion that the time had arrived for the introduction of complete uniformity of rate, ${ }^{\mathbf{I}}$ and recommended a uniform initial rate for letters of 15 centimes for 15 grammes, and a uniform rate of 10 centimes for postcards.

Further consideration of the proposals was interrupted by the dissolution of the Chamber. In the next session, $M$. Caillaux, Minister of Finance, adopted the report of the Commission, and in April 1878 the rate for letters was reduced to 15 centimes for each 15 grammes, or fraction of

I "Nous avons jugé cette réforme insuffisante; elle ne serait pas de nature à donner une satisfaction réelle à notre industrie et à accélérer suffisamment le mouvement de la correspondance. On pouvait discuter peut-être l'opportunité de la mesure; mais dès que cette mesure est reconnue nécessaire, elle doit être complète, de manière à produire tous ses effets. . . .

"La réforme à 20 centimes entrainerait donc un déficit total de 12 millions; et celle à 15 centimes, de 27 millions; le rapprochement de ces deux chiffres suffit à démontrer que le sacrifice n'est pas assez considérable pour hésiter à faire une réforme complète en réduisant immédiatement la taxe à 15 centimes." Rapport portant fixation du Budget générale, déposé le 31 juillet 1877. 
15 grammes. The general rate was thus brought to the level of the local rate, which now disappeared.

The results of this reform were eminently satisfactory. The total number of letters, which had during the years 1872 to 1877 increased by only $4,365,412$, or some one and onethird per cent. per annum, increased from 318,659,158 in 1877 to $403,853,626$ in 1879 , or 26 per cent. in two years, and from 1879 to 1889 the rate of increase was 6.6 per cent. per annum. The Government had estimated that the reduction would involve a loss to the revenue of some 15 millions for the first year. The actual loss was $15,323,571 \mathrm{fr}$.

These figures are figures of gross revenue. The figures for net revenue are less satisfactory, both in character and in the amounts indicated. Their character is unsatisfactory because the expenses of the postal and telegraph departments were not separate; and the figures for net revenue therefore represent the net revenue on the whole service, both postal and telegraph, and not merely for the postal traffic alone. At this time, however, the telegraph business was small comparatively, and the figures indicate generally the result of the reform. In 1877 the net revenue was $47,706,293 \mathrm{fr}$. In 1878 it fell to $29,343,953$ fr., and in 1879 to $21,084,699$ fr., from which date there was a gradual, but steady, recovery. In 1888 it had reached $48,811,146$ fr. 25 , an amount higher than that of 1877, and in 1889 the net revenue passed 53 millions, a sum never before reached in France. ${ }^{x}$

The rate fixed in 1878 , although marking a considerable reduction of the previous rate, was felt to be unsatisfactory. One of the principal reasons invoked as justifying the suggestion for a further reduction of the rate, was that the number of letters actually posted in France was much less than the number posted in other countries. This circumstance was attributed partly to the high initial rate, and partly to the fact that the progression of charge was directly proportionate to the increase of weight. The initial rate was in point of fact much higher than the corresponding rate in other countries. The Press often called attention to the unfavourable position in France in this respect, and developed

- Rapport portant fixation du Budget générale, Chambre des Députés, 1898, No. 498 . 
public opinion strongly in favour of a reduction. Representations from business houses, chambers of commerce, and conseils généraux were constantly received by Parliament. The question was frequently advanced in the Legislature, and numerous suggestions for legislation were put forward by members. Thus, in $1897 \mathrm{M}$. Chassaing proposed, among other reforms, the reduction of the letter rate to 10 centimes for each 15 grammes. Although admitting the desirability of granting the boon, the Budget Commission were unable to recommend that course on account of the serious effect on the net revenue which must be anticipated. ${ }^{\mathrm{x}}$

In 1900 M. Millerand, Minister for Commerce, Industry, Posts, and Telegraphs, in a report to the President, ${ }^{2}$ recommended a reduction of the rate on the grounds that it would give satisfaction to the public, and, at the same time, increase appreciably the number of letters transmitted by post. $\mathrm{He}$ suggested the following scale :-

Letters not exceeding 15 grammes

From 15 to 50 grammes .. ..

Over 50 grammos.
.. $\quad$.. 10 centimes

.. $15 \quad$,

.. $\quad . \quad 5 \quad "$ for each 50 grammes, or fraction of 50 grammes

I Their remarks are characteristic of the attitude adopted towards the reform. They said :-

"L'adoption de cette proposition de M. Chassaing aurait pour effet de créer dans le Budget de 1898 un déficit qu'il ne paraît guère possible d'évaluer à moins de 33 millions. Quel qu'il puisse être, dans la situation actuelle, il serait indispensable de le oombler et l'on ne pourrait pour cela recourir qu'd des ressources nouvelles. L'auteur de la proposition n'en indique pas. Il se borne d demander l'abandon d'une recette sans dire par quoi cet abandon serait compensé. Sera-ce à l'impôt qu'il faudra s'adresser? Mais ce n'est pas seulement d'une diminution de recette qu'il s'agira. On a vu qu'une augmentation de dépense était le corollaire immédiat de la proposition, car plus prompt et plus sensible sera l'effet de la réduction de tarif, plus pressante sera la nécessitê d'ouvrir de nouveaux bureaux, de créer de nouveaux courriers, de renforcer le personnel chargé de la manipulation et de la distribution, plus tôt s'imposera l'obligation de réorganiser le service de Paris.

"C'est là une œuvre où l'initiative et l'intervention du Gouvernement sont nécessaires.

“Mais, en tout cas, et pour ce qui concerne la Commission du Budget de 1898, un abandon de recettes de 21 millions ayant lui-même pour conséquence une augmentation de dépense de 17 millions ne lui ont pas paru admissibles."-Rapport portant fixation du Budget générale, Chambre des Députés, 1897, No. 2701, p. 49.

${ }^{2}$ Rapport sur les conditions du Fonctionnement de l'Administration des Postes et des Télégraphes, par A. Millerand, le Ministre du Commerce, de l'Industrie, des Postes, et des Télégraphes, 12 May 1900. 
Such a reduction would bring the rate of letter postage down to the level of the existing rate for postcards; and M. Millerand regarded the reduction of the latter rate to 5 centimes as an inevitable corollary, and a reform which might safely be made. ${ }^{x}$ Assuming this further reduction, and applying the proposed reduced rates to the statistics of existing traffic-ignoring both the probable increase of traffic and the increase of expenses which would result from the increase of traffic-it was estimated that the loss to revenue would be-

$$
\begin{array}{llllllr}
\text { On single letters } & . . & . . & . . & . . & . . & 34,071,584 \\
\text { On heavy letters } & . . & . . & . . & . . & . . & 4,707,836 \\
\text { On charged letters } & . . & . . & . . & . . & . & 404,787 \\
\text { On postcards .. } & . . & . . & . . & . . & . . & 2,569,787 \\
& & & & \text { Total } & . . & 41,753,994
\end{array}
$$

The reduction of revenue would be $35 \cdot 6$ per cent. of the total yield.

The reform of 1878 had entailed an increase of working

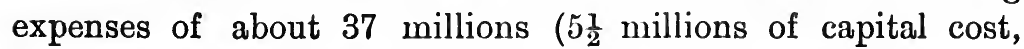
and $31 \frac{1}{2}$ millions of annual expenses). The increase of traffic from the proposed reform would, however, be 17 per cent. less than the increase after 1878 (because the reduction was five-fifteenths of the rate instead of six-fifteenths as in 1878), and the increase of cost would therefore be proportionately less. Calculated on this basis, the increase was estimated at $31,037,829$ fr. $(4,920,000$ fr. capital expenses and $26,117,829$ fr. annual).

In all, therefore, the reduction would involve a loss of revenue of $41,753,994 \mathrm{fr}$., and an increase of expense of $31,037,829 \mathrm{fr}$. - a total loss of $72,791,823 \mathrm{fr} .^{2}$

In order as far as possible to replace this loss, M. Millerand proposed to abolish the special tariff for papiers d'affaires and subject them to letter postage, and also to increase the rates on small packets of printed matter, other than news-

× "En tout cas les résultats de l'expérience faite à l'étranger prouvent que l'on peut abaisser la taxe des cartes postales jusqu'à la moitié de celle des lettres simple sans craindre que les cartes fassent concurrence aux lettres et que la généralisation de ce mode de correspondance à prix réduit amène une diminution des revenus de la poste."-M. Millerand, op. cit.

Ibid. 
papers and periodicals. ${ }^{\mathrm{I}}$ The deficit to be looked for in the first year would then be 16,233,833 fr., and might be estimated to disappear in the eighth year. The gross revenue would recover in the third year. The Government was not, however, prepared to sacrifice the revenue, and the proposal was deferred.

The question still continued to receive attention in the country and in Parliament. ${ }^{2}$ At length, in view of the persistent agitation, 3 the Government in 1906, on the recommendation of the Budget Commission, resolved to face the inevitable loss of revenue and make the reduction. The result was in many ways satisfactory. The number of packets sent at the letter rate of postage increased very considerably. A large quantity of traffic was diverted from the cheaper open post to the letter post, in order to obtain the advantage of secrecy, some large business houses sending at the letter rate millions of communications which would, under the old rates, have been sent by the open post. In 1905, before the reduction, the number of packets passing by post was 2,371,000,000. In 1907 the number had increased to $2,720,000,000$, and in 1908 to $2,802,000,000$. The loss of net revenue was nevertheless very great. The gross revenue was diminished by some 12 millions, and the expenses increased by $21 \frac{1}{2}$ millions. The net revenue fell from $91,750,000 \mathrm{fr}$. in 1905 to $59,750,000 \mathrm{fr}$. in 1906 .

The reduction of 1906 placed France in a position of equality with most other nations as regards the initial rate for

I On such packets the rate was 1 centime for each 5 grammes. M. Millerand was of opinion that any rate less than 5 centimes involved a loss to the net revenue. In 1877 it had been estimated that the average cost of dealing with a postal packet (taking all classes into consideration) was 8 centimes : in 1889 it had been estimated at $5 \cdot 5$ centimes. The Budget Commission of 1901 estimated the cost at 4 centimes.-See Rapport portant fixation du Budget générale, Chambre des Députés, 1901, No. 1866.

2 "C'est tomber dans la banalité de dire que la France n'occupe pas dans le monde, au point de vue du trafic postal, un rang correspondant à l'importance de sa population, de son commerce, de son industrie, et de sa haute civilisation."-Ibid.

3 "Depuis de longues années, les chambres de commerce et la Presse toute entière réclaimaient une réforme depuis quelque temps réalisée dans la plupart des pays étrangers. Mais le souci de l'équilibre budgétaire avait toujours fait ajourner la réduction à 10 centimes de la taxe des lettres." -Ibid., Sénat, 1906, No. 477 . 
letters. Indeed, the French rate was slightly lower than that in several other countries. Thus, the equivalent of the German and Austrian initial rates was $12 \cdot 2$ centimes, of the Swedish 13.8 centimes, and of the English 10.5 centimes. But as regards the weight allowed for the initial rate, and also as regards the rates for heavier letters, the position was still unsatisfactory. The maximum weight allowed to pass at the initial rate was 15 grammes, and the rate for a letter of 250 grammes was $1 \mathrm{fr}$. 70. In Germany the rate for a letter of that weight was 24.4 centimes, in England $26^{\circ} 2$ centimes, and in Switzerland 10 centimes. Attention was therefore now directed to a modification of the scale of rates for the heavier letters. The Budget Commissions of 1908 recommended the reform. ${ }^{2}$ In their view the unfavourable comparison with other countries in this respect could be justified neither by logic nor by regard to the interests of the Treasury. Logically, a rate of postage ought to be proportionate to the cost of the service performed, and this was far from varying in accordance with the weight of postal packets.3

The number of heavy letters was, moreover, small proportionately, and the effect on the Treasury of a reduction of rate for such letters would be slight. Indeed, it was thought an increase of revenue might be anticipated, since, in addition to the natural increase resulting from the reduction, there would, as in 1906, be a tendency for many packets sent by the open post to be sent under the advantage of the closed post. It was urged that the reduction should be accompanied

x On the proposal at the Universal Postal Congress of 1907 to increase the weight unit for international letters, the Budget Report (Chambre des Députés, Session 1909, No. 2767) contained the following:-

"Alors que tous nos voisins ou presque tous s'étaient conformés à partir du ler octobre 1907, aux indications du Congrès de l'Union postale universelle, il était humiliant pour la France de montrer que des préoccupations purement fiscales l'empêchaient d'adopter, avec le même empressement que l'Allemagne, la Belgique, l'Angleterre ou la Suisse, la réforme."

" Rapport portant fixation du Budget générale, Sénat, 1908, No. 340. Ibid., Chambre des Députés, 1908, No. 2032.

3 “ Il n'en coute pas plus pour timbrer, trier, transporter et distribuer un objet pesant qu'un objet léger. Tout au plus doit ou tenir compte de l'encombrement produit par les objets volumineux et du surcroit de travail qu'occasionne le contrôle obligatoire du poids des objets pesantes, en graduant les tarifs suivant une progression nettement décroissante par rapport au poids." -Ibid. 
by certain modifications in the minor rates, which would lead to a desirable simplification of rates: the special rate for commercial papers should be abolished, and the general rate for postcards should be made 5 centimes; the whole of the reforms being carried out at the same time, in order that the increases might be seen in their proper relation to the compensating reductions. Otherwise the public might forget the benefits, and resent the increases. The net loss of revenue was estimated at 4 million francs. ${ }^{\text {I }}$

The law of the 8th April 1910 increased the unit of weight for letters to 20 grammes. For the heavier letters the rates were: from 20 to 50 grammes, 15 centimes; from 50 to 100 grammes, 20 centimes; and so on, adding 5 centimes for each 50 grammes or fraction of 50 grammes up to the maximum weight allowed, viz. 1 kilogramme. The special rate for commercial papers over 20 grammes in weight was abolished. The privileged rate was retained for packets weighing not more than 20 grammes, Parliament refusing to agree to its total abolition.

Note.-On the 1st January 1917, as a war measure, the general letter rate was raised from 10 centimes to 15 centimes.

I See table of financial effect, Rapport portant fixation du Buclget générale, Sénat, 1910, No. 115. 


\section{LET'IER POST IN GERMANY I}

A system of messengers (Boten-Anstalten) existed in Brandenburg as early as the first half of the sixteenth century, and in 1604 a master of the messengers (Botenmeister) was appointed, whose duty was to control the sending and receiving of all despatches. 2 The incorporation of Prussia and Cleve in the Mark of Brandenburg rendered necessary the improvement and extension of the messenger service, and in 1614 the Elector John Sigismund appointed twenty-four messengers, who were paid at a fixed rate, according to the length of the route traversed. Thus, for the Strasburg, Cologne, and Düsseldorf routes the payment was 10 thalers, and for the Cracow, Königsberg, and Mainz routes, 8 thalers. Once a year they were supplied with an outfit of clothing. When not travelling, they were required to report themselves every hour to the Botenmeister, and to hold themselves in readiness at all times to set out if necessary without delay. The journeys were made according to set times, and the messengers, who carried both letters and parcels, were provided with a way-bill, on which the times of arrival at and departure from the various points were entered. The BotenAnstalten really comprised two kinds of undertakings-the so-called Post-boten and the Landkutschen. The former were the ordinary messengers; the latter a kind of stage-coach system, which carried both passengers and merchandise. 3 The rates of charge were based on the actual length of the journey, and also upon any accidental circumstance which

- Prior to the date of the establishment of the Imperial German Post Office, the text deals more particularly with the rate in Prussia. For a sketch of the Thurn and Taxis posts in Germany see infra, Appendix A, pp. 349 ff.

2 .H. von Stephan, Geschichte der preussischen Post, Berlin, 1859, p. 12.

3 F. Hasss, Die Post und der Charakter ihre Einkïnfte, Stuttgart, 1890, p. 92. 
might have a relation to the question, such as high general prices. ${ }^{x}$

In 1634 a riding post between Cöln a. d. Spree and Crossen was established, and shortly afterwards a similar post to Glogau, in order to provide a means of communication between the Government and the Swedish Army. For the same purpose in 1635 a daily messenger service (Botenpost) was established from Tangermünde to Berlin, and in 1646 a military post (Dragonerpost) was established between Berlin and Osnabruck, in connection with the conference preceding the signing of the Treaty of Westphalia.

All these services were for the conveyance of the Court and Administrative correspondence only. The Botenmeister nevertheless frequently undertook the conveyance of private letters, for which special charges were made, and often the messengers themselves clandestinely carried private letters.

In 1618 the Botenmeister of Berlin established a special messenger route for the conveyance of private letters (Ordinari-Boten-Cours) from Berlin to Leipzig and Hamburg, and at about the same time the Botenmeister of Königsberg established a similar route to Danzig. In other large towns messenger services for the conveyance of ordinary letters were established by private individuals, but these services were often inefficiently conducted. The messengers followed no fixed route, and the services were irregular and unsafe. They were at best only makeshifts.

As the result of a variety of circumstances, the establishment of regular posts became a necessity in the time of the Great Elector. The extension of the Brandenburg territory, and the political developments, rendered it desirable to adopt all possible means for binding together the entire territory. Regular posts would also contribute to the national welfare and assist industry and commerce, although there was little prospect that at the outset they would prove profitable. ${ }^{2}$ In 1646 a riding post between Königsberg and Danzig was established; shortly afterwards a post between Berlin and Königsberg, and thereafter others. In 1649 the control of all the posts was definitely assumed by the Electoral administration. 3

F. Haass, op. cit., p. 94.

2 H. von Stephan, op. cit., p. 15.

3 Ibid., p. 17. 
In general the posts went twice weekly; stages were erected for the exchange of horses and postilions. At first, postilions were changed every twelve (German) miles,' ${ }^{\mathbf{I}}$ and horses every four (German) miles. Later, the stages for the changing of horses were reduced to three miles. The usual speed of the posts, travelling day and night, was one mile an hour, and punctuality was insisted on. ${ }^{2}$ The journey from Berlin to Königsberg occupied four days, and that from Königsberg to Cleve ten days.3 There was at first no delivery service, and all letters must be obtained at the post office, where the people were consequently in the habit of congregating to await the arrival of the post. 4 The postage was retained by the Postmaster as the remuneration for his services. For the actual management and conduct of the service he drew on the State funds to the extent of some 6,000 thalers annually, and all official despatches were consequently conveyed free. This charge diminished, however, with the years, and in course of time the service came to yield a profit to the State. In the Postmaster's patent granted in 1661 it was provided that a portion of the proceeds of postage should be accounted for to the State treasury. 5

The rates of postage were at first fixed according to ancient custom, but they were on several occasions reduced. The postage on a letter not exceeding half an ounce in weight sent from Berlin to Wutzkow, from Breslau to Wutzkow, or

1 German mile $=7 \cdot 5$ kilometres. Distances are given throughout in German miles.

2 H. von Stephan, op. cit., p. 62.

3 Ibid., p. 18.

4 "Dass unter solchen Umständen boi Aukunft der Posten namentlich an bedeutenderen Orten ein grosser Zusammenlauf von Menschen stattfand, ist begreiflich. Auch finden wir mehrere Rescripte wider das tumultuarische Treiben des Publicums vor den Posthäusern."-Ibid., p. 61.

5 In 1662 the posts yielded 7,000 thalers surplus (revenue 17,000 thalers, expenditure 10,000 thalers) ; in 1672, 10,433 thalers (revenue 24,539 thalers, expenditure 14,106 thalers); in 1682, 29,058 thalers (revenue 51,959 thalers, expenditure 22,901 thalers; and in 1688, 39,213 thalers (revenue 79,971 thalers, expenditure 40,758 thalers). The net revenue of the posts was generally devoted to the payment of State officials, to the improvement of means of communication (building of canals, etc.), and to beneficence. For example, the Elector, during the severe illness of his first wife, made a vow to found an almshouse and ordered 6,000 thalers yearly to be assigned for its support. Of this sum 2,000 thalers were laid on the post revenues.-Ibid., p. 60 . 
from Berlin to Frankfort, was 2 groschen, and from Berlin to Magdeburg, $1 \frac{1}{2}$ groschen. ${ }^{x}$

With the growth of commerce and the establishment of the travelling post and parcel post, the service became more and more successful financially. In 1695 the expenses represented some 50 per cent. of the gross revenue. By 1712 they had fallen to some 41 per cent. The gross revenue was at the same time rapidly increasing. The net revenue, which was, of course, increasing still more rapidly, was in 1695 about 62,000 thalers, and by 1712 had risen to some 137,000 thalers.

The rates of postage were modified in 1699, and again in 1712; but as the old rates were retained as the basis of both revisions, the charges remained for fifty years substantially unchanged. A letter from Berlin to Hamburg now cost $2 \frac{1}{2}$ groschen, to Bremen 3 groschen, to Dresden 2 groschen, to Frankfort-on-Main 3 groschen, and so on.

During the next fifty years prices were gradually, but steadily, rising in Prussia. The Seven Years' War produced a sudden and very considerable rise in the prices of all agricultural products. And not only did the purchasing power of money fall owing to the scarcity and high price of provisions, but its value also decreased through depreciation. $^{2}$ The cost of conducting the postal service rose correspondingly, and the financial difficulties were increased owing to the falling off of traffic consequent on the war. At the end of 1761 the King was asked to agree to a contribution in aid, but assistance was not forthcoming. Something had to be done; and on the 27th January 1762, in common with the general increase of taxation, the rates for parcels and for value letters were increased 100 per cent. ; the travelling post rates, which varied from 3 to 4 groschen per mile, were increased by 1 groschen per mile; and the fees for guides, which were about 6 groschen per station, by about 2 groschen per station. The letter rate remained unchanged.3

I A groschen was roughly the equivalent of a penny. The value of money was then about four times its present value.

2 The price of a bushel of rye in Berlin, which from 1740 to 1756 had varied from 23 groschen to a thaler, rose to 4 thalers.

3 The edict of the 27th January proclaiming the higher rates remarked that the raising of the letter rate would be detrimental to the public and prejudicial to the credit of the service, and that " in spite of the high price of corn and the 
In the early part of 1766 a new tariff was introduced. The rates for parcels fixed in 1762 were maintained, and new and higher rates for letters were introduced. The increase in the general rates varied from about 15 per cent. to about 50 per cent. The minimum, which for letters passing between many neighbouring places had formerly been only 6 pfennigs, was increased to 1 groschen.

The raising of the rate led to a large amount of fraud, and caused much public inconvenience. The revenue did, indeed, increase in the first year quite appreciably; but in the second and third years, instead of the normal yearly increase, there was a notable decrease. Complaints against the new rates were widespread, and it was alleged that the increased charges embarrassed commerce. In 1770 the rates for heavy letters, printed matter, and documents were reduced again to those of 1712. The rates had previously been based on a variety of considerations, ${ }^{\mathrm{I}}$ but this miscellaneous basis was now put aside and a uniform system established, the same letter rate being applied throughout the State.

The coinage edict of 1821 , by which the thaler' wạs divided into 30 silver groschen instead of 24 groschen às previoủsly; made necessary an alteration of the postage charges, and amended rates were established on the 1st January 1822. No account was taken of a less amount than a half-groschen, and odd amounts were reckoned at the next half-groschen above, with the result that in certain cases the rate became higher than formerly.

A reduction of the rates of postage was in contemplation, but while the discussions on the proposals were in progress, the State finances became somewhat straitened. It became necessary to look about for fresh revenue, and a Commission appointed to consider the question recommended depreciation of money, raising of the letter rate could not be thought of, and that in the neighbouring States this measure, however soon it might be set aside, had worked to their disadvantage."-H. von Stephan, op. cit., p. 292.

x "The encouragement of a particular business or manufacture in a particular place; the better opposing of the competition of a neighbouring route; tenderness for existing difference in newly acquired districts; the difference in the price of corn in a province, and at an earlier date even of money, weight, length of the miles, as also, in the case of travelling post charges, the season of the year; all these circumstances were often brought into consideration in the fixing of postage rates."-Ibid., p. 296. 
that more revenue should be obtained from the Post Office. The Postmaster-General pledged himself to bring up the surplus from 700,000 or 800,000 thalers, where it then stood, to a million, and, if possible, to $1,200,000$ thalers. Accordingly, in 1824 the rates of postage were revised, and, in general, increased. In many cases the increase was as much as 20 per cent., and the tariff as a whole was the highest ever fixed in Prussia. The chief characteristics of this important change were that letter and parcel rates were reckoned according to the direct distance (Luftlinie) between the post offices, and not according to the distance by way of the post routes, or the time occupied on the journey, or any of the other considerations which had previously entered into the reckoning. All special rates for individual routes and places were abolished.

The new rates were, for a single letter not exceeding $\frac{3}{4}$ loth ( $\frac{3}{8}$ ounce) in weight-

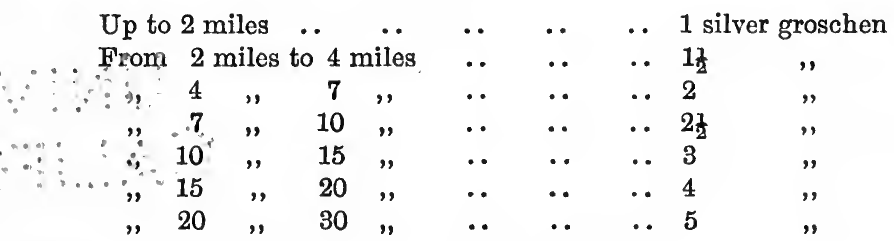

and for each 10 miles further, 1 silver groschen more.

A map of distances was prepared, and every post office was furnished with a table compiled from this map, showing the distances between that office and all other post offices in Prussia, together with the corresponding rates of postage. ${ }^{\mathrm{x}}$ Formerly, direct rates of postage existed only between a limited number of post offices, and letters for any other places were charged an additional rate (Binnenporto) in respect of the distance not covered by the ordinary rate. This charge was now abolished. Each post office could calculate the rate to any other post office by means of its table of rates. There was, however, an additional charge (Landporto) in the case of places at which there was no post office, but which were

I The ascertainment of the direct distances was commenced in 1823. It was completed in a year and a half (including two revisions), and a map of distances prepared. There were 1,386,506 distances to measure, and the measuring was done by land surveyors. The distances so measured were tabulated for practical use by postal officials.-H. von Stephan, op. cit., p. 746, n. 3 ; Moch, Archiv für Post und Telegraphie, 1893, p. 2. 
situated on the post routes. It was arranged that letters might be despatched to or from such places so long as the post-messenger was not thereby delayed on his journey, and for the forwarding of any such letters to or from the nearest post office the lowest rate of postage was charged, reckoned as from the nearest post office. Letters up to 1 ounce in weight were sent by riding post. Letters exceeding 1 ounce in weight were sent by parcel post (Fahrpost), and were charged the corresponding rate, unless the sender expressly requested transmission by riding post.

For the longer distances the rates were higher than previously. The rate for the greatest distance within the Prussian postal territory, which under the old rates was 18 silver groschen for a single letter-that is, for a letter up to $\frac{3}{8}$ ounce in weight-was now 19 silver groschen. The reduction was greatest for letters going only short distances. The rate for the shortest distances was reduced from $1 \frac{1}{2}$ silver groschen to 1 silver groschen. But the higher rates applied to letters passing between the great centres, and these formed the greater part of the whole number. In addition, the progression of the scale of weights was made very rapid. From the earliest days of the Post Office in Prussia the progression of weight had been by the half-ounce, and this had not been changed even in 1766. The scale was now made-

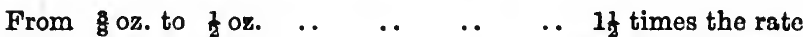

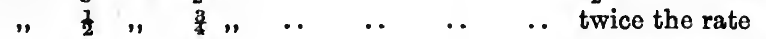

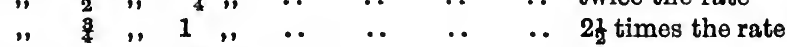

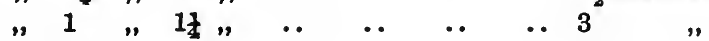

$$
\begin{aligned}
& \text { " } 1 \frac{1}{1}, \quad 1 \frac{1}{2}, \quad \ldots \quad \text {. }
\end{aligned}
$$

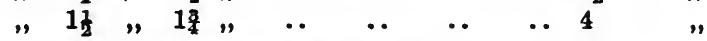

and so on for each quarter-ounce a half rate more.

The year 1824 was also noteworthy for the experimental establishment in the district of the Frankfort-on-Oder post office of a rural delivery system. This was the first step towards the general extension of the rural delivery throughout Prussia. The experiment was successful, and the system was extended in the following year. For delivery by the rural

3.The rates were to be rounded up. One or 2 pfennigs were to be counted as 3 pfennigs, 4 or 5 pfennigs as 6 pfennigs, 7 or 8 pfennigs as 9 pfennigs, and 10 or 11 pfennigs as 1 silver groschen. 
letter-carriers an additional charge was made for each letter, according to the following scale :-

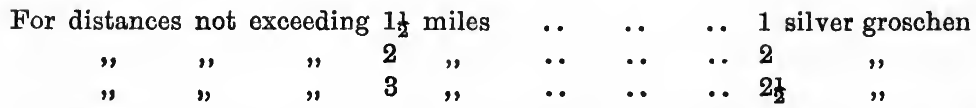

For the longer distances the rates of 1824 were found to be oppressive for ordinary letters, and burdensome to commerce and literature. Financially also the increase was not a success. For 1824, the last year of the old rates, the surplus was 823,229 thalers, an increase of 100,325 thalers over the surplus of 1823. The surplus for 1825, the first year of the new rates, was $1,121,616$ thalers, an increase of 298,387 thalers over the surplus of 1824. Apparently, therefore, the new rates had produced an immediate increase of net revenue. This was, however, not the case. While the actual proceeds of postage in 1824 were 73,152 thalers greater than in 1823, the proceeds of postage in 1825 were only 80,890 thalers greater than in 1824. ${ }^{\mathrm{I}}$ The increased yield of postage was therefore quite small. And even this small increase disappeared in 1826. For that year the yield of postage was only 40,547 thalers greater than in 1825, and in 1827 there was an actual falling off of 41,942 thalers. The increase of net revenue was therefore attributable to other causes. Thus, for example, in 1825 , by some means or other, a reduction of no less than 136,160 thalers was effected in the expenses of the service.

The rates were soon found to need amendment. Changes were made in the subsidiary rates, the rates for commercial papers, for magazines, etc., but the letter rate remained unchanged until 1844, when a considerable reduction was made. The following rates for a single letter (not exceeding $\frac{3}{8}$ ounce in weight), were established :-

\begin{tabular}{|c|c|c|c|c|c|c|c|c|c|}
\hline \multirow{2}{*}{\multicolumn{5}{|c|}{$\begin{array}{l}\text { Not exceeding } 5 \text { miles .. } \\
\text { From } 5 \text { miles to } 10 \text { miles }\end{array}$}} & .. & .. & .. & \multicolumn{2}{|c|}{1 silver groschen } \\
\hline & & & & & . & .. & .. & $1 \frac{1}{2}$ & ", \\
\hline ", & 10 & " & 15 & $"$ & $\cdots$ & . & .. & 2 & ", \\
\hline " & 15 & , & 20 & , & . & .. & .. & $2 \frac{1}{2}$ & , \\
\hline , & 20 & $"$ & 30 & $"$ & $\cdots$ & $\cdots$ & $\cdots$ & 3 & ", \\
\hline , & 30 & $"$ & 50 & $"$ & . & .. & .. & 4 & , \\
\hline$n$ & 50 & ," & 100 & $"$ & . & .. & .. & 5 & , \\
\hline
\end{tabular}

For each further 100 miles within the

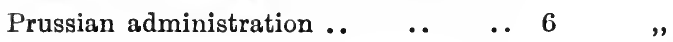

I H. von Stephan, op. cit., pp. 760 and 761 . 
These rates were applied to letters, printed matter sent under band, and letters containing samples of merchandise. It was estimated that this change would reduce the gross receipts from postage by 700,000 thalers, and the net revenue for 1845 was estimated at 700,000 thalers instead of $1,400,000$ thalers. The actual decrease in 1845 in the gross receipts from postage was, however, only 302,563 thalers, and the actual falling off in net revenue only 346,208 thalers. The gross revenue soon recovered, and in 1847 exceeded that of $1844 .^{\mathrm{I}}$

The Prussian administration, while not prepared to introduce complete uniformity of rate irrespective of distance, were yet desirous of simplifying the rates, and of removing from them any trace of the fiscal tradition, so far as this course could be followed without involving serious sacrifice of net revenue. ${ }^{2}$

In September 1848 the distinction between the letter rate and the rate for printed matter and documents was abolished, and on the 1st October 1848 the following scale of weights for all letters, publications, etc., was introduced, viz.:-

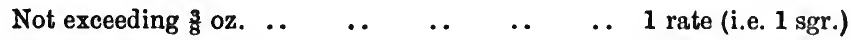

$$
\begin{aligned}
& \text { From } \frac{3}{8} \text { oz. to } \frac{1}{2} \text { oz. } \quad . . \quad \ldots \quad \text {.. } \quad \text {.. } \quad \text {.. } 1 \frac{1}{2} \text {, }
\end{aligned}
$$

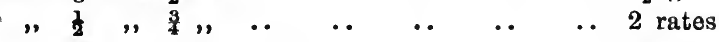

$$
\begin{aligned}
& \text {, } \quad \begin{array}{lllllllllll} 
& 3 & 1 & 1 & \ldots & \ldots & \ldots & \ldots & \ldots & 2 \frac{1}{2},
\end{array}
\end{aligned}
$$

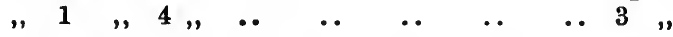

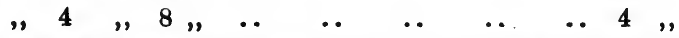

and over 8 ounces 4 rates, until the charge was less than double parcel rate.

The rates were still based on the old theory of distance. The Prussian administration feared that a complete reform

I This does not take into account the normal yearly increase, which was 120,000 thalers under the old rates. If that be taken into account there was still a loss in 1847. Thus:-

\begin{tabular}{c|c|c|c}
\hline Year. & $\begin{array}{c}\text { Probable Gross Postage } \\
\text { Receipts under Old } \\
\text { Rates. }\end{array}$ & Actual Yield. & Loss. \\
\hline 1844 & $4,765,000$ & $4,628,133$ & 136,867 \\
1845 & $4,885,000$ & $4,325,570$ & 559,430 \\
1846 & $5,005,000$ & $4,514,338$ & 490,662 \\
1847 & $5,125,000$ & $4,771,392$ & 353,608 \\
\hline
\end{tabular}

2 Ibid., p. 763. 
of the rates on the English model would have a disastrous effect on the postal revenue, and so upset the equilibrium of the State finance. They had, of course, the experience of England to guide them, and they had not failed to note the large reduction of net revenue which the adoption of the reform of 1840 had entailed. In the following year, however, a great step was taken in the direction of the new system. By the law of the 21st December 1849 the following simplified rates of postage, to take effect from the 1st January 1850, were established:-

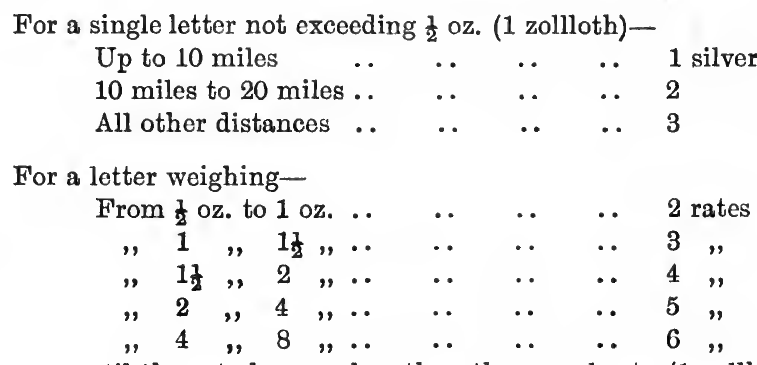

and so on, until the rate became less than the parcel rate $\left(1\right.$ zollloth $=1 \frac{1}{8}$ loth $)$.

The reductions in Prussia were in all cases made with careful regard to the possible financial results. The desire to remove all trace of the fiscal tradition did not extend to a desire to relieve the Post Office of its revenue-producing function, and the actual loss of net revenue which resulted in Prussia from the introduction of cheap postage was much less than the loss in England. ${ }^{x}$ The set-back to the revenue consequent on the reduction of 1844 was recovered in 1847 ; the set-back consequent on the reduction of the rates of value letters and parcels in 1848 (on the average some $66_{3}^{2}$ per cent.) was recovered in 1852 ; and that occasioned by the reform of the 1st January 1850 was recovered in 1853. But the reform of 1850, which retained the three distance charges, was far from being a complete reform of the character of that in England.

× "Die preussische Postverwaltung war bei Einführung der weitgreifenden Taxermässigungen mit grosser Vorsicht und mit weiser Berechnung aller in Betracht kommenden Vorstände schrittweise zu Werte gegangen und hatte die Erleichterungen ohne bedeutender Opfer aus der Postkasse erkauft." Moch, Archiv für Post und Telegraphie, 1893, p. 40. 
No change of importance was made in the ordinary letter rate between 1850 and 1860 . In the latter year the maximum weight for packets passing by letter post was fixed at half a pound (15 loth). ${ }^{\mathrm{A}}$ A further step towards simplicity and reduction of the letter rate was taken in 1861,2 when the weight scale was revised and the three steps established in 1849 abolished, two only being substituted. Letters up to half an ounce in weight were to pass at the single rate, and letters exceeding that weight at double rate. The three distance zones were maintained.

The special fee for delivery which was collected from the addressee by the post office of destination was still in force. It was, of course, in effect, an increase of the normal rate of postage, and as such it lay as a heavy burden on the letter traffic. In the case of packets of printed matter not exceeding half an ounce in weight it amounted to 100 per cent. on the normal rate. It was, moreover, disproportionate to the cost of the service of delivery.3 Since 1850 the Prussian administration had incessantly urged the abolition of the charge. Special charges for delivery had already been abolished in England, in France, and in other of the larger States: The efforts of the administration were, however, frustrated by the Minister for Finance, who was unable, from regard to the needs of the national exchequer, to abandon the revenue obtained from this source. These financial considerations delayed the abolition of the charge by at least a decade.4 The existence of the charge was found to be especially unfortunate in regard to foreign letters, since its collection was regarded by foreign administrations as an addition to the ordinary postage and consequently an evasion of the terms of agreements under which foreign rates had been fixed. The charge was ultimately abolished in 1862.5 In order to avoid inconvenient reduction of revenue, it was arranged that the abolition should be effected gradually: for certain classes of traffic as from the date of the coming into force of the Act, for other classes as from the 1st July 1863, and for the remainder as from the 1st July 1864.

I Regulation of 21st December 1860.

2 Law of 21st March 1861.

3 Moch, Archiv für Post und Telegraphie, 1893, p. 42.

4 Ibid.

5 Law of 16th September 1862. 
The political events of the years 1864 and 1866 occasioned far-reaching modifications of the postal service in Germany. After the expulsion of Austria from the German league, Prussia took over the administration of the postal service in the duchies of the Elbe. Prussia had also absorbed the kingdom of Hanover. The territory of the Prussian postal administration was thus largely extended; and in addition the Prince of Thurn and Taxis relinquished in favour of the Crown of Prussia the control which he had exercised over the postal service in eighteen States. ${ }^{\mathrm{I}}$

The North-German Union was established in 1867, and the postal arrangements for the whole territory of the Union were unified. Up to this time ten independent postal administrations had existed in this territory, ${ }^{2}$ and the rates of these administrations differed in various particulars. The Prussian rates were applied temporarily to all postal traffic passing between the old and new Prussian territories, and the rates of the Union service were applied to traffic passing between the territories forming the NorthGerman Union.

The continuance of these conditions was not consistent with a unified administration of the postal affairs of the whole North-German Union, and a reform of the rates became necessary. Germany was in 1867 almost the only one of the great States of the world which still maintained a scale of rates of postage for letters graduated according to distance. Prussia had already repeatedly endeavoured to introduce the principle of uniformity of rate irrespective of distance which had been adopted by all others, or at least to secure further simplification; but advance in this direction had always been hindered by financial considerations. 3 The political developments now opened the way for a thorough reorganization of the rates, and this was achieved by the law of the 4th November 1867. This law, which took effect from the 1st January 1868, established uniform rates for letters, irrespective of distance, of the following

x Law of 16th February 1867. See infra, Appendix, p. 355.

2 Prussia, Hanover, the two Mecklenburgs, Oldenburg, Brunswick, Saxony, Hamburg, Bremen, Lubeck, and the Thurn and Taxis posts.

3 Moch, Archiv für Post und Telegraphie, 1893, p. 44. 
amounts -1 sgr. (= 10 pf.) for letters not exceeding half an ounce in weight, and 2 sgr. for all letters of greater weight.

After the refounding of the German Empire in 1870, there was fresh legislation in regard to the Post Office. ${ }^{I}$ Among other changes, the limit of weight for the single letter was fixed at 15 grammes, and the limit of maximum weight at half a pound. This law also abolished the charge for rural delivery, a long-desired reform which had been frequently urged upon the Reichstag. In order to assist further the interests of residents in the country, it was arranged that on payment of a monthly fee of $5 \mathrm{sgr}$. letters might be handed to and delivered by the post messenger, in a closed pouch, at places on his route.

The rates established under this law have remained in operation substantially unchanged up to the present time. The most important modification was made in 1900, when the maximum limit of weight of the single letter was raised from 15 to 20 grammes. Under these rates the letter post has developed continuously. In 1872 the total number of letters passing by post within the territory of the Imperial Post Office was 422 millions, and in 1910 the number had increased to 2,026 millions. As in other countries, the letter rate has proved extremely profitable. The net revenue of the Imperial Post Office in 1872 amounted to 4.7 million Marks, and in 1910 to 88 million Marks. In Germany, however, the railways are State-owned, and the Imperial Post Office is not required to pay to the railways a full equivalent for the services performed. The value of the service performed by the railways on behalf of the Post Office for which no charge is made against the Post Office is not definitely known. ${ }^{2}$ The newspaper traffic, the parcel post, and the Imperial Telegraph Service are carried on at heavy loss. The Post Office also performs numerous services, such as those in connection with the National Insurance schemes, for which it receives no monetary credit; and there is no doubt that taken by itself the letter traffic

- Law of 28th October 1871.

2 For 1906 it has been estimated at 41,693,017 M. P. Ullrich, Dis Finanzen der Reichs-Post und Telegraphen Verwaltung, Stettin, 1913, p. 54, n. 5. 
is largely profitable at the existing rates, even when full allowance has been made for all legitimate charges against the service.

\section{Note on Rural Delivery}

Until the eighteen-thirties there was no State provision for the letter traffic in country districts. Residents in the country must deliver all their letters at, or fetch them from, the nearest post office, which was done on market-day or by messengers. In 1824 a beginning was made in Prussia by the introduction experimentally of a delivery service at certain post offices. In the following years the number of rural deliverers and the number of posting-boxes in the villages were increased, and a uniform delivery fee (Landbestellgeld) of 1 silver groschen instituted. The delivery fee was abolished on the 1st January 1872 (law of 28th October, 1871). This meant the abandonment of a yearly revenue of $1 \frac{1}{2}$ million Marks.

In spite of the increase in the number of post offices there were still in 1880 as many as 19 million people, the greater half of the whole nation, and 17,000 localities, outside the limits of the postal service. I

In 1880 a great step forward was taken. The number of rural deliverers was largely increased, and also the number of postal stations in the country (Posthülfstellen).2 A daily delivery was extended to the greater number of places, the rural routes in most cases being so arranged that the deliverer returned by the same route, thereby enabling an answer to be sent the same day to letters received on the outward journey.3

× J. Jung, Entwickelung des deutschen Post und Telegraphenwesen in den letzten 25 Jahren, Leipzig, 1893, p. 45.

2 The following table (J. Jung, loc. cit.) shows the increase in the number of rural deliverers:-

$\begin{array}{lccccc}1868 & 1870 & 1875 & 1880 & 1885 & 1891 \\ 8,021 & 8,334 & 11,405 & 11,480 & 20,386 & 25,649\end{array}$

3 In a number of cases the deliverer was provided with a vehicle for the sake of speed, and worked out from the railway. In 1898 there were 2,365 such services.-Handwörterbuch der Staatswissenschaft, Jena, 1901, p. 137. 


\section{THE RATE FOR NEWSPAPERS}

\section{NEWSPAPER POST' IN ENGLAND}

IN England newspapers have enjoyed special privileges in regard to transmission by post since about the middle of the seventeenth century. The origin of the privilege is to be looked for in the special circumstances under which the early newspapers, and the newsletters and newsbooks from which they were derived, were issued, and the means by which the news included in them was obtained.

At that period the post was the chief means by which news could be collected or distributed. The newsletters were distributed by post, ${ }^{\mathrm{I}}$ and the news which they contained was for the most part obtained through the agency of the Post Office from correspondents in various parts of the country. It was, indeed, an important part of the function of the Post Office to furnish news to the Court, and to the other departments of State, as well as to the general public. ${ }^{2}$

× “There was a profession of 'news writers,' or correspondents, who collected such scraps of information as they could from various sources, and for a subscription of three or four pounds per annum sent them every post-day to their employers in the country."-A. Andrews, The History of British Journalism, London, 1859, vol. i. p. 14.

2 E.g., "To Mr. Neale, Deale, 27 Nov. 1674.

“. . You should give me a Constant Accompt (as $\mathrm{m}^{\mathrm{r}}$ Lodge was wont to doe) of all Newes that happens in your Parts. It is Expected from me at Whitehall, and muoh wondered at, $\mathrm{y}^{\mathrm{t}}$ my officers doe not give me $\mathrm{y}^{\mathrm{e}}$ first, and best Accompt of all that Passes, all Newes, Comeing (Probably) first to theire hands. I Pray be Carefull, and punctuall herein hereafter. I shall be ready, in all things (as I have bin) to shew myself

-Documents from Peover Hall, British Official Records.

"Yrs, \&c." 
In 1659 General Monck appointed Henry Muddiman, a journalist who had already issued the Parliamentary Intelligencer and the Mercurius Publicus, to write on behalf of the Royalist cause. In consideration of his services he was, after the Restoration, given the privilege of free transmission for his letters. ${ }^{x}$ This gave him an advantage over other journalists, and his newsletters and newsbooks became extremely popular. In 1663, however, he was supplanted by Roger L'Estrange, a Royalist who had not to that time been properly recompensed for his faithfulness. L'Estrange was an able writer, who after the passing of the Licensing Act of 1662 had been requested to draw up proposals for the regulation of the Press. As a reward for his services in that connection he was given the office of Surveyor of the Press, his remuneration being the sole privilege of writing and publishing newsbooks and advertisement. L'Estrange also secured the privilege of free postage from Lady Chesterfield, one of the farmers of the Post Office. ${ }^{2}$

L'Estrange's privilege put an end to Muddiman's newsbooks, but in no way interfered with his newsletters and his right to free postage. He was able, therefore, to continue

"The Post Office Packets in those days were carriers of news as well as of the mails. The officers had instructions to record most carefully in their journals full details of any events of public importance occurring in the countries which they visited. These journals, which frequently contained news later and more authentic than any which had yet reached London, were sent up from Falmouth immediately after the arrival of the Packets, and lay at the Post Office open to the inspection of the merchants."-A. H. Norway, History of the Post Office Packet Service, London, 1895, p. 37.

"An old instruction was renewed in 1812, that all postmasters should transmit to me (the Secretary), for the information of his Majesty's Postmaster-General, an immediate account of all remarkable occurrences within their districts, that the same may be communicated, if necessary, to his Majesty's principal Secretaries of State. This has not been invariably attended to, and I am commanded by his Lordship to say, that henceforward it will be expected of every Deputy."-Cited (without giving source) by J. W. Hyde, A Hundred Years by Post, London, 1891, p. 91.

"The mail-coach it was that distributed over the face of the land, like the opening of apocalyptic vials, the heartshaking news of Trafalgar, of Salamanca, of Vittoria, of Waterloo."-De Quincey, The English Mail-Coach.

I "As it seems clear that the 'Remonstrance' (The Remonstrance and Address of the Army) was framed by Clarges, Henry Muddiman must have settled its wording and final form, as he did that of many other documents. . . . For this reason, after the Restoration, he became sole privileged journalist of the kingdom, and was granted the privilege of free postage for his letters like the officers of State."-J. B. Williams, A History of English Journalism, London, 1908, p. 176.

2 Calendar of State Papers, Charles II, vol. 139, No. 61. 
his newsletters, and did so with great success. After the Restoration Muddiman had attached himself to Sir Edward Nicholas, one of the principal Secretaries of State, and his Under-Secretary, Joseph Williamson, from whom he had been in the habit of obtaining part of his news. Williamson was a grasping man, who became jealous of the success of the newswriters, and finding that L'Estrange was unpopular, .conceived the idea of getting the control of the whole ‘business into his own hands. He therefore suggested that Muddiman should go to Oxford, where the Court had removed owing to the plague, and publish a new journal in opposition to L'Estrange. While Muddiman was at Oxford, Williamson would obtain by an agent in the Post Office, James Hickes, the names of all his correspondents. ${ }^{x}$ The plan was eminently successful, and on the 16th November 1665 the Oxford Gazette appeared, to be transformed a few months later, with its twenty-fourth issue (5th February 1665-6), into the London Gazette. Muddiman, however, gained knowledge of Williamson's designs regarding his correspondents, and on the 8th February 1666 left the Gazette. Williamson thereupon took control of its publication, and, with the assistance of Hickes, continued its issue. $\mathrm{He}$ appointed correspondents in all the leading seaports, and in a few other English towns, and also in continental cities, who were required to furnish accounts of passing events. In return for their services the correspondents received regularly copies of the Gazette. Both the letters from correspondents and the Gazettes which were their reward passed free of postage. ${ }^{2}$ The regularl supply of a copy of the Gazette was so great a privilege that it was often regarded as sufficient wages for a post-messenger or even a deputy-postmaster. 3

J. B. Williams, A History of English Journalism, p. 190.

- Calendar of State Papérs (Domestic Series), 1665-6, p. viii.

3 "I find that the South Wales maile is much retarded in your Stage; particularly that $\mathrm{y}^{\mathrm{x}}$ riding sorvant calles at severall places by $\mathrm{y}^{\mathrm{e}}$ way; and that you allow him noe other wages, but what heo getts (by a Gazette News-letter, wch you give him ye benefitt of) from severall Gentlemen near ye Roade, and this hinders $\mathrm{y}^{\mathrm{e}}$ due course of the post, not only to $\mathrm{y}^{\mathrm{e}}$ Damage and discreditt of $\mathrm{y}^{\mathrm{e}}$ office, but to $\mathrm{y}^{\mathrm{e}}$ prejudice of publique businesse; it is much complained of and I canot longer dispence with it; wherefore I Give you this freindly admonicon and remaine

"Yox, etc.

“Mr. Davyes, Feb. 8th, 1672."-Doouments from Peover Hall, British Official Records. 
This became a recognized practice before the end of the seventeenth century, and the privilege was regarded as forming part of the ordinary emoluments of the deputypostmasters. ${ }^{\text {I }}$ The Gazettes were sent out from London by officers known as Clerks of the Road, under the frank of these officers; and the privilege of franking these Gazettes became extended so that the Clerks of the Road ultimately became entitled to frank any newspaper to whomsoever addressed.2 In the eighteenth century the Clerks of the Road developed the exercise of their privilege. They accepted subscriptions and undertook the supply of newspapers generally throughout the country. They became, in fact, newsagents. Their newspaper business was something quite apart from their duties as officers of the Post Office. It was conducted in a separate building, by a separate staff, and they found it very lucrative. 3 The postage on newspapers at the letter rate would have been prohibitive. Hence newspapers either went under frank or did not go by post at all, and the whole business of distribution through the post fell into the hands of the Clerks of the Road. Their

"I am clearly of your opinion, that Hercford and the Hay is ye best roade for the Pembroke Maile, the onely difficulty will be to bring you and Mr. Phillpotts to reason. ...

"I pray consider these 2 Points, that $y^{\mathrm{e}}$ Hay being in your Branch will much Encrease your share, and it is easier to send thither than to Abergaveny -if you will joyne Issue in this Proposall I will give $y^{\mathrm{e}}$ Contrey $\mathrm{y}^{\mathrm{e}}$ Satisfaction to turne the Roade that Way; and by ye tyme I have your answer I shall be ready, to give directions for the Change; you must provide a fitt person, to keepe the office at Hay and for his Encouragem ${ }^{t}$ I will send him a Gazette by every Post, few of $y^{\mathrm{e}}$ By offices expect more, and some make great Suite and would pay money for the Imployment. I pray close $w^{\text {th }}$ me herein, being desirous to Continue-I pray give me your opinion of sending $y^{\mathrm{e}}$ Maile into Wales 3 tymes a weeke, as I doe to all other places.

"I am, Yrs, etc.

“Mr. Awbrey, Brecon, 1st April, 1675."-Documents from Peover Hall, British Official Records.

1 H. Joyce, History of the Post Office, p. 50.

2 Tenth Report of the Commissioners on Fees and Emoluments, 1788, p. 28.

"For Post Office purposes the kingdom was divided into six roads-the North Road, the Chester or Holyhead Road, the Western Road, the Kent Road, and the Roads to Bristol and to Yarmouth; and these roads were presided over by a corresponding number of clerks in London, whose duty it was to sort the letters and to tax them with the proper amount of postage."-H. Joyce, ibid., p. 47 ; cf. infra, Appendix B, p. 404.

3 Eignteenth Report of Commissioners of Revenue Inquiry, 1829, Appx., p. 486. 
profits were in part applied to the discharge of certain payments-the salaries of some of the inferior clerks and some charitable payments-in connection with the Post Office. ${ }^{I}$

In 1764 the privilege was explicitly recognized by statute, ${ }^{2}$ but the same Act gave a severe blow to the whole system by authorizing members of Parliament to send newspapers free of postage. The members did not confine the exercise of the privilege to newspapers sent by or to them for their own use, but granted orders for free postage to booksellers and newsagents on a liberal scale. 3 The booksellers naturally

2 "That the six Clerks of the Road are also allowed to frank newspapers from the London office.

"That the newspapers franked by them are not included in any of the accounts of Deductions in respect of Franks. That the profits arising from their franking newspapers may amount to $£ 3,000$ or $£ 4,000$ p. ann., and that a considerable allowance is made thereout to the Comptroller, Deputy-Comptroller, By Night Clerk and six assistants; all of whom as well as the six Clerks of the Roads would without such advantage be very insufficiently provided for." Evidence of Anthony Todd, Secretary to the Post Office. Report of Committee appointed to enquire into the several frauds and abuses in relation to the sending or receiving of letters and parcels free from the Duty of Pustage (Commons Journal, March 28, 1764).

"The Profits derived by the Clerks of the Road from the privilege of sending Newspapers into the Country free of Postage, were so considerable that they were not only able to make a good Provision for their Families but also to pay thereout an Annual Sum of $£ 1,300$ to Officers and Clerks in this Dept. in Aid of their Salaries, which on that Account were proportionately small from the Public ; and this Situation of Clerk of the Roads was looked up to as the Reward of their long and arduous Labour in the subordinate Stations of the Office. Twenty years before, of the sum of $£ 8,660$ paid to the 39 Officers of the Inland Dept., $£ 2,060$ was paid by the Public and $£ 6,600$ from the profits on the circulation of newspapers."-Tenth Report of the Commissioners on Fees and Emoluments, 1788, p. 28.

$=4$ Geo. III, cap. 24.

3 "The Produce of this Privilege has long been decreasing, and is now reduced to one-third the above sum from the operation of an Act of 1764 by which members of both Houses were empowered to have Newspapers, Votes, and all other printed Parliamentary Papers, sent by post in their Names, free from Postage, upon a written Notice of the Direction of such Papers being sent to the Postmaster-General by the respective Members, whose names were to bc used instead of the former Mode of franking Newspapers the same as Letters. The Printers, News Sellers, and others, availing themselves of this Privilege, have obtained numerous Orders, readily granted, under the Persuasion of increasing the Stamp Revenue. The present Number of Orders in the Office is 6,751, and the Number of Newspapers sent weekly by the Post in Consequence thereof is 47,017 ; these Dealers are enabled to supply their Customers in the Country at a cheaper Rate than the Clerks in the Office can, who are loaded with Out Payments from their Profits, and are obliged to purchase their Papers at an advanced Price from an Officer appointed by the Postmaster-General to supply them."-Tenth Report of the Commissioners on Fees and Emoluments, 1788, p. 29. 
cut the prices charged by the Clerks of the Road. The charge of the latter had been $£ 5$ a year for a daily paper, and £2 10s. a year for an evening paper. The booksellers in 1770 advertised a charge of $£ 4$ a year for a daily paper, and 22 a year for an evening paper. ${ }^{\mathbf{I}}$ As a result a large part of the traffic went to the booksellers, and the profits of the Clerks of the Road fell so rapidly that it was soon found necessary to relieve them of the charges on their profits. ${ }^{2}$

Efforts were made to check the abuse of the privilege of franking of newspapers held by members of Parliament under the Act of 1764. An Act of 1802 (42 Geo. III, cap. 63) required not only that the member should sign the newspaper packets, but that the whole superscription, together with the date of posting and the name of the post-town in which the paper was intended to be posted, should be in his handwriting. The member must, moreover, himself be in the post-town where the paper was posted on the date shown on the paper. These regulations were not long maintained. They were probably too stringent to be enforced, and in the course of a few years the appearance on the newspaper or wrapper of any member's name, whether written by himself or by any other person, or even printed, was sufficient to secure free transmission through the post. In 1825 the conditions were definitely repealed, and newspapers became legally entitled to free transmission by post. 3

There were reasons why the Government and the Post Office did not suppress the extension of the privilege accorded to newspapers. At this time heavy general taxes

A. Andrews, The History of British Journalism, London, 1859, vol. i. pp. 210-11.

2 "The Postmaster-General, sensible of this Diminution, lately directed the Payments thereout to the other Officers and Clerks in the Office to be discontinued, and reimbursed some of them out of the Revenue; but this is not the only Expence to which the Public is subjected by the Increase of these Orders. The Number of Newspapers to be forwarded every Night is now so great, that ... a separate Office is allotted . . . and 18 Extra Persons are employed, at an Annual Expence of $£ 100$, to perform the Duty of sorting and packing up the Newspapers ; besides it is in Proof that Letters and written Papers are frequently enclosed in them, by which the Revenue is defrauded, without a Possibility of Prevention, while the present Mode continues; as the number is by far too great to admit of a general Search for Enclosures."-Tenth Report of the Commissioners on F'ees and Emoluments, 1788, p. 29.

36 Geo. IV, cap. $68, \S 10$. 
were imposed on newspapers-the paper duty, the advertisement duty, and the stamp duty.

These charges had been first imposed in the early years of the eighteenth century, when newspapers were changing character, and they were in the nature of restrictions on the liberty of the Press, a continuation of the restrictions which had previously been maintained by means of Licensing Acts. ${ }^{x}$ Newspapers were at that time ceasing to be mere chronicles of events, and were beginning to publish comments and to criticize persons and parties. A Bill to impose a tax of $1 \mathrm{~d}$. a copy on all periodical publications was brought into Parliament in 1701, but was abandoned owing to the opposition of the newspaper proprietors, who represented that they were in the habit of selling their papers at a $\frac{1}{2} \mathrm{~d}$. a copy. ${ }^{2}$ In 1712 a message from the Crown, adverting to the undesirable character of the new development of newspaper enterprise, recommended that a remedy be found without delay. The result was the imposition of a stamp duty of $\frac{1}{2} d$. the sheet on all newspapers of a sheet and a half. 3 The privileges with regard to their transmission by post were, however, in no way interfered with.

In 1776 the tax was raised to $1 \frac{1}{2} \mathrm{~d}$. a copy, in 1789 to $2 \mathrm{~d}$., in 1794 to $2 \frac{1}{2} \mathrm{~d}$., and in 1815 to $4 \mathrm{~d}$., at which amount it stood until 1836. In 1819 onerous restrictions with regard to registration, bonds, and sureties were imposed, mainly with the view of preventing the issue of publications of undesirable character. 4

" "Was there no way by which, without the necessity of constant contention, private men might be prevented from using the Press to make their opinious public? The pamphleteers were not rich, but they were often persons of education, and not penniless. When only a few copies of their writings were wanted they could pay for them, but now that reading was become more common, and that great numbers of copies were printed, the cost had, to a great extent, to be paid. by the readers. If these sheets could be taxed their distribution might become difficult, and when any one attempted to evade the tax he could be punished, not as a libeller, but as a smuggler." - Collet Dobson Collet, History of the Taxes on Knowledge, London, 1899, vol. i. p. 7.

2 Chambers's Encyclopadia, London, 1908, vol. vii. p. 473.

3 "There was no doubt but that, in the first instance, the stamp duty upon newspapers had been imposed for political purposes."-Attorney-General, 26th March 1855, Parl. Debates (Commons), vol. cxxxvii. col. 1129.

4 “Whereas many papers containing observations upon Public Acts tending to excite the hatred of the public to the constitution of this realm, and also vilifying our holy religion, have lately been published in great numbers, and 
In consideration of these charges the Government were prepared to allow free transmission by post. Moreover, the franking privilege of the Clerks of the Road was favoured as an economy. They argued that as these officers received considerable sums from their newspaper business their salaries from the Post Office were correspondingly low, and if the newspaper business were taken from them it would be necessary for the Post Office to make good the loss in income which they would suffer. ${ }^{\mathrm{I}}$ It would seem that there was at this time no conception of charging a rate of postage on newspapers; and so far the authorities were right in thinking the abolition of the privilege would cause an addition to the expenses of the Post Office, in compensation for which there would be no increase in revenue. Whatever were the taxes paid to other departments, it was clearly in the financial interest of the Post Office, so long as newspapers passed free by post, to retain a system which enabled certain of its officers to obtain part of their income from special arrangements for the distribution of the newspapers, instead of from Post Office funds.

The Clerks of the Road still held an advantage over the ordinary newsagents. The local postmasters acted as their agents, and they had, moreover, the important privilege of posting their papers later. Newsagents were not permitted to post after seven o'clock, but the Clerks of the Road could post as late as eight o'clock. They were able, therefore, to retain a considerable business. In 1829 it was estimated that as many as one-eighth of all the newspapers sent out from London were sent by the Clerks of the Road.2 The privilege of late posting was withdrawn in 1834, and their business then ceased. 3

at a very small price, and it is expedient that the same should be restrained."Preamble of the "Six Acts," 1819.

x "Sir Francis Freeling states that he succeeds to the enjoyment of the privilege of franking which had previously appertained to the situation of the Comptroller of the Inland Office, when he held the situation of Principal and Resident Surveyor, and that it was deemed a measure of economy to provide for the remuneration of this officer by these means in lieu of salary." -Eighteenth Report of the Commissioners of Revenue Inquiry, Post Office, 1829 , p. 26.

2 About 12 millions a year. Ibid., p. 464.

3 H. Joyce, History of the Post Office, p. 419. 
It seems anomalous that at the same time that the Government, with the object of restricting the publication and distribution of newspapers, imposed a heavy stamp duty and a duty on advertisements, they should have assisted, by allowing free transmission by post, the distribution of such newspapers as were able to survive the impositions; but the heavy taxes were intended to prevent the issue of cheap newspapers, and expensive papers could only find sale among those who were not attracted by dangerous doctrines, political or otherwise. I In the view of the Government this aristocratic character ensured, moreover, a high moral tone in the Press. Without such taxes the English Press might become a moral danger and might conceivably sink to the level of the American Press of the day, which, according to some eminent persons, was very low indeed. ${ }^{2}$ The question of free transmission by post received little attention. Chief interest was centred on the allegation that the stamp duty so raised the price of legitimate newspapers as to place them beyond the reach of any but the well-to-do.

The question of allowing the free publication of newspapers, or of, at least, reducing the heavy burdens under which they lay, became urgent after the passing of the Reform Act of 1832.3 The increase in the number of people directly interested in political affairs through the extension of the franchise, and the awakened general interest in social and economic problems, not only produced a great demand for

$x$ "These laws (the Six Acts) wore specially directed-not against the morning Newspapers, which had been cajoled or frightened into comparative silence, or shared in the then general feeling in favour of a 'strong Government'-but against the Radical writers and speakers, 'Cobbett, Wooler, Watson, Hunt,' as Byron reminds us, all of whom had contributed, by cheap political publications and strong political harangues, to raise a demand for reform, loud enough and daring enough to be most troublesome to the authorities."-F. K. Hunt, The Fourth Estate, London, 1850, vol. ii. p. 49.

2 "Newspapers are so cheap in the United States, that the generality even of the lowest order can afford to purchase them. They therefore depend for support on the most ignorant class of the people. Everything they contain must be accommodated to the taste and apprehension of men who labour daily for their bread, and are of course indifferent to refinement either of language or reasoning." - Quoted by Lord Sandon, 20th June 1836; Parl. Debates (Commons), vol. xxxiv. col. 649.

3 The duties on newspapers at that time were (1) the duty on paper, 3d. per pound weight (4d. a sheet), (2) a duty of $4 \mathrm{~d}$. a copy, (3) a duty of $3 \mathrm{~s}$. $6 \mathrm{~d}$. on every ạdvertisement, 
newspapers, but made necessary provision for the dissemination of accurate political intelligence. ${ }^{I}$ Numerous unstamped papers, which found a ready sale, were issued in various parts of the country, in defiance of the law. Thus, in London, one of these papers, The Poor Man's Guardian, an able and "Socialistic" paper, bore on its title-page a notification that it was deliberately published contrary to law, in order to test "the power of right against might." 2

The Government took strong action against such publications. Numerous prosecutions were undertaken, and a large number of persons in various parts of the country were imprisoned; but the circulation of the papers could not be checked. Popular sentiment was largely on the side of the

" "The change which had taken place in the political condition of the country made it essential to communicate to the people sound political knowledge and information. He would say that the security of that House, living, as it did, in the affections of the people-of the Government, possessing, as it did, the confidence of the people-and of the Monarchy, reigning, as it did, and as he trusted it ever would, in the hearts of the people, depended upon the diffusion of sound political knowledge."-Chancellor of Exchequer, 20th June 1836 ; Parl. Debates (Commons), vol. xxxiv. col. 634 .

2 "Many of these publications circulated to the amount of several thousand copies weekly ; their sale, in several instances, was larger than the sale of some among the most popular legitimate papers; their influence over large bodies of the working classes was much greater."-E. Lytton Bulwer, 14th June 1832 ; Ibid., vol. xiii. col. 623 .

"You have laws imposing severe penalties upon those who are guilty of breaches of these laws; but it has been found impossible to stop the sale of those cheap and obnoxious publications by fiscal laws; and the success with which they are broken, the sympathy excited in favour of the offenders, and the assistance which they receive, only give encouragement to pursue the same course. I have been informed that, within the last fortnight or three weeks, between forty and fifty persons have been taken before the police magistrates, and convicted for selling these publications."-Mr. O'Connell, 14th June 1832 ; Ibid., vol. xiii. col. 637 .

"As long as the Tories were in power Lord Liverpool, or even Canning, could consistently advocate the restriction of political discussion. But the fact that the Whigs had now held office since 1830, and that the tax remained undiminished, was only to be explained by their rooted disbelief in every principle which they professed to hold.

"Year after year Place had brought the question forward. Evcry year the Chancellor of the Exchequer declared himself in favour of repeal in principle, and every year the Government, for reasons which they dared not avow, continued the tax. Meanwhile the Commissioners of Stamps so used their power of prosecution as to set up a peculiarly odious form of censorship. The Penny Magazine, for instance, was allowed to circulate unstamped, while the Poor Man's Guardian was prosecuted."-Graham Wallas, The Life of Francis Place, Lيondon, 1898, p. 336 , 
publishers and sellers of unstamped papers, sympathy being so strong that frequently subscriptions for their benefit were raised. ${ }^{\mathrm{I}}$

It became apparent very soon after the passing of the Reform Act that the heavy duty could not be maintained. It was indeed so high, and the sale of the unstamped publications was so great, that in the years after 1831 there was an actual diminution in the yield of the stamp duty. In 1836 the Government were constrained to deal with the question. They introduced a Bill providing for the reduction of the duty from $4 \mathrm{~d}$. a sheet to $1 \mathrm{~d}$. a sheet. The Chancellor of the Exchequer said that the reduction was simply a concession to public necessity and expediency. If the duty were maintained at its then existing level, public feeling against it would increase, and might lead to a general disposition to encourage illegal publications. The reduction would, moreover, assist the moral improvement of the people.

The reduction of the duty was not carried without opposition. The Times, which had attained its position under the old duties, and the other great newspapers then successfully conducted, were opposed to the reduction, foreseeing the possibility of the rivalry of new and cheap competitors. ${ }^{2}$ An attempt was made to argue that the benefit would not accrue to the public, since the public did not in general buy newspapers but went to the public-house to hear them read. Such persons would still go to the public-house, and would therefore derive no benefit from the reduced price: the advantage would be with the publican. On the other hand, it was anticipated that the reduction of the duty would

I "The market for a Newspaper at twopence appeared to be insatiable, and this ready demand produced an ample supply. In vain the police apprehended hawker after hawker; in vain the Stamp Office gave the informers and detectives additional premiums for vigilance, the trade went on with an exciting degree of activity. As the London gaols became crowded with 'victims,' the public sympathies were touched, and a fund was raised by subscription to support the families of the men and women (for women were seized and imprisoned) whilst under sentence."-F. K. Hunt, The Fourth Estate, London, 1850, vol. ii. p. 75.

z "This tax was a charter to the existing newspapers-it was not they who suffered from it-it was the public-it was the Government-it was order-it was society that suffered."-E. Lytton Bulwer, 22nd May 1834; Parl. Debates (Commons), vol. xxiii. col. 1195. See also G. J. Holyoake, Sixty Years of an Agitator's Life, London, 1893, vol. i. p. 288. 
so cheapen the newspapers that they would be brought within reach of all. Mr. Spring Rice said he knew that "the newspaper was one of the great attractions to take the poor man from home to visit the public-house; if, therefore, the adoption of this proposition tended to keep the poor man at home, it would afford a great moral aid to the improvement of the people." $x$ The moral uplifting of the poor man was a mighty shibboleth in those days, and one which gave a power to these arguments.

The rates fixed by the Act of 1836 were 1d. for the first sheet, not exceeding 2,295 superficial square inches, and a halfpenny for a second sheet not exceeding 1,148 square inches. The existing provisions with regard to registration and sureties were continued. They were considered of importance, in view of the likelihood of the establishment of cheap irresponsible papers which might be found publishing slanderous and scurrilous, if not blasphemous, statements.

There is little doubt that the Government had in mind a wish still to keep some restriction on the Press, and the Radicals always took that view. The penny duty undoubtedly had the effect of preventing the issue of really cheap newspapers. ${ }^{2}$ Although in Parliament the Government argued that they were entitled to the penny as a postage charge, 3 it is unlikely that they did not realize how illogical it would be to charge a penny stamp duty on every copy of a newspaper that was printed, in order to secure the free transmission by post of such copies as the publisher might wish to distribute by that means.4 The proportionate

I Parl. Debates (Commons), vol. xxxiv. col. 625 .

2 "2755. Chairman: That penny which was left when the stamp was reduced, was called by some noble Lord the worst penny of all; and was not it always foreseen by those who looked deeply into the subject, that the retention of that penny just made the difference between not being able to circulate a cheap paper and being able to circulate it?-It makes all the difference, I think."-Evidence of Mr. H. Cole, Report from Select Committee on Newspaper Stamps, 18th July 1851.

3 "The penny was avowedly retained in 1836 not for the purposes of revenue but as a compensation to the State for services performed in the transmission of newspapers by post."-Viscount Canning, 24 th May 1855; Parl. Debates (Lords), vol. cxxxviii. col. 954 .

$4 \mathrm{McCulloch}$ has some remarks which indicate the line on which was justified the practice of charging the stamp duty on every copy of a newspaper, in order that a portion of them might be transmitted by post without further charge;- 
numbers of newspapers sent or not sent by post would not be the same for all publications. Such a provision was therefore bound to work unequally. Moreover, the new duty meant that it would still be impossible to issue a newspaper at the price of one penny, and the cheap newspaper was still barred. The duty was in fact still a restrictive tax; and by those who were opposed to all "taxes on knowledge," of which the newspaper duty had been considered one, the question was never regarded as settled by this reduction.

The official Whigs did not say much on the question of the restrictive character of the duty. The Radicals were not so careful to hide the repressive side. While not suggesting that the Government (with whom they voted) desired the continuance of a restrictive duty, they roundly accused the Opposition of desiring to restrain the dissemination of intelligence, "in order to keep up their influence over a

"Impolicy of Imposing a Postage on Newspapers.-The duties now substantially repealed produced, in $1853, £ 412,220$ nett, no inconsiderable sum in a period of war. In point of fact, however, they could hardly be called duties, and ought rather to have been regarded as a payment for the trouble and expense attending the conveyance and distribution of newspapers by post. But supposing such to be the case, it was argued that the duty should be so limited, that is, that it should only be imposed on papers carried by the post. Matters of this sort are not, however, to be decided by mere logical considerations. The effect of the new plan is to confine, in a greater or less degree, according to circumstances, the circulation of newspapers to the districts within which they are published; and this certainly is not a desirable object. . . Under the new plan the charge for conveyance, or it may be postage, being added to the price of the metropolitan journals, they will be dearer than the local papers, and people in many, or rather perhaps in the majority of instances, will be disposed to prefer the low-priced though inferior journal published at their door, to the superior but higher priced journal of the capital.... On the whole, therefore, we anticipate little or no advantage from the new plan. But we are, at the same time, ready to admit that no system of this sort can be safely judged $a$ priori; and that the results of experience may differ very widely from those of theory." -J. R. McCulloch, Commercial Dictionary, London, 1856, p. 893.

× "We are living under a disguised censorship of the Press. I use the word advisedly; and I find that generally where there is an avowed censorship of the Press there are no taxes on knowledge; no stamp duty and generally no paper duty. From the time when the stamp duty was first imposed in the reign of Queen Anne, the number of newspapers has been very much diminished by the stamp. For instance, Steele's Spectator was nearly if not quite ruined by it; and from that time to this the amount of revenue has never been so large as to be a serious subject of consideration."-Evidence of Collet Dobson Collet, Report from the Select Committee on Newspaper Stamps, 18th July 1851, p. 113 , 
certain class of people, and at the same time to perpetuate the ignorance which had hitherto hung about them." I

After the passing of the Act with its definite postal privilege for newspapers coming within its provisions, questions arose as to the status with regard to transmission by post of certain publications which were not newspapers of the ordinary type, but rather of the nature of critical or literary reviews. The proprietors of these publications desired to transmit by post a part of their issues. They were not, however, prepared to pay at the letter rate by the ounce, but wished to bring under the Stamp Act that portion of their impression which would pass by post, and pay duty accordingly on those copies only. This course was agreed to by the Government in $1838,{ }^{2}$ subject to a maximum limit of weight per copy of 2 ounces. The privilege was at first conceded only to periodicals, termed "class" newspapers, dealing with a particular subject and addressed to a certain class of the community, such as, for instance, papers relating to law, medicine, or architecture. It was restricted to papers dealing with what might be termed the higher intellectual subjects. These were held to form fair ground of exemption;

' Mr. Roebuck, 20th June 1836; Parl. Debates (Commons), vol. xxxiv. col. 653.

2 Treasury Minute, No. 21,355, 28th November 1838: "It appears that these papers, though stamped as newspapers, are not according to Law Newspapers, and consequently need not have been stamped, but that the proprietors have caused them to be stamped for the purpose probably of obtaining the facility of passing them free of postage.

"My Lords consider that all publications which are in the construction of the law newspapers and are compelled to be stamped are in equity entitled to the privilege of passing free of postage, but with respect to publications, which like these now under consideration are not properly newspapers, or necessarily stamped, they are of opinion that they are not in equity entitled to the privilege, and that my Lords must take into consideration the convenience of the public service and the other circumstances of the case. My Lords are desirous of affording every fair facility which may not be inconsistent with the proper despatch of the mails, and in this view they consider that a limit of weight may be properly applied, and adverting to the average weight of a large newspaper, they are of opinion that the limit may be properly fixed at 2 ounces.

" They are pleased therefore to direct that for the future in all cases where applications are made for the transmission of any stamped publication through the post free of postage, if it shall appear that such publication is legally a newspaper and compelled to be stamped such paper shall pass postage free whatever may be its weight, and that when such publication may not appear to be strictly a newspaper, still it should be permitted the indulgence in case the weight shall not exceed 2 ounces." 
but other specialist papers relating to subjects less intellectual then appeared; such as papers relating to turf news, or reporting cases before the police courts. These papers being entirely devoted to one subject, it became a question whether the privilege of stamping only a part of their impression could be given them. Instead of attempting any sort of discrimination in such cases, the Government made one general rule that all papers devoted to the discussion of one subject should be accorded the privilege. Thereupon a great variety of such papers came into existence, and very soon some of them began to include in their issues matter which could only be regarded as news of a general character. This raised a further question: how much such general news should be regarded as destroying the "class" character of the publication. The Government found themselves in a difficulty. If the law was not rigorously enforced, the papers paying the tax raised a great outcry against the injustice to themselves; and if the law was enforced in respect of those "class" publications which published general news, there was a great outcry against the discrimination between the "class" papers. I

The whole position in regard to these papers became unsatisfactory and anomalous. ${ }^{2}$ It was, in point of fact, found impossible to enforce the law. The outbreak of the Crimean War led to a development which reduced the whole position to absurdity. Publications were issued giving the latest and fullest available intelligence from the seat of war. These publications confined themselves strictly to the subject of the war. They published nothing on any other topic; and on that ground, although devoted entirely to the publication of news of burning interest, they claimed to be exempt from the newspaper duty in common with all other "class" newspapers. 3

- Parl. Debates (Commons), vol. cxxxvii. col. 1130.

2 "If a tradesman at the present time carries his circular to the Board of Inland Revenue, he obtains the postal privilege on the condition of his declaring his circular to be a newspaper, although, if the Board of Inland Revenue were afterwards to prosecute him for not stamping his entire impression, he would be entitled to go into a Court of Justice and there to ccritend that that was not a newspaper which he himself had declared to be a newspaper in order to obtain the postal privilege for part of his impression."'-Mr. Gladstone, 19th March 1855 ; ibid., vol. cxxxvii. col. 791.

3 - The Solicitor of the Board of Inland Revenue, being examined before a 
In the Session of 1854 the House of Commons passed a Resolution, although it was opposed by the Government, affirming that the laws in reference to the periodical press and newspaper stamp were "ill-defined and unequally enforced," and that the subject demanded the early consideration of Parliament. The Government gave the matter their attention. Mr. Gladstone, then Chancellor of the Exchequer, prepared a plan which was embodied, with modifications, in a Bill introduced in the following Session by his successor. This Bill provided for the abolition of the duty except on such copies as it might be desired to send by post. The proposal was welcomed as the abolition of the last of the taxes on knowledge, and a liberation of the Press. ${ }^{\text {I }}$ The only serious opposition to the Bill was made on the ground that in the exceptional circumstances of the time-the nation being engaged in a war-the loss of revenue could be ill-afforded; and that the withdrawal of the duty would lower the moral character of the Press, and open the way for seditious and blasphemous publications and for unrestrained libellous attacks on the Government, on public authorities, and private individuals. ${ }^{2}$ The Government justi-

Committee upon the subject of class publications, was asked why class publications were not subjected to the compulsory stamp. Inadvertently, instead of saying that they were exempted because they were addressed to a particular class of the community, he said that it was because they related only to one subject. In giving that reason, he made a slight error of statement. That error has now been taken up in different parts of the country, and a number of periodicals have appeared, such as the War Telegraph and the War Times, containing intelligence relating exclusively to the war, which they say is 'one subject,' and so saying, set the Board of Inland Revenue at defiance." Chancellor of the Exchequer, 19th March 1855; ibid., vol. exxxvii. col. 804.

" I am quite satisfied, from years of attention to this subject, that there never was so large a measure involved in a small measure, so to speak, as is the case with regard to this proposition for making the Press free. I am willing to rest on the verdict of the future, and I am quite confident that five or six years will show that all the votes of Parliament for educational purposes have been as mere trifles compared with the vast results which will flow from this measure, because, while the existing papers will retain all their powers of usefulness, it will call to their aid numbers of others not less useful, and while we continue to enjoy the advantage of having laid before us each morning a map of the events of the world, the same advantage will be extended to classes of society at present shut out from it."-John Bright, 19th March 1855 ; ibid., vol. cxxxvii. cols. 810-11.

2 "Another objection, and that of a more serious character, has been brought under my notice by various persons, who have described the proposition to repeal the compulsory newspaper stamp as one which would be most dangerous to society. It has been described as a measure which will open the floodgates of 
fied their proposals on the ground that the administration of the existing law had become exceedingly difficult, and that the resolution of the previous session condemning the ambiguity of the existing law and the unsatisfactory character of its administration left them little choice in the matter. ${ }^{x}$

An amendment to the Bill of 1855, proposing the reduction of the stamp duty to $\frac{1}{2} \mathrm{~d}$., which was in effect providing for the transmission of newspapers by post at the uniform rate of $\frac{1}{2} \mathrm{~d}$., was opposed by the Government. There was no desire to make the.postage of newspapers a source of revenue. On this point there was general agreement. At the same time there was no disposition to carry newspapers at less than cost. Sir Rowland Hill, in the course of his evidence before the Committee of 1851, had said that the Post Office could profitably carry newspapers at a penny, ${ }^{2}$ and that it was unlikely that they could be carried profitably for a halfpenny.

sedition and blasphemy, and which will inundate the country with licentious and immoral productions, which will undermine the very foundations of society, and scatter the seeds of revolution broadcast over the land. These expressions are not exaggerated representations of the opinions which have been communicated to me from many quarters since this measure has been under my consideration."-Chancellor of the Exchequer in House of Commons, 19th March 1855 ; ibid., vol. cxxxvii. col. 782.

"The Right Hon. Gentleman who has just resumed his seat (Mr. Disraeli) has spoken of the 'liberty of the Press.' That has been long spoken of. It has been said that it must be 'free as the air we breathe ; take it away, we die.' But, Sir, what is the 'liberty of the Press'? It is the liberty of a certain number of persons to slander anonymously whomever they please, against whom you have no redress. It is freedom to the anonymous libeller."-Mr. Drummond in the House of Commons, 23rd April 1855; ibid., vol. cxxxvii. col. 1680.

" "This is not merely a fiscal matter, because, as I have already stated to the Committee, the existing law respecting the stamp duty upon newspapers has been brought into a most inconsistent state by a succession of indulgences which were made for the benefit of a certain class of newspaper publications. The consequence of these indulgences is, that the greatest difficulty exists in the administration of the present law."-Chancellor of the Exchequer in House of Commons, 19th March 1855; ibid., vol. cxxxvii. col. 802.

2 "Q. 1852. Mr. Cobden: Would the carrying of newspapers be profitable to the Post Office at the present rates, provided you were left to adopt your own regulations as to the transmission of newspapers without the intervention of the Board of Inland Revenue?-In one sense it would be profitable and in another it would not. If we were to charge against the newspapers a share of the fixed expenses of the establishment, then it is very questionable whether it would be profitable; but if you consider, as we probably should, that the expenses of the establishment are incurred in respect of the letters, and only calculate the additional expense which would be thrown upon us for the transmission of newspapers, then I think we shpuld find them profitable. 


\section{Members of the Government and other members of the House} were convinced that a halfpenny rate would involve a loss, and they opposed the amendment on that ground. ${ }^{\text {I }}$

The Act 16 \& 17 Vict. cap. 63 (1853) had reduced the stamp duties on newspapers, ${ }^{2}$ and repealed the duties on advertisements. A further Act (the Newspaper Stamp Duties Act of 1855, 18 \& 19 Vict. cap. 27), repealed the stamp duty, as such, in respect of newspapers, and provided that periodical publications conforming to certain conditions should be entitled to free transmission by post, if "printed within the United Kingdom on paper stamped for denoting the rate of duty now imposed by law on newspapers." The chief conditions were that the publication should be issued at intervals not exceeding thirty-one days, should bear the title and date of publication at the top of every page, and should not be printed on or bound in pasteboard or cardboard. The maximum limit of weight for publications not strictly newspapers, which in 1854 had been raised to 3 ounces, was now abolished, and newspapers and all other stamped periodical publications were

"Q. 1853: Having an immense organization at the Post Office with a certain amount of fixed charges, with a large amount of postmen necessarily travelling over the whole of the kingdom, you would find it profitable to carry newspapers for a penny, in addition to the letter carrying, would you ?-Yes.

"Q. 1854: Therefore, if the newspaper stamp were abolished, and you were left to regulate the postage at the Post Office, you would deem it profitable to carry newspapers at a penny each?-Yes, certainly we should: what I mean is, that the carrying of newspapers would not increase our expenses to the extent of a penny each.

"Ans. 1912: I was in hopes that we might distribute them at a halfpenny, if we could have completed a plan in the simple form in which it presented itself to my mind at first.

“Q. 1913: The plan is so far under consideration, and, perhaps, these difficulties may be got over?-I cannot bold out any expectation of that; I think I have considered it sufficiently to see that those difficulties are all but insuperable." -Evidence of Sir Rowland Hill, Report from Select Committee on Newspaper Stamps, 18th July 1851.

" He believed it would be admitted that there was no wish to make revenue out of this carriage of newspapers; but, on the other hand, the newspaper interest had no right to ask that their productions should be carried at less than cost price. It should be as near as possible an equal bargain between the parties, by which neither the revenue on the one hand, nor the newspapers on the other, should gain. . . . He believed it was the opinion of the Post Office that a halfpenny would not be sufficient to cover the expenses of transmission."-Lord Stanley, 23rd April 1855; Parl. Debates (Commons), vol. cxxxvii. col. 1664.

a The duty was reduced to 1 d. upon a sheet containing a superficies not exceeding 2,295 inches. 
made subject to the same restrictions as to number of sheets and extent of letterpress, etc. Concurrently with the passing of this Act, the book post rates were reduced with the view of permitting the transmission of unstamped newspapers at low rates of postage. ${ }^{x}$

Under the Act of 1855 , stamp duty at the rate payable at that time under the existing law must be paid in order to secure the privilege of free transmission of newspapers by post. The duty was chargeable according to the number of sheets; and in the case of some leading newspapers, such as The Times and the Illustrated London News, amounted to $1 \frac{1}{2} \mathrm{~d}$. per copy for each issue. The proprietors of these publications in 1858 approached the Post Office with the view of obtaining a reduction of the charge for the transmission of their papers by post. This request was submitted by the Post Office, and was met by the Government in a liberal spirit. In view of the importance now attached by Parliament to the free circulation of newspapers, as shown by the removal of taxation from them, an object of scarcely inferior importance to the circulation of letters, it was now decided that since the whole of the existing system rested on the assumption that the free circulation of newspapers in general was an object of importance, and one to be attained even at a disproportionate cost to the Post Office, a line should not be drawn so as to exclude from the lowest rate one paper, and that paper the one with the largest circulation. Such was the result of the existing limitation to 4 ounces of the weight of newspapers which might be carried by the post for $1 d$, and the limit was therefore raised from 4 ounces to 6 ounces.

In 1866 the question was raised in the House of Commons whether the Post Office charge could be redaced, especially in view of the fact that railway companies were distributing newspapers at a uniform sate of $\frac{1}{2} \mathrm{~d}$. a copy. In 1869 the question was again raised in Parliament. A resolution was moved in favour of an inland rate of $\frac{1}{2} \mathrm{~d}$. for 2 ounces on printed matter, and a postage of $\frac{1}{2} \mathrm{~d}$. on newspapers. It was urged that the concession would be of special value in rural districts: it would indeed "be hard to say what the effect might be in time on the social condition of the people." 
In several continental countries newspapers were already transmissible by post at very low rates. Against the possible objection that by introducing a rate lower than the $1 d$. rate they were jeopardizing its maintenance for letters, and that the proposal might therefore lead to a general $\frac{1}{2} \mathrm{~d}$. rate, it was argued that so far from that being the case, the best way of ensuring the permanence of the $1 \mathrm{~d}$. rate was to grant the concession asked. ${ }^{x}$

The Marquess of Hartington, the Postmaster-General, was unable to accept the motion because he thought such proposals, before being assented to by the House, should be thoroughly looked into to discover whether there was a reasonable probability that the loss of revenue would or would not be a permanent loss, and the Post Office should be given ample time to consider whether the additional duties which would be thrown upon it could be undertaken with due regard to other services, which were of greater importance than the transmission of circulars or newspapers. The influx of a largely increased number of circulars and newspapers would cause serious embarrassment in the practical working of the Post Office, and might impair the efficiency of the service in respect of letters. The primary business of the Post Office being the "rapid and punctual transmission of letters," such a result would give just cause for dissatisfaction.

The Marquess of Hartington asked that the motion should not be pressed. The Chancellor of the Exchequer told the House that he had not got $£ 300,000$ to give away. Mr. Gladstone also emphasized the seriousness of the financial aspect of the proposals, and assured the House that the Government honestly intended to investigate the question, however much their suggestion for deferring a vote upon it might look like a pretext for evading it altogether. But when the Chancellor of the Exchequer moved the previous question, the motion was lost by a large majority. A main contention of the advocates of the reduction of rate was that in many

I "Another objection might be urged that, by once touching the permanency of the $1 \mathrm{~d}$. rate they were endangering its stability, and that if the edge of the wedge were once inserted it might lead to the uniform rate of $\frac{1}{2} d$. He shared no such apprehension, and believed that the wisest way to maintain the permanency of the 1d. xate was to remove the cause of the agitation."-Mr. Graves, 6th April 1869; Parl. Debates (Commons), vol. cxcv. col. 241. 
foreign countries-in France, in Belgium, in Switzerland, in the United States-extremely low rates of postage for newspapers were in operation, and what was possible in those countries ought to be possible in England.

Following this vote in the House of Commons the matter was further considered at the Post Office, and in the next session an Act was passed providing that any newspaper conforming to certain conditions, the chief of which were that it should be issued at intervals of not more than seven days and should consist wholly or in great part of political or other news or of articles relating thereto or to other current topics, should be entitled to transmission by post at the rate of $\frac{1}{2} d$. per copy irrespective of weight. The privilege of retransmission was withdrawn. ${ }^{x}$

The statutory basis of the newspaper post has remained unchanged since 1870, and the provisions of the Act of 1870 were included in the Post Office Act of 1908, which contains - the present authority for the privilege. There has been'some necessary interpretation by the Post Office of the definition of a newspaper as given in the Act. The chief points on which difticulty has arisen are (1) as to the amount of news-matter required in a publication, and (2) as to the character of the matter which can be accepted as newsmatter. The Act provides that the publication should consist "wholly or in great part of political or other news or of articles relating thereto, or to other current topics." This

I "A newspaper with an impressed stamp circulates free for fifteen days. It is the last relic of the old taxes on knowledge. The law is complicated and leads to fraud by the abuse of free transmission. An unstamped newspaper now goes at the rate of $1 d$. for every 4 ounces, and every fraction of 4 ounces. About 35,000,000 newspapers pass through the Post Office annually with an impressed stamp, and about the same number without. What we propose to do is to abolish the impressed stamp altogether, at a loss to the Revenue of $£ 120,000$. . . . Then we propose to carry all newspapers which weigh less than 6 ounces for a $\frac{1}{2}$ d. That will be limited to bona fide newspapers; but we propose, instead of $1 \mathrm{~d}$. for every 4 ounces and fract: on of 4 ounces, to charge $\frac{1}{2} \mathrm{~d}$.for every 2 ounces of other printed matter. There will in this way be a loss to the Post Office, over and above that incurred by the abolition of the impressed stamp, of $£ 250,000$ a year. There may be besides some additional expense in connection with building and the increase in the number of persons to be employed; but this has not been estimated for, and the amount cannot be very large."-Chancellor of the Exchequer, 11th April 1870; Parl. Debates (Commons), vol. co. col. 1636. The limitation to 6 ounces was withdrawn. Ibid., vol. cciii. col, 1383. 
requirement is considered to be satisfied if as much as onethird of the publication consists of matter accepted as news. The proportion, when fixed, was based on an examination of the proportion of news-matter contained in the average newspaper, and represents the actual proportion then generally met with. There is no provision regarding the proportion to be maintained between the size of a newspaper within the meaning of the Act and its supplement, but, under the accepted interpretation of the statute, a newspaper may contain a supplement of equal size, and that supplement may consist wholly of advertisements. The result of this is that publications containing a proportion of only one-sixth of news-matter may pass at the newspaper rate of postage. As to the second requirement, a strict interpretation of the regulation is not insisted on, and, in general, articles, pictures, or drawings relating to any matters of current or topical interest are accepted.

This lack of precision in the provisions of the Act, and the consequent difficulty of framing or enforcing regulations restricting the privilege within even reasonable limits, have been largely taken advantage of, especially in recent years, by the publishers of trade and fashion papers, with the result that publications weighing in some cases as much as 3 pounds are sent through the post at the usual newspaper rate of a halfpenny. Nor are the enormous weight of these papers, and the large proportion of advertisement matter, the only objections. The news-matter on which they rely as entitling them to the newspaper privilege is often of the most doubtful character, consisting largely of accounts of shop sales or of commercial exhibitions, with lengthy descriptions of the articles displayed.

This abuse of the privilege is, however, confined to a comparatively small proportion of the newspapers entitled to transmission at the newspaper rate. With the fall in the price of paper, and the improvements in printing methods and machinery, all newspapers have tended to increase in size. But in general the increase has been small. In 1855 the average weight of newspapers passing by post was $3 \cdot 1$ ounces, ${ }^{\mathbf{I}}$ and in 1913 it had increased to $4 \cdot 1$ ounces. The number of papers entitled to the privilege which could be regarded as

I Parl. Debates (Commons), 7th May 1855, vol. cxxxviii. col. 197. 
excessively heavy is not more than about 50 (out of a total of some 2,200), 1 and although practically all these papers are published in London, and are largely distributed through the post, they do not form more than a small proportion of the total number of packets passing by newspaper post. But such of these publications of vast bulk and weight as are sent at the newspaper rate derive a great advantage - an advantage measured by the heavy loss incurred by the Post Office in respect of each such publication.2

Many of the moderately heavy papers, such as the ordinary sixpenny London newspapers, are for the most part in compliance both with the letter and the spirit of the regulations, and their transmission at the $\frac{1}{2} \mathrm{~d}$. rate is not, perhaps, open to serious objection. But there can be little doubt that if the possibility of developments in the publication of trade journals such as have occurred, had been foreseen, some provision would have been made for the prevention of the transmission at heavy loss to the Post Office of large numbers of publications which are, in effect, trade catalogues. While the newspaper post involves a very considerable loss, it affords the public a useful facility, and one which is largely availed of for the purpose the Act of 1870 was intended to assist, viz. the dissemination of intelligence. 3

The rate has proved too high to secure a large postal traffic in newspapers. The total number passing by post within the United Kingdom in 1913 was some 200 millions, which, in days when individual daily newspapers publish as many as a million copies of every issue, is only an insignificant portion of the newspaper traffic of the country. It is also only a small portion of the total postal traffic, which in the same year amounted to some 6,000 millions. In this respect there has been a great transformation. Under the old conditions newspapers were distributed almost exclusively by post, and formed a large proportion of the total

I In 1899 the number of registered newspapers which normally exceeded 8 ounces in weight was 29.

- See infra, p. 293. The size and weight of many of the large trade papers has decreased in consequence of the war.

3 "Newspapers and books are carricd at a low rate for the sake of the education and general information of the people."-Mr. W. Monsell (PostmasterGeneral), 14th March 1871; Parl. Debates (Commons), vol. cciv, col, 2014. 
number of postal packets and by far the greater bulk of all the mails, ${ }^{1}$ while now they form only an inconsiderable proportion both in bulk and number. The Post Office has no monopoly of the distribution of newspapers, and for the most part newspaper publishers themselves provide for the distribution of by far the larger part of their issues. In all the large towns this is the case. ${ }^{2}$ Private enterprise can of course compete wherever the traffic would be profitable, and private agencies provide satisfactorily for the distribution of the vast proportion of newspapers, it being found practicable throughout a large part of the country to place newspapers on sale at the published price; and in all such cases payment of postage, which in the days of the halfpenny newspaper represents an additional charge of 100 per cent. on the published price, is out of the question. Only those for the more remote towns and country districts are left to the Post Office ; but the newspaper traffic by post, although conducted at a loss, comprises so small a part of the whole postal traffic, that the result on the finances of the Post Office is not serious. If, however, such an unremunerative rate were applied to a class of traffic likely to assume large proportions the result would be financially disastrous, and this is the answer to such suggestions as those of Mr. Wells to extend the newspaper rate to other classes of printed matter.3

In 1854 the average weight of the mails which loft London daily was 279 cwt. of which 219 cwt. consisted of newspapers.

a Only some 150 copies of the Daily Mail are delivered in London by the post each day.

3 "There is no reason whatever why the Post Office should charge a man threepence or fourpence for a book and a halfpenny for these vast trade circulars, and it would be the simplest, as well as the wisest and most beneficial of reforms, to bring the book post down to the newspaper level." H. G. Wells, Mankind in the Making. London, 1914, chap. ix.

The following further suggestions by Mr. Wells are reprinted here for the consideration of postal reformers. Their adoption involves merely an extension of the principle of State benefit.

"Now, in the first place, the post office as one finds it in Great Britain might very well be converted into a much more efficient distributing agency by a few simple modifications in its method. At present, in a large number of country places in Great Britain, a penny paper costs three-halfpence including the necessary halfpenny for postage, and the poorer people can afford no paper at all, because the excellent system in practice abroad of subscribing to any registered periodical at the post office and having it de- 
In 1913 the privilege of transmission at the $\frac{1}{2} \mathrm{~d}$. rate was extended to colonial newspapers, registered for the purpose in this country.

NoтE.-On the 1st November 1915, as part of the war increases of postage, the rate on newspapers was altered to $\frac{1}{2} d$. for every 6 ounces or part of 6 ounces.

livered with the letters has not been adopted. Government publications and Government maps, which ought also to be obtainable at a day's notice, through the Post Office and post free, have to be purchased at present in the most devious way through a remote agent in London. There is no public reason whatever why a more intimate connection should not be established between the Stationery Office and the Post Office."-Ibid.

"It would be the simplest thing in the world to have a complete, business-like catalogue of Government publications, kept standing in type and reissued and reprinted quarterly, distributed to every post office, and by its means one ought to be able to order whatever one wanted at once, pay for it on the spot, and get it delivered to any address in Great Britain in the next twenty-four hours."-Ibid. 


\section{NEWSPAPER POS'T IN CANADA}

No special provision for the transmission of newspapers had been made in the Act of 1765 which first prescribed rates of postage for the Canadian territories. Consequently, if sent in the mails, they were, in strictness, liable to postage at the ordinary rates for letters and packets. Those rates would generally have amounted to at least a shilling a copy, and would therefore have prevented altogether the distribution of newspapers by post. Postage was in practice waived, newspapers being allowed to pass by post on payment of a small charge quarterly to the Deputy Postmaster-General, who retained the proceeds as a perquisite of his office. The amount was at first a mere trifle; but in later days it formed the greater part of his emoluments. The precise date at which this arrangement was established is uncertain. It certainly existed in Nova Scotia in 1770, and probably commenced on the first publication of a newspaper in Canada. ${ }^{\mathrm{I}}$ The rates charged were low, and were varied from time to time at the will of the Deputy Postmaster-General. The following, which were charged in Canada in 1840, may, however, be regarded as typical :-

$$
\begin{aligned}
& \text { For a weekly paper } \quad \text {. } \quad \text {.. } \quad \text {.. } \quad \text {.. } 1 \text { 1s. } 0 \text { d. currency a quarter } \\
& \text {,, bi-weekly ,, .. } \quad \text {. } \quad \ldots \quad \text {.. 1s. 3d. , , ", }
\end{aligned}
$$

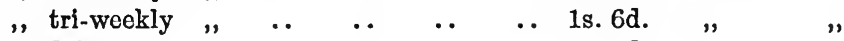

$$
\begin{aligned}
& \text { "daily } \quad \text { " } \quad \ldots \quad \text {. } \quad \ldots \quad \text {. } 2 \text { 2s. 3d. , , }
\end{aligned}
$$

In the Maritime Provinces the rates were somewhat lower, the charge for a weekly paper being only 2s. 6 d. a year.

These amounts were payable by the proprietor of the paper, and were accepted only in respect of papers sent regularly.

- Report of Special Committee, House of Assembly, Lower Canada,11th February 1832, p. 10. 
Papers mailed casually by persons other than publishers, and denominated "transients," were charged 1d. currency each. The publishers thought even these moderate charges objectionable, and the feeling against them was increased when it became known that they rested on no legal authority, but solely on the custom of the office and the sanction of Sir Francis Freeling; and that the proceeds, instead of being accounted for as part of the general Post Office revenue, were appropriated by the Deputy Postmaster-General. They were also objected to as arbitrary and inequitable, since papers were charged the same rate whether they were conveyed 20 miles or 200 miles. As letters were at that time charged on a scale of rates graduated according to distance, the application of the principle of uniformity to the newspapers was naturally not appreciated; and in view of the heavy charges incurred for transportation it could not have been justified on economic grounds.

The resentment against the charge first took definite form in the Lower Provinces. In 1830 a Mr. Ward, a publisher, petitioned the Nova Scotian House of Assembly to be relieved from the charges on his newspapers. A Committee of the House, which considered the matter, found that under the Imperial Acts it was no part of the duty of the Deputy Postmaster-General to receive or transmit newspapers, other than those received from Great Britain, and that the Deputy was therefore justified in making the charge complained of. They found also that sixty years earlier the Deputy made a yearly charge of $2 \mathrm{~s}$. $6 \mathrm{~d}$. on each newspaper sent by post, and that at that time all editors acquiesced in the charge. At the same time the Committee regarded the charge as so undesirable that they recommended the House should grant a sum to remunerate the Deputy for his services in transmitting newspapers, in order that the charges might be abolished.

The Deputy Postmaster-General in the Lower Provinces was himself a publisher, and it was alleged that he was interested directly or indirectly in every newspaper published in Nova Scotia, with the exception of two, with the result that, while all the newspapers in which he was interested passed free of postage, the two outsiders were made to pay. The Deputy Postmaster-General himself seemed to think 
the arrangement was best kept in the background. When questioned by the House of Assembly, he adopted a reticent attitude and made equivocating statements. He gave particulars purporting to show the amounts paid as postage in respect of certain newspapers controlled by him, and on further interrogation by the House of Assembly admitted that the journals paid no postage.

Meanwhile, publishers in both Lower and Upper Canada also were working for the abolition of the Deputy Postmaster-General's privilege. In December 1830 a publisher of Montreal, Mr. R. Armour, approached Sir Francis Freeling, declaring that the subject might eventually involve a question of high constitutional importance, viz. "to what extent the Post Office of Great Britain is authorized by law to regulate the internal Post Office establishments of the Colony, and to draw a Revenue therefrom." $\mathrm{He}$ received no satisfaction from Sir Francis Freeling, who replied that the charges were "the long established and authorized perquisite of the Officer in question (the Deputy Postmaster-General) and that all Newspapers circulated by post in British North America otherwise than under his privilege are liable by Law to the charge of the full rates of Postage."

Mr. Armour then petitioned the local Legislature, and towards the end of the year a Committee of the House of Assembly was appointed to consider the whole question of the management of the Post Office in the province of Lower Canada. The Committee found it impossible to obtain any useful information concerning the finances of the service from the Deputy Postmaster-General, Mr. T. A. Stayner, whose attitude was a source of much irritation, resulting in great intensity of feeling both against the privilege of the Deputy and the administration of the service from London.

In 1832 the publishers in Upper Canada, who were working in concert with the publishers of Lower Canada, also succeeded in obtaining the appointment of a Committee of the House of Assembly. This Committee, in its Report, challenged the legality of any postage charge whatever raised in the province under authority of the British Postmaster-General, 
In 1833 the publishers in Nova Scotia submitted a petition to the King, but obtained no satisfaction. ${ }^{\text {I }}$

In the Lower Provinces there was a sentiment in favour of the free transmission of newspapers, which had been encouraged, if not originally induced, by the circumstance that for a considerable period the holder of the office of Deputy Postmaster-General for those provinces, Mr. Howe, took little trouble to enforce the payment of that postage which, when paid, was his perquisite, preferring to forgo the proceeds rather than incur the risk of odium which might attach to any attempt to enforce his privilege. ${ }^{2}$

In $1842 \mathrm{Mr}$. Edmund Ward, the publisher of the Federation Sentinel, petitioned the Lieutenant-Governor and House of Assembly in New Brunswick for the abolition of the postage rate on newspapers, on the grounds that it was illegal, a tax on knowledge, and of no benefit to the public revenue, since the proceeds were retained by an official already adequately remunerated for his services. The petition was submitted to the Home authorities; and the Solicitor to the Post Office advised that, since the Act of 1837 repealed the Act of the 4th of George III, cap. 34, the charge on newspapers made by the Deputy Postmaster-General in North America rested on no legal basis, and long established usage and custom was the only justification for allowing newspapers

- Sir Francis Freeling replied to the petition. He said the practice of his Deputy in North America was not illegal, but was based on an Act of Parliament authorizing certain of his officers to circulate newspapers by post; that as it had been in existence since the first establishment of the Post Office in the colony, the petitioners must have entered into the business with a full knowledge of the oharge to which their publications would be subject if sent by post; there was no stamp duty in the colonies to give the publishers a right to free transmission; and, moreover, the amount of the charge was less than the similar charge in the United States.

2 "Mr. Howe was very loose, and rarely took any steps to obtain or enforce the payments of the amounts due to him for the transmission of Journals through the Post. ...

"I cannot look upon it as the mere collection of a private source of emolument to the officer, but I conceive that the Department is interested in the question not only inasmuch as the amount received from this source goes in aid of a larger salary to the officer, but that whenever the time comes that the substitution of a postage rate on newspapers supersedes the present mode of sending them, a due enforcement of such rate will be most unfavourably received, if a free transmission has been previously permitted from the negligence of the party to whom the collection of the charge was deputed and whose perquisite it was." Report of Mr. Page, 1842 (British Official Records). 
to pass by post at less than the legal rate. The House of Assembly in New Brunswick also took up the question on their own account. Like the Nova Scotians, they were anxious to facilitate the distribution of newspapers. They regarded the charge for postage as an odious tax on knowledge, and in 1844 , in a joint Address to his Majesty, recommended its abolition.

In 1842 the House of Assembly of Nova Scotia also petitioned for the abolition of postage on newspapers and pamphlets, contending that the proceeds of the postage rate, which was collected from the country districts, on which it lay as a heavy burden, did not benefit the general revenue, since they were appropriated by the Deputy PostmasterGeneral, and that the newspapers were well-nigh the only vehicle of information in the province. In reply, the British authorities pointed out that since pamphlets were charged as letters in England, the Treasury could not sanction free transmission in the colonies; moreover, even with the existing rate, the number of newspapers sent by post was increasing so rapidly that it was becoming a matter of some difficulty, on account of the bad condition of the roads in the province, to provide for their transmission from place to place. Free transmission was therefore not conceded; but in July 1844 certain changes were made in the general system of rates, and the Deputy Postmaster-General's newspaper privilege was withdrawn, a uniform rate of $\frac{1}{2} \mathrm{~d}$. per sheet for transmission to any point in Nova Scotia, New Brunswick, Canada, and Prince Edward Island being established.

When the Post Office service throughout British North America was unified and transferred to provincial control, the then existing rates of postage on newspapers and pamphlets were continued, but power was reserved to each Legislature to authorize transmission within its respective province free of postage. By virtue of this power Nova Scotia in 1852 abolished altogether the rate of postage on newspapers, taking pride in the fact that they were the first authority in British North America to grant the boon. New Brunswick soon followed suit. But the result of this, coupled with the reduction in letter postage at the unification, was 
adverse to the finances of the service in these provinces. For several years the accounts showed a deficit, which was met by the provinces cheerfully as a contribution of no less value than contributions made for roads, bridges, and schools. ${ }^{\mathrm{I}}$

In connection with the changes introduced at the time of the Confederation, a charge for the transmission of newspapers by post was made general throughout the federated area. The charge met with considerable opposition from the Maritime Provinces, which thus lost the boon of free transmission. ${ }^{2}$ It was justified as nothing more nor less than a simple charge for freight, the remission of which would be to offer a bounty to a particular industry. The possibilities of usefulness of the Post Office would, it was argued, be greatly reduced if the service were loaded with the burden of the gratuitous distribution of newspapers throughout so vast a country; since, if from the diminution of revenue which such a course must produce, the department were forced to look to Parliament for assistance, Parliament would be disposed to discourage the establishment of new offices in the thinly settled districts, where it was of the greatest importance that they should be found. 3

The arguments of members from the Maritime Provinces were somewhat diverse. They said there was an essential distinction between letters and newspapers, in that letters were private communications between individuals, while newspapers were in some measure the organs of communication between the Government and the people, and furnished the only means by which to acquire that acquaintance with the law which everybody was presumed to possess. Newspapers

s "It may fairly be viewed in the samo light as the amounts annually granted by the Legislature for roads and bridges, and for the support of common schools. The mail carriage to all parts of the province secures us the travelling public conveyance which would not otherwise exist, and the very large amount of newspapers, etc., which pass through the Post Office affords strong evidence that the Department may be considered a branch of our educational system."-Postmaster-General of New Brunswick, 1857.

2 "Already they found a tax proposed on every poor man who took a newspaper for the information of his family; a stamp tax, an impost unknown in the Maritime Provinces, and one which had cost England half this continent."-Mr. Macdonald in Canadian House of Commons, 12th December 1867 (Ottawa Times).

3 Sir John A. MacDonald in Canadian House of Commons, 20th December 1867, ibid. 
occupied a similar position to that of schools, and presented one of the easiest channels of enlightenment. In many cases, for the ordinary folk no other means of education were open. On them the tax would be an imposition which might be contrasted, it was said, with the favour accorded to the commercial and wealthy classes by the reduction in the postage on letters.

It was further argued that in the existing state of the Dominion, owing to the presence of a certain amount of sectional feeling and mutual hostility between different portions of the country, which could be attributed largely to the lack of that sort of information which newspapers could provide, it would be folly to hinder the freest possible distribution. ${ }^{\mathrm{I}}$ Moreover, a postage charge would fall unequally. The large towns and thickly populated areas would be able to obtain their papers by means of the railroad or other agency at little cost; but the outlying districts, which ought to be treated with special favour by the Legislature, would have no alternative to the payment of postage. The large newspapers would be able to distribute their issues by express, while the smaller ones would be compelled to use the post. The "tax" would yield only some $\$ 25,000$ a year in Nova Scotia; and for such a paltry sum it surely could not be wise to levy this "tax upon knowledge," which "of all the heavy burdens laid upon Nova Scotia was the most oppressive." 2

These arguments were ineffective, and a rate which averaged half a cent a copy was imposed. In 1875 the rate was modified, and made a bulk rate of 1 cent a pound, an extremely low rate. The average weight of newspapers at that "time was so small that, in the case of certain typical papers selected by the Government for the purpose, it was found that the numbers required to make up a pound were from ten to fifteen. In 1874 the total yield under the old rate had been only some $\$ 36,000$. The new rate was therefore

x "If ever there was a time when it was necessary for the interests of the whole Dominion that just the sort of information which newspapers conveyed should be disseminated through all the Provinces, it was now."-Hon. Dr. Tupper in Canadian House of Commons, 20th December 1867 (Ottawa Times).

2 Mr. Savary in Canadian House of Commons, 20th December 1867 (ibid.). 
likely to yield only some $\$ 6,000$ a year, and the advocates of free transmission argued that as such a small sum would hardly be worth the trouble of keeping the accounts, the Government, having gone so far, might well have taken a step further and abolished altogether the postage on newspapers. The Government defence was that the rate proposed was the lowest possible, and to mail free the papers published in the various parts of the Dominion would be to impose too heavy a burden upon the public treasury. ${ }^{\mathrm{I}}$

The Canadian people had only to wait a few years for the boon. In 1882 an Act was passed "to provide for the free transmission of Canadian newspapers within the Dominion." No discussion on the measure took place in Parliament, and authoritative statements of the reasons inducing the adoption of so generous a policy are not to be obtained; ${ }^{2}$ but in well-informed quarters it is held that, in general, the leniency shown to newspapers is not due solely to the acceptance by Parliament of the arguments usually advanced in their favour, plausible and convincing as they probably are to many minds, but has always been dictated more or less by fear of the political power wielded by them; or, what is really the same thing, as a result of direct pressure at Ottawa by the newspaper proprietors, based on their influence with the electors or the chiefs of parties, and exercised in their own interests. 3

In this view, the ultimate step taken in 1882 marked no concession to popular sentiment, but the climax of the power of the newspaper interest, and a consummation for which they had long striven.

At the same time the total abolition of postage on news-

× Hon. Mr. Mackenzie in Canadian House of Commons, Parl. Debates, Canada (Commons), 22nd February 1875.

2 "There was good reason for the enactment of the old law that made the rate for the carriage of newspapers a cent a pound, and there never was even a semblance of sense or reason or any request for the repeal of that law. The truth is that its repeal was a mere whim of a gentleman of the Senate, who, anxious to pose in the niche of personal popularity, jollied through Parliament a measure that has cost this country in postal rates millions of dollars, creating a big deficit in the spending department, which has stood in the way of reform every time a reform was proposed."-Mr. Ross Robertson, Parl. Debates, Canada (Commons), 13th May 1898.

3 See Parl. Debates, Canada (Commons), 11th July 1900. 
papers was in accord with the widespread feeling, which had from an early period found expression in the Legislatures of the Canadian provinces: the feeling that newspapers are of great educational value, especially in new countries and in countries with an extended franchise, such as had been the Canadian provinces almost from their first organization; that in such countries it was necessary to educate the sovereign people; and that newspapers afforded the best and most practicable way. ${ }^{\mathrm{I}}$

During the period of free transmission, which continued some seventeen years, the number and gross weight of newspapers sent through the post increased enormously, and the privilege was considerably abused. Numerous publications were constantly appearing demanding free transmission, and in many cases they were of very questionable character; that is to say that, while conforming to the letter of the requirements of the law, they were often not genuine newspapers at all, but mere vehicles for the distribution of trade advertisements. The vast increase in the cost of dealing with the quantity of newspapers sent through the mails became a question for serious consideration. Heavy demands were being made by the railway companies for increases in the amount of their remuneration for the conveyance of mails, on the ground of the increase in tonnage due to the very large numbers of newspapers being sent. The actual statistics of the Post Office traffic in Canada are illuminating on this point. In 1897 the total weight of newspapers passing in the mails was $16,500,000$ pounds, and the estimated number of newspapers $175,000,000$. For the same year the total number

I The following remarks by Sir Charles Tupper in the Dominion House of Commons, though made at a somewhat later date, will illustrate this. He said: "There is abundant evidence that manhood suffrage in the Dominion is a far higher franchise than manhood suffrage in Great Britain, for the reason that there are tens of thousands of electors in the United Kingdom who go to the polls without having the remotest idea not only of public questions before the country, but, if their lives depended on it, they could not state who is the Prime Minister of Great Britain to-day. I give that as an indication of the great advance the people of Canada have made in intelligence; and the thorough knowledge which the mass of the people here have in respect of the political issues, and all other questions of that kind, as well as general information, rests largely on the fact that newspapers have so largely increased in circulation until they now reach almost every individual in the country."-Sir Charles Tupper, Parl. Debates, Canada (Commons), 13th May 1898. 
of letters passing through the post was $123,000,000$, and their total weight $5,000,000$ pounds. ${ }^{\mathrm{r}}$

In 1898 the Canadian Government desired to reduce the internal letter postage, which still stood at 3 cents, to the almost universal rate of 2 cents; ${ }^{2}$ but the loss of revenue which such a reduction would entail was so great that they were driven to seek fresh revenue to meet the deficiency. In view of the abuses of the newspaper privilege, and the generally unsatisfactory position which had developed, this was thought to be a suitable occasion for the reimposition of postage on newspapers.3 The rate proposed was $\frac{1}{2}$ cent a pound. Opposition to the change was made on the same grounds as in 1867 : that newspapers were the real educators of the people, that the dissemination of intelligence, particularly of political intelligence, was of the utmost importance, and that no impediment should be put in the way of their freest possible distribution.

The great necessity for a new source of postal revenue made it impossible, however, to continue the free privilege in its entirety, and the $\frac{1}{2}$-cent bulk rate was carried. The free privilege was continued for local papers distributed within a

I In Great Britain the figures are in very different proportion. While the letters are $3,500,000,000$, the newspapers are only some $200,000,000$. The circumstances of the two countries are in such contrast that the figures afford no basis for argument as regards the relative postage rates: but they illustrate very effectively a fundamental difference in the general character of the two postal services. In Great Britain the number of separate newspaper mails is extremely small proportionately to the number of letter mails. In Canada the proportions are almost reversed. The postmen on delivery in Great Britain carry their letters and packets in a light canvas bag, and the number of newspapers taken out by any one postman is quite small (the proportion is about one newspaper to twenty-five packets of other description). In Canada the lettercarriers are weighted with newspapers, carried either strapped in a bundle or stuck in a satchel which is full to overflowing. In effect, the general practical arrangements in Canada must be made largely with a view to the handling of vast quantities of newspapers, while in Great Britain the arrangements are in general based on letter traffic, and, except at the largest offices, the arrangements for newspapers are incidental. Letters, however, receive first consideration in Canada, and the discrimination in their favour against the newspaper matter, in point of promptness of handling, is carried to much greater lengths than in Great Britain.

Cf. supra, p. 57.

3 "I trust that after the reimposition of postage on newspapers has been fairly in working order, we shall then have the Post Office a self-sustaining department." - Sir William Mulock, Postmaster-General, Parl. Debates, Canada (Commons), 1st April 1898. 
radius of ten miles, in order to enable the country papers to compete with the papers of the large towns. The country papers are very jealous (and perhaps somewhat fearful) of the great city papers, although the telegraph has given the country papers an advantage in point of time. This is of great value in a country of enormous distances-especially in the case of daily papers-but is yet not of vital importance in the case of weekly newspapers, which do not rely so much on late news. The competition of the weekly papers of the great cities is severe; and the radius of competition even of their daily papers is considerable. The letter-carriers of Ottawa were at that time daily engaged in carrying free enormous quantities of newspapers published in Montreal or Toronto. ${ }^{\mathrm{I}}$

The rate fixed in 1898 was not intended to be permanent; and in 1900, when the revenue had become sufficiently buoyant to warrant the step, a Bill was introduced to reduce the postage on newspapers to $\frac{1}{8}$ of 1 cent a pound for transmission in the province or territory of distribution. The general purpose of the Bill was to reduce the rate for limited distances, and the province or territory was adopted as the most convenient unit of area. Newspapers were being posted literally by the ton, and the department thought it unreasonable to convey car-loads of such mail from ocean to ocean for the same rate as for any shorter distances within a province. ${ }^{2}$ The Bill passed the Lower House, although it was severely criticized as introducing the vicious principle of provincial legislation; and "a serious aggravation of the tyrannical injustice" was that a distinctive tax would be placed on city publications, while preferential privileges would be given to country newspapers. 3

- Sir William Mulock, Parl. Debates, Canada (Commons), 1st April 1898, col. 2915.

2 "Hon. gentlemen are entirely in error in assuming that the length of the journey does not make extra cost. It lays the foundation for extra claims by railways, and there is in the department at present, on the part of practically all the railways in Canada, application for increased payment. It is quite impossible to treat newspaper postage in the same way as letter postage."-Sir William Mulock, ibid., 11th July 1900.

3 "This new Bill is little else than a special tax and handicap on certain Montreal newspapers, which are the only ones which have the bulk of their circulation outside of their own province. We have always favoured newspaper postage, but we are not favourable to its being collected off a few papers, and 
The Postmaster-General explained that with a bulk rate it was possible to make nice distinctions of rate in regard to distance travelled, which would be quite out of the question with a rate such as that for letters charged separately on each individual item; the charge for the transportation of a letter for a short distance would be so small that no division of coin could be found to correspond to it, but with matter mailed by the ton and wagon-load, and paid for by the ton and wagon-load, the charge could well be adjusted for distance : but he admitted that he had made no calculation as to whether the $\frac{1}{8}$ cent a pound would cover the cost of newspapers within the bounds of each province. ${ }^{x}$ The Bill was rejected by the Senate on account of the undesirability on general political grounds of introducing any sort of distinctions based on the provincial boundaries.

The proposal was revived in another form in 1903. It was then proposed to reduce the postage to $\frac{1}{4}$ cent a pound on newspapers when the distance of transmission did not exceed 300 miles. The Postmaster-General said definitely in Parliament that the rate would not cover the cost, and, further, that the reduction would involve a loss of revenue of from $\$ 50,000$ to $\$ 75,000$ a year on a total revenue from newspapers of from $\$ 100,000$ to $\$ 125,000 .^{2}$ The reduction was carried; and in 1908 the reduced rate of $\frac{1}{4}$ cent a pound was extended to all newspapers passing within the Dominion, when posted in bulk. The privilege is availed of by the publishers of many periodicals which are virtually nothing more than advertising media; but this abuse has not assumed serious proportions, and with the finances of the department in a flourishing state, it has not been felt necessary to curtail the privilege, although it involves great loss.3

thus making them pay for the carriage of their own mails."-Mr. Foster, Parl. Debates, Canada (Commons), 10th July 1900.

Sir Wilfrid Laurier made some interesting observations. He said : "A newspaper is merchandise, a letter is not. A letter simply conveys to somebody the views and thoughts of another. But newspapers are merchandise, and the publisher of a newspaper a manufacturer of merchandise which be sells. Now, I do not see any reason why this class of merchandise should not pay freight for its transportation as well as any other class of merchandise."-In Canadian House of Commons, 10th July 1900.

- Bir William Mulock, ibid., 11th July 1900.

Ibid., 3rd July 1903,

3 Ibid., 25th Jạnuary 1905 , 


\section{NEWSPAPER POS'I (SECOND-CLASS MAIL) IN THE UNITED S'TA'TES OF AMERICA}

A system for the distribution of newspapers by post, analogous, though not identical, with that which grew up in Great Britain, existed from an early period in America. There the privilege of franking newspapers was a perquisite, but it was not the perquisite of one officer, as in England. All postmasters exercised the privilege as part of their general privilege of franking all their correspondence, the arrangement being part of their emoluments as postmasters; and postmasterships were much sought after by newspaper publishers, who were thereby enabled to obtain free of charge the advantage of the distribution of their publications by what in most cases was the best, if not the only, available means.

The most notable example was Benjamin Franklin, who was for nearly forty years connected with the Post Office in North America, first as Postmaster of Philadelphia, and afterwards as joint Postmaster-General for the northern part of North America, and who, throughout this period, was able to circulate his publications by post free of charge. The Post Office, especially in regard to the exercise of this privilege, is regarded by Americans as having been an important factor making for a general understanding between the colonies, and a conception of the possibility of common

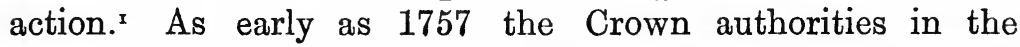
colonies were looking with a jealous eye on the unrestricted distribution of newspapers, and were contemplating measures for preventing the dissemination of objectionable ideas. ${ }^{2}$

× "The growth of the Post Office from this humble beginning solidified the American Colonies and made independence possible."-The American Post Office, by Nathan B. Williams. Reprinted as Senate Document No. 542 of the 61 st Congress, 2nd Sess., p. 5.

2 E.g., "Mr. Franklin has in particular the great Advantage of circulating his Papers free, and receiving intelligence, which he may make the best or 
As the friction between the colonies and the Mother Country grew in the years that followed, the Crown postmasters became more and more active in their endeavours to hamper the distribution by post of newspapers which published improper intelligence, or proclaimed improper political doctrines. In 1774 Franklin was dismissed, and his dismissal has been ascribed to a desire to impede the distribution of his publications. ${ }^{x}$

There is no doubt that the Crown authorities attempted through the postmasters to prevent the distribution of colonial newspapers, and it was this action which led in the first instance to the suggestion for the establishment of an independent American Post Office. ${ }^{2}$ The resolutions of the Continental Congress by which the American office was established in 1775 did not provide for the transmission of newspapers. Nor does the ordinance of the 21st October 1782 prescribe any rates for their transmission; but licenses the postriders to carry them, presumably outside the mail, the charges made by them for the service to be retained by the riders as a perquisite.

The statute of 1792 first fixed rates for newspapers, as follows: 1 cent a copy when sent for distances less than 100 miles, and $1 \frac{1}{2}$ cents a copy when sent for distances greater than 100 miles. This charge was opposed in Congress, and efforts were made to legalize free transmission by extending, so as to cover the transmission of newspapers, the general privilege of franking conferred by the Bill on members of Congress, on the ground that as the Government of the country was a government of opinion, which always depended ultimately on the suffrages of the people, much greater reliance was to be placed on the confidence of the people than on any other circumstance. Such confidence could

worst Use of in the present Situation of Affairs."-Minutes of Pennsylvania Council, 21st March 1757.

The Council recommended that the Postmaster be commanded to be extremely cautious "to prevent the publication of improper intelligence," and that the Governor should be authorized to excrcise a censorship on the publication of news.

I It was in point of fact due to his action in submitting to the Assembly of Pennsylvania English official letters addressed from the Governor of the colony which had come into his hands.

2 See supra, pp. 64-5. 
only result from the fullest information, which the people had a right to expect, not only as regards the actions of the Government but as regards the principles on which they were grounded. ${ }^{x}$

Some members were disposed to approach the question from the financial side, and contended that the rates proposed were not sufficient to discharge the expense of the service. The middle way between economic rates and free transmission was finally adopted.

An Act of 1794 amended the rates on newspapers and provided a further special rate for magazines and pamphlets. Newspapers might now pass from any one place to any other within the same State for 1 cent; magazines and pamphlets at 1 cent a sheet for distances not exceeding 50 miles; $1 \frac{1}{2}$ cents a sheet for distances over 50 miles and not exceeding 100 miles; and 2 cents a sheet for any greater distance. A suggestion was made in Congress to reduce the newspaper rate to half a cent for distances not exceeding 100 miles, and 1 cent for any greater distance; on the ground that it was desirable to encourage the distribution of newspapers from the seat of Government and the large towns, since such papers must contain more complete information than the country publications, which could only publish selections from the metropolitan papers. There was, however, a feeling that country papers performed a useful function and should be encouraged.

The rates on magazines were altered in 1825 to $1 \frac{1}{2}$ cents a sheet for any distance not exceeding 100 miles and $2 \frac{1}{2}$ cents for any greater distance, when published periodically and sent to subscribers; and 4 cents on each sheet for distances under 100 miles, and 6 cents a sheet for any greater distance, when not published periodically. In 1845" the free privilege for

I "To take it (the franking privilege) away would be levelling a deadly stroke at the liberty of the Press; the information conveyed by franks may be considered as the vital juices, and the channels of the Post Office as the veins; and if these are stopped, the body must be destroyed; it is treading on dangerous ground to take any measures that may stop the channels of public information. ... It is the duty of the members to dispense the newspapers among those people who cannot, perhaps, otherwise obtain them, under the protection of franks. . . The establishment of the Post Office is agreed to be for no other purpose than the conveyance of information into every part of the Union." Debates and Proceedings in the Congress of the United States, 16th December 1791 (pub. Washington, 1849). 


\section{NEWSPAPER POST IN THE UNITED STATES 151}

newspapers was first introduced, those of not more than 1,900 square inches in size, posted by the editors or publishers, being allowed to pass free within 30 miles of the place of publication. Smaller newspapers, if conveyed more than 30 miles, were charged the rates fixed by the Act of 1794 (which had been re-enacted by a statute of 1825); and newspapers of greater size were charged a uniform rate of 2 cents without regard to distance. Pamphlets, magazines, periodicals, and all printed or other matter, were to be charged by weight: $2 \frac{1}{2}$ cents for the first ounce, and 1 cent for each additional ounce or fraction of an ounce, without regard to distance.

The free privilege for local newspapers was withdrawn in 1847, except as regards copies exchanged between publishers. The latter privilege was continued from a desire to assist the country publisher, who seems always to have had friends in Congress, and who was in the habit of obtaining much of the information published in his papers from the great Atlantic cities, and other large towns which were centres of political or other interests. The free privilege was not long withheld. ${ }^{x}$ An Act of 1851 again extended it to all weekly newspapers sent from the office of publication to bona fide subscribers within the county where published, provided the newspaper did not exceed 3 ounces in weight; with a scale of postages graduated according to distance for papers sent out of the county where published. A graduated scale for pamphlets, periodicals, magazines, and all other printed matter, was also established by this Act. In the following year a rate of 1 cent was fixed for each newspaper, periodical, unsealed circular, or other article of printed matter, not exceeding 3 ounces in weight, sent to any part of the United States; and for every additional ounce or fraction thereof, 1 cent additional. In 1861

I "The poisonous sentiments of the cities, concentrated in their papers, with all the aggravation of such a moral and political cesspool, will invade the simple, pure, conservative atmosphere of the country, and meeting with no antidote in a rural Press, will contaminate and ultimately destroy that purity of sentiment and of purpose which is the only true conservatism. Fourierism, agrarianism, socialism, and every other ism, political, moral, and religious, grow in that rank and festering soil. . . . Relieve them (the country papers) from the burden of postage and they can successfully compete with the city publishers. Reduce the rate of postage on newspapers and pamphlets, and you diffuse light and knowledge through the land."-Mr. Venables in House of Representatives, 18th December 1850 (Congressional Globe). 
the rate of postage on any newspaper, periodical, unsealed circular, or other article of printed matter, not exceeding 3 ounces in weight, conveyed over the overland route between any State or Territory east of the Rocky Mountains and any State or Territory on the Pacific, was made 1 cent. The letter rate between the same areas was 10 cents per $\frac{1}{2}$ ounce.

A statute of 1863 classified mail matter, defining three groups. Newspapers, magazines, and pamphlets fell into the second group, which comprised all printed matter issued at stated intervals, but different rates were fixed for different sections of such matter. On printed matter issued weekly and sent to regular subscribers, the rate was 5 cents a quarter for publications not exceeding 4 ounces in weight, with an additional rate for every additional 4 ounces or fraction thereof. If issued seven times a week, the rate was 35 cents a quarter for every 4 ounces. If issued less frequently than weekly, the charge was 1 cent a copy not exceeding 4 ounces in weight, and small newspapers might be sent in packages and charged the same rates by weight. On transient ${ }^{1}$ second-class matter, and miscellaneous matter of the third class - the third class included all other printed matter-the rate was fixed at 2 cents for each 4 ounces or fraction thereof.

The rates of 1863 were slightly modified in 1872, and a local delivery rate of 1 cent was established for newspapers. Two years later a new method of charging postage on newspapers and periodicals posted by publishers or newsagents was introduced. Instead of being charged on each individual packet, postage was to be charged on the gross weight of the newspapers posted by a publisher, irrespective of the number of separate packets to be handled. The rate was 2 cents a pound on newspapers and periodicals published weekly, and 3 cents on those issued less frequently than once a week. These rates only applied to such newspapers and periodicals as were mailed from a known office of publication, or news agency, to regular subscribers or newsagents, and did not apply to those for local delivery. By a statute of 1876 publications designed primarily for advertising purposes, or for circulation free, or at nominal rates, were made third-

I.e. odd packets posted by members of the public, as against the regular bulk postings of publishers. 
class matter, and thus excluded from the privilege. In 1879 the present rate of 1 cent a pound (bulk rate) and a revised classification were established. Matter was admitted to the second class on the following conditions:-

First.-It must regularly be issued at stated intervals as frequently as four times a year, must bear a date of issue, and must be numbered consecutively.

Second.-It must be issued from a known office of publication.

Third.-It must be formed of printed paper sheets, without board, cloth, leather, or other substantial binding, such as distinguish printed books for presorvation from periodical publications.

Fourth.-It must be originated and published for tho dissemination of information of a public character, or devoted to literature, the sciences, arts, or some special industry, and having a legitimate list of subscribers; provided, however, that nothing herein contained shall be so construed as to admit to the second-class rate regular publications designed primarily for advertising purposes, or for free circulation, or for circulation at nominal rates.

In 1894 the privilege was extended so as to include under certain conditions the periodical publications of benevolent or fraternal societies; and again in 1900, to include the periodical publications issued by State departments of agriculture.

It was provided by the statute of 1879 that a supplement may be enclosed with a second-class publication, without subjecting it to extra postage, provided that it is germane to the publication which it supplements, that is to say, is matter supplied in order to complete that to which it is added or supplemented, but omitted from the regular issue for want of space or time, or for greater convenience. It must, however, in every case be issued with the publication.

Since the establishment of these conditions and rates, there has been a steady and growing increase in the amount of second-class matter sent through the mails. In 1879, under the old rates, the total weight sent at the pound rate was $51,125,500$ pounds. In the following year the total weight was $61,822,629$ pounds; and by 1910 the total had increased to $817,772,900$ pounds, that figure representing an increase of no less than 94,539,718 pounds on the total for 1909 .

During the whole of this period the accounts of the Post Office in the United States had in two years only (in 1882 and 1883) shown a surplus of revenue over expenditure. In view of the vast quantity of matter sent in the mails at very low rates, the question naturally suggested itself whether, seeing 
that it was necessary year by year to call on the public treasury for funds to meet the deficiency in the Post Office accounts, it would not be practicable, and equitable, to obtain an increased revenue from this class of traffic. The fact that considerable abuses of the second-class mail privilege had grown up made consideration of the question the more necessary.

Periodicals obtained so great a privilege as compared with ordinary books, that publishers sought devious ways to obtain the advantage of the pound rate. Books termed a "library" were issued periodically, with a frequency sufficient to meet the requirements of the Act, numbered in series, and devoted to literature or science; were issued from a known office of publication, and with a list of subscribers. Complying thus with all the requirements of the Act, there seemed no ground on which these publications could be refused admission to the second-class privilege, and they were accordingly entered. The practice grew, and a multitude of libraries, comprising books on every conceivable subject, were distributed through the mails as second-class matter. The Act permitted the posting of sample copies, and as no limit to the number of such copies was fixed, the mails were burdened with vast quantities of sample copies of publications which, while complying with the letter of the statute, as did the "libraries," were in reality mere advertising media. The subscription list was extremely small in comparison with the number of sample copies sent out, and in many cases the subscriptions had been obtained by the offer of premiums at least equal in value to the subscriptions. Another abuse appeared. Under the law, copies of newspapers and periodicals mailed under the second-class privilege which were found to be undeliverable were, when returned to the publisher, liable to postage at the rate of 1 cent for each 4 ounces; but newsagents had the right to send second-class mail to one another, and in order to avoid the higher rate on returned copies, the publishers arranged a scheme by which the copies were returned by one newsagent to another newsagent whose office was near by the publisher's office. These abuses assumed such proportions that in 1889 the Postmaster-General, Mr. Wanamaker, brought them to the notice of Congress and asked a remedy. Nothing was 
done, however. In $1892 \mathrm{Mr}$. Wanamaker again complained of the sahe gross abuses, and especially of the book abuse, which had then become, he said, "a practice of so long standing that it has crystallized into law, allowing to papercovered books which are simply numbered, and dated, and designated as periodicals, though in reality not so, the privileges of genuine periodicals." I He also attacked with vigour the sample-copy abuse. ${ }^{2}$

Several Postmasters-General caused estimates to be made of the actual cost to the Post Office of the handling and transmission of the second-class mail. An estimate made in 1894 indicated the cost of transportation for all mail matter as 8 cents a pound, and on that basis second-class matter at that time involved a loss of nearly 17 million dollars for transportation alone. In 1897 the total loss on account of the second-class mail was estimated at 26 million dollars. A further estimate made in 1901 indicated that the cost of transportation of second-class matter was at least 5 cents a pound, and that the cost of handling was a further 2 cents, giving a total cost of 7 cents a pound on matter for which postage at the rate of only 1 cent a pound was paid. 3

In 1905 Postmaster-General Cortelyou submitted an estimate which put the loss on second-class matter at some $\$ 27,000,000$ a year; and he recommended that the whole question should be considered by Congress, and a law enacted

Report of Postmaster-General, 1892, p. 68.

2 "The law cannot be so construed as to permit such an abuse-an abuse that, while operating to load down the mails with immense masses of stuff of insufficient value to command cash-paying subscribers to any extent, would be a wrong to every business institution which issues its advertising circulars and other matter in an undisguised manner and therefore pays the lawful rate of postage on them."-Ibid., p. 72.

3 "The most urgent need of the postal service is the rectification of the enormous wrongs which have grown up in the perversion and abuse of the privilege accorded by law to second-class matter. This reform is paramount to all others. . . F For this costly abuse, which drags on the Department and weighs down the service, trammels its power and means of effective advancement in every direction."-Ibid., 1899, pp. 4 and 5.

In 1900 it was stated that the whole cost of the extension of the rural free delivery service could be met from tho saving which would result from the elimination of the second-class mail abuses.-Ibid., 1900, p. 13.

In 1901 it was described as " the one great overshadowing evil of the service, because it underlies and overtops all other rcform and advance."-Ibid., 1901, p. 4. 
which should simplify the tests by which mail matter was classified.

These vigorous and oft-repeated recommendations of successive Postmasters-General, though not resulting in legislation, at length achieved a result in the appointment in 1906 of a joint Commission of Congress on second-class mail matter. The Commission held meetings in New York, and took evidence from the Post Office department and from representatives of each national organization of publishers in the United States. Their report, presented in January 1907, was in no sense conclusive. Their chief difficulties had arisen from the impossibility of obtaining from the department any statistics as to the cost of mail matter class by class-a difficulty which is inherent in Post Offices conducted on the modern system of accounting for postage of all classes by postage labels of the same type, and handling all classes of matter promiscuously; and their chief recommendations were that the department should take fresh statistics with regard to all mail matter, ${ }^{\mathbf{I}}$ and make an analysis of operating expenses with a view to apportionment between the various classes of mail matter. The Commission was so dissatisfied with the department's position with regard to the ascertainment of a proper division of the total expenses, that they recommended the appointment of a further Commission to examine thoroughly "the whole business system " of the Post Office, and particularly to determine, if possible, firstly, the actual cost of all the postal services; secondly, the proper apportionment of that cost between the various classes of mail matter; and thirdly, what modifications of the system of bookkeeping and accounting were desirable. ${ }^{2}$

By a statute of the 2nd March 1907, Congress authorized the appointment of a joint Commission "to make an investigation into the business system of the Post Office and postal service." The same gentlemen who had composed the Commission of 1906 were appointed to the new Commission, but its labours led to no practical result.

I There had been, under an Act of 26th June 1906, a weighing of second-class matter from 1st July to 31st December 1906.

2 Report of Postal Commission on Second-class Mail Matter, 1907. Known as the Penrose-Overstreet Commission, from the names of two of its members. 
The other recommendation of the Penrose-Overstreet Commission, viz. that further statistics should be obtained with regard to second-class matter, was also adopted by Congress, and the statute authorizing the Commission on business methods also authorized the taking of statistics of the weight, number of pieces, and average haul of all classes of mail matter, separately, and the average load of all cars by which it was forwarded by railway. With the statistics so obtained as a basis, ${ }^{2}$ the department undertook the task, which, as stated by the Commission of 1906, had previously been impossible of performance, of calculating the actual working cost assignable respectively to the various classes of mail matter. A Committee, which was appointed in October 1908, and reported in November 1909, arrived at the conclusion that the cost of dealing with second-class mail matter was about 9 cents a pound. The whole subject was before the Committee on the Post Office and Post Roads of the House of Representatives in January and February 1910. Many representatives of the publishing interest attended and gave evidence, and the

I The actual statistics to be obtained were defined thus :-

"The Postmaster-General shall cause a record to be kept from July first to December thirty-first, nineteen hundred and seven, inclusive, of the woight in pounds, respectively, of first-class, second-class, free, paid-at-the-pound-rate, and transient, third-class, and fourth-class matter and all franked and penalty matter and the equipment carried in connection therewith.

"For thirty days during such period he shall require a record to be kept of the weight of each of the classes above specified despatched from such post-offices as he shall determine to be representative for the purpose and have computed thereon, in the most practicable way, the average haul of the mail of the different classes and sub-classes as hereinbefore set out. For seven days during such period he shall cause a record to be kept of the revenue received from each of the classes and sub-classes of mail matter hereinbefore specified and a count of the number of pieces of each class and sub-class, showing also for the first class the number of letters, postal cards, and other matter separately, and for thirty consecutive days during such period he shall cause a record to be kept for the purpose of ascertaining the average load of railway post-office cars other than storage cars, the average load of storage cars, and the average load in compartment cars.

"Such record shall be reported to Congress by May first, nineteen hundred and eight, and the sum of three hundred thousand dollars, or so much thereof as may be necessary, is hereby appropriated, out of any money in the Treasury not otherwise appropriated, to cover the expense of such weighing and counting and the recording and compilation of the information so acquired, and the rent of necessary rooms in the city of Washington, and the same shall be immediately available."-Statute of 2nd March 1907.

Special Weighing of the Mails, 1907. Document 910, 60th Congress. 
department's calculations were subjected to examination and criticism. ${ }^{\text {I }}$

Congress and the Executive were still, however, unable to arrive at a satisfactory conclusion on the question, and on the 4th March 1911 a joint resolution of Congress authorized the appointment of a further Commission on second-class mail matter, this time not a Congressional Commission. A judge, the president of a university, and a business gentleman were appointed to the Commission, which held sessions in New York in the latter part of the year, and took evidence from the Post Office department and representatives of the publishing interests. They found that the data available were insufficient to enable them to determine the total cost to the Post Office of the services performed in respect of second-class mail matter; but they were able to estimate the cost in regard to certain items of the expenses of the Post Office. The cost under those headings, which must, of course, be less than the total cost, they found as $5 \frac{1}{2}$ cents a pound for ordinary paid-at-thepound-rate matter and 5 cents a pound for free and transient matter. ${ }^{2}$ That part of the general expenses of the service which the Commission were unable to assign satisfactorily between the various classes of mail matter was estimated by the Post Office department to amount to over 2 cents a pound for second-class mail matter. 3 On this basis, of course, a heavy increase in the rate of postage would be warranted; but in view of the uncertainty of the effect of the competition of the express companies which would result from a large increase in the rate of postage, of the fact that the publishers' business established in faith of constancy of the postage would seriously suffer from such a sudden increase, and of the well-known policy of encouraging distribution of educational literature, 4 the Commission hesitated to recommend any large increase, and contented themselves with recommending that the rate be raised from 1 to 2 cents a pound.

- Hearings before Committee on Post Office and Post Roads (House of Representatives), January-February 1910.

$=$ Report of Commission on Second-class Mail Matter. Appendix to Message of President of 22nd February 1912, pp. 137-8.

3 Ibid., p. 129.

4 "The historic policy of encouraging by low postal rates the dissemination of current intelligence, and the extent to which it has proved successful, should not be overlooked." -Ibid., p. 143. 
Given that the actual cost of the handling and transporting of second-class mail matter is on the average 9 cents a pound (regarding which the department is quite satisfied) and a rate of postage for such matter of 1 cent a pound, the department has, on the face of things, a strong case ; and it is not necessary to ascribe other motives in order fully to explain and justify the course it has adopted. But the publishers felt that they were not favourably regarded by the Republican Administration. They claim, and the claim is admitted in influential quarters immune from pressure from them, that they are largely responsible for the establishment of the insurgent wing of the Republican party, whose action against the late Administration proved so disastrous to the fortunes of the party. In the course of these political activities they have made enemies; and they conclude that in the Republican party, many of whose members have been disgraced, if not indeed driven from public life, there has arisen a strong feeling against the publishers. The activity of the department against the second-class rate is alleged to have begun after the publication of articles in the magazines exposing the corruption in the cities, and incidentally reflecting on members of the Republican party. Moreover, the department's most drastic recommendations have been directed not against second-class matter as a whole, but against the periodicals; and they have been made under the guise of preventing, as contrary to the intent of the statute, the dissemination at the second-class rate of vast quantities of advertising matter. Thus, the department has recommended that that portion of periodicals which consisted solely of advertising matter should be charged at a higher rate than the rest of the publication (which would be allowed the second-class rate), while nothing at all was proposed as regards ordinary newspapers, a discrimination which cut the publishers of the periodicals deeply.

The representations of the Post Office department, extending over some twenty years, and of most decisive and emphatic character, have not yet succeededr: in obtaining legislation for the reform of the years back the department arrived at the conclusion that the authority of the existing law was sufficient to enable the more flagrant abuses to be checked, if not eliminated. A series 
of rulings were thereupon promulgated, and by this means some of the worst abuses have been removed, such as, for example, the transmission as second-class matter of "libraries," issued as periodicals. These rulings were resented by the publishing interests, with whom it was a source of great complaint that the interpretation of the statute defining second-class mail matter was left to arbitrary decision by officials of the department. ${ }^{x}$ The intense feeling in America against any sort of bureaucracy, and especially against a bureaucracy of the central Government, leads to a natural jealousy of the exercise of this power, and as a remedy the suggestion was advanced that provision should be made, first, for questions of the interpretation of the Act to be decided in the first instance by a permanent Commission located at Washington, on which the publishers should be represented; and secondly, that there should be an appeal from the decisions of this Commission to the ordinary courts of justice.

The department admits that its position with regard to the interpretation of the statutes is unsatisfactory. Under the existing system, all manner of questions are asked regarding the private business of the publisher, and the decisions from Washington are often delayed. ${ }^{2}$ But as against the contention of the department, which was for an amendment of the law, the publishers contended that the law, while no doubt not altogether perfect, was in the main sound and just, and the rate of postage of 1 cent a pound was as great a boon as was ever conferred by Congress. They denied that it was in any sense a subsidy.3 They also denied the existence of a deficiency,

I "If the Republic of our patriotic love is to live and our people preserve their liberties, the sheet-anchor of their salvation is a free, independent, untrammelled and fearless Press, and we believe that to maintain this happy condition publishers must not be subjected to any arbitrary authority that claims and exercises the power to destroy by closing the mails against them without the right to appeal to the courts, a right that is held sacred by every citizen, however humble, whenever and wherever his opportunity to earn a livelihood in an honourable business is called in question or denied him."-Evidence of Mr. Wilmer Atkinson of Philadelphia, Pa., Report of Commission on Second-class Mail Matter, 1906, p. 412.

2 "Publishers are now sometimes kept on the anxious seat for months awaiting decisions which may wreck their businesses." -Evidence of Mr. Madden, Third Assistant Postmaster-General.-Ibid., p. 89.

3 "'There is no 'subsidy' at all, as claimed by the foolish, but simply that the lawmakers of the greatest Government on earth have been wise enough to see to 
and contended that so far from its being true that the Post Office business involved a loss, there was each year a profit of millions of dollars. This result they arrived at by estimating the cost to the Post Office of the distribution of Government free matter, and the cost of the rural free delivery, which they added together, setting the total against the deficit shown in the published accounts of the department. By this means a balance of profit was obtained for each year. The estimated postage payable at the usual rates in respect of the free matter was of course an item legitimately to be added to gross revenue; but it was doubtful whether the cost of the rural delivery service could be deducted from gross expenses, as the publishers insisted, on the ground that the service was "extraordinary."

The publishers made a further allegation. At that time the express companies cut even the very low existing centa-pound rate on second-class mail matter for short distances, and if that rate were raised the range of their competition would be extended. With a 2-cent rate a much greater proportion of the traffic would inevitably fall to them. This would, of course, be very advantageous to the companies, to whom, as to railways, any increase in the volume of traffic handled would be welcome. These express companies had for many years been faithful supporters of the Republican party, and behind the suggestion to increase second-class rates the publishers were convinced there was a desire on the part of the leaders of the party to reward their faithful allies. ${ }^{\text {I }}$

But perhaps the chief contentions of the publishers, which the Post Office was bound to some extent to admit, and would in any case find it difficult to meet, were the claim that newspapers create a vast quantity of first-class mail ; and the claim that since the payment made to the railway companies in

it that the people shall have periodical literature within easy reach, and with as little expense as possible."-Evidence of Wilmer Atkinson, ibid., p. 441.

" "Who knows but that the onerous restrictions of the department have some connection with the efforts of the express companies to have second-class mail rates increased, and by both means drive the publishers of the country to employing the express companies to carry their publications? Such would not be beyond the craftiness of these skilled farmers in the field of legislation." Nathan B. Williams, The American Post Office, 1910 ; Document 542, 61st Congress, and Session, p. 40. 
respect of the transportation of the mail is based on a sliding scale, decreasing as the volume of traffic increases, the weight of second-class matter brings down appreciably the rate actually to be paid.

Some who appeared before the Commission of 1911 were inclined to go beyond these general contentions as to the relative claims of second-class matter, and to assail the whole administration of the department from the economic standpoint; challenging especially the relations with the railway companies, and arguing that the payment made for the conveyance of mails was not equitable when compared with the charges made by the companies for similar services performed for the express companies.

Notwithstanding these contentions, there can be no question that the transmission of the second-class mail at the present rates involves the department in heavy loss; and that Congress, not unaware of this, attaches importance to the advantages which a low rate for such matter confers. The Commission were satisfied on both points. It is, however, doubted by many whether the effect of this privilege has been altogether salutary from the educational point of view. It has encouraged to an almost incredible extent the publication of periodical magazines, and many of these magazines are of $a$ high order of merit as periodical publications. The United States leads the world in the publication of this kind of matter. $^{\mathbf{I}}$ But the reading matter which is found in these publications is to a large extent light and trivial. The publication of serious intellectual works has shown little advance in recent years, ${ }^{2}$ and there is a fairly widespread feeling in

" "Yet we publish more periodicals than Germany, France, Russia, Great Britain, Switzerland, Belgium, and Holland aggregated, and yon may then add all the other countries of Europe, then Canada and Mexico. Then add all the Central American States, and the South American States, and the African Colonies-North, South, East, and West. You must still add Australia, and Hindoostan, and all other Asiatic countries, including Japan and China, and even then you haven't reached the end of the story. You then have only 40 per cent. of the total against our 60."-C. W. Burrows, One Cent Postage, etc., Cleveland, Ohio, 1911, p. 11.

2 "The great decrease in all the more serious departments of literature, as well as in some of the lighter ones, is a curious and unexplainable condition of our book production. Scientific and philosophical writings are as conspicuous through their absence as are the simply amusing books."-Publishers' Weekly (Now York), 3 th January 1904. 
America that the two developments are connected. But that is a matter difficult to determine.

In any case, many people are proud of the development in periodicals, and the department, in spite of its efforts, has so far failed to secure any increase of rate. Although the PostmasterGeneral and the President ${ }^{x}$ adopted the recommendations of the Commission of 1911, and urged their consideration on Congress, Congress has not taken action, and has, indeed, forbidden the department to extend certain arrangements for the use of freight trains for the transmission of second-class matter, whereby a saving of expense could be secured, a phenomenon probably explicable by the constitution of American politics. ${ }^{2}$

Message to Congress, 22nd February 1912.

2 "No lobby ever sent to Washington in furtherance of the most corrupt legislation has ever been more persistent or dealt less fairly with both legislators and public than the lobby that has worked for the retention of the second-olass mail graft."-O. W. Burrows, One Cent Postage, eto., Cleveland, Ohio, 1911, p. 4. 


\section{NEWSPAPER POS'I IN FRANCE}

IN France, printed matter, whether issued periodically or otherwise, seems always to have enjoyed a lower rate of postage than the written letter. Before the Revolution there was diversity of practice as regards the rate of postage charged on newspapers. Some privileged papers paid only 5 or 6 deniers the sheet, while others paid 8 deniers. All the rates were purely arbitrary. When the Committee on Public Taxation of the National Assembly considered the question of fixing the rate for newspapers, they considered not only how to regularize the rate, but also whether they could raise it. Viewed from the economic standpoint, the rate was thought by some to be inadequate. The Committee was satisfied that not only would the new rates cover the cost of the service, but that there would also be a slight profit, although they felt it would not be proper, or even possible, to make that part of the business of the Post Office a really lucrative source of revenue. ${ }^{2}$

The decree of 17-22 August 1791 established the rate of

1 "Je vois que le prix du port des journaux fera d'un vingt-quatrième du prix des lettres. Le prix n'est sans doute pas suffisant pour les frais de la poste, et je ne crois pas que l'envoi des journaux doive être à la charge de la nation."-M. Biozat, Assemblée Nationale, 17 août 1791 (Le Moniteur Universel).

z "Si vous examinez cet objet sous un point de vue fiscal, je vous dirai qu'en augmentant le tarif, vous diminuez le produit, en rendant la circulation de plusiours feuilles impossible. Le plus léger surbaussement de taxe priverait de tout bénéfice les autres des productions périodiques les plus utiles, telles que les journaux d'agriculture, de physique, d'histoire naturelle, de médecine, eto., qui, par leur nature, ne sont pas susceptibles d'avoir un grand nombre de souscripteurs. Et les journaux que l'on aurait peut-être en vue d'écarter sous le poids d'un impôt onéreux seraient précisément ceux que l'avide curiosité du public ferait résister à la surtaxe. Personne d'ailleurs ne révoquera ne doute que, de tous les commerces, celui des idées soit le plus précieux, et je crois que vous devez le favoriser de toutes les manières." - M. Larochefoucault, Assemblée Nationale, 17 aout 1791 (ibid.). 
8 deniers per sheet for daily newspapers (and other daily publications), and 12 deniers per sheet for other periodical publications. Pamphlets or unbound books were charged a sou the sheet. Bound books were not allowed to pass by post. It is unlikely that these rates were remunerative. They were modified several times during the next few years; but although the modifications were in the direction of increase, the rates for newspapers still compared very favourably with the rates for letters. ${ }^{x}$

A. law of 6 messidor, an IV (1795), established a rate of 5 centimes for newspapers and other periodical publications delivered in the place of publication, and 10 centimes for all other destinations; but this discrimination was removed by the law of 4 thermidor, an IV, which substituted a general rate of 4 centimes the sheet. An attempt was made by the administration to raise the rates on newspapers and books. As regards newspapers the proposal was, however, rejected by the Conseil des Anciens.

In 1796 a new rate for newspapers and other periodical publications was established, viz. 4 centimes for each sheet. For other printed matter the rate was fixed at 5 centimes per sheet.2 This law failed to prescribe the limits of size of the sheets according to which postage was to be charged, an omission supplied by an ordinance of the 5th March 1823, which fixed the dimension of the sheet at 24 centimetres by 38 . The newspapers interested tried to resist this restriction, contending that the ordinance was illegal, because the laws of 1796 prescribed no limit and the Government could not impose one by ordinance: for such a purpose a new law was necessary.

The law of the 27 frimaire, an VIII (17th December 1799), had established a scale of charges according to weight, and the

- The increase during the Revolutionary period was nevertheless considerable. Before the Revolution the cost of distributing 60,000 prospectuses by post was 200 livres. Under the rates then in operation it would be 3,000 livres, and under the new rates then (1796) proposed, 7,500 livres. Before the Revolution a volume could be sent from one end of France to the other for 12 sous.-A. Belloc, Les Postes françaises, Paris, 1886, p. 353.

" "Le conseil des Cinq-Cents, considérant qu'il importe de faolliter la circulation des ouvrages périodiques, brochures, catalogues, et prospectus tant pour encourager la libre communication des pensées entre les citoyens de la République que pour augmenter le total du revenu public. . . ."-Proclamation, 1796. 
rates were fixed according to the distance actually traversed, under the arrangements then existing. This restriction, which was unfortunate, because the services existing during the Revolutionary period were not of a character to serve as a basis for the future, was felt to be onerous, and numerous complaints were lodged by communes which felt themselves placed under a disadvantage.

In 1827 the rates were revised and placed on a more stable basis. ${ }^{2}$ The principle first established in 1791, of charge according to the distance between two places reckoned as the crow flies, was re-established; and a provision was inserted in the law to meet the difficulty which had arisen as to the legality of the ordinance of 1823, purporting to fix the size of the sheets on which the postage on printed matter was calculated. Postage on newspapers and periodicals was made 5 centimes for each sheet of 30 square decimetres for all destinations; but the charge was reduced by one-half for newspapers and periodicals circulated within the department where they were published, the reduced rate being established with the view of protection of the country Press, whose subscribers were in general local, against the competition of the Parisian Press. In 1830 the rate of 5 centimes the sheet for newspapers and other periodical publications was reduced to 4 centimes. The rates of 1827 remained otherwise unchanged.

In 1850 the newspaper tax and the postage were assimilated -that is to say, newspapers were subjected only to one tax, and payment of that tax secured the right of transmission by post. The tax was at the rate of 5 centimes per sheet of 72 square decimetres or less for newspapers published in the departments of Seine and Seine-et-Oise, and 2 centimes for those published elsewhere. All newspapers on which a tax of 5 centimes was paid, were entitled to free transmission by post throughout France. Those on which a tax of 2 centimes was paid, were entitled to free transmission by post within the department in which they were published and the adjoining departments. In order to obtain transmission by post throughout France, an additional sum of 3 centimes per paper must be paid on these latter newspapers. ${ }^{2}$ The Minister of Justice, in introducing the measure in the National As-

s Law of 15th March 1827.

2 Law of 16th July 1850. 
sembly, explained that it would serve a double purpose : on the one hand it would give an increase of revenue of some six millions a year; and on the other it would safeguard society against detestable doctrines, because it would fall specially on those evil newspapers and books ${ }^{1}$ which were circulated at a low price in town and country, propagating prejudices and error, exciting the passions and corrupting the conscience of the public. ${ }^{2}$

Louis Napoleon Bonaparte, in 1852, desirous that there should be no obstacle in the way of his ultimate assumption of absolute power and the Imperial crown, issued a decree further restricting the Press in France. The publication of newspapers or periodicals dealing with political or economic questions, unless authorized by the Government, was forbidden; and the rates of postage in force prior to the law of 1850 were imposed on newspapers, in addition to the tax imposed by that law. 3 The same principles led to the discrimination introduced in 1856 between political and nonpolitical papers. The former were subjected to a higher rate of postage than newspapers of a non-political character, because the Government felt it to be necessary that there should be some moderating influence to check the effect of political journals in times of intense political excitement, and adopted this expedient. 4

The rates for printed matter had for a long period caused considerable confusion, and given rise to many complaints from members of the public. They were still determined according to the linear surface of the sheets, a method which was found to cause considerable embarrassment and difficulty in its practical application. To all other classes of postal traffic the more logical and more convenient principle of charge according to weight had already been applied, and in

There was also at this time a tax on books.

2 M. Rouher, Assemblée Nationale, 21 mars 1850 (Le Moniteur Universel).

3 Decree of 17 th February 1852.

4 The political Press was somewhat strictly controlled. The law of 1814 on the liberty of the Press, which was continued by the Press law of the 27th June 1849 , imposed on every printer the obligation to deposit with the Procurator Imperial every article treating of political matters or social economy twenty-four hours before publication, under penalty of a fine of 100 to $500 \mathrm{fr}$. A decree of 1852 subjected political publications to a stamp duty. 
1856 this principle was applied also to printed matter of all descriptions. Weight was made the basis of the charge, without reference to superficies or to distance, except that for political reasons the privilege of half-rates for newspapers circulating in the department in which they were published was continued. $x$ The reduction of the actual rates made by this law was slight, and was estimated not to have any appreciable effect on the total revenue. In any case the question was " regarded less from the financial point of view than from the point of view of the satisfaction which it would give to the needs of commerce and industry and of private intercourse in general." 2 The new rate was 1 centime for each 10 grammes, with a minimum of 4 centimes for political, and 2 centimes for non-political newspapers.

This reduction of rate, together with the reduction for other printed matter, for samples, and for commercial papers, resulted in a large increase in the number of bulky packets sent by post. In order to ensure prompt delivery, it was found necessary in Paris to separate to some extent the letter-post traffic from the traffic sent at the lower rates, and the principle of providing a separate staff of postmen for the delivery of newspapers, magazines, samples, etc., was introduced.3 The application of this principle has since been extended, and the two kinds of traffic are now dealt with in Paris altogether separately, by separate staffs of officers.

The newspaper rates were next revised in 1878. The discrimination between political and non-political newspapers

" "Les journaux n'étant plus dangereux et ne pouvant plus faire que du bien, l'honorable membre eût désiré qu'une légère réduction des droits de poste leur permît d'acquérir une existence plus sûr, plus indépendante, afin qu'on pût les retrouver fidèles et dévoués, si la France avait encore des jours difficiles à traverser. Nul n'a oublié, en effet, l'admirable attitude de la Presse départmentale au milieu des événements de 1848, son empressement à se rallier à la cause du Président de la République, le courage que ses rédacteurs ont montré pour la défense de l'ordre, courage que quelques-un on payé de leur vie.

"Telles sont les considérations d'équité et de politique qui avaient fait réclamer en faveur de la Presse départmentale une réduction de taxe. Tout ce que la commission a pu obtenir, c'est qu'il n'y aura pas d'aggravation de taxe lorsque le numéros circuleront dans les départments limitrophes. Rien ou à peu près rien ne sera donc changé aux charges que les journaux de province ont supportées jusqu'à ce jour."-M. Paul Dupont, Chambre des Députés, 31 mai 1856 (Le Moniteur Universel).

$=$ Motif du loi, cited A. Belloc, op. cit., p. 542.

3 Ibid., p. 545. 
was abolished, but the privilege accorded to local newspapers was continued. The new rates were :-

1. Two centimes for the first 25 grammes and 1 centime for each further 25 grammes or fraction of 25 grammes for newspapers published in the departments of Seine and Seine-et-Oise and circulating outside the department where published; and for newspapers published in other departments and circulating outside the department where published and the adjacent departments.

2. One centime for the first 25 grammes and $\frac{1}{2}$ oentime for each additional 25 grammes or fraction of 25 grammes for newspapers published in the departments of Seine or Seine-et-Oise and circulating within the department where published.

3. One centime for the first 50 grammes and $\frac{1}{2}$ centime for each additional 25 grammes or fraction of 25 grammes for provincial papers other than those of Seine and Seine-et-Oise, circulating within the department where published or adjacent departments.

The existing rate for inland newspapers, which is based on the law of the 16th April 1895, is as follows :-

Two centimes for each copy up to 50 grammes, and 1 centime for each 25 grammes or fraction of 25 grammes above 50 grammes.

Only half these rates is charged when the papers circulate within the department in which they are published or the adjacent department.

In $1908^{x}$ the rates in respect of newspapers sorted and bundled according to the offices of destination and the post routes, were reduced to 1 centime for the first 50 grammes and 1 centime for each additignal 25 grammes or fraction of 25 grammeshalf this rate being charged for papers circulating within the department of publication or the adjacent departments.

The value of a centime is roughly one-tenth of a penny. It is hardly necessary, therefore, to point out that these rates are divorced entirely from economic considerations, and are to be explained only on political and administrative grounds. ${ }^{2}$

- Law of 29th April.

" "La poste perd sur le transport des journaux et des imprimés.

“Pour l'année 1889, M. Jaccottey (Traite de législation et d'exploitation postales, p. 329) calculait que le coût, c'est-ì-dire la dépense moyennement, fait pour un objet quelconque de correspondance, n'avait pas été supérieur à $0 \mathrm{fr} .055$. Il fixait de même le produit moyen des imprimés, par unité, à $0 \mathrm{fr} .023$, et il évaluait la perte du Trésor à 25 millions. . . .

"Le nombre des imprimés de toute catégorie était a cette époque de 800 millions. ...

“ Or, il y a eu, en 1895, dans la circulation intérieure :-

“ $514,957,761$ journaux ayant rapporté $8,378,873$ fr. soit, par unité, 1 centime 62, 472,202,885 imprimés de toute nature, dont 82,597,172 sou 
It has been estimated that in 1895 the loss on printed matter of all kinds was 36 million francs.

In France, as in other countries, the privilege of transmitting periodical publications at a specially low rate of postage was much availed of for the transmission of advertising matter, of publications which were essentially of the character of catalogues or prospectuses rather than newspapers properly speaking. A law of $1908,{ }^{x}$ passed with a view, among other things, of minimizing this abuse of the privilege, restricted the application of the reduced rate to publications issued not less frequently than once a month. The new regulation had good results, restricting, as was desired, the number of periodical publications not legitimately entitled to the privilege. It had also a result which was regarded by Parliament as undesirable: it shut out from the privilege the numerous quarterly journals of scientific and learned societies. ${ }^{2}$

By the same law the minimum rate of postage for small packets of printed matter sent under loose band, the imprimés non urgent, was raised from 1 centime to 2 centimes. The result of this was a little unsatisfactory. In order to evade the higher charge, advertisers took to printing in newspapers, circulating at 1 centime, announcements formerly sent out separately as loose leaflets, a manœuvre which struck doubly: not only was the legitimate rate of postage evaded, but instead of dealing with the matter as non-urgent at its convenience, the Post Office was obliged to treat it in the

enveloppes, avec un produit total de 13,791,025 ou par unité 2 centimes 92 . Pour ces 987,160,646 journaux, périodiques, imprimés de toute catégorie, circulent ì prix réduit, la recette total a été de $22,169,975$ fr. et le produit moyen de 2 centimes 245 .

"La perte a donc été de près de 36 millions."-Rapport portant fixation du Budget, Chambre des Députés, 1907 ; No. 2701 , p. 37.

s 29th April 1908.

2 "Il serait à désirer qu'on pât remédier à une conséquence regrețtable do la disposition particulière qui réserve aux seuls journaux paraissant au moins une fois par mois le tarif spécial accordé à la Presse.

“ En fermant la porte aux feuilles d'annonces trimestrielles on l'aussi fermée aux bulletins et annales de même périodicité publies par un grand nombre d'associations et de sociétés (sociétés littéraries, archéologiques, scientifiques, agricoles, syndicats professionels et agricoles, associations professionelles amicales d'instituteurs, sociétés de secours mutuels, etc.), qui doivent être encouragées par tous les moyens au lieu d'être gênées dans leur essor."-Ibid., Sénat, 1908, No. 340, p. 84. 
same way as all other newspaper matter-that is, to give it the benefit of equal treatment with matter sent at the letter rate.

\section{Note on Supplements.}

A decree of the 24th November 1860 gave to the two Chambers the constitutional right of discussing the policy of the Government at home and abroad, and as a natural corollary of this it was desired to secure the untrammelled publication and distribution of reports of the debates. This was attained by exempting from postage the supplements of journals when they were devoted entirely to the reproduction of the official reports of the proceedings of the Chambers, the motifs des projets de lois, reports of parliamentary commissions, or official documents deposited by the Government at the office of the Chambers.

The Press law of the 11th May 1868 extended the exemption to supplements devoted to the extent of one half to the publication of reports of parliamentary debates or documents, but only on condition that the supplements contained no advertisements. The privilege was continued by the law of 1878. I In order to obtain the privilege the supplements must be printed on sheets detached from the main publication, but they must be enclosed with the publication. They must not exceed in size that part of the paper subject to postage, and if sent separately, they are liable to postage at the ordinary rate. In 1869 the official reports of parliamentary debates were exempted from postage when sent by the printer to the editors of country papers, or by those editors to their subscribers, if enclosed with the local paper.

M. Jaccottey's view is that in order to conform to the spirit of the law, the rate for periodicals ought to be confined to newspapers and other periodical publications devoted to letters, science, and arts; and that it is an abuse of the privilege that commercial advertising should avail itself of the privilege by, say, publishing at regular intervals successive editions of library

s Defined thus in the law of 1878: "Pour moitié au moins de leur superficie a la reproduction des débats des Chambres, des exposés des motifs des projets de lois, des rapports de commissions, des actes ot documents officlels, et des cours, officiels ou non, des halles, bourses, et marchés." 
catalogues, or by borrowing the titles of illustrated journals, their outside covers, and the methods of distribution, and inserting in them prospectuses which are not of the nature of periodicals. ${ }^{x}$

Ordinary supplements may be enclosed in newspapers. They are weighed with the paper, and postage is charged according to the total weight. If sent separately, they are regarded as a number of the paper, and postage is charged accordingly. In order to obtain the benefit of the privileged rate, all supplements must bear printed indication of the fact that they are supplements, and must bear the title and date of the main paper. ${ }^{2}$

These definitions were amplified by the administration in 1896 by an instruction (No. 468) which provided that detached advertisement sheets of any sort, issued exceptionally (feuilletons, fiction, stop press news, late articles, pictures, artistic engravings, or others), which are the genuine production of the publication, whatever the size and shape or pagination, ought to be regarded as fulfilling the conditions prescribed by law for supplements and to be admitted to the privilege of the reduced rate.

P. Jaccottey, op. cit., p. 322.

2 Certain questions arose on this point, and the Council of State decided that there was no need to inquire whether the printed sheet added to the newspaper constituted an accidental and unforeseen addition, whether it was the production of the paper, whether it really appertained to the paper, nor whether it was printed at the same time. All that was necessary, in order that it might be regarded as a supplement, was that it should bear the title and date of the number which it accompanied.-Ibid., p. 325.

The Keeper of the Seals concurred in this opinion, and held that it was unnecessary to inquire into the circumstance in which the supplement was joined to the paper, whether it was special or whether it was printed at the same time; but that the supplement ought to fulfil the conditions imposed on all newspapers, to mention the title of the paper, together with the date or serial number, and to preserve, at least materially, the appearance of an annexe to the principal journal.-Ad. Frault, Manuel postal, thérique et pratique, Paris, 1893, pp. 385-6. 


\section{NEWSPAPER "POS'T IN GERMANY}

From the time of their first publication in Germany, newspapers have been distributed through the post. Little is known of the precise arrangements under which they were at first transmitted, but there is no doubt that they were accorded privileged conditions as compared with ordinary letters. The postmasters were themselves largely interested in the publication of newspapers. ${ }^{\mathrm{I}}$ By 1712 the conduct of newspaper businesses by postmasters had become recognized as a common and long-established arrangement. ${ }^{2}$

The distribution of the newspapers was largely made through the post, and a rate of charge, built up of two elements, came into existence. The first element was the "discount" (der Rabatt). This was a payment made by the publisher to the postmaster as remuneration for the work of the latter in connection with the posting and despatch of the papers and the collection of subscriptions. This discount was arranged between the postmaster and the publisher, and generally took the form of a fixed percentage proportion of the published price (Erlasspreis). The second element was the "percentage" (die Provision). This was in addition to the published price. It was collected from the addressee, and belonged partly to the postmaster at the place of destination and partly to the postmaster at the place of publication. 3 The rates were fixed by the postmasters at their discretion, and gross irregularities and anomalies in the rates resulted.

- The second oldest newspaper in Germany, the Postavisen, which appearod in Frankfurt in 1617, was published by the Taxis Postmaster, Johann von den Birghden. Of. B. Faulhaber, Geschichto des Postwesens in Frankfurt-am-Main, Frankfurt, 1883, p. 62.

2 Dr. Artur Bchmidt, Finanz-Archiv, 1906, vol. 23, part i. p. 64; Archiv fiur Post und Telegraphie, 1884, p. 290.

3 Archiv für Post und Telegraphie, 1884, p. 291. 
Public complaint arose, and it was found necessary for the State to assume control of the traffic and fix definite rates of charge. This course was first adopted in Prussia in 1821, when the following rates were established $x$ :-

4 pf. for each whole sheet of the primary publication (Hauptblattes

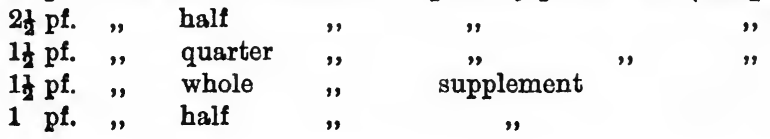

This method of charge did not, however, prove altogether satisfactory, because the term "sheet" was not defined with any degree of precision. It was thought that a better basis for the rate might be found in the price at which the newspapers were sold to the public, because, it was argued, the price must stand in exact proportion to the number and size of the copies, and also to their real value. Accordingly, in 1848 the rate was fixed generally at 25 per cent. of the published price. $^{2}$ At a somewhat later date this rate was reduced to $12 \frac{1}{2}$ per cent. of the published price in the case of newspapers appearing less frequently than four times a month.3 In 1871 the minimum yearly rate payable in respect of any newspaper was fixed at 4 sgr. 4

The application of this tariff resulted in many cases in considerable discrepancies between the amount charged and the service rendered. The improvements in the manufacture of paper and in the methods of printing, particularly the introduction of the rotary press, had cheapened the processes of production, and led to a great expansion of the newspaper trade. With this expansion came a more than proportionate expansion of the business of advertising. The result was that, as in England and America, the newspapers increased in

× Regulativ über die künftige Verwaltung des Zeitungswesens, 15th December 1821.

2 Decree of 26 th June 1848.

3 Statute of 4th November 1867, fixing rates of postage for the North German Union :-

“Diese Bestimmung entsprang aus der Erkenntniss, dass die weniger häufig erscheinenden Zeitschriften durch die volle Besorgungsgebühr von 25 pct. des Verlagspreises um so härter getroffen würden, als letzterer der Natur der Sache nach in vielen Fällen verhältnissmässig hocb sei."-Archiv für Post und Telegraphie, 1884, p. 296.

4 Statute of 28th November 
bulk; but so far from there being a corresponding increase in price, there was in point of fact a very considerable decrease. Moreover, advertisements became a more important source of revenue than the subscriptions themselves. A rate of charge based on the selling price, which might have been reasonable when newspapers were produced under the old conditions, was totally inapplicable under the altered circumstances. ${ }^{\mathrm{x}}$

The financial results proved extremely unsatisfactory. From the causes indicated, the average weight of the individual copies of newspapers continued to increase, while at the same time the price (and with the price, the postage) continued to decrease.

In 1897 the administration of the Imperial Post Office estimated that the total cost of the transmission of newspapers by post in Germany, for staff, post offices, transport, equipment, etc., was $6,178,362$ M., or about $\frac{66}{100} \mathrm{pf}$. per copy. ${ }^{2}$ The number of newspapers transmitted by post in Germany was at that time about a thousand millions annually, and the total postage received in respect of them was less than 5 million M., or on the average about

- “Wir haben heute in Deutschland Blätter, deren Jahresabonnement jährlich 2 Mark beträgt, und solche, deren Jahresabonnement bis 40 Mark beträgt. Die Post erhebt nun an Gebühr 25 Prozent von dem Abonnementspreise, womit sie die Beförderungskosten decken muss. Die Post erhält für dieselbe Leistung von einem täglichen Blatte, welches 40 Mark Abonnementspreis erhebt, 10 Mark pro Jahr und von dem andern täglichen Blatt, welches bloss 2 Mark erhebt, 50 Pfennig pro Jahr. Das ist ein ganz unhaltbarer Zustand. Wenn Sie beide Blätte nun auf ihren Inhalt prüfen, was erblicken Sie da? Auf der einen Seite Inseratenblatt, das den Text als Nebensache behandelt, das mit sehr niedrigen Redaktionskosten hergestellt wird. Auf der anderen Seite haben Sie ein Blatt, zu dessen Herstellung hervorragende Kräfte, mit einem Worte Intelligenz erforderlich ist, und dass die Intelligenz nicht billig ist, wissen wir alle miteinander; diese muss bezahlt werden. Für die Post bildet die Hauptsignatur der Zeitungen : viele Anzeigen-schweres Gewicht; niedriger Abonnementspreis-niedrige Postprovision (weil die Herstellungskosten durch die Inserate gedeckt werden). Die Post macht in Folge dessen ein schlechtes Geschäft damit. Ein Blatt mit wenigen Anzeigen bedeutet auch gleichzeitig ein geringeres Gewicht und einen höheren Abonnementspreis, und das setzt eine hohe Postprovision voraus.

“ Das sind Erscheinungen, über die seit Jahrengeklagt wird, und die durch die neue Vorlage in eln gerechteres Verhältniss zu Leistung und Gegenleistung gebracht werden sollen."-Abgeordneter Dietz, Reichstag, Official Reports, 15th November 1899, vol. iv. p. 2799.

= Dr. Artur Schmidt, Finanz-Archiv, vol. 23, part i. p. 69. 
$\frac{1}{2}$ pf. per copy $;^{1}$ in the case of a number of papers the postage was as little as 1 pf. per copy. ${ }^{2}$ The annual loss to the administration on account of the newspaper traffic was therefore on the average $\frac{16}{100} \mathrm{pf}$. per copy, or a total of about $1,600,000$ M. a year.

For many years the question was before the Budget Commission of the Reichstag, and a change soon followed the publication of this estimate. New rates, based on entirely new principles, were established in 1899.

When the Act establishing the new rates was in preparation, the Imperial Post Office administration based their proposals mainly on the principle that the charges should cover the cost of the service rendered.3 The original proposals to the Reichstag were accordingly calculated to secure an increased revenue of $1 \frac{1}{4}$ million $M$. The Budget Commission, however, so modified the proposals as to reduce this amount to $300,000 \mathrm{M}$., and further modifications were made in the Reichstag itself, with the result that under the new rates the administration was left to work with an even greater loss than formerly. 4

The large publications of the great cities, supported as they were to a large extent by the advertisements they carried, had obtained a wide circulation, to the prejudice of the

I In 1871 the number of newspapers passing by post was 203 millions, and the average postage $\frac{87}{100} \mathrm{pf}$. per copy.

2 Reichstag, Official Reports, vol. iv. pp. 2923-4: "Seit 20 Jahren ist im Reichstag sowohl als auch in der Budgetkommission erneut die Forderung aufgestellt worden, es soll ein anderer Tarif aufgestellt werden. In der Budgetkommission ist namentlich in den letzten zehn Jahren von den verschiedensten Parteien anerkannt worden, dass die Post bei der Beförderung der Zeitungen thatsächlich mit Verlust arbeitet, und dass demzufolge seitens der Zeitungen eine höhere Gebühr entrichtet werden müsste. Ich kann den Herren nur das Beispiel, welches in der Budgetkommission des öfteren erläutert worden ist, wieder vorführen. Wir befördern rund 400 Millionen Drucksachen; für diese, 400 Millionen Drucksachen nehmen wir 15 Millionen ein. Demgegenüber stehen eine Milliarde Zeitungsexemplare und eine Einnahme von noch nicht 5 Millionen."-Von Podbielski (Postmaster-General), 21st November 1899.

3 " Es musste ein Tarif gefunden werden, der auf dem Grundsatz der Abwägung der Leistung und Gegenleistung beruht, der der Postverwaltung eine mässige Mehreinnahme wenigstens für die Zukunft, wenn auch nlcht für die unmittelbare Gegenwart sichert."-Dr. Oertel, 15th November 1899 ; Reichstag, Official Reports, vol. iv. p. 2801.

4 Von Podbielski, 21st November 1899 ; Reichstag, Official Reports, vol. iv. p. 2924. 
provincial Press. ${ }^{x}$ With a view to affording some measure of protection to the provincial Press as against the Press of the large cities, proposals were made in the Reichstag for the adoption of a zone rate for newspapers on the ground that the cost to the Post Office for distributing newspapers at great distances was appreciably greater than the cost of distribution in the case of newspapers sent short distances only, and that a zone rate would therefore be just. 2 The authorities were not, however, prepared to adopt this proposal, which they characterized as retrograde and unnecessary. 3 They considered that if the rate were raised for the longer distances the traffic would be taken away from the Post Office by private enterprise, and if the rate for the shorter distances were further lowered, the revenue from newspapers would be still further, and undesirably, reduced.

The new scheme of rates of 1899 was based on three considerations: the length of time covered by the subscription,

" "Die Inseratenpresse macht eine sehr starke Konkurrenz auch der Provinzialpresse, der kleinen Presse. Die erstere hat langsam den Abonnementspreis so weit herabgedrückt, dass schliesslich die Provinzpresse, wenn sie nicht zu Grunde gehen wollte, gleichfalls mit einer Ermässigung des Abonnementspreises hat vorgeben müssen, mit einer Ermässigung, die sich wirthschaftlich nicht aufrecht erhalten lässt. Die Abonnementspreise sind hier und da so niedrig geworden, dass manche Verleger wohl Ursache gehabt haben, zu schreien, man möge ihnen seitens der Post durch einen gerechten Tarif entgegenkummen, um die furohtbare Konkurrenz in etwas zu mildern."-Abgeordneter Dietz, 15th November 1899 ; Reichstag, Official Reports, vol. iv. p. 2799.

" "Dor Zonentarif ist meiner Ansicht nach vollkommen gerechtfertigt auch vom Gesichtspunkte der Leistung und der Gegenleistung aus. Die kleine Provinzpresse bleibt auf einen kleinen Verbreitungsbezirk beschränkt, und dort ist sie in vielen Exemplaren an einem and demselben Orte verbreitet. Die grosse Presse dagegen geht in einzelnen Exemplaren durch das ganze Reioh, sie verursacht demgemäss der Post bedeutend mehr Kosten und Lasten, mehr Arbeit als dio kleine Presse. Der Herr Staatssekretär des Roichspostamts hat das in der Kommission selbst zugeben müssen. Er wies z. B. darauf hin, dass schon jetzt durch die grosse Anzahl von Blättern, welche von Berlin aus in die Provinz hineingehen, die Post gezwungen wäre, tagtäglich einen Extrapostwagen zu stellen, welcher lediglich Zeitungen von hier nach Köln mit der Eisenbahn befördert; die Beförderung dieses einen Wagens koste der Post 120,000 Mark. Bei dieser Beförderung kommt aber im grossen und ganzen nur die grosse oder die farblose Presse, welche zu einem billigeren Preise gegeben wird, in Betracht. Die kleine Provinzpresse macht der Post nicht derartige Ausgaben, wie ich bereits vorhin betont habe. Daher erscheint es angebracht, dass wir zwei Zonen schaffen, dass die Zeitungen in der ersten Zone zu einem billigeren Satze versendet werden als diejenigen in der zweiten Zone."-Dr. Marcour, 15th November 1899; Reichstag, Official Reports, vol. iv. p. 2796.

3 Von Podbielski, 15th November 1899; ibid., vol. iv. p. 2797. 
the frequency of issue, and the weight of the newspaper; and the rates were reckoned in the following way :-

(a) Two pf. for each month of sending.

(b) $15 \mathrm{pf}$. yearly for papers appearing once weekly or less frequently, and $15 \mathrm{pf}$. yearly more for each further publication weekly.

(c) 10 pf. yearly for each kilogramme of the yearly weight, subject to a free weight of 1 kilogramme yearly for each of so many editions as the rate $(b)$ is applied to. ${ }^{x}$

The weight for any year was to be fixed according to the actual weight of the numbers of the paper during the previous year, and for new publications the rate was to be applied quarterly on the basis of the weight of such numbers as had appeared. The publisher was required to deposit with the Post Office a complete copy of each issue for the purpose of calculating the weight charge.

Financially, the result of the rates has been unsatisfactory; the amendments of the proposals of the postal administration which were made by the Reichstag could hardly have had any other effect. From the year 1871 to the year 1902 the increase in the number of newspapers was 508 per cent. $(1871,2024$ millions ; 1902, 1,157 millions), but the increase in newspaper postage was only about 378 per cent. $(1,760,326 \mathrm{M}$. in 1871 and $6,659,735 \mathrm{M}$. in 1902) ; and if the cost of the service remained approximately the same as in 1897 , which there is little reason to doubt, the loss to the administration was about a million Marks.

In the case of a number of papers a higher rate of postage became payable; but in the case of some of the expensive illustrated and scientific publications the new rate represented a considerable reduction. Thus, in one case, the rate became $2 \mathrm{M}$. 9 pf. instead of $96 \mathrm{pf}$. yearly, while in another the rate was reduced from $7 \mathrm{M}$. 20 pf. to $50 \mathrm{pf}$. yearly. ${ }^{2}$

But the reduction of rate did not represent the whole disadvantage. The greater part of the issue of illustrated and

- Statute of 20 th December 1899 :-

" (a) 2 Pf. für jeden Monat der Bezugszeit.

“(b) 15 Pf. järlich für das wöchentlich einmalige oder seltenere Erscheinen, sowie 15 Pf. jährlich mehr für jede weitere Ausgabe in der Woche.

“( (c) 10 Pf. jührlich für jedes Kilogramm des Jahresgewichts unter Gewährung eines Freigewichts von je $1 \mathrm{Kg}$. jährlich für soviele Ausgaben, wie dẹ Gẹüụhr zu (b) unterliegen."-Article 1 (sec. iii), Law of 20th December 1899.

? Dr, Artur Schmidt, Finanz-Archio, 1906, vol, 23, part i. p. 74, 
scientific journals and trade papers had formerly been distributed through the ordinary channels of the publishing trade. Now that the postage rates were in many cases so largely reduced, it became cheaper in those cases to distribute a larger number by post, and this course was naturally adopted. Increase in the number sent by post in such circumstances simply resulted in increased financial loss.

An indication of the extent of the privilege which the newspapers enjoy as compared with other printed matter may be obtained by comparing the revenue which was actually obtained from the newspapers with the revenue which would have been obtained from the same number of packets of ordinary printed matter of similar size and weight. In 1900, in the inland service in Germany, some 440 million packets of ordinary printed matter were transmitted, and the postage on them amounted to $21,133,499 \mathrm{M}$. If the 1,150 million newspapers had yielded postage in the same proportion, they would have brought in a revenue of some 55 millions of Marks, whereas in actual fact they yielded only some $6 \frac{1}{2}$ millions. ${ }^{x}$

The present rate rests on the two grounds of frequency of issue and weight of copies. It is therefore in practice more difficult to apply than the former rate based simply on the price, since the weight factor is variable and requires exact determination in every case. Moreover, the Reichstag forbade rounding up of the weight, which would be essential if a rate in even pfennigs were to be ascertained. The calculation of the actual rate must be carried to the second decimal place in pfennigs, and a rounding up of broken pfennigs is permitted only at the final settlement for the regular subscription period. This complexity has, of course, added largely to the cost of administration, without a corresponding increase in revenue.

It is anticipated that with the growth of the newspaper traffic the loss to the postal administration will tend to increase rather than to diminish. There is, however, no disposition to restrict the privilege accorded to newspapers. The attempt made by the administration in 1899 to secure an increased revenue from them was, as explained, frustrated

? Dr, Artur Sçhmidt, ibid., p. 69, 
by the Reichstag. Since 1852 the Post Office has held the monopoly of the distribution of political newspapers, and the general advantage resulting from such an effective control of the dissemination of public intelligence no doubt explains the continuance of so favourable and unremunerative a rate. ${ }^{\mathbf{I}}$

\section{Note on Delivery Fees for Newspapers.}

House-to-house delivery of newspapers was introduced in 1828, the lowest charge (i.e. in addition to ordinary postage) being $30 \mathrm{pf}$. quarterly.

In 1872 a uniform delivery fee was fixed for town and country. For papers appearing weekly or less frequently the charge was $15 \mathrm{pf}$., for papers appearing two or three times weekly $25 \mathrm{pf}$., for papers appearing four to seven times weekly 40 pf., and for papers appearing more frequently than seven times weekly 50 pf. quarterly. The system of charging delivery fees has been continued, and those at present in operation are :-

(b)

$(p)$

(q)

(r) For official gazettes

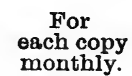

. 2 pf.

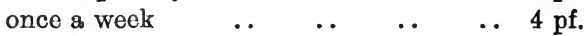
twice a week $\quad$.. $\quad$.. $\quad$.. $\quad$.. 6 pf.

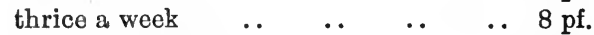
four times a week $\quad \ldots \quad \quad \ldots \quad \quad \ldots 10$ pf. five times a week .. $\quad \ldots \quad \ldots \quad \quad \ldots 12$ pf. six or seven times a week $\quad \ldots \quad \quad \ldots 14 \mathrm{pf}$. eight times a week $\quad \ldots \quad \ldots \quad \ldots 16$ pf. $\begin{array}{lllllllll}\text { nine times a week } & \ldots & \ldots & \ldots & 18 & \mathrm{pf} \text {. }\end{array}$ ten times weekly .. $\quad \ldots \quad$.. $\quad \ldots 20$ pf. eleven times weekly $\quad \ldots \quad \ldots \quad \ldots 22$ pf. twelve to fourteen times weekly $\quad \ldots 24 \mathrm{pf}$. fifteen times weekly $\quad \ldots \quad$. $\quad \ldots 26$ pf. sixteen times weekly $\quad \ldots \quad \ldots \quad \ldots 28$ pf. seventeen times weekly .. $\quad$. $\quad \ldots 30$ pf. eighteen times weekly $\quad . \quad \ldots \quad \ldots 32 \mathrm{pf}$.

.. 2 pf. ${ }^{2}$

The delivery fees are collected in advance for the complete subscription period. In 1910 the amount collected for delivery in towns was $19,604,234 \mathrm{M}$., and for delivery in the country districts $5,770,896 \mathrm{M}$.

- Cf. Dr. Artur Schmidt, Finanz-Archiv, vol. 23, part i. p. 79.

${ }^{2}$ Allgemeine Dienstanweisung für Post und Telegraphie, Berlin, 1901, Absch. nitt V, i. pp. 69-70. 


\section{Note on Special Supplements.}

Special advertisement supplements were permitted to be sent by post together with newspapers by the order of 30th September 1871. These supplements in form or character must not be similar to the main newspaper. They must not be printed at the same office, and no charge might be made for their insertion. A special supplement must not exceed one sheet and must not be bound. The newspapers in which they were inserted must bear a notification to that effect in a prominent position. All copies of the supplement must be submitted to the Post Office and the postage paid in advance. They were then stamped at the office of posting, and if not posted within three days the postage might be forfeited. The rate for each supplement was $\frac{1}{12}$ sgr. ${ }^{\mathrm{I}}$

The number of such supplements was not as great as was anticipated, the chief reason for which was that the postage was still too high and the regulations too complicated.

In 1873 the rate was reduced to $\frac{1}{2} \mathrm{pf}$. for each copy, with a reduction of 50 per cent. when as many as 7,200 copies were posted at the same time. The obligation to submit all copies to the Post Office for stamping, and the requirement to post them within three days thereof, were at the same time removed, and the simple obligation to give previous notice

- Archiv fur Post und Telegraphie, 1880, p. 278. The present regulations are as follow:-

"Als aussergewöhnliche Zeitungsbeilagen werden solche . . . die nach Form, Papier, Druck oder sonstiger Beschaffenheit nicht als Bestandtheile derjenigen Zeitung oder Zeltschrift erachten werden können, mit welcher die Versendung erfolgen soll.

“Jede Versendung aussergewöhnlicher Zeitungsbeilagen muss von dem Verleger bei der Verlags-Postanstalt unter Entrichtung der Gobühr für so vieleExemplare, als der Zeitung $u$. beigelegt werden sollen, vorher angemeldet werden. Das Einlegen in die einzelnen Zeitungs a. Exemplare ist Sache des Verlegers.

"Aussergewöhnlichc Zeitungsbeilagen dürfen nicht über zwei Bogen stark, auch nicht geheftet, geklebt oder gebunden sein; die einzelnen Bogen müssen in der Bogenform zusammenhängen. Die Postanstalten sind zur Zurückweisung solcher Beilagen befugt, die nach Grösse und Stärke des Papiers oder nach ihrer sonstigen Beschaffenheit zur Beförderung in den Zeitungs packeten nicht geeignet erscheinen.

“Die Gebühr für aussergewöhnlicho Zeitungsbeilagen beträgt 1 Pf. für je 25 Gramm jedes einzelnen Beilage-Exemplars. Ein bei Berechnung des Gesammt betrags sich ergebender Bruchtheil einer Mark wird nöthigen Fallen auf eine durch 5 theilbare Pfennigsumme aufwärts abgerundet."-Allgemeine Dienstanweisung fur Post und Telegraphie, Berlin, 1901, Abschnitt V, i. p. 17. 
of posting substituted. The obligation to indicate on the newspapers that a special supplement was enclosed was also withdrawn.

In 1874 the regulations were further relaxed. Special supplements were allowed to be printed at the same office as the newspaper, and charges for the advertisement might be made. ${ }^{x}$ The limit of size was extended to two sheets, at which it remains. ${ }^{2}$

In 1900 (20th March) the rate was changed to $\frac{1}{4} \mathrm{pf}$. for each 25 grammes weight for each supplement. The number of special supplements in 1910 was 214 millions.

× Archiv für Post und Telegraphie, 1880, p. 279.

2 22nd August 1874. 


\section{THE RATE FOR PARCELS}

\section{PARCEL POST IN ENGLAND}

The London Penny Post established by William Dockwra in 1680 was in some degree a parcel post, but throughout the country no sort of parcel post service existed until the introduction of the regular system in 1883 . The weight limit for packets sent by Dockwra's post was at first fixed at 1 pound, but it was afterwards extended. ${ }^{x}$ The Penny Post was employed to such an extent for the transmission of bulky packets and parcels that delivery was retarded, and it was found necessary to reduce the number of such parcels. The privilege of sending parcels even of 1 pound weight was accordingly withdrawn in $1765 .{ }^{2}$ The letter rate charged by the ounce was sufficiently high to restrict effectively the number of packets of large size entrusted to the post.3 In their Report of 1797 on the Post Office, the Select Committee on Finance recommended a reduced rate for the heavier packets

3hen in 1700 Dockwra was dismissed from the comptrollership, one of the charges against him was that he forbade the acceptance of band-boxes or other parcels over 1 pound in weight-to the great inconvenience of traders and the peril of many sick folk who might have received "phisick" by the Penny Post.

25 Geo. III, cap. 25.

3 "In 1839 Sir John Burgoyne wrote to complain that, for a packet of papers sent to him at Dublin, which had been forwarded from some other part of Ireland by mail-coach, as a letter, instead of a parcel (i.e. a coach-parcel), he had been charged a postage of $£ 11$; that is to say, for a packet which he could easily have carried in his pocket, he was charged a sum for which he could have engaged the whole mail-coach, i.e. places for four inside and three outside passengers, with their portmanteaus, carpet bags, etc."-The Post Office of Fifty Years Ago, London, 1890, p. 7. 
and small parcels, in order to encourage their transmission by post, but the suggestion met with no favour.I For many years afterwards the official view was that it was desirable to confine the post to light packages, and that any increase in the number of heavy packets would disorganize the service, which existed to provide for the expeditious transmission of light letters. Its arrangements had been made with this object, and to load it with a large number of heavy packets would be subjecting it to an unfair strain, under which it would inevitably break down. ${ }^{2}$ So long as the delivery of parcels is provided for by foot (or cycle) post, it is impossible to raise indefinitely the limit of weight for individual parcels.

The establishment of the Book Post in 1847 was, of course, a step in the direction of a general Parcel Post. The Post Office having by this means become the carrier of small parcels containing goods of a certain class, the demand for a post for parcels of any kind of goods was inevitable. In the 'sixties there was considerable agitation for extended parcel post facilities. The familiar argument was advanced that the Post Office had already an establishment for the collection and delivery of letters in some twelve thousand districts, and that this establishment might be used, to the great advantage of the public, to afford any additional services within its capacity; that, as all the main establishment

" "It has been suggested that if the proportional charge on Letters by Weight was more gradual, many Things which now pass as Parcels by the Mails and augment the Profit of the Proprietors would be sent by the Post on Account of the superior Safety.

"It is certain that great Numbers of small Parcels are sent by the Mail Coaches at an inferior Rate of Carriage, which, considering this Establishment as a Species of exclusive Carrying Trade, must subtract considerably from its Revenue." Seventh Report, July, 1797 (Commons Reports, vol. xii. p. 189).

2E.g., in 1829 the Secretary reported: "With respect to the conveyance of Pamphlets and Periodical Publications by the Post, Treasury has expressed itself to me as decidedly hostlle to any such infraction of the carrying Trade of the Country. It is moreover physically impossible. We have the greatest difficulty in conveying Letters, Newspapers, and official packets; many of the official forms, etc., remain some days until we can take them by the Mail Coaches." And in 1847, when Sir Rowland Hill put forward his proposal for a Book Post, Colonel Maberley, then Secretary, said: "The Post ought to be confined to small packets as much as possible and to convey large packets only when the necessity is urgent." $\mathrm{He}$ was especially afraid of the inconvenience which would be caused to foot-messengers.-British Official Records. Cf. 10 \& 11 Vict., oap. $85, \S 2$. 
charges were paid-rent, salaries, etc.-an additional service could be rendered without adding proportionately to the expenses. It was urged also that the sample post rate was too high and was fenced by troublesome regulations; that the book rate was also too high; that there was no reason why the book trade should be favoured; that in respect to the mass of the people the charges were so high as to impose on the transmission of small articles the same sort of prohibition that was placed on the transmission of letters under the old postal system; that a comprehensive system could not be carried out by the railways until the railways would cooperate; that even if the railways did co-operate they had not means at their disposal equal to those of the Post Office; that a parcel post system was already in operation in several continental countries; and that, in fine, by the establishment of a similar service in this country an immense boon would be conferred on the public.

The Post Office was, however, not farourably disposed towards the idea. It was proposed to meet the agitation to some extent by reducing the rates of postage on the heavier letters, and thus to carry small parcels under the guise of letters. This proposal was not, however, carried through. In 1871 the rates for letters of medium weight were reduced, but those on letters above 12 ounces were retained at a height which could only be regarded as prohibitive. ${ }^{x}$

The public agitation in favour of a parcel post service continued; and when in 1878 a large number of the railway companies announced that they proposed to convey small parcels over any part of their lines at low uniform rates, attention was called to the fact in the public Press, and suggestions made that the Post Office should co-operate by undertaking the delivery of the parcels. The official view was now somewhat more favourable to the idea. An international parcel post service had been established in 1880 in connection with the Universal Postal Union, and this fact had strengthened public opinion in favour of a parcel post service in this country. It was recognized that such a service would afford undoubted advantages to the public, especially in rural districts. It would provide facilities which private 
enterprise had not seen fit to undertake. It would provide a service reaching to all parts of the country, for which there was no other equally suitable machinery.

The Post Office could not, however, in establishing a parcel post service, act as freely as in its arrangements for the conduct of the letter service. The conveyance of the parcels from place to place was likely to prove a serious undertaking, and for such conveyance the Post Office was dependent on the railway companies. In the case of letter mails the cost for conveyance is a very minor part of the total expenses of the service, but when negotiations with the railway companies were begun it was soon found that such would not be the case with parcel mails. The companies, regarding the parcel traffic as to a large extent their own proper business, ${ }^{x}$ were not disposed to agree to easy terms, and there was the further difficulty that numerous companies had to be satisfied, since it was desired to establish the system under an agreement which should include all the principal companies. ${ }^{2}$ From the first, the question of the remuneration of the companies was approached from a point of view totally different from that in which their remuneration for the ordinary letter mails was regarded. Letter mails are conveyed as entities, and the company have never been concerned with the number of letters enclosed in the mail or the amount of postage paid. They arrange for the conveyance of a given number of mails,

"As they had always done. "The Post Office has recently absolutely entered into competition with the Railway Oompanies. As carriers, the Companies derived considerable profit from parcels. The Post Office, finding that railways afford the means of carrying any quantity of bulk, has seen fit to undertake the conveyance of books and other parcels at very reduced postal rates. If the Post Office should extend its operations a little further, it must be brought into absolute antagonism with the Companies. Books are heavier articles than laces or muslins, or many other fabrics, the conveyance of which enters largely into railway receipts. The Post Office having made book parcels profitable, may try to turn to account the conveyance of other, whether lighter or heavier, articles of trade. It might be thought advisable to carry a small valuable parcel to Aberdeen for $2 \mathrm{~d}$., a rate at which Railway Companies, having to pay interest on capital, certainly cannot hope to compete with a department which insists on the right of travelling on their roads at the mere actual cost. You will not, therefore, fail to see that the Post Office arrangements may be carried to a point at which great injustice would be done to Railway Companies." Robert Stephenson before the Institution of Civil Engineers, January 1856 (S. Smiles, Life of George Stephenson, London, 1857, p. 525).

2 See Leslie Stephen, Life of Henry Fawcett, London, 1885, pp. 417-18. 
and are remunerated accordingly. But with parcels the question was approached as one for the determination of just remuneration of the companies for conveying, not mails containing parcels, but single parcels. And the question to be settled was what proportion of the postage paid on the individual parcels should go to the companies. In view of the heavy expenses of every description which would be incurred and of the large number of heavy letters which would be transferred to the parcel post, causing a considerable reduction of revenue, the Post Office declined to accept less than half the total receipts, and after some demur the companies agreed. The rates of postage proposed were two in number-for parcels not exceeding 2 pounds in weight, 6d.; for parcels not exceeding 4 pounds in weight, 1s.

Difficulties arose subsequently as to the amount of freedom of action to be left to the Postmaster-General and the duration of the agreement. The first proposal was for an agreement in perpetuity; and the draft agreement gave the companies what was called a "partnership interest" in the parcel post business. It was, however, regarded as essential that the parcel post business should be no less under the control of the Postmaster-General than the existing letter post, and that, on the expiration of any agreement made with the railway companies, the statutes relating to the conveyance of letter mails by railway should apply to parcel mails.

After the failure of the first scheme, negotiations with the railway companies were suspended, but the public agitation for a parcel post was daily gathering strength, and in February 1882 the Postmaster-General again approached the companies. The new proposals were somewhat different from those originally made. A scale with four rates (3d. for 1 pound, rising to 1s. for 7 pounds) was now suggested by the Post Office, largely in deference to the strong disposition of the railway companies in favour of an increased number of rates. The low initial rate of $3 \mathrm{~d}$. for 1 pound was now proposed on the ground that a large proportion of the business to be done would be between the large towns and the rural districts. For the development of such business a low initial rate was essential; and as such parcels would not be likely to be to any large extent railway borne, 
the Post Office would obtain almost the whole of the proceeds of the postage. It was, moreover, now taken into reckoning that a considerable increase in the number of letters would result, since numerous communications relative to parcels posted would pass, and the revenue would thus benefit indirectly. The letter service would benefit, too, in other ways : it would be relieved of heavy packages; and the existence of a parcel post service would justify the provision of more efficient services in rural districts. The rates proposed were in general very much higher than those at the time existing in Germany, France, Switzerland, and Belgium, and they were estimated to yield a profit.

In the further negotiations serious difficulty was encountered on two points only: (1) the proportion of postage to be paid to the companies, and (2) the length of time for which the agreement should be made. The earlier agreement had been for an equal division between the Post Office and the railway companies of the postage paid on all parcels. It was now decided that payment could only be made in respect of parcels actually conveyed by railway. The companies thereupon asked a higher proportion. They anticipated that parcel post traffic would be largely long-distance traffic, involving in many cases transfers on the journey; and although they expected to retain a good deal of the short-distance traffic, they could only achieve this by reducing their rates generally, especially the rates for small parcels. After some higgling, they agreed under protest to accept 55 per cent. of the postage on all such parcels as should be conveyed by railway. They also agreed to the limitation of the duration of the bargain, and the term was fixed at twenty-one years.

The agreement was embodied in the Post Office (Parcels) Act of 1882.' The companies parties to the arrangement undertook the service of conveying the post parcels from the vehicles of the Postmaster-General at the despatching railway station to the vehicles of the Postmaster-General at the station of destination-that is to say, they undertook all handling of parcel mails on railway stations and transfer to and from trains and from train to train where necessary-in consideration of payment of 55 per cent. of the postage paid

× $45 \& 46$ Vict., cap. 74 . 
on all parcels conveyed by railway for the whole or part of their journey, the Post Office being required to keep a record of the amount of postage paid on every such parcel. The remuneration was to be paid to the Railway Clearing Committee in London, by whom it would be distributed between the various companies. The agreement was to continue for twenty-one years, and thereafter until terminated by either party. The Postmaster-General retained the power of revising the rates of postage, but in the event of such revision the companies might claim revision of the terms of their remuneration (even during the first twenty-one years). In any case, on the termination of the agreement, the statutes governing the conditions under which ordinary mails are conveyed by railway, and the determination of the remuneration of railway companies in respect of such conveyance, were to apply equally to the conveyance of parcel mails by railway.

The Postmaster-General has twice exercised his right of revising the rates of postage, and in each case the rates were lowered. The companies have not exercised their right to ask for a revision of the terms of their remuneration, and the provisions of the Act therefore continue in operation. In the first complete year of the service (1884-5) the number of parcels conveyed was some 23 millions. The increase in the traffic has been large and constant. In 1912-13 the total number of parcels exceeded 130 millions.

The service affords a great public convenience, and the simplicity of its rates is an undoubted boon. The uniform rate has, however, proved unsatisfactory in some respects. At all points at which the traffic would be profitable, the Post Office is open to the competition of private enterprise; but for that part of the traffic for which the uniform rate must inevitably be unprofitable (unless it be fixed so high as to be exorbitant for short-distance and average-distance traffic) there will naturally be no competition. The number of local, or short-distance, parcels is consequently small, and the number of parcels sent for long distances, to remote places, is comparatively large. No great use is, however, made of the post for the transmission of parcels of agricultural produce from rural districts. There is a moderate traffic in butter and eggs from Ireland to England, and in cream from the West of 
England. Proposals for the introduction of a specially low rate for agricultural products have frequently been considered, but there are obvious objections to the establishment of a special rate for a special class of traffic. Moreover, for parcels from country districts the present uniform rate is often ludicrously low. The cost of preparing and packing each separate small consignment for transmission by post is, however, considerable, and only the affluent are able to indulge in that method of obtaining food supplies. ${ }^{x}$ The exceptional character of the Post Office traffic in parcels, and the small degree in which the rates of charge measure the utility of the service of transportation which they cover, are well illustrated by the statistics of the traffic, which indicate that the total numbers are unaffected by fluctuations in general trade, and that the reductions of the rates which have been made since the establishment of the service have had no appreciable effect on the volume of traffic. ${ }^{2}$ The actual rates for the heavier parcels are probably more profitable than the rates for light parcels, since the principle of degression is not much recognized in the scale of rates. This view is confirmed by the fact that the post is little used for heavy parcels, the average weight of a post parcel being no more than 2.8 pounds. It is, as a matter of fact, not improbable that the parcel post service as a whole is conducted at heavy loss. 3

Note.-As a war measure the rates were increased on 1st November 1915 by 1d. at each step in the scale, and are now as follow :-

\begin{tabular}{|c|c|c|c|c|c|c|c|c|}
\hline \multirow{2}{*}{\multicolumn{5}{|c|}{$\begin{array}{l}\text { Parcels not exceeding } 1 \mathrm{lb} . . . \\
\text { Exceeding } 1 \mathrm{lb} ., \text { not exceeding } 2 \mathrm{lb} .\end{array}$}} & $\cdots$ & .. & .. & $4 \mathrm{~d}$. \\
\hline & & & & & -. & .. & .. & $5 d$. \\
\hline ", & 2 & ," & ", & 3 , & .. & .. & .. & $6 \mathrm{~d}$. \\
\hline ", & 3 & " & ", & 5, & . & .. & $\cdots$ & 7d. \\
\hline " & 5 & " & ", & 7 , & .. & .. & .. & $8 d$. \\
\hline$"$ & 7 & $"$ & $"$ & 8 ", & .. & .. & .. & $9 \mathrm{~d}$. \\
\hline ", & 8 & ", & ", & 9, & .. & .. & .. & 10d. \\
\hline " & 9 & ", & ", & 10, & .. & .. & .. & 11d. \\
\hline$"$ & 10 & ", & ," & 11, & .. & .. & $\cdots$ & $1 \mathrm{~s}$. \\
\hline
\end{tabular}

I Jevons had foreseen that the rich would benefit; but he anticipated a large general traffic in household supplies. See W. S. Jevons, "A State Parcel Post," Contemporary Review, London, 1879, p. 209.

- See graphs at pp. 371 and 372 , infra.

3 The estimates on which this statement is based are given below at p. 311, Cf. Leslie Stephen, loc, cit. p. 420 . 


\section{PARCEL POST IN THE UNITED STATES OF AMERICA}

Several causes operated to prevent the early establishment in the United States of a parcel post system. The two factors of extent of territory and sparsity of population, which had from the first so greatly influenced the policy of the Government towards the Post Office, were of much greater importance in regard to a parcel post system. The weight of the individual letter is very small, and as the cost of transportation depends in most cases entirely on weight, the system of uniform rates which had been introduced in England had not been found impossible of adoption in the United States. But with parcels, cost of transportation is an appreciable item for every parcel, and in a country of vast distances there must be an appreciable variation in the actual cost for each parcel. Consequently, any uniform rate which would render the service self-supporting must be measurably above the rate which would suffice for local and short-distance traffic, and measurably below the rate which would be necessary for long-distance traffic. Private agencies would therefore cut such a rate and absorb all the short-distance traffic, while the long-distance traffic would be left to the Post Office, and would be carried at a loss. This had been found to be the case with second-class matter, where weight is an important factor, and also with the fourth-class matter. The establishment of a parcel post system, therefore, would involve a reconsideration of the fundamental principles on which the rates of postage were in general based.

The creation, in 1863, of a third class of miscellaneous mail matter $\mathbf{x}$ was virtually the establishment of a limited parcel post. The rate for third-class matter, 2 cents for each 4 ounces or fraction thereof, was increased in 1879 to 
1 cent an ounce. These rates were comparatively high; and as the limit of weight was 4 pounds, the traffic naturally never assumed large proportions. With the establishment in 1880 of an international parcel post in which the United States participated, although having no real internal parcel post, it was inevitable that the question of establishing a system equal in scope to those of other countries should arise. For forty years there was a demand, becoming more general and insistent, for the establishment of such a general parcel post.

Active official support was first given to the proposals for a parcel post in 1890 and 1891 by Postmaster-General Wanamaker, who explained that although the demand for such a system was widespread, the greatest pressure came from "interior places," which were, in fact, really most in need of it, because they had no facilities for obtaining small packages of merchandise from the towns. ${ }^{1}$ Opposition to any sort of parcel post came then, as always, from the express companies, who, although not able or not desirous of affording a service to all parts, were much concerned at the prospect of losing traffic. Mr. Wanamaker proposed to propitiate them by transferring to them a considerable amount of traffic deemed by him to belong properly to the express companies, viz., traftic carried by the Post Office for the other Executive departments free of charge, under "penalty frank," 2 and comprising many packages of considerable weight and bulk. Mr. Wanamaker also desired to put a stop to the transmission, as second-class matter, of periodicals which were really ordinary books, by transferring such traffic to the express companies. Although in favour of a full parcel post system, and recognizing that there was a strong desire in the country for the boon, Mr. Wanamaker was not prepared to advocate its immediate establishment. He thought other reforms should take precedence; such as free-delivery extension, postal telegraph, postal telephone, and 1 cent postage on land and sea, all of which, except the extension of free delivery, are still waiting adoption.

A number of postmasters criticized the suggestions of the Postmaster-General in 1890 regarding parcel post, but most of

- Annual Reports of the Postmaster-General, Washington, 1890 and 1891.

2 I.e. under the Government frank, for the fraudulent use of which a penalty of $\$ 300$ is imposed. 
them had, by 1891, expressed themselves in favour of a full parcel post system, and according to Mr. Wanamaker the remainder were "probably interested express agents." The situation was in some respects unsatisfactory. It was a common practice for business firms to contract with express companies to carry large quantities of small packages at a rate per package just below the rate of postage. The express companies took such of the packages as they thought fit to handle, and left the Post Office to carry the remainder, all long-distance traffic, and unprofitable both to the express companies and to the Post Office. But the companies were secured by their profit in the short distances. Naturally, therefore, they offered strenuous opposition to the establishment of a parcel post. ${ }^{x}$

With the establishment of rural mail delivery there arose a new demand for a parcel post. Persons living on the rural routes desired to take advantage of the new service for the delivery of small parcels of merchandise of all kinds, foodstuffs, tobacco, dry goods, etc., which they would order from the local store-keeper by post or by telephone. The rate then payable on such parcels was the general rate for fourth-class matter, viz. 16 cents a pound, which for parcels of goods of small intrinsic value was prohibitive. In response to this demand, the first definite proposals for a parcel post ${ }^{2}$ were put forward by the department in 1904, when the establishment of a special rate of 3 cents a pound was suggested, with a maximum limit of weight of 5 pounds, for parcels from any distributing office for rural routes to any patron on the routes from that office. Such a rate "would be a great convenience to the patrons and become a source of revenue to the department." The rate of 3 cents was estimated to be ample remuneration in such cases, because there would be no expense for railway transportation, and as it would be merely employing. a system already established, there would be no additional

\& "In point of fact there are but four strong objections to the parcels post, and they are the four great express companies, who would be just as well off with an 8. or 11-pound parcel post if the heavy freight of the Executive Departments and the immense packages of bogus serial books that are now thrown upon the mails were shut out and turned over to the express companies, where they belong."-Report of the Postmaster-General, Washington, 1891, p. 114.

I Ibid., 1904, p. 2. 
expense for delivery: the rural carriers could easily perform the service. ${ }^{\mathbf{T}} \quad$ They had at first been allowed to carry express packages, but the privilege had been subsequently withdrawn. They were, however, still authorized by law to carry merchandise for hire, on behalf of patrons of the rural routes, and to carry passengers. In general, their work for the Post Office only employed them to the extent of 30 per cent. of their full capacity, and a large unutilized margin therefore existed.

The proposal was again advanced in following years. Postmaster-General Meyer interested himself in the question, and advocated in speeches in various parts of the country the immediate adoption of a parcel post system. In 1907 he suggested the introduction of a local parcel post service experimentally. He made at this time numerous treaties with foreign countries for parcel post services between those countries and the United States, at a general rate of 12 cents a pound. The result was that parcels could be posted at any town in the United States for transmission to places in, say, Europe or Australia, at the rate of 12 cents a pound, but could only be posted for transmission to another town in the United States on payment of a rate of 16 cents a pound. When this situation was realized, there was naturally a good deal of irritation, and the existence of such an anomaly was made an argument for a domestic service. ${ }^{2}$

The preferential rate obtained by parcels going abroad continued to be a strong argument in favour of a general parcel post, and members of Congress constantly referred to it in the discussions on the subject.

There was, moreover, and still is, an important body of opinion which goes much further than the advocacy of a parcel post system. In that view, the express companies are the enemy or, at any rate, the oppressive character of the express rates is viewed so seriously that no solution of the present difficulties of the country, and especially of the " high cost of living" problem, is thought possible short of a complete

Cf. supra, p. 127, note 2.

2 "When the British Government can secure better mail facilities in the United States for the English people than Uncle Sam can secure in this country for our own people, it is time that somebody be heard from."-Mr, Hartranft, Secretary of the Postal Progress League of California. 
express service run by the general Government. Relief will only be found under some system which will bring the producer of the necessaries of life into direct relationship with the consumer, ${ }^{\mathrm{I}}$ in order that the enormous middleman's charges be eliminated and the consumer obtain the produce at a price not greatly above the actual cost of production. The railways refuse to handle shipments less than 100 pounds, and their minimum charge is 25 cents. The ordinary consumer who requires consignments of much less than 100 pounds' weight has no use for such a service. For shipments of less weight, the only service available is the express service, the minimum rate for which, in general 25 cents, is too great for farm products, which are usually of low value and could not bear a rate of 25 cents. The express service, which is restricted to the railway system, has, moreover, no means of reaching that vast body of the people, estimated at some $40,000,000$, who are living on the farms, and who alone are able to supply the desired traftic in food-stuffs. The Government has in recent years, at heavy expense, extended to some 20 millions of people the benefits of free mail delivery, and the intention of the advocates of a Government express service, a "postal express," is that the State should take over the express companies, paying them fair compensation for their property, and work their service in conjunction with the rural mail delivery. By this means an extensive service could be provided at reasonable rates of charge. ${ }^{2}$

In February 1908 Bills were introduced in the Senate to increase the limit of weight of fourth-class matter, and to provide a rural delivery parcel post for merchandise and other articles mailed on rural delivery routes. Legislation did not, however, result.

Meantime, the feeling in favour of a parcel post was spreading, more especially in the farming districts. In November 1911 a Sub-Committee of the Senate Committee on Post Offices and Post Roads was appointed to examine

× "The difficulty now lies in the absence of a connected transportation conduit, which will receive the small shipment at the farm and convey it, like a letter, direct to the consumer."-Hon. David J. Lewis, Postal Express, 1912, 62nd Congress, 2nd Sess., Doc. No, 379, p. 5 .

2 Ibid. 
the practicability of establishing a parcel post system. The Sub-Committee was appointed on a resolution of the Senate, moved by Senator Jonathan Bourne, Jr., the Chairman of the Senate Committee on Post Offices and Post Roads, and there is indication that the adoption of the system had already been practically decided upon, the real question before the Sub-Committee being that of its practicability as an immediate proposition. The Post Office representatives advocated a limited experimental introduction of parcel post on rural routes and in the city delivery offices. They were impressed with the radical differences between the United States and most other countries where parcel post was in operation, and hesitated to recommend the introduction of a general service. But the members of the Sub-Committee had in mind to introduce as soon as practicable a complete system by the method of enlarging the scope of the fourth-class regulations and reducing the rates of postage. Numerous witnesses appeared before the Sub-Committee, representing general societies of business men, such as the National Dairy Union, the Associated Retailers of St. Louis, Mo., and the Retail Dry Goods Association of New York; educational or social societies, such as the American Library Association, the Postal Progress League, and the Knights of Labour ; farmers' societies, such as the State Granges and the Farmers' Educational and Co-operative Union of America. Several farmers, lawyers, and other gentlemen appeared to give their own personal views. The chief opposition to the parcel-post came from the representatives of the retailers, who stand in constant fear of losing their business to the mail-order or catalogue houses. The business of these houses is very large, amounting in the aggregate to nearly $\$ 200,000,000$ per annum, and there is perhaps some reason for the local merchants' apprehensions. The bulk of the mail-order traffic is, however, distributed as freight. But the country merchants were much alarmed, and there were doleful prophecies of the results of a parcel post. The local merchant was represented as the mainstay of the country-side. He it was who sustained the country town, which afforded so valuable a local market for the farmer. He it was to whom alone that same farmer could look for credit to tide him over bad times. He it was 
who made the country town a social centre where the farmer might come into touch with civilization and refinement. And on the continuance of the prosperity of the country merchant depended the continuance of the army of travelling salesmen, without whose patronage railroads would be driven to reduce the number of trains, hotels would go out of business, and throughout the country accommodation for travellers would be found extremely poor. In short, parcel post would reduce the country merchant to the same condition as the small shopkeeper in Europe; and the country towns would become mere hamlets and deserted villages. ${ }^{\mathrm{I}}$

The parcel post was, of course, as likely in 1912 to prove a blow to the express companies as in the earlier years when they had so strongly resisted any proposal for its introduction. In face, however, of the strong and widespread movement in the country in its favour, they realized that they would be unable always successfully to resist its establishment, and no open opposition to the proposals of 1912 was encountered from them. They did not appear before the Senate Sub-Committee.

The Sub-Committee saw no insuperable difficulty in the way of introducing a general system at once. Moreover, they were impressed by the fact that a parcel post system was in operation in most other countries of the world, even in Australia, a country slightly larger in area than the United States and much more sparsely populated, where the two factors which so radically distinguished the United States from most other countries in which a parcel post had been established were met with in even greater degree.

When the questions of the desirability and practicability of establishing a system had been decided, there still remained the difficult and important question of the scheme of rates of charge on which the system should be based. Some of the

'Mr. S. Norvell : "I found the conditions in Europe very much worse than I had anticipated. I found the way the people lived was entirely different from what I had anticipated, and no man who has simply lived in this country and has read in a general way about the conditions in Europe can appreciato how the people live in Europe without going among thom and studying the subject. The business of Europe, while in the aggregate, of course, it is very large, as a matter of fact is a peanut business."-Hearings before the Sub-Committee on Parcel Post, Washington, 1912, vol. ii. p. 496. Cf. Address at Atlantic City, N.J., 16th November 1911. 
witnesses before the Sub-Committee advocated a uniform rate, representing that a graduated rate was undesirable and would be unacceptable, as giving a special privilege to certain sections of the people. A more general opinion was that a flat rate would be unsound economically. With such a rate, the express companies would step in and take all the profitable traffic ; and it would, moreover, be necessary to fix the rate so high as to render it prohibitive for goods of low value and for the purpose of moving traffic on the rural routes. In a country of vast extent the actual cost to the Government for the transportation of parcels of the same weight would differ widely in proportion to the distance for which they were conveyed in the mails, and the differences would be sufficiently great to render it easily possible to graduate a scale of postage approximately in accordance with the distance and the actual cost. The department estimated the cost of transportation for mail matter to be 1.32 cents for each 200 miles, and taking this as a basis, differential rates in respect of transportation were arrived at for a series of zones.

The charge for handling, i.e. for collection, delivery, administrative and all other incidental services, was calculated as an altogether separate item. The Sub-Committee had the evidence of Mr. John L. Newbold, a gentleman of long experience in a transport business which dealt mainly with small parcels for delivery within the limits of the City of Washington, and was therefore in a high degree comparable to delivery service which would be performed by the Post Office in respect of parcels. Mr. Newbold offered to contract with the Government to handle all post parcels for delivery within the City of Washington at 5 cents a parcel, with a limit of weight of 25 pounds. Estimates by similar delivery companies in New York City indicated the cost to them of packages up to 25 pounds, which was a little over 5 cents per package. The department's estimate of the handling cost of fourth-class. matter showed a cost of a fraction under 3 cents for the first pound, with an approximate increase of 20 per cent. for each additional pound.

These data furnished a basis for calculating rates of postage, when the limitation of the zones had been determined, a matter of some little difficulty. The first, and most obvious, 
suggestion was that the zones should be reckoned as from each post office, but in view of the fact that there were some 60,000 post offices in the United States, grave practical difficulties would arise with a scheme providing for special rates from each post office. It was then thought the State might be adopted as the unit of area, but the States differ so widely in area that such a system would have resulted inequitably, giving equal postage charges for very unequal services. A citizen in Texas or New York State, for example, would be able to send his parcel many times as far as a citizen of Massachusetts or Delaware. The same objection applied, though not in so great degree, to the county as a unit of area. Moreover, these units would be liable to arbitrary change. Failing the discovery of any satisfactory unit based on the political divisions, recourse was had to purely theoretical divisions, based on the imaginary lines of latitude and longitude. The actual degree parallels were rejected as the limits of the units of area because, within the quadrangle formed by them, there would be a maximum zone distance of some 80 miles; while at the same time, for transmission between two places perhaps only two miles apart but lying on different sides of the line, postage would be chargeable as for the second zone. This difficulty was overcome by an ingenious suggestion, which emanated from the department, to divide the degree quadrangles in four, that is, into squares of 30 minutes dimension, and to allow the sending of parcels at the first zone rate from or to places in every contiguous quadrangle.

Under this method, which was adopted, the United States is divided into 3,500 units of area, which are definite, neverchanging, and practically uniform in size, the slight difference in area depending on the distance from the Equator being negligible. Each unit is given an index number, and all post offices in the unit have the same index number. Each unit has its own zone limits, which apply equally to every office in the unit. So that in order to discover for what zone postage is to be charged between two places, it is only necessary to ascertain what are the zone limits for the units of area in which the places are respectively situated. A simple reference to a guide showing in what unit of area the post office of 
destination falls, and a consultation of the zone map of the office at which the packet is posted, that is, a map showing the boundaries of each zone measured from the unit of area in which the office is situated as centre, gives in a very short space of time the rate applicable to the parcel.

A simplification of rates and regulations is always attended by a diminution of the difficulties of administration, by economy of actual working, and by convenience to the public. In connection with the proposed parcel post the department, with these objects in view, suggested the abolition of the separate class for printed matter, and its amalgamation with the parcel post matter, thus reducing the number of classes of mail matter to three. The Chairman of the Senate SubCommittee adopted this suggestion, and embodied it in the Bill which he prepared and introduced in the Senate on the 16th May 1912, retaining, however, a rate of 1 cent per ounce up to 4 ounces, in order to provide for circular matter which, under the third-class rate, passed at 1 cent for 2 ounces. This was apparently a doubling of the rate, but as the average weight of circulars is under 1 ounce, in actual practice the great bulk of them would continue to pass at 1 cent. This provision would, however, raise the rate on all catalogues and circulars weighing more than 1 ounce; and although 90 per cent. of the number of pieces of third-class matter actually posted are under 4 ounces in weight and would have fallen under the proposed special rate, and 50 per cent. are under 1 ounce in weight and would have passed for the same amount as under the existing third-class rate, viz. 1 cent, this provision of the Bill was strenuously opposed by printers and catalogue houses. Not regarding the consolidation of the two classes as in any way essential to the establishment of a parcel post system, the Senate Committee on Post Offices and Post Roads, when they came to consider the Bill, decided to eliminate that feature.

In general this Bill represented the conclusions of the Sub-Committee, and, apart from the foregoing change, was substantially accepted by the Senate Committee. The only other amendments made were an increase of the number of zones from six to eight, with the view of " protecting the local merchant in the field of his business," and a slight raising of 
the rates for the shorter distances, partly from a fear that the rates proposed in the Bill would not be self-sustaining, and partly from a desire further to protect the local retail merchant against the catalogue houses.

The essential provisions of the Bill, as thus amended, were embodied in the Post Office Appropriation Bill for the fiscal year 1913, were accepted by Congress, and became law on the 24th August 1912. The actual zones and rates fixed were as follows :-

First zone: All territory within quadrangle or unit of area and every contiguous quadrangle.

Second zone: All units of area outside the first zone within a radius of, approximately, 150 miles from the centre of a given unit of area.

Third zone: The same within a radius of, approximately, 300 miles.

Fourth zone: The same within a radius of, approximately, 600 miles.

Fifth zone: The same within a radius of, approximately, 1,000 miles.

Sixth zone: The same within a radius of, approximately, 1,400 miles.

Seventh zone: The same within a radius of, approximately, 1,800 miles.

Eighth zone: All units of area outside the seventh zone.

The rates were:-

On rural route : 5 cents for the first pound or fraction of a pound, and 1 cent for each additional pound or fraction of a pound.

\begin{tabular}{|c|c|c|c|c|c|c|c|c|}
\hline \multirow{2}{*}{$\begin{array}{l}\text { First zone } \\
\text { Second zone }\end{array}$} & \multirow{2}{*}{ 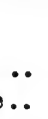 } & \multirow{2}{*}{$\begin{array}{l}\ddot{*} \\
\ddot{0}\end{array}$} & \multirow{2}{*}{$\begin{array}{l}\cdots \\
\cdots\end{array}$} & \multicolumn{3}{|c|}{$\begin{array}{l}\text { First Pound. } \\
5 \text { cents. }\end{array}$} & \multicolumn{2}{|c|}{$\begin{array}{c}\text { Each additional } \\
\text { Pound. } \\
3 \text { cents. }\end{array}$} \\
\hline & & & & .. & 6 & , & 4 & , \\
\hline Third zone & .. & .. & .. & .. & 7 & , & 5 & $"$ \\
\hline Fourth zone & .. & . & .. & .. & 8 & , & 6 & , \\
\hline Fifth zone & .. & .. & -. & .. & 9 & , & 7 & , \\
\hline Sixth zone & .. & .. & . & . & 10 & , & 9 & , \\
\hline Seventh zone & & .. & .. & .. & 11 & , & 10 & $"$ \\
\hline Eighth zone & .. & .. & .. & .. & 12 & $"$ & 12 & \\
\hline
\end{tabular}

Although, of course, with the body of the people the main arguments had been the ordinary contentions of the advantage of such a system as providing a most convenient facility for persons in all parts of the States, and especially in the rural districts, whereby they would be able by the utilization of existing machinery to have articles of all descriptions brought to their doors, yet in Congress the argument was largely based on the possibility of finding in the parcel post a means of reducing the " high cost of living," a problem which is giving much anxiety to politicians in America. By means of the parcel post, producer and consumer are to be brought into 
direct relations the one with the other. All middlemen and their profits will be eliminated, and either the producer will get more for his products or the consumer will pay lesswhich of these will happen does not appear : probably in some degree both are hoped for.

The experience of England may not be any indication of what will happen in America. But it is certain that in England the produce sent direct from farm to consumer, whether eggs, butter, or poultry, is not obtained by the consumer at less cost than he could buy it in his own town. There is an advantage, but it rests solely in quality. The products obtained from the farm are more fresh, are probably better altogether, but the price is not less. In England these considerations have been sufficient to prevent the wholesale use of the parcel post for food-stuffs. It is, in fact, in general used for such traffic only by those people to whom a little extra expense is not an object of consideration. The conditions in America seem, however, to be substantially different from those in this country, and a large development of parcel post business of this character is anticipated. ${ }^{\mathrm{I}}$

On the 15th August 1913 the limit of weight was increased to 20 pounds in the local, first, and second zones; and on 1st January 1914 the limit in local, first, and second zones was further increased to 50 pounds, and in the remainder of the zones to 20 pounds. On the 16th March 1914 books and printed matter were admitted to the fourth class, or parcel post, with a rate of postage of 1 cent for each 2 ounces up to 8 ounces, the ordinary parcel post pound rates to apply to packets exceeding 8 ounces in weight.

I "The department believed and still believes that the parcel post, in time, will become an important factor in improving and cheapening the food supply of the great cities. Hence, on March 25, 1914, twelve of the large post offices were designated for special test of a farm-to-city service. Farmers were invited to register their names and designate the commoditios they desired to sell. Lists of farmers and of the articles each offered were then printed and distributed by the carrier force. The results exceeded expectations; shipments of country products at the twelve offices named so materially increased that now eighteen additional offices have been named for similar exploitation of the farm-to-city service. Tho department's preliminary experience warrants the conclusion that direct shipment of food products that are consumed substantially in the same form in which they are produced offers practical possibilities of reducing the cost of living."-Report of Postmaster-General, Washington, 1913-14, p. 12. 


\section{PARCEL POST IN THE UNITED STATES 203}

The service, as a whole, has been enormously successful. It is estimated that in the second year the post office was handling parcels at the rate of $800,000,000$ annually, a figure which may be compared to its advantage with that for the United Kingdom. In the United Kingdom the annual number of parcels posted is some $130,000,000$, say three per head of the total population as compared with eight per head in the new service in the United States. 


\section{PARCEL POST IN FRANCE}

THE conveyance of parcels of merchandise, which had been undertaken by the early posts in France, was abandoned to private enterprise in 1795. $\mathrm{x}$ When, therefore, proposals were made for the establishment of an international parcel post service, France was without an internal service of the kind. She became, nevertheless, a party to the Convention of 1880 , which established an international service, ${ }^{2}$ availing herself of the privilege reserved to those countries without an inland parcel post service, of arranging for their obligations under the terms of the Convention to be assumed by railway and steamship companies. A contract was concluded with the administration of the State railways, the six great railway companies, and the shipping companies in receipt of subsidies for the conveyance of mails, under which those bodies undertook to conduct a service on behalf of the postal administration in accordance with the provisions of the Convention. They were to receive in its entirety the prescribed territorial transit rate of 50 centimes on every parcel, but not the surtax of 25 centimes. 3 The payment of 50 centimes per parcel was to be divided by the companies among themselves if the parcel was conveyed by more than one party, and constituted the full remuneration for the entire service performed, including the customs formalities. The contracting companies were required to print at their own cost a list of places served, and to keep the list available for reference by members of the public.

The establishment of an international service of this kind necessitated the provision of facilities for the transmission of

- Law of 9 vendémiaire, an VI. 2 Vide infra, p. 279.

3 Art. $5 \S 2$, Convention of 1880. 
ordinary inland parcels within France. ${ }^{\mathrm{I}}$ The companies were accordingly required to undertake also the transportation of inland parcels upon their railways and the delivery of inland parcels in localities adjoining their lines under the same conditions and for the same remuneration as in the case of parcels in the international service. A difficulty existed in the fact that small parcel traffic (l'envois par messagerie) was subject to special taxation. ${ }^{2}$ These taxes frequently exceeded the charge for transmission, and in some cases the value of the parcel itself. In order to encourage the use of the service, these taxes were reduced or modified by a series of laws at a sacrifice of revenue exceeding two and a half million francs a year. The service, which was established on the 1st May 1881, did not include the whole of France, but extended only to localities served by the State railways, the six contracting companies, and certain subsidiary companies which contracted for the business with the larger companies. The maximum limit of weight was fixed at 3 kilogrammes, and the rates of postage were 60 centimes for parcels transported from railway station to railway station, and 85 centimes for parcels delivered at the residence of the addressee. The service became immediately popular, the number of parcels posted during 1881 being at the rate of over half a million a month.

Soon after its establishment the service was extended to the smaller subsidiary lines, and to districts not served by railway. The latter extension, which it was not found easy to arrange, was provided for by introducing into the contracts for the conveyance of the ordinary mails in those districts a clause empowering the administration to require the contractor to convey post parcels for a remuneration of 15 centimes per

1 "En obtenant ainsi lo concours des compagnies pour le transport des colis internationaux, M. le Ministre devait évidemment être frappé des conditions dans lesquelles allait se trouver la circulation des colis à l'intérieur. Tandis que les premiers circuleraient en France avec la plus grande facilité à un prix forte réduit, notre commerce intérieur non seulement continuerait à payer des taxes de transport relativement élevées, mais encore resterait assujetti à tous les inconvénients qui résultent de la multiplicité des taxes et du manque d'entente entre los compagnies."-Journal Officiel de la République française, 27 janvier, 1881, p. 474.

${ }^{2}$ (1) La taxe sur la grande vitesse; (2) l'impôt du timbre; (3) la taxe de plombage; (4) le droit de statistique. 
parcel-the amount to be increased to 25 centimes for parcels delivered at residence.

The Lisbon Congress (1885) raised the limit of weight in the international service from 3 kilogrammes to 5 kilogrammes, but a corresponding increase was not made in the internal French service until 1892. The maximum limit of weight was raised to 10 kilogrammes in 1897, and the following rates of postage are now in operation:-

\begin{tabular}{|c|c|c|}
\hline Weight. & $\begin{array}{c}\text { Delivered at } \\
\text { Railway Station. }\end{array}$ & $\begin{array}{c}\text { Delivered at } \\
\text { Residence or } \\
\text { Poste Restante. }\end{array}$ \\
\hline 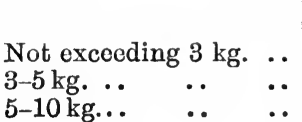 & $\begin{array}{l}\text { fr. } \\
0.60 \\
0.80 \\
1 \cdot 25\end{array}$ & $\begin{array}{l}\text { fr. } \\
0.85 \\
1.05 \\
1.50\end{array}$ \\
\hline
\end{tabular}

Cumbersome parcels are charged rates 50 per cent. greater than the ordinary rates. ${ }^{2}$ Parcels redirected or returned to sender are subject to an additional rate of postage, and to a tax (droit de timbre) of 10 centimes.3

Parcels for despatch are accepted only at the railway stations or offices of the companies or by their agents. They are delivered at the stations of the companies or at their offices in towns or at the offices of their agents, to be called for, or they are delivered at residence; but the latter service is undertaken only when a delivery service organized by the companies, or their agents, for their own purposes already exists.

Parcels are accepted for localities not served directly by the contracting companies, but such parcels are conveyed only to the point served by railway nearest to the place of destination. It is left to the public to provide for their further transmission. In the case of parcels delivered only at the railway station, an advice of delivery is sent to the addressee by the company or their agents within twenty-four hours of the receipt of the

- Tarif pour le Transport des Colis Postaux, Paris, 1913, p. 38.

2 "Sont considérés comme encombrants: les colis dépassant 1 m. 50 dans un sens quelconque; les colis qui, par leur forme, leur volume ou leur fragilité, ne se prêtent pas facilement au chargement avec d'autres colis, ou qui demandent des précautions spéciales."-Ibia., p. 6.

3 Ibid., p. 17. 
parcel. This advice is sent by post, and the postage, 5 centimes, is recovered from the addressee. If parcels are not called for within eight days, the sender is asked to give instructions regarding their disposal.

The control of the service in districts served by railway rests entirely in the hands of the railway companies. The postal administration takes no part directly in its management, but co-operates with the companies by affording certain small facilities in regard to parcels. For example, on payment of the usual delivery fee of 25 centimes a parcel may be delivered from the railway station to the local post office, where it will be retained in the poste restante. In districts not reached by the railway or their agents, the management of the service falls on the postal administration. The service in such districts is, however, far from complete. There are in France some 36,000 communes, but the parcel post service extends only to some 12,000 railway stations, and only at about onehalf of these can parcels be delivered at the residence of the addressee. ${ }^{I}$ To a limited extent a service is given in certain localities not directly served by railway. In these cases, which are arranged only with the concurrence of the companies, the service is conducted by the ordinary road carriers. ${ }^{2}$ The extension of the service in the rural districts is one of the problems which face the postal administration. 3

A local parcel post service was established in Paris in 1881 by arrangement with the Compagnie des Messageries Nationales, but it did not prove profitable, and was discontinued in

- Rapport portant fixation du Budget générale, Bénat, 1911, No. 189.

2 "Il faut que le bureau soit situé sur le parcours d'un courrier en voiture, et que les Compagnies de chcmins de fer veuillent bien consentir à accepter les colis à acheminer sur lo bureau de poste. . . . Bref, tout compte fait, il n'y a pas une commune sur six en France où l'on puisse reçevoir à domicile un colis postal."-Ibid., Chambre des Députés, Session 1907, No. 1247.

3 "Il faudrait apporter au sorvice des colis postaux des perfectionnements que les compagnies se refuseront à effectuer et qui semblent plutot du ressort de l'Administration. La reception et la distribution des colis postaux dans les communes rurales est une de ces améliorations désirables.

"Il est inutile d'insister sur l'importance économique de cette question. Les colis postaux fournissent ou devraient fournir un moyen facile et rapide de transport à bon marché; ils devraient favoriser aussi bien les intérêts du commerce que ceux de l'agriculture. Il s'en faut de beaucoup qu'ils rendent tous les services que l'on est en droit d'en attendre."-Ibid., Sénat, 1911, No. 189 , 
1887. A new service was set up in 1890. The contractor is required to make two deliveries on week-days and one on Sundays and feast days (les jours fériés), and to maintain an office in each arrondissement. The system has, however, developed. Three daily deliveries are now given, and nearly 500 offices have been opened. The rate of postage is 25 centimes for parcels not exceeding 5 kilogrammes, and 40 centimes for parcels between 5 and 10 kilogrammes.

The total number of inland parcels posted during the year 1913-14 was about 52 millions. 


\section{PARCEL POS'T IN GERMANY}

IN the days of the horse-posts it was obviously undesirable to burden the mails with weighty packages, and the transmission of parcels by post was from the first discouraged in Germany, although not forbidden. Parcels were charged as letters by the half-ounce, a sufficiently high rate to prevent the use of the posts for their transmission to any inconvenient degree. The first Imperial posts did not, indeed, undertake the transmission of parcels. The business was left to private enterprise, and was conducted by the Botenanstalten. The posts - themselves were, however, made use of for the transmission of parcels of merchandise for private individuals at least 'as far back as the Thirty Years' War. Owing to the dislocation of industry and commerce during that war and the high rates of postage charged, the number of parcels was extremely small, and their transmission was confined to limited areas. ${ }^{\mathrm{x}}$

As early as 1635 the messengers were allowed to carry parcels so long as their travelling was not thereby impeded," and in 1652 a regular parcel service was in operation between Basel and Zurich, Schaffhausen, Lindau, and Ulm. In 1660 the Great Elector ordered that no parcels should thenceforward be carried by the posts free of postage. This may perhaps be taken as the origin of a recognized parcel post service in Prussia. 3

The rates charged were at first based on the numerous diverse circumstances which governed the early letter rates.

* F. Haass, Die Post und der charakter ihre Ein Künfte, Stuttgart, 1890, p. 95.

2 Ordinance issued at Breslau; C. H. Hull, Die deutsche Reichs-Packetpost, Jena, 1892, p. 1.

3 C. H. Hull, ibid. p. 2. 
They were increased in the event of any rise in the price of provender, and varied according to the mode of transmission and according as the parcels were sent by day or night, in fine weather or in bad weather. ${ }^{x}$ In some cases the rate was varied according to the nature of the contents of the parcels.

In 1699 a tariff, under which the rates were regulated according to the distance and without reference to the mode of transmission, was established between certain offices in Prussia, and in 1712 this tariff was extended generally. The rate from Magdeburg to Stendal was 3 groschen per pound, to Leipzig 5 groschen per pound, and to Berlin 7 groschen per pound. In 1713 the summer and winter rates were abolished in Prussia. The rate for ordinary parcels from Berlin to Hamburg was 1 groschen per pound, from Berlin to Magdeburg $7 \mathrm{pf}$. per pound, from Berlin to Frankfort $4 \mathrm{pf}$. per pound, from Berlin to Leipzig 1 groschen per pound, etc. For provisions the rates were reduced by one-half, and for fancy goods the rates were doubled, a method of charge which gave rise to many practical difficulties.

In Saxony, by an ordinance of the 27th July 1713, parcels were divided into four classes, as follows :-

1. Packets of Documents (Akten-Pakete). The letter rate was applied to these in the following manner :-

1-4 pound parcels were charged as $2 \frac{1}{2}$ ounces

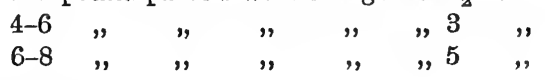

2. Money and fancy goods-

For the value of

1-3 miles 100 thaler current 2 groschen

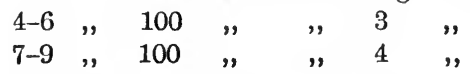

and so on up to 30 miles. (Note.-Distances are given in German miles throughout.)

E.g., "Wann die Botten innerhalb Landes verschickt werden, soll Ihnen von Jeder Meill Ein Groschen und sechs Pfennig des tages und dan zween Groschen, so des nachtes, und im bösenschnoe und regenwetter lauffen, sowohl auch des tages zween Groschen warttgeld, endtrichtet und gegeben werden."-Post und Botenordnung, 20 Juni 1614, Brandenburg ; cited F. Haass, ibid. 
3. Commercial goods-

\begin{tabular}{c|r|r|r|r|r|r|r|r|r|r}
\hline & \multicolumn{1}{c}{ Miles. } \\
Weight. & \multicolumn{1}{|c|}{$1-3$} & $4-6$ & $7-9$ & $10-12$ & $13-15$ & $16-18$ & $19-21$ & $22-24$ & $25-27$ & $28-30$. \\
& & & & & & & & & & \\
\hline & & & & & & & & & & \\
Pounds. & Gr. & Gr. & Gr. & Gr. & Gr. & Gr. & Gr. & Gr. & Gr. & Gr. \\
1 & 1 & 2 & 3 & 4 & 5 & 5 & 6 & 6 & 7 & 8 \\
2 & 2 & 3 & 4 & 5 & 6 & 7 & 8 & 8 & 10 & 11 \\
3 & 2 & 3 & 5 & 6 & 8 & 9 & 10 & 12 & 14 & 15 \\
10 & 5 & 7 & 9 & 13 & 17 & 23 & 24 & 32 & 38 & 44 \\
100 & 14 & 24 & 34 & 50 & 58 & 70 & 79 & 90 & 110 & 124 \\
& & & & & & & &
\end{tabular}

The weight was calculated for each pound up to 10 pounds, then for 15 pounds and 20. For parcels weighing more than 20 pounds tho rate increased for each 10 pounds.

4. Valuable goods, e.g. gold, silver, cloth of gold, brocade, were charged double the rate for commercial goods.

In 1741 a parcel rate was established in Brunswick and Lüneburg, based simply on weight and distance, without reference to the nature of the contents. ${ }^{\mathrm{r}}$

The Prussian rates of 1712 continued in force until 1762, when a general revision of postal rates was necessitated by the financial difficulties resulting from the outbreak of the Seven Years' War. The rates for ordinary commercial transport in Prussia rose to such a degree that the post, still working on rates fixed in 1712, became the cheapest means of transport.

Consequently the parcel post traffic increased, but it was found that the expenses of the service were not covered by the revenue derived from the parcels. The rates were accordingly increased on the simple plan of raising them all by 100 per cent. (except in Ostfriesland, where the increase was 50 per cent.). A further revision of the rates was made in 1766. Apart from the fact that the rates were further increased, this revision was in many respects beneficial, since it intro-

The new parcel rates were, e.g. :-

\begin{tabular}{c|c|c}
\hline Weight. & Up to 2 Miles. & 15-16 Miles. \\
\cline { 2 - 3 } Pounds. & Pf. & Gr. pf. \\
1 & 8 & 1 8 \\
$2-10$ & 5 & 110 \\
$10-30$ & 3 & $-\frac{6}{6}$ \\
$30-60$ & 1 & \\
\hline
\end{tabular}


duced a uniform and definite rate for the whole country. ${ }^{\text {I }}$ In 1770 the rates of 1712 were restored.

Up to this time the rates had been based partly on the actual length of the post routes, partly on the time occupied by the post-messengers in traversing the routes. They therefore varied according as the roads were good or bad. ${ }^{2}$ In 1801 a mathematical measurement of the roads of Prussia was made, and thereafter the time factor was eliminated and the rates based on distance only. The distance was measured, not in a direct line, but by way of the post routes.

The events of the Napoleonic period resulted in a great increase of prices in Prussia, and in order to meet the additional expense of conducting the posts, the rates were increased by 50 per cent. between 1805 and 1811, but the general basis of charge remained unchanged. In 1824 important modifications were introduced. The discrimination according to the nature of contents of parcels was abolished, and the rates were based solely on considerations of weight and distance of transmission. Further, the distance between post offices was no longer to be reckoned according to the distance by way of the post routes, but according to the direct distance. 3 The general parcel rate was fixed at $3 \mathrm{pf}$. per pound for each 5 miles, with a minimum charge of twice letter rate for parcels not exceeding 4 pounds in weight, and three times letter rate for parcels weighing more than 4 pounds. In the case of several parcels directed to the same place, the postage was reckoned according to the total weight. The PostmasterGeneral was authorized to increase the rates in the event of a rise in the cost of forage. 4

A special rate, in addition to ordinary postage, was also introduced in respect of parcels directed to or sent from offices for

× The rates of 1766 compared with those of 1712 as follows : For the transmission of a pound parcel from Berlin-

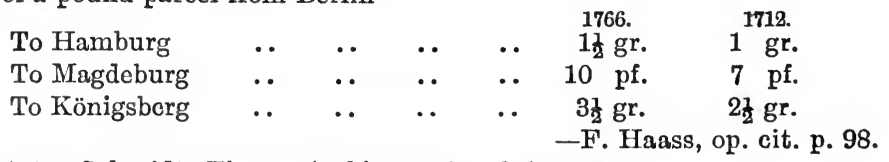

2 Dr. Artur Schmidt, Finanz-Archiv, 1906, vol. i. p. 80 .

3 H. von Stephan, op. cit. p. 746.

${ }_{4}$ Moch, Archiv fir Post und Telegraphie, 1893, p. 6. If the average price of oats in the most important districts in Prussia should exceed a thaler a bushel, the rate might be increased from 3 pf. to 4 pf. 
which no normal rate had been fixed. In 1826 a reduction of postage by 10 per cent. was authorized where the total yearly weight of parcels was between 10,000 and 20,000 pounds, and of 15 per cent. where the total yearly weight exceeded 20,000 pounds. This reduction was, however, abolished in 1848 .

With the introduction of railways and the transformation of the transportation industry which ensued, the rates of 1824 were found to be too high. In 1842 they were accordingly reduced by one-half, experimentally, but only in respect of parcels sent on certain railway routes. In 1847 this reduction was extended to all railway routes, ${ }^{\mathbf{}}$ and in 1848 the rate for parcels not conveyed exclusively on railway routes was reduced to $2 \mathrm{pf}$. per pound for each 5 miles. The distinction was, however, found inconvenient and was removed in 1852.2 A general rate of $1 \frac{1}{2}$ pf. per pound for every 5 miles was then established, with a minimum postage of twice letter rate, and a provision that odd ounces, which had previously been ignored, should be charged as a full pound, and that when several parcels were directed to the same address the postage must be reckoned for each parcel singly.

Under the German-Austrian Postal Union, established in 1850 , it was at first arranged that separate parcel rates should be charged by each administration to and from the frontier, according to its own inland rates. Later the rate was fixed at 2 pf. per pound for each 5 miles, to be charged by each administration concerned in the transmission. In 1857 one definite parcel rate was established for the whole territory of the Union, graduated according to direct distance, viz. 2 pf. per pound for each 4 miles, with minima of from $1 \frac{1}{2}$ to $7 \mathrm{sgr}$. The whole revenue from parcels was credited to a common fund and divided according to certain percentages.

A new parcel rate, based on weight and distance only, was established at the founding of the North German Union in 1867. The method of calculating the distance of transmission for the purpose of determining the postage charge was also modified. The then existing arrangement in Prussia, based on the regulations of 1824 , provided that the rate should in all cases be reckoned according to the actual distance between the post offices concerned. Under this method, when a new post office was established, a parcel rate for every other

I Cabinet Order of 5th March 1847.

2 Law of 2nd June 1852. 
post office must be calculated, causing much labour and wasting much time. This method was now abandoned. The whole territorye of the North German Union was divided into imaginary squares, with sides 2 miles in length, the points of intersection of the diagonals being taken as the centres from which all distances were calculated. ${ }^{x}$ The rates between any offices in two different squares were made identical. Such a method rendered unnecessary the calculation of a special rate of postage for every post office, and also rendered unnecessary any fresh calculations of rates in respect of any new post offices. The progression of distances was by stages of 5 miles up to 30 miles, of 10 miles from 30 to 100 miles, and of 20 miles thereafter, the increase in the length of the steps being justified on the ground that the cost of transportation does not increase in direct proportion to the distance. ${ }^{2}$ The rate was $2 \mathrm{pf}$. per pound for each step in the scale of distances. The rate of 1867 was applied to the Imperial Post Office by the law of 28th October 1871 . This tariff, with its comparatively small progressions of distances, was found inconvenient, especially with the large growth of the traffic. The rates had, moreover, been found too high for small parcels sent over long distances. In point of fact, by far the greater part of parcels under the weight of 5 kilogrammes were less than $2 \frac{1}{2}$ kilogrammes in weight. New parcel rates were accordingly introduced on the 1st January 1874.3 For all parcels not exceeding 5 kilogrammes in weight, uniform rates were established, on the ground that an increase of postage according to the distance of transmission was unjustifiable in the case of light parcels.4 For the first 10 miles the rate was $25 \mathrm{pf}$., and for all other distances $50 \mathrm{pf}$. A zone tariff based on six zones of distance was established for parcels of greater weight than 5 kilogrammes. For the first 5 kilogrammes such parcels were charged the uniform rate applicable to parcels not exceeding 5 kilogrammes in weight,

- A similar system had been introduced in the German Postal Union in 1858. The sides of the squares were, however, 4 miles long, and were too large for the smaller distances of the North German Union.

? Motiv zur Posttaxnovelle vom 4 November 1867 ; cited F. Haass, op. cit. p. 100.

3 Law of 17th May 1873.

4 Motiv zur Posttaxnovelle vom 17 Mai 1873, 
and the following table shows the charges for the weight exceeding 5 kilogrammes :-

\section{Distance.}

Zone I Not exceoding 10 miles

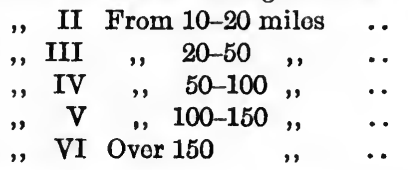

For each kg. aftor

$$
\begin{aligned}
& \text {. } \quad . . \quad \quad \ldots \quad \frac{1}{2} \operatorname{sgr} .(5 \text { pf. }) \\
& \begin{array}{llll} 
& . . & \ldots & 1
\end{array} \\
& \begin{array}{llll}
\text {. } & \ldots & \ldots & 2,
\end{array} \\
& \text {. } \quad \text {.. } \quad \text {.. } 3 \text {, } \\
& \begin{array}{lllll} 
& . & \ldots & \ldots & 4,
\end{array}
\end{aligned}
$$

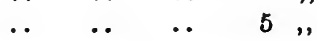

For cumbrous and unwieldy parcels an additional charge not exceeding 50 per cent. of the ordinary postage might be made. With the increase of traffic it was found impossible to forward all the parcels by the postal trains, and the Post Office was only permitted to send a limited quantity of parcels by the ordinary express trains. ${ }^{x}$ In 1880 it was arranged that parcels which must be delivered without delay-e.g. those containing fish or flowers-should be forwarded by express train on payment of a special fee of 1 Mark each. In 1886 this additional fee was made applicable to all urgent parcels, whatever the contents.

The tariff of 1873 has proved too high both for heavy and for very light parcels, and some curious anomalies result from the combination of zone rates and uniform rates. A parcel of $5^{\star}$ kilogrammes sent for any distance greater than 10 miles costs $50 \mathrm{pf}$. Eight parcels of 5 kilogrammes each could, therefore, for 4 Marks be sent for any distance; but if made up into one parcel of 40 kilogrammes the postage would be 7 Marks 50 for places in the third zone (20 to 50 miles), and for places in the sixth zone (over 150 miles) no less than 18 Marks. $^{2}$ It is therefore to the advantage of

I Railway postal law of 20th December 1875.

2 The parcel rate for 20 kilogrammos sent as one parcel or as four parcels each of 5 kilogrammes in each zone would be as follows:-

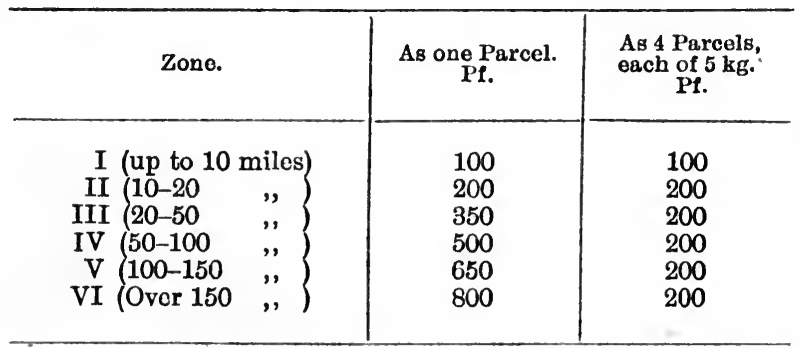

-C, H. Hull, op. cit. p. 21 . 
the public to divide a heavy parcel, though such a proceeding obviously increases the cost to the administration of its handling and transmission. The despatch of heavy parcels by post is naturally discouraged, and the proportion of such parcels is decreasing. ${ }^{x}$ Of the total number of parcels sent by post in 1900, more than 88 per cent. were less than 5 kilogrammes in weight, and the number of greater weight than 10 kilogrammes formed less than 3 per cent. The average amount of postage per parcel on parcels falling in Zones III, IV, V, and VI is not appreciably greater than that on parcels falling in Zone II. ${ }^{2}$ The number of heavy parcels in the higher zones is, therefore, negligible, 3 and is least in the highest zones. 4

x Parcels in Imperial German Postal Service (Inland) :-

\begin{tabular}{c|c|c|c|c}
\hline Year. & $\begin{array}{c}\text { Parcels not } \\
\text { exceoding 1 kg. }\end{array}$ & $\begin{array}{c}\text { From 1 } \\
\text { to } 5 \mathrm{~kg} .\end{array}$ & $\begin{array}{c}\text { From } 5 \\
\text { to 10 kg. }\end{array}$ & $\begin{array}{c}\text { Over } \\
10 \mathrm{~kg} .\end{array}$ \\
\cline { 2 - 3 } & Per cent. & Per cent. & Per cent. & Per cent. \\
1875 & 25 & 50 & 18 & 7 \\
1880 & 20 & 58 & 17 & 5 \\
1885 & 18 & 61 & 17 & 4 \\
1890 & 15 & 65 & 18 & 3 \\
1900 & 12 & 69 & 17 & 2 \\
\hline
\end{tabular}

-Finanz-Archiv, 1906, vol. i. p. 89; C. H. Hull, op. cit. p. 28.

2 Average postage per parcel (pf.) :-

$\begin{array}{ccccccc}\begin{array}{c}\text { Zone. } \\ \text { Ortssendungen }\end{array} & \ldots & \ldots & \ldots & \ldots & 26 \cdot 2 & 26.8 \\ \text { I } & \ldots & \ldots & \ldots & \ldots & 32 \cdot 3 & 29 \cdot 7 \\ \text { II } & \ldots & \ldots & \ldots & \ldots & 62 \cdot 1 & 57 \cdot 4 \\ \text { III } & \ldots & \ldots & \ldots & \ldots & 66 \cdot 5 & 57 \cdot 4 \\ \text { IV } & \ldots & \ldots & \ldots & \ldots & 69 \cdot 3 & 57 \cdot 4 \\ \text { V } & \ldots & \ldots & \ldots & \ldots & 74 \cdot 3 & 58 \cdot 5 \\ \text { VI } & \ldots & \ldots & \ldots & \ldots & 86 \cdot 6 & 73 \cdot 8\end{array}$

-Ibid., p. 24.

3 Average weight of parcels in Imperial German Postal Service (Inland) :-

\begin{tabular}{c|c|c|c}
\hline Year. & $\begin{array}{c}\text { All parcels. } \\
\text { Kg. }\end{array}$ & $\begin{array}{c}\text { Parcels not } \\
\text { exceeding 10 kg. }\end{array}$ & $\begin{array}{c}\text { Paroels over } \\
10 \mathrm{~kg} .\end{array}$ \\
\hline & $4 \cdot 3$ & $3 \cdot 6$ & $16 \cdot 2$ \\
1875 & $4 \cdot 2$ & $3 \cdot 8$ & $15 \cdot 4$ \\
1880 & $4 \cdot 1$ & $3 \cdot 8$ & $15 \cdot 0$ \\
1885 & $4 \cdot 0$ & $3 \cdot 9$ & $14 \cdot 5$ \\
\hline
\end{tabular}

-Ibid., p. 26.

4 "Angenommen es hätte Im Jahre 1890 unter 10 packeten das Gewicht eines in Zone III $12.4 \mathrm{Kg}$. ; eines in Zone IV $8.7 \mathrm{Kg}$. ; eines in Zone V 7.5 Kg., 
In the case of very light parcels also the rate is excessive. The number of parcels under 1 kilogramme in weight, which in 1870 formed about 30 per cent. of the total, fell in 1874 to $26^{\circ} 6$ per cent., in 1878 to 21.8 per cent., and in 1910 to 12.616 per cent. ${ }^{x}$ Similarly the rates for the longer distances are too high generally, and the number of parcels falling under the higher zone rates is extremely small. In $1887,42.5$ per cent. of the total number of parcels were delivered within the first zone, and 84 per cent. within the first three zones, those in the sixth zone forming only 064 per cent. ${ }^{2}$ Notwithstanding these defects in the scheme of rates, the total number of parcels has largely increased, 3 and the cheapness of many of the rates has led to the development of a traffic in certain food-stuffs, and has encouraged numerous localized industries.4

oder eines in Zone VI $6.9 \mathrm{Kg}$, das der anderen neun jo $5 \mathrm{Kg}$. betragen, so stände der Durchschnittsportobetrag schon auf seiner thatsächlichon Höhe."C. H. Hull, loc. cit. p. 25.

statistik der Deutschen Reichs-Post- und Telegraphen-Verwaltung, 1910, Berlin, 1911, p. 20.

2 An analysis of the traffic of the Imperial Post Office gives the following result :-

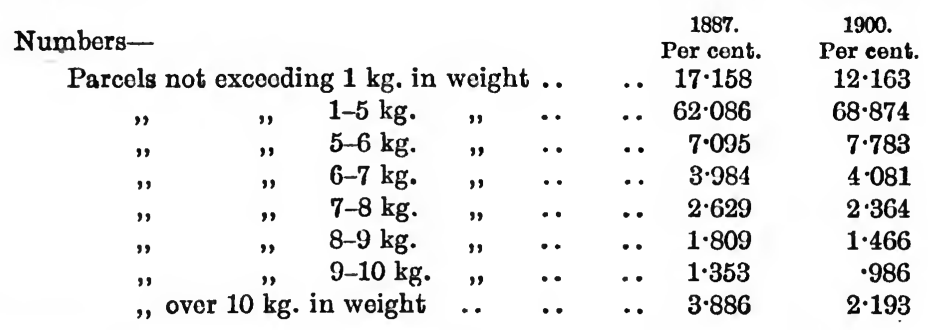

Revenue and distance of transmission-

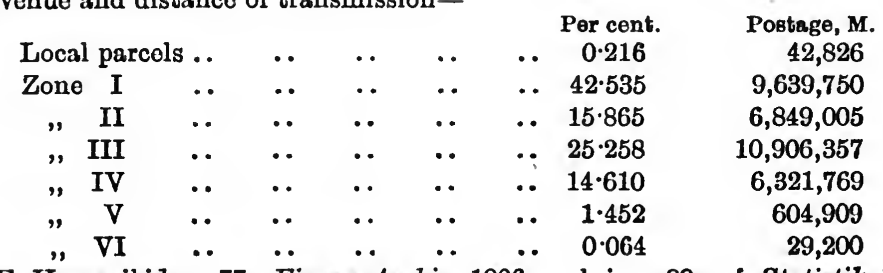

-F. Hass, ibid. p. 77 ; Finanz-Archiv, 1906 ; vol. i. p. 89 ; cf. Statistik, 1900, p. 31.

3 Total number in 1870,37 millions; in 1880,60 millions; in 1890, 97 millions; in 1913, 280 millions.

4 "Infolge soine Billigkeit hat sich für viole Handels- und Erwerbszweige eln unmittelbarer Verkehr zwischen Produzenten und Konsumenten entwickelt 
In view of the small number of heavy parcels it has been suggested that the post should be restricted to parcels not exceeding 10 kilogrammes in weight, parcels of greater weight being left to the railways. ${ }^{x}$ This would result in the exclusion of about 3 per cent. only of the parcels. The proposal is, however, objected to on the ground that the postal service for such parcels ought not to be withdrawn unless the railways can afford as punctual, speedy, and cheap a service as the Post Office; ${ }^{2}$ an argument which is sound only if the present rate is profitable to the Post Office (which is doubtful), or otherwise so long as it is assumed that the Post Office ought to continue the present service for the public advantage, regardless of considerations of cost and revenue.

To meet the difficulty with light parcels a lower rate has been proposed for parcels under 1 kilogramme in weight, but a further modification in favour of parcels between 1 kilogramme and 5 kilogrammes in weight is deprecated as involving an undesirable complication of the uniform rates. 3 The parcel post business is conducted as part of the general Post Office business, and consequently it is not possible to eliminate from the general expenses of the whole service the expenses incurred in dealing with parcels. It cannot be said, therefore, whether either the light parcels or the heavy parcels,

(Butter-, Fleisch-, Fischsendungen, u.s.w.), der frühor durch Zwischenhandel verteuert und erschwert wurde. Ganz neue Erwerbszweige haben sich gebildet, indem Erzeugnisse, die früher am Produktionsorte fast gar nicht verwertbar waren, in Massen billig nach weit entfernten Gegenden versandt werden können, um dort Verwertung zu finden. Auch die Hausindustrie ist durch direkten Bezug von Rohstoffen für Spinnerei, Weberi, u.s.w., neu belebt worden."-Dr. Artur Schmidt, Finans-Archiv, 1906, vol. i. p. 84.

I “" 'Der Eisenbahn den Gross- und Massenverkehr, der Post den Kleinverkehr,' empfiehlt auch de Terra. In der Tat erscheint dieser Vorschlag verlockend. Denn die Post kann den ungeheueren Paketverkehr schon jetzt nur mit Mühe bewältigen und ist zu dem Zwecke oft zur Einstellung kostspeiliger Transportmittel (Eisenbahnbeiwagen) genötigt."-Ibid., p. 90.

$=$ Ibid., p. 91 .

3 “Abgesehen aber von diesem reln politischen Einwand würde die Aufstellung eines komplizierten Zonentarifs bei dem heutigen Umfang des Packetverkehrs den Dienst unerträglich erschweren und verzögern. Es lässt sich wohl fragen ob, wenn jedes Packet auf seine Beförderungsentfernung zu prüfen wäre, der Dienst sich technisch durchführen liesse, wenigstens zu Gebühren, welche den Verkehr nicht allzusehr einschränken würden."-C. H. Hull, op. cit. p. 31 ; vide also Dr. Artur Schmidt, Finanz-Archiv, 1906, vol. i. p. 87, 
the short-distance parcels or the long-distance parcels, are or are not profitable to the administration, or, indeed, whether the parcel post service as a whole is a remunerative service or otherwise; but German writers on the subject hold the opinion that the cost of the service exceeds the revenue derived from it. ${ }^{\mathrm{x}}$

- E.g. " Es ist sogar wahrschoinlich, dass, wenn zu den Kosten der Eisenbahnloistungen für Packetpostzwocko ein Betrag für Verzinzung des Eiscnbahn-Anlagokapitals noch hinzugerechnet wird, dio Packetpost dann mit oinem Defizit arbeitet."-C. H. Hull, op. cit. p. 152 ; ibid., p. 139 . Cf. G. Cohn, Finanzwissenschaft, Berlin, 1889, p. 383, F. W. Grunow, Zur Reform des Paketportos in Deutschland und Österreich-Ungarn, Leipzig, 1898, p. 131 ; contra, Handwörterbuch der Staatswissenschaft, Jena, 1910, vol. vi. p. 1092. 


\section{MINOR RATES}

\section{(I) BOOK POST}

\section{United Kingdom}

IN 1847 Sir Rowland Hill proposed the provision of special facilities for the transmission by post in the United Kingdom of books and other printed matter. He thought such a concession expedient as a matter of policy, especially. in view of the "state of the public mind on the important subject of education." A low rate of postage would facilitate the transmission of scientific and literary reports and other documents "tending to the extension and diffusion of knowledge," and would be highly prized by the Literary and Scientific Societies, which were a feature of those days. Private families, especially the rural clergy, would also in that way be enabled to obtain valuable publications otherwise, to them, unattainable. Sir Rowland Hill recognized that there were objections to the granting of a special rate for a special class of matter; but he argued that, in effect, the proposal was nothing more than an extended application of an existing principle, applied to newspapers and Parliamentary Proceedings, and (in regard to certain places abroad) ordinary periodical publications. ${ }^{x}$

The rate proposed was $6 \mathrm{~d}$. per pound, which was virtually the rate charged on newspapers, with this difference to its advantage, that, whereas $6 \mathrm{~d}$. paid on newspapers would represent six packets to be dealt with separately, 6d. paid under the proposed book post rates would be in respect of one

x British Official Records, 1847. 
packet only. The high minimum charge of $6 \mathrm{~d}$. was proposed as a security against fraud: with such a minimum there would be no temptation to send a packet as a cover for a written communication. As a measure of economy it was proposed to send the packets by the day mails as far as possible, by this means avoiding loading heavily the important night mail trains and adding to their cost; and it was anticipated that the rates proposed would yield some profit to the revenue.

Objection was raised on the ground that the post ought to be confined to small packets as far as possible, and should convey large letters and packets only when necessity was urgent: heavy packets would impede the work of the Post Office, and would cause inconvenience in many ways, especially as regards foot-messengers; ${ }^{x}$ but, as it was not thought likely that any very great number of book packets would be posted, the objection was not upheld, and the cheaper rate was introduced. At first various restrictions were imposed, and considerable public dissatisfaction resulted, especially in regard to certain of the regulations. These regulations were consequently relaxed in 1853 so as to allow practically any printed matter to pass at the book rate. In 1855 the rate was reduced, ${ }^{2}$ and in 1856 circulars were admitted at the privileged rate. As a result of this the number of book packets increased rapidly. In 1855 the total number was $3,000,000$; in 1856 the number increased to $6,000,000$; and in 1862 reached 14,000,000. In 1866 the rates for heavier packets were further reduced. The rate for packets over 8 ounces in weight became 1d. for each 4 ounces, instead of $2 \mathrm{~d}$. for each 8 ounces.

In 1870, when the $\frac{1}{2} d$. rate for newspapers and for postcards was established, 3 an important change in the book post was made. As the result of pressure from the public and $a$ vote in the House of Commons in favour of a reduction, carried against the wishes and recommendation of

- British Official Records, 1847.

- The new rates were-

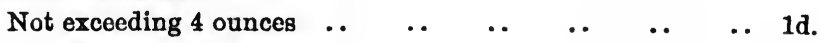

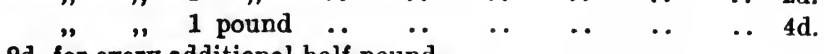

. See supra, pp. 129-131. 
the Government, ${ }^{1}$ the rate on book packets was reduced to $\frac{1}{2} \mathrm{~d}$. for every 2 ounces.

Since 1870 the regulations governing admission to the book post have been modified from time to time, chiefly in the direction of enabling the formal documents of commerce to pass at the reduced rate. All documents admitted to the privilege must conform to certain requirements, and it is obvious that all such documents must be open to inspection by the Post Office. It is therefore an indispensable requirement that the documents be sent in open covers. Thus arises that curious distinction between the "closed" post and the "open" post, a lower rate of postage being given to packets containing articles or documents of a certain description, on condition that the contents are open to inspection by the postal authorities.

In 1897 the ordinary letter rate was made $1 \mathrm{~d}$. for the first 4 ounces, and $\frac{1}{2} \mathrm{~d}$. for each additional 2 ounces. The book post, therefore, disappeared, except as regards packets not exceeding 2 ounces in weight; and in 1904 its name was changed to the "Halfpenny Packet Post." It is available for practically all the formal documents of commerce, and, in addition, many other packets of miscellaneous character, and remains a most important branch of Post Office traffic. ${ }^{2}$ In 1913-14 the number of halfpenny packets

I 6th April, 1869; Parl. Debates (Commons), vol. cxov. col. 258.

"The Post Office revenue is derived mainly from the circulation of letters which pay 1d. for half an ounce, and if they exceed half an ounce, another $1 \mathrm{~d}$. The writers of those letters are not necessarily rich people, or persons to whom the postage is a matter of indifference; they are, in a certain sense, the helots who bear the burden of the expense of the Department. Is it, then, not a question worth considering, whether-supposing we accede to this request and carry 2 ounces of printed matter for a $\frac{1}{2} \mathrm{~d}$., for the benefit of a particular class of the community-that might not interfere with the possibility of maintaining the 1d. postage on letters?"-Chancellor of Exchequer in House of Commons, 6th April 1869 ; Parl. Debates (Commons), vol. cxcv. col. 254.

2 The growth of the traffic is shown by the following table:-

\begin{tabular}{|c|c|c|c|}
\hline Year. & & & $\begin{array}{l}\text { Average Annual } \\
\text { Number of Book Packets. }\end{array}$ \\
\hline $1872-76$ & ०. & •. & $143,000,000$ \\
\hline $1882-86$ & .. & .. & $323,000,000$ \\
\hline $1892-96$ & .. & .. & $570,000,000$ \\
\hline $1900-05$ & .. & .. & $811,000,000$ \\
\hline $1909-10$ & .. & .. & $974,000,000$ \\
\hline $1912-13$ & .. & .. & $1,079,000,000$ \\
\hline 1913-14 & .. & .. & $1,172,000,000$ \\
\hline
\end{tabular}

-The Post Office: An Historical Summary, London, 1911, p. 14 ; and Annual Reports of Postmaster-General. 
(excluding postcards) was no less than 1,172 millions, or about one-fifth of the total number of packets passing by post in the United Kingdom.

When on the 1st November 1915 the postage on letters over 1 ounce in weight was increased, the book post was re-established as it had existed prior to 1897, except for unimportant modifications of the regulations. It had been proposed to abolish altogether the $\frac{1}{2} d$. rate of postage, ${ }^{\mathrm{I}}$ but in view of strong representations from the printing trade, and of the hostility of the general public, this proposal was abandoned.

\section{France}

Particulars of the earlier rates of postage charged on printed matter in France cannot now be ascertained, but they appear always to have been lower than the rates for letters. Before the Revolution an octavo book could be sent for any distance for 12 sous, and the postage on circulars was less than a centime. ${ }^{2}$

By the decrees of 17-22 August 1791, a rate for daily newspapers of 8 deniers the sheet was established, and a rate of 12 deniers the sheet for other newspapers and for periódical publications. During the succeeding years the rates were modified a number of times. In 1796 the following rates were established:-

4 centimes the sheet for newspapers;

5 centimes the sheet for unbound books, catalogues, and prospectuses.

A distinction was always made between ordinary printed matter and periodical publications.

In 1827 the size of the sheet which was the basis of the charge was fixed at 25 square decimetres. The system of charge by weight was applied to printed matter in 1856, with the following rates:-

1 centime for each 5 grammes up to 50 grammes 10 centimes from 50 to 100 grammes

1 centime for each 10 grammes beyond 100 grammes.

- See First Report of the Committee on Retrenchment in the Public Expenditure, 1915 (Parliamentary Papers, Cd. 8067 and Cd. 8068); Times newspaper, 28th September 1915.

2 A. Belloc, Les Postes françaises, Recherches historiques, Paris, 1886, p. 353.

3 Law of 4 thermidor, an IV (22nd July 1796). 
These rates were increased by some 50 per cent. in 1871. After the establishment of the Universal Postal Union the rates in the internal service were in some cases higher than those in the international service, and it became advantageous to commercial men to post their packets abroad. The French administration were then required under the international convention to distribute them in France without receiving any postage. ${ }^{I}$ This anomalous situation was put an end to in 1878, when the following rates were established:-

When sent under band-

1 centime for each 5 grammes up to 20 grammes

5 centimes from 20 grammes to 50 grammes;

5 " for each 50 grammes or fraction of 50 grammes thereafter.

When sent in open envelopes-

5 centimes for each 50 grammes or fraction of 50 grammes.

The rates have since been reduced, and are now as follow:-

2 centimes for packets not exceeding 15 grammes in weight

3 " between 15 grammes and 50 grammes

$5 \quad$, , 50 grammes and 100 grammes

5 , for each 100 grammes or fraction of 100 grammes thereafter.

The number of packets of printed matter has increased rapidly, as the subjoined table shows:-

\begin{tabular}{|c|c|c|c|c|c|}
\hline & & & & & $\begin{array}{l}\text { Number of Packets of Ordinary } \\
\text { Printed Matter }\end{array}$ \\
\hline 1877 & .. & .. & .. & .. & .. $195,148,116$ \\
\hline 1883 & .. & .. & .. & .. & .. $315,315,725$ \\
\hline 1889 & .. & .. & .. & .. & .. $406,252,198$ \\
\hline
\end{tabular}

The administration are given power to delay the despatch or transmission of packets of ordinary printed matter should circumstances render that course desirable.

In 1827 a special rate of 5 centimes for those delivered locally, and 10 centimes for others, was conceded to certain formal printed documents, such as notifications of births, marriages, or deaths. In 1856, to these were added prospectuses, catalogues, prices current, and cartes de visite. These documents must be sent under band or in open envelopes. The special rates on these classes of packets

×. Jaccottey, op. cit. p. 327. 
have been continued. Under an order of the 26th November 1909 the rate for cartes de visite was made 2 centimes when sent under band, but formulas of courtesy must not appear on the cards. Cartes de visite sent in open envelopes are still charged 5 centimes.

\section{Germany}

In Prussia the order of 1712 did not provide a special rate for ordinary printed matter sent by letter post. A reduced rate of two-thirds that for ordinary merchandise was, however, provided for books and other similar matter, ${ }^{\text {I }}$ under the name of Schriften und Aktentaxe, when sent by parcel post. $^{2}$

In 1821 special rates were prescribed for various classes of printed matter sent under band (Versendung unter Kreuzband), viz. books, music, catalogues, prospectuses, prices-current, printed circulars, as follow-

$$
\begin{aligned}
& \text { For each ordinary sheet of printed matter or for eight sheets }
\end{aligned}
$$

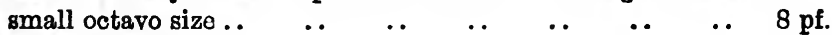

$$
\begin{aligned}
& \begin{array}{lllllllll}
\text { For a half sheet } & . & . . & . . & . . & . . & . . & . . & 5 \text { pf. }
\end{array}
\end{aligned}
$$

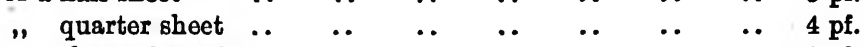

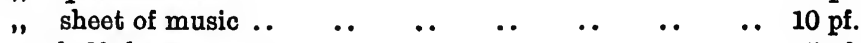

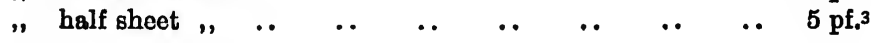

The sheets were to be sent under band, and the name of the sender and the number of sheets were to be written on the outside. The sending of written matter in such packets was forbidden, under penalty of a fine of ten times letter postage on a packet of the same size. In 1824 the rate for matter sent under band (printed lottery winning lists, etc., were now included) was made a quarter letter rate, and, like other rates, was made chargeable according to direct distance of transmission. When, in 1850,4 the rates for letters were revised and reduced, the rate for matter sent under band

\footnotetext{
x "Gedruckte Bücher und Aemter-Rechnungen, Akzise-, Zoll-, und Messzettel, sowie für Stempelpapier."-Archiv für Post und Telegraphie, 1880, p. 268.

2 This rate was, e.g., 2 groschen per pound from Berlin to Xanten or Duisburg, 1 groschen to Hamburg, and 2 pf. to Spandau.-Ibid., p. 269.

3 Ibid.

${ }^{4}$ Law of 21 st December 1849.
} 
was continued at a quarter letter rate, and became (for 1 loth Zollgewicht $=1 \frac{1}{8}$ loth Prussian)-

\begin{tabular}{|c|c|c|c|c|c|c|}
\hline $\mathrm{Jp}$ & aan miles & .. & .. & $\cdots$ & . & $\frac{1}{4}$ sgr. \\
\hline 10 to 20 & , & . & $\cdots$ & $\cdots$ & $\cdots$ & gr. \\
\hline Over 20 & ", & & .. & .. & . & .. \\
\hline
\end{tabular}

With the exception of the name and address of the addressee no writing was permitted on these packets, but by the order of the 29th May 1848 the writing of the name and address of the sender and the date was permitted.

With the increase in the number of packets sent under band at the reduced rate, there grew up an increasing abuse of the privilege by the enclosure in such packets of written communications. In order to check this, it was provided in 1843 that when any large number of such packets were posted by the same person, a few of the packets should be examined in the presence of the sender. No penalty was at first imposed; but in 1850 it became necessary to take action, and the royal order of the 12 th June 1804, prescribing a penalty of 10 thalers in cases where a letter was enclosed in a packet passing at a rate less than letter rate, was made applicable to the case of packets sent under band; and the regulation of the 15th December 1821, prescribing a surcharge of ten times letter rate for a packet of like weight, was made applicable to cases where a communication was written on the printed sheet sent at the reduced rate. ${ }^{\mathrm{I}}$

In 1850, when the German-Austrian Postal Union was founded, a uniform rate of 4 silverpfennigs for each loth was introduced for packets sent under band. Following the establishment of the Union, the Prussian administration ( $\$ 50$ of law of 5th June 1852) fixed a uniform rate for its own service of 6 silverpfennigs for each loth. For local packets sent under band (Stadtpost-Kreuzbandsendungen) a rate of 1 sgr. for each packet was introduced, reduced to $4 \frac{1}{2} \mathrm{pf}$. for each packet when as many as 100 packets were posted at the same time, or $6 \mathrm{pf}$. each when from 25 to 100 were posted at one time. The definition of printed matter entitled

I The first penalty applied also to sample packets. 
to the privilege' ${ }^{1}$ was now enlarged.2 The penalty for misuse of the privilege was made a surcharge of four times the amount of the postage, but not less than 5 thalers, which might be increased fourfold on repetition of the offence. In 1854 the maximum charge for packets sent under band was fixed at six times letter rate, in order to get rid of the anomaly of a higher charge on heavy packets sent under band than on letters.3 The fact that packets under band could be sent for $4 \mathrm{pf}$. throughout the territory of the Union, but that for transmission within the Prussian territory the charge was 6 pf., and that in consequence Prussian commercial men were posting their packets abroad in large numbers, led to a reduction of the rate in 1856 to 4 pf. for each loth. 4

The large increase of traffic which resulted made desirable a simplification of the definition of packets entitled to the privilege. Only communications of general application could pass, and the officials found themselves often in doubt as to the application of the existing definition. Thus, notices of the despatch of goods, invitations, or printed letters could not be sent at the privileged rate, while, e.g., notices of marriages could. So far as the Union was concerned, in 1860 the privilege was limited to documents reproduced by mechanical means.5 The maximum limit of weight was reduced from 16 loth to $\frac{1}{2}$ pfund (15 loth). This definition was introduced in the Prussian inland service in 1861. The rate of postage was also modified in that year. The rate of $4 \mathrm{pf}$. for each loth was retained, but with the proviso that the charge on packets sent under band should not exceed twice letter rate. This effected a great reduction of charge for the heavier packets. Whereas previously the rate for a packet under band weighing 10 loth, sent more than 10 German miles, had been 18 sgr., it now became 6 sgr. $^{6}$ In 1865 a special rate of $4 \mathrm{pf}$. for printed matter sent in the form

x "Zeitungen, Journalc, Preis-Courante, gedruckte Cirkularien, Empfehlungsschreiben, Correkturbogen ohne beigefügtes Manuskript und gedruckte LotterieGewinnlisten."

2 To include " Druckschriften, Ankündigungen und sonstige Anzeigen."

3 Archiv fiur Post und Telegraphie, 1880, p. 273.

4 Order of 11th April 1856.

5 Archiv fiur Post und Telegraphie, 1880, p. 274.

6 Ibid., p. 275. 
of an open card was introduced in Prussia. ${ }^{\mathbf{x}}$ The simplification of definition and reduction of rate resulted in a large increase of traffic.

In 1867, when the North German Postal Services were unified, the penalty for abuse of the privilege was reduced to a surcharge of four times letter rate, but not less than a thaler; and the law of 1871, founding the Imperial Post Office, abolished the fine because it had been found that the offences were for the most part committed through ignorance of the regulations. Slight changes were made in the regulations under which printed matter was admitted to the privilege, but no change was made in the rates of charge.

The law regarding the Imperial Post Office (28th October 1871) left the fixing of rates for printed matter to the Imperial Chancellor. The maximum limit of weight was raised from $\frac{1}{2}$ pound (250 grammes) to 1 pound (500 grammes). The rates of postage were $\frac{1}{3} \mathrm{sgr}$. for each 40 grammes up to 250 grammes, with a maximum of $2 \mathrm{sgr}$; from 250 to 500 grammes, 3 sgr. ${ }^{2}$ The large increase of traffic resulting from the reductions in the rates for printed matter and for samples caused practical difficulties, and in 18733 the acceptance of letters, postcards, printed matter, and samples was to be only in the Briefkasten.

In 18744 the limit of weight for printed matter was raised to 1 kilogramme, and the rate was made-

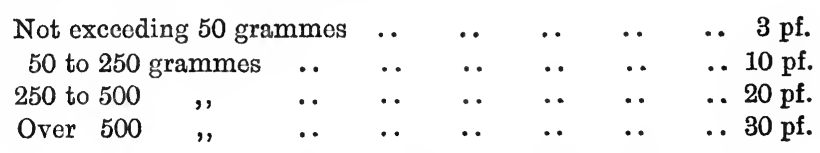

In 1879 (order of 8th March) the definition of printed matter was further extended.5

The tariff of 1874 raised by about 50 per cent. the postage on packets between 50 and 100 grammes. Against this protests were made, especially since the rate for the transmission

x Archiv für Post und Telegraphie, 1880, p. 276.

= Ibid., p. 278.

3 Order of 3rd March 1873.

4 Order of 18 th December 1874.

5 " Alle durch Buchdruck, Kupferstich, Stahlstich, Holzschnitt, Lithographie, Metallographie, und Photographie vervielfältigten Gegenstände" (Sofern sie nach ihrer Form und sonstigen Beschaffenheit zur Versendung mit der Briefpost geeignet erscheinen).-Archiv für Post und Telegraphie, 1880, p. 281. 
of such packets for the furthest points of the Universal Postal Union was no greater than the rate for transmission within Germany. In 1890 the rates were modified, packets between 50 and 250 grammes being divided into two groups, 50 to 100 grammes, and 100 to 250 grammes. The rate for the first was made 5 pf., for the latter it remained $10 \mathrm{pf}$. The increase of the maximum limit of weight has led to practical difficulties. ${ }^{\mathrm{x}}$

This traffic has attained large proportions. In 1910 the number of packets of printed matter passing in the inland service was nearly a thousand millions. ${ }^{2}$

\section{(II) SAMPLES}

\section{UNITED KINGDOM}

In England, letters containing samples and patterns were from the first establishment of the Post Office charged with double postage. In 1753, arising out of the general dissatisfaction with the Post Office felt at that time by the trading public, the legality of the double charge was contested. Merchants, while admitting that any letter containing a pattern or sample which should weigh as much as an ounce must pay at the ounce rate, contended that, if weighing less than an ounce, the letter should be charged according to the number of sheets of paper, and that the pattern which was enclosed should be ignored.3 The Act of the 9th of Anne prescribed the postage on "every single letter or piece of paper" not of the weight of one ounce, and prescribed that "a double letter" should pay double

" "Auch der Erhöhung des Meistgewichts lässt sich das Wort nicht reden. Mit dieser Massnahme wächst sofort die Unhandlichkeit der Sendungen und damit die Vermehrung und Kostspieligkeit der Betriebsmittel. Bereits jetzt müssen zur Bewältigung der Massen v.a. in den Bahnposten, besondors infolge der vielfach vertretnen Rollenform, ausserordentliche Austrengungen gemacht werden. Zudem bietet das billige Paketporto hinreichend günstige Gelegenheit zur Versendung schwerer Drucksachen. Zu einer Aenderung des Drucksachentarifs liegt demnach ein Bedürfniss nicht vor."-Finanz-Archiv, 1905, vol. ii. p. 178.

2 Statistik der Deutschen Reichs-Post-und Telegraphen-Vervaltung, 1910, p. 15.

3 H. Joyce, History of the Post Office, p. 177. 
rate. ${ }^{x}$ The contention of the merchants was that the enclosure of a pattern or sample did not convert a single letter into a double letter, and that to constitute a double letter there must be a second sheet of paper-a contention which is sound enough if postage be regarded as a tax on communications and not as a mere charge for the conveyance of a packet. At Bristol, Manchester, and Gloucester, legal proceedings were taken against local postmasters for demanding and receiving more than the legal postage. In each case a special verdict, in almost identical terms, was given, and the Postmasters-General were advised by the Attorney-General that the decision was likely to go against the Crown if they brought up one of the verdicts for argument. In their difficulty they resorted to Parliament, and obtained specific statutory authority for an additional charge in respect of patterns and samples. ${ }^{2}$

This state of affairs continued until 1795, when samples were given a definite statutory privilege. Under an Act of that year it was provided that a packet of patterns or samples might pass as a single letter on condition that it did not exceed 1 ounce in weight, that it was open at the sides, and that it contained no writing other than the name and address of the sender and the price. 3 This privilege was continued by the Act of 1801.4 In 1805 an additional penny was charged on all such packets.5 In 1812 a further addition to the postage was made, viz. an addition of $2 \mathrm{~d}$. for every "letter, packet, or cover not exceeding an ounce in weight" and containing a pattern or sample, if "closed or not open at the sides," or an addition of 1 d. if

I " For the Port of every Single Letter, or Piece of Paper, to or from any Place not exceeding Eighty English Miles distant from the said General Post Office in London, and within that Part of Great Britain called England, and not coming from or directed on Shipboard, Three-pence; and for the like Port of every Double Letter, Sixpence; etc."-9 Anne, cap. 10, §6.

2 "For every Single Letter or Cover containing One or more Paper or Papers with Patterns, or containing One or more Pattern or Patterns of Cloth, Silk, Stuff, or One or more Sample or Samples of any othcr Sort of Goods, or One or more Piece or Pieces of any Sort of Thing enclosed therein, or affixed thereto, though not Paper, if the same together do not weigh an Ounce Weight, the Rates payable for a Double Letter shall be paid, and no more."-26 Geo. II, cap. $13, \S 8$.

335 Geo. III, cap. 53, $\S 9$.

441 Geo. III, cap. 7, $\$ 11$.

545 Geo. III, cap. 1 , 1 . 
open at the sides. ${ }^{\mathrm{I}}$ By the consolidating Act of 1837 it was provided that packets or covers containing patterns or samples and not exceeding an ounce in weight, if open at the sides and without any "letter or writing in, upon, or within such packet or cover," other than the name and address of the sender and the price, should be charged as single letters, but "letters not open at the sides containing patterns or samples and not exceeding 1 ounce in weight" were to be charged as double letters. ${ }^{2}$ In 1839 the Treasury were empowered to fix rates of postage for all letters by weight, 3 and in 1840 rates of postage, charged according to weight alone, "without reference to the number of sheets or pieces of paper, or enclosures," were legalized.4 This Act contained no special provision in respect of packets containing samples or patterns.

On the 1st October 1863, with the declared object of benefiting trade and commerce by affording facilities for the cheap transmission of bona fide trade patterns and samples of merchandise throughout the country, an "Inland Pattern and Sample Post" was established. Since the Post Office, and the Post Office alone, had the means of conveying such articles at a moderate rate of charge to and from all parts of the country, including even the most remote, it was thought some special concession ought to be made. The privilege was, however, restricted within narrow limits, as it was feared that a large increase in the number of moderately heavy packets would impede the work of the Post Office. It would, moreover, seriously affect the amount of the payments to railway companies for the conveyance of mails, a matter of grave anxiety to the Post Office at that time.5 The privilege was therefore restricted to genuine samples, and no article of intrinsic value might be sent at the reduced rate.

The original rates were :-

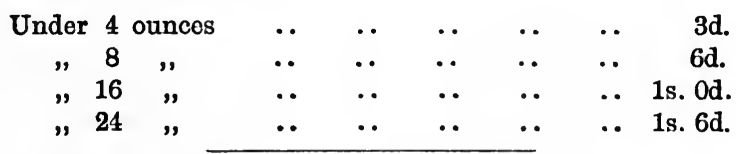

- 52 Geo. III, cap. 88, $\$ 2$.

32 \& 3 Vict., cap. 52, § 1 .

27 Will. IV \& 1 Vict. , cap. 34, § 28.

$43 \& 4$ Vict., cap. $96, \S 4$.

5 Vide Annual Reports of the Postmaster-General, 1859 et seg. 
The computations of the financial effects of the rates were made-as was usual in such cases-by estimating the effect on the gross revenue, taking into account the probable increase in the number of packets, and estimating also what additional expense would be incurred in dealing with the additional traffic. ${ }^{\mathrm{I}}$ The main financial principle seems to have been that as the letter rate was enormously profitable, a reduced rate for a comparatively small volume of traffic could be given without involving actual loss, and without any serious result on the net revenue.

In 1864 the rates were reduced by one-third. In 1865 the exclusion of articles of intrinsic value was abandoned; but there was no relaxation of the essential condition that the articles must be bona fide samples. In 1866 there was a further slight modification of the rates. The number of packets sent at the privileged rate increased from half a million in 1864 to a million in 1865, and by 1868 the number had reached three millions.

The facilities afforded by this post were taken advantage of to a large extent for the forwarding of small packets of goods on sale or in execution of an order. It was estimated that at least half the packets were not genuine samples at all, but contained goods of this kind; and the definite restriction of the post to its original purpose of carrying trade samples and patterns was deemed necessary. This was provided for in the Act of 1870, the rate of postage being at the same time reduced to $\frac{1}{2} \mathrm{~d}$. for every 2 ounces.

The enforcement of the restriction gave rise to considerable public dissatisfaction. It was apparent that fairly general use had been made of the sample post for the transmission of small parcels of all kinds of goods. Many persons living in remote parts of the country were in the habit of obtaining supplies of goods of various kinds by this means; and it was alleged that by the facilities afforded by this post' some industries, such as lace-making, were actually created in certain districts, or at any rate were greatly helped. The post was also much used for the sending of small personal gifts.

Public agitation against the restriction became so strong

× British Official Records, 1863. 
that the postal authorities, although apparently holding the view that a general parcel post was indefensible in principle, became fearful that, unless the public were given some concession on this point, an attack might be made on the $1 d$. rate for ordinary letters. Such an attack, if successful, would of course have been fatal to Post Office revenue. It was proposed, therefore, to make definite provision for the transmission by post at low rates of postage of small packets containing articles other than samples. A rate for small parcels, whatever the contents, would at the same time remove the difficult and unsatisfactory task of deciding what was or was not a sample or pattern. These objects might be secured by a general reduction of the rates for inland letters; and this course was ultimately adopted, after some hesitation from fear of the effect on the revenue. The rates on the heavier inland letters were accordingly reduced by Treasury Warrant of 16th August 1871, and the sample post at the same time abolished. ${ }^{x}$

In the early 'eighties there was a strong demand from the public for the re-establishment of the sample post. The advantage to trade was emphasized, and attention was called to the existence of a privileged rate for samples on the Continent and in the international service. The existence of a low sample rate in the international service led, indeed, to a curious development. As samples which, if posted in this country, would be charged $2 \mathrm{~d}$., could be posted on the Continent for foreign transmission at a charge of 1d., several firms in England were in the habit of sending large numbers of sample packets in bulk to Belgium, where they were posted at the 1d. rate addressed to places in England. The result of this manœuvre was that, instead of receiving the inland postage of $2 \mathrm{~d}$. for these packets, the British Post Office performed practically the same service in respect of

See supra, p. 31.

"Tho publio felt aggrieved at the restriction, and, as the difficulty of defining samples in all cases could not be overcomo, it was decided to reduce the inland letter postage to such an extent as would enable the public to send through the post in closed covers not only patterns and samples, but also any light articles for a moderate charge; thus abolishing altogether the distinction between letters and samples, and providing a cheap and convenient post for small parcels." Seventeenth Report of the Postmaster-General, London, 1871, p. 4 . 
them as if they had been posted in England, but received nothing, since under the Postal Convention the whole of the postage on foreign letters is retained by the country of origin. It was estimated that there was in this way a loss to revenue of $£ 1,000$ a year.

It was in great part the existence of this anomaly which led to the re-establishment of the sample post in 1887. No exact estimate was made of the cost of dealing with sample packets, but the authorities stated that the rates proposed, viz. under 4 ounces 1 d., over 4 ounces and under 6 ounces $1 \frac{1}{2} d$., and over 6 ounces and under 8 ounces $2 d$. ( 8 ounces to be the maximum weight), would be remunerative, and that any immediate loss to revenue in consequence of the reduction in rates would therefore be likely soon to be made up. This statement must, however, have been based on general considerations and estimates. In the following year the Secretary to the Post Office (Sir Arthur Blackwood) told a Select Committee of the House of Commons that the Post Office had not any return of the cost per million letters, or any return of that kind by quantity, and that the Post Office could not give the actual cost per million letters. ${ }^{\mathrm{x}}$

The post, which was re-established in the interests of trade and could only be used by traders, was continued until 1897, when the Jubilee reductions brought down the postage on ordinary letters to the level of the sample rate.

The sample post was never more than a very minor part of the Post Office business. In 1865, when the total number of letters passing by post was some 700 millions, the number of samples was one million. In 1870 the number of samples was four millions. In 1896, the last year of its existence as a special rate, the number of samples was nine millions. In that year the number of letters, etc., was some 3,000 millions.

As a result of the increase of letter postage on the heavier

I Report of Select Committee on Estimates of Revenue Departments, 1888, p. 24.

It may be noted, in justification of the view sometimes advanced that additional traffic can without loss be undertaken by the Post Office at rates lower than those for the main services, that in this case the Post Office anticipated that no direct additional expense would be incurred in the provinces in dealing with the increase of traffic, and that in London the additional expense would only amount to some $\$ 500$ a year. 
letters, as a war measure, it has been deemed necessary to re-establish the inland sample post. On the 1st November 1915 the post was accordingly re-established substantially as it existed prior to 1897 . The rates of postage are the same, and the regulations practically unaltered.

\section{France}

In France, by the decree of 17-22 August 1791 (Article 16), samples were accorded a privileged rate of one-third letter postage, with the reservation that in no case could the postage charged be less than that on a single letter. In 1848, when a low uniform rate for letters was adopted, it was thought that the privilege given to samples need not be continued. The suppression of the special privileged rate was found almost to exclude samples from the mails, and in 1856 they were again given a privilege by the extension to them of the rates and conditions applied to printed matter. ${ }^{I}$ The limit of weight for samples was fixed at 3 kilogrammes, and the limit of each dimension at 45 centimetres; but these limits were found to be too great. The post became encumbered with large packets which it could not enclose in the mails, and which, as a matter of fact, it had not the means of dealing with. Consequently, in 1858 the limit of weight was reduced to 300 grammes, and the maximum dimension to 25 centimetres. ${ }^{2}$ It was still found, however, that packets of samples gave rise to considerable embarrassment in the service. Their irregular size rendered stamping more difficult, and their volume and the unsatisfactory manner in which they were made up for the post caused inconvenience, especially in the travelling offices, where space is limited.

The object in view in establishing the sample rate had been to encourage trade by the distribution of trade samples, and not to found a new general means of conveyance for small parcels. But commercial houses were not slow to take advantage of the means afforded for the distribution of small

See supra, p. 223.

$=$ Arrête of 4 th March 1858. In 1881 these limits were raised slightly-to 350 grammes and to 30 centimetres respectively. 
packages of goods. At first it was made a condition of acceptance at the privileged rate that the articles should bear the name of the dealer or maker, but this precaution was abandoned before long. ${ }^{\mathrm{I}}$

A minimum rate of 1 centime for packets not exceeding 5 grammes in weight had been fixed in 1856. This proved too low, and in 1871 the minimum was raised to 30 centimes, which proved to be too high. The number of samples, which in 1869 had been $9,751,970$, fell in 1872 to $3,461,981.2$ In December 1873 this rate was reduced by one-half, and in August 1875 the rate was fixed at 5 centimes for each 50 grammes. Under this rate the numbers increased rapidly : $5,267,964$ packets were sent through the post at the sample rate in 1874, and by 1889 the numbers had risen to $25,731,985$. The present rate is 5 centimes per 50 grammes, with a maximum limit of 500 grammes. The number of sample packets in the year 1912-13 was about 78 millions. 3

\section{Germany}

Samples were first given a privilege in Prussia in 1825.4

Packets containing samples were then given single letter rate up to $1 \frac{1}{2}$ loth, and half the letter rate for heavier packets. They must either be sent enclosed in a letter or attached to a letter, and the letter must not exceed $\frac{3}{4}$ loth in weight.

In 1850 the following rates for samples were established:-

$$
\begin{aligned}
& \text { Not exceeding } 10 \text { German miles .. } \quad \text {. } \quad \ldots \quad \ldots \quad \text {.. } 1 \text { silver groschen }
\end{aligned}
$$

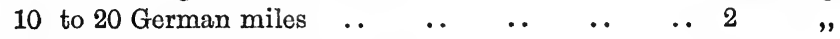

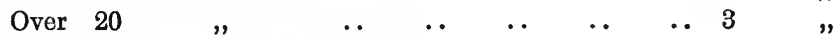

and for heavier packets, half letter rate.

Under the Austro-German Postal Union, established on the 6th April 1850, the ordinary rate for single letters was

I In 1871 the Compagnie des Chemins de Fer de l'Est filed a petition in which they contested the right of the Post Office to send samples of merchandise by railway without specially remunerating the railway company. They claimed that under the law they were obliged to carry free only "letters" and "despatches." The case was, howevor, decided against the company.P. Jaccottey, op. cit., p. 334 .

2 Ibid., p. 333.

3 Statistique générale du service postal, Berne, 1914, p. 7.

4 Archiv für Post und Telegraphie, 1880, p. 270. 
charged in the case of samples for each 2 loth, according to distance. In 1852 the Prussian internal rates for samples were brought into accord with those of the Union. Samples must be sent in unsealed covers and must be easily recognizable as such. The maximum weight was 16 loth, and the maximum charge was not to exceed six times letter rate.

In 1853 a further privilege was conceded. When sent together with a letter, samples might be enclosed in sealed covers; but in order to enable the administration to maintain a control over the use of the privilege, the postal officials were empowered at discretion to require the sender to open such packets. ${ }^{\mathrm{x}}$

In 1860, when the Austro-German Postal Union was renewed, the limit of weight for samples was reduced to $\frac{1}{2}$ pound (15 loth). Following this reduction the Prussian rates for samples were reduced in 1861: for samples weighing more than 2 loth only the rate for a double letter (according to distance) was to be charged. The reduction was not followed by any large increase in the number of sample packets. Every sample must still be accompanied by a letter, a circumstance which made the application of the sample rate heavy. With a view to the further encouragement of the traffic this requirement was removed in 1863, and the despatch of samples under band, in envelopes, little bags, or similar covers, authorized. New rates were introduced as follows : $4 \mathrm{pf}$. for each $2 \frac{1}{2}$ loth. To prevent abuse of the privilege it was provided that no article of marketable value could be sent at the reduced rate. The packet must be marked to show that it contained a sample, and might also bear the name and address of the senders, the trade mark, and the number of samples and prices.

In 1871 the rate for the Imperial Postal Service was made $\frac{1}{3}$ sgr. for each 40 grammes with a maximum of 2 sgr. Practical difficulties arose from the great increase of traffic which followed this reduction of rate. Large packets and packets of awkward shape were posted, causing practical difficulties, especially in the sorting carriages, and it was found necessary to decline to accept samples over the counter, and to forbid the acceptance of samples in roll form. The sample rate

- Archiv fiur Post und Telegraphie, 1880, p. 273. 
was, moreover, complicated as compared with the letter rate. While there were but two rates for letters, there were five for samples, viz. 4, 8, 12, 16, and $20 \mathrm{pf}$. In 1875 the sample rate was simplified by the introduction of a single rate of $10 \mathrm{pf}$. for all sample packets, with a maximum limit of weight of 250 grammes.

The maximum limit of weight was raised in 1898 to 350 grammes, and in 1914 to 500 grammes. The present rates for samples are:-

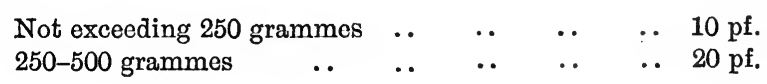

Prepayment is compulsory.

The sample post traffic has increased, but has not attained large proportions compared with letters. In 1878 the number of samples was 4,389,000 and in 1913-14, 87 millions (inland service). The minimum rate (10 pf.) is high compared with the minimum rates for ordinary printed matter and newspapers, and a minimum rate of 5 pf. has been suggested. ${ }^{\mathbf{}}$

\section{(III) COMMERCIAL PAPERS}

\section{United Kingdom}

Letter postage was found to be high for the formal documents of commerce, and from very early times there has been a disposition to accord an exceptionally low rate to such documents. The Act of 1660 conferred a special privilege on merchants' accounts not exceeding one sheet of paper, bills of exchange, invoices, and bills of lading. They were to be "without rate in the price of letters," that is to say, no account was to be taken of them. This privilege was continued by the 9th of Anne. ${ }^{2}$ The PostmastersGeneral contended that the privilege was granted in the case of letters for foreign transmission only, but the merchants affected to interpret the Act as applying in the ease of inland letters also. They naturally pointed out that

I Dr. Artur Schmidt, Finanz-Archiv, 1905, vol. ii., p. 180.

$=9$ Anne, cap. 10, § 13. 
restriction of the privilege to foreign letters imposed on traders within the realm a burden of postage not imposed on traders beyond the sea, ${ }^{\mathrm{I}}$ and the Postmasters-General found so much difficulty in maintaining the additional charge in the case of inland letters that they were ultimately driven to apply to Parliament, in 1720 , for the express sanction of law. ${ }^{2}$ From this time commercial or other papers obtained no special advantage over ordinary letters in the inland service; and in 1801, when the Post Office was endeavouring by all possible means to increase its net revenue, the privilege in the case of foreign letters was withdrawn.3

The introduction of a specially low rate for commercial documents was considered in the 'thirties of last century by the Treasury Commissioners of Inquiry into the Management of the Post Office, who recommended the adoption of a general $\frac{1}{2} \mathrm{~d}$. rate. 4 Nothing came, however, of this suggestion.

The privilege to commercial papers has since been restored by little and little as extensions of the book post, established in 1847 (q.v.), and at the present time most of the formal documents of commerce not exceeding 2 ounces in weight pass at the reduced rate of $\frac{1}{2} \mathrm{~d}$.

\section{France}

\section{(Papiers d'Affaires)}

In the French service commercial papers (papiers d'affaires) constitute a special category of postal packets. Documents included under this heading may be described briefly as papers

× H. Joyce, History of the Post Office, p. 332.

26 Geo. I, cap. 21.

341 Geo. III, cap. 7, \$ 4 .

4 "We find that in France, and generally on the Continent, the circulation of Prices Current, at a low charge, is encouraged by the Government, and we are of opinion that any facility which can be given for the transmission of mercantile information must tend to promote the commercial interests of the country; we therefore beg to recommend to your Lordships, in the first place, that English Prices Current, and Publications of a similar nature published in this country, be permitted to pass through the medium of the Post Office without the imposition of a charge so high as to impede their general circulation. . . We hope ... your Lordships may find it practicable to permit the free transmission of Prices Current by post, if printed on paper bearing a halfpenny stamp."-Fifth Report of Commissioners (11th April 1836), pp. 3, 4. 
and documents, whether wholly or partly written, containing communications which are not of a personal character.

Until 1856 such papers were charged at the same rate as letters. This rate was found to be burdensome, $\mathbf{r}$ and in 1856 a rate of 1 centime for each 10 grammes was established-the same rate as that for samples and ordinary printed matter-but the minimum charge was fixed at 50 centimes. In 1871 the rate was altered to correspond with that for samples. It now became 30 centimes for the first 50 grammes, and 10 centimes for each further 50 grammes. As a consequence of the adhesion of France to the Universal Postal Union, the rate, together with that for samples, was changed in 1875 to 5 centimes for each 50 grammes. The discarding, in the case of papiers d'affaires, of the principle of a minimum charge equal at least to the minimum charge for letters, had unfortunate results. It has been found extremely difficult always to distinguish between documents entitled to be regarded as papiers d'affaires and documents which are of a personal character, and therefore subject to letter postage. The privilege is at present restricted to packets weighing not more than 20 grammes, and the rate of postage is 5 centimes. Packets weighing more than 20 grammes are subject to letter postage.

The number of packets passing as papiers d'affaires increased rapidly, but still forms only an inconsiderable fraction of the total number of postal packets. In 1856 the number was 39,747 ; in 1889 it exceeded 15 millions; and in 1913 it reached 58 millions.

It is necessary to issue a long and detailed list showing the kinds of documents admissible at the reduced rate, and the difficulty of administering the rate is considerable.

\section{Germany}

\section{(Geschäftspapiere)}

After the abolition of the old Prussian Schriften und Aktentaxe $^{2}$ in 1861, neither the North German Bund nor

I "Cette assimilation los soumettait a des taxes exorbitantes; clle provoquait la fraude, et multipliait les contraventions au monopole de la poste." P. Jaccottey, op. cit., p. 319.

2 See supra, p. 225. 
the Imperial administration granted a special rate for wholly or partly handwritten communications which were not of the nature of personal and individual correspondence. Either letter or parcel rate must be paid on such packets. In the international service the rate for such was the same as the rate for printed matter, and the unfavourable position in the inland service in this respect gave rise to public complaints. In 1900, therefore, a special class of packets, named Geschäftspapiere, was introduced in the internal service of the German Imperial administration. Papers partly or wholly written, but not of the nature of private or personal communications, were admissible at a reduced rate of postage. ${ }^{1}$ Except for local traffic the new rates were:-

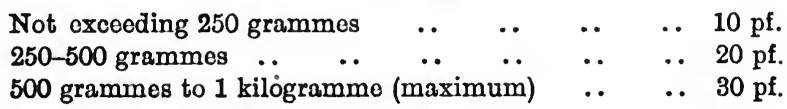

Compared with the total postal traffic the number of packets passing at the reduced rate is quite small, but it is increasing, and is sufficiently large to indicate that the privilege affords a considerable advantage to the public.

The number of packets of Geschäftspapiere was:-

$\begin{array}{llllllll}1904 & . . & . . & . . & . . & . & . . & 10,793,620 \\ 1907 & . . & . . & . . & . . & . . & . . & 16,789,260 \\ 1910 & . . & . . & . . & . . & . & . . & 23,632,220 \\ 1913 & . . & . . & . . & . . & . . & . . & 34,328,950\end{array}$

\section{(IV) POSTCARDS}

The idea of postcards originated with Dr. H. von Stephan, who submitted a proposal for their introduction at the meeting of the delegates of the German Postal Union at Karlsruhe in

x "Als Geschäftspapiere sind zu gelassen : alle Schriftstücke und Urkunden, ganz oder teilweise mit der Hand geschrieben oder gezeichnet, welcho nicht die Eigenschaft einer eigentlichen und personlichen Korrespondenz haben, wie Prozessakten, von öffentlichen Beamten aufgenommene Urkunden jeder Art, Frachtbricfe oder Ladescheine, Rechnungen, Quittungen auf gestempelten oder ungestempelten Papier, die verschiedenen Dienstpapiers der Versicherungsgesellschaften, Abschriften oder Auszüge aussergerichtlicher Verträge, gleichviel ob auf gesternpelten oder ungestempelten Papier geschrieben, handschriftliche Partituren oder Notenblätter, die abgesondert versandten Manuskripte von Werken oder Zeitungen, korrigierte Schülerarbeiten mit Ausschluss jeglichen Urteils über die Arbeit, Militarpässe, Lohn-, Dienst oder Arbeitsbücher, u.s,w, ( $\$$, Postordnung)."-Finanz-Archiv, 1905, vol. ii., p. 180. 
1865. Dr. von Stephan had realized that the ordinary form of the letter missive, although most suitable in many ways for many kinds of correspondence, was not always convenient. Much commercial correspondence might be conducted with briefer and less formal communications, and for such short and urgent messages a simple and less costly means would be welcomed.

The proposal was therefore for the issue of cards which should be addressed on the front, and at the back should bear the written message. ${ }^{\mathrm{I}}$ The cards should be transmitted unenclosed. The proposal was not well received by the delegates. It was, however, revived in 1869 by Professor Herrmann of Vienna, who brought it to the notice of the Austrian postal administration. It was viewed favourably by that administration, and the cards were introduced in the Austrian service on the 1st October 1869, being sold at the price of 5 kreuzer. The innovation was an immediate success, nearly three million cards being sold in the first three months; and following on this success the cards were soon introduced in most other countries.

Except in France, and for the first two years in Germany, the rate charged has from the first been one-half the minimum rate for letters. In France the minimum for postcards bearing ordinary messages has never been less than 10 centimes. $^{2}$ This reduction of 50 per cent. cannot be justified

I U'Union postale, Berne, 1st July 1876.

2 A proposal to introduce postcards in France was made by $M$. Wolowski in the National Assembly on the 23rd August 1871, in the debate on the Bill for raising the rates of postage. The proposal was rejected on account of the probable effect on the revenue. The cards would no doubt substitute letters to some extent, and at the time,"of course, the chief object in view was an increase of revenue. M. Wolowski repeated his proposal in 1873 as an amendment to the Budget. He was able to point to the effect in England of the introduction of postcards-an increase of 6 per cent. in the number of letters, as compared with an increase of 4 per cont. in the year preceding their introduction. Tho proposal was opposed by the Budget Commission and by the Government, but the amendment was voted by the Assembly and was incorporated in the law of the 20th December 1872. The rate of postage was fixed at 10 centimes for cards circulating within the area served by the same office and 15 centimes for others. (The minimum letter rate was at this time 15 centimes for letters circulating in the area served by the same office and 25 centimes' for others.) In 1878 the rate was made uniform at 10 centimes for all cards. This rate still continues in respect of cards bearing written messages in the nature of personal communications, but it has been reduced to 5 centimes in respect of picture postcards or 
on any ground of cheaper handling. The manipulation and conveyance of postcards is perhaps slightly less expensive than that of ordinary light letters, but any such difference is small, and in point of fact postcards are usually regarded as causing a little more trouble in the process of sorting. For all practical purposes it may safely be assumed that postcards and ordinary light letters involve approximately the same cost for their handling and transmission. $x$ This difference in the rates of postage charged on ordinary light letters and postcards, respectively, is therefore either a standing evidence of the fiscal character of the rate for light letters, or of the uneconomic character of one or other of the rates, or of both.

The postcard has proved immensely popular. Its use for formal and unconfidential communications is a great convenience. By avoiding the necessity for folding and enclosing in envelopes, time is saved in the making up of correspondence for the post; and the saving in postage when a quantity is sent out is very considerable. The cards are a convenience also in the practical working of the Post Office service. Their use diminishes both the weight and bulk of the mails; on account of their lightness and uniformity of size and shape large numbers can be packed together in small space. In this respect they contrast strongly with the irregularly shaped packets of books or of general merchandise, which represent the maximum of encumbrance to Post Office working. The introduction of the picture postcard gave a great impetus to the use of this means of correspondence. Except in France, the traffic has assumed large dimensions. In the United Kingdom in 1913-14 the total number of postcards was about $926,000,000$, while the total number of packets passing at the letter rate was about $3,478,000,000 .{ }^{2}$

commercial advertisement cards which do not bear a written communication of more than five words. The circulation of postcards is naturally much rostricted, and the reduction of the general rate to 5 centimos is much desired. There has been a good deal of discussion of the matter by the parliamentary Budget Commissions, but financial considerations have so far prevented the concession of this boon.

See infra, pp. 303-4; ef. C. H. Hull, op. cit., p. 146.

2 Annual Report of Postmaster-General, 1913-14, p. 1, 


\section{(V) RATE FOR PRIN'TED MATTER FOR THE BLIND}

The low rate for matter printed in raised type for the use of the blind is a purely philanthropic concession. ${ }^{\mathrm{I}}$

In the United Kingdom the rates are :-

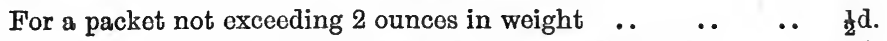

" exceeding 2 ounces and not exceeding $5 \mathrm{lb}$. .. $1 \mathrm{~d}$.

" $" 5 \mathrm{lb}$. " , $\quad 6 \mathrm{lb}$. . $\quad . .2 \mathrm{~d}$.

It will be noted that the initial penny rate is maintained (the 2 ounces for $\frac{1}{2} \mathrm{~d}$. being merely the ordinary printed matter rate), but a comparison with the ordinary parcel post rates (see Chapter III) will show that if, as there is reason to believe, those rates are unremunerative, the rates for literature for the blind must involve a heavy loss on each packet. The number of packets is, however, only some 300,000 per annum.

Similar low rates are in operation in other countries. In the United States packets containing matter of this kind are carried free.

\section{(VI) MINOR RA'TES IN THE UNITED STATES AND CANADA}

In the United States and Canada a special method of differentiating rates of postage has been adopted. All postal traftic is termed "mail matter," and is classified in four groups, to each of which is applied an appropriate rate. The classification, which is almost identical in the two countries, is based partly on the general character of the packets (size, shape, etc.), but more largely on certain general principles of administration, and on the intrinsic value of the contents. Thus the ordinary letter, which is the most important and valuable traffic, is placed in the first class of mail matter, and is charged the highest rate. Newspapers and periodicals, which are regarded as of great importance in aiding the education and enlightenment of the people, are placed in the

× E.g., "As to books for the blind, there can be only one opinion. The afflicted must be looked after before anybody else."-Sir Adolpho Caron, Parlia. mentary Debates, Canada (Commons), 13̣th May 1898. 
second class of mail matter and are given the lowest rate. ${ }^{x}$ Books and all other printed matter, commercial papers, postcards, etc., are regarded as of less importance than letters, and are deemed to be less entitled to encouragement from the State in their distribution, but still entitled to preferential treatment as compared with packets containing miscellaneous articles. They are accordingly placed in the third class of mail matter, and are given a rate intermediate between that of the first class and that of the second. All other articles sent by post-the residuum of postal packets-are placed together in a fourth class of mail matter, to which is applied a rate higher than the third-class rate, but considerably lower than the first-class rate. ${ }^{2}$

The rates for first-class matter (letters) and second-class matter (newspapers and periodicals) in the United States have been dealt with. They may be repeated here for purposes of comparison: the rate for letters is 1 cent for each 2 ounces or fraction of 2 ounces; the rate for newspapers is 1 cent a pound or fraction thereof when sent from publisher to subscriber-when sent otherwise the rate is 1 cent for every 4 ounces. On third-class matter the rate is 1.cent for each 2 ounces or fraction thereof, and on fourthclass matter the rate is 1 cent for every ounce or fraction of an ounce. With the view of encouraging agriculture, seeds, cuttings, bulbs, scions, roots, and plants are given the same rate as ordinary printed matter in the third class.

In Canada the rate of postage on first-class matter is 2 cents per ounce or fraction of an ounce, except on postcards, for which the rate is 1 cent, and local or "drop" letters, on which the rate is also 1 cent (supra, p. 255). On

I Cf. supra, Chapter II.

2 "Inland post comprehends all matter deposited in a post office in Canada for delivery either from the same or from any other post office in Canada.

"Such matter is divided into four classes:-

"(1) Letters, posteards, and all matter either wholly or partly in writing or typewriting, except the manuscript of books or newspapors and ccrtain documents of the Dominion and Provincial Governments and of Municipal Authorities, which belong to Class 3 .

"(2) Newspapers and periodicals.

"(3) Printed matter not included in Class 2, samples, and certain miscellancous matter.

"(4) Merchandiso."-Canada Official Postal Guide, 1912, p. 4. 
second-class matter the rate is $\frac{1}{4}$ cent a pound when posted by publishers to subscribers, otherwise 1 cent for each 4 ounces or fraction thereof. On general third-class matter (including samples) the rate is 1 cent for each 2 ounces or fraction thereof: a special rate of 2 cents for the first 4 ounces and 1 cent for each additional 4 ounces or fraction thereof is given for seeds, cuttings, roots, bedding-plants, scions, or grafts. The object of this privilege is evident. The rate on fourth-class matter is 1 cent for each ounce or fraction thereof.

These rates have not been calculated with reference to the cost of the service in each case. Classification was introduced in the United States Postal Service as far back as 1863, but until 1906 no attempt had been made to apportion the total cost between the various classes. The estimate then made showed that the second-class mail involved a heavy loss, probably equal to six or seven times the rate of postage. ${ }^{\mathrm{I}}$

× See supra, p. 158. 


\section{LOCAL RATES}

\section{United Kingdom}

Local postal services, providing for the delivery of local letters at reduced rates of postage, existed in the United Kingdom over a long period. The first service was established in London in 1680. Up to this time the business of the Post Office had been restricted to the transmission of letters between the post towns, and no rate of postage existed except in respect of letters sent over appreciable distances. ${ }^{\text {I }}$ The idea of a local service seems to have originated with a Mr: Robert Murray; but the London local post was actually established by William Dockwra, "a merchant, a Native and Citizen of London, formerly one of his Majesty's SubSearchers in the Custom House of London." Other citizens of London were concerned in the undertaking, which was established without reference to the authorities of the Post Office, and was intended to be purely a private commercial undertaking. ${ }^{2}$

Under Dockwra's scheme London, with Westminster and the suburbs, was divided into seven districts or "precincts," in each of which was a "sorting house." Scattered over the City and suburbs were from four hundred to five hundred receiving houses for the taking-in of letters. Messengers called at the houses for letters every hour. Letters and parcels not exceeding 1 pound in weight or $£ 10$ in value were accepted and conveyed at the uniform charge of $1 \mathrm{~d}$., payable in advance.

- Sec infra, pp. 336-7.

2 See The Practical Method of the Penny Post, London, 1681. 
The service was not restricted to letters for delivery within the London area and the surrounding district. Letters which were to be transmitted through the General Post ${ }^{x}$ were accepted at any of the receiving offices, and conveyed to the General Post Oftice in Lombard Street; and letters received in London by the General Post were delivered by the penny post, if for places outside the General Post delivery.2 This facility proved of much advantage to the public, and led to a large increase in the number of General Post letters. When well established, Dockwra's new system proved profitable and attracted the attention of the authorities of the General Post Office. They contended that the service was an infringement of the monopoly conferred on the PostmastersGeneral by the Act of 1660,3 and in 1683, at the instance of the Duke of York, in whom were vested the profits of the General Post Office, an action was brought against Dockwra to restrain him from continuing a breach of the privilege of the Postmasters-General. Dockwra was ordered by the court to pay nominal damages, and was forbidden to continue his penny post.

The post was not, however, abolished, but was taken over and managed by the Postmasters-General. Although the service had been decided to fall within their monopoly, the rates charged rested on no legal authority. No statute authorized the conveyance anywhere of letters at the rate of 1d. No authority existed for any rate below the minimum General Post rate of $2 \mathrm{~d}$., under the Act of 1660 , a state of affairs which continued until the passing of the Act of 1711 . A penny rate of postage was then fixed for all letters "passing or repassing by the carriage called the Penny Post, established and settled within the cities of London and Westminster, and borough of Southwark, and parts adjacent, and to be received and delivered within 10 English miles distant from the General Post Office in London." 4 At first the service had included only the cities of London and Westminster, the

"The "Goneral Post" was the term applied to the service throughout the country as distinguished from local services.

2 The General Post Office only provided for the delivery of letters within a restricted area. See Ninth Report of Commissioners of I'ost Office Inquiry, 1837, p. 5 .

312 Car. II, cap. $35, \S 2$.

49 Anne, cap. 10, § 6 . 
borough of Southwark, and the immediate suburbs; but the residents in the neighbouring towns and villages, recognizing the advantage of the system, soon asked that it might be extended to include their respective localities, voluntarily agreeing to pay an additional penny on delivery, on each letter. This further charge was at first appropriated by the messengers as their remuneration; but as the amount received by them in this way was found to exceed what might fairly be regarded as reasonable wages, the second penny was in 1687 made part of the ordinary revenue of the Post Office. There was, however, no legal authority for the collection of this additional charge, which remained a voluntary payment until $1730 .^{x}$

The limit of weight for packets sent by the penny post was also extended, parcels of considerable size and weight being accepted. The rate of postage, however, remained uniform at a penny. One of the charges against Dockwra in later years, when he was dismissed from the office of Comptroller of the Penny Post, to which he had been appointed under William III, was that he forbade the taking in of any but very.small band-boxes, and all parcels over 1 pound in weight. ${ }^{2}$

The penny post was found to be a great convenience to Londoners and dwellers in the vicinity. 3 It facilitated both local intercourse and, through its connection with the General Post, general intercourse with all parts of the country. It was also advantageous in a way which was not satisfactory to the Postmaster-General. For some years before its establishment there had been much difficulty from the evasion of postage resulting from the illicit transmission of letters. Carriers, especially, made a business of the conveyance of letters. The difficulty had been so serious that in the reigns

× 4 Geo. II, cap. 33. See D. Macpherson, op. cit., vol. iii., p. 169.

2 Ninth Report of the Commissioners of Post Office Inquiry, 1837, pp. 1 and 2.

3 "We have said that to us who live at the end of the nineteenth century it may appear incredible that up to April 1680 the General Post Office in Lombard Street was the only roceptacle for letters in the whole of London. But it is by no means certain that our descendants may not think it moro incredible still that London, with all its boasted progress, has only now recovored a post which, in point of convenience and cheapness, at all approaches that which an onterprising citizen established more than two hundred years ago." $-\mathrm{H}$. Joyce, History of the Post Office, pp. 41, 42. 
both of Charles II and of James II special officers had been appointed whose duty it was to search any person or vehicle suspected of carrying clandestine mails. The establishment of the penny post led to a very large development of this traffic. Previously, when the carriers arrived with the letters, there was no means at their disposal for effecting distribution and delivery within London, other than by themselves delivering the letters individually, or by employing special messengers, or, in the last resort, by employing the General Post, to avoid whose charge was the whole object of entrusting letters to the carriers. The penny post removed this difficulty, and the public were not slow to avail themselves of the opportunity afforded. ${ }^{\mathrm{x}}$

The penny post did not, however, mark the limit of possibility in the way of cheap postal facilities. In 1708 Charles Povey established a halfpenny post in London, and found. this low rate profitable. His undertaking, like that of Dockwra, proved to be an infringement of the monopoly of the Postmasters-General, and was suppressed within a few months, although Povey was very reluctant to discontinue his service. ${ }^{2}$

The London penny post was for a long period the only local post in the kingdom. Its advantages were, however, generally recognized, and the Post Office Act of 17653 gave to the Postmasters-General power to establish penny posts in any town where that course seemed to them expedient. Under this authority numerous penny posts were established in all parts of the country. As many as 202 such penny posts were established between 1830 and 1837. They were established only when it could be reasonably anticipated that the yield of

I "No stage-coach entered London without the driver's pockets being stuffed with letters and packets, and he was moderate indeed if he had not a bagful besides. The waggoner outstripped his waggon and the carricr his pack-horse: and each brought his contribution. The higgler's wares were the morest protext. It was to the letters and packets that he looked for profit." - - H. Joyce, ibid., p. 55.

"When threatened by the Postmasters-General with prosccution "according to the utmost rigour of the law," he replied, according to their account, that " he should not be so unjust to himself as to lay down his undertaking at our domand, that his case was not as Mr. Dockwra's was, neither did we live under such a constitution as he did when the penny post was first set up (that is, an arbitrary government and bribed judges)."-Ninth Report of the Commissioners of Post Office Inquiry, 1837, p. 71.

35 Geo. III, cap. 25, § 11. 
the penny postage would cover the expenses of the service; but when once established they were not usually discontinued, even if the revenue fell below the expenses. ${ }^{x}$ Like the London penny post, these local services included the area surrounding the town in each case. For transmission within a penny post area the rate of postage was $1 \mathrm{~d}$.; for transmission to another such area the general rate was charged in addition; and another penny was charged in respect of the second penny post.

The conveyance of parcels ceased in 1765. The Act of that year ${ }^{2}$ forbade the transmission by the penny post of any packet over 4 ounces in weight unless it had passed, or was intended afterwards to pass, by the General Post. During all this period, however, the people of London enjoyed an efficient postal service which in point of lowness of charges was in advance of anything they have enjoyed since, unless the privileges of the postcard and the halfpenny post, that is, of a rate half the minimum (and only) rate of the penny post, can be set against the cheap transmission of considerable packages by the old service.

A further Act of 17943 empowered the Postmasters-General at their discretion to extend the limits of the post beyond the 10-mile circle prescribed by the Act of 1711 . No additional postage was imposed on letters delivered beyond the 10-mile circle. Under the Act of 1730 the charge would be $2 \mathrm{~d}$. An additional rate of $1 d$. was, however, imposed on all letters posted within the extended limits and beyond the 10-mile circle; and also on all letters posted without the original limits of the penny post and delivered within those limits, i.e. the cities of London and Westminster, and the borough of Southwark, with their suburbs. By this Act prepayment of postage, hitherto compulsory in the penny post, was made optional.

An Act of 18014 raised to $2 \mathrm{~d}$. the rate for letters passing by the penny post, whether or not they were to pass by the General Post, within the original limits of the penny post. For letters passing by the penny post, posted or delivered outside the original limits, no additional rate was prescribed.

Ninth Report of the Commissioners of Post Office Inquiry, 1837, p. 66.

25 Geo. III, cap. 25, § 14.

334 Geo. III, cap. 17.

441 Geo. III, cap. 7. 
The charge was already $2 \mathrm{~d}$. ; and the rate of postage on letters passing by the London local post therefore now became uniformly $2 \mathrm{~d}$. Henceforward the service was known as the " twopenny post.".

The Act of 1801 contained an important clause (clause 5) of general application, providing that the Postmasters-General might at discretion undertake the conveyance and delivery of letters "directed to persons abiding in towns, villages, and places (not being post-towns)," for such sums as might be agreed upon between the Postmasters-General and the inhabitants. Under this provision it was found possible to extend the service to a considerable number of places. ${ }^{\mathrm{x}}$

An Act of $1805^{2}$ imposed an additional charge of $1 d$., making $3 \mathrm{~d}$. in all, on letters sent by the twopenny post and not passing by the General Post, directed to or sent from places beyond the limits of the General Post delivery ; and on every letter passing by the General Post and directed to places beyond the limits of the General Post delivery, and delivered by the twopenny post, an additional charge of $2 \mathrm{~d} .3$ There were now, in reality, two local posts in the London area-the twopenny post, for letters transmitted between places within the limits of the delivery of the General Post ; and the threepenny post, for letters directed to or sent from places within the limits of the local service, but beyond the limits of the General Post delivery. In 1831 the limits of delivery of the twopenny post were extended to include all places within a radius of 3 miles of the General Post Office; and in 1833 the limits of the threepenny post were extended to include all places beyond the 3-mile limit, and not exceeding 12 miles from the General Post Office. 4 No further modifications of importance were made before the establishment of uniform penny postage.

I Ninth Report of the Commissioners of Post Office Inquiry, 1837, p. 6.

45 Geo. III, cap. 11.

3 Clause 1.

4 These changes followed the recommondations of the Commissioners of Revenue Inquiry, who, in their Twenty-first Report (1830), remarked strongly on the intricacy and confusion of the boundaries of the posts in London, viz. the General Post, the Forcign Post, the twopenny post (town delivery), and the twopenny post (country delivery). All these had different delivery aroas, and in addition there was the "threepenny post town delivery," comprising the area lying between the limits of the General Post delivery and those of the town delivery of the twopenny post. 
The introduction of a uniform rate of postage for the whole country of $1 \mathrm{~d}$., only half the lowest rate which had been charged in the London local post, obviously made unnecessary the continuance of that post, and also of the penny posts scattered up and down the country; or rather extended to the whole country the benefit of rates based on items of local cost only, since the system of uniform postage irrespective of distance rests on the recognition of the preponderating cost of the local or terminal services, and the relatively insignificant cost per letter of the service-conveyance from place to place-which depends on the distance of transmission.

Financially the London penny and twopenny posts were always successful. Under the penny rate the profits had approached half the gross receipts-in 1800 they were 43 per cent.- and under the twopenny rate at once rose to more than 60 per cent., in 1825 reaching 67 per cent. The net revenue, which in 1801 under the penny rate was $£ 16,286$, had in 1837 under the twopenny rate risen to $£ 73,334 .^{\text {I }}$

\section{Canada}

Special local rates have from quite early dates been in operation in America. If in England the lowest rate fixed for General Post letters had been found too high to afford reasonable accommodation for the public in London and other cities, it may well be imagined that the lowest rate in Canada, gauged as it was to the needs of a service which should cover

The following statement shows the rates charged in the twopenny post :-

"For overy letter transmitted by such Post within the limits of delivery for the time being of the General Post $\ldots$.. . .

"For every letter transmitted by such Post between a place within the said limits and any place beyond the same, or between places, both

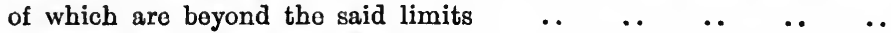

"And for overy letter originally sent by tho General Post directed to places beyond the said limits, and for every letter originally sent by the Twopenny Post, and afterwards passing through the General Post,

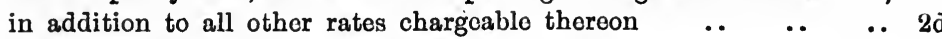

"Newspapers sent by the Twopenny Post, and not passing or intended to pass by the General Post, aro charged each.. .. . . 1d.

"But nowspapers by the General Post and delivered by the Twopenny Post, received by the Twopenny Post and afterwards passing by the General Post, have, since August 1836, been exempted from postage."-Ninth Report of the Commissioners of Post Office Inquiry, 1837, p. 4. 
a country of vast area and ill-provided with roads, would be found altogether high for local letters. Moreover, in most places no sort of delivery service existed. Local letters could only be placed in the post office to be called for by the persons to whom they were addressed. In Canada the actual cost of the conveyance of the mail was consequently disproportionately high compared with other expenses of the service, and the justice of a lower rate for such letters as obtained no benefit from that expenditure naturally suggested itself. The lowest rate fixed by the Act of 1765 for transmission within Canada of a single letter was $4 d$., and, rather than charge such a rate on local letters, the deputies in Nova Scotia allowed such letters to be deposited in the post office free.

At Confederation a special rate for local letters of 1 cent per $\frac{1}{2}$ ounce was established. At this time there was still no authorized house-to-house delivery of letters in any part of Canada, and local letters were actually what they are always termed, viz. "drop" letters. They were letters dropped into the post office letter-box and handed out at the office to the addressee on application. When in 1875 delivery by lettercarrier was introduced in certain towns, the drop-letter rate was not disturbed. It was thought, however, that a postage charge of 1 cent was not sufficient to cover the cost of the service of delivery at the place of address, performed by an expensive establishment of letter-carriers; and in 1889, on that ground, though much against the wishes of the mercantile community, the rate was raised to 2 cents an ounce in cities and towns where the system of delivery by letter-carrier was established, the existing rate of 1 cent per $\frac{1}{2}$ ounce being continued in other cities and towns.

The ordinary letter rate was still 3 cents. This change therefore left all local letters with a lower rate than ordinary letters. ${ }^{\mathrm{I}}$

The 2-cent rate proved to be too high. Much dissatisfaction resulted, and evasions were constant. In defiance of the

I "It is on this principle that it has been found that where a letter has been dropped into the post office in a city, and delivered by a letter-carrier, it does not pay to deliver it for 1 cent, which is just half the rate charged in any other country in the world; and this provision is to assimilate the rate to that prevailing in other countries."-Mr. Haggart, Parliamentary Debates, Canada (Commons), 9th April 1889. 
law, which conferred on the Postmaster-General the monopoly of the carriage of letters, merchants made arrangements for the transmission and delivery by their private messengers of their letters for local delivery. The evil assumed such proportions that the suppression of the private carriage of local letters was deemed out of question, and the Government concluded that the only satisfactory solution of the difficulty was the re-introduction of the general 1 cent drop-letter rate. ${ }^{x}$ So great was the number of drop letters sent otherwise than through the Post Office that no actual loss of revenue was anticipated from a reduction of the rate, which should bring back those letters to the post. This anticipation was more than realized. In a very short time after the passing of the Act of 1898 legalizing the reduction to 1 cent, the gross revenue from local letters surpassed that obtained under the 2-cent rate.

\section{France}

In 1653 a local service (la petite poste) was established in Paris by M. Velayer. He obtained from the King the exclusive privilege of erecting letter-boxes, which were opened three times daily, in various parts of the city, ${ }^{2}$ and set up an office in the royal palace at which tickets bearing the words "Port-payé le ... du . . . de l'an 1653" might be purchased at the price of a sou. No money was paid to the letter-carrier by persons posting or receiving letters. A label was affixed to the letter, which was then delivered without further charge. 3 The service was not a success and was discontinued.

" We have been influenced to make this change from the fact that in large cities and towns the departmental stores, the manufacturing establishments, and other concerns which do a large postal business, use the messenger service to deliver their letters as they found it cheaper, and in this way a large amount of revenue was lost to the Post Office. . . . Several firms will amalgamate their messenger service, employing say five or ten boys, to whom they will pay 1 cent or $\frac{1}{2}$ cent for each letter, and in that way they will make a profit. Of oourse, this action on their part is illegal, but it is one of those illegalities that we can hardly prosecute, and we thought it was better to adopt the uniform 1-cent rate which we had formerly." - Hon. R. Lemieux (Postmaster-General), Parliamentary Debates, Canada (Commons), 16th June 1908.

2 A. de Rothschild, Histoire de la Poste aux Lettres, Paris, 1879, p. 98.

3 "16 août 1653.-On fait à sçavoir à tous ceux qui voudront écrire d'un quartier de Paris en un autre, que leurs lettres, billets ou mémoires seront 
In 1759 a local postal service was re-established in Paris by $M$. de Chamousset. The new service was avowedly in imitation of the London penny post. The rate was 2 sous for a letter not exceeding 1 ounce in weight, delivered in Paris, and 3 sous if delivered in surrounding villages not served by the general post. This venture proved more successful than the earlier service of $M$. Velayer. At the outset it employed about two hundred men, and the profits for the first year were 50,000 livres. But its founder, M. de Chamousset, met with no better fate than Dockwra, the founder of its prototype. Such large profits could not escape the notice of the Government, and the service was taken over by the King, Chamousset being given a pension of 20,000 livres as its inventor. ${ }^{\text {I }}$ The service was continued, and its success led to the establishment of similar local services in other towns-Bordeaux, Lille, Lyons, Nancy, Marseilles, Montpellier, Nantes, Rouen, Strasburg, etc. ${ }^{2}$

The ordinary letter rate in France remained at a moderately high level until a comparatively late date, and a special rate for local letters continued until 1878. In that year the ordinary rate for letters was reduced to 15 centimes, the level of the existing local rate, and since that time local letters have enjoyed no special privilege in France.

\section{Germany}

In Germany the delivery of local letters in towns was for a long period conducted as a private undertaking of the postmaster or letter-carrier. Between 1842 and 1852 it was made

fidèlement portés et diligemment rendus à leur addresse, et qu'ils en auront promptement responce, pourvu que lorsqu'ils escriront, ils mettent avec leurs lettres un billet qui portera : port-payé, parce que l'on ne prendra point d'argent; lequel billet sera attaché à la dite lettre, ou mis autour de la lettre ou passé dans ou en telle autro manière qu'ils trouveront à propos, de telle sorte néanmoins que le commis le puisse voir et oter aisément. La date sera remplis du jour ou du mois qu'il sera envoyé. Le commis général qui sera au Palais rendra de ces billets de port-payé à coux qui en voudront avoir, pour lo prix d'un sol marqué; et chacun est adverti d'en acheter pour sa nécessité le nombro qu'il lui plaira, afin que lorsqu'on voudra escrire, l'on ne manque pas pour si peu de chose à faire ses affaires." - Advertisement issued by M. Velayer, cited A. de Rothschild, Histoire de la Poste aux Lettres, Paris, 1879, p. 101.

A. de Rothschild, ibid., p. 145.

2 A. Belloc, Les Postes françaises, Paris, 1886, p. 200. 
a branch of the general postal service, and the delivery charge (Ortsbestellgeld), which, in general, had been retained by the letter-carrier as wages, was, in the latter year, made payable to the general revenue. An arrangement was also made for the acceptance and delivery of local letters, at the rate of 1 sgr. I If the letters were called for at the post office (and the service of delivery at the house therefore not performed) the rate was reduced to $\frac{1}{2}$ sgr. ; and when one person posted as many as one hundred local letters at the same time, the rate for each letter was no more than $4 \frac{1}{2}$ pf. (reduced in 1860 to 4 pf.), including delivery at residence. When as many as fifty were posted at one time, the rate was reduced to $\frac{1}{2}$ sgr. By a regulation of the 21st December 1860 the limit of weight for the single letter was, however, raised to $\frac{1}{2}$ pound, and a rate of 2 sgr. imposed on heavier letters, but the rates were not otherwise materially changed. The law of 16th September 1862 abolished the delivery fee on ordinary letters. In $1865^{2}$ the rate for local packets of printed matter was reduced to $4 \mathrm{pf}$.

When, at the foundation of the North German Union in 1867, the postal rates were reorganized, the question of the local rates proved to be one of some little difficulty, since the existing rates differed very considerably in the different parts of the Union. The Prussian rates were high as compared with the rates in some other States; and any rate which could be applied generally was likely to represent a considerable reduction of the Prussian rates, but a considerable increase of the rates in other States. The reorganization of the local rates was consequently delayed. After much discussion a new local rate for places in the former Prussian postal territory (excepting Berlin and Hamburg) was established: 3 for ordinary letters $\frac{1}{2}$ sgr., for printed matter and samples $\frac{1}{3}$ sgr. In Hanover the local letter rate was made $\frac{1}{3}$ sgr.; in Brunswick $\frac{1}{4}$ sgr.; and in Cassel, Erfurt, Frankfort-on-Main, and Hamburg similar rates were established.4

From the 1st January 1875 a uniform rate of 5 pf. for

I Moch, Archiv für Post und Telegraphie, 1893, p. 38.

2 30th May $1865 . \quad 3$ Order of 22nd October 1869.

4 Moch, ibid. 
local letters was introduced throughout the Imperial postal territory. The rate was irrespective of weight, but there was a maximum limit of 250 grammes. Ah other local packets (postcards, printed matter, and samples) were subject to the ordinary rates of postage. No special local rate was fixed for parcels: the lowest zone rate was payable, and was, of course, in effect a local rate. The general application of the new letter rate would, in certain cases, have resulted in increased rates, and in those cases (Constance, Darmstadt, and Karlsruhe) a rate of $3 \mathrm{pf}$.- the equivalent of the previously existing rate-was established. In Berlin, in view of the specially expensive arrangements for the delivery of letters, the rate of $10 \mathrm{pf}$. for local letters remained in force. ${ }^{\mathbf{I}}$

For the delivery of local parcels no charge had previously been made beyond the rate of local postage, although in respect of all packets from outside a delivery charge was collected. From the 1st January 1875, however, local parcels were made liable to a delivery charge. ${ }^{2}$ In general, the local rates introduced on the 1st January 1875 remained for more than a quarter of a century unchanged, but in course of time difficulties in their administration developed. The order of the 18th December 1874 had prescribed a special local rate for letters only; for all other kinds of postal traffic the ordinary rates remained applicable. Consequently, a local postcard was charged the same postage as a letter weighing 250 grammes; similarly the rates for printed matter or samples for local delivery were high when compared with the rate for local letters. Such rates were, moreover, anomalous when compared with the rates for long-distance traffic, which, for postcards, printed matter, and samples, were much less than for letters. In fact, for local delivery printed matter and samples had only to be placed in sealed covers in order to pass at the rate of $5 \mathrm{pf}$.

In many of the larger towns the delivery of local letters was undertaken by private enterprise at rates much lower than those of the Imperial Post Office. The undertakings secured a very large proportion of the local traffic, and found even

Moch, ibid.

2 Administrative order of 18th December 1874. 
these low rates very profitable. Moreover, the large increase in the number of post offices, and the withdrawal of numerous places from the areas assigned to certain offices, had led, in many cases, to great difficulties in deciding whether letters were subject to the general or the local rate of postage. ${ }^{x}$

The regulations governing local traffic were accordingly revised under the law of the 20th December 1899. Local rates were considerably reduced in amount, and were made applicable to all traffic passing between a town area and the neighbouring area (Nachbarorts-Verkehr), ${ }^{2}$ by which the advantage of these rates was greatly extended. In order to enable the Post Office adequately to fulfil its public functions, as the phrase went, it was thought necessary, in view of the development of the private undertakings, to confer upon it the exclusive right to deal with local traffic. At first the proposal was to extend the monopoly only to closed letters, but the Reichstag widened the prohibition, and forbade private undertakings to conduct arrangements for the transmission of letters, sealed or unsealed, postcards, printed matter, or samples addressed to particular persons. 3

The traffic left open to private enterprise, viz. the delivery of unaddressed open letters, parcels, newspapers, and magazines, was regarded by most of the proprietors as insufficient to warrant the continuance of their undertakings, and on the 1st April 1900 almost all the private establishments of this kind were discontinued. The proprietors were, however, compensated by the State for the loss of their profits.4 The first undertaking of this kind had been established in Berlin in the 'seventies, under the title Briefund Druckschriften-Expedition. Its success led to the establishment in Berlin and various other places of similar

I Moch, Archiv für Post und Telegraphie, 1900, p. 735.

" "Als Nachbarorte ein Sinne des Gesetzes sollen solche Orte der engen unmittelbaren Nachbarschaft gelten, deren bebaute Ortsgrenzen nicht zu weit von einander entfernt bleiben und die wegen ihrer Lage und ihres wirtschaftlichen Zusammenhanges als ein einheitlicher Verkehrsbezirk (Taxgruppe) angesehen werden können, ferner aber solche Orte, die zwischen zwei hiernach eine Taxgruppe bildenden anderen Orten an der diese verbindenden Strasse oder Eisenbahn liegen, auch wenn ein wirtschaftlicher Zusammenhang hier nicht vorhanden ist."-Moch, ibid.

3 Ibid., p. 736 ; Articles 2 and 3 of law of 20th December 1899.

4 Reichstag, Official Reports, vol. ii., p. 1006. 
undertakings, some of which were profitable, but most of which were unsuccessful. The cheaper rates, however, attracted a considerable volume of traffic, and at the time of their suppression some seventy-seven such undertakings were in existence. Most of them were not of long standing, only fourteen of the seventy-seven having been founded in the 'eighties, forty having been founded in the years 1895-6-7, in a period of speculation resulting from the high dividends paid by the Berliner Packetfahrt-Aktiengesellschaft. The size of the undertakings varied largely. In some cases the whole business was conducted by the members of a family; in others as many as a hundred men were employed; and in the case of the Berliner Packetfahrt-Aktiengesellschaft the letter traffic alone employed a thousand men. The amount of traftic dealt with was considerable, and large additions to the postal staff were found necessary. ${ }^{x}$ Some of the employees of the private establishments were taken over by the Imperial Postal Administration, and a sum of $1 \frac{1}{2}$ million marks was paid as compensation to employees who were not taken over.

Although special provision had been made in the statute with regard to the amount of compensation to be paid to the proprietors, the determination of the actual amount was a matter of some difficulty, owing largely to the unsatisfactory and unreliable manner in which the accounts of many of the undertakings had been kept. ${ }^{2}$ In several cases also the owners asked exorbitant amounts.

After much negotiation the sum to be paid was finally decided. It amounted to some six million marks. In order to get rid of the private establishments for the handling of private letters, etc., the Imperial Administration therefore paid in all (i.e. including the compensation to the employees of the private undertakings) a sum of about $7 \frac{1}{2}$ million marks.3

x " Um ein klar wirkendes Bild von dem Umfange der Verkehrszunahme zu geben, sei nur erwähnt, dass die Ober-Postdirektion in Berlin im Kalenderjahre 1900 eine um 106 Beamte und 1,606 Unterbeamte höhere. Personal verstärkung für ihren Bezirk hat eintreten lassen mussen als im Jahre vorher; am 1 April 1900 sind allein-ohne die zahlreichen Aushülfskräfte-860 Unterbeamte neu eingestellt worden."-Deutsche Verkehrs-Zeitung, Berlin, 8th March 1901, p. 131.

2 Ibid.

3 Ibid., p. 132. 
The new rates were as follow ${ }^{\mathrm{I}}:-$

(a) Letters-

Not exceeding 250 grammes in weight $\quad . . \quad \ldots \quad 5$ pf.

(b) Postcards ..

(c) Printed matter-

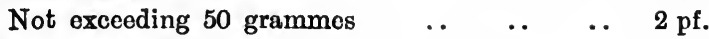

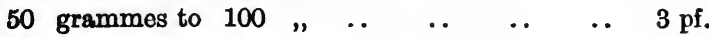

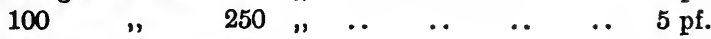

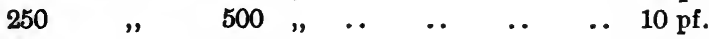

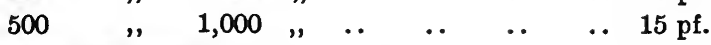

(d) Commercial papers-

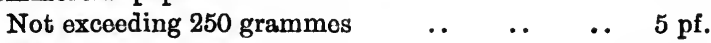

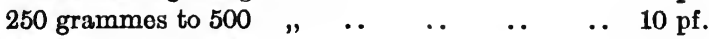

(e) Samples-

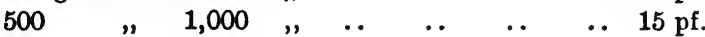

$\begin{array}{lllll}\text { Not exceeding } 250 \text { grammes } & \text {. } & \text {.. } & \text {.. } & 5 \mathrm{pf} \text {. }\end{array}$

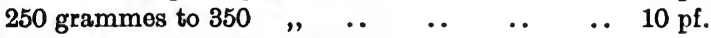

$(f)$ Mixed packages of $(c),(d)$, and $(e)$

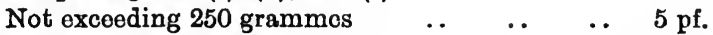

250 grammes to $500 \quad, \quad$.

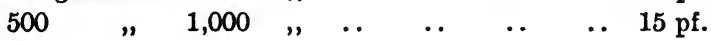

These rates, applied throughout the Imperial postal territory, including Berlin, which thus for the first time obtained the advantage of local rates; and in 1902 they were extended to all places which had a post office for only part of the year, such as small watering-places, summer resorts, and beauty spots. ${ }^{2}$

The result of the reduced rates was not satisfactory financially. It was not, of course, possible to calculate with any exactness the actual cost of the service performed by the Post Office in respect of local traffic; but such estimates as the administration were able to make tended to show that the cost exceeded the revenue, and that the local business was therefore conducted at some loss.3 Consequently, when in 1906 Imperial requirements made it necessary to obtain an increased revenue from the Post Office, the administration placed the burden on the local traffic, although not without some opposition in the Reichstag. On the 1st July 1906 the rates for local traffic, with the exception of the

- Order of 20th March 1900. Seo Moch, Archiv fïr Post und Telegraphie, Berlin, 1900, p. 737.

2 Order of 29th March. W. Hess, ibid., 1910, p. 448.

3 Reichstag, Official Reports, 17th May 1906. 
rate for local letters, were made the same as the general rates for transmission throughout the Imperial postal territory.

The rate for letters remained as formerly, $5 \mathrm{pf}$. for letters not exceeding 250 grammes in weight. ${ }^{x}$

${ }^{x}$ Finanz-Archiv, 1906, vol. ii., p. 253. 


\section{INTERNATIONAL RATES}

\section{(I) INTERNATIONAL LETTER POST}

THE adoption in numerous countries of the principle of uniformity of rate for inland postal traffic, and the enormous simplification of the system of rates and of their practical administration which it achieved, led naturally to an endeavour to effect a like simplification of the rates for postal traffic exchanged between the various countries. The rates in operation varied enormously, not only as between different countries, but frequently in respect of letters passing between the same two countries.I

× "Une partie des pays qui ont pris part au Congrès de Berne avait fixé le maximum du poids des lettres à 250 grammes; l'autre partie n'avait fixé aucune limito de poids. Dans certains pays, l'épaisseur des lettres était limitée. Au Danemark, par exemple, elle ne pouvait pas dépasser 25 centimètres. La Grande-Brotagne avait fixé le maximum de dimension des lettres pour l'étranger a 2 pieds (60 contimètres) en longueur et à 1 pied ( 30 centimètres) en largeur ou épaisseur.

"Le port des lettres se calculait tantôt pas $7 \frac{1}{2}$ grammes, tantôt par 10 grammes et tantôt par 15 grammes; parfois aussi l'échelle de progression ne comportait que deux poids (lettres de 15 grammes et lettres de plus de 15 grammes).

"Les taxes des lettres d'un pays différaient presque pour chaque pays correspondant; en outre, la taxe d'une lettre pour un seul et même pays variait fréquemment suivant la voie d'expédition. L'Allemagne n'avait pas moins de 7 taxes pour les lettres affranchis à destination des autres pays d'Europe (abstraction faite des taxes réduites pour les rayons limitrophes); la France n'en avait pas moins de 6, et la Grande-Bretagne pas moins de 9; les Etats-Unis d'Amérique en avaient 5 pour leurs rapports aveo 10 pays européens. La moins élevée de ces taxes était, pour l'Allemagne, de 10 pfennig jusqu'd 15 grammes (20 pfennig de 15 à 250 grammes); pour la France, dè 25 centimes par 10 grammes; pour la Grande-Bretagne, de 3 pence par $\frac{1}{2}$ once; pour les EtatsUnis d'Amérique, de 6 cents par $\frac{1}{2}$ once. La plus élevée était, pour l'Allemagne, de 30 pfennig par 10 grammes; pour la France, de 70 centimes par 10 grammes ; 
The arrangements for the exchange of such traffic between different countries had been conducted under conventions and agreements entered into by the countries immediately concerned, and the rates to be charged were prescribed by these conventions or agreements. Foreign rates were often built up by the addition of a rate for the transmission abroad to the ordinary rate chargeable for the inland transmission. The fact that numerous rates were chargeable for one and the same letter in respect of its transmission within the same country thus naturally made the rates charged for transmission abroad likewise numerous. In many cases there was an additional variation in the rate of postage between two countries according as one or other route was followed. And not only were the international rates of postage high and complicated. The methods employed for accounting between the countries respectively concerned in regard to the proceeds of postage on international letters were equally complicated and burdensome.

In 1850 the necessity for some simplification of the arrangements for the interchange of correspondence led to the formation of the Austro-German Postal Union by Prussia and Austria. The chief feature of the arrangement was the adoption of a common rate of postage for the whole territory of the Union, moderate in amount, and based on a small number of zones of distances. The advantages resulting from the Union were soon apparent. Other German States

pour la Grande-Bretagne, de 6 pence par $\frac{1}{1}$ once; pour les Etats-Unis d'Amérique de 10 cents par $\frac{1}{2}$ once.

"Les taxes des lettres à destination des pays d'outre-mer variaient davantage encore; elles étaient, en outre, toujours extrêmement élevées. Une lettre affranchie de l'Allemagne pour le Pérou, à expédier par la voie de Hambourg, payait 100 pfennig par 15 grammes; si elle était expédiée par la voie d'Angleterre ou de France, elle payait 120 pfennig par 15 grammes. Pour une lettre d'une $\frac{1}{2}$ once de la Grande-Bretagne pour la Bolivie, l'expéditeur devait payer 1 shilling 6 pence et une taxe additionnelle était, en outre, réclamée du destinataire. Une lettre simple de la Russie pour la Cochinchine (voie des paquebots français) payait 75 kopecks; de l'Autriche pour la République de Honduras (voie de Panama), 84 kreuzer; de l'Italie pour la République Argentine ou l'Uruguay (voie de Belgique), 2 lire 40 centesimi.

"Pour ses relations avec le Japon, la Russie ne disposait pas de moins de 9 voies d'éxpédition, pour lesquelles il existait 8 taxes différentes rien pour les lettres affranchies."-M. E. Ruffy, L'Union postale universelle; sa fondation et son développement, Lausanne, 1900, pp. 20, 21. 
joined, and within a short time the question of extending it to foreign countries was mooted. At a Conference held in Berlin in 1851, a general European Postal Union was adumbrated.

The first definite suggestion for the general re-organization of international postal traffic on a common basis came, however, from America. In 1863, Mr. Blair, PostmasterGeneral of the United States, in a note to the postal administrations of the world, suggested the assembling of a Congress representative of all nations for the discussion of the subject. The proposal was favourably received by fifteen administrations, $\bar{x}$ representing nine-tenths of the commerce and nineteen-twentieths of the correspondence of the world. The representatives of these administrations (with the exception of Ecuador) met at Paris in May 1863.

The Conference was not empowered to enter into any definite arrangement for the amelioration of the system of international postal traffic. Its function was simply to discuss and proclaim general principles applicable to the conduct of the traffic, with a view to their ultimate adoption by the nations of the world. The discussions centred on the three fundamental questions of uniformity of weights, uniformity of rate, and simplification of accounting. ${ }^{2}$ Thirty-one articles of agreement were adopted. 3 These articles recommended, inter alia, the adoption for ordinary letters of a unit of weight and a progression of weight of 15 grammes; and for corrected proofs, samples, and documents not in the nature of a letter, a unit and progression of 40 grammes. The Conference was convinced that transit charges were often an invincible obstacle to the establishment of a really advantageous international system, and recommended that the transit rate for each country should never exceed half the postage reckoned at the inland rate of the country traversed, and that for small

\footnotetext{
- Austria, Belgium, Costa-Rica, Donmark, Ecuador, Spain, France, Great Britain, Italy, Holland, Portugal, Prussia, the Sandwich Islands, Switzerland, and the Hanse Towns.

${ }^{2}$ M. E. Ruffy, L'Union postale universelle ; sa fondation et son développement, Lausanne, 1900, p. 13.

3 Or, as they were called, "principes généraux de nature à faciliter les relations de peuplé à peuple par la voie de la poste et pouvant servir de base aux convontions internationales destinées à régler ces relations." - Ibid.
} 
countries it should be even less. For sea transit the Conference recommended that in no case should the charge against an administration in respect of such transport be greater than the actual charge made on the country of destination by the shipping agency by whom the mails were conveyed.

Although its conclusions were without the sanction of authority, the Conference was nevertheless of great assistance to the development of an international system. It brought into prominence the obstacles in the way of international postal intercourse, and the difficulties which must be removed before a common system could be founded. And it formulated general principles which might with advantage be observed in the making of fresh agreements between individual countries, and might serve as a basis for a common agreement. Its conclusions were, as a matter of fact, so used in numerous instances.

Towards the end of 1868 Dr. von Stephan, of the postal administration of the North German. Union, published in the official journal of the Union a definite project for a postal union between all civilized nations, and proposed a discussion of the project at a universal Congress. The proposal was taken up by the administration of the North German Union. The diplomatic arrangements for calling a Conference were, however, interrupted by the FrancoGerman War of 1870. After the conclusion of peace, the proposal was again taken up, and the Swiss Government undertook the task of inviting the administrations of the chief countries to send representatives to a Congress at Berne. The invitation was readily accepted, and the Congress met in 1874.

The proposal submitted to the Conference was that the Union should cover the following categories of postal traftic:-

(1) Letters.

(2) Postcards.

(3) Newspapers and other printed matter.

(4) Samples.

(5) Commercial papers.

Each contracting State should fix its own international 
rates, under the limitation that for letters the rate should not exceed $4 \mathrm{~d}$., or 40 centimes; and for newspapers or other printed matter, for samples or commercial papers, should not be less than $1 \mathrm{~d}$., or 10 centimes. There should be no division of postage, but each State should retain the postage which it collected. Each State should give liberty of transit, and transit charges should be abolished, except in the case of extraordinary charges or services. ${ }^{x}$

The proposals which gave rise to most discussion were those for the establishment of a uniform rate, and for the gratuitous transit of mails across the territory of intermediate countries. The vast number of rates actually existing was made an argument in favour of the uniform rate; and a low rate was recommended on the ground that it was well known that, although low rates imposed a temporary monetary loss, they were in a broad view profitable to the finances of the State. ${ }^{2}$ It was urged that as all rates were already tending to equality, the Congress, by establishing uniformity, would only be advancing by a few years an existing tendency. The principle of uniformity of rate and of weight was adopted unanimously, the rate of charge being fixed at 25 centimes, and the unit of weight, and progression in the scale of weight, at 15 grammes. The rate of charge, 25 centimes (with the reservations 3), was arrived at by consideration of the case of the most unfavourably situated country as regards conditions of transit, viz. a case in which there would be five intermediate countries, and consequently five transit rates. As most, if not all, of the countries represented had already adopted inland penny postage, this rate, assuming 10 centimes (or $1 \mathrm{~d}$.) to be a reasonable charge for the inland service at both ends, left 15 centimes ( $1 \frac{1}{2} \mathrm{~d}$.)

I Documents du Congres postal international, Berne, 1874, pp. 3-7. Seo M. E. Ruffy, ibid., pp. 39, 40 and 41 .

2 Documents du Congres postal international, Berne, 1874, p. 23.

3 "Toutefois, comme mesure de transition, il est réservé d̀ chaque pays, pour tenir compte des convenances monétaires ou autres, la faculté de percevoir une taxe supérieure ou inférieure a ce chiffre, moyennant quelle ne dépasse pas 32 centimes et ne descende pas au dessous de 20 centimes. . . .

"Pour tout transport maritime de plus de 300 milles marins dans le ressort de l'Union, il pourra être ajouté au port ordinaire une surtaxe qui ne pourra pas dépasser la moitié de la taxe générale de l'Union fixée pour la lettre affranchie." -Article 3 of Convention, ibid., p. 140. 
to cover the cost of transmission from country of origin to country of destination; and there was in addition the optional margin up to 32 centimes which might be taken advantage of, if a charge of 25 centimes was thought by any administration to be too little. A proviso was added that for all sea transits exceeding 300 nautical miles a surtax not exceeding half the general rate of the Union might be added to the postage charge, whether for letters, samples, printed matter, or commercial papers.

A reduced rate for commercial papers, samples of merchandise, newspapers, books, pamphlets, catalogues, etc., was adopted without discussion, the delegates no doubt basing their action on the existence of similar reduced rates in many countries. The minimum rate for such packets was fixed at 7 centimes, and the unit of weight and the progression of weight at 50 grammes. The maximum weight for samples was fixed at 250 grammes, and that for other articles at 1,000 grammes. A proposal to increase the weight for samples was opposed by Dr. von Stephan on the ground that it would cause practical inconvenience in the post offices.

M. Radoikovitch, the Serbian delegate, proposed a modification of the progression of rate. He suggested that the packets should be divided into two categories-those not exceeding 300 grammes, and those over 300 grammes in weight. For the lighter packets he proposed a progression of 50 grammes, and for the heavier packets a greater progression. For the sake of simplicity it was considered preferable to retain the single progression, and the proposal, which met with no support, was withdrawn.I All packets (samples, etc.) sent at the lower rate must be sent under band or in open envelopes, or made up in such a way as to admit of their being easily examined.2

The proposal for gratuity of transit was advanced with a view to simplification of the administration of the Union. Its adoption would have made all countries independent, so far as expenses and accounting were concerned, of intermediate countries, and would have assisted the adoption of a low

I Documents du Congrès postal international, Berne, 1874, pp. 41-2.

2 Règlement de Détail, secs. xi, xii and xiii, ibid., p. 158. 
rate of postage. It was, however, resolutely opposed by those countries which, owing to their geographical situation and the means of communication which they controlled, were called upon to serve as intermediaries to a special degree. The case of Bèlgium was of particular importance. It naturally resulted from her situation that she was called upon to perform for other countries a transit business much greater than that performed by other countries for Belgium. The net revenue accruing to the Belgian administration from this source was very considerable. ${ }^{x}$ France and Italy were in a somewhat similar position, mainly owing to the transmission of the mails between England and India by the overland route. France rejected entirely the principle of gratuitous transit.

It was feared that if an administration derived no benefit from transit traffic it might be led to discourage it, to the detriment of general facilities for the transmission of mails, and the Congress arrived at the conclusion that some method of specially remunerating all countries for transit services ought to be devised. A simple reservation as regards special expenses caused by transit traffic was objected to on the ground that in most cases the internationel traffic was forwarded by the ordinary means and no special expense was caused-the real causes of Post Office expenses being the services of despatch and delivery. ${ }^{2}$ Indeed, it was contended on this ground that the transit of international mails could not be regarded as a service rendered.

Agreement was reached on most of the points raised by the proposals, and a Convention constituting an International Postal Union, under the title "L'Union générale des Postes," 3

" "La Belgique occupe une position pour ainsi dire unique dans le monde. Placée au centre de la partie la plus riche, la plus active et la plus peuplée de l'Europe, elle forme, en quelque sorte, le carrefour des grandes voies postales de notre continent. Il s'en suit que la Belgique rend de très grands services à tous les Etats de l'Europe, tandis qu'elle-même n'a à réclamer que fort peu de services de ses voisins."

Belgium received 946,235 fr. net annually in respect of transit traffic, and the ratio between the transit services rendered by Belgium to other countries and by other countries to Belgium was 20 to 1.-Documents du Congres postal international, Berne, 1374, pp. 37-8.

2 Ibid., p. 23.

3 Changed in 1878 to "L'Union postale universelle." 
was signed on the 9 th October 1874 , to become operative on . the 1st July 1875. The chief provisions of the Convention in regard to the rates of postage were as follows:-

(1) The rate of postage for the Union was fixed-

(a) At 25 centimes for single letters, with liberty for each country, as might be necessary on account of its monetary system or for other reasons, to fix a higher or lower rate, provided that such rate was not greater than 32 centimes, and not less than 20 centimes.

The unit of weight for a single letter was fixed at 15 grammes, and the scale of progression was by steps of 15 grammes.

(b) For postcards, half the rate for letters.

(c) For printed matter, samples, and commercial papers the unit rate was fixed at 7 centimes, with liberty for each country to fix a rate not exceeding 11 centimes or less than 5 centimes.

The unit weight was fixed at 50 grammes, and the progression of weight was by steps of 50 grammes. The maximum limit of weight for samples was fixed at 250 grammes, and for printed matter and commercial papers at 1,000 grammes. ${ }^{\mathbf{r}}$

(2) In cases where letters were forwarded by sea for distances over 300 miles, a surtax not exceeding half the general Union rate of prepaid postage might be added to the normal rate.

(3) The proposal as to the division of postage was accepted, with slight amplification.

(4) Transit payments, that is, rates of payment by one administration to another administration in respect of the transmission of closed mails over the territory of the second administration by means which it provided, were fixed at $2 \mathrm{fr}$. per kilogramme for mails containing letters and postcards, and 25 centimes per kilogramme for mails containing other articles. The rates were increased to $4 \mathrm{fr}$. and to 50 centimes, respectively, when the distance of transmission exceeded 750 kilometres on the territory of one administration. In the case of sea transits exceeding 300 nautical miles, the despatching country was required to pay to the administration which provided the service, the expenses of the transportation, not exceeding $6 \mathrm{fr}$. 50 per kilogramme for letters and 50 centimes per kilogramme for other articles.

\section{In November 1875 the Indian Post Office administration} applied for admission to the Union. A further Conference at Berne was thereupon called to consider this request. Representatives of a large majority of the signatories of the Treaty of 1874 attended the Conference, and other questions were raised. France, Spain, and Holland asked for the admission of their respective colonies; Brazil submitted a declaration of adhesion; and Great Britain intimated that Canada and

x Those countries which were unable to adopt the metric system of weights were given liberty to substitute the ounce avoirdupois (28.3465 grammes), a halfounce being reckoned the equivalent of 15 grammes, and 2 ounces the equivalent of 50 grammes.-Documents du Congres postal international, Berne, 1874, p. 66. 
Newfoundland would submit applications. The original Union had been limited to the European countries, Turkey (including Turkey-in-Asia), Russia-in-Asia, Northern Africa, Egypt, and the United States of America ; and these further developments widened the problem before the Congress. Instead of merely considering the question of admitting India, it was called upon to face the possible extension of the Union to the remotest parts of the globe.

The question of transit rates, particularly of transit rates by sea, became therefore one of very great importance and difficulty, since it was necessary to fix such rates as would permit of the maintenance of that uniformity and lowness of the rates of postage which were the fundamental bases of the Union. On this point there were prolonged and difficult discussions. The French delegates submitted a proposal for the application of the treaty of Berne to all quarters of the globe, with a uniform transit rate of 6 fr. 50 per kilogramme for letters and 50 centimes for printed matter, etc. ${ }^{x}$

The countries which maintained the more important and costly maritime services were not, however, prepared to submit to the loss of revenue which the adoption of the proposed transit rates would entail. ${ }^{2}$

Germany submitted a scheme for classifying all countries of the world outside the Union into four groups with four graduated maritime transit rates of 6 fr. $50,25 \mathrm{fr}$., $40 \mathrm{fr}$. and 60 fr. per kilogramme, respectively, for letters, and 50 centimes, 1 fr., 1 fr., and 2 fr. per kilogramme for printed matter, etc.,3 a proposal which was opposed as contrary to the funda-

1 "En accédant, disent-ils, a l'Union postale, la France s'est imposé des sacrifices considérables dont elle a d'avance calculé la portée. Elle est prête à en faire de nouveaux aujourd'hui en vue de compléter la grande œuvre de Berne; et, à ce propos, M. Ansault a cru devoir déclarer que los subsides accordés à des lignes de paquebots ne peuvent pas être considérés comme ayant un caractère postal, c'est-à-dire, que l'on ne doit pas chercher dans le produit de la taxe des lettres une rémunération de ces services, lesquels sont établis principalement pour les besoins du commerce et de l'industrie, aussi bien que dans un intérêt politique. En proposant une taxe maritime de fr. 6.50 par kilogramme de lettres et de 50 ct. par kilogramme de journaux, le Gouvernement français a eu en outre pour but de faire cesser une anomalie injustifiable aux. yeux du public, a savoir qu'une missive pour les Colonies françaises paie une taxe plus élevée qu'une lettre pour la partie la plus reculée des Etats-Unis d'Amérique."-Actes de la Conference postale de Berne, 1876, p. 29.
2 Ibid., p. 30.
3 Ibid., pp. 13, 14. 
mental principle of uniformity, and calculated to give rise to difficulties and complications. Moreover, the zones, being reckoned as from Europe, were not applicable as between the distant countries themselves, e.g. between Mexico and the West Indies. ${ }^{I}$

The Conference was able to arrive at an agreement only as regards the admission of British India and the French Colonies in Asia, Africa, America and the Pacific. The entry of these territories was fixed for the 1st July 1876, and the general international rates of postage and transit rates, fixed under the Convention of 1874 , were made applicable to the new territories of the Union, except that for transit by sea for distances exceeding 300 nautical miles a surtax equal to the full postage rates (32 centimes and 11 centimes) was authorized, instead of a surtax of half rates fixed under the original treaty; and the transit rates in respect of mails for or from these territories for distances of more than 300 nautical miles were made 25 fr. per kilogramme for letters and postcards, and 1 fr. per kilogramme for printed matter, samples, and commercial papers.

The later Congresses have added numerous services to those provided under the original scheme, such as, e.g., reply-paid postcards. For the most part, however, these additional services are of minor importance, and concern only a small part of the international traffic, ${ }^{2}$ the bulk of which still passes under the main divisions established at the first Congress.

In connection with the rates applied to those classes of the traffic there are three chief points of importance-the initial charge, the scale of weights, and the transit rates. The question of modifying the international letter rate, which had remained unchanged since the foundation of the Union, was raised at the Washington Congress in 1897. The Austrian delegate proposed, not indeed that the initial charge should be reduced below 25 centimes, but that the maximum weight allowed for the single letter should be increased from 15 grammes to 20 grammes. The British and

- Actes de la Comférence postale de Berne, 1876, p. 34.

2 Thus in 1913-14 the number of foreign reply-paid postcards in the case of the United States was 130,596. The total number of foreign postcards posted in the United States in the same year was $42,252,570$. 
French delegates opposed the proposal. ${ }^{x}$ The French delegates said it would involve a loss of more than a million francs to their administration. In some cases, e.g., Italy, the raising of the limit would have had the effect of rendering the international service cheaper than the internal service. In the end the proposal was rejected.

The subject of transit rates, which had not been seriously considered since the first Congress, was also raised at the Congress of Washington (1897), two proposals in regard to it, by Germany and by Austria-Hungary respectively, being under discussion. In the original project of the Union, gratuitous transit had been proposed, with the reservation that remuneration should be paid in cases of special expenses occasioned to an intermediary by the transit of foreign mails. The new German proposal was for the abolition of all transit payments except in those cases where, according to the statistics of the international service, a payment of more than $50,000 \mathrm{fr}$. a year was due, and in those cases the actual amount due to be reduced by 25 per cent., or at least by $50,000 \mathrm{fr}$. ; to make the amount payable only by those countries whose share exceeded 10,000 fr.; and the reduction of the maritime transit rate from $15 \mathrm{fr}$. to $10 \mathrm{fr}$. This proposal was avowedly a step towards completely gratuitous territorial transit. The Austrian proposal was for gratuitous transit for all correspondence sent $\dot{a}$ découvert, and a reduction of the transit rates for closed mails. Gratuitous transit, to which, as already stated, the German proposal admittedly tended, was advocated by the delegates of the South American countries, but was opposed by several other countries, especially by Belgium, France, and Italy. As at the first Congress, the delegates of

I “M. Buxton Forman, délégué de la Grande-Bretagne, ne voit pas l'utilité de la mesure proposée, qui, en son pays du moins, n'est pas demandée par le public. Il serait d'ailleurs presque impossible à l'Administration britannique d'y adhérer. . . " The French view was stated by M. Ansault : " La modification demandée ne répond à aucun besoin. Les statistiques tenues en France témoignent que le poids moyen de la lettre n'atteint pas 10 grammes; il reste donc une marge de 5 grammes avec le poids actuel. C'est largement suffisant; en augmentant cette marge, on risquerait de provoquer le groupement des lettres au détriment de la recette postale."-Documents du Congrès postal de Washington, 1897, p. 421.

In the same year the limit of weight for the single letter in the British inland service was raised from 1 to 4 ounces. 
the latter countries called attention to the great expense to which they were put in providing transport for transit mails, and rejected altogether the idea of gratuitous transit. In face of this opposition, the proposals could not be carried in their entirety. The transit rates were, however, considerably reduced, and simplifications in the method of ascertaining the amounts payable in respect of transit were introduced. The land rates were reduced from 2 fr. per kilogramme for letters and postcards and 25 centimes per kilogramme for other articles, to 1 fr. 90 and to $23 \frac{3}{4}$ centimes for the years 1899 and 1900 , to $1 \mathrm{fr} .80$ and to $22 \frac{1}{2}$ centimes for the years 1901 and 1902, and to $1 \mathrm{fr}$. 70 and to $21 \frac{1}{4}$ centimes for and after 1903. The maritime transit rates were similarly reduced. Countries whose expenses for the transit of foreign mails exceeded the receipts, and those whose combined receipts and expenses for that purpose did not exceed 5,000 fr. per year, were excused all payment under this head.

At the next Congress, held at Rome in 1906, the question of reducing the letter rate and transit rates was again discussed. Proposals to raise the limit of weight for single letters from 15 grammes to 20 grammes were submitted by several States. It was pointed out that, although in general sufficient, the limit of 15 grammes was often exceeded, and frequently the weight of letters required to be tested, causing inconvenience both to the public and the postal administrations. The German delegate expressed the opinion that the public were anticipating some concession, and that as reduction of the initial rate of 25 centimes was impossible, an increased limit of weight would no doubt be appreciated. ${ }^{\text {I }}$ The British delegates pointed out that the equivalent of 20 grammes in British weight was $\frac{2}{3}$ or $\frac{3}{4}$ ounce, a unit which would be highly inconvenient and could not be adopted. They would have accepted a limit of 30 grammes; but in many countries the existing limit of weight for the initial letter rate in the inland service was 20 grammes, and the introduction of a higher initial weight in the international service might lead to difficulties in the case of those administrations which desired to retain the lower limit in the inland service. On these grounds they inclined to the

- Documents du Congrès postal de Rome, 1906, vol. ii., p. 163. 
maintenance of the status quo. The delegates of the United States, Italy, and Turkey supported the British view. The Italian delegates pointed out that the result would in effect be to compel those countries in which the limit was 15 grammes to introduce modifications into their internal service-a position which it was obviously undesirable for the Congress to take up. Japan advocated the maintenance of the existing limit, because the effect of raising it would be to render further reduction of transit rates still more difficult. In the end the proposal was adopted by thirteen votes against twelve. ${ }^{\mathrm{I}}$ Countries using the avoirdupois system were to regard 1 ounce as the initial weight limit.

Gratuitous transit was still unacceptable to the majority, 2 but both land and sea charges were reduced. The land transit rates were reduced to $1 \mathrm{fr}$. 50 per kilogramme for letters and postcards and 20 centimes per -kilogramme for other articles, for distances not exceeding 3,000 kilometres; to $3 \mathrm{fr}$. per kilogramme for letters and postcards and 40 centimes per kilogramme for other articles, for distances between 3,000 and 6,000 kilometres; to 4 fr. 50 per kilogramme for letters and postcards and 60 centimes per kilogramme for other articles, for distances between 6,000 kilometres and 9,000 kilometres; and to $6 \mathrm{fr}$. per kilogramme for letters and postcards and 80 centimes per kilogramme for other articles, for distances exceeding 9,000 kilometres.

The sea transit rates were reduced to 1 fr. 50 per kilogramme for letters and postcards and to 20 centimes for other articles, for distances not exceeding 300 nautical miles; to 4 fr. per kilogramme for letters and postcards and to 50 centimes for other articles, for distances exceeding 300 nautical miles, between countries of Europe, between parts of Europe, Africa, and Asia on the Mediterranean and Black Seas, and between Europe and North America; to 8 fr. per kilogramme for letters and postcards and to 1 fr. for other articles, for all routes not falling under the above headings. At this Congress the question of reducing the international

Ibid., vol. ii., p. 165.

2 "Pour nous, le service gratuit est un rêve, un beau rêve, si vous voulez, mais que nous ferions bien, en gens pratique, de laisser aux rệyeurs,"-A. B. Walkley, British Delegate, ibid., vol. ii., p. 106. 
letter rate was raised by Sir J. G. Ward, the Australasian delegate. In 1901 New Zealand had introduced a universal penny rate for letters, and the financial results of the change had been regarded as satisfactory. The loss of revenue was some $£ 80,000$ in the first year, reduced to $£ 50,000$ in the second. There was an increase of 35 per cent. in the number of foreign letters posted in the first year, as compared with an increase of 1.76 per cent. for the last year under the $2 \frac{1}{2} \mathrm{~d}$. rate. ${ }^{\mathrm{I}}$

The proposal met with strong opposition and little support. The opposition was based entirely on financial considerations, many of the delegates stating that their administrations were unable to face the sacrifice of revenue involved. In this connection the term "sacrifice of revenue" means sacrifice of gross revenue, and not necessarily that the carrying of foreign letters at a penny would on the whole result in actual loss through the cost of service being greater than a penny, although it is probable that the cost of a foreign letter weighing as much as an ounce would be slightly more than a penny. ${ }^{2}$ The proposal was defeated by eighteen votes to three.3

I Documents du Congrès postal de Rome, 1906, vol. ii., p. 168.

2 "The British Post Office itself is unable to agree with the New Zealand Government that the sacrifice of net postal revenue involved would be 'temporary in duration and inconsiderable in amount.'

"The experience of the British Post Office in connection with the Imperial Penny Postage Scheme shows that if the increased cost of dealing with increased quantities of postal matter be taken into account, as it should be, the department has not recovered, and cannot recover, the loss of net postal revenue involved by the reduction of the Imperial letter rate, which was estimated in 1898 at $£ 108,000$ for the first year.

"Recent calculations show that, in the case of a letter for a foreign country, the expense to the Exchequer can be taken at about one penny per half-ounce rate, and in the case of a letter for a Colony, where a long sea transit is generally involved, at about a penny farthing, excluding the heavy cost of subsidized packet service."-Papers laid before the Colonial Conference, 1907: Memorandum by General Post Office (Cd. 3524), p. 499. It was estimated that the introduction of universal penny postage, together with the ounce unit (vide supra), would involve an initial loss of $\$ 640,000$ a year. Ibid., p. 500 .

3 The United States, Australasia, and Egypt voted in favour of the universal penny rate. Canada, Great Britain, British India, and Japan abstained from voting. The remainder voted against the proposal.-Documents du Congrès postal de Rome, 1906, vol. ii., p. 181. 


\section{(II) INTERNATIONAL PARCEL POST}

The Universal Postal Union as at first constituted provided only for the transmission of what may be regarded in the broad sense as letter post traffic. It made no provision for the transmission in the international service of packages of ordinary merchandise. Such packets could in strictness only be forwarded at the letter rate, which was almost prohibitive; although frequently they were forwarded at the sample rate, in which case the weight of the packet was strictly limited. The French administration proposed, in the project of the Congress of Paris of 1878, to extend in that direction the facilities provided by the Union, by amplifying the definition of samples to include small parcels of ordinary goods, ${ }^{x}$ a proposal which was rejected by a majority of the administrations. It was, however, submitted to the Congress under another form. The German administration proposed, not the extension of the sample privilege, but the establishment of a new service, which should provide for the transmission of parcels of general merchandise not exceeding 3 kilogrammes in weight, the parcels to be charged a rate of postage sufficient to reimburse the administrations for the expenses of transmission. Although this proposal was favourably received, many of the delegates had no power to enter into any arrangement of that nature. The question was therefore referred to the International Bureau, with instructions to call a special Conference for its consideration, if on investigation that course should be found desirable.

× "Chaque jour de nouvelles difficultés surgissent, soit dans les rapports du public avec les Administrations, soit dans les rapports entre les Administrations, sur la definition de l'échantillon. Tel objet est admis dans un pays et refusé dans un autre. Ici, on repousse un article sans valeur, uniquement parce qu'il est entier et on en exige la détérioration ou lacération; là, au contraire, ce même article passe sans observation, par la raison qu'il n'est sujet à aucun droit de douane. Cette dernière doctrine paraissant la plus logique et la plus conforme a l'esprit libéral de l'Union, qui ne saurait refuser au commerce des facilités compatibles avec les exigences du service, on a pensé que, sous la double réserve d'une limite de poids de 300 grammes et de la prohibition des articles sujets aux droits de douane, il y aurait un simplification, profitable a tout le monde, a étendre la qualification d'échantillons aux menus objets, même entiers et non détériorés."-See M. E. Ruffy, L'Union postale universelle: sa fondation et son développement, Lausanne, 1900, p. 67. 
At this time the circumstances in the different countries in regard to the transmission of small parcels varied. In some a service was provided by the Post Office; in others, the majority, the business was left to the railways or other forms of commercial transport. In all cases the services between different countries were regulated by conventions and agreements on such terms as could be mutually arranged between the contracting parties. In general the rates of postage were based on the rates for inland transmission in each of the countries concerned. They were often extremely complicated, and several administrations had mutually agreed to a uniform rate for parcels not exceeding 5 kilogrammes in weight.

The suggestion for a special Conference was, in general, well received, and the Conference met in Paris in 1880. All the countries of Europe (except Greece), Canada, the United States, Egypt, British India and Persia, were represented. The fact that in many of the countries the Post Office had not at that time undertaken the transmission of parcels was a serious obstacle to the adoption of any sort of general agreement; and on the question of rates there was divergence of opinion whether the principle of uniformity should be accepted, and a fairly high maximum limit of weight conceded at a low uniform rate of postage, in order that the service might be of real advantage to the public, or whether the rates should be graduated according to scales of weight and distance.

The original suggestion had been for a limit of 3 kilogrammes, but at the Conference a proposal for a limit of 5 kilogrammes was submitted. Several delegates were unable to accept the higher maximum, and the limit originally proposed was retained. ${ }^{x}$ As regards the rates of postage to be charged there was also diversity of opinion. Some delegates held that the rate should be so fixed as to avoid the possibility of the service involving an administration in

I "La proposition d'élever le poids des paquets de 3 à 5 kilogrammes modifie notablement l'économie du projet; c'est la substitution d'un vrai service de messagerie au transport de simples colis postaux. Le Gouvernement anglais estime que le transport de paquets d'un tel poids est de domaine de l'industrie privée."-S. A. Blackwood, Documents de la Conférence postale de Paris, 1880, p. 60 . 
loss, while others, in view of the public benefits to be derived from the establishment of the service, were prepared to agree to rates which might prove insufficient to cover the expenses. ${ }^{x}$ Simple uniform rates were regarded as a cardinal feature of a postal service for parcels. ${ }^{2}$

After prolonged discussion agreement was finally arrived at, and a Convention was signed by all the delegates, with the exception of those representing Great Britain, British India, Holland, and Persia, to be brought into operation on the 1st October 1881.

Financial considerations were the chief obstacle in the way of the participation of Great Britain. 3

The contracting parties undertook to provide a mutual service for the interchange of parcels not exceeding 3 kilogrammes in weight. Liberty of transit was guaranteed throughout the territory of each contracting country, and for transit services the respective countries were to be remunerated as follows: The administration of the country of origin was required to pay to the administration of each other country concerned in the transmission, and to that of the country of destination, 50 centimes for each parcel in respect of land transit. In cases where a sea transit was involved, the sum of 25 centimes for each parcel was payable on sea routes not exceeding 500 nautical miles; 50 centimes for routes between 500 and 1,000 nautical miles; 1 fr. for routes between 1,000 and 3,000 nautical miles; 2 fr. for routes

× "Si on transporte à perte, plus le trafic sera grand, plus les dépenses augmenteront. Il serait en désaccord avec les vrais principes d'économie politique, d'entreprendre un service postal dont les frais pèseraient sur une autre branche de l'exploitation ou seraient à la charge du Trésor. Un économiste aussi distingué que M. Fawcett ne pourrait admettre cette théorie."-S. A. Blackwood, Documents de la Conférence postale de Paris, 1880, p. 60.

"M. Günther fait remarquer à M. le délégué de la Suède que le nombre des colis échangés entre la Suède et l'étranger n'étant pas très important, son Administration aurait a faire peu de sacrifices."-Ibid., p. 55.

2 "Il paraît de toute nécessité d'adopter un droit uniforme, car autrement, avec un tarif variable suivant le poids ou le lieu de destination, on aurait un service des messageries, avec de nombreuses taxes, graduées, et non plus un service très simple de colis postaux."-M. le Président; ibid., p. 55.

3 "Quant à la taxe internationale de 50 centimes, sans addition possible, elle ne peut être accepté par l'Administration britannique qu'elle constituerait en perte. La taxe devant être partagée entre l'État et les Compagnies, une somme de 50 centimes ne couvrirait les frais."-S. A. Blackwood, ibid. 
between 3,000 and 6,000 nautical miles; and $3 \mathrm{fr}$. for all routes exceeding 6,000 nautical miles. The rate of postage was based on the foregoing payments, and amounted to as many times 50 centimes as there might be administrations concerned in the transmission, with the addition of all rates for sea transit, and with the reservation that each country might charge an additional 25 centimes (raised in certain cases to 50 , to 75 centimes, or to $1 \mathrm{fr}$.). In addition, the country of destination might charge a delivery fee of 25 centimes. It was not anticipated that these rates would in all cases be sufficient to cover the expenses of carrying on the service, but the general advantages were regarded as adequate compensation for any monetary sacrifice which might be entailed. ${ }^{x}$ Any administration which did not at that time conduct a parcel post service was authorized to arrange for the international service to be undertaken on its behalf by railway and steamship companies.

At the Lisbon Congress in 1886 the maximum limit of weight was raised to 5 kilogrammes, at which point it remains, and special rates were established for parcels which, on account of their size, shape or fragility, were inconvenient for transmission. ${ }^{2}$ Such parcels, which had previously been

I "Le commerce surtout vous saura le meilleur gré d'avoir élevé jusqu'à 3 kilogrammes le poids des petits colis transportés par la poste, et d'avoir abaissé la taxe à un chiffre minime. Dans bien des cas même, ce prix ne sera pas l'équivalent des frais; et les Gouvernements qui consentent à ce sacrifice méritent une gratitude toute particulière; je vous l'exprime ici bien volontiers et bien hautement au nom de la France, au nom de l'Europe et au nom de l'humanité, qui profiteront si largement du progrès nouveau que vous venez de réaliser."-M. Barthélémy Saint-Hilaire, Foreign Minister of France, to the Conference; Documents de la Conférence postale de Paris, 1880, p. 180.

a The convention of Washington, 1897, defined cumbersome parcels (colis encombrants) as follows:-

“(a) Les colis dépassant 1 mètre 50 centimètres dans un sens quelconque;

“(b) Les colis qui, par leur forme, leur volume ou leur fragilité, ne se prêtent pas facilement au chargement aveo d'autres colis ou qui demandent des précautions spéciales, tels que plantes et arbustes en paniers, cages vides ou renfermant des animaux vivants, boites à cigares vides ou autres boites en fardeaux, meubles, vannerie, jardinières, voitures d'enfants, rouets, vélocipèdes, etc.

“Les Administrations qui n'admettent pas les colis encombrants ont la faculté de limiter à 60 centimetres le maximum de dimension de ces objets. Les Administrations qui assurent des transports par mer ont aussi la faculté de limiter à 60 centimètres le maximum de dimension et à 25 décimètres cubes le volume des colis postaux destinés à être transmis par leurs services maritimes 
excluded altogether from the service, were now admitted, subject to a rate of postage 50 per cent. greater than the rate on ordinary parcels.

At the Congress of Washington in 1897, power to charge special rates was given to the administration of British India, viz. a rate not exceeding $1 \mathrm{fr}$. for land transit, a surtax not exceeding $1 \mathrm{fr}$. 25 on each parcel posted or delivered in British India, and a scale of rates graduated according to weight on all parcels posted in British India, provided that the average receipt of the Indian administration did not exceed 1 fr. 75 for each parcel.r The special transit charge was abandoned at the Rome Congress of 1906.

No changes of importance were made at the Rome Congress of 1906. Several proposals in regard to the maximum limit of weight were discussed. The Bulgarian delegates proposed an increase of the maximum to 50 kilogrammes, but the proposal found no support. ${ }^{2}$ The Swiss delegate proposed an increase to 10 kilogrammes. This met with some support; but in view of the practical difficulties which would have been imposed on certain administrations in dealing with parcels of so great a weight, the proposal was negatived.

The Indian delegate proposed the insertion of a provision enabling any country to charge postage on parcels originating in that country according to a scale of weights of its own choice, in substitution for the existing single rate. 3

et de ne les accepter au dela de ces limites qu'à titre de colis encombrants." -Documents du Congrès postal de Washington, 1897, p. 887.

Ibid. pp. 881-2.

2 "M. Herman, délégué do la France, déclare qu'il est impossible d'ontrer dans les vues de l'Administration bulgare, laquelle semble ne plus tenir compte de l'idée première qui a conduit a la création des colis postaux pour l'échange d'objets de petit poids, à des prix très modérés. En créant les colis postaux, les Administrations participant n'ont pas eu l'intention de faire concurrence aux compagnies de transport. Si les tarifs des articles de messagerie sont trop élevés, ce n'est pas évidemment à l'Union postale de les diminuer."-Documents du Congrès postal de Rone, 1906, Berne, 1906, vol. ii., p. 381.

3 "Il n'y a aucun besoin ou avantage a son avis, d'avoir une taxe uniforme pour les colis de même catégorie de poids expédiés de différents pays. Pour les lettres, cette uniformité a l'avantage, pour l'expéditeur, de connaitre, dans n'importe quel pays, le prix du port des lettres. Mais, pour un colis postal, l'expéditeur doit toujours aller au bureau de poste pour y déposer la déclaration en douane et, aussi, pour connaitre le tarif qui varie selon le nombre des pays 
The general proposal was rejected, ${ }^{\mathbf{x}}$ but a clause was added provisionally according to India the faculty of applying to parcels posted in India a tariff graduated by weight, provided the mean of the rates was not in excess of the normal rate of the Union.

The land transit rate remained unchanged, viz. 50 centimes for each country participating in the territorial transit.

Russia was given power to collect a transit fee of $1 \mathrm{fr} .25$ per parcel in respect of both Russia-in-Europe and Russiain-Asia, separately; and Turkey to collect a transit rate of 1 fr. 25 on a parcel sent across Turkey-in-Asia. Owing to the undeveloped state of the transport services in Persia, that administration was empowered provisionally to decline the transport of parcels for and from other countries.

The maritime transit rates were reduced to the following :-

25 centimes for transits not exceeding 500 nautical miles

50 centimes

$500-2,500$

1 fr.

$1 \frac{1}{2} \mathrm{fr}$.

$2 \mathrm{fr}$.
,

,

,

,
$2,500-5,000$

$5,000-8,000$

exceeding 8,000

$\begin{array}{ll}, & , \\ , & , \\ , & ,\end{array}$

For parcels not exceeding 1 kilogramme the transit rate should in no case exceed $1 \mathrm{fr}$.

et services intermédiaires."-M. Kisch, Delegate for India, Documents $d u$ Congres postal de Rome, 1906, Berne, 1906, vol. ii., p. 391.

× "N'est-ce pas précisément l'unité de tarif qui caractérise le colis postal? Elle est très appreciée du commerce dont elle facilite les opérations. Si l'on entre dans la voie de la taxation au poids, comme pour les articles de messagerie, ce sera un recul."-M. Mazoyer, Documents du Congrès postal de Rome, 1906, Berne, 1906, vol. ii., p. 393. 


\section{VII}

\section{AN ANALYSIS OF COST}

\section{METHOD}

The Post Office ${ }^{x}$ performs but one service in respect of the ordinary postage paid on a packet, under whatever rate or regulations the packet is posted. Whether the packet be a letter, a postcard, a halfpenny packet, a newspaper packet or a parcel, ${ }^{2}$ the service performed in respect of the ordinary postage is simply to transmit the packet without delay to the place of its address. 3

x The analysis relates to the British inland service in 1913-14.

2 The number of packets sent at the blind post rate is very small comparatively (some 300,000 a year), and those packets are therefore not considered separately.

3 In general, for any supplemental service an additional fee is charged, the only exceptions being that, in the case of a packet sent at the letter rate of postage, if the person to whom it is addressed cannot be traced, the packet is returned to the sender without charge; and that under certain conditions the address written on any packet (but not the name of the person to whom it is addressed) may be amended, and the packet sent forward, without payment of additional postage. Parcels are forwarded to a second address in this way free of charge only when the first address and the substituted address are within the delivery of the same post office, or are within the same " town delivery area." In certain circumstances the Post Office itself undertakes to amend the address and forward packets in this way free of charge-that is to say, to " redirect." These are, however, minor services, and apply only to a small fraction of the total number of packets posted. For example, the actual proportion redirected is as follows:-

Per.cent. of Total Number posted.

\begin{tabular}{|c|c|c|c|c|c|c|}
\hline \multirow{2}{*}{\multicolumn{7}{|c|}{ 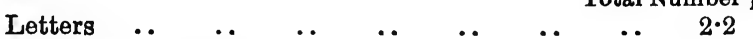 }} \\
\hline & $\because$ & $\because$ & ・・ & -. & & \\
\hline Postcards & . & .. & .. & . & .. & $4 \cdot 0$ \\
\hline Halfpenny packet & .. & . & .. & .. & .. & • 0 \\
\hline Newspapers & .. & .. & .. & .. & .. & $1 \cdot 7$ \\
\hline
\end{tabular}

The service of free redirection applies to all classes of packets; but for the return to the sender in case of non-delivery of postcards, halfpenny packet, 
There are, of course, several intermediate stages in the progress of the packet from the place of posting to the place of delivery. Under the most favourable circumstances, as in the case of a letter from one small town to another small town for which there is a direct mail, the packet is handled two or three times by various officers; and in many cases, as with the letters from a suburb of one large town to a suburb of another large town, or to a place in a rural district or vice versâ, as many as ten or twelve times.

Although the character of the service to be performed, viz. transmission to the place of its address, is identical in every case, the character of the packet naturally has considerable influence on the nature and cost of handling at the various stages, and the methods adopted in dealing with the packet. But the operations are in essence the same, and the chief difference is in the amount of time occupied and the nature of the office fittings employed.

This variation of cost and method does not correspond with variation in the rate of postage paid on the packets. Except in the case of parcels, all distinction on the basis of rates of postage disappears once the sorting office is reached.

In regard to the chief indoor operations there is, except at the smallest offices, complete separation between packets sent by parcel post and all other packets; but parcels are in some cases taken out with other packets for delivery at the same time and by the same officer. Except in rural districts they are, however, generally taken out separately for the first morning delivery, and frequently for the last evening delivery. Speaking broadly, there is as regards delivery, as for other operations, essential separation between parcels and all other classes of packets.

In regard to packets other than parcels, the chief, and in many cases the only, separation in actual handling is as between those packets which can be passed through the

or newspapers, an additional rate of postage is charged, and the packets are only so returned when they bear on the outside a written or printed request for return in case of non-delivery. This inquiry relates only to the cost of the simple transmission and delivery of the packet, and consideration of all other services, such as registration or express delivery, is excluded. 
stamping machine and those which cannot; and between those packets which can conveniently be dealt with at the ordinary letter-sorting frames, and tied in bundles for enclosure in the mail-bags, and those which on account of their irregular size and shape are sorted at pigeon-hole frames, and cannot be tied in bundles, but are forwarded loose in the mail-bags. The dividing line is almost identical in both cases, and is determined by the size and shape of the packet. In the largest offices more divisions are made, in some cases as many as five. ${ }^{I}$

The more usual number is three, "short letters," "long letters," and other packets. ${ }^{2}$ The division of the packets is made in all cases, not with reference to the various rates of postage under which the packets may have been posted, but with the view simply of securing that packets of the same shape and size shall, as far as possible, be brought together, and their subsequent handling thereby facilitated.

In cases where there are four or five such divisions of the packets, the separation is likewise made from considerations independent of the rates of postage, although it happens that, as a rule, a large proportion of the packets posted under a given rate fall into a certain group. Thus all postcards fall to be handled with the short letters; all newspapers fall to be handled with the heavier packets sent at the letter rate; and a large proportion of the halfpenny packets, viz. the short halfpenny packets, fall to be handled with the short letters.

There are in general three methods of handling. The

I In London there are the following divisions:-

(1) "Short Letters" (including postcards and a large proportion of the halfponny packets). Halfpenny packets which are of such size as to admit of handling with the short letters are roferred to as " short halfpenny packets."

(2) "Long Lotters" (for the most part letters of foolscap size).

(3) "Circulars" (that is, packets sent at the letter rate or by the halfpenny packet post, posted in large numbers at one time and generally of uniform size but which cannot conveniently be dealt with at the ordinary letter-sorting frames).

(4) "Packets" (that is, packets which are bulky or of irregular shape and cannot therefore be sorted at the ordinary sorting frames).

(5) "Newspapers."

2 Divisions 2 and 3, and divisions 4 and 5, described in the preceding footnote, being combined, 
sorting is done either at the ordinary open frames, or at the newspaper frames, or directly into the mail-bags, the two latter methods being alternative. Short letters are dealt with at the ordinary sorting frames. Long letters (which include a large proportion of "circulars") are dealt with in some cases at the ordinary frames, and in some cases at the frarnes provided for the larger packets (the "newspaper" frames). All other packets are dealt with at the newspaper frames, or are sorted directly into the mail-bags in those cases where frames for hanging the bags are provided. Stamping is performed either by hand or by machine.

When first brought into the sorting office the packets are placed on an open table, and the ordinary letters, circular letters, and postcards are arranged in order with the addresses in the same direction, or, as it is termed, "faced." Simultaneously, all other packets are picked out for treatment separately. The postage labels affixed to the letters and other packets are then obliterated with a dated stamp. After stamping, the letters and packets are taken to the respective sorting tables, where they are separated (in one or more operations) into groups corresponding to the various towns to which they will be despatched. Before enclosure in the mail-bags, all short letters, postcards, and short halfpenny packets, and some of the long letters, are tied in bundles, other packets being sent loose.

From the first office of destination many of the packets are sent forward to another office, since it is naturally not possible always to enclose a packet in a direct mail-bag for the town to which it is addressed. These packets are resorted and despatched. The letters, etc., for immediate delivery do not require to be faced, as they are received in bundles, in which they are arranged with the addresses in the same direction. But, except when received for the first morning delivery, letters are stamped to show the date and time of receipt, after which they are sorted in the order of delivery, and delivered by the postmen.

In the delivery of the packets one division is made, viz. between the short letters, postcards, and short halfpenny packets, which are tied in bundles; and the letter packets and 
halfpenny packets of irregular size and shape, and the newspapers, which are carried loose in the delivery bag. The postman takes out of his bag a bundle of letters, etc., from which he delivers in order. These have been sorted up in the order of delivery at the sorting office, so that no time is lost in finding the proper letter for delivery. It is not possible, however, to arrange the irregular-shaped packets in this manner. When the postman has such a packet to deliver, he has first to find it among those in his bag. He then frequently finds that it is too large to be put through the letter-box, and further time is lost in gaining the attention of the householder.'

There is, therefore, in the matter of delivery, a heavy balance against the heavier and more bulky packets, as compared with the short letters, postcards, and short halfpenny packets.

As regards the actual transmission from post office to post office, there is only one real division of the whole of the packets, viz. that between the parcel post on the one hand, and the whole of the remaining classes of packets on the other. In a number of cases separate mails are made up for newspapers and large packets; but compared with the total number of mails, the number of such separate mails is small, and the arrangement may be regarded as exceptional. In a considerable number of cases, however, packets sent at the parcel post rate are enclosed in the same mail-bag with packets sent at other rates. The arrangement is made somewhat extensively for mails from a post town to subordinate and other small offices in the immediate neighbourhood, but only exists in those cases where the number of parcels to be enclosed is small. As in every case where on the average as many as eight parcels are available at the time of despatch a separate mail may be made up, the arrangement does not exist extensively between any large centres with any considerable traffic; but it has been extended in recent years, and the total number of parcels forwarded

I The postman does not rely on his memory to discover at which houses he has packets to deliver. Usually he reverses in the bundle of letters that letter for delivery next preceding a packet. A complication is thus introduced in the preparation of the short letters for delivery. 
in this way forms an appreciable proportion of the total number of parcels sent by post. There is in these cases, so far as mails conveyed by railway are concerned, complete separation in regard to one important element of cost, viz. the cost of conveyance. Separate payment for the conveyance of parcels is made under the arrangement established by the Parcel Post Act; while comprehensive payments are made for the conveyance of all other packets, arranged by negotiation with the individual railway companies or, failing agreement, fixed by the Court of Railway and Canal Commission in the manner prescribed by statute. ${ }^{\mathbf{I}}$

The handling of a postal packet from posting to delivery therefore comprises the following operations in order:-

$$
\begin{aligned}
& \text { Collection, } \\
& \text { Facing, } \\
& \text { Stamping, } \\
& \text { Sorting, }
\end{aligned}
$$

\author{
Conveyance, \\ Stamping, ${ }^{2}$ \\ Sorting, \\ Delivery ;
}

and in the case of those packets which pass through more than one office there are, for every such office, the additional operations of sorting and conveyance. 3

The bags are conveyed between the various post offices by

I $2 \& 3$ Vict., cap. 98 and $56 \& 57$ Vict., cap. 38.

$=$ In recont years the stamping at the office of roceipt has been to a large extent dispensed with.

3 In addition to these principal operations there are certain minor operations. The packets are in general sorted on frames, from which they are collected at intervals and taken to the despatching table for enclosure in the mail-bags. Here the short letters, etc., are tied in bundles (as explained above), and in many cases a label is affixed, on which the name of the office of destination is written by the despatching officer. Next a letter bill is prepared. On this are entered particulars of the mail and of registered letters. The bundles of letters, etc., the loose packets, the registered letters and the letter bill (to which are tied all packets which are insufficiently prepaid and are to be charged on delivery), are enclosed in a mail-bag on which is stencilled the name of the office of destination, and in some cases particulars of the route to be followed. The bag is then tied, sealed, and sent forward. The despatch of each bag is recorded, as is the receipt of each bag from another office.

The opening of bags at the office of receipt also comprises a distinct series of operations. First the letter bill is obtained and examined. The receipt of the registered letters and charged packets is verified, and the letters and packets are withdrawn for special treatment. The bag is then emptied on the "opening table," reversed, in order to ensure that no packets are over. looked, and the contents distributed for sorting. 
mail-van (horse-drawn or motor), by mail-cart, by railway, or in a few cases by carrier-cycle, tricycle, or motor-cycle.

The vans, carts, or cycles of course convey the bags from office to office, but when the bags are sent by railway it is necessary to provide for their conveyance to and from the railway stations. This is largely done by mail-van, mailcart, or carrier-tricycle; but in a great number of cases throughout the country, where only two or three small bags are concerned, their conveyance between the station and the post office is provided for by cycle postman or "runner" service; that is to say, the bags are fetched or taken by a postman or porter.

\section{COST}

In order to ascertain the cost of dealing with postal packets of the various classes, the relative cost, and the actual cost, of the various operations must be ascertained, and all general charges apportioned.

The cost of the "postal" service, shown in Table B, $\mathrm{x}$ i.e. the cost of the whole of the services controlled by the Post Office, less the cost of the telegraphs and telephones, may be grouped, as shown in Table $\mathrm{C}$, under the following main headings :-

(1) Cost of Staff,

(2) Cost of Conveyance of Mails,

(3) Cost of Buildings,

(4) Cost of Stores, and Miscellaneous Expenditure.

\section{STAFF}

Since parcels are, to a considerable extent, dealt with separately, it has been possible to estimate the relative cost of the manipulative services in regard to parcels on the one hand, and all other postal packets (letters, postcards, halfpenny packets, and newspapers) on the other. The ratios of cost are shown in Table $D$, and the total cost of the manipulative services in respect of parcels calculated on this basis is shown in Table F.

- See infra, p. 297 (from Postmaster-General's Report, 1913-14, Appx. N). 
No similar ratios of relative cost have been estimated in regard to the various classes of packets other than parcels, since they are dealt with together, and it is necessary, therefore, to ascertain the actual cost for staff under the various headings of collection, stamping, sorting, and delivery. As regards collection, it is difficult to discover a basis on which a computation of the relative cost for the different classes of packets may be made, because the cost varies greatly, not only as between each class, but from place to place, in regard to any particular class of packet. Many of the ordinary letter packets are posted in large numbers at head post offices, and in respect of packets so posted there is no cost of collection. Light letter packets and halfpenny packets (especially halfpenny packets) are, moreover, handed in at post offices in considerable numbers for prepayment of postage in cash. In that case the cost of subsequent handling is slightly reduced, because under the regulations for such prepayment the packets must be tied in bundles with the addresses in the same direction, that is to say, the operation of facing must be performed by the person who posts the packets. Against this, however, must be set the very considerable expense incurred both in towns and rural areas for the collection of ordinary light letter packets, postcards, halfpenny packets, and newspaper packets from posting boxes, and the cost of van services, which are frequently provided for the collection of letters from business premises. Very little of the cost of these services can be attributed to the heavier letter packets, which are to a large extent handed in at the post office counter to be weighed. This involves considerable expense, which corresponds to cost of collection, and may be dealt with under that heading. The best estimate that can be made is that the cost of collection per packet is approximately the same in all cases.

Facing and stamping may be regarded as one operation, the one being really preparatory to the other. Here there is less difficulty. The relative cost per packet may fairly be taken as the ratio of the time taken in performing the operation in the case of each class of packet. In regard to facing and stamping, and also in regard to sorting, the letter packets proper, that is to say packets sent at the ordinary letter rate 
of postage, fall in general into three classes according to the facility with which they can be handled, viz. (1) "short letters," (2) "long letters," (3) "letter packets" (that is, the bulky packets sent at the letter rate). ${ }^{\mathrm{I}}$ In order to complete the calculation, the number of packets which fall respectively into these three classes must be estimated.

It has been indicated that the actual division is made according to the size and shape of the packets. The division corresponds approximately with variation in weight. Few packets weighing more than $\frac{3}{4}$ ounce would come within the class of short letters, that is, of letters which can be dealt with at the ordinary sorting frames; but as there is no analysis of the number of packets of less than 1 ounce weight, there is no alternative to the adoption of 1 ounce as the limit of this class. ${ }^{2}$ The effect of this is slightly adverse to the short letters and favourable to the heavier packets. As between long letters and the heavier packets the limit is less definite. In many cases packets of the same weight fall into one or other class according to their size or shape, but the mean weight of such indeterminate packets is roughly 4 ounces, and that weight is adopted as giving the mean upper line of division for long letters.

In Table $\mathrm{H}$ are shown the relative rates of stamping and sorting for each of the various classes of packets.

The proportionate cost per packet of stamping and of sorting, based on the rates shown in Table $\mathrm{H}$, is given in Table J.3 The actual cost is shown in Table $\mathrm{L}$.

As regards the cost of delivery some difficulty presents itself. Letter packets, postcards, halfpenny packets, and newspaper packets are, in all cases, taken out for delivery by the same postman, and it is not possible, therefore, as with stamping and sorting, to ascertain the rates of work for the various classes of packets. But the features in the different packets which lead to differences in the rate of

Cf. supra, p. 285.

- See The Post Office, an Historical Summary, London, 1911, p. 11.

3 There is practically no short-distance newspaper traffic, and it is probable that, on the average, newspaper packets undergo one more intermediate handling than packets sent at the letter rate. In the absence of precise information, no adjustment of the relative cost for sorting has been made on this account. The result will, therefore, be slightly to the advantage of the newspaper packets. 
sorting, viz. weight and irregularity of shape and size, lead also to differences in the time taken for delivery. In practice the postman makes a division of the packets; and the time occupied in the delivery of the bulky and irregular packets is greater proportionately, as compared with the time occupied in the delivery of ordinary letters, than is the time occupied in sorting. It is not possible, however, to estimate with any degree of exactness the relative amount of time actually occupied in delivering packets of the various classes, and for the division of the cost of delivery (Table $J$ ) the rates adopted for the division of the cost of sorting are taken. This method favours the bulky and irregular-shaped packets.

\section{Conveyance}

The cost of conveyance of letter mails by railway forms by far the greater part of the whole cost of conveyance. The cost of conveyance of letter mails by road and sea, estimated on such data as are available, is shown in Table M. As the total cost of the conveyance of mails is known, the total cost of the conveyance of parcel mails can be ascertained (Table M). The best basis for division of this cost is the gross weight of the various classes of packets. Payment is made purely on a weight basis in respect of the conveyance of a very large proportion of the mails, and, so far, division on the basis of weight is correct. But payment for the conveyance of a proportion of the mails is made on the basis of the cost of providing for the conveyance, and more or less independently of the weight carried. This applies in the case of mail-carts, motor-vans, or special trains which do not carry a full load. The amount paid in such cases is a single sum, calculated, so far as letter mails are concerned, without reference to the fact that postal packets of different classes are to be conveyed-without indeed, in some cases, much reference to the fact that any given quantity of mails is to be conveyed. In the absence of an assigned basis of payment which can be used to divide such sums, the division between the various classes of packets is made in proportion to the total weight of each class. In Table $\mathrm{N}$ is shown the division of the whole cost of conveyance of letter mails between the various classes on this basis. 


\section{General Charges}

Separate statistics are obtainable (Table B) in regard to (a) buildings and office fittings, and (b) stores, but no exact estimate can be made of the cost of administration and accounting.

The cost for buildings and office fittings is divided as between parcels and other packets on the basis defined in Table $\mathrm{D}$; and as between the various classes of packets other than parcels, on the basis of the gross weight of the packets (Table O).

The cost for stores, including the small sum under the heading "Miscellaneous Expenditure," is similarly divided as between parcels and other packets. As between the various classes of packets other than parcels, the cost is divided on the basis of simple numbers (Table P).

The cost for administration and accounting, which is comparatively small, ${ }^{x}$ cannot be stated exactly. It is contained in the total cost of staff (Table C), and is consequently divided between the various classes in the same proportion as the cost of the manipulative staff.

Tables A to $Q$ show the complete calculation.

Table $Q$ shows the final result, which is that the average total cost of dealing with postal packets is as follows:-

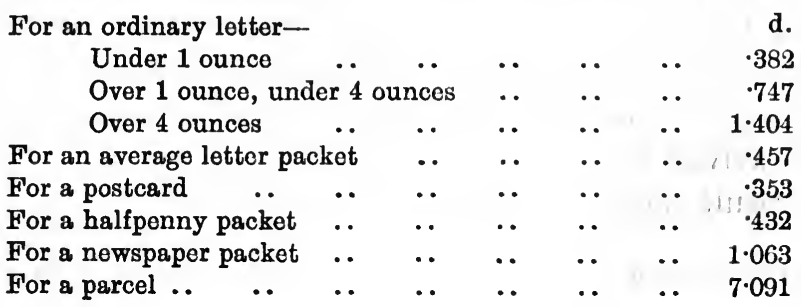

For the letter packets under 1 ounce in weight, for those between 1 ounce and 4 ounces in weight, for the halfpenny packets and for the postcards, the estimated average cost will be approximately the actual cost per packet; but in the case of letter packets over 4 ounces in weight and newspaper packets, the variations in weight and convenience of handling are considerable, and there will be an appreciable variation

I It has been estimated at $\cdot 075 \mathrm{~d}$. per letter. 
for individual packets above and below the estimated average cost. The cost will vary with the weight and size (but not proportionately), and the deviation will be greatest in the case of the heavier packets, since with both these classes the average weight of the great bulk of the packets is less than the general average. Of all letter packets, postcards, halfpenny packets and newspapers, the number exceeding 4 ounces in weight forms less than 10 per cent. With so small a proportion of heavy packets the result may be taken as almost exact in the case of the lighter packets. It is not in excess of the actual cost, because the calculation, taken as a whole, is biassed in favour of the heavier packets.

The resultant figures are figures of average cost. They represent the cost of those packets in each class in respect of which the average amount of service is performed, and not exceptional cases, as when packets travel over very long distances, or when a packet is redirected or returned to the sender, in which latter cases obviously double the normal service is performed.

The calculation is approximate in that at certain points it has been necessary to frame estimates on imperfect data. This is inevitable in dealing with a service conducted over a large area and under diverse conditions. I In general the manner in which the result is affected by the use of imperfect data has been indicated. These variations have been borne in mind throughout, and, as their effects are produced in varying directions, the combined effect is not such as to invalidate the results arrived at.

The result suggests the following conclusions :-

(1) That no class of packet sent at the letter rate of postage involves a loss to revenue;

(2) That there is a large profit on ordinary light letters ;

(3) That in the case of packets of the weight of about 4 ounces the profit is less, but is still appreciable;

(4) That there is a considerable profit on postcards ;

(5) That there is a profit on the halfpenny packets ;

(6) That there is a heavy loss on the newspaper packets, averaging nearly $\frac{1}{2} \mathrm{~d}$. per packet;

(7) That as regards packets other than parcels, the principle of uniformity of rate, irrespective of distance, is well founded. The cost of conveyance (.07d. per 
packet) is still, in the phrase of Sir Rowland Hill, "not expressible in the smallest coin ";

(8) That as regards the cost of conveyance there is no case for a reduced rate of postage for local letters ;

(9) That as between local letters and other letters there is appreciable difference in the cost of handling, but this difference would not be sufficient to justify a discrimination measurable in coin ;

(10) That the parcel post is conducted at considerable loss. If the cost be taken, as shown in Table $L$, at $7.091 \mathrm{~d}$. per parcel, the loss is on the average almost $2+d$. per parcel, or nearly $£ 1,250,000$ on the total number of parcels dealt with in 1913-14. The matter is, however, complicated by the question whether a strictly mathematical proportion of the total expenses of the Post Office can fairly be charged against the parcel post. ${ }^{x}$

- See supra, p. 127, n. 2, and infra, p. 334. 
TABLE A

TOTAL NUMBERS DEALT WITH IN THE UNITED KINGDOM, 1913-14.

\begin{tabular}{lllll|c|}
\hline Letters &.. &.. &.. &.. & $3,488,800,000^{1}$ \\
Postcards &.. &.. &.. &.. & $924,250,000^{2}$ \\
Halfpenny & Packets.. &.. &.. & $1,211,400,000^{3}$ \\
Newspaper & Packets.. &.. &.. & $207,100,000$ \\
Parcels &.. &.. &. &.. & $133,663,000^{4}$ \\
\hline & Total &.. &.. & $5,965,213,000$ \\
\hline
\end{tabular}

I In this number 35.5 million undelivered packets and 124.5 million redirected packets are included twice. The service performed in respect of both these classes of packet is, however, at least twice as great as that performed in respect of an ordinary packet; and as it is desired to estimate the cost of the normal service, no adjustment of the numbers is made on this account.

The total number actually delivered was $3,477,800,000$, but of these, $162 \cdot 3$ millions were foreign and colonial letters. As the number of foreign and colonial letters despatched (184.3 millions) exceeds the number received, and a foreign or colonial letter received plus a foreign or colonial letter delivered may be taken as equivalent to an inland letter fully dealt with, the number delivered in the United Kingdom has been adjusted by adding half the difference between the number of foreign and colonial letters despatched and received respectively.

2 Number of postcards delivered, 926.5 millions.

Number of foreign and colonial postcards delivered in the United Kingdom, $23 \cdot 3$ millions; number despatched, $18 \cdot 8$ millions.

3 Number of packets actually delivered, $1,172 \cdot 3$ millions.

Number of foreign and colonial packets of printed matter, commercial papers, and samples received, $44 \cdot 7$ millions; number despatched, $122 \cdot 9$ millions.

${ }_{4}$ Number of parcels delivered, 132,700,000. Number of foreign and colonial parcels received, 1,991,975; number despatched, 3,917,860. 


\section{TABLE B}

STATEMENT OF EXPENDITURE IN THE YEAR 1913-14 IN CONNECTION WITH THE POSTAL SERVICES, INCLUDING MONEY ORDER AND POSTAL ORDER BUSINESS, BUT EXCLUDING POST OFFICE SAVINGS BANK AND GOVERNMENT ANNUITY BUSINESS.

$\begin{array}{lllllll}\text { (a) Salaries, Wages and Allowances .. } & . & \ldots & \ldots & . & & 10,538,318\end{array}$

(b) Rent, Rates, Office Fittings, Water, Light and Heating .. 268,981

(c) Conveyance of Mails (excluding Payments to Foreign and Colonial Administrations) :-

$£ \quad £ \quad £$

By Rail-

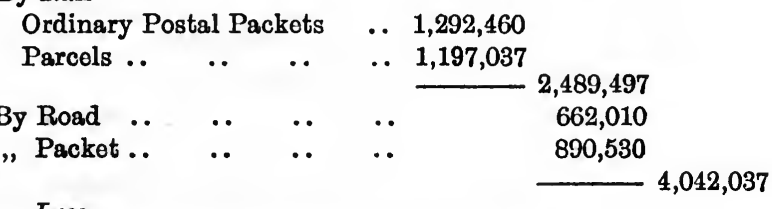

Less-

Contributions received towards the cost of Packet and

$\begin{array}{lllllll}\text { Mail services } & \text {.. } & \text {. } & \text {. } & \text {.. } & \text {. } & 130,335\end{array}$

(d) Purchase of Stores and Uniform Clothing $\quad . \quad$. .

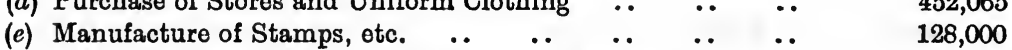

$(f)$ Travelling, Law Charges, and Incidental Expenses .. $\quad$.. $\quad 180,527$

(g) Estimated Rental Value of premises belonging to the Post

$\begin{array}{lllllll}\text { Office used for Postal purposes } & \text {.. } & \text {. } & \text {. } & \text {. } & & 278,344\end{array}$

(h) Estimated Pension liability for the year $\quad$.

Amount expended by other Government Departments in respect of various services rendered, viz. :-

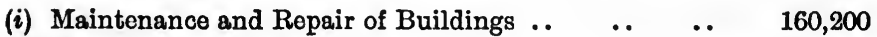

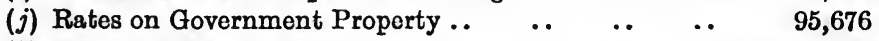

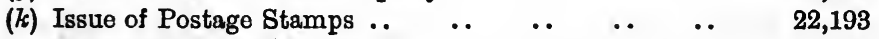

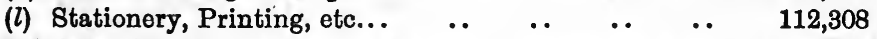

(m) Cost of Audit (Exchequer and Audit Department) .. $\quad 3,612$

(n) Net Revenue contribution to the Exchequer for the year .. $6,193,989$

-Annual Report of the Postmaster-General, 1913-14, Appx. N, p. 92. 


\section{TABLE C}

STATEMENT OF EXPENDITURE, SUMMARIZED AND ADJUSTED. Items in TABLe B.

Net Cost.

(a) and (h) Staff, $£ 11,707,724$.

Deduct-

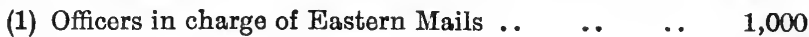

(2) Post Office Agencies Abroad ..

(3) Cost of Services to other Departments excluding 516,789

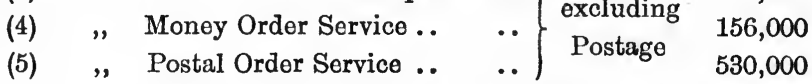

(6) „, Registration and Insurance Service .. 264,000

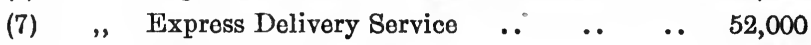

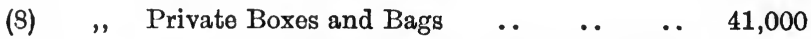

(9) " Cash on Delivery Service, Reply Coupons, Certificates of Posting, Late Fee $\begin{array}{llllll}\text { Services, etc. } & \text {.. } & \text {. } & \text {.. } & \text {.. } & 50,000\end{array}$

Proportion allocated to Staff $1,444,264 \quad 10,263,460$

$(b),(g),(i)$, and $(j) \quad$ Buildings, $£ 803,201$.

\section{Deduct-}

In respect of (3), (4), (5), (6), (7), (8), and (9) above $\quad . . \quad 96,587 \quad 706,614$

(c) Conveyance of Mails, £3,911,702.

\section{Deduct-}

(1) Packet Services outside the United Kingdom .. 582,935

(2) Conveyance of Mails across Panama $\quad$.

(3) Receipts from Foreign Countries for Land Transit 51,000

$(d),(e),(k)$, and $(l) \quad$ Stores, $£ 714,566$.

$636,866 \quad 3,274,836$

\section{Deduct -}

In respect of (3), (4), (5), (6), (7), (8), and (9) above $\quad \ldots \quad 86,938 \quad 627,628$

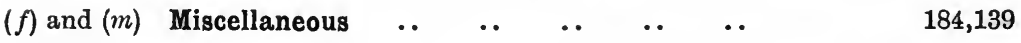

Total .. .. $£ 15,056,677$ 


\section{TABLE D}

\section{COST OF STAFF AND BUILDINGS.}

In the examination of proposals for revisions of staff and accommodation at post offices, the whole work of the offices is roduced to a common denominator for each chief division of the work, and is stated in terms of that denominator.

Thus all indoor work is reduced to and expressed in terms of units representing the work in connection with 1,000 letters posted and delivered, the term "letter." in this connection covering all packets sent by post other than parcels. There are no ratios for the separate classes of "letters."

All outdoor work is reduced to and expressed in terms of a unit of 1,000 letters (posted and delivered), i.e. the complete service.

For office accommodation the unit is 1,000 letters posted or delivered, whichever is the greater number at the office in question.

Certain ratios are taken for the expression in terms of letters of the various divisions into which the work performed by the post office falls.

As between letters and parcels the ratios are as follow :-

Units Ratios.

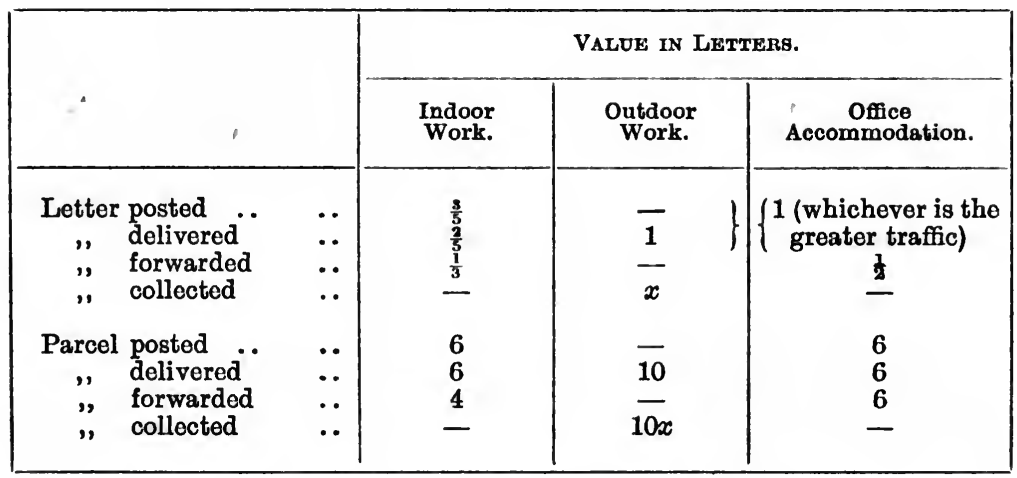

1,000 letters (weekly) $=1$ unit of postal work.

For each unit of work so determined there is a corresponding normal cost.

For indoor work the normal cost is approximately $£ 15$, for outdoor work $£ 2210$ s., and for office accommodation $£ 210$ s., per annum.

Since the unit to which a certain normal cost is allowed is built upon calculations which give a parcel a definite relative value as compared with a letter, the ratios show the relative cost to the Post Office of a letter and of a parcel. 


\section{TABLE E}

\section{RELATIVE COST OF STAFF FOR LETTERS AND PARCELS.}

It is estimated that on the average more than half the total number of letters are not sent forward direct to the post office of destination, but are forwarded from the office at which they are posted to an intermediate office; that is to say, more than half the total number of letters travel in two mails, and incur $\mathbf{a}$ handling at an intermediate office. The handling at that office is termed "forwarding." The letters are termed "forward letters." I Expressed in another way, the estimate is that all letters are forwarded, on the average, in 1.6 mails.

It is estimated that on the average a greater proportion of parcels travel in this way in two mails. The actual estimate is that a parcel travels in 1.8 mails.

Hence-

Total handling of 1 letter $=1$ letter posted +1 letter delivered +0.6 letter forwarded.

Total handling of 1 parcel $=1$ parcel posted +1 parcel delivered +0.8 parcel forwarded.

Now a letter forwarded $=\frac{1}{3}$ letter posted and delivered (Table D).

And a parcel forwarded $=\frac{1}{3}$ parcel posted and delivered (Table D).

Hence total handling of 1 letter $=1.2$ letter posted and delivered.

And total handling of 1 parcel $=1.26$ parcel posted and delivered.

The ratio between the total cost of handling (indoor) of 1 letter and the total cost of handling (indoor) of 1 parcel is therefore-

$$
1 \cdot 2 \times 1: 1 \cdot 26 \times 12=1: 12 \cdot 6
$$

The normal unit cost for indoor work is $£ 15$ (approximately).

For outdoor work the ratio is $1: 10$, and the normal unit cost $£ 2210$ s.

The ratio for all indoor and outdoor services is therefore approximately $1: 11$.

"This definition indicates the strict nature of "forward" packets. In practice it is, however, impracticable to divide postal packets precisely on these lines, and the actual statistics of "forward" packets are not exactly accurate. The practical division approximates, however, to the line of the exact division. 


\section{TABLE $\mathrm{F}$}

\section{ACTUAL COST OF STAFF FOR LETTERS AND PARCELS.}

The total cost of handling a parcel is $\mathbf{1 1}$ times the total cost of handling a packet other than a parcel (Table E).

In 1913-14 the total number of parcels dealt with was $133,663,000$ (Table A).

The cost of handling these parcels was equivalent to the cost of handling $133,663,000 \times 11=1,470,293,000$ packets other than parcels.

In 1913-14 the total number of packets other than parcels dealt with was $5,831,550,000$ (Table A).

And the total cost of staff engaged in dealing with all packets, including parcels, was $£ 10,263,460$ (Table C).

Hence the total cost of handling $133,663,000$ parcels was

$$
£ 10,263,460 \times \frac{1,470,293,000}{7,301,843,000}=£ 2,066,642 .
$$

And the total cost of handling $5,831,550,000$ packets other than parcels was $£ 8,196,818$. 


\section{TABLE G \\ ANALYSIS OF COST OF STAFF.}

LetTer Mails.

Total Cost, £8,196,818.

The handling of postal packets falls into the following groups of operations :-

(a) Collection and delivery,

(b) Facing, stamping, and sorting,

(c) Administration and accounting.

The cost of administration and accounting when reduced to the individual packet is extremely small. In general also it varies to some extent with the size of the packet. Thus the newspaper packets and the halfpenny packets, which are considerably heavier than the ordinary letters, notoriously involve more difficulty and expense in administration; and the postcard, the lightest postal packet, notoriously involves least difficulty and expense in administration. Parcels undoubtedly involve much more expense for accounting than any other class of packet; so that if the expense for administration and accounting be divided in the ratio adopted for sorting, stamping, collection, and delivery, which also depends largely on the weight of the packet, no appreciable error is introduced. No attempt is made, therefore, to isolate the expense for administration and accounting.

The total cost of collection and delivery is estimated to be double the total cost of facing, stamping, and sorting.

The cost of delivery is estimated to be four times the cost of collection.

The cost of sorting is estimated to be four times the cost of facing and stamping.

The total cost of handling packets other than parcels (excluding cost of conveyance) $=£ 8,196,818$.

Hence-

\begin{tabular}{|c|c|c|c|}
\hline \multicolumn{3}{|c|}{ mit. } & $£$ \\
\hline Tota & cost & f collection & $=1,092,909$ \\
\hline " & " & facing and stamping & $=546,455$ \\
\hline$"$ & ," & sorting & $=2,185,818$ \\
\hline " & ", & delivery & $=4,371,636$ \\
\hline & & Total & $£ 8,196,818$ \\
\hline
\end{tabular}


TABLE $\mathrm{H}$

RELATIVE RATES OF SORTING AND STAMPING.

\begin{tabular}{|c|c|c|c|c|c|}
\hline & & & & $\begin{array}{l}\text { Relative Rate } \\
\text { of Stamping. }\end{array}$ & $\begin{array}{l}\text { Relative Rate } \\
\text { of Sorting. }\end{array}$ \\
\hline \multicolumn{4}{|c|}{ Ordinary Letter Packets- } & & \\
\hline & & & .. & 1,000 & 100 \\
\hline \multicolumn{4}{|c|}{ (b) over 1 oz., not exceeding 4 oz. .. } & 75 & 75 \\
\hline (c) over 4 oz. .. & .. & .. & .. & 75 & 60 \\
\hline $\begin{array}{lll}\text { Postcards } & . . & . .\end{array}$ & .. & .. & .. & 1,000 & 100 \\
\hline Halfpenny Packets.. & .. & .. & .. & 750 & 90 \\
\hline Newspaper Packets & .. & .. & .. & 80 & 70 \\
\hline
\end{tabular}

Note I. The rates both as regards stamping and as regards sorting are not actual but relative rates. In both cases the handling of an ordinary light letter is taken as the standard with which the rate of handling other articles is compared. The table is intended to indicate, e.g., that if in a given period of time 100 ordinary light letters would be sorted, only 75 letters weighing between 1 ounce and 4 ounces, or only 90 halfpenny packets, would be sorted in the same period; or if in a given period of time 1,000 ordinary light letters would be stamped, only 75 letters over 1 ounce in weight, or only 80 newspapers, would be stamped in the same period. All that is aimed at is the normal relative rate of sorting for each class of packet. It is not necessary to ascertain the normal absolute rate.

Notr II. Rates of Stamping. - In determining rates of stamping, a serious complication is introduced by the use of machines (both hand and power) at many offices for stamping certain classes of packets. In London, where approximately one-third of the total number of postal packets is posted, power machinestamps are employed, except at a few of the sub-district sorting offices, at which hand machine-stamps are still employed. There are a few of the smaller offices at which all the stamping is done by hand, but the number of such offices and the number of packets so stamped is negligible. The power machine stamps at rates varying from 12 to 16 times as great as that of an officer stamping by hand; the hand machine stamps at a rate about ten times as great.

Power machine-stamps are in use in the provinces in towns in which approximately a quarter of the total number of postal packets is posted.

Hand machine-stamps are in use in other towns in the provinces where approximately one-twelfth of the total number of postal packets is posted.

In the remaining towns there is hand stamping only.

The foregoing estimates give an average rate of stamping throughout the kingdom for those classes of packets which are of a size and shape to pass through the machine-stamp, where available, of about ten times as great as that of an officer stamping by hand. 


\section{TABLE H (continued)}

This figure must now be applied to the various classes of packets shown in the table, in conjunction with the rates of hand-stamping for such packets as cannot be passed through the machine-stamp.

(a) Practically all letters under 1 ounce,can be passed through the machinestamp if available. Hence the rate for this class is ten times the rate of hand-stamping.

(b) None of the second or third classes of packets can be passed through the machine. Further, these packets are of irregular shape and are therefore much less convenient to deal with than ordinary letters. The rate of hand-stamping is therefore only about three-fourths the rate for ordinary letters.

(c) All postcards can be passed through the machine-stamp if available. The rate is therefore ten times the rate of hand-stamping.

(d) A large proportion of halfpenny packets cannot, on account of their size and shape, be passed through the machine-stamp, and the figure for the machinestamp must be considerably reduced for these packets. The nearest estimate that can be formed for these packets is $7 \cdot 5$ times the rate for hand-stamping.

(e) Newspapers cannot be passed through the machine-stamp, but in a number of cases the wrappers are taken to the post office before the newspapers are enclosed in them for cancellation of the postage stamps (in order to secure a prompt despateh when the newspapers are actually posted). The rate for such stamping is slightly greater than the rate of hand-stamping for ordinary letters. On the other hand, the rate of stamping newspaper packets is not more than two-thirds the rate of hand-stamping ordinary letters. The nearest estimate that can be formed for all newspapers is that the rate of stamping is four-fifths the rate of hand-stamping ordinary letters.

Nоте III. Rates of Sorting.-(a) The average rate of sorting for ordinary letters is taken as the unit.

(b) The rate of sorting letters and the rate of sorting postcards may be taken as identical.

(c) Owing to the irregular shape of newspaper packets, and letter packets over 4 ounces in weight, the average normal rate of sorting must be taken as considerably less than that for letters.

Both classes are usually sorted at the packet tables and not at the ordinary letter frames.

(d) The letter packets between 1 ounce and 4 ounces in weight present some difficulty, since they include a considerable number of long letters, which are sorted at the ordinary letter frames at nearly the same rate as short letters, while the rest are sorted at the packet tables at about the same rate as the heavier packets. The figure should obviously be between $(a)$ and $(c)$.

(e) The halfpenny packets also fall into two classes: (1) those sorted as short letters, and (2) those sorted at the newspaper frames. A very large proportion fall into the second class, and the average normal rate of sorting, as in the case of the second class of letter packets, is intermediate between $(a)$ and (c). 


\section{TABLE J}

STAFF.

This table shows the relative cost per packet, based on the rates of work (Table $\mathrm{H}$ ), the cost of an ordinary letter being taken as the unit.

\begin{tabular}{|c|c|c|c|c|}
\hline Description of Packet. & Collection. & $\begin{array}{l}\text { Facing and } \\
\text { Stamping. }\end{array}$ & Sorting. & Delivery.2 \\
\hline 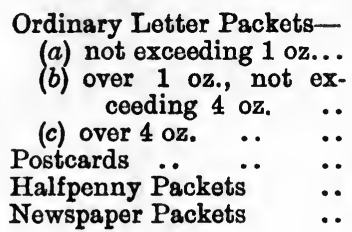 & $\begin{array}{l}1 \\
1 \\
1 \\
1 \\
1 \\
1\end{array}$ & $\begin{array}{l}1 \\
62 \\
6 \frac{8}{3} \\
6 \frac{2}{8} \\
1 \\
14 \\
64\end{array}$ & $\begin{array}{l}1 \\
1 \\
1 \frac{1}{8} \\
1 \frac{2}{3} \\
1 \\
1 \frac{1}{9} \\
1 \frac{3}{7}\end{array}$ & $\begin{array}{l}1 \\
1 \frac{1}{8} \\
1 \frac{2}{3} \\
1 \\
1 \frac{1}{9} \\
1 \frac{3}{7}\end{array}$ \\
\hline
\end{tabular}

1 Adjusted to allow for the fact that two men are needed to work the machinestamp. The cost of the machine-stamp itself is a negligible item.

2 For the relative cost of delivery the same rates are taken as for the cost of sorting. There are no data on which any actual comparison can be based, but it is obvious that the same features, viz. irregularity of shape and size, which lead to differences in the cost of sorting lead to similar differences in much the same degree in the cost of delivery.

\section{TABLE $\mathrm{K}$}

\section{STAFE (RELATIVE COST).}

This table shows the ratios in Table $J$ weighted according to the number of packets in each class.

\begin{tabular}{|c|c|c|c|c|}
\hline Description of Packet. & Collection. & $\begin{array}{l}\text { Facing and } \\
\text { Stamping. }\end{array}$ & Sorting. & Delivery. \\
\hline 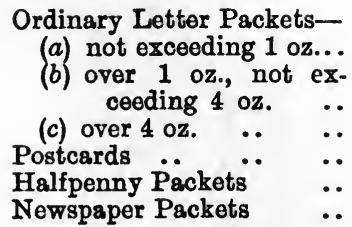 & $\begin{array}{l}1 \\
0.113 \\
0.045 \\
0.306 \\
0.402 \\
0.069\end{array}$ & $\begin{array}{l}1 \\
0.755 \\
0.299 \\
0.306 \\
0.503 \\
0.430\end{array}$ & $\begin{array}{l}1 \\
0 \cdot 151 \\
0.075 \\
0.306 \\
0.447 \\
0.098\end{array}$ & $\begin{array}{l}1 \\
0.151 \\
0.075 \\
0.306 \\
0.447 \\
0.098\end{array}$ \\
\hline
\end{tabular}




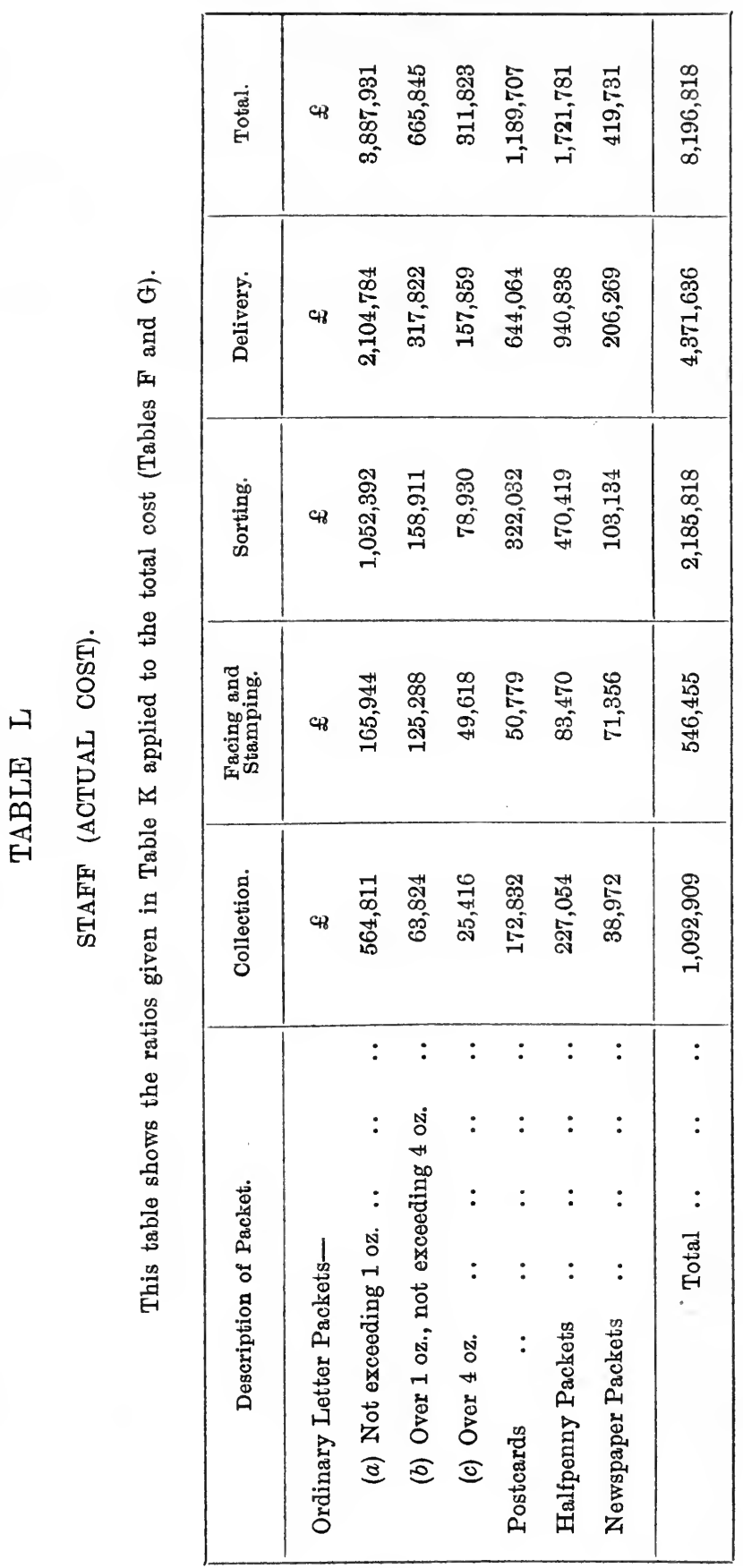




\section{TABLE M}

\section{CONVEYANCE.}

Total Cost of Conveyance of Mails within the United Kingdom :
(a) For Conveyance by Railway .. $\quad$.. $\quad$.. $2,435,566$

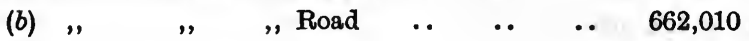

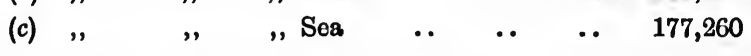
Total .. .. $£ 3,274,836$

Of the payment for conveyance by railway, $£ 1,238,529$ is the cost of the conveyance of letter mails, and $£ 1,197,037$ the cost of the conveyance of parcel mails.

The payment for conveyance by road is, on such estimate as can be made, assignable in equal proportions between letter mails and parcel mails.

Of the payment for conveyance by sea, $£ 150,000$ is, on such estimate as can be made, assignable to the conveyance of letter mails.

The cost of the conveyance of letter mails is therefore-

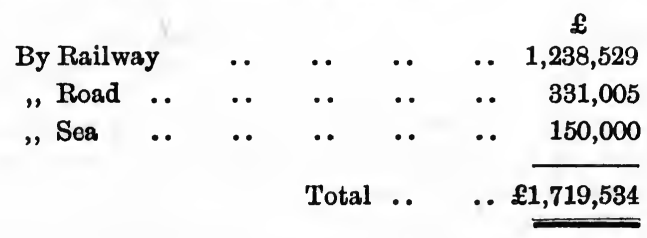

And the cost of the conveyance of parcel mails is-

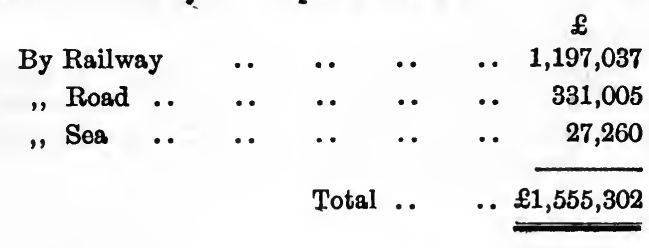




\section{TABLE $\mathrm{N}$ \\ CONVEYANCE : ANALYSIS OF COST.}

Letter Mails.

Total Cost, £1,719,534.

Cost of conveyance is assigned between the various classes of packets in proportion to the gross weight.

\begin{tabular}{|c|c|c|c|c|c|}
\hline \multicolumn{4}{|c|}{ Description of Packet. } & Gross Weight.x & $\begin{array}{c}\text { Cost of } \\
\text { Conveyance. }\end{array}$ \\
\hline \multicolumn{4}{|c|}{ Ordinary Letter Packets- } & lb. & $£$ \\
\hline \multicolumn{4}{|c|}{ (a) Not exceeding $1 \mathrm{oz}$. } & $67,200,000$ & 437,734 \\
\hline \multicolumn{4}{|c|}{ (b) Over 1 oz., not exceeding $4 \mathrm{oz}}$. & $41,700,000$ & 271,600 \\
\hline (c) Over 4 oz. .. & . & $\cdots$ & $\cdots$ & $54,000,000$ & 351,700 \\
\hline Postcards .. .. & .. & .. & $\cdots$ & $8,203,000$ & 53,450 \\
\hline Halfpenny Packets & .. & .. & .. & $37,705,000$ & 245,600 \\
\hline Newspaper Packets & .. & .. & $\cdots$ & $55,192,000$ & 359,450 \\
\hline
\end{tabular}

- The average weight of letter packets not exceeding 1 ounce is 0.357 ounce. The average weight of all letter packets is 0.747 ounce. In the case of packets between 1 ounce and 2 ounces the average weight is assumed to be 1.4 ounces; and $2 \cdot 6$ ounces in the case of those between 2 ounces and 4 ounces.

Of ordinary letter packets, 86.34 per cent. do not exceed 1 ounce in weight, 5.25 per cent. are between 1 ounce and 2 ounces, and 4.53 per cent. are between 2 ounces and 4 ounces in weight.

The average weight of a postcard is 0.142 ounce, of a halfpenny packet 0.498 ounce, and of a newspaper packet 4.264 ounces $(97.57$ per cent. containing only one newspaper, average weight $4 \cdot 159$ ounces ; 2.43 per cent. containing two or more newspapers, average weight 8.461 ounces). 


\section{TABLE O}

\section{B U I L D I N G S.}

Total Cost, £706,614.

Twelve times as much office accommodation is required in respect of a parcel as in respect of a packet other than a parcel (Table D).

Hence-

The total cost of buildings may be divided as between parcels on the one hand and all packets other than parcels on the other hand in the ratio-

$$
133,663,000 \times 12: 5,831,550,000
$$

i.e. $1: 3 \cdot 6357$

The total cost for buildings chargeable to parcels is therefore $£ 152,428$, and the total cost for buildings chargeable to other packets is 2554,186 .

The latter sum is assigned between the respective classes of packets in proportion to the gross weight of each class (Table N) as follows :-

Cost for Buildings.

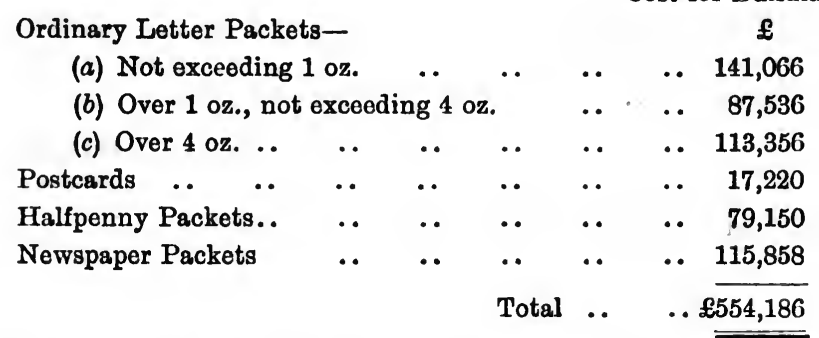

This division gives an advantage to the light packets as compared with the heavier packets sent by Letter Post; but, as between parcels and other packets, an advantage is given to parcels (cf. supra, Table E). 


\section{TABLE P \\ STORES AND MISCELLANEOUS EXPENDITURE.}

Total cost, $£ 811,767$.

As between parcels and other packets respectively, this amount is assigned on the unit basis, reckoning one parcel equivalent to twelve other packets (Table D).

As between the various classes of packets other than parcels, the amount is assigned on the basis of simple numbers.

Ordinary Letter Packets-

\&

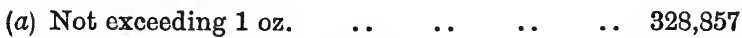

(b) Over 1 oz., not exceeding 4 oz... $\quad \ldots \quad \ldots \quad 37,251$

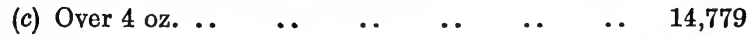

$\begin{array}{lllllllll}\text { Postcards } & \text {.. } & \ldots & \ldots & \ldots & \ldots & \ldots & \text {. } & 100,904\end{array}$

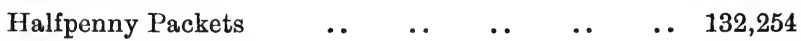

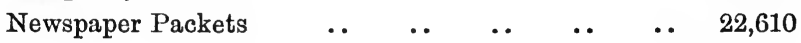

$\begin{array}{lllllllll}\text { Parcels } & \ldots & \ldots & \ldots & \ldots & \ldots & \ldots & \ldots & 175,112\end{array}$

Total $\quad . \quad \ldots £ \overline{\$ 11,767}$

This method gives an advantage to the heavy packets. 


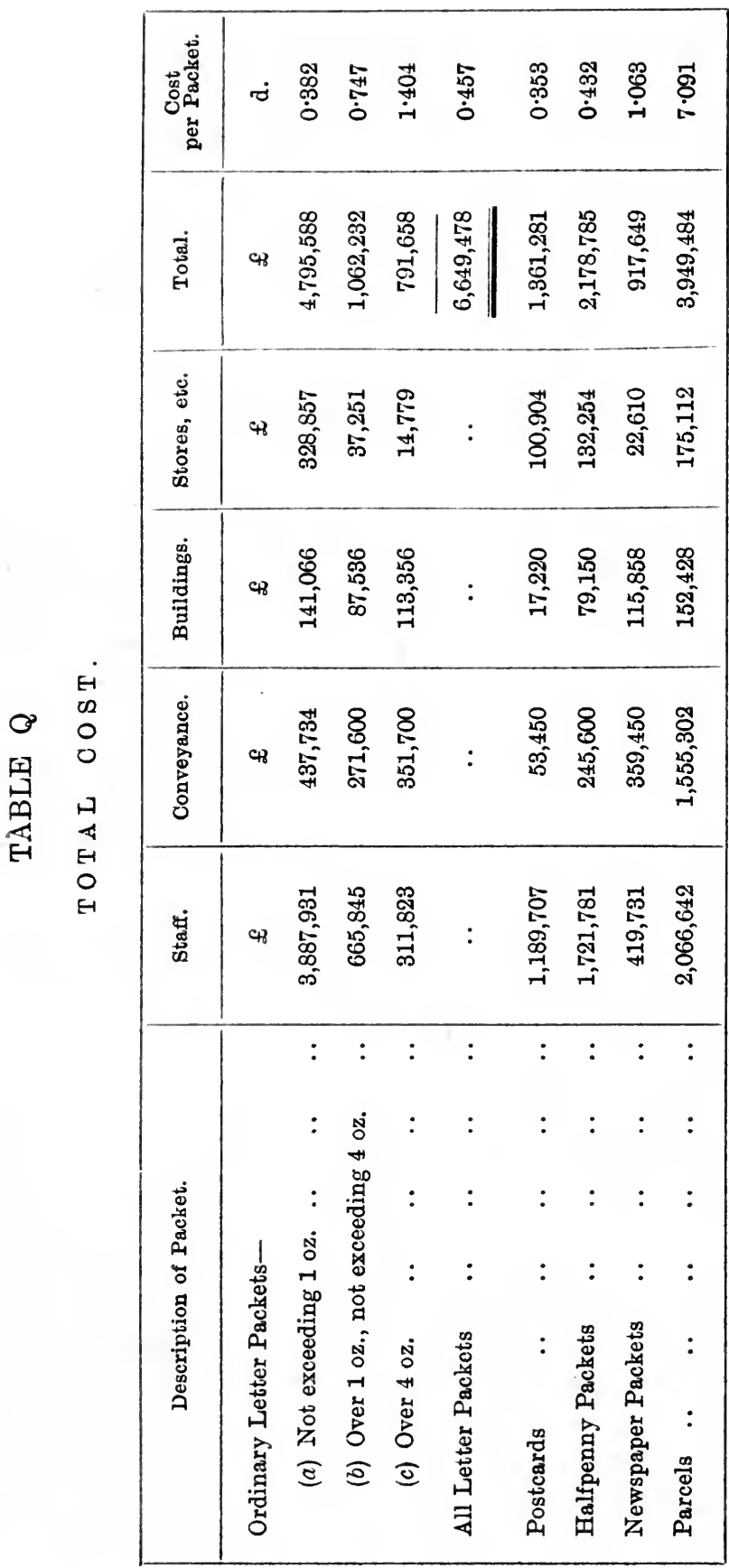




\section{VIII}

\section{CONCLUSION}

IN relation to the rate of postage, the traffic of the Post Office falls into two main groups: on the one hand light letters and packets approximating to that type, and on the other the heavier packets and parcels. This division corresponds with an important difference in the practical working of the Post Office service, the task of providing for the transmission of ordinary letters, hundreds of which can be conveyed by foot-messenger without difficulty, being one entirely different from that of providing for the transmission of larger packets, a few scores of which would render necessary the use of a vehicle.

As to the transmission of letters, Sir Rowland Hill first perceived the significance of the fact that with objects of light weight the cost of conveyance, even over great distances, is small, and in his scheme of reform he consciously applied this fact to the determination of the rate of letter postage. This consideration remains; and as regards the ordinary letters of business or private communication-the average weight of which is less than half an ounce-the principle of uniformity of rate irrespective of distance, which is now the characteristic of letter postage, is well founded. Of the whole expense of conducting the postal services, the expense of the actual conveyance of a letter from place to place is not only small as compared with the cost of the terminal services of collection and delivery, but is actually so small in amount that no monetary system provides a coin of sufficiently small value to make its collection a practical possibility. The 
uniform rate, by making practicable the system of prepayment of postage by means of adhesive labels, has, moreover, effected great economy in the working of the service, and its simplicity is a boon to the public, the more so as it has been possible to fit the common rate to a popular coin. A low uniform rate is, however, only made possible from the financial standpoint by the Post Office monopoly of the carriage of letters, although that monopoly is justified on other grounds. With a uniform rate, owing to the varying conditions under which the service is conducted in different districts, there is inevitably a variation in the amount of profit. In certain cases, the rate is actually unprofitable; and were private undertakings permitted to compete for the more profitable traffic, such as the local traffic in large centres of population, the profits of the Post Office would be reduced to vanishingpoint.

Improvements in the means of communication have naturally had considerable effect on the development of the Post Office. The introduction of the stage-coach in the eighteenth century, and of railways and steamboats in the nineteenth, in turn revolutionized the methods of general transportation. By these improvements the capacity of the Post Office was largely increased, and regularity, rapidity, and increased frequency of service made possible. But such general improvements, while of the utmost importance as regards the capacity and character of the Post Office service, can affect the rates of postage only so far as they affect the cost of transportation of the mails, or, by largely increasing traffic, enable economies of business on a large scale to be secured. The stage-coach cheapened the cost of transportation, but, in England, had no effect on the rates of postage, because at the time of its introduction the charges were of a purely fiscal character, and the benefit of cheaper transportation was not passed on to the users of the Post Office. The effect of the introduction of the railway has, at any rate as regards letter postage, not been much greater. Sir Rowland Hill's reform, which standardized letter postage, was based on the ascertained cost of conveyance of mails by stage-coach. $\mathrm{I}$ He found the cost of such conveyance too

s Life of Sir Rowland Hill and History of Penny Postage, vol. i., p. 249. 
small to be taken into account; and the introduction of the railway could not, of course, improve such a situation. ${ }^{\mathbf{I}}$

The ordinary light letter, weighing on the average considerably less than an ounce, comprises the overwhelming bulk of Post Office traffic, and the heavier letters occupy a quite subsidiary place. With the growth of Post Office traffic, and the consequent economies resulting from business on a large scale, the profits of the Post Office have gradually increased, but not to such an extent as to admit of the reduction of Sir Rowland Hill's penny rate without destroying the net revenue. Any reduction has been limited to the heavier letters.

The penny rate for the ordinary letter, though so moderate, is considerably in excess of the average cost even of longdistance letters. ${ }^{2}$ Its maintenance, therefore, depends not on economic, but on general political and financial considerations. The question is, what general considerations shall be allowed to govern the rate? Shall it be fixed on the simple basis of cost and revenue, or shall it be fixed at such a level as to yield a surplus revenue? In other words, is it thought that the general public advantages which would result from a reduction of postage to the cost basis would counterbalance the disadvantages which would result from the loss of public revenue? This question will, of course, be answered in accordance with the varying circumstances in the different countries and at different times. 3

x Sir Rowland Hill was strongly of opinion that the use of the railway increased the cost of conveyance of mails (Life of Sir Rowland Hill and History of Penny Postage, vol.i., pp. 329 and 412). The cost of conveyance by stage-coach from London to Edinburgh was, according to Sir Rowland Hill, about $\frac{1}{36}$ th of a penny per letter, and less for the whole country (ibid., vol.i., p. 249; Post Office Reform: Its Importance and Practicability, pp. 18-19). The cost of conveyance by railway at present averages for the whole kingdom about $\cdot 05 \mathrm{~d}$. per letter.

an important fact in this connection is that the service is adjusted to the circumstances of the respective countries. Thus, in England and France, provision is made for the delivery of letters at every house in the country, while in the United States and Canada there is in general no house-to-house delivery in rural districts. Until recently there was no rural delivery service of any kind in the latter countries. Letters could be obtained only at the rural post offices. And the system now being introduced provides only for delivery into roadside boxes at the points on the rural deliverer's route nearest to the house of the addressee. Such adjustments, of course, materially affect the cost and profit of the service.

3 E.g. the war increases in the United Kingdom and in other countries. The point is further considered in the Appendix "Post Office Revenue," infra, p. $358 \mathrm{ff}$. 
An important consideration in relation to any proposal for reduction or increase of the letter rate, or, indeed, of any rate of postage, is, of course, the probable effect on the volume of traffic. Sir Rowland Hill, when he put forward his plan, laid stress on the increase in the number of letters which he anticipated would follow the adoption of his proposal. Since that time it has become almost an axiom that a reduction of rate will naturally and inevitably be followed by an increase of the traffic, more or less considerable, according as the reduction is large or small. Indeed, some writers have thought that the new postal system was based on a law of fixed relative proportions between a reduction of rate and the corresponding result on traffic. In point of fact, Sir Rowland Hill's estimates were based only partially on the probable effect of the reduction in stimulating traffic, and rather on the anticipation that, with a rate reasonably low, all that vast letter traffic which it was well known was being unlawfully dealt with outside the Post Office would be attracted to the lawful service. It is probable that a point of approximate satiety can be reached in the reduction of postage rates no less than in the reduction of the price of other commodities. A reduction would then result in only slightly increased consumption of the commoditythat is, in the case of letters, increase of the number posted. Per contra, a moderate increase of rate would result in a comparatively small reduction of the number of letters. ${ }^{\mathbf{x}}$ But moderate variations of postage on ordinary letters are difficult to make, since popular charges, such as a penny or halfpenny, while they offer obvious advantages from many points of view, are not susceptible of slight modifications.

The variation of rate according to the weight of the packet is a point which has received insufficient attention. There can be no doubt that the cost to the Post Office of performing the service it affords in respect of packets of any kind entrusted to it increases with the increase of the weight and size. But it does not increase proportionately. A letter of 8 ounces does not cost twice as much to collect, transmit, and deliver as a letter of 4 ounces. The operations of

I Graphically, the variation of the number of letters with changes in the rate of postage would be represented by an asymptotic eurve. 
stamping, sorting, and making up for despatch occupy more time and cause more inconvenience in the case of the larger packet, but the difference is slight when compared with the difference in size and weight. Nor does the cost of conveyance vary directly with the weight. In any system of rates, therefore, which are accurately adjusted to the cost of the service, the rate of charge must increase considerably less rapidly than the increase in weight, that is to say, the rate would be degressive. Of modern postage rates very few are constructed on this principle, and to that extent they are uneconomic. In the case of letters, since the weight of the packet is normally unimportant, and simplicity of charge very important, this factor has been for the most part ignored.I

The same consideration which makes the uniform rate irrespective of distance economically just in the case of ordinary letters, takes away any ground on the score of cost of service for a special rate for local letters lower than the general uniform rate. On the other hand, the considerations which make for monopoly and unified control in the case of a general service, do not apply with the same force in the case of a service limited to a small area. In the latter case, competition can much more easily be set up; and as the uniform penny rate is much higher than the cost of service even in the case of long-distance letters, competing agencies, which can leave aside unprofitable districts, such as the rural districts, can secure a profit on a local service while charging much lower rates. The maintenance of a local rate for letters side by side with a uniform rate 100 per cent. greater for all distances outside the local area, as in Canada, is nevertheless inconsistent from the economic standpoint.

The postcard, which may be regarded as a development of the letter post, is, in effect, an admission that the letter rate is much higher than the cost of service. The difference in cost of service in the case respectively of a light letter and

I It appeared in the English letter rate of 1885, but disappeared with the changes of 1897 . It has been reintroduced into the letter rate with the war changes of November 1915, and the result is an awkward scale. 
a postcard is negligible. Indeed, in some respects light letters are more easily and more rapidly handled than postcards. From that standpoint, therefore, there is nothing to justify the difference of 100 per cent. in the rate of charge, and the lower rate is an arbitrary concession. The logical ground for its existence is rather to be looked for in the familiar and generally accepted principle applied to the determination of transportation rates by railway, by road, or by sea, viz. charging "what the traffic will bear," or the variation of the rates according to the intrinsic value of the goods transported.I Many messages are sent on postcards which otherwise would be sent as closed letters. But, at the same time, many messages are sent on postcards which otherwise would not be sent at all. This has been especially the case since the introduction of the picture postcard.

These remarks apply equally to the lower rate which has been conceded to circular letters. Both rates represent a great concession relatively to the letter rate, and under them a large traffic has grown up. ${ }^{2}$ They "closely approximate to the actual cost of service, and probably yield a small profit. They are of great importance in the general scheme of rates, because they provide a cheap means for the transmission of a very large proportion of ordinary personal and commercial messages, and thus indirectly strengthen the position of the profitable penny rate for ordinary letters.

The picture postcard has strengthened the position of the letter rate in another way, viz. by raising the cost of sending a postcard, so that in many cases it is now greater than that of a letter. A common charge for a picture

3 This point is dealt with more fully in connection with the parcel rate.

The whole question of subsidiary rates is dismissed by Bastable with the following :-

"One of the principal distjnctions now turns on the character of the articles transmitted. Circulars and postcards would not bear the same charge as ordinary letters. The transmission of newspapers gives a yet smaller fund of utility on which to levy a tax, and is affected by the competition of carrying agencies. The result is seen in the lower halfpenny rate."-C. F. Bastable, Public Finance, London, 1903, p. 208.

2 In England two-fifths of the total number of postal packets pass at a halfpenny. 
postcard is a penny; the cost of sending a communication on such a card by post is then three-halfpence, whereas the cost of a letter is only a penny plus the very slight cost of the paper and envelope.

The newspaper rate involves some new considerations. The original aim of the posts was the distribution of a certain form of intelligence. They had by the seventeenth century developed into an instrument whose main function was the distribution of letters. The first postal traffic in packets which were not letters was that in newspapers. The early newspapers were, however, in fact as well as in some cases in name also, merely news "letters," and it would have been surprising, therefore, had the posts not been made use of for their distribution. For newspapers, however, the charges have from the first been of a fundamentally different character from those for letters, and the traffic in newspapers, so far from being a source of profit, has in general resulted in heavy loss. There are certain general considerations which render the application of the rates of postage charged on letters inappropriate. The bulk and weight of a single newspaper is usually much greater than the bulk of a single letter; and if the newspaper were charged at the same rate and on the same basis as the letter, viz. by weight, it must in general be charged several times the rate for an ordinary letter. Such a charge would be unjust, because, as already pointed out, the cost of performing the services of transportation and delivery does not increase in direct proportion, or anything approaching direct proportion, to the increase of weight. If a newspaper is regarded as a very heavy letter, the importance of the factor of weight is at once perceived. Weight charges levied on newspapers should at least be on a degressive scale. But any system of charge by weight proportioned to letter postage must lead to a higher charge than that for a single letter. How much higher is of little consequence, because even the rate for single letters would be almost prohibitive for ordinary newspapers. The papers would either be excluded from the mails and despatched by private agencies, where such agencies exist, or, in countries where the Post 
Office holds the monopoly of the carriage of newspapers, the traffic would be greatly restricted.

A lower rate for newspapers is also justified on the principle of charging "what the traffic will bear." But the chief reason is that it has usually been considered desirable to encourage the distribution of newspapers for the benefit of the public; and in its origin, the special rate for newspapers seems to rest rather on the two general considerations of the expediency of providing for the easy distribution of intelligence, and the impossibility of charging newspapers with the same rate as letters.

Merchants' and manufacturers' samples are not, of course, strictly speaking, of the nature of correspondence, and their conveyance by post represents in some aspects an expansion of function. The main function of the Post Office is the distribution of letters, or, as it may be expressed generally, the distribution of any species of communication between persons, reduced to material form, whether as manuscript letters, postcards or circular letters, printed or written, or even in the form of newspapers. For samples of merchandise some relationship to ordinary communications may perhaps be claimed. They are themselves often the necessary complement of letters of business and are forwarded in order to convey a precise notion of the commodities with which the business is concerned, a purpose served much more effectively by the small sample than by the descriptive letter, which would be the only alternative. So far, then, as the Post Office is intended to assist the transmission of information of whatever sort, the carriage of merchants' samples is perhaps a legitimate part of its function, especially as the encouragement of trade is no small part of its main function. The transmission of small packets not inconvenient to handle and transport, although essentially different in make-up from letters, was therefore a natural development when advantage to commerce would result.

The impracticability of charging the ordinary letter rate, since such a charge would have been prohibitory, which has influenced the newspaper rate, is equally applicable to samples. The case for a lower rate was strengthened by 
the consideration that commerce would benefit, and the general considerations of the justice of a lower weight-rate for moderately heavy packets and for packets of less intrinsic value, applied to sample packets, no less than to newspapers, although this point of view was not perhaps consciously adopted. Based on these considerations, a special rate was given to samples, fixed more or less arbitrarily, and without examination into the question of what rate would be the lowest profitable rate for the business.

The basis of the book rate is only to a slight degree economic, that is to say, related to the cost of providing the service. The justification for a low rate rests for the most part on the same considerations as the privileged rate for newspapers: the desirability of assisting the education of the people and the utility of books for the purpose, the comparatively low intrinsic value, and the impossibility of charging the scale of rates applied to letters-even less possible in the case of books than in the case of newspapers.

The exceptionally low rate for printed matter for the blind has been given as a measure of philanthropy. By its means, although at some loss to postal revenue, the effect of the disadvantage of bulk and weight in such printed matter, which results from the affliction, is in a large degree removed. ${ }^{x}$

The question of the rate to be applied to parcels is one

T The concession of specially low rates for these classes of packets has given rise to a noteworthy general line of division between postal packets. All packets passing at privileged rates must obviously be subject to examination and check by the Post Office in order to ensure that the privilege is not abused, a necessity which leads immediately to the principle of the "open" post, as contrasted with the "closed" post, the ordinary sealed letter packet. The difference in charge is not, however, based on the consideration that the packets are open to inspection. The effect is in the reverse direction. The view of practical officers is that, other things being equal, the treatment of a packet sent by the Open Post is more expensive to the Post Office than its treatment if sent by Letter Post.

The requirement is imposed in order that compliance with other conditions may be ensured. In none of the five countries are ordinary letters allowed to pass at postcard rate if merely enclosed in open covers. But a printed circular letter, if sent in a sealed cover, would lose its claim to the privileged rate. 
of considerable difficulty. While considerations of public utility would probably make it undesirable for the State to derive a profit from the business, they would hardly extend to the point of conducting a large transportation business at a loss, and the results in England and Germany show bow important and difficult is the problem of fixing remunerative rates. The rates for newspapers, samples, ordinary printed matter, etc., have been accorded not solely with reference to the cost of the service, but on grounds more or less political and social as regards the fact of granting a privileged rate, and more or less empirical as regards the fixing of the actual amount of the charge. For the most part this method has answered sufficiently well, the reason being that the cost per packet is comparatively small, and the privileged traffic has not generally assumed large proportions relative to the letter traffic. These empirical methods cannot, however, be applied in the case of parcels. The expense of the service performed by the Post Office is not, as with a letter, actually small, and confined to that of collection at one end and delivery at the other end of the journey, with a negligible cost (per packet) for transmission between the points of origin and destination. Cost of transportation itself becomes an appreciable item in respect of every parcel. For this transportation the Post Office is in the main dependent on the railways, and in the determination of its cost the principles determining ordinary railway rates must necessarily apply.

Those principles are complex and to a large degree indeterminate. On the problem of railway and other transport rates many volumes have been written, and many more will yet be written before a solution is arrived at. ${ }^{\mathrm{I}}$ Railways,

I "Fixing a railway rate is, in one word, an art-not a science, and it is an art which, in Bagehot's phrase, must be exercised 'in a sort of twilight, ... in an atmosphere of probabilities and of doubt, where nothing is very clear, where there are some chances for many events, where there is much to be said for several courses, where, nevertheless, one course must be determinedly chosen and fixedly adhered to.' "-W. M. Acworth, Elcments of Railway Economics, Oxford, 1905, p. 73.

"The problem of railway rates has not, like that of postal charges, passed beyond the domain of current discussion. This is in part due to the fact that railways are universally regarded as a source of profit, to companies when privately owned, to the State when public property; but it is in larger measure 
like the Post Office, are unable to allocate the actual working costs with any degree of precision between the various kinds of service they perform. Like the Post Office, they have one general set of expenses, although they have diverse sources of revenue. ${ }^{\mathrm{I}}$ Even if the cost of service could in each case be definitely ascertained, its adoption as the sole basis of the rates would prove unsatisfactory. ${ }^{2}$ For the most part the principles on which the rates are actually fixed resolve themselves into a consideration of "what the traffic will bear," that is to say, the test by actual observation and computation, strengthened, if need be, by actual experiment, of the rates which will yield the maximum advantage to the railway company.

The advantage to the railway conducted under private management may be defined to be the excess of receipts from the traffic over the out-of-pocket expenses actually incurred in handling the traffic. To obtain this maximum it has been found necessary to vary the charge according to the nature of the goods. Elaborate, detailed classifications of goods have been arranged with distinct scales of rates for each class, devised on the basis of charging each

due to the fact that the social significance of railways is not yet clearly understood. The problem of railway rates is a problem by itself, and stands as one of the most important of the unsettled problems of the day." -H. C. Adams, Science of Finance, New York, 1909, p. 280.

I "The cost of the service of transport for any given commodity cannot, under the varying conditions of railway operation, be even approximately calculated. The first insuperable difficulty is the division of the expenditure for any given work. Though railway economists have endeavoured, by means various and ingenious, to allocate the different items of railway expenditure, they have been unable to determine such a relatively simple matter as the division between passenger and goods traffic, and though estimates have been formulated, many of the charges have been allocated to one head or another by arbitrary decision, and not as a result of positive knowledge."-Railway News, London, 6th September 1913, p. 396.

2 "Though all the rates must be so fixed as to pay all the expenses both of coustruction and working, separate rates cannot be fixed according to cost of individual service or even according to the average cost of services to traffic i $n$ the same group. For in the first place the cost of the service cannot be ascertained. And secondly, if it could be ascertained, it would be of no use as a standard. To charge the average cost would be to drive away a large portion of the traffic and so increase almost proportionately the average cost of the remainder. This increase would then drive away a fresh portion, and so once more increase proportionately the cost to that still remaining. And so on."-W. M. Acworth, "The Theory of Railway Rates," Economic Journal, London, 1897 , p. 324. 
kind of goods with the rate likely to yield to the railway the maximum of advantage as defined above. ${ }^{\mathrm{I}}$ Although somewhat crude and a little empirical, certainly largely arbitrary, this method has been almost universally adopted for the determination of railway charges. ${ }^{2}$

A characteristic feature of such charges is that account is invariably taken of the distance over which the goods are transported. In contrast with this, the principle of uniformity of rate irrespective of distance has been universally adopted in regard to all postal packets other than parcels, and to some extent for parcels. The application of the principle to parcels rests, however, on other grounds than its application to letters. Sir Rowland Hill himself never contemplated that the principle was necessarily applicable to all matter which might be sent by post. 3 The circumstances under which he made his discovery, and the facts on which he relied, make it plain that, in the absence of other overpowering considerations, the grounds advanced in the case of light letters will not justify uniformity of rate irrespective of distance for packets of

"The process is in practice worked out as follows. First comes classification. The whole of the commodities known to commerce are entered on a list divided into classes, eight in number here, six in France, and about ten in number in the United States. To each class belongs a normal scale of rates, ranging, let us say, from $\frac{3}{4} \mathrm{~d}$. per mile in the lowest to $4 \mathrm{~d}$. per mile in the highest. The classification undoubtedly takes account of greater or less cost of carriage to the companies, arising out of the differences of packing, liability to theft or damage, proportion of space occupied to weight, etc. But it is safe to say that its main principle is, the more valuable the commodity, the higher the rate it can afford to pay."-Ibid., p. 325.

2 "Historically this theory has been recognized and approved by English legislation from the time when Adam Smith applauded the equity of statutory turnpike tolls at the rate of one shilling for a light carriage and eightpence for a heavy dray, through the whole long series of Canal Acts and Railway Acts, down to the elaborately careful revision of the railway companies' charging powers in the series of Provisional Order Confirmation Acts dated 1891 and 1892. The opinion of modern economists all over the world as to the justice of the underlying principle may be conveniently summarized in a sentence borrowed from the first annual report of the American Interstate Commerce Commission : 'With this method of arranging tariffs little fault is found, and perhaps none at all by persons who consider the subject from the standpoint of public interest.' "-Ibid., p. 317.

3 "One great element of the reform introduced by you in the postage was, that there should be one uniform rate throughout?-Yes, it was proposed with a view to simplification, but the principle has been carried to an extent that I did not contemplate, and did not recommend."-Evidence of Sir Rowland Hill, Report of Select Committee on Newspaper Stamps, 1851, Question No. 1945. 
considerable weight, which necessarily involve appreciable cost for transportation. From the financial point of view, the uniform rate is, moreover, inapplicable to any class of traffic not secured to the Post Office by monopoly, since private undertakings will always step in and take away the profitable sections.

For heavy parcels a uniform rate cannot be justified. There are, however, certain considerations not purely economic which may be held to justify a uniform rate for small parcels, especially if it be held that the State may conduct such a business for the advantage of the public, and abandon to some extent ordinary commercial balancing of cost and revenue.

Simplicity, afforded in a high degree by the uniform rate, facilitates the administration and practical conduct of Post Office business, and is, therefore, desirable, even if a little unjust. Complicated rates are an unfailing source of irritation to the public as well as a source of embarrassment to the staff, and there is not much doubt that one feature of the parcel post which commends it to the public favour is the simplicity of its rates. ${ }^{\mathrm{I}}$ There is, moreover, to be considered the view that it is no part of the duty of the Post Office to provide services in towns or districts for which private industry gives adequate services, but rather to cover the whole country, so that the public may always have ready to hand a means of forwarding small packages of goods to friends or relatives, or traders to customers, in other parts of the country. Such a service has many features which distinguish it from business undertakings of the ordinary type. In this way uniform rates may prove justified; since if in regard to any local service, or the service between any two points, the uniform rate, which must necessarily in certain cases yield considerable profit, is found burdensome, it is in all such cases open to private industry to provide the remedy. In the case of light parcels the cost of the services of collec-

I In the same way that the soap-makers of Port Sunlight secured a large sale by the simple expedient of refraining from varying the price of their tablets of soap with the variations in the cost of raw materials, making the adjustment in the weight of the tablets instead of in the price; and for the same reason that many people prefer restaurants widely known and with numerous branches, not always because the charges are less, but because it is well known what the charges and what the service obtained will be. 
tion and delivery is much greater than that of conveyance; and the variation of the total cost with distance of transmission is small proportionately. The uniform rate can therefore be fixed near the level of the cost. But even for such parcels it is economically unsound. It cannot be fixed at a really low level, because it is to be applicable to a parcel sent across the whole territory of a postal administration; and with such a parcel, even if weighing only 1 pound, the cost of transportation is an appreciable item.

The uniform rate for parcels is an expedient for smooth working rather than a scientific rate, and against the acceptance of uniformity of rate as a principle must be placed the fact that railway companies have not adopted it. The actual results of the uniform rate have not been altogether satisfactory. The small use of the post for the transmission of the heavier parcels appears to indicate that the rate for such parcels is, in general, too high. ${ }^{\mathbf{I}}$ For local traffic in small towns, where cost of conveyance is negligible, it is almost prohibitive, ${ }^{2}$ and is much higher than the rates charged by competing agencies.

The considerations in favour of a degressive rate apply with greater force to parcels of moderate weight than to the comparatively light packets which pass at the letter rate, and this feature should receive fuller recognition in the determination of parcel rates than has hitherto been the case.

To sum up: there are important differences between the letter and parcel traffic: (1) the letter traffic is a monopoly in which the more profitable business belongs to the State as well as the unprofitable, while the parcel business is not a monopoly, and any traffic which proves profitable may at once attract private competition; (2) in the letter traffic the cost of transmission for a given distance is negligible, and in the parcel traffic it is important; (3) the social argu-

In the United Kingdom less than 50 per cent. exceed 2 pounds in weight, and not more than 1 per cent. exceed 10 pounds. The proportion for shortdistance parcels is much less, and the proportion for foreign parcels is very much greater, over 15 per cent. being above 10 pounds in weight.

2 Even in the London postal area, which is of considerable extent, the local traffic is quite small, amounting to some four or five million parcels only per annum in a total traffic of some 130 millions. 
ments which make it desirable for the State to secure as wide as possible a diffusion of letters containing information, of newspapers, books, and samples, do not apply in the same way, or to the same degree, to the traffic in parcels containing goods.

In essentials the case of international rates differs little from that of inland rates. The work in connection with a letter falls into three main divisions: (1) at the place of posting; (2) transmission from place of posting to place of delivery; and (3) at the place of delivery. In the case of inland letters, the first and third factors preponderate to such a degree that their cost alone need be taken into consideration in fixing the rate. The factor of transmission can be ignored. In the case of letters from one country to another, the services at the offices of posting and delivery are performed under different, instead of under the same, administrations, but for all practical purposes are otherwise unaffected. The only factor seriously affected is that of transportation.

The variation in the cost for transportation ${ }^{\mathrm{I}}$ depends largely on distance, and in that respect various countries are affected in varying degrees, not only as regards the actual distances over which their letters for or from places abroad are sent, but in the way in which those distances compare with the distances over which letters in the inland service are conveyed; and the question therefore wears a different aspect in the different countries. Thus a very large proportion of letters in the British service are forwarded over greater distances than letters in the inland service. The same thing is probably true of France and Germany. Distances in the inland services of the United States and Canada are, however, comparable with the distances in the international services in Europe, and in many cases with distances in their own international services. If, therefore, mere distance of transmission were the only consideration, there would obviously be little to urge against the applica-

I I.e. the actual cost incurred by a Government in providing packet services, not the amounts paid to intermediate countries as "transit rates" under the International Convention, 
tion of the ordinary penny letter rate for inland transmission, at least to the traffic of the whole of Europe, just as it has been applied to the tralfic of the whole of the United States and Canada. ${ }^{\mathrm{x}}$

But it is doubtful whether inland distances are really comparable with international distances. The cost of maintaining lines of communication between distant countries is often altogether out of proportion to the quantity of mails conveyed; and the sums paid, although ostensibly payments for the conveyance of mails, are often really subsidies, paid sometimes in order to assist the shipping or other industry, sometimes for political purposes. ${ }^{2}$ They cannot, therefore, be used as a basis for calculating the amount of postage which should be charged on private letters.

This was particularly the case in earlier times.3 With the expansion of commerce and the establishment for com-

s Total area of Europe $\quad$. $\quad \ldots \quad \ldots \quad$.. $3,800,000$ square miles.

$$
\begin{aligned}
& \text { " " United States (with Alaska) .. 3,600,000 ", }
\end{aligned}
$$

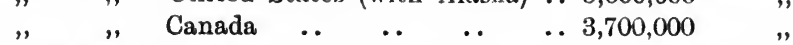

Of the total area of Europe, Russia accounts for some 2,100,000 square miles.

2 E.g. the transportation of Indian mails through France and Italy. For this service a special train in each direction between Calais and Brindisi is provided by the French and Italian Governments, and the payment made by the British Government in respect of the service is much in excess of the ordinary transit rates fixed by the Postal Union Convention.

3 The following particulars relate to the British Packet Service in 1860 :-

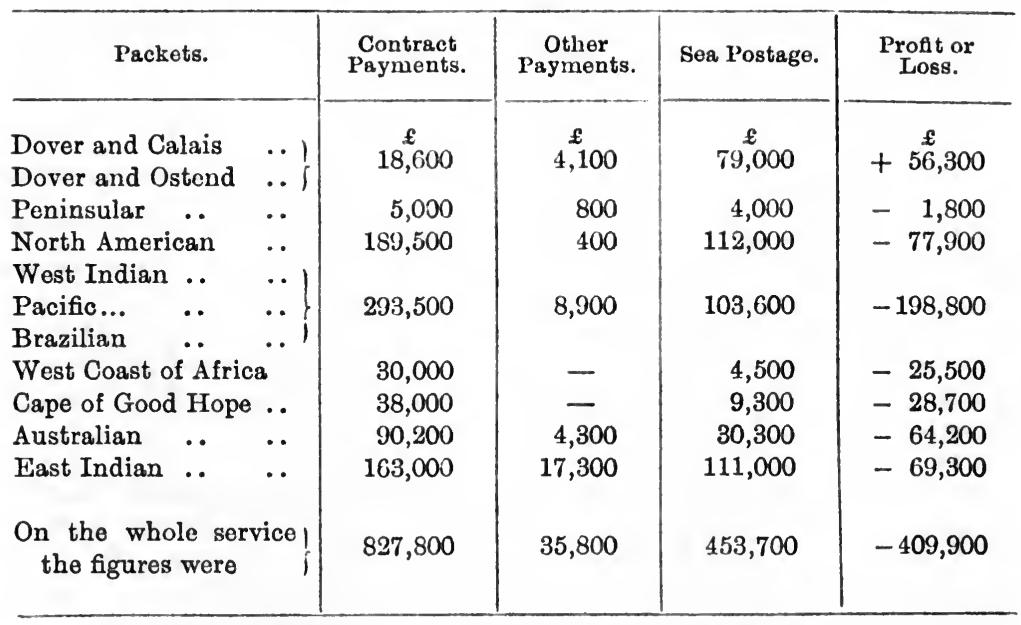


mercial purposes of regular lines of steamers between the principal countries of the world, the task of the Post Office has been much simplified, and, notwithstanding the growth of mails, the cost actually reduced. ${ }^{\mathrm{I}}$ It is, however, still heavy, and in some cases the payments include an element of subsidy. The cost of transmission by sea of a foreign letter in the British service is on the average $\frac{1}{4} \mathrm{~d}$. Foreign rates are not, however, fixed on a simple cost basis. The reduction to a penny of the letter rate between Great Britain and all parts of the British Empire; between Great Britain, Egypt, and the United States; and between the United States and Germany and France, has been made from considerations of general advantage, political or otherwise, rather than from considerations of immediate profit or loss on the postal service.

The international parcel post has always been regarded as primarily commercial, ${ }^{2}$ and the service has been deliberately restricted to small parcels on the ground that the conduct of an ordinary transportation undertaking is not a postal function, and that the admission of heavy parcels would render impossible the maintenance of the postal principle of uniformity of rate. Parcel mails are in the international service frequently denied the privilege of rapid transmission accorded to letter mails. 3 The developments of the present war have emphasized the essential distinction to be drawn between communications on the one hand, and packages of goods sent by parcel post on the other.

The general basis of postal rates is naturally affected in some degree by the fact that the Post Office is a State undertaking, and the propriety of Government control deserves

In 1860, when the total number of foreign letters was very much less than at present, the cost of the British foreign packet service was some $£ \$ 60,000$, and in 1913 the cost had fallen to some $£ 700,000$.-Annual Reports of the PostmasterGeneral, 1860, pp. 34-7; 1913-14, p. 51.

2 Vide supra, Chapter VI.

3 E.g., parcel mails are not forwarded by the train between Calais and Brindisi run specially for the Indian mails. Parcels are, it is true, forwarded to America by the Cunard packets which carry the letter mails, but this arrangement is due to special circumstances. The Cunard line, being heavily subsidized (with other than Post Office ends in view), is required to carry all mails tendered. Otherwise it might be found economical to send parcels by slower cargo boats. 
consideration. Adam Smith, with his individualistic leaning, was bound to touch on the question of a State Post Office. He thought there was no objection to the conduct of the Post Office by the Government, ${ }^{1}$ and economists since his day have generally followed his view. ${ }^{2}$ This acceptance of State control as theoretically justifiable has probably been induced by the logic of facts rather than by the recognition of any peculiar characteristics tending to that view discoverable in the postal service as an industrial organization. 3

The transmission and delivery of letters for private individuals may have some affinity to the transmission of official despatches, but in theory such affinity is slight, especially in regard to the transmission and delivery of local letters. Because the Government had found it essential for its own

- Wealth of Nations, ed. 1904, vol. ii., p. 303.

2 "The business being one which both can and ought to be conducted on fixed rules, is one of the few businesses which it is not unsuitable to a Government to conduct."-J. S. Mill, Principles of Political Economy, London, 1871, vol. ii. bk. v. chap. v. $\$ 2$.

"It is clear that the restriction put upon the liberty of trade by forbidding private letter-carrying establishments is a breach of State duty. It is also clear that were that restriction abolished, a natural postal system would eventually grow up, could it surpass in efficiency our existing one. And it is further clear that if it could not surpass it, the existing system might rightly continue; for the fulfilment of postal functions by the State is not intrinsically at variance with the fulfilment of its essential function."-Herbert Spencer, Social Statics, London, 1910, p. 120.

Professor Cannan sums the matter up from the point of view of modern opportunism :-

"Much too great importance is commonly attributed to this part of State action: the sale of commodities. We may be sure that if the State had not happened to undertake the business of carrying letters, some private organization would have been established for the purpose. Whether it would have done the work better or worse than the present State Post Office does it, is a question which we have no means of answering. So, too, on the other hand, if the State in this country had undertaken the provision of railways, we should have had a railway system of some sort; it might have been a better or it might have been a worse system; whether it would have been better or worse would have depended on the wisdom of those who had the largest share in devising and extending it, and who these persons would have been, and what their wisdom would have been, we have no means of telling."-Edwin Cannan, Elementary Political Economy, London, 1903, p. 132.

3 "Before the rise of the economic schools that opposed industrial action on the part of the State, the method of public postal service was firmly established, and was seen to give, on the whole, sufficiently satisfactory results. It, therefore, escaped the hostile criticism that economists freely bestowed on the less efficient public departments."-C. F. Bastable, Public Finance, London, 1903, p. 208. 
purposes to establish a system of posts, it did not necessarily follow that the Government must assume also the function of conveying letters for private individuals. But the Post Office is one of those organizations in the case of which the normal influence of economic forces tends to exclude competition. Its operations are spread over large areas, and duplication of services over large areas would result in waste of effort and increase of expenses. Competing postal establishments would exhibit the same glaring economic waste as competing arrangements for the supply of gas, water, or electricity. The service thus almost certainly becomes a monopoly; and its nature makes the assumption of its management by the State advantageous. In times of war, State monopoly of the means of communication (postal, telegraph, telephone, and wireless) is essential. Even if these services were in private hands at the outbreak of war, the first action of the Government would undoubtedly be to assume control.

A further reason justifying the conduct of the postal service by the Government rather than by private enterprise is that it is a necessity for the State to provide a means for the regular transmission of intelligence by letter of script throughout its territory. If the working of the service were left to private enterprise, it would be certainly confined to such routes as were found profitable, and those parts of the country in which profitable routes could not be established would be left unserved. The State alone can secure the establishment of a complete service, in which regard must not be confined to considerations of mere profit. ${ }^{\mathrm{I}}$ There are also minor features which render State management peculiarly applicable to the postal service. The actual operations are simple. As Adam Smith said: "There is no mystery in the business." 2 The

1 "He was always eager to improve the mail service to remote towns; and would observe that one good result of State management was the consideration of out-of-the-way places. A private management, he said, might probably have introduced a halfpenny post in London, and have left the country worse served than at present."-Leslie Stephen, Life of Henry Fawcett, London, 1885, p. 438.

2 "The Post Office is properly a mercantile project. The Government advances the expense of establishing the different offices and buying or hiring the necessary horses or carriages, and is repaid with a large profit by the duties upon what is carried. It is perhaps the only mercantile project which has been successfully managed by, I believe, every sort of Government. The capital to be advanced is not very considerable. There is no mystery in the business. The 
work is for the most part of a routine character, and calls for no special skill or knowledge. That is not to say that in the performance of the actual duties there is no room for the acquirement of considerable manipulative skill. It means that in principle the chief operations are simple, and may be reduced to routine processes. There is the further important consideration that the operations of the Post Office are intimately connected with the daily life of the people, and are constantly subject to public observation and criticism.

Assuming a State parcel service, there is to be considered the question whether that service should be attached to the letter post or whether it would be more economical to set up a separate service. It might appear at first sight that this question has been determined by the practice. But as the financial scheme of the letter post rests on the fact that the actual transportation of the letters occupies, as regards expense, a quite subsidiary place, ${ }^{\mathrm{x}}$ it is difficult to discover any special relation between the letter post and a business which is really part of the general transport industry. It may in some instances be advantageous to utilize for parcels the service provided for the transmission and delivery of letters. An organization reaching to all parts of the country is ready to hand, and one which, in rural districts especially, is often not employed to its full capacity. It may therefore in some cases manifestly be economical to give additional work to the service; but, at the same time, the provision of a service for parcels may in other cases add unduly to the cost of the general service-as, for example, when it becomes necessary to make special arrangements on account of occasional variations in the numbers of parcels. ${ }^{2}$

In any case, a postal service should be limited to parcels of moderate size and weight, because the Post Office, as at present organized, is for the most part adapted to the handling of packets which can be delivered by foot-messengers. In rural

returns are not only certain but immediate."-Wealth of Nations, ed. 1904, vol. ii., p. 303.

Vide supra, p. 26.

2 In the United Kingdom the expense incurred in providing specially for the disposal of parcels in this way often exceeds the total amount of the postage paid on the parcels. 
districts this is almost universally the rule. ${ }^{x}$ It is frequently necessary in the towns to separate entirely the parcel post traffic from the ordinary light letter post traffic (except in those parts of the service where the parcel post traffic is very restricted), to provide a separate staff, and to furnish different equipment. ${ }^{2}$ In effect, two establishments are maintained. A separate parcel staff could, of course, collect and deliver traffic of any dimensions or character. But difficulties would arise in regard to the transportation from town to town of heavy parcels, 3 and in rural districts their distribution could not be undertaken without a reorganization of the general arrangements of the mail service. Any sort of regular houseto-house delivery would be enormously expensive. To a large extent-in the United Kingdom at any rate-such a service would be a duplication of services already provided by railway companies, and consequently economically wasteful.

The transportation of parcels is, indeed, in many aspects a service more appropriate to the railways than to the Post Office. The Post Office, for example, is handicapped as compared with the railways by the fact that, while the larger part of its traffic in parcels must under present conditions necessarily be conveyed by railway for some part of the journey, the actual points of despatch and receipt of the

I In the United Kingdom, horse-posts or cycle-posts are in general provided in view of the length of the route to be traversed, rather than in view of the weight of traffic to be carried.

= The need for such a separation between ordinary letters and packets of appreciable weight is felt even in regard to the letter post itself. In England, the extension of the weight limit for penny letters, and the reduction of the rates for the heavier letters, has led to serious practical difficulties and has impeded smooth and rapid working. In the larger offices the letter post traffic is dealt with in two divisions: (1) the lighter, homogeneous traffic, the light letters and postcards; and (2) the heavier packets, and packets of irregular shape (p. 285). In France, the extension of the maximum limit of weight gave rise to similar difficulties; so much so that the question of establishing a separate slower post for such packets has been seriously considered. In Paris, at the present time, there is a completely separate indoor and outdoor staff for the newspapers and packets.

3 It is only necessary to glance into a van containing railway parcels in order to realize how impossible it would be to apply to such packages the usual postal method of enclosure in sacks; and conveyance $\dot{a}$ decouvert by railway companies on behalf of the Post Office would give rise to obvious practical difficulties. In Germany and Switzerland postal parcels are so despatched, but the railways are State-owned in those countries, and the service is in many respects a railway service. 
parcels by the Post Office are not in the large majority of cases adjacent to the railway stations from or at which the traffic is despatched or received by railway. ${ }^{\mathrm{I}}$ It is, in consequence, necessary in such cases for the Post Office to provide a service between the respective railway stations and post offices. ${ }^{2}$ If the railway companies provided adequate collection and delivery services there would be no need for division of the function with the Post Office. In many districts, however, the railway companies would find the provision of any sort of regular and universal service unremunerative, and this is probably the ultimate reason why the State has found it necessary to intervene. In the United States the introduction of a parcel post, and its extension to heavier parcels, was arowedly in a large degree due to the fact that in many parts of the country the railways, which are in private hands, did not provide any service for parcels. Where a service was provided by the railways, the rates and conditions were not satisfactory, and the establishment of a parcel post represents an attempt to prevent the full application of the principle of charging "what the traftic will bear."

The Post Office, moreover, as a public undertaking, cannot bargain freely for special facilities or terms with individuals or firms having large numbers of parcels for delivery within a limited area. Without such specialization the Post Office must often be unable to offer the most economical service, and private carrying agencies secure the business. In those countries where a parcel post is in operation, the Post Office does not rank as a transportation agency comparable with those of the commercial world. The traffic which it secures is private and personal rather than commercial, to a large degree exceptional traffic which the machinery of the ordinary commercial transportation agencies cannot, or at any rate in general does not, deal with-traffic for remote and isolated

\footnotetext{
The railways frequently establish receiving offices in various parts of a town. The services necessary for the conveyance of parcels from these offices to the railway stations are not, however, comparable with the services for closed parcel mails between the post offices and the stations, but rather with the services between branch post offices and the chief post office. The service from the chief post office to the railway station is a further service.

2 In France heavy parcels are not accepted at post offices, but must be taken to a railway station. Vide supra, p. 206.
} 
residences, spasmodic in character, and, compared with the total traffic in parcels, small in amount. ${ }^{x}$ The uniform rate favours such traffic, but the expense to the Post Office is disproportionate to the revenue. From the broader standpoint this is perhaps not altogether loss to the State, since by this means local industries are often brought in touch with markets which could not otherwise be reached, and the rural population is enabled to obtain from the towns many amenities not otherwise procurable.

Viewed in the light of these considerations, and especially of the fact that it is open to competition at all points where its rates would prove profitable, it will not appear extraordinary that the parcel post is less successful financially than the letter post. ${ }^{2}$ The conditions under which postal business is conducted render it impossible to earmark the expenses properly chargeable to the parcel post, since expenses are for the most part incurred jointly. But the parcel post is to a large extent a secondary service engrafted on the letter post, and is perhaps not properly chargeable with a mathematical proportion of the total cost of the two services based on the relative cost of handling individual letters and individual parcels. Theoretical estimates of the cost of the parcel post must, therefore, be accepted with reserve. But a proved moderate loss on the parcel post would not be conclusive against the propriety of its maintenance. Postal rates are simple, definite, and generally known; and every post office is a receiving agency. It is convenient to use the post, which offers the further advantages of quick transmission, and the greater degree of security attaching to a State institution. The line on which a postal service for small parcels can best be justified is that by the utilization of existing machinery for the disposal of additional traffic, not so large as to overburden or disorganize the practical arrangements, a useful public advantage can be secured without inordinate cost. Nevertheless, the parcel post service is not a true postal service, but rather a commercial undertaking.3 The question

I The general proportion of parcels to letters for the United Kingdom as a whole is 1 in 40 ; but on some of the remoter rural routes the proportion of parcels frequently rises to 1 in 20 , and sometimes to more than 1 in 10 .

2 Vide supra, pp. 190 and 219.

3 The naval operations during the present war in regard to noutral mails 
of the legitimacy of State control, which in the case of the letter post is of academic interest only, is therefore of real importance in the case of a parcel service, and those who have a distrust of all State interference in industry may legitimately argue that it should stand aside from the parcel business.

have brought out clearly the essential distinction between letters and parcels. The arguments as to the customary inviolability of mails have been based on the idea of free communication. But parcels containing goods, possibly contraband, e.g. rubber, obviously cannot claim the privileges of communications, and the right of sea-power to interfere with parcel mails has been admitted. "The Government of the United States is inclined to regard parcels post articles as subject to the same treatment as articles sent by express or freight in respect of belligerent search, seizure, and condemnation."-United States Note to Great Britain, 10th January 1916. 


\section{APPENDIXES}

\section{APPENDIX A}

\section{RATES OF INLAND LETTER POSTAGE CHARGED IN ENGLAND, 1635-1915}

Witherings' Rates, 1635.

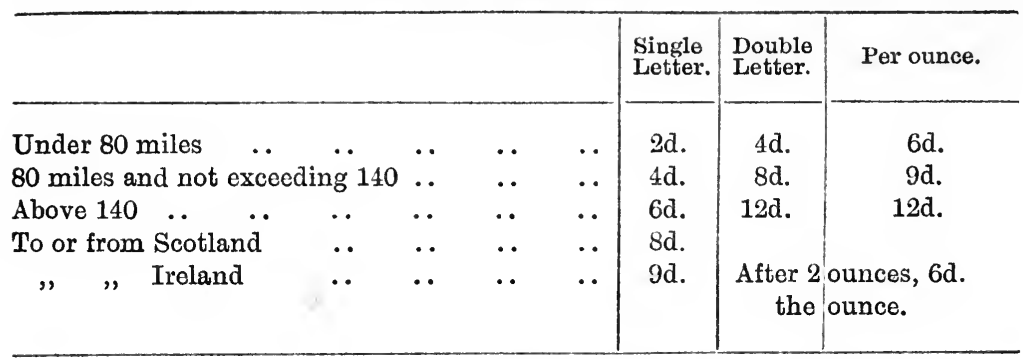

-Royal Proclamation of 31st July 1635.

This was the introduction of postage in the modern sense. The object of the exceptional rate for Ireland was to avoid interference with a Proclamation recently issued there by the Lord Deputy and Council.

"A single letter is one written on one sheet of paper sealed; a double letter is one sheet of paper which covers another sheet sealed up; a treble letter proportionately."-Calendar of State Papers (Domestic Series), 1658, p. 368.

\section{Ordinance of 1657.}

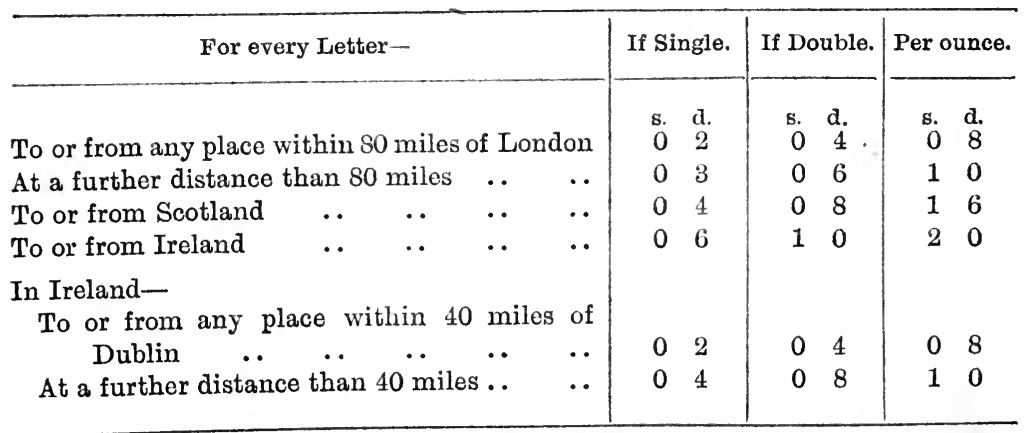


Act of 1660 (12 Car. II, Cap. 35).

\begin{tabular}{|c|c|c|c|c|c|c|c|}
\hline & & & & & $\begin{array}{c}\text { On Single } \\
\text { Letter. }\end{array}$ & $\begin{array}{c}\text { On Double } \\
\text { Letter. }\end{array}$ & Per ounce. \\
\hline \multicolumn{5}{|l|}{ From London- } & d. & d. & d. \\
\hline 80 miles and under & . & .. & .. & . & 2 & 4 & 8 \\
\hline A bove 80 miles .. & .. & .. & .. & .. & 3 & 6 & 12 \\
\hline To or from Berwick & .. & .. & .. & .. & 3 & 6 & 18 \\
\hline \multicolumn{8}{|c|}{ From Berwick within Scotland- } \\
\hline 40 miles and under & .. & .. & . & .. & 2 & 4 & 8 \\
\hline Above 40 miles .. & .. & .. & .. & .. & 4 & 8 & 12 \\
\hline To or from Dublin & .. & .. & .. & .. & 6 & 12 & 24 \\
\hline \multicolumn{8}{|c|}{ From Dublin within Ireland- } \\
\hline 40 miles and under & .. & .. & .. & .. & 2 & 4 & 8 \\
\hline Above 40 miles .. & .. & .. & .. & .. & 4 & 8 & 12 \\
\hline
\end{tabular}

N.B.-There were no cross posts. Between two, towns not on the same post road, however near, letters could circulate only through London, and whenever a letter passed through London an additional rate was imposed, e.g. from Bristol to Exeter (less than 80 miles) a letter would be sent via London and charged two rates for over 80 miles.

1711 (9 Anne, Cap. 10).

\begin{tabular}{|c|c|c|c|c|c|c|c|}
\hline & & & & & Single. & Double. & Ounce. \\
\hline \multicolumn{5}{|l|}{ From London- } & d. & d. & d. \\
\hline 80 miles and under & . & . & . & .. & 3 & 6 & 12 \\
\hline Above 80 miles .. & .. & .. & .. & .. & 4 & 8 & 16 \\
\hline To Edinburgh & . & . & . & .. & 6 & 12 & 24 \\
\hline To Dublin ... & . & .. & .. & .. & 6 & 12 & 24 \\
\hline \multicolumn{8}{|c|}{ From Edinburgh within Scotland- } \\
\hline 50 miles and under & .. & .. & .. & .. & 2 & 4 & 8 \\
\hline \multicolumn{5}{|c|}{ Above 50 miles and not exceeding 80 miles. . } & 3 & 6 & 12 \\
\hline Above 80 miles ... & .. & .. & .. & .. & 4 & 8 & 16 \\
\hline \multicolumn{8}{|c|}{ From Dublin within Ireland- } \\
\hline 40 miles and under & .. & .. & $\cdots$ & . & 2 & 4 & 8 \\
\hline Above 40 miles .. & .. & .. & .. & .. & 4 & 8 & 16 \\
\hline
\end{tabular}

The initial charge was raised from $2 \mathrm{~d}$. to $3 \mathrm{~d}$. The area of the penny post delivery was therefore restricted to the 10-mile circle from the General Post Office. Previously, towns within about 20 miles had been served by the penny post, but an additional penny was charged for all packets delivered in the suburbs. 
1765 (5 Geo. III, CAP. 25).

For Great Britain-

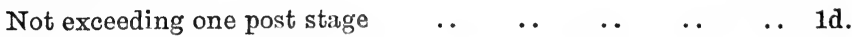

For England only-

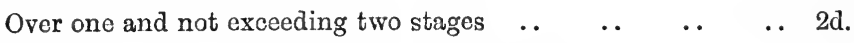

No change was made in other inland rates.

\section{4 (24 Geo. III, Senss. 2, Cap. 25).}

The rates of 1765 were increased by $1 \mathrm{~d}$. for a single letter for distances under 150 miles, and $2 \mathrm{~d}$. for greater istances.

1796 (37 Geo. III, CAP. 18).

Within England, Wales, and Berwick-

For a Single

Letter.

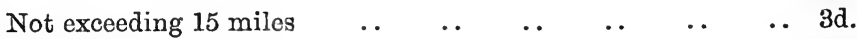

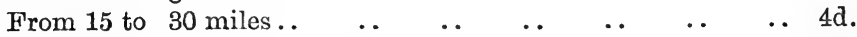

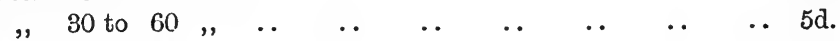

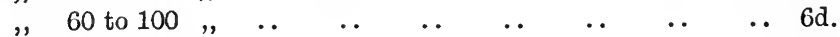

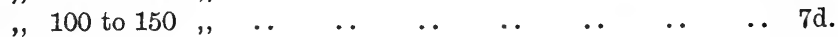

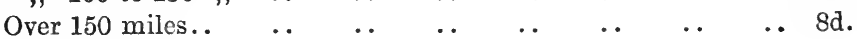

Within Scotland-

$\begin{array}{llllllll}\text { In addition to existing rates } & \ldots & \ldots & \ldots & \ldots & \ldots & 1 \text { d. }\end{array}$

1801 (41 Geo. III, CaP. 7).

Within Great Britain-

$\begin{array}{llllllll}\text { Not exceeding } 15 \text { miles } & . . & . . & . . & \text {.. } & \text {.. } & \text {.. } & 3 \mathrm{~d} \text {. }\end{array}$

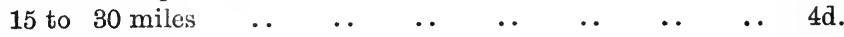

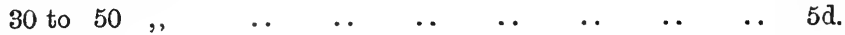

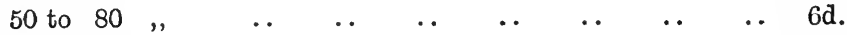

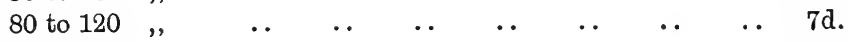

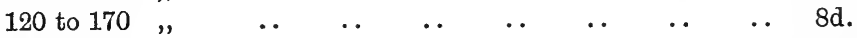

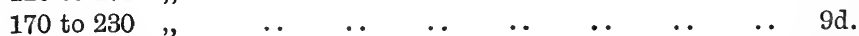

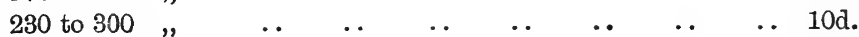

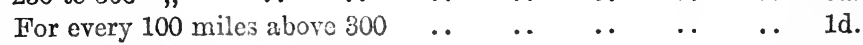

1805 (45 Geo. III, CAP. 11).

Within Great Britain, in addition to existing rates-

1d. for a single letter

2d. ", double ,"

3d. ", triple ",

4d. , an ounce letter. 
1812 (52 Geo. III, Cap. 88).

Within Great Britain-

For a Bingle

\begin{tabular}{|c|c|c|c|c|c|c|c|c|c|c|c|}
\hline \multicolumn{5}{|c|}{ Not exceeding 15 miles $\quad .}$. & & & .. & . & .. & $\therefore$ & $4 \mathrm{~d}$. \\
\hline Above & 15 & it & rceedir & & $\mathrm{m}$ & & .. & .. & .. & .. & $5 \mathrm{~d}$. \\
\hline$"$ & 20 & ", & ", & & & & .. & .. & .. & .. & $6 \mathrm{~d}$. \\
\hline$"$ & 30 & , & , & & & & .. & .. & -. & .. & $7 d$. \\
\hline " & 50 & " & $"$ & & & & .. & .. & .. & $\cdots$ & $8 \mathrm{~d}$. \\
\hline$"$ & 80 & $"$ & $"$ & & & & .. & $\cdots$ & .. & $\cdots$ & 9d. \\
\hline$"$ & 120 & $"$ &, & & & & .. & .. & .. & .. & $10 \mathrm{~d}$. \\
\hline$"$ & 170 & $"$ & " & & & & .. & .. & .. & .. & $11 \mathrm{~d}$ \\
\hline ", & 230 & $"$ & ", & & & & .. & .. & .. & .. & $12 \mathrm{~d}$ \\
\hline " & 300 & ", & , & & & & .. & .. & .. & .. & $19 \mathrm{~d}$ \\
\hline ," & 400 & " & " & & & & .. & .. & .. & - & $14 \mathrm{~d}$. \\
\hline ", & 500 & ", & , & & & & .. & .. & .. & . & $15 \mathrm{~d}$. \\
\hline$"$ & 600 & $"$ & ", & & & & .. & .. & .. & . & $16 \mathrm{~d}$. \\
\hline ", & $700 \mathrm{r}$ & & .. & .. & & & .. & .. & .. & .. & $17 d$. \\
\hline
\end{tabular}

These rates were re-enacted by 1 Vict., cap. $34, \& 3$. The usual increased charges for double, treble, and ounce letters applied throughout. Additional rates were charged in respect of conveyance by packet boat, e.g. for a single letter between Holyhead and Dublin, 2d.; in respect of Menai Bridge, 1d.; in respect of Conway Bridge, 1d.; and in respect of any letter conveyed in Scotland by a mail carriage with more than two wheels, t d. (Seo 1 Vict., cap. 34, §§ 3,5,6 and 7). ${ }^{x}$

By 2 and 3 Vict., cap. 52, the Treasury was empowered to regulate rates of postage, and subsequent changes have been made by Treasury Warrant.

1840.

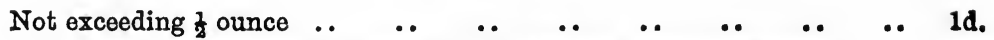
(uniform rate irrespective of distance of transmission). For each additional ounce, or fraction of an ounce, $2 d$.

2d.

\section{5.}

Rate for letters exceeding 1 ounce in weight reduced to $1 \mathrm{~d}$. for each ounce, or fraction of $\frac{1}{2}$ ounce, after the first ounce.

- For particulars of other Acts relating to packet postage, and of Aats relating to Ship Letters, and to rates of postage within Ireland, see Schedule $\Delta$ of 1 Vict., cap. 32. Rates for transmission within Ireland were also flxed by 1 Vict., cap. 34 (§ 4). 


\section{1.}

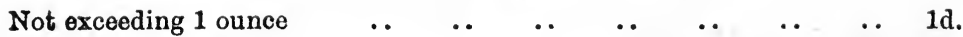

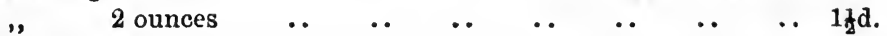

For every additional 2 ounces or fraction of 2 ounces up to 12 ounces, $\frac{1}{2} d$.

For letters exceeding 12 ounces in weight, 1d. per ounce, including the first ounce.

\section{5.}

Rate of $\frac{2}{2} d$. per ounce after the second ounce continued without limit.

1897.

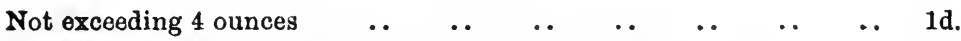

For every 2 ounces, or fraction of 2 ounces, thereafter, $\frac{1}{2} \mathrm{~d}$.

1915.

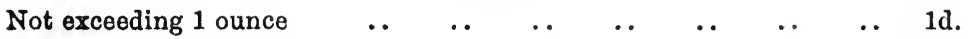

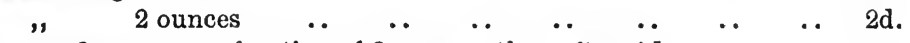

For every 2 ounces, or fraction of 2 ounces, thereafter, $\frac{1}{2} d$.

\section{FOREIGN RATES IN THE BRITISH SERVICE}

One of the earliest regular posts in England was the post to Dover, established for the transmission of despatches to and from the Continent. ${ }^{\text {T }}$ This post early assumed considerable importance relatively to the other posts. The settlement of foreign artisans in this country, in consequence of the persecutions on the Continent, naturally led to the growth of a considerable intercourse with places abroad. There was besides a large cloth trade. Letters were not, however, sent exclusively by the King's post. Frequently the merchants made their own arrangements for the conveyance of their letters; and since one of the functions of the post in those days was to enable the authorities to keep a close watch on all correspondence passing within the realm, in order that conspiracies against the State might be detected, this proceeding of the merchants was viewed by the Government with much jealousy. It led to the first assumption by the State of the monopoly of the carriage of letters. In 1591, before the use of the posts for the transmission of inland letters for private individuals had been officially recognized, a royal proclamation forbade the conveyance of letters to or from places outside the realm except by the King's post. A further proclamation to the same effect, so far as it related to foreign letters, was issued in $1609 . .^{2}$

In 1619 the foreign post was separated from the ordinary post, and a foreigner, Matthew De Quester, who had been appointed by

$$
\text { s Vide supra, p. 6, n. } 1 . \quad \text { 2 Ibid., p. } 7 .
$$


Lord Stanhope, then Master of the Posts, to superintend the foreign post, was appointed to control the service. In 1626 De Quester published the following tariff applicable to foreign letters :-

To or from the Hague, Brussels, Paris, and Vienna $\quad . \quad 30$ s.

To or from any part of Germany .. $\quad$. $\quad \ldots \quad$.. 68 .

From Venice for a single letter $\quad \ldots \quad$.

From Venice for any letter other than a single letter .. 2s. 8d.

From Leghorn and Florence for a single letter .. .. 1 .

From Leghorn and Florence for any letter other than a $\begin{array}{llllllll}\text { single letter } \quad \ldots & \ldots & \ldots & \ldots & \ldots & \ldots & \text { 3s. the ounce. }\end{array}$

The tariff was incomplete, but is noteworthy as the first set of rates of any description issued in England for the conveyance of letters by post. Stanhope had charged certain fees on letters for the Continent. On letters to or from Amsterdam or Hamburg, for example, his fee had been $8 \mathrm{~d} .^{2}$ But, until this time, no general table of rates had been issued.

By the Ordinance of $1657^{3}$ the following rates for foreign letters were established:-

\begin{tabular}{|c|c|c|c|}
\hline & $\begin{array}{c}\text { For a } \\
\text { Single } \\
\text { Letter. }\end{array}$ & $\begin{array}{l}\text { Double } \\
\text { Letter. }\end{array}$ & $\begin{array}{c}\text { Per } \\
\text { ounce. }\end{array}$ \\
\hline & d. & d. & d. \\
\hline $\begin{array}{l}\text { To Leghorn, Genos, Florence, Lyons, Mar- } \\
\text { seilles, Aleppo, Constantinople .. }\end{array}$ & 12 & 24 & 45 \\
\hline $\begin{array}{l}\text { To St. Malo, Morlaix, Nieuhaven .. } \\
\text { To Bordeaux, Rochelle, Nantes, Bayonne, }\end{array}$ & 6 & 12 & 18 \\
\hline Cadiz, Madrid $\quad$.. $\quad$. & 9 & 18 & 24 \\
\hline $\begin{array}{l}\text { To Hamburg, Frankfort, Cologne .. } \\
\text { To Dantzic, Leipsic, Lübeck, Stockholm, }\end{array}$ & 8 & 16 & 24 \\
\hline . Copenhagen, Elsinore, Königsberg .. & 12 & 24 & 48 \\
\hline
\end{tabular}

No rates were fixed for letters passing outside Europe.

These rates were not substantially altered by the Act of 1660 , although in some cases a variation according to the route followed. was introduced. For example, a letter sent to the North of Italy via Lyons was charged 3 d. more than a letter sent direct.

Under James II rates of postage (6d. a single letter, 1s. a double letter, and $2 \mathrm{~s}$. the ounce) were fixed for letters to and from Jamaica, although no service to and from the island was provided by the Crown.

- Calendar of State Papers (Domestic Series), 1625-6, p. 523.

\% H. Joyce, History of the Post Office, p. 12.

3 H. Scobell, A Collection of Acts and Ordinances, London, 1658, p. 513. 
In 1686 regular mail services were established under contract between Dover and Calais and between Dover and Ostend, and in 1687 a service between England and Holland. It is probable that packets were sailing between Dover and Calais before that time, ${ }^{x}$ but in general the cross-Channel services had previously been conducted by boats hired casually for the conveyance of particular mails. For the Calais service a sum of $£ 1,170$ a year was paid, and for the Dutch service a sum of $£ 900$ a year. ${ }^{2}$

Letters from abroad brought by merchant ships (known as "ship letters") were by the Ordinance of 16573 and by the Act of 1660 made subject to postage on arrival in this country. Such letters were required to be given up to the postmaster at the port of arrival, who forwarded the letters to London, where they were charged with the proper amount of postage. No payment was made to the shipmaster in respect of letters handed over to the Post Office in this way, and no penalty was incurred if the letters were not so handed over. This part of the Act consequently remained a dead letter. The farmers of the Post Office saw, however, that it would be profitable to them to offer a small pecuniary inducement to the shipmasters, and accordingly offered to pay a penny for every letter brought by private ship and handed over by the shipmaster to the postmaster of the port of arrival.4 As the farmers were able to eharge the legal rate of inland postage on all such letters, there was a sufficient margin to leave a profit after payment of the penny. Tho regular ship letter fee, which was afterwards legalized, originated in this practice.

Most of the ship letters came to the port of London, and the establishment of the penny post in 1680 had a serious effect on the proceeds of the ship letter money. If the letters were for delivery in London, they could be dropped into the penny post for delivery at a penny each, whereas if handed in to the General Post Office as ship letters they would be charged at the appropriate foreign rates, according to their place of origin. Thus, letters from Marseilles for delivery in London would be charged 1s. each, although the service actually performed by the Post Office was no greater than that performed for a penny in the penny post. The foreign rates, as applied to ship letters, were therefore for the most part a simple tax, and the use of the penny post was greatly resorted to.5 The Postmasters-General protested continually against this fraud on the

IH. Joyce, ibid., p. 72. 2 Ibid., p. 73 . 3 H. Scobell, ibid.

4 Historical Summary of Post Office Services, London, 1911, p. 47.

3 The number of letters still handed in to the General Post Office was, however, quite considerable. Thus, in 1686, 60,447 ship letters were received.-Vide F. Joyce, ibid., p. 74. 
revenue; and in 1696, in order to put a stop to it, two officers were appointed whose duty it was to receive letters and packets from all " masters of ships and vessels, mariners, and passengers as shall be by them hereafter brought in any ships or vessels into the Port of London." 1

The payment of a penny a letter to the shipmasters was without legal sanction until the Act of $1711 .^{2}$ This Act revised the foreign rates, in general in an upward direction, the increase on the rates of 1660 varying from $1 \mathrm{~d}$. to $3 \mathrm{~d}$., and first established statutory rates for letters passing to or from the colonies. From London to or from the West Indies the rate was $18 \mathrm{~d}$. for a single letter, and to or from New York 12d. The rate to the West Indies was, in 1765, reduced to 1s. for a single letter, and this rate became in course of time the standard for all colonial letters.

In 1796, in addition to the ordinary shilling rate, letters from the colonies were subjected to a charge at the inland rate in respect of transmission within this country: e.g., a letter from America would be charged the shilling rate, and the inland rate from Falmouth to its destination. An addition of $4 \mathrm{~d}$. was also made to the rates on letters to or from places abroad, other than places in the colonies. In 1805 an additional penny was laid on letters between Great Britain and the American Colonies.

The Act of 1711 had made illegal the despatch by private ship of letters which could be sent by the regular packets; but for places to which no packet service existed, shipmasters were free to accept and carry letters, and to charge what fees they chose. So far as it directed that all letters for places abroad should be sent by packet where a packet service existed, the Act was ineffective. From the chief coffee-houses in the City of London it was customary to collect letters to be sent in this way by private ship where no packet service existed. This practice was extended to those places to which there was a packet service, and became generally recognized. Shipmasters usually charged a fee of $2 \mathrm{~d}$. per letter, 3 and the whole traffic was conducted independently of the Post Office.

No attempt was made to collect postage on letters conveyed by private ship, whether received or despatched by such ship, except in respect of transmission within the kingdom. The penny authorized by the Act of 1711 went to the master of the ship. About the year 1790 Frederick Bourne, a clerk in the foreign department of the Post Office, suggested a scheme which should bring all ship letters into the post and subject them to postage for foreign transmission. He proposed that inward ship letters should be charged

I London Gazette, No. 3247, 21st-24th December 1696; cited H. Joyce, ibid., n. 2. $\quad 29$ Anne, cap. 10, § $16 . \quad 3$ H. Joyce, ibid., p. 329. 
a uniform rate of $4 \mathrm{~d}$., and outward letters should be charged half the packet rate; for those places to which there was no packet rate, the rate was to be based on what the packet rate might be presumed to be if a packet service existed. In view of the long period during which the provisions of the Act of Anne had not been enforced in this respect, Pitt was unwilling to attempt to suppress the illegal practice which had grown up. He considered that in respect of outward letters the service performed by the Post Office, which amounted to no more than sealing the bags and handing them to the shipmaster, was insufficient to justify compulsory payment of packet postage. The proposal was therefore adopted only as a permissive measure: merchants were given the option of handing their letters to the Post Office. The Act authorizing the change empowered the Post Office to despatch and receive letters by vessels other than the regular sailing packets. On letters despatched by private ship the Post Office was authorized to charge half the packet rates in the case of letters for places to which a packet service existed; in cases in which no rate of postage was established, the charge was to be half the rates then paid, as near as could be ascertained. ${ }^{x}$ On letters brought in by such vessels, in addition to the inland postage, a charge of $4 \mathrm{~d}$. a single letter, and so in proportion, was authorized. A fee of $2 \mathrm{~d}$. was payable to the master of the ship in respect of every letter delivered to or received from him by the Post Office in proper course.

A Ship Letter Office was opened on the 10th September 1799. No vessel was allowed to make entry or break bulk until letters brought by it had been handed over to the Post Office. The chief object in view was not, however, achieved. Letters sent out of the country by private ship still continued for the most part to be handed to the shipmaster without the intervention of the Post Office. Efforts were made to secure the assistance of coffee-house keepers as agents of the Post Office, but without success; and for many years the proportion between incoming and outgoing private ship letters was eighteen to one. ${ }^{2}$

In 1814 a further Ship Letter Act 3 raised the rate on inward single letters from $4 \mathrm{~d}$. to $6 \mathrm{~d}$., and made it compulsory to hand all outward ship letters to the Post Office to be charged. The East India Company, whose servants had previously been allowed to send and receive letters free, protested strongly against the new Act, although the official correspondence of the Company had been exempted. The Company pointed out that the Post Office

× Act of 39 Geo. III., cap. 76, $\S \S 1$ and 2 ; H. Joyce, ibid.; J. C. Hemmeon, History of the British Post Office, p. 124.

2 H. Joyce, ibid., p. 330.

354 Geo. III, cap. 169. 
maintained no packet communication with the East Indies, and to charge postage was to levy a charge where no service was performed, and in effect to lay a tax on letter-writing. They had a stronger weapon than sound argument: the ships sailing between England and India were to a large extent controlled by them, and the Act laid no compulsion on the owners of private ships to carry letters for the Post Office. When, therefore, the Post Office requested the Company to carry post letters to India, the Company replied that they did "not see fit to authorize the commanders or owners of any of their ships to take charge of any bag of letters from the Post Office subjected to a rate of postage for sea conveyance." $x$ In consequence of this difficulty an Act was passed in 1815 making it compulsory on all shipmasters to carry such mails as should be tendered to them by the Post Office. The Post Office was required to pay the owners a reasonable sum as remuneration for the carriage of the letters, the ordinary fee of $2 \mathrm{~d}$. a letter still being paid to the commander as a perquisite. The East India Company was placated by the concession of further exemptions in its favour. By this Act the rate of postage to India or the Cape was fixed at 14d. the ounce on letters, and on newspapers at $3 \mathrm{~d}$. the ounce-the first enactment providing a lower rate for newspapers than for letters in the foreign service. ${ }^{2}$

The result of this Act was eminently satisfactory. In the first eighteen months or so the postage on letters for India and the Cape of Good Hope amounted to $£ 11,658$, while the amount paid for the conveyance by private ship was only $£ 1,250$; although it should be explained that expense was incurred for less than half the number of despatches, the remainder being conveyed by his Majesty's ships, or by ships of the East India Company which were placed at the disposal of the Post Office free of charge.

Other minor changes were made in subsequent years. In 1836 a postal treaty was arranged with France, under which certain rates-in general, rates slightly lower than those previously in force-were agreed for all letters passing through France.

The rates for colonial letters were revised when uniform postage was introduced in the inland service. They were made chargeable according to weight, and for transmission to any port in the colonies were fixed generally at $1 \mathrm{~s}$. the $\frac{1}{2}$ ounce.

In 1850, on political grounds, the Postmaster-General 3 proposed the establishment of a general 1s. rate for all colonial letters. The proposal was not immediately adopted, but a few years later a rate of $6 \mathrm{~d}$. the $\frac{1}{2}$ ounce was established for all parts of the Empire

s. Joyce, ibid., p. 362.

2 Ilbid., p. 363; 55 Geo. III, cap. 153 .

3 The Marquis of Clanricarde. 
except India, the Cape, Mauritius, and Tasmania. This rate was extended to all the colonies in 1857, and to the United States in 1868. In 1869 the rate for letters to the United States, Canada, and Prince Edward Island was reduced to 3d. In 1875 the Universal Postal Union rate of $2 \frac{1}{2} \mathrm{~d}$. came into operation. The next great advance was the result mainly of the efforts of Sir J. Henniker Heaton, who for many years advocated the facilitation of postal intercourse, especially within the Empire. In 1898 penny postage was established between the United Kingdom and all the chief colonies except Australia, the Cape, and Natal. In 1905 these colonies joined, and were followed by Egypt and the Sudan.

In 1907 a special rate of 1 d. a pound was established for magazines and trade journals posted in the United Kingdom for Canada. The rate did not cover the cost of service, and its justification is to be sought in political considerations. In order to secure the low rate Canada undertook to defray the whole cost of ocean transport. Difficulties in regard to the financial arrangements arose subsequently, and on the 1st January 1915 the rate was altered to the following, viz. $1 \mathrm{~d}$. for the first 6 ounces, $1 \frac{1}{2} \mathrm{~d}$. for $1 \frac{1}{2}$ pounds, $2 \frac{1}{2} \mathrm{~d}$. for $2 \frac{1}{2}$ pounds, and so on.

Under the old system the rates of postage were for the most part nominal, that is to say, no attempt was made to adjust the rates to the actual cost of providing the service, although in allocating between the different States the total amount of postage, a rough assignment as between land and sea services was made. ${ }^{x}$ The usual $6 \mathrm{~d}$. rate for single letters to and from the various colonies illustrates this. The actual cost of service must have varied greatly. In the case of the colonies other considerations, mainly political, were allowed to enter. In the case of foreign countries the whole arrangements for the interchange of correspondence were based on such agreements as could be arrived at, and the actual rates of

s "The principle upon which the postal communication between England and the Australian colonies has latterly been conducted is, that a postage of $6 \mathrm{~d}$. for a single letter has been charged, of which $4 \mathrm{~d}$. was understood to represent the sea rate, $1 \mathrm{~d}$. for collecting or delivering a single letter in any part of the United Kingdom, and the same in any part of the colonies; so that the whole cost of sending a letter from any part of the United Kingdom to any part of the Australian colonies, or vice versê, should not exceed $6 \mathrm{~d}$.

"As the whole cost of the packet service has hitherto been borne by the Imperial Government, the portion of the postage which represented the sea service has been accounted for to the Home Post Office, so that of the 6d. charged, $5 \mathrm{~d}$. has been appropriated to England, and $1 \mathrm{~d}$. to the colony receiving or despatching the letter, as the case might be."-Second Report of the PostmasterGeneral, London, 1856, p. 66. 
postage were determined in that way. ${ }^{x}$ The chief difficulties in negotiations occurred in connection with the division between the contracting parties of the postage collected. The packet service was often conducted at a loss, and the rates of postage on foreign and colonial letters were not, in general, fixed with a view to rendering the service self-supporting, although this was regarded as a condition to be aimed at. ${ }^{2}$

By the Consolidating Acts of 1837 ( 1 Vict., cap. $34 \& 36$ ) the Postmaster-General was empowered to require the masters of outward-bound vessels to accept mails, and to deliver them without delay on arrival at the port of destination, under penalty of $£ 200$.

The general character of the foreign packet service was entirely changed by the introduction of steam propulsion, which greatly shortèned the length of voyages and introduced a degree of punctuality and regularity hitherto undreamt of. Until this time the Post Office had, for many long-distance services, relied on its own packets; i.e. packets sailing under contract expressly for the conveyance of the mails and under the control of the Post Office. In 1818 , with the introduction of steam vessels, this policy was changed and that of Crown ownership of the packets adopted. This method was found extremely costly, and the Commissioners of Revenue Inquiry reported emphatically against it. 3

The policy of providing for the service by contract was then reverted to. It now appeared, however, that vessels sailing for commercial purposes could be counted upon to sail and arrive regularly, and the Government desired therefore to make use of them for the despatch of mails. It was proposed to forward mails by the Great Western under the powers conferred on the PostmasterGeneral by the Act of 1837 (1 Vict. 34, $\S 19$ ) for the prescribed remuneration ( $\$ 24)$. The owners refused to carry mails on these terms, and the Law Officers advised that the Postmaster-General had no power, either by Statute or Common Law, to compel the owners to carry mails.4 It was not found necessary, perhaps it was not deemed wise, to follow up the question of powers. In 1839 a contract was entered into with Samuel Cunard for the provision of a steamship service between England and North America, at a cost to the Post Office of $£ 55,000$ a year. This policy proved successful. It has been followed in the case of all the great routes, and has continued until the present day.

In considering the question of the rates of postage the sums

× Cf. H. Joyce, ibid., pp. 138-9.

2 Cf. note 1, opposite. 3 18th Report, 1829, and 22nd Report, 1830.

4 Historical Summary of Post Office Services, p. 52. 
paid to the shipping companies are a little misleading. The payments were not then, and are not now, made solely from regard to the fact that the vessels convey mails. Other considerations, such as the desirability of encouraging the shipping industry, its value to the commerce of the nation, and the value of a strong mercantile marine as a naval reserve, have always entered largely into the question. It was in accordance with this view, and largely on account of abuses in the administration of the services by the Post Office which had come to light, that the control of the Post Office packet services and of contracts for the conveyance of mails by sea was in 1837 transferred from the Post Office to the Admiralty. The control was in 1860 retransferred to the Post Office, but the amount of the subsidies paid to steamship companies conveying mails has continued to be influenced by other than purely Post Office considerations. The chief development in this direction has been a legal decision obtained in 1889, in a dispute between the Post Office and the Cunard Steamship Company, which arose from an attempt by the Post Office to introduce the American system of despatching mails by the fastest ships available, and paying, not a general subsidy, but a sum calculated on the basis of the weight of mails carried. The High Court ruled that the Postmaster-General is entitled to have all such mails as he may think fit received on board any of the Company's ships and conveyed and delivered at the ports of destination without delay. ${ }^{\mathrm{x}}$ Failing agreement as to the payment to be made in respect of such services, the Post Office can fall back on its statutory right to the conveyance by merchant ship of all letter mails at the rate of a halfpenny a letter.

The extension of penny postage to all countries has been prevented simply by financial considerations. ${ }^{2}$ In 1910 the question of establishing penny postage with France received a good deal of public attention both in this country and in France, but the Government were not prepared at that time to face the sacrifice of revenue.

I Historical Summary of Post Office Services, p. 55.

z "The advantage of Imperial unity, which was held in 1898 to justify the sacrifice of revenue incidental to a measure calculated to bind together the United Kingdom and her possessions beyond the seas, cannot, of course, be urged as a plea in favour of universal penny postage; but apart from all other arguments for and against the proposal, the decisive consideration is that the British Government are not at present in a position to bear the very heavy loss that would be involved in the reduction of foreign postage from $2 \frac{1}{2}$ d. to $1 \mathrm{~d}$."-Papers laid before the Colonial Conference, 1907 ; Memorandum by General Post Office (Cd. 3524), p. 500. 


\section{THE THURN AND TAXIS POSTS IN GERMANY}

The great number of the principalities which made up the Germany of the early Middle Ages, the mutual jealousy of the princes, and the indefinite authority of the Emperor, made the introduction of any sort of general system of communication extremely difficult. But for a long period before posts of the ordinary type were established in Germany, there existed throughout the Empire a system of messengers (Boten-Anstalten).

These establishments were maintained by the political administration, by the scholastic institutions, by political corporations, by merchant bodies, or by private individuals. ${ }^{\mathrm{I}}$ Their function was to effect the exchange of the correspondence of their founders. In addition, the occasional posts (Metzger), merchants travelling to the fairs, judicial and Imperial messengers, and pilgrim monks were much employed for the carrying of letters.

The system of Boten-Anstalten was widely extended, and its functions were not limited to the conveyance of letters. ${ }^{2}$ Its messengers travelled some of the great routes, such as HamburgStettin-Danzig; Hamburg-Leipzig-Nuremberg ; Cologne-FrankfortAugsburg; and these services were more or less permanent in character. Services on other routes were established to meet local or temporary needs, such as the assembly of the Reichstag, the meeting of the Electors, Peace Congresses, War Conferences, and fairs; and these services were discontinued when the occasion which had required them disappeared.

The organization of this system of messengers resembled in many ways that of ordinary posts : it was established and managed by the political authorities; the services were regular; the routes were fixed and stages were appointed; and the messengers undertook the conveyance of letters, goods, and persons, by foot, horse, or wagon. 3 At a later date letter-carriers were employed in some instances for the delivery of letters conveyed by the messenger services. A

' H. von Stephan, Geschichte der preussischen Post, Berlin, 1859, p. 3.

= "Kommt es doch vor, dass ein Bote eines deutschen Reichsfürsten ausser dem Botenlohn noch eine besondere Vergütung beansprucht, weil er auf dem Botengange gleichzeitig einige Schweine für die Herrschaft nach dem Bestimmungsort hat treiben müssen. Da diese Begleitung auf kein besonders lebhaftes Gangtempo schliessen lässt, so dürfen wir es dem Garzonus nicht verdenken, wenn er die deutschen Boten zum Wetteifer mit ihren Collegen im alten Persien ermahnt, deren Geschwindigkeit Xenophon in der Kyropädie mit dem Fluge der Kraniche vergleicht."-Ibid., p. 15.

3 Ibid., p. 4. 
charge of 3 pf. was raised on letters so delivered, the delivery charge on letters obtained directly from the Botenmeister being 1 pf. ${ }^{\text {I }}$

The intellectual awakening of the early sixteenth century, the great discoveries of that period and their effect on commerce, together with the tendency then developing towards amalgamation of the principalities and creation of larger political entities, all increased the necessity for an efficient system of intercommunication. The result is seen in the establishment of an Imperial system of posts. ${ }^{2}$

The regular Imperial posts were established towards the end of the fifteenth century by the Emperor Maximilian I. Johann von Taxis was the first Imperial Postmaster, and the earliest record of his tenure of the office is in 1489.3 A decree suppressing the system of Boten-Anstalten and the Metzger-posten was issued, but these posts continued, and it was discovered at a later date that their continuance was not incompatible with the maintenance of a system of Imperial posts.4

The Imperial posts were to provide more particularly for the transmission of despatches, and their immediate object was to provide a means of obtaining information regarding the Turks, and a means of communication with the princes of neighbouring territories.5 Their history is inseparable from that of the family of Thurn and Taxis, to whom their management was from the first entrusted. This family was of Italian origin, and before the establishment of the Imperial posts, Roger the First of Thurn and Taxis had established a horse-post between Italy and the Tyrol,

× B. E. Crole, Geschichte der deutschen Post, Eisenach, 1889, p. 214.

2 "Die Vereinigung Oesterreichs mit den Burgundischen Niederlanden ruft die erste Reichspost, die Vereinigung von Brandenburg, Preussen, Cleve und Hinterpommern unter einem Scepter die erste Brandenburgische Staatspost hervor."-H. von Stephan, op. cit., p. 5.

3 F. Ohmann, Die Anfänge des Postwesens, Leipzig, 1909, pp. 49, 86, and 92.

4 “(1) Die Unterhaltung solcher Boten lange Jahre vor Errichtung der Posten üblich gewesen; (2) dem Taxis ,wäre nur das Post, nicht das Botenwesen zu Lehen gegeben; (3) es würden ihnen (den Boten nämlich) viele Waren und Kostbarkeiten anvertraut, welche sie überliefern und dafür stehen, welches wieder der Postillone Werk nicht sei ; (4) die Posten dienten wohl zu Briefen, nicht aber zu Bestellung anderer Sachen, also könnten Posten und Boten wohl nebeneinander bestehen."-Imperial Rescript of 1686, given by Beust, Teil 1, s. 149 ff. ; cited F. Haass, Die Post und der Charakter ihre Einkiinfte, Stuttgart, 1890 , p. 93.

5 " For very good and potent reasons, especially on account of the troublesome war, as also for the purpose of obtaining good and reliable information about the Turks, the hereditary enemies of the whole of Christendom, and other potentates, adjacent to the Empire, in order that the Emperor, the King, and other potentates may exchange their correspondence."-Dr. Joseph Rübsam, L'Union postale, 1892, p. 126. 
which proved of so much value to the Empire that as a reward Roger was made a chevalier. On the routes along which the Imperial posts were laid, stages were fixed at intervals of about 5 (German) miles, and messengers were stationed at each stage. ${ }^{x}$ These messengers from the first enjoyed the privilege of exemption from all taxes and charges in all the countries through which the post routes passed. The posts were solely for the service of the Emperor, and at his charge; and at first, like the earlier messenger services, were established temporarily for special purposes, such as the movements of the Imperial Court, or to meet necessities arising from war; or permanently to provide services between distant and newly acquired territory. ${ }^{2}$

In 1500 Francis von Taxis was appointed capitaine et maitre de nos postes at Ghent by Philip the Fair, son of the Emperor Maximilian I, and in 1505 a convention was concluded between Philip and von Taxis under which the latter undertook to establish a line of posts between the Court of Maximilian I, the Court of the French King, and the Spanish Court, for a payment of 12,000 livres a year. The German and Spanish services were intended to maintain permanent and regular communications. The French post was intended to facilitate diplomatic intercourse. 3 The time occupied in the transmission of letters between Innsbruck and Brussels at this period was $5 \frac{1}{2}$ days in summer and $6 \frac{1}{2}$ days in winter; between Paris and Brussels 44 hours; and between Granada and Brussels 15 days.

Owing to financial difficulties the payments to von Taxis from the royal exchequer could not be kept up, and in order to maintain the service another source of revenue had to be discovered. It was found in the acceptance for transmission by the posts of private letters, and in allowing the use of the posts by private persons desirous of travelling. This was made part of the ordinary business of the posts, with the reservation that the use of the posts by private persons should not interfere with or impede the official service. 4

I "Es lag allweg 5 Meil wegs ein Post von den andern, einer war zu Kempten, einer zu Bless, einer an dor Bruck zu Elchingen und also fortan imerdar 5 Meil wegs von einander und must allweg ein Pot des andern warten, und so bald der ander zu ihm ritt, so bliess er ein hörnlin, das hört ein bott der in der Herberg lag und must gleich auf sein. Einer musste all Stund ein Meil, das ist 2 Stund (wohl für den Fussgänger berechnet) weit reiten, oder es ist ihm am Lohn abzogen, und musten sie reiten Tag und Nacht."-_Memminger Chronicle," cited F. Ohmann, Die Anfänge des Postwesens, Leipzig, 1909, p. 102.

2 Dr. Joseph Rübsam, ibid., p. $157 . \quad 3$ Ibid., p. 127.

4 "Contrary to what was usually the case with the postal arrangements in antiquity and the Middle Ages, the institution founded by Francis von Taxis, though chiefly intended to serve the purposes of the State, assumed from its 
In 1512 the Emperor Maximilian conferred on Francis von Taxis, and on several others of his family, titles of hereditary nobility in the Empire and in the Austrian and Burgundian dominions, together with the dignity of Count Palsgrave. ${ }^{\mathrm{I}}$ In 1516 the Taxis posts were extended to Verona, Rome, and Naples, and were improved and accelerated. In 1615 the office of Imperial Postmaster-General was conferred on Lamoral von Taxis and his descendants as an hereditary fief.

The actual development of the posts was of a twofold character. At first the Taxis family were able to establish their posts in various parts of the Empire without opposition; the princes were themselves satisfied with their messenger systems, and were indisposed to establish posts on account of the heavy cost. But after a time, when the profitable character of the Taxis posts became apparent, ${ }^{2}$ the princes questioned the right of the Imperial Postmaster-General to lay posts within their territories, and claimed that they alone possessed that right. 3 In 1597 the posts were proclaimed an Imperial reservation, 4 but this theory was never accepted by the princes. 5 The Taxis posts, therefore, never became general throughout the Empire. Rights were obtained in certain States, so that they became an important system reaching many parts of the Empire; but they did not altogether supplant the territorial services. ${ }^{6}$

In the early part of the seventeenth century the struggle against the monopoly of the Imperial posts developed. The States were jealous of the growing power of Austria, and political affinities were weakening. There was, moreover, some feeling against such an office being held by an alien family.7 The Palatinate, Würtemberg, Saxony, Brandenburg, and Mecklenburg established posts within their respective territories. ${ }^{8}$ The whole question became involved

very beginning a character of public utility and political economy, for it was at the disposal of anybody wanting a rapid, cheap, and safe means of conveyance for his letters."-Dr. Joseph Rübsam, ibid., p. 128.

I Ibid., p. 130.

$=$ Von Beust, cited H. von Stephan, op. cit., p. 6.

3 B. E. Crole, Geschichte der deutschen Post, Eisenach, 1889, p. 201 ; H. von Stephan, Geschichte der preussischen Post, Berlin, 1859, pp. 6-10.

4 Proclamation of 6th November 1597 ; B. E. Crole, op. cit., p. 205.

5 An account of the struggles between the Taxis family and the princes is given in Crole's Geschichte der deutschen Post (Part III, chaps. iv. and v.).

6 “Trotz der Ausdehnung der Taxis'sche Posten im 'Reich' hörte das Botenwesen in den einzelnen Ländern und in den Reichsstädten keineswegs auf sondern entwickelte sich fort und fort und hatte seine Botenmeister, auch Postmeister und andere Bedienstete."-B. E. Crole, op. cit., p. 213.

7 Ibid., p. 231.

8 E. Gallois, La Poste et les Moyens de Communication des Peuples à travers les Siecles, Paris, 1894, p. 94. 
with the disputes which led up to the Thirty Years' War, and the princes found their position indirectly strengthened by the Peace of Westphalia, which contained no settlement of the disputes regarding the posts, but merely referred the question to the next Reichstag. Attempts were made to extend the Imperial posts, but much opposition was encountered. Nevertheless, the system continued to expand and attained considerable dimensions. The family held the exclusive right of carrying passengers as well as letters; and it was estimated that during the eighteenth century the house of Thurn and Taxis received a gross sum of 20,000 livres per day, and a net profit of four millions a year. Some 20,000 men, and a greater number of horses, were employed in the service. ${ }^{x}$

The Revolutionary Wars were disastrous to the system. The Taxis posts were in many instances replaced by territorial posts, ${ }^{2}$ and by the Peace of Luneville (1801), which made the Rhine the boundary between France and Germany, the family lost control of all their posts to the west of the Rhine. They were, however, compensated for the loss of the revenues of those posts by a grant of territory (Reichs-Deputationshauptschluss of 25 February 1803).

In the following years the Prince of Taxis strengthened his position by a series of agreements with the German States, but with the establishment in 1806 of the Confederation of the Rhine and the abdication of the Emperor, the Holy Roman Empire and the Imperial posts fell together. In 1814 Prince Charles Anselm of Thurn and Taxis attempted unsuccessfully to regain possession of the posts in the Low Countries. The territorial posts were not, however, altogether satisfactory, and the rights of the Taxis family were restored by the Agreement of 1815, establishing the German Confederation; in pursuance of which the family recovered the posts in Electoral Hesse in 1816, in Schwarzburg-Rudolstadt, Oldenburg, and Saxe-Coburg in 1817, Hesse-Darmstadt in 1818, and Würtemberg in 1819. The posts in other States were recovered in subsequent years, and in 1848 the Taxis posts comprised an area of 2,675 square (German) miles, with a yearly income of a million Marks. 3 In most cases a rent was paid to the State for the privilege of conducting the posts. Thus, Würtemberg received a

B. E. Crole, op. cit., p. 247.

2 The territory of the Taxis posts shrank between the years 1790 and 1811 from 3,922 square (German) miles to 745 square (German) miles, and a number of territorial posts took the place of the Imperial posts. In 1810 there were no less than 43 of these territorial posts. -Die Brieftaxe in Deutschland, Freiburg im Breisgau, 1862, p. 4 ; C. F. Müller, Die Furstlich Thurn und Taxis'schen Posten und Posttaxen, Jena, 1845, p. 7.

3 Oskar Grosse, Die Beseitigung des Thurn und Taxis'schen Postwesens in Deutschlased, Kinden in Westf., 1898, p. 33. 
yearly payment of 70,000 florins, the Grand Duchy of Hesse of 25,000 florins, and Electoral Hesse of 40,000 thalers. ${ }^{\text {I }}$ In addition, the Governments of the respective States were given considerable privileges in regard to free transmission of State correspondence, etc. The rates of postage charged compared favourably with those charged in the States in which territorial posts were established. ${ }^{2}$ In 1850 the rates were simplified by the introduction of a scale based on three distance zones: not exceeding 15 miles, $4 \mathrm{kr}$. (1 sgr.); from 15 to 30 miles, $7 \mathrm{kr}$. ( $2 \mathrm{sgr}$.); and for distances exceeding 30 miles, $10 \mathrm{kr}$. ( 3 sgr.). In 1861 these rates were reduced to 3,6 , and $9 \mathrm{kr}$. respectively for the three zones. 3 In addition there was a local rate of $2 \mathrm{kr}$. ( $\left(\frac{1}{2} \mathrm{sgr}\right.$.) for letters delivered within a distance of 3 miles. In some of the towns a still lower local rate, $1 \mathrm{kr}$. ( $\frac{1}{4} \mathrm{sgr}$.) was in operation. 4

The Taxis posts were, however, still regarded with a good deal of jealousy, although it was recognized that in some ways the system was advantageous in providing a unified postal service for a large part of Germany at a time when it would have been difficult to arrange directly between the various States for the maintenance of a common service.

The situation was materially changed when, after the events of 1864-6, Prussia absorbed the duchies of the Elbe, Hanover,

× C. F. Müller, op. cit., p. 13.

2 The rates for a letter weighing 1 loth ( $\frac{1}{2}$ ounce) were :-

\begin{tabular}{|c|c|c|c|}
\hline $\begin{array}{l}\text { Distance } \\
\text { (German } \\
\text { Miles). }\end{array}$ & $\begin{array}{l}\text { In Würtemberg } \\
\text { (Taxis Posts). }\end{array}$ & \multicolumn{2}{|c|}{$\begin{array}{c}\text { In Prussia } \\
\text { (State Post). }\end{array}$} \\
\hline $1-3$ & $2 \mathrm{kr} .=$ & $2 \frac{1}{4}$ sgr.* & $1 \frac{1}{3} \operatorname{sgr} . \dagger$ \\
\hline $3-6$ & $3 \mathrm{kr} .=$ & 3 sgr. & $21 \mathrm{sgr}$. \\
\hline $6-12$ & $4 \mathrm{kr} .=1 \mathrm{sgr} . \quad 1 \frac{5}{7} \mathrm{pf}$. & $4 \frac{1}{2}$ sgr. & $3 \mathrm{sgr}$. \\
\hline $12-18$ & $6 \mathrm{kr} .=1 \mathrm{sgr} .8 \frac{4}{7} \mathrm{pf}$. & 6 sgr. & $3 \frac{3}{4} \mathrm{sgr}$. \\
\hline $18-24$ & $8 \mathrm{kr} .=2 \mathrm{sgr} . \quad 3 \frac{s}{7} \mathrm{pf}$. & $7 \frac{1}{2}$ sgr. & $4 \frac{1}{2} \operatorname{sgr}$. \\
\hline $24-30$ & $10 \mathrm{kr} .=2 \mathrm{sgr} .10 \frac{2}{7} \mathrm{pf}$. & $7 \frac{1}{2}$ sgr. & $4 \frac{1}{2}$ sgr. \\
\hline $30-36$ & $12 \mathrm{kr} .=3 \mathrm{sgr} .5 \frac{1}{7} \mathrm{pf}$. & 9 sgr. & $6 \mathrm{sgr}$. \\
\hline $36-42$ & $14 \mathrm{kr} .=4 \mathrm{sgr}$. & $10 \frac{1}{2} \mathrm{sgr}$ & 6 sgr. \\
\hline $42-48$ & $16 \mathrm{kr} .=4 \mathrm{sgr} . \quad 6 \frac{\mathrm{e}}{7} \mathrm{pf}$ & $10 \frac{1}{2} \mathrm{sgr}$ & 6 sgr. \\
\hline $48-54$ & $18 \mathrm{kr} .=5 \mathrm{sgr} .1 \frac{5}{7} \mathrm{pf}$. & 12 sgr. & $7 \frac{1}{2}$ sgr. \\
\hline $54-60$ & $20 \mathrm{kr} .=5$ sgr. $8 \frac{4}{7} \mathrm{pf}$. & 12 sgr. & $7 \frac{1}{2}$ sgr. \\
\hline
\end{tabular}

* Rates established 18th December 1824.

† Rates established 1st October 1844.-Ibid., pp. 9 and 39.

3 K. A. H. Schmid, Zur Geschichte der Briefporto Reform in Deutschland, Jena, 1864, p. 36.

4 Oskar Grosse, Die Beseitigung des Thurn und Taxis'schen Postwesens in Deutschland, pp. 98-9. 
Electoral Hesse, the Grand Duchy of Hesse, Nassau and Frankfort. Prussia, of course, desired to assume control of the posts in these territories, which formed a large part of the whole Taxis system. After some discussion of the rights of the Taxis family, as a result of which it appeared that legally the system was well grounded, and could not be taken, therefore, from the Taxis family without compensation, the Prussian Government decided to buy up the rights of the family in the new Prussian territory. ${ }^{x}$ The taking over of these posts would have left so small a system in the hands of the Taxis family that they preferred to negotiate for the transfer of the whole system to Prussia. The compensation to be paid was based mainly on consideration of the net revenue of the Taxis posts.

During the years $1855-65$ this had been as follows :-

$\begin{array}{lllllllll}1855-6 & . . & . . & . . & . . & . . & . . & . . & 405,582 \\ 1856-7 & . . & . & . . & . & . . & . . & . . & 579,218 \\ 1857-8 & . . & . . & . . & . . & . . & . . & . . & 692,884 \\ 1858-9 & . . & . . & . . & . . & . . & . . & . . & 500,412 \\ 1859-60 & . . & . . & . . & . . & . . & . . & . . & 638,801 \\ 1860-1 & . . & . . & . . & . . & . . & . . & . . & 648,519 \\ 1861-2 & . . & . & . . & . & . . & . . & . . & 464,751 \\ 1862-3 & . . & . & . . & . & . . & . . & . & 583,409 \\ 1863-4 & . . & . . & . . & . . & . . & . . & . . & 753,917 \\ 1864-5 & . . & . . & . . & . . & . . & . . & . . & 724,4052\end{array}$

The amount of compensation was agreed at three million Marks. The sum was voted by the Prussian Parliament without debate, and on the 1st July 1867 Prussia assumed the control of the entire Taxis system of posts. The administration was amalgamated with that of the ordinary Prussian posts.

\section{PARCEL POST IN CANADA}

Difficulties arising from the circumstances of the country made the early establishment of a parcel post system impracticable. ${ }^{3}$

For many years, however, a strong feeling in favour of a parcel post system existed, especially among the farmers of the West; and with the establishment of a service in the United States in 1913 it became impossible to withhold a similar service from Canada. The question was discussed in Parliament in January 1913, and, as the immediate adoption of a system was obviously desired, the

Ibid., p. 47.

2 Ibid., p. 66.

3 The conditions were in many respects similar to those obtaining in the United States. Vide supra, p. 191. 
Government undertook to give the matter fullest consideration, with the view of submitting a scheme at an early date. The matter was really of some urgency since, under an existing Convention, although no internal parcel post service was in operation, Canada was called upon to carry throughout her territory parcels originating in the United States; and in June 1913, when the success of the service in the United States was seen to be assured, a Bill was introduced authorizing the establishment of a parcel post in Canada.

There could be no question of applying a flat rate in a country of such vast territories and scattered population $;^{x}$ and the Canadian system, like the American, is based on zones of distance. The limits of the zones correspond with the provincial boundaries. Each province forms a zone, with a flat rate within its borders; a rate as for an additional zone is charged on parcels crossing into an adjoining province; and a rate as for a third zone on parcels crossing an intermediate province to a third province; and so on. The three maritime provinces are grouped together as one zone, and a special local zone rate is given for parcels delivered within 20 miles of the place of posting. This local rate is independent of the provincial boundaries. It is a concession to the storekeepers of the smaller towns, given chiefly for their protection against the competition of the great departmental stores of Montreal, Toronto, and Winnipeg.

The determination of the actual amount of the rates was left to the Post Office department, with the proviso that they must be such as would make the service self-supporting.

The service was introduced in April 1914, with the following rates of charge:-

(a) Five cents for the first pound and 1 cent for each additional pound or fraction thereof, up to four pounds, and 2 cents for each subsequent pound up to eleven pounds within a radius of 20 miles from the place of mailing, irrespective of provincial boundaries.

(b) Ten cents for the first pound and 4 cents for each subsequent pound or fraction thereof, for all points in the province in which a parcel is posted, outside of the 20-mile radius.

(c) Ten cents for the first pound and 6 cents for each additional pound or fraction thereof, for all points outside the province in which a parcel is posted, and beyond the 20-mile radius, with an additional charge of 2 cents a pound

" "In England you have thickly congested rural districts, large towns every few miles, and tremendous cities : in Canada you have a population of less than $8,000,000$ spread over a vast area, with few cities or large towns, and with vast spaces that must be traversed where no population exists. . . We are giving, as compared with England, a flat rate in an area twice as great as Britain gives parcel post, and where all the conditions are much less favourable."-Hon. $L$. Pelletier, Parl. Debates, Canada (Commons), 4th June 1913. 
for each province that has to be crossed to the destination of the parcel, not including the province in which it is to be delivered, up to a maximum of 12 cents a pound.

An additional charge to meet the extra cost of transportation is made on parcels addressed to or posted at offices in certain outlying districts when the parcels have to be conveyed on stage routes over 100 miles in length.

Statistics of the number of parcels dealt with are not taken by the Canada Post Office.

\section{THE SUPPLEMENTAL SERVICES}

In connection with the transmission of postal packets, other services, which are supplemental, and in some cases complementary, have been added, e.g. registration and insurance, in order that senders may protect themselves against loss or damage of packets in the post. ${ }^{2}$ Closely allied to the transmission of ordinary letters is the transmission of money from place to place, and from early times the Post Office has also undertaken this function for appropriate fees. This is the money order and postal order business. These services apply only to a very small proportion of the total number of packets posted, and may in general be regarded as exceptional. 3

In addition to these supplemental functions, the Post Office has usually been called upon to undertake services which have little or no relation to the transmission of letters from place to place. Thus, the British Post Office conducts a Savings Bank, undertakes the issue of certain local taxation licences (gun and dog licences, etc.) on behalf of the Inland Revenue Department and local authorities, pays Old Age Pensions, sells stamps on behalf of the National Health and Unemployment Insurance Commissioners, exhibits certain Government notices in the windows of post offices, and, in general, stands ready to perform any service to which, by reason of its ramifications reaching to the remotest part of the kingdom, it may be specially well adapted.4 In many countries the Post Office has assumed the control of the telegraph or telephone systems, or

× Canada Official Postal Guide, 1917, pp. 27-8.

2 Such improvements as the introduction of letter-cards, reply-paid postcards, etc., afford conveniences to the public, but they have little bearing on general questions of rates of charge. The number of such articles passing by post is insignificant in comparison with the total postal traffic.

3 Thus, in the United Kingdom, the number of letters registered in 1913-14 was 68 per cent. of the total number posted. The tuial cost of the supplemental services, including registration, insurance, and express delivery, was in 1913-14 only about a million, out of a total cost for all postal services of over $£ 17,000,000$ (Annual Report of the Posimaster-General, 1913-14, p. 92).

4 "In the present century the Post Office has assumed three new functions- 
both-this, of course, largely in consideration of the close affinity between the essential character of those services-transmission from place to place of information and intelligence-and the primary function of the Post Office; and in consideration of the tendency of those services, like the letter service, to develop on monopolistic lines. ${ }^{x}$ In continental countries the Government control of the telegraphs has been regarded as a military necessity. ${ }^{2}$ The assumption of these functions has no necessary relation to the rates charged for the transmission of packets, but the circumstances under which the services are conducted, whether at a profit or at a loss, may indirectly affect the rates.

\section{POST OFFICE REVENUE}

In England, Germany, and France the Post Office has, almost from the first, been a source of revenue to the State. What has happened has been that since the reform the Governments have been glad to take whatever net revenue a penny rate would yield, but, in general, they have not been prepared to raise that rate in order to obtain a greater revenue.3 The only one of the five

the transmission of money, and telegrams, and the custody of savings. These are alike only in requiring a widespread system of branch offices."-A. M. Ogilvie's article on "The Post Office" in R. H. Inglis Palgrave's Dict. Political Economy, London, 1899, vol. iii. p. 175.

"The so-called 'Post Office' is in fact a collection of different, though connected, industries."-C. F. Bastable, Public Finance, London, 1903, p. 206.

${ }^{\prime}$ See H. R. Meyer, Public Ownership and the Telephone in Great Britain, New York, 1907.

2 "To-day, State ownership is the general rule over Europe, and only in America is there private ownership on a large scale. It is significant that the first seizure of this monopoly of the State was in France, on the simple ground that it was not safe to allow so important a device to be in other than the hands of the State. In 1837 a law was passed making every kind of telegraph a State monopoly. This was due to Napoleonic influence. It was not until 1870 that the British Government claimed the monopoly."-John Lee, Economics of Telegraphs and Telephones, London, 1913, p. 2.

3 "No man can feel a more intimate conviction than I do that, whatever our financial difficulties may be, we must not take measures to meet them which should bear upon the comforts of the labouring classes. . . Well, then, I must, with my sense of public duty, abandon the idea of raising a revenue from the Post Office."-Sir R. Peel, 11th March 1842, Parl. Debates (Commons), vol. lxi. col. 434 .

"If, therefore, it should also happen that it (the penny) is the best rate adapted ultimately to produce the largest amount of money profit, such a coincidence would be the result of accident, not of design."-Report from Select Committee on Postage, 1843; evidence of Sir Rowland Hill, Answer 74.

"The Post Office, and, since the fall in silver, the Mint, both produce in England a net revenue, but the yield of revenue ought to be considered as purely 
countries which does not make, and on principle does not wish to make, a revenue out of the Post Office is the United States of America.

The penny letter rate is not by any means as low as the cost of the service. It is, however, not a burdensome charge in any circumstances, and, although so much greater than the cost, represents in a large number of instances much less than the full measure of benefit which the provision of the service confers on the beneficiary. This is, of course, the ordinary case of the purchaser of a commodity securing a "consumer's surplus." ? Rates which yield a profit of 50 per cent. (pp. 76 and 311) must, however, be admitted to contain some element of taxation. In France particularly the Post Office occupies a definite place in the fiscal system. ${ }^{2}$ There is, however, considerable diversity of opinion among economists with regard to the theoretical character of this revenue. Indeed, the general classification of public revenues is itself not yet agreed upon.3 Under any classifi-

incidental if not accidental."-J. Shiold Nicholson, Principles of Political Economy, London, 1901, vol. iii. p. 372.

As a war measure the United Kingdom has now increased the rate on letters over one ounce in weight. Such letters are, however, only a small proportion of the total number of letters posted (vide supra, p. 33). Canada has imposed a war tax of one cent on all letters, and on postcards (supra, p. 57).

- Vide Alfred Marshall, Principles of Economics, London, 1907, vol. i. p. 124.

"If I put a letter in the pillar-box rather than walk half a mile to deliver it by hand, it is clear that I value the service at one penny at least, and if its true value is to be taken at less than a penny, it must be assumed that some one would have carried the letter for less than a penny if the Post Office monopoly had been absent. But to deal thoroughly with this question it would be necessary to enter on a discussion of the Austrian theory of value and Marshall's conception of 'consumer's rent.' "-E. Cannan (Memoranda on Classification and Incidence, p. 163).

2 "Notre système fiscal demande aux impôts indirects la plus grande partie de nos recettes budgétaires. Les allumettes sont lourdement taxées. Écrire une lettre est, malgré tout, moins indispensable a l'homme qu'allumer du feu. Tant que les objets de première nécessité sont frappés, il n'y a pas raison décisive pour refuser de laisser prélever sur les correspondances de toutes sortes un impôt indirect, qui apparait, dans les écritures budgétaires, commo un excêdent de recettes des Postes, Télégraphes, et Téléphones sur leurs dépenses.

“Si légitimes que soient en principe les bénéfices de l'État-postier, tenons pour certain que le public, a moins de quelque catastrophe imprévue, ne permettra pas de les accroitre beaucoup, et que les Ministres de Finances de demain auront beaucoup de peine a conserver le peu qui leur on reste."-Rapport portant fixation du Budget général, Chambre des Députés, Session 1909, No. 2767.

3 "The widest division of public revenue is into (1) that obtained by the State in its various functions as a great corporation or 'juristic person,' operating under the ordinary conditions that govern individuals or private companies, and (2) that taken from the revenues of the society by the power of the sovereign.". F. Bastable, Public Finance, London, 1903, p. 158. Cf. C. C. Plehn, Intro- 
cation there is difficulty in assigning a place for the Post Office revenue. With the simplest and most fundamental division it has been regarded as falling under one or other heading, according to the notion of the writer, or in accordance with certain changes of conception based on variations in attendant circumstances. ${ }^{x}$

The difficulty of classification arises from the fact that of the total amount of the postage charges actually levied, only a portion can in any case be regarded as taxation. A person who purchases a commodity from the State, but in purchasing it is charged something more than its actual value, is not taxed to the extent of the whole of the amount which he is charged. There can be no taxation in that part of the amount for which he receives equivalent value in the commodity purchased. It is easy to say of the gross postal revenue that so much is tax (i.e. the net revenue), and so much is cost of service (i.e. the actual expenses), though it may not be easy to justify even this distinction; ${ }^{2}$ but what principle is to be followed in determining whether a particular postage charge (e.g. the letter rate or the parcel rate), or any part of it, is taxation?

Taxes are reckoned according to the rate of charge. Thus, the income tax is $2 \mathrm{~s}$. $3 \mathrm{~d}$. in the pound on earned incomes; but approached in this way postage is not a tax. If the charge only covers the cost of the service, there can be notax. ${ }^{3}$ And when there

duction to Public Finance, New York, 1909, p. 79; E. R. A. Seligman, Essays in Taxation, New York, 1913, p. 400, et seq.; see also Bastable, op. cit., p. 156.

I E.g. "The common mode of levying a tax on the conveyance of letters is by making the Government the sole authorized carrier of them, and demanding a monopoly price. When this price is so moderate as it is in this country under the uniform penny postage, scarcely if at all exceeding what would be charged under the freest competition by any private company, it can hardly be considered as taxation, but rather as the profits of a business; whatever excess there is above the ordinary profits of stock being a fair result of the saving of expense, caused by having only one establishment and one set of arrangements for the whole country, instead of many competing ones."-J. S. Mill, Principles of Political Economy, London, 1871, vol. ii. p. 461.

$=$ Vide note 2, opposite.

3 "Wherever the benefit to the individual can be even approximately estimated there is a strong presumption in favour of levying the cost incurred from him and converting the tax into a 'fee." -C. F. Bastable, op. cit., p. 267.

"To be properly remunerative to the State, as to a private individual, the price at which a commodity is sold must be sufficient to pay interest on the capital invested in the business, that is to say, to pay for the use of the property which must be used in producing the commodity, as well as to pay the more immediate cost of its production in wages and materials. There is no ground at all for the theory sometimes put forward that the State should deliberately abstain from making a profit from the working of an institution like the Post Office. Taxpayers are indeed nearly all users of the Post Office, and users of the Post Office are nearly all taxpayers, but there is nothing to show that people are taxed in the 
is a surplus (above normal commercial profit) it cannot be argued that the whole charge becomes a tax. The solution seems to be that in such a case it is neither tax nor industrial price. It contains elements of both, and cannot be classed wholly under either. ${ }^{\mathrm{x}}$

The differing analyses of Post Office revenue result largely from their being based on consideration of the balance-sheet of the Post Office, as indicating whether postal charges are to be regarded as taxes. ${ }^{2}$ The character of postal charges should not, however, be

same proportion as they use the Post Offico-the largest taxpayers are not necessarily the largest users of the Post Office. Consequently it is not a matter of complete indifference whether the State, which in this case means the taxpayers, makes a profit on the business or not. The only question difficult to decide is how much interest on the capital invested the State ought to obtain, in order to make the business remunerative but not a source of taxation. When the State has no monopoly, or only a monopoly secured by driving out all competitors in fair commercial rivalry (if such a case has ever occurred), it may charge what it can get for the commodity sold without making the business a source of taxation. But when the State has conferred on itself a monopoly of a business, it is evident that to charge the price which would bring in the largest profit would often be simply equivalent to laying a tax on the commodity. In this case, the price charged should only be such as would produce a rate of interest which would satisfy private individuals or joint-stock companies, supposing there were no monopoly. The rate of interest should be reckoned in relation to the actual market value of the property used, not in relation to what it may have originally oost the State. When the State makes a bad investment the loss should be written off once for all as soon as it is discovered. If, for instance, a State has bought telegraph apparatus for far more than it is worth, there can be no reason why the senders of telegrams, and not the whole body of taxpayers, should pay for the mistake."-Edwin Cann?" m! lementary Political Economy, London, 1903, pp. 130-1.

The cost which ought in strictness to be taken is the cost of the most economical private commercial undertaking which would provide an equal service if the monopoly of the Post Office were withdrawn:-

"I do not regard the greater part of the Post Office revenue as a tax at all. If all of it were earned by doing for the public on a large scale work that no private company could do as cheaply, because it would have to do it on a small scale, then I should say that none of the Post Office revenue was a tax. That part, however, of its revenue which it gets by prohibiting others from performing services for the public is a tax."-Alfred Marshall, The Times, 6th April 1891.

"The terms "Mixed Taxes" and "Quasi-Taxes" have been applied to charges of this character. "Mixed Taxes, or Quasi-Taxes, naturally arise when a governing body makes demands for payments, and gives something in return, but without any pretence of equivalence between individual payments and individual returns."-R. Jones, The Nature and First Principle of Taxation, London, 1914, p. 7.

2 E.g. "Many definitions of the word 'tax' have been proposed, but I know of none which would include just so much of the Post Office revenue as happens to be in excess of the amount expended in the year and no more.

"I believe that the desire to reckon this amount and no more as a tax, arises from a somewhat dim impression that it is the sum which the State 
determined by reference solely to the amount of the surplus revenue. The true classification rests on the conception that the character of public revenue (including Post Office revenue) varies with varying circumstances. ${ }^{x}$

The penny letter rate is a source of very considerable profit, and is therefore not a pure price. Nor can it be said that this penny rate, although it is the source of practically all the profit, is a pure tax. In the case of a large number of letters there is no surplus beyond the cost of the service, and often the cost is greater than the yield of the postage on the particular letters dealt with. In such cases the rate does not contain any element of tax. In other cases the proportion of surplus over cost which the rate yields is exceedingly large. ${ }^{2}$ But in all cases it contains some element of remuneration

exacts in excess of what a private company, without any legal or natural monopoly, would have to be satisfied with for performing the same services. But it is not. In the first place, such a private company would expect and receive about 3 per cent. on its capital in addition to the mere working expenses. We do not know what the capital of the Post Office is, but it must be very great, seeing that all the more important offices are owned in foe simple. Secondly, a company would raise new capital for new buildings and the purchase of more land, instead of defraying the, expense as if it were current working expenditure. Thirdly, a company would not 'encourage thrift' by giving away upwards of $£ 700,000$ a year to the depositors in the savings bank, by paying $2 \frac{1}{2}$ per cent. Fourthly, in all sorts of ways the Post Office is not conducted as a commercial enterprise would be. For example, it spends more than a company would do in the less profitable districts.

"The only argument I know of in favour of treating the so-called ' net revenue' alone as a tax, thus breaks down. If any part of the gross revenue is a tax, the whole must be."-E. Cannan (Memoranda on Classification and Incidence, p. 163).

I "The payment for the same service may be a price in one State, a fee in a second, or a tax in a third. . . . The controlling consideration in the classification of public revenues is not so much the conditions attending the action of government or the kinds of businesses conducted by the government, as the economic relations existing between the individual and the government."- E. R. A. Seligman, Essays in Taxation, p. 423.

2 This has been held a justification for regarding the letter rate as a whole as a pure tax:-

"A special service is no doubt rendered to each contributor of the tax, as well as a general service to the whole community, by means of the facilities of communication always available; but the charge is what is technically known as a tax, and the fact that a particular, as well as a general, service is rendered, does not alter the tax nature of the charge. Apart from the theory it has also to be considered that the productive portion of the Post Office revenue is derived from charges where the cost is very little-from letters, for instance, in the metropolitan district, or in and between great centres of population, where the cost of conveyance and delivery does not exceed, probably, one-tenth of a penny per letter, and the surplus of nine-tenths is spent on other services of the Post Office on which there is a deficit."-Sir Robert Giffen, K.C.B. (Memoranda on Classification and Incidence, p. 94). 
for service rendered. That part of it which is appropriated to cover the cost of conducting the service is of the nature of a price for a service rendered. The remaining part (when found), after allowance has been made for the element of monopoly, is a tax. ${ }^{x}$ But it does not exist in all cases. Three categories of letters are therefore found; and the letter rate in general may, according to the circumstances under which the service is rendered, be (1) of composite character, partly price and partly tax, (2) a pure price, (3) a mere fee.

The other rates (excepting for the moment the parcel rate) have all for some specific purpose of State been fixed at a lower level than the letter rate; but, for the most part, without any nice adjustment to the cost of service. Consequently these subsidiary rates are not prices, and do not contain any element of taxation. ${ }^{2}$ They are, however, charges made to individuals in respect of certain services performed by the State, and fall, therefore, under the heading of fees.

The parcel rates in England and Germany may be put under the same heading. In both cases the service is conducted at a loss, and the charges cannot therefore be regarded as prices. In

The argument is that in large towns the cost of the service is infinitesimal, and the charge is therefore tax. Obviously this has no application to country services.

Plehn does not take this view :-

" Postal surplus not the result of taxation.

"There are some writers who regard any surplus acquired in this way as practically the result of taxation, and class any charge for the public service, above the cost thereof, as a special tax. This classification presupposes that the service is, by nature, of a public character, an assumption contrary to the fact, for no function except that of governing itself, in the narrowest possible sense, is by nature of a public character, nor, on the other hand, by nature of a private character. On this consideration, therefore, it is better to class these gains, not as taxes, but as the earnings of a public industry."-C. C. Plehn, Introduction to Public Finance, p. 358.

" "On the purely financial side the gain from the service must generally be a small one; the return for capital employed is little, and the only remaining element would be the economy that results from the application of monopoly, and the consequent unity of the service. Any further charge is really a form of taxation."-C. F. Bastable, Public Finance, London, 1903, p. 209.

"When we come to look more closely into the essential character of this 'public utility' in respect of its oconomic and financial value, it will appear that in this case an important administrative function has attached to it, as it were involuntarily, an effective contrivance for the levying of a tax, suoh as to require that the Post Office be taken up in connection with the theory of taxation."-G. Cohn, Science of Finance, translated by T. B. Veblen, Chicago, 1895, p. 126.

2 The rates for postcards, printed matter, and samples roughly correspond with the cost of service and are perhaps to some extent prices. 
the United States and in Canada the law provides that the rates for parcels must in all cases be such as to yield a revenue sufficient to cover the cost of the service, and the presumption is therefore that in those countries the rates will partake of the nature of prices. ${ }^{\mathrm{x}}$

Although there has been diversity of opinion regarding the nature of Post Office revenue, there has been remarkable unanimity as to the propriety of raising a net revenue for the State on the service for the transmission of letters. In the days of high rates and relatively high revenue it was not challenged. ${ }^{2}$ Sir Rowland

- The suggested classification, if satisfactory from the speculative point of view, does, however, give rise to practical difficulties. In public financial statements it is, of course, impossible to show the actual nature of the revenue on such a basis. The only practicable course is to classify as a whole the gross revenue and the net revenue for the entire service. There is difference of opinion even as to this apparently simple problem. The common-sense solution would seem to be that recommended by Sir Edward Hamilton, viz. to reckon the net revenue as a tax and the balance of gross revenue as payment for services rendered; although in view of the complications resulting from the existence of unremunerative services, and the failure to make proper allowance in respect of the capital employed in the service, such a course is unscientific and misleading.

"The whole of the receipts from the various sources administered by the Post Office has always been treated in our Public Accounts as 'Non-Tax Revenue.' It is all carried to the Exchequer; and the whole cost is annually provided by Parliament. Therefore, to omit altogether this public receipt from a classification of taxes would seem to be the natural course to take. But the charge which is made for the carriage of letters, telegrams, and parcels, so far as the Post Office services are a State monopoly, is unquestionably ' an obligatory contribution by persons in respect of or incidental to something which they do.' Accordingly, to take no account of this charge, which nobody can avoid, would be to omit something which falls within our definition of a tax. At the same time it is obvious that to treat the whole of the Post Office revenue as a tax would for present purposes be misleading, inasmuch as the amount actually expended by the State represents direct and immediate service rendered to those who write letters or send telegrams. Regard being had to these considerations, when balanced one with another, it appears to me that the least incorrect course to adopt is to treat as a tax the amount by which the revenue derived from Post Office services exceeds the cost of administering those services."-Sir E. W. Hamilton, K.C.B. (Memoranda on Classification and Incidence, p. 36).

See also p. 361, n. 2, supra.

2 "There cannot be devised a more eligible mothod than this of raising money upon the subject; for therein both the Government and the people find a mutual benefit. The Government acquires a large revenue, and the people do their business with greater ease, expedition, and cheapness than they would be able to do if no such tax (and of course no such office) existed."-Sir William Blackstone, Commentaries on the Laws of England, London, 1783, vol. i. p. 324.

"Nor, while the rates of postage are confined within due limits, or not carried so high as to form any serious obstacle to correspondence, is there, perhaps, a more unobjectionable tax."-J. R. McCulloch, Taxation and Funding, p. 320. 
Hill's reform took away any sort of feeling that the revenue obtained from the Post Office lay as a burdensome tax, but the amount of surplus revenue was still so considerable that it could fairly be regarded as containing an element of tax. ${ }^{x}$ It has, moreover, steadily increased, and its existence been made the justification for claims for further reductions of rate. ${ }^{2}$

The use of the Post Office for the purpose of taxation, that is, the refusal to give away in improvements of service, or by reduction of rates, the net surplus of revenue, is accepted by economists as justifiable, 3 and the public acquiesces. The sur-

I "The Post Office in reality is neither a commercial nor a philanthropic establishment, but simply one of the revenue departments of the Government. It very rightly insists that no country post office shall be established unless the correspondence passing through it shall warrant the increased expense, and it maintains a tariff which has no accordance whatever with the cost of conveyance. Books, newspapers, and even unsealed manuscripts, can be sent up to the weight of 4 ounces for a penny; whereas if a sealed letter in the least exceeds $\frac{1}{2}$ ounce it is charged 2d. It is obvious that the charges of the Post Office are for the most part a purely arbitrary system of taxes, designed to maintain the large net revenue of the Post Office, now (1867) amounting to a million and a half sterling.

"It will thus be apparent that Sir Rowland Hill's scheme of postal tariff consisted in substituting one arbitrary system of charges for a system more arbitrary and onerous."-W. S. Jevons, Methods of Social Reform, London, 1883, p. 280.

2 "Will it pay?

"I will here lay down what may seem to financiers in this House a somewhat startling position. I hold that the State has no right to make a profit out of the Post Office. (Cheers.) . . . Probably half the letters sent are business letters; and another very large share is sent by persons of small means who have many stern inducements to take care of their pence. In other words, one half of your postal revenue is derived from a tax on the machinery of trade, and another large share from the poorest class of citizens.

"This is practically a tax on commerce."-Sir J. Henniker Heaton, Parl. Debates (Commons), 30th March 1886.

3 " Regarded as a tax diffused over the whole community, it is on the whole defensible, though the tendency to insist that the postal profits shall be devoted to improving the service is already becoming more pronounced."-C. F. Bastable, op. cit., p. 575.

"The Post Office, therefore, is at present one of the best sources from which this country derives its revenue. But a postage much exceeding what would be paid for the same service in a system of freedom is not a desirable tax. Its chief weight falls on letters of business, and increases the expense of mercantile relations between distant places. It is like an attempt to raise a large revenue by heavy tolls : it obstructs all operations by which goods are conveyed from place to place, and discourages the production of commodities in one place for consumption in another; which is not only in itself one of the greatest sources of economy of labour, but is a necossary condition of ulmost all improvements in production and one of the strongest stimulants to industry and promoters of 
plus is obtained with the minimum of sacrifice on the part of those who pay, and it would be difficult to discover a tax in substitution which would fall as lightly. Apart from the fact that rates higher than would be necessary for defraying the actual cost of the service must of necessity operate to some extent to the disadvantage of trade and commerce, ${ }^{\mathrm{I}}$ there is little to urge against the raising of revenue from the Post Office, especially as it is obtained from such popular charges as a penny and a halfpenny, which are well within the reach of the poorest. Payment is, moreover, in a large degree voluntary. The number of letters which a private individual must write, and cannot avoid writing, in the course of a year is very small. If he has anything of importance to write, he does not think a penny an excessive sum to pay for its transmission. If he has nothing to write, there is no law to compel him to pay postage. The profits of postage are, however, large; and the existence of the State monopoly, and the essentially fiscal character of the rates charged, should not be overlooked.2

civilization."-J. S. Mill, Principles of Political Economy, London, 1871, vol. ii. p. 462.

"It may happen (quite acceptably) that a surplus comes in from an undertaking which is primarily carried on for administrative purposes alone. A striking instance of this is afforded by the letter post. If the administrative purpose in question admitted of no aim beyond the covering of its own expenses, such a surplus would have no meaning, or at any rate no other meaning than that of a surplus in the hands of a consumers' club, which is returned to the members, on the closing of the accounts for the year, in the proportion in which they have contributed to it. The fact that the postal service not only retains any such surplus but even (with due regard to its primarily administrative function) consciously seeks it, is to be explained on the ground that, without hindrance to the administrative function, the different abilities of the citizens to contribute to public purposes may be drawn on by this means, with desirable results which are not attainable in any other way."-G. Cohn, op. cit., p. 94. Cf. The Development of the Post Office, Fabian Research Department, London, 1916, pp. 43-7.

* The extent to which any such disadvantage may be experienced is, of course, largely minimized by the existence of a low rate containing no element of tax, (see supra Chapter IV) for most of the formal documents of commerce.

2 "It is wholly misleading to point to the fact that the business of the Post Office now yields a very considerable profit, and to suggest that increased remuneration can easily be provided from that source. That profit is not in a bag to be drawn upon at will. It goes into the National Exchequer, and forms part of the revenue of the country, and if two or three millions is taken from it, the deficit in the Exchequer must be made good in other ways. And it has never been admitted, nor can it now be admitted, that the profits of the Post Office belong in equity to the staff rather than to the taxpayer. The Post Office is not like a private business. Parliament has established a monopoly, and has fixed certain rates of postage. If Parliament chose to relax that monopoly, or 
to reduce those rates of postage, the profit would straightway disappear. It does not do so, because it desires to retain for the Exchequer the sums so brought.

"Parliament has also established the sixpenny telegram, extended the telegraph service into remote rural districts, and has given very cheap rates to the Press. This has resulted in the telegraphs being worked at a loss of over a million a year. No one would suggest that it would be just, because of this loss, to reduce the wages of the men and women employed in the telegraph service, and it is equally beside the mark to quote the profits on the postal side as though the pay of the staff should be determined by their amount."-The Right Hon. Herbert Samuel, British Postmaster General, to a deputation from the staff, 19th November 1913. 


\title{
RATES OF POSTAGE
}

\author{
VII. GRAPHS
}

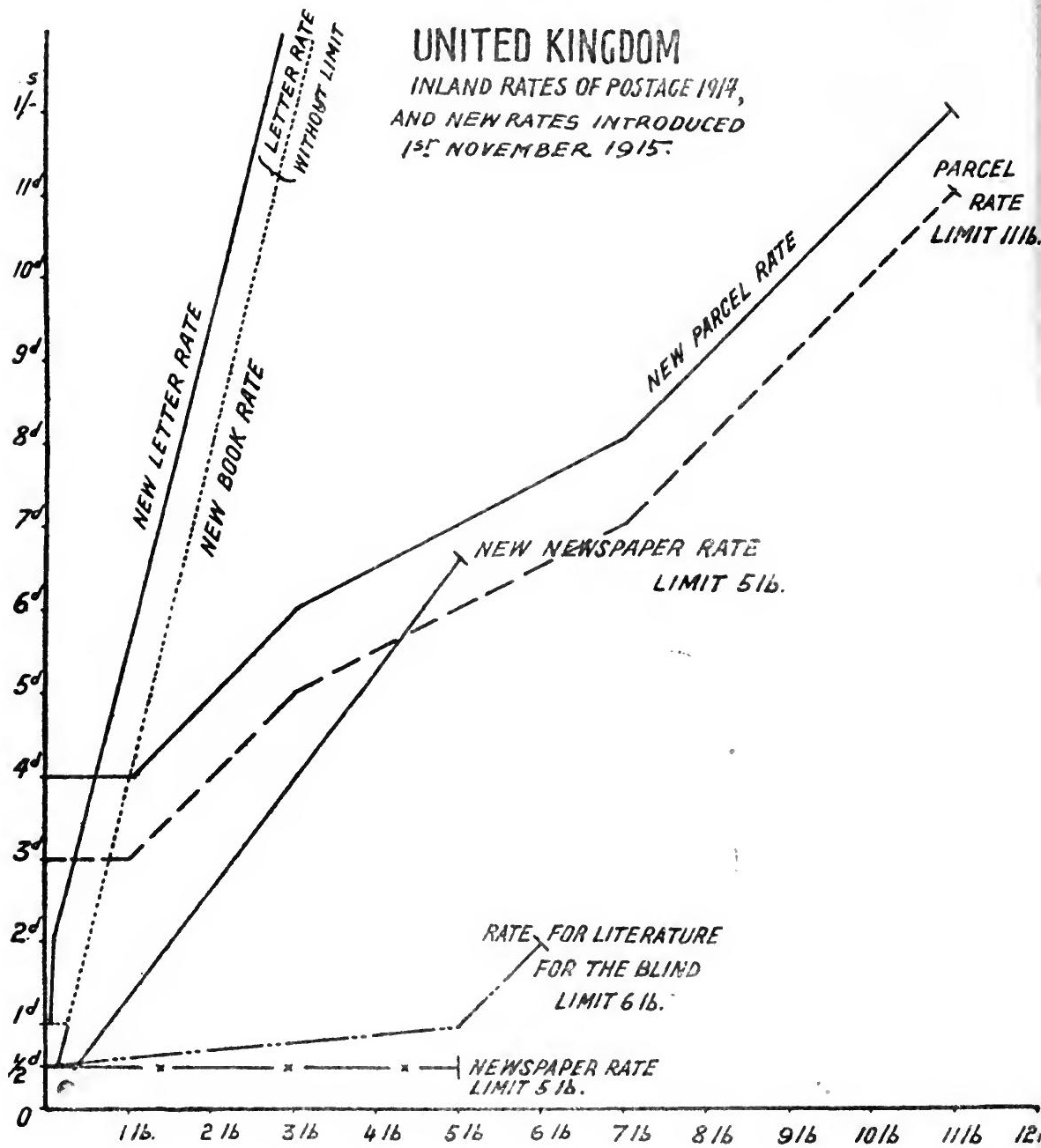




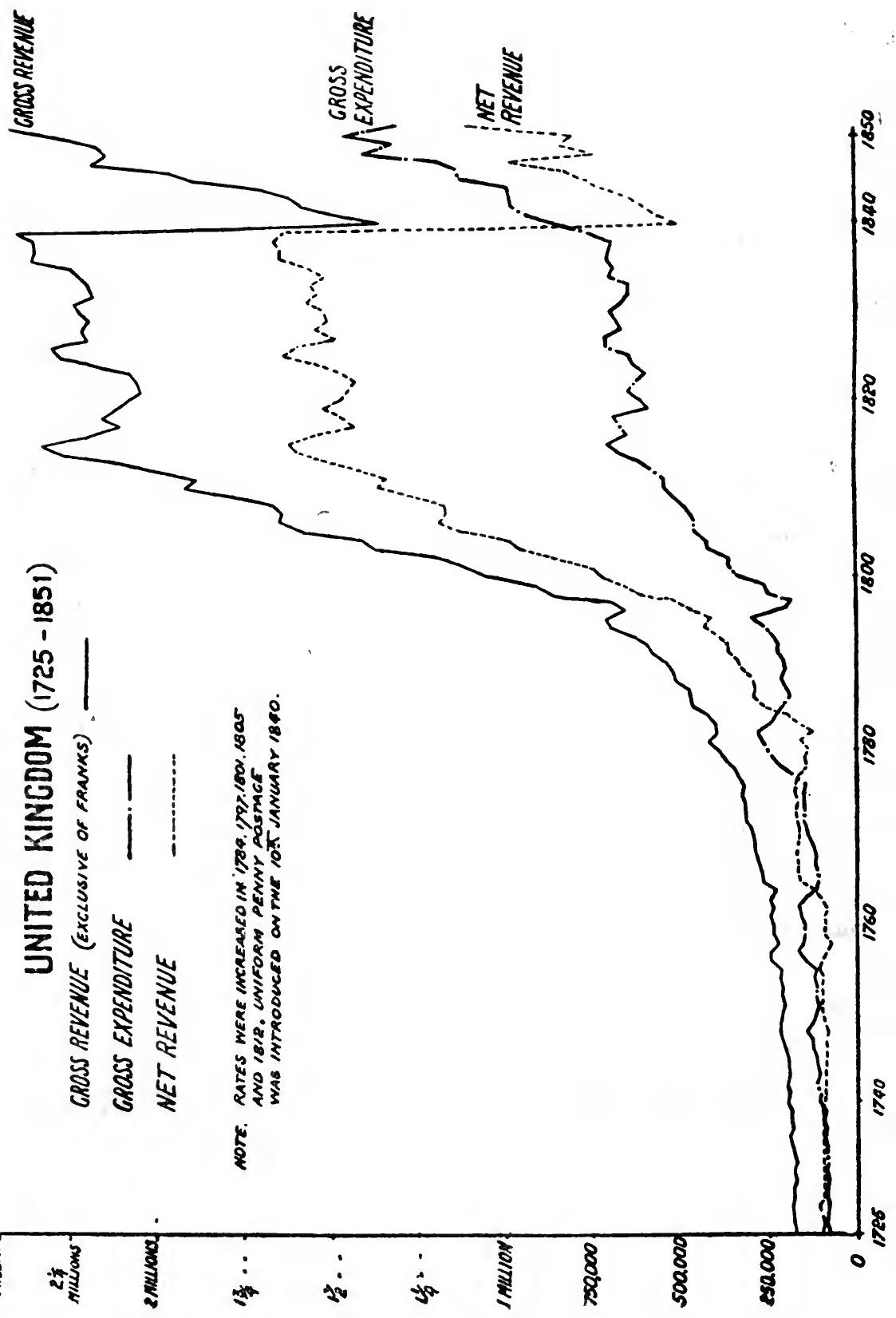




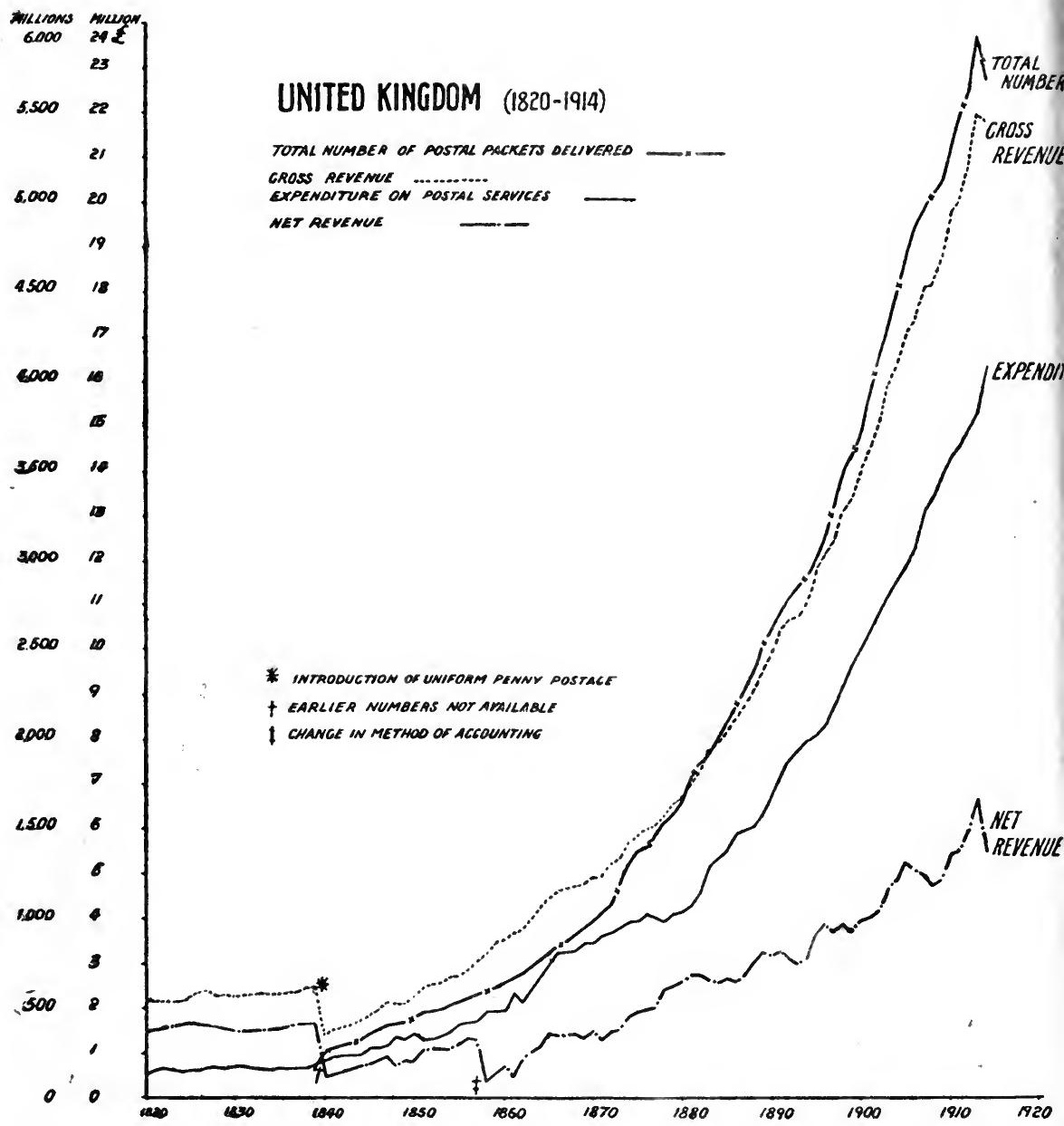




\section{MILONS MILIOAS}

3.0

2. 8

2. 6

150

2.4

2. 2

2.0

1. 8

1. 6

1.2

1.0

o. 8

0.6

0. 4

o. 2

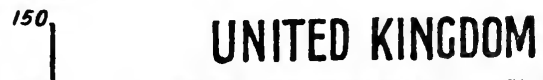

GROSSPOSTACE 


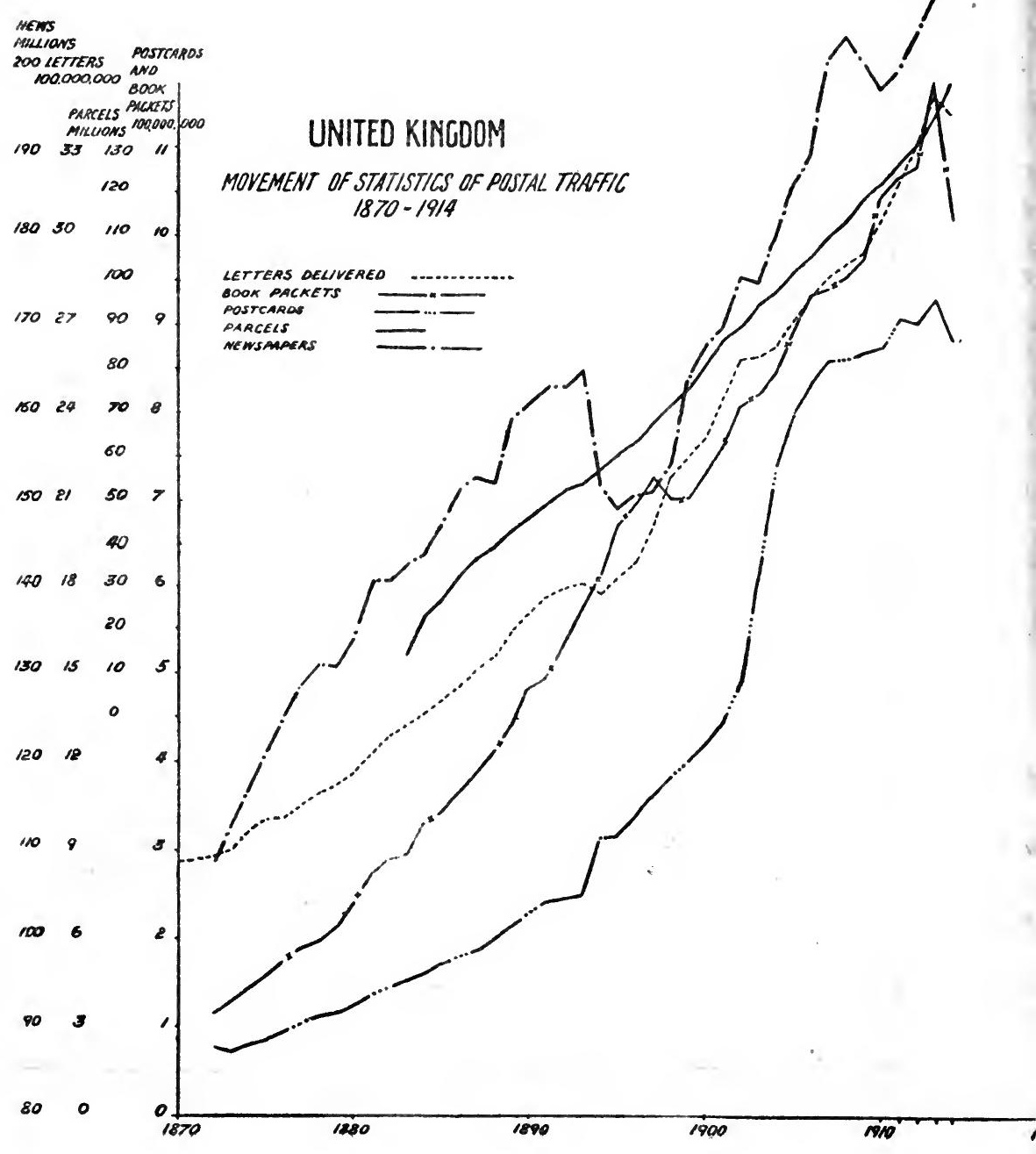




\section{UNITED KINGDOM}

NUMBER OF LETTERS DELUVERE PER MEAD

OF POPULATION (1854-1914)

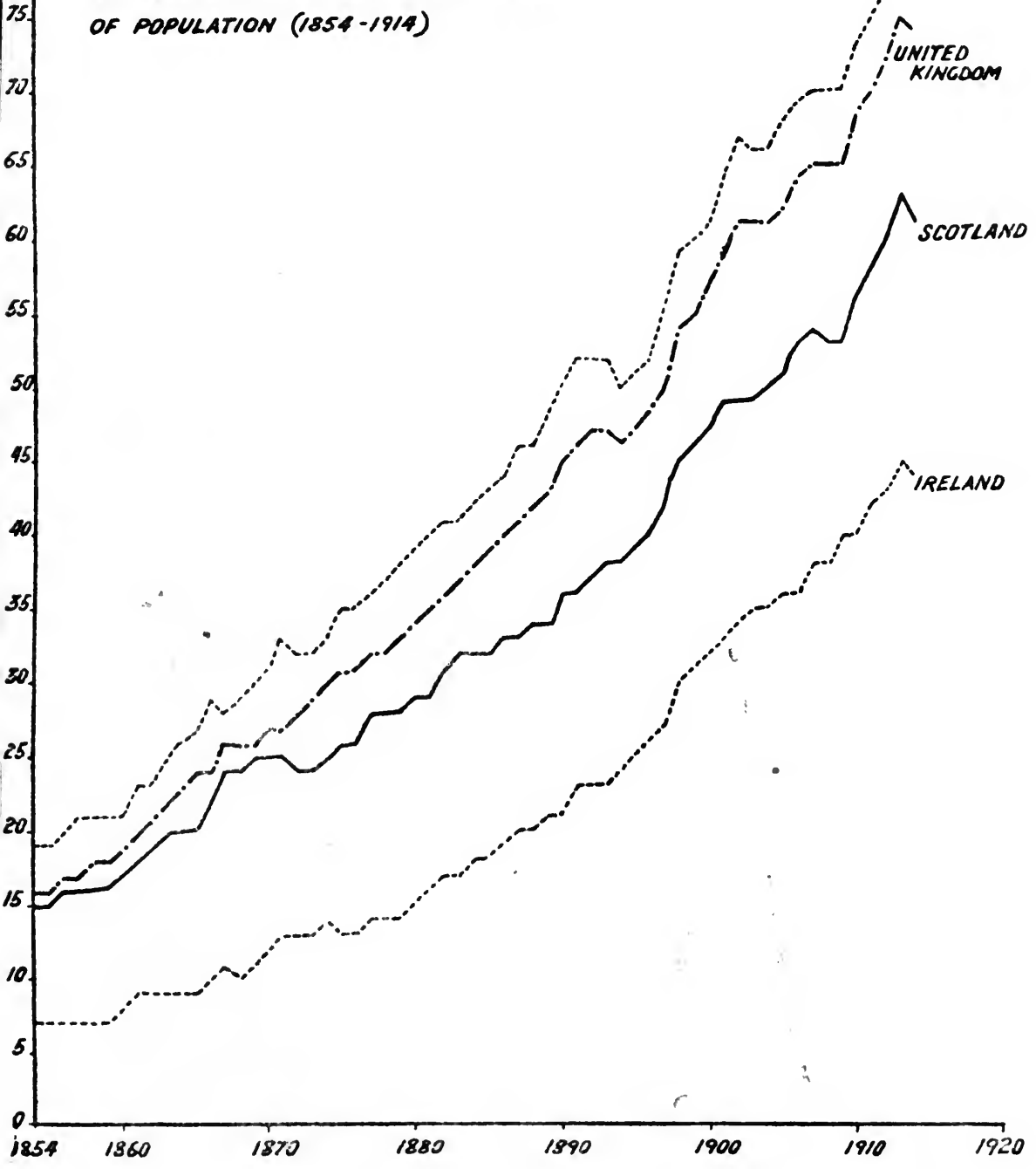




\section{APPENDIX B}

\section{DOCUMENTS AND EXTRACTS ILLUSTRATING ASPECTS OF POSTAL HISTORY}

\section{(i) Ancient Posts.}

Persia (circa B.c. 500).

"IN Darius's idea of government was included rapidity of communication. Regarding it as of the utmost importance that the orders of the Court should be speedily transmitted to the provincial Governors, and that their reports and those of the royal secretaries should be received without needless delay, he established along the lines of route already existing between the chief cities of the Empire, a number of post-houses, placed at regular intervals, according to the estimated capacity of a horse to gallop at his best speed without stopping. At each post-house were maintained, at the cost of the State, a number of couriers and several relays of horses. When a despatch was to be forwarded, it was taken to the first post-house along the route, where a courier received it, and immediately mounting on horseback, galloped with it to the next station. Here it was delivered to a new courier, who, mounted on a fresh horse, took it the next stage on its journey; and thus it passed from hand to hand till it reached its destination. According to Xenophon, the messengers travelled by night as well as by day; and the conveyance was so rapid that some even compared it to the flight of birds. Excellent inns or caravanserais were to be found at every station; bridges or ferries were established upon all the streams; guard-houses occurred here and there, and the whole route was kept secure from the brigands who infested the Empire. Ordinary travellers were glad to pursue so convenient a line of march; it does not appear, however, that they could obtain the use of post-horses, even when the Government was in no need of them.

"Note.- It was not the distance a horse ridden gently could 
accomplish in the entire day, but the distance he could bear to be galloped once a day. From the account which Herodotus gives of the post-route between Sardis and Susa, we may gather that the Persians fixed this distance at about fourteen miles."-George Rawlinson, The Five Great Monarchies of the Ancient Eastern World, London, 1871, vol. iii. pp. 426-7.

\section{Roman Empire.}

"The advantage of receiving the earliest intelligence, and of conveying their orders with celerity, induced the Emperors to establish throughout their extensive dominions the regular institution of posts. Houses were everywhere erected at the distance only of five or six miles; each of them was constantly provided with forty horses, and, by the help of these relays, it was easy to travel an hundred miles in a day along the Roman roads. The use of the posts was allowed to those who claimed it by an Imperial mandate; but though originally intended for the public service, it was sometimes indulged to the business or conveniency of private citizens (Pliny, though a favourite and a minister, made an apology for granting post-horses to his wife on the most urgent business)."-Edward Gibbon, The History of the Decline and Fall of the Roman Empire, London, ed. 1896, vol. i. p. 50.

\section{Arabia.}

"The first traces of the Arabian postal arrangements date from about fifty years after the death of Mahomed. Calif Mdowija, who died in 679, is regarded as the founder of the Arabian posts. Kodama, a native of Bagdad, who died in 959, gives an account of the service in his work called The Book of Taxes. There were 930 postal stations on the six great highroads starting from Bagdad. At some stations there were relays of horses, but in Syria and Arabia the messengers rode on camels; and in Persia the letters were conveyed from station to station by messengers on foot. The postal service under the Califs was an independent branch of the administration, and in addition to the conveyance of despatches and travellers was added the supervision of all the authorities in outlying possessions. Of the two classes of superior postal officers, the nowaqquium was the postmaster who received the postal packets and letters and attended to their conveyance, whereas the farwaneqqyun was a kind of chief postmaster at the capital of a province, who controlled the work of the postmasters and made his own report on all the civil and military authorities to 
the central office in Bagdad. These reports were so valuable that Calif Abu Djafar Manssur is eredited with the statement: 'My throne rests on four pillars, and my power on four men-a blameless kazi (judge), an energetic chief of police, an honest minister of finance, and a faithful postmaster who gives me reliable information on everything.' It has been said that the Roman cursus publicus, the frumentarii, the agentes in rebus, and the curiosi served a similar purpose, but the Arabian arrangement was more systematic. In the Post Office of the Califs the letters and packets posted, as well as those received from other places, were entered in special lists, where their number and address had to be stated. This practice was observed in India till a few years ago, and it will thus be seen that the letter bill of the modern posts was in use already among the Egyptians in 270 B.c., and also among the Arabs. From the information that has been preserved, it is inferred that the Arabian posts did, to a certain extent, transmit private letters, but this was not done officially, and the couriers and postmasters conveyed such correspondence, along with the official despatches, on their own account."-I. G. J. Hamilton, Outline of Postal History, Calcutta, 1910, p. 4.

\section{Mexico.}

"Communication was maintained with the remotest parts of the country by means of couriers. Post-houses were established on the great roads, about two leagues distant from each other. The courier, bearing his despatches in the form of a hieroglyphical painting, ran with them to the first station, where they were taken by another messenger and carried forward to the next; and so on till they reached the capital. These couriers, trained from childhood, travelled with incredible swiftness-not four or five leagues an hour, as an old chronicler would make us believe, but with such speed that despatches were carried from one to two hundred miles a day. Fresh fish was frequently served at Montezuma's table in twenty-four hours from the time it had been taken in the Gulf of Mexico, two hundred miles from the capital. In this way intelligence of the movements of the royal armies was rapidly brought to Court; and the dress of the courier, denoting by its colour the nature of his tidings, spread joy or consternation in the towns through which he passed."-W. H. Prescott, History of the Conquest of Mexico, London, 1903, pp. 20, 21.

A similar system existed in Peru (W. H. Prescott, History of the Conquest of Peru, Philadelphia, 1874, vol. i. p. 69). 


\section{China.}

"From the city of Kanbulu $x$ there are many roads leading to the different provinces, and upon each of these, that is to say, upon every great highroad, at the distance of twenty-tive or thirty miles, accordingly as the towns happen to be situated, there are stations, with houses of accommodation for travellers, called yamb or posthouses. These are large and handsome buildings, having several well-furnished apartments hung with silk, and provided with everything suitable to persons of rank. Even kings may be lodged at these stations in a becoming manner, as every article required may be obtained from the towns and strong places in the vicinity; and for some of them the Court makes regular provision. At each station four hundred good horses are kept in constant readiness, in order that all messengers going and coming upon the business of the grand khan, and all ambassadors, may have relays, and, leaving their jaded horses, be supplied with fresh ones. ... When it is necessary that messengers should proceed with extraordinary despatch, as in the cases of giving information of disturbance in any part of the country, the rebellion of a chief or other important matter, they ride two hundred, or sometimes two hundred and fifty miles in the course of a day."-Travels of Marco Polo the Venetian, London, 1904, pp. 190 et seq.

\section{(ii) NUnCII ANd CURSores.}

"The Royal Nuncii et Cursores constituted a very important branch of the Royal Establishment, and the payments to them form a very large and important item in the Household and Wardrobe Accounts from the earliest period when those accounts exist.

"These Messengers were employed both in England and in foreign parts, and as well on affairs of State as what may be considered as the private and confidential business of the Crown and Royal Family and the individuals attached to or composing the Royal Court. These Messengers, so attached to the Court, became the foundation of the establishment, which about the time of Henry VIII, or somewhat earlier, assumed the form of the regular establishment of the Post; and the information connected with them is important, as showing that the institution was intimately connected with the person of the sovereign, and that, in the first instance, it was his convenience that was sought. Those servants who, by usage, were more particularly employed on State affairs, probably became those who are now specially termed the 'Queen's 
Messengers." - Report from Secret Committee on the Post Office (Commons), 1844, Appx., p. 21.

\section{(iii) Witherings' Scheme for the Reform of the} Posts, 1635.

A Proposition for setling of Staffets or pacquet posts betwixt London and all parts of his Maiesties dominions, for the carrying and recarrying of his subiects lres. The cleere proffitt whereof to goe towards the payment of the Postm ${ }^{\mathrm{rs}}$ of $\mathrm{y}^{\mathrm{e}}$ Roades of England, for $\mathrm{w}^{\text {ch }}$ his $\mathrm{Ma}^{\text {tie }}$ is now chardged $\mathrm{w}^{\text {th }} 3400 \mathrm{l}$. $\mathrm{p}$ añm.

In the first place, a certen office or compting house to be by his $\mathrm{Ma}^{\text {tie }}$ appointed $\mathrm{w}^{\text {th }}$ in the cittie of London, of purpose for carrying out \& receiving in of all Lres to be conveyed from $y^{\theta}$ cittie of London into all $\mathrm{p}^{\text {ts }} \mathrm{w}^{\text {th }}$ in his $\mathrm{Ma}^{\text {ts }}$ dominions \& answers thereof retorned to the said Cittie of London, according as occasion shall serve.

Inprimis, for the Northerne and Scotland roade, All lies to be put into one Portmantle that shalbe directed to Edenburgh in Scotland, and for all places of the $\mathrm{s}^{\mathrm{d}}$ roade, or neere the $\mathrm{s}^{\mathrm{d}}$ roade, to be accordinglie put into $\mathrm{y}^{\mathrm{e}} \mathrm{s}^{\mathrm{d}}$ Portmantle, $\mathrm{w}^{\text {th }}$ pticuler baggs directed to such Postm $^{\text {rs }}$ as live upon the Road neere unto any Cittie or Towne Corporate.

\section{As for Example-}

One Bagge to be directed to Cambridge $\mathrm{w}^{\text {th }}$ such lres therein as shalbe directed to that place or neere thereunto; to take port for them as is now pd to the Carriers, $\mathrm{w}^{\text {ch }}$ is Two pence a single lĩe, and so accordinglie as they shalbe in bignes. At Cambridge a footpost to be provided, $\mathrm{w}^{\text {th }}$ a knowne badge of his $\mathrm{Ma}^{\text {ts }}$ Armes, whome upon the markett daies is to goe to all Townes $\mathrm{w}^{\text {th }}$ in $6: 8:$ or 10 miles, there to receive \& deliver all such lies as shalbe directed to those places. The lres that the $\mathrm{s}^{\mathrm{d}}$ footpost shall then and there receive, hee is to bring them to the $\mathrm{s}^{\mathrm{d}}$ Towne of Cambridge before the retorne of the Portmantle out of Scotland, $\mathrm{w}^{\text {ch }}$ is to retorne at a certen daie \& houre, by $\mathrm{w}^{\text {ch }}$ meanes they maie be upon the verie instante comeing back of the $\mathrm{s}^{\mathrm{d}}$ Portmantle, as before, put into a little bagge, $\mathrm{w}^{\mathrm{ch}} \mathrm{s}^{\mathrm{d}}$ bagg is to be put into $\mathrm{y}^{\mathrm{e}} \mathrm{s}^{\mathrm{d}}$ Portmantle as aforesaid. It is alwaies to be understood that upon the verie instant cominge of the Portmantle to Cambridge, the bagg of lires for that place \& thereaboutes ymmediatly to be tooke out of the $s^{d}$ Portmantle; the said Portmantle being presentlie to goe forwards, night and day, $\mathrm{w}^{\text {th }}$ out stay, to Huntingdon, $\mathrm{w}^{\text {th }}$ fresh horse \& man. At $\mathrm{w}^{\text {ch }}$ place the like rule is to be observed as before at Cambridge, \& so the $\mathrm{s}^{\mathrm{d}}$ 
Portmantle is to goe from Stage to Stage, night \& day, till it shall come to Edenburgh. The bags of lres to be left at all Stages as at Cambridge and Huntingdon, as before.

Only it is to be understood, that the further the lies shall goe, the port thereof is to be advanced, as to $3^{\mathrm{d}}, 4^{\mathrm{d}}, \& 6^{\mathrm{d}}$, \& to Scotland more. By this way of carrying and recarrying of lies, His $\mathrm{Ma}^{\text {ts }}$ subjects shall, once in 6 daies, receive answer from Edenburgh in Scotland, and so consequently from all $\mathrm{p}^{\text {ts }}$ betwixt London \& Scotland.

The daie and howre of the comeing and going of the $\mathrm{s}^{\mathrm{d}}$ Portmantle to and from London to be alwaies certaine. $\mathrm{By}^{\text {ch }}$ meanes all Stages upon the Road will knowe at what certen howre the Portmantle is to come to $y^{\mathbf{b}}$ place.

It is truth it maie be alledged, that some Citties \& Townes of noate will lye so farre from any of the mayne Roads of England, as Hull $\&$ other Townes of noate upon the Sea coasts, as that it wilbe impossible for a footman to carry and recarry the $\mathrm{s}^{\mathrm{d}}$ lires $\mathrm{w}^{\text {th }}$ in such time as shalbe limitted: for remedie thereof a horse is to be provided for the $\mathrm{s}^{\mathrm{d}}$ footpost, for the execucon of the $\mathrm{s}^{\mathrm{d}}$ service $\mathrm{w}^{\text {th }}$ more expedicon.

The like rule is to be observed to Westchester \& so to Ireland.

The like rule is to be observed to Oxford, Bristoll, \& so to Ireland.

The like rule is to be observed to Worcester, Shrewesbury, and so to $\mathrm{y}^{\circ}$ Marches of Wales.

The like rule to be observed to Exceter, \& so to Plymouth.

The like rule to be observed to Canterbury, \& so to Dovor.

The like rule to be observed to Chelmesford, Colchester, and so to Harw $^{\text {eh. }}$

The like rule to be observed to Newmarket, Bury, Norwen, and so to Yarmouth.

In the first place, it wilbe a great furtherance to the correspondency betwixt London \& Scotland, \& London \& Ireland, and great help to Trades, \& true affeccon of his $\mathrm{Ma}^{\text {ta }}$ subiects betwixt theis kingdomes, which, for want of true correspondency of lires, is now destroyed, \& a thing above all things observed by all other nations.

\section{As for Example-}

If anie of his $\mathrm{M}^{\text {ats }}$ subiects shall write to Madrill, in Spain, hee shall receive answer sooner \& surer then hee shall out of Scotland or Ireland. The lres being now carried by carriers or footposts 16 or 18 miles a day, it is full two monthes before any answer can be received from Scotland or Ireland to London, $\mathrm{w}^{\text {oh }}$ by this Conveyance all lĩes shall goe 120 miles at $y^{\mathrm{e}}$ least in one day \& night. 
It will Secondlie be alledged, that it is a wrong to the Carriers that bring the said letters. To which is answered, a Carrier setts out from Westchester to London on the Mundaie, $\mathrm{w}^{\text {ch }}$ is 120 miles. The $\mathrm{s}^{\mathrm{d}}$ Carrier is 8 daies upon the Road, and upon his cominge to London delivers his letters of advise for his relodinge to Westchester againe, and his forced to staie in London two daies at extraordinary charges before he can get his loding redy.

By this Conveyance lres wilbe frō Westchester to London in one day \& night, so that the $\mathrm{s}^{\mathrm{d}}$ Carriers loading wilbe made ready a weeke before the $\mathrm{s}^{\mathrm{d}}$ Carriers shall come to London, and they no sooner come to London but maie be redy to depte againe.

The like will fall out in all other pts.

Besides, if at any time there should be occasion to write from anie of the coast Townes in England or Scotland to London, by this Conveyance lres wilbe brought ymmediatly : \& from all such places there wilbe weekely advise to \& from London.

\section{As for Example-}

Anie fight at Sea : any distress of his $\mathrm{Ma}^{\text {ts }}$ shipps, ( ${ }^{\text {ch }}$ Godd forbidd), anie wrong offered by any other nation to any of $y^{\circ}$ Coaste of England, or anie of his $\mathrm{Ma}^{\text {ts }}$ forts : the Posts being punctually paid, the newes will come sooner then thought.

It wilbe, thirdlie, alledged that this service maie be ptended by the Lo: Stanhope to be in his graunt of Post $\mathrm{M}^{\mathrm{r}}$ of England. To $\mathrm{w}^{\mathrm{ch}}$ is answered, neither the Lo : Stanhope, nor anie other that ever enjoyed the Postm ${ }^{8}$ place of England, had any benefitt of the carrying and recarrying of the subiects Lres : beside, the profitt is to paie $y^{\bullet}$ Posts of the Road, $\mathrm{w}^{\text {eh }}$ next unto his $\mathrm{Ma}^{\text {tie }}$, belong to $\mathrm{y}^{e}$ office of the $\mathrm{s}^{\mathrm{d}} \mathrm{Lo}$ : Stanhope, and upon determinacon of any of the $s^{d}$ Posts places, by death or otherwise, the Lo: Stanhope will make as much of them as hath heretofore bin made by this said advancement of all theire places.

The Lord Stanhope now enioying what either hee or any of his Predecesso ${ }^{8}$ hath ever heretofore done to this day.

(Indorsed by Sec. Coke)

"Proposition for Missive Letters."

-Report from Secret Committee on the Post Office (Commons), 1844, Appx., pp. 55-6.

(iv) The Monopoly and the General Farm of the Posts.

No. 1.

"Whereas heretofore sundry wayes have bene devised to redresse the disorders among the postes of our realme in generall, and par- 
ticularly to prevent the inconveniences, both to our owne service and the lawfull trade of the honest merchants, by prohibiting that no persons whatsoever should take upon them, publiquely or privately, to procure, gather up, receive ... any packets or letters to or from the countreys beyond the seas, except such our ordinarie posts and messengers for those parties, etc."-Royal Proclamation, April 26th 1591.

No. 2.

"There has long been a constant trade betwixt London and Norwich in sundry sorts of stuffs and stockings made in Norwich and Norfolk, which trade has always been maintained by the merchants of Norwich employing their stocks in buying wares of the makers and sending them up weekly in carts by common carriers to London, whence they are dispersed into all parts of this kingdom, and also exported to foreign parts, in which intercourse of trade we always had our letters safely and speedily carried by our common carrier, by a horseman, not in manner of postage by change of horses, but as is usual by common carriers, and for little or no charge to us. Of late Mr. Witherings has intercepted our letters and molested our carriers, forbidding them to carry any of our letters otherwise than to go along with their carts, and no faster."-Petition to Privy Council, 1638; J. W. Hyde, The Post in Grant and Farm, London, 1894, p. 131.

No. 3.

“. . . By a Proclamation dated about July 1635 his Majestie did expresse his pleasure, that Thomas Witherings should have the carriage of the said letters who would settle it in a better and more speedy course; thereupon he undertook the said work, and for a long time, after his said undertaking, it cost him some weeks $20 l$. $30 l$. $40 l$. more than he received, to the great weakening and hazard of the ruine of his estate. It is verie true, that untill he had his patent of his Office granted unto him for his life, which was in the yeare 1637, he did in some places lay horses of his owne, in others he did make use of the ordinarie Post-horses, and because be desired quick dispatch, hee paid them for a guide and a horse to carrie the male 6d. per mile, after not conceiving a guide necessarie he made only use of one horse, and paid 3d. per mile. . . for the other Posts, they have 3d. per mile which is more than ordinarie pay. But the objection which seems to carrie the greatest shew, or colour of probabilitie with it is: That the $\mathrm{P}^{\text {mes }}$ had formerly 
4,000l. per annum fee, onely for carrying his Majesties packets, that Witherings hath reduced this to 2,053l. per annum, and yet puts a greater burthen upon them by carrying his male; hath displaced many of them and received 4,000l. for Post places."-Full and cleare answer to a false and scandalous Paper entituled: The humble Remonstrance of the grievances of all his Majesties Posts of England, together with Carriers, Waggoners, etc., 1641, pp. 2, 3.

\section{No. 4.}

Reasons presented to the Committee for Postmasters why the office should not be farmed:-

(1) What is of public interest, if farmed, often becomes a great public grievance.

(2) The postmasters who have served faithfully and others who run best to Lynn, Yarmouth, etc., must be restrained and will complain as they did in 1642 to the late Parliament which ordered them redress.

(3) By farming, the pay of postmasters will be made so inconsiderable that they will grow careless.

(4) The expectations of the people now at this juncture so highly raised to hopes of ease and freedom, will be disappointed when they see new monopolies.

Suggestions for reducing the office into one channel, for easing the people, encouraging the postmasters and raising money for the public :-

1. To declare it unsafe for private persons to erect post stages without licence.

2. To chose faithful persons in all the roads and appoint a supervisor on each road.

3. To declare that you have appointed them postmasters and give power to their controller only to sign labels for speedy conveyance of mails and give them writs of assistance.

Signed by Robert Girdler and seven others.-Calendar of State Papers (Domestic Series), 26th November, 1652.

No. 5 .

Offers of the well-affected postmasters to the Posts' Committee. ...

The order of the Council in the case of the Inland Post Office being that it be improved to the greatest advantage either by farm or account, they conceive the advantages consist not so much in the 
advance of money, as the service and safety of the State, and beg to offer,

1. That persons of known integrity may be employed in all parts, and a sufficient salary allowed, as becomes a trust of that great concernment.

2. That a fit person be appointed for the control thereof, according to orders from the State, etc.

3. As righteousness exalteth a nation, it is hoped that after the expense of so much blood and treasure, the very things adjudged and condemned in others (viz. monopolies) will not now be practised, but that next to public safety, you will be tender of the people's just liberty; for both by the laws of God and man it is lawful for every man to employ himself in a lawful calling, especially in that to which he has been bred, and it is also lawful for divers men to employ themselves in one calling, otherwise there must be as many callings as men.

4. For avoiding of many inconveniencies that will follow in the farming of it, viz.

The persons depositing or obliging themselves for so much money a year, will not lay out themselves and their estates without expectation of profit, which must arise either out of the people's letters or postmasters' labour, besides the hazard to the Commonwealth; for notwithstanding the faithfulness of the postmasters yet if they will not do their work at their rates (which may prove an oppression too heavy, like that in Egypt) others shall.-Calendar of State Papers (Domestic Series), May 1653.

No. 6.

"Petition of John Mann, Mayor, and 22 aldermen \& inhabitants of Norwich :-

" Having much commerce with London we have always employed a faithful and careful messenger to carry letters, bills of exchange, etc., but he has lately been molested by John Manley whose agents have not only rifled and detained our letters and goods, but charged more than double price for small parcels of ware, which is a greater burden to many of us than the monthly assessment. . . .

"Having bought our liberties at vast expense of blood and treasure, we hope not again to be troubled with distasteful monopolies but to have liberty to convey our letters freely." - Calendar of State Papers (Domestic Series), 1653-4, p. 25.

No. 7.

"Also it hinders a man to be as civil as otherwise he would, or might be, in having, or returning an accompt to, or from his friend, 
many a man in these times being forced to set a greater value of $6 \mathrm{~d}$. or $3 \mathrm{~d}$. then of three times as much in former times, when money was more plentiful; and certainly any man but a Farmer wil confess it to be a strange imposition, that a man cannot have an accompt of the condition of his Wife or Family, without paying thrice as much as he need; \& it seems as unreasonable for a man to be forced to pay $3 \mathrm{~d}$. for what may be done for a penny, (in relation to Letters) as for a man to be compelled to pay thrice as much for meat or any other commodity, as the price currant." J. Hill, A Penny Post, London, 1659, p. 7.

No. 8.

1657, CAP. 30.

Postage of England, Scotland, and Ireland settled.

"Whereas it hath been found by experience, That the Erection and Settling of one General Post Office, for the speedy Conveying, Carrying, and Re-carrying of Letters by Post, to and from all Places within England, Scotland and Ireland, and into several parts beyond the Seas, hath been, and is the best means, not only to maintain a certain and constant Intercourse of Trade and Commerce betwixt all the said Places, to the great benefit of the People of these Nations, but also to convey the Publique Despatches, and to discover and prevent many dangerous, and wicked Designs, which have been and are daily contrived against the Peace and Welfare of this Commonwealth, the Intellegence whereof cannot well be Communicated, but by Letter of Escript,

"Be it Enacted by His Highness the Lord Protector and the Parliament, And it is Enacted and Ordained by Authority thereof, That from henceforth there be one General Office, to be called and known by the name of the Post Office of England, and one Officer from time to time to be nominated, etc."-H. Scobell, $A$ Collection of Acts and Ordinances, London, 1658, p. 511.

(v) Extract from “The Present State of London," By Tho. de Laune, Gent., London, 1681.

Of the Post-office.

This Office is now kept in Lumbard-street, formerly in Bishopsgate-street, the Profits of it are by Act of Parliament settled on his Royal Highness the Duke of York. But the King by Letters Patents, under the Great Seal of England, constitutes the PostMaster-General. 
From this General Office, Letters and Packets are dispatched :

\section{On Mondays-}

To France, Spain, Italy, Germany, Flanders, Sweedland, Denmark, Kent, and the Downs.

On Tuesdays-

To Holland, Germany, Sweedland, Denmark, Ireland, Scotland, and all parts of England and Wales.

On Wednesdays-

To all parts of Kent, and the Downs.

On Thursdays-

To France, Spain, Italy, and all parts of England and Scotland.

On Fridays-

To Flanders, Germany, Italy, Sweedland, Denmark, Holland, Kent, and the Downs.

\section{On Saturdays-}

All parts of England, Wales, Scotland, and Ireland. Letters are returned from all parts of England and Scotland, certainly every Monday, Wednesday, and Friday; from Wales every Monday and Friday; and from Kent and the Downs every day: But from other parts more uncertainly, in regard of the Sea.

A Letter containing a whole sheet of Paper is convey'd 80 Miles for $2 \mathrm{~d}$. two sheets for $4 \mathrm{~d}$. and an Ounce of Letters for $8 \mathrm{~d}$. and so proportionably; a Letter containing a sheet is conveyed above 80 miles for $3 \mathrm{~d}$. two sheets for $6 \mathrm{~d}$. and every Ounce of Letters for $12 \mathrm{~d}$. A sheet is conveyed to Dublin for $6 \mathrm{~d}$. two for a shilling, and an Ounce of Letters for $12 \mathrm{~d}$.

This Conveyance by Post is done in so short a time, by night as well as by day, that every 24 hours, the Post goes 120 Miles, and in five days, an answer of a Letter may be had from a Place 300 Miles distant from the Writer.

Moreover, if any Gentiemen desire to ride Post, to any Principal Town of England, Post Horses are always in readiness, (taking no Horse without the consent of his owner) which in other Kings Reigns was not duly observed; and only $3 \mathrm{~d}$. is demanded for every English Mile, and for every Stage to the Post-Boy, 4d. For conducting.

Besides this Excellent convenience of conveying Letters, and Men on Horse-back, there is of late such an admirable commodiousness, both for Men and Women of better rank, to travel from London, and to almost all the Villages near this great City, that the like hath not been known in the World, and that is by Stage-Coaches, wherein one may be transported to any place, sheltred from foul Weather, and foul ways, free from endamaging 
ones Health or Body by hard jogging, or over violent motion; and this not only at a low price, as about a shilling for every five Miles, but with such velocity and speed, as that the Posts in some Foreign Countries, make not more Miles in a day; for the StageCoaches, called Flying-Coaches, make forty or fifty Miles in a day, as from London to Oxford or Cambridge, and that in the space of twelve hours, not counting the time for Dining, setting forth not too early, nor coming in too late.

The several Rates that now are and have been taken for the Carriage of Letters, Pacquets, and Parcels, to or from any of His Majesties Dominions, to or from any other parts or places beyond the Seas, are as followeth, that is to say,

s. d.

Morlaix, St. Maloes, Caen, Newhaven, and places of like distance, Carriage paid to Rouen

Hamburgh, Colen, Frankfort, Carriage paid to Antwerp, is $\quad \cdots\left\{\begin{array}{lll}\text { Single } & 0 & 8 \\ \text { Double } & 1 & 4 \\ \text { Treble } & 2 & 0 \\ \text { Ounce } & 2 & 0\end{array}\right.$

Venice, Geneva, Legorn, Rome, Naples, Messina, and all other parts of Italy by way of Venice, Franct pro Mantua

Single 009

Double 16

Treble $2 \quad 3$

Ounce 28

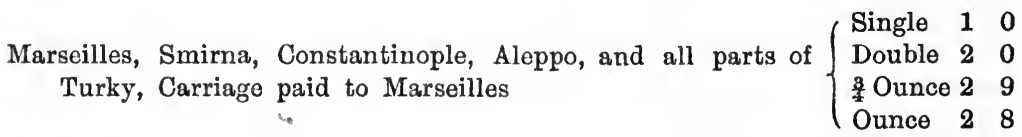

And for Letters brought from the same places to England $\quad \cdots\left\{\begin{array}{lll}\text { Single } & 0 & 8 \\ \text { Double } & 1 & 4 \\ \text { Treble } & 2 & 0 \\ \text { Ounce } & 2 & 0\end{array}\right.$

The $\begin{array}{lll}\text { Single } & 0 & 4\end{array}$ Diep, Bulloign, Abbeville, Amiens, St. Omers, Montrel $\left\{\begin{array}{lll}\text { Double } & 0 & 8 \\ \text { Treble } & 1 & 0\end{array}\right.$

Ounce 10

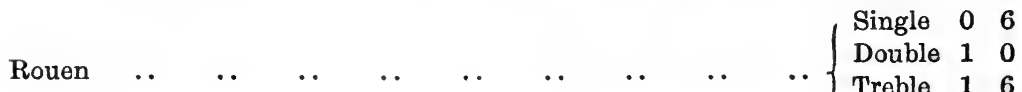

Treble 16

Ounce 16

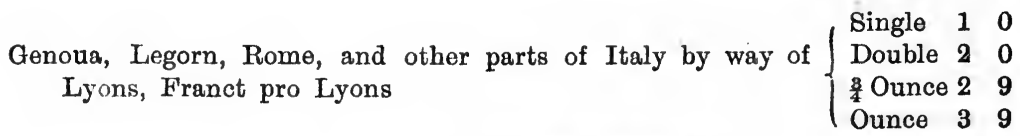

The Carriage of Letters Outwards-

To Bourdeaux, Rochel, Nants, Orleans, Bayon, Tours, and places
of like distance, Carriage paid to Paris $\left\{\begin{array}{lll}\text { Single } & 0 & 9 \\ \text { Double } & 1 & 6 \\ \text { Treble } & 2 & 3 \\ \text { Ounce } & 2 & 0\end{array}\right.$ 


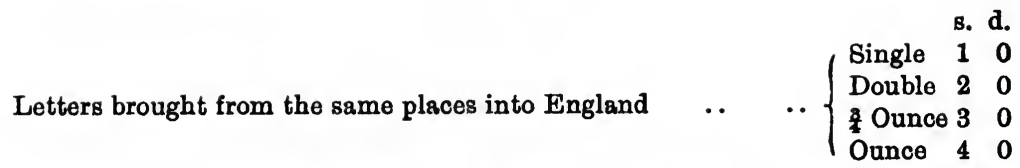

The Carriage of Letters Outwards-

To Norembourgh, Bremen, Dantzick, Lubeck, Lipswick, and $\left\{\begin{array}{lll}\text { Single } & 1 & 0 \\ \text { Double } & 2 & 0 \\ \text { other places of like distance, Carriage paid to Hamburgh } & \text { Ounce } 3 & 0 \\ \text { Ounce } & 4 & 0\end{array}\right.$

Paris $\quad\left\{\begin{array}{lll}\text { Single } & 0 & 9 \\ \text { Double } & 1 & 6\end{array}\right.$

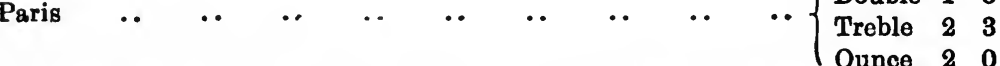

Dunkirk, Ostend, Lisle, Ipers, Cambray, Ghent, Bruxels, Bruges, (Single 08 Antwerp, and all other parts of Flanders. $\quad$ Double 14 Sluce, Flushing, Middleburgh, Amsterdam, Rotterdam, Delph, $\left\{\begin{array}{l}\text { Treble } 20 \\ 0\end{array}\right.$ Hague, and all other parts of Holland and Zealand.

Ounce 20

All Merchants Accounts, not exceeding a Sheet, Bills of Exchange, Invoices, Bills of Lading, shall be allowed without rate in the price of the Letters, and also the Covers of the Letters not exceeding a Sheet, to Marseilles, Venice, or Legorn, towards Turkie.

The said Office is managed by a Deputy, and other Officers to the Number of seventy seven persons; who give their actual attendance respectively, in the dispatch of the business.

Upon this Grand Office, depends one hundred eighty two DeputyPost-Masters in England and Scotland; most of which keep Regular Offices in their Stages, and Sub-Post-Masters in their Branches; and also in Ireland, another General Office for that Kingdom, which is kept in Dublin, consisting of Eighteen like Officers, and Forty-five Deputy-Post-Masters.

The Present Post-Master-General, keeps constantly, for the transport of the said Letters and Pacquets;

$$
\begin{aligned}
& \text { Between England and .. } \quad \ldots \quad \ldots\left\{\begin{array}{l}
\text { France, two Pacquet-Boats. } \\
\text { Flanders, two Pacquet-Boats. } \\
\text { Holland, three Pacquet-Boats. } \\
\text { Ireland, three Pacquet-Boats. }
\end{array}\right. \\
& \text { And at Deal, two Pacquet-Boats for the Downs. }
\end{aligned}
$$

All which Officers, Post-Masters, Pacquet-Boats, are maintained at his own proper Charge.

And as the Master-piece of all those good regulations, established by the present Post-Master-General, for the better Government of the said Office, he hath annexed and appropriated the Market-Towns of England, so well to their Respective Post-Stages, that there is no considerable Market-Town, but hath an easie and certain Con- 
veyance for the Letters thereof, to and from the said Grand Office, in the due course of the Males every Post.

Though the Number of Letters Missive in England, were not at all Considerable in our Ancestors days, yet it is now so prodigiously great, (since the meanest People have Generally learned to write) that this Office is Farmed for above 40, rather 50,000l. a Year.

\section{(vi) The Cross Posts.'}

No. $1(a)$.

To the $R^{t}$. Hon ${ }^{\text {ble }}$. Sidney $L^{d}$. Godolphin Lord High Trearer of England.

May it please $\mathrm{y}^{\mathbf{r}}$. Lo ${ }^{\mathrm{pp}}$.

My Lord Grandville and seaverall Gentlemen of Cornwell having represented to Us that by reason of the Post Road passing along the South Coast of Cornwell seaverel Inland Towns are under great disadvantages in their Correspondence paying two pence $\mathrm{p}^{\mathbf{r}}$ Letter over \& above the Common Postage being serv'd only by a By Post ; We did give directions to Our Deputys of Exeter, Plym ${ }^{\circ}$, and Lanceston to meet and Consult what Method might be proper to serve those parts more conveniently, and at as Easie an Expence to Her $\mathrm{Ma}^{\text {ti }}$. as might be, and to Report to Us their Opinion of that Matter with an Estimate of the Charge; which they accordingly did, and have proposed a Scheme of that Matter how 'tis to be performed with the Charge of each Stage, which amounts according to their Computation to about $£ 260 \mathrm{p}^{\mathbf{r}}$ Ann a Sum more considerable than We at first apprehended; but We doubt the Charge Her $\mathrm{Ma}^{\text {tie }}$. will be put to will Scarce be recompenced by the increase of Letters upon Settling such a Stage, especially when We consider the great Number of Letters for that Country which pass Frank: If $\mathrm{Y}^{\mathbf{r}} \mathrm{Lo}^{\mathrm{pp}}$. shall think fitting a Post be Settled for the Midland Towns, as well as for the South Coast, We shall upon $\mathrm{y}^{\mathbf{r}}$ Directions endeavour to do it with the best Husbandry We can, and as We hope to the Satisfaction of the Country, and shall lay before $\mathrm{Y}^{\mathbf{r}}$. Lo ${ }^{\mathrm{pp}}$. an Establishm ${ }^{t}$. to be approved by $\mathrm{Y}^{\mathbf{r}}$. Lop .

We have indeed found by Experience in other Places, That where We have made the Correspondence more Easie and Cheap, the Number of Letters has been thereby much increased; and therefore do believe such a Settlement may be attended with the like effect in those Parts. All which is humbly Submitted to $\mathrm{y}^{\mathbf{r}}$. Lo ${ }^{\mathrm{pp}}$.

GeN $^{L}$. Post Office,

R. C. T. F.

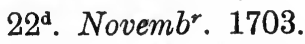

${ }^{x}$ From the British Official Records. 
No. $1(b)$.

After my hearty Comendations, Whereas my very good Lord John Lord Grandville and seaveral Gentlemen of Cornwall have Represented to you, That by reason of the Post Road passing along the South Coast of Cornwall, Seaveral Inland Towns are under great disadvantages in their Correspondence; Whereupon you have proposed to Me the Settlement of a New Post for the Midland Towns, as well as for the South Coast, the better to Serve those parts, the Charge whereof will Amount to Two hundred and Sixty pounds p. Ann I approve of what you have proposed, And do hereby Authorize and Require you to Settle and Establish such a Post accordingly. But you are at twelve months End to Represent to Me or the Lord High Treasurer or Commiss ${ }^{\text {rs }}$. of the Treasury then being, how far such a Post doth answer the Expence Her Ma ${ }^{\text {tee }}$. is at in Settling the Same. And for so doing this shall be $\mathrm{y}^{\mathrm{z}}$. Warrant. Whitehall Treary Chambers the 7th December 1703.

To my very loving Friends

Godolphin.

$\mathrm{S}^{\mathrm{r}}$. Rob ${ }^{6}$. Cotton $\mathrm{Kn}^{\mathrm{t}}$. and

S. Thoms. Frankland Bart.

Her $\mathrm{Ma}^{\text {tles }}$. Post-Mr. Gen'.

No. 2.

St. Robert Cotton $\mathrm{Kn}^{\mathrm{l}}$. and Sir Thomas Frankland Baronet Her $\mathrm{M}^{\text {toes }}$. Post Master Gen'. in the Kingdoms of England Scotland and Ireland and in all Her $M^{\text {atlos }}$ other Dominions Territorys and Isles thereunto belonging in Europe Affrica and America.

To all People to whom this shall come Greeting know ye, that whereas the County of Lincoln has not hitherto been Served so well with the Correspondence by Letters as other parts of the Nation, several Towns therein not having had the Convenience of a Post at all, and others having been obleig'd to pay an extraordinary Tax above the Common Postage, We have thought it proper to appoint Mr. Richard Bigg of Winslow in the County of Buckingham Gentleman, and Mr. Richard Dixon of Bourn in the County of Lincoln Gentleman (having receiv'd good Testimony of the fidelity and Loyalty of both and each of them to Her $\mathrm{Ma}^{\text {tie }}$. and reposing great trust \& confidence in the knowledge Care and Ability of them both) to be our lawfull and Sufficient Deputys with full Power and Authority to Erect Settle and Establish Posts in such Towns of the said County for the Carrying and Conveying the Letters as well those called the London Letters as the By Letters of the said County, as shall be judged most proper for Her $\mathrm{Ma}^{\text {tles, }}$. Service, and the improvem? 
the Correspondence of the said County and to Agree and Contract with such Persons as the said Richard Bigg and Richard Dixon or either of them shall think fitt to Agree and Contract with for performing the Riding part through such Stages as shall be Erected by them or for keeping Letter Offices in any Towns of the said County, And do by these presents Depute Constitute Authorise and Appoint the said Rich . Bigg and Richard Dixon to be our Lawfull and Sufficient Deputys in manner and form aforesaid from the tenth day of August next ensuing the date hereof during such time as We or the Postmaster Gen'. for the time being shall think fit under such Conditions payments and Instructions to be faithfully observ'd perform'd and done by the said Rich ${ }^{d}$. Bigg and Richard Dixon their Deputys and Servants as they shall from time to time receive from the Gen ${ }^{1}$. Post Office in London in writing Subscribed by Us our Deputy or Deputys in the Post Office, in Witness whereof We the said $\mathbf{S}^{\mathrm{r}}$. Robert Cotton and Sir Thomas Frankland have hereunto sett our hands \& Caused the Seal of the said Office in such Cases used to be affixed this fourth day of August 1705.

R. C. T. F.

No. 3.

To $\mathrm{y}^{\mathrm{e}} \mathrm{Rt}$. Honble $\mathrm{y}^{\mathrm{e}}$ Lords Com ${ }^{\mathrm{rs}}$. of his Majestys Treary.

May it please your L.sps-

A Proposall having some time since been made to your Lordsps That a Cross Post might be settled between Bristol \& Shrewsbury, you were pleased to refer $\mathrm{y}^{\ominus}$ same to Us to Consider of it \& Report Our opinions thereupon $\mathrm{w}^{\text {ch }}$ Wee did accordingly and acquainted yo Lordsps Wee did hope Wee should find some persons who would at their Owne Cost and Charges undertake to Settle a Cross Post, upon such terms as his Majesty would not be a loser and the people receive the benefit they proposed.

The Establishing such a Cross Roade would undoubtedly be of great Use to Trade \& Convenience to $y^{\bullet}$ People and appeares to be very much desired by the several Countrys thro' $w^{\text {ch }}$ it wou'd pass; but as at present it might become loss to $y^{e}$ Revenue Wee think it Our Duety to lay $\mathrm{y}^{\mathbf{e}}$ whole state of the Case before Yor Lorsps to receive yo further Directions and have hereunto annexed a scheme both of the Charge \& loss that may accrew to the Office thereby.

Wee must observe to yo ${ }^{\mathbf{r}}$ Lordsps That Lond ${ }^{\circ}$. (from $y^{\theta}$ establishing of a post Office) having been esteemed the Center all letters passing thro' one Road to an other thro' Lond ${ }^{\circ}$. have been constantly taxed with a double post first to Lond $d^{\circ} \cdot \mathrm{y}^{\mathbf{n}}$ to $\mathrm{y}^{\mathbf{e}}$ places where to they were directed, but the settling of this Cross Post $\mathrm{w}^{\text {ch }}$ will Cause a direct Intercourse between $y^{\ominus}$ West Bristol \& Chester Roades, all lres, 
passing that way can only be Charged $\mathrm{w}^{\text {th }}$ a single Post according to $\mathrm{y}^{\bullet}$ distance of one place from an other; but $\mathrm{y}^{\mathbf{n}}$ it ought to be considered on the other hand That the passing thro' Londe is both tedious and Chargeable, and a more Speedy Conveyance would in all probability produce of an encrease of $\mathrm{y}^{\circ} \mathrm{n}^{\circ}$. of letters besides the bringing such into $\mathrm{y}^{\ominus}$ Office as are now Conveyed by Carryers; for where ever there are any Townes $\mathrm{w}^{\text {eh }}$ have Comerce one $\mathrm{w}^{\text {th }}$ an other so as to occasion a Cons ${ }^{t}$. Intercourse by Carryer or Tradesmen Wee do find it a General Practice to Convey at y ${ }^{\circ}$ same time a Considerable No. of lres as pticularly between Bristol \& Worcester \& Worcester \& Shrewsbury; where there are two persons that make it their business to Colect \& disperse letters and make a Considerable advantage by it. That if $\mathrm{y}^{\bullet}$ settling this Roade should have $\mathrm{y}^{\prime}$ good effect to suppress all these By Posts (as in all probability it will) notwithstanding at present there will be some Loss the Revenue in time may be Improved by it; and Wee do find that the Cross

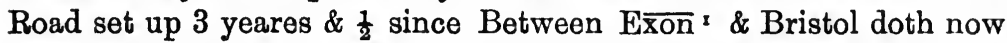
produce about $255 l$. p. annum neat proffit, but in regard this is altogether new Wee can not possibly be so much Masters of it as to know $\mathrm{w}^{\mathbf{}}$. terms to propose to any undertakers that may be equall between the King and them and therefore if yo* Lordsps do agree to the Proposal Wee are of opinion it may be most proper to be set up and managed for his Majesty and Carryed on as far as Chester. . . .

\section{(vii) The Early Posts in North America. ${ }^{2}$}

No. $1(a)$.

To the Right Honble the Lords Comrs. of his Majesty's Treas'y.

Thomas Neale Esq ${ }^{\text {re }}$. humbly sheweth

That their sacred Majesty's by their letters pattents bearing date the 17th day of February 1692 granted to the said Thomas Neale a power of settling Post Offices in North America to be executed by a person to be nominated by the said Thomas Neale and Deputed by the Postmaster Generall of England and thereby directed that accounts shall be kept of the Charge and produce of the said Post Offices, and transmitted to the Right Honble the Lord Treasurer or Lds. Comissioners of the Treasury for the time being.

That in pursuance of this Grant Andrew Hamilton Esq ${ }^{\text {ro }}$. was nominated and Deputed to erect Post Offices, who hath at Thomas Neales great Charge settled 'em 700 miles in Length, upon the Continent of America and kept true accounts of the Expences and proffits thereof, which acc ${ }^{\text {ta }}$. sworne to by the said Deputy Post-

Exeter.

a From the British Official Records. 
master before the Governor of New Yorke are now humbly laid before your Lordshipps and an abstract of it for yor. Lordspps. ease.

That the said Deputy Postmaster is come over to give your Lordshipps Information of all matters relating to that subject which your Lordshipps shall think fit to enquire of, and hath proposed the Method contained in the Memoriall annexed as of absolute necessity in his opinion to support the Post, which proves a great service to the Crowne as well as advantage to his Majesty's subjects residing in those Colliny's and Trading thither.

All which is humbly submitted to your

Lordshipps Judgment \& direction.

Tho : Neale.

No. $1(b)$.

To the Right Honourable the Lords Com ${ }^{\text {rs }}$. of his Majesty's Treasury.

The Memoriall of Andrew Hamilton Esqr. Deputed by the Postmr. Generall of England, to mannage the Post Office in North America, humbly offered.

The Post Office in North America produces these good Effects.

It encreases Trade and Correspondence betwixt the Colonys there.

It affords Merchts. more frequent opertunitys of Corresponding with Europe.

It contributes much towards putting the Kings subjects in security in time of Warr by ye. frequent Conveyance of Intelligence when allarms happen, for want of wch. many familys have been cutt off before the settling of the Post.

And it readily conveys Court Packets from the Colony, where they are delivered to those whither they are addressed without any expence to the Crowne, or said Coliny, besides many other advantages.

But not withstanding these Publick and private benefits arising by it and the unspeakable Loss to those Collonys and England should the Post fall Yet the Undertaker besides a Considerable sume he hath been out of pocket already (above the Produce in carrying it on) must still be in disburse for support of it or must let it fall.

To prevent which it is humbly offered that a postage upon all letters as well those that come from beyond sea to North America as what go's from Colony to Colony may be ascertained by an act of Parliament in England. 
That no Masters of ships or sailers bound to America shall receive any letters but at the Post Office to be appointed for that purpose.

That in like manner no Masters of shipps shall receive letters in America that are directed to Europe or from one part of America to another but from the respective Post Offices in the ports where they load or from whence they saile which said Post Offices shall put the letters in a Maile and take a Receipt of the Master that he shall deliver them in to the first Post Office where he shall arive free of charge, for which he shall be allowed in America a penny a letter for his Care excepting such letters as concerne the ship or cargoe which the freightors or owners if they think fit may commit to the care or charge of the Master or friend.

Excepting also such letters of Merchants as may Contain Bulky accounts which no Master is intended to be hindered of carrying as also excepting such letters which the agents or propriotary governments may send to the Respective Governors whose agents they are. It being only hereby intended that the bulke of letters $\mathrm{w}^{\mathrm{ch}}$ hitherto have gone very loosely, to the great Loss of Merchants may for the future be conveyed in Mailes to prevent frauds or inconveniencys which have often hitherto happened.

That the said Master shall under a Penalty be obliged to call at the respective post offices where he shall load for the Maile and if none be ready to be sent that he bring with him a Certificate for his Justification that he called.

The method at present used to get letters transported to America is this-

The Masters bound thither put up bags in Coffee houses wherein the letters are put and for which one penny a letter is usually paid and $2 d$. if it exceeds a single letter.

This is Lyable to several abuses.

First any one under pretence that he wants to have his letters up again may come to those bags and take out other mens letters and thereby discover the secrets of Merchants and tis in their power intirely to $\mathrm{w}^{\text {th }} \mathrm{draw}$ them.

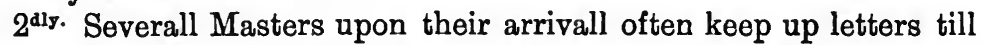
they have disposed of their Loading and are ready to saile again, and then Drop them to the great hurt of those that are concerned, which inconveniencys would be prevented if letters were delivered from the Post Offices in Mailes and likewise delivered by them in Mailes into the Post Office where they arrive. Offices may be erected in London and other sea Port Townes in England that Trade with America and so they may be in Ireland and the same penny a letter which is paid into the Coffee houses would support such offices in England and Ireland to receive such letters. 
Such offices will be a great convenience to lodge such letters as may concerne his Majestys affairs in America.

If Masters were obliged to receive letters to and from America from the Post Office only, in Mailes and delivered them so at the first post office they arrive at; there would be saved to the King a penny a letter, which now Masters of shipps and passengers Receive, for every American letter they deliver at the respective Offices and whereas now many letters are delivered by Masters and passengers themselves to the persons concerned, all those letters would then be brought into the Post Office to the encrease of that Revenue.

That it be provided that the Post and his horse shall go fferry ffree.

That the rates following may be set upon letters-

To or from Europe or to the West Indies to North America six pence p. single letter $12 \mathrm{~d}$. p. double $18 \mathrm{~d}$. for a packet if a packet contain nothing but Invoices, accts. Gazetts \&ca. to be accounted but as a single letter.

Upon Inland letters as followes-

d.

Where the distance from New Yorke to Boston is within 80 miles the postage 6

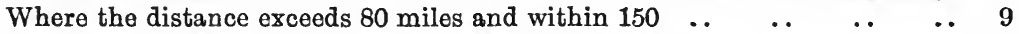

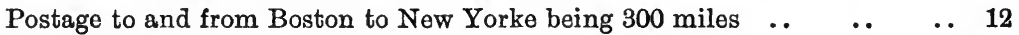

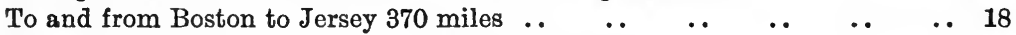

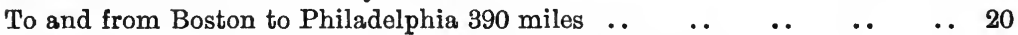

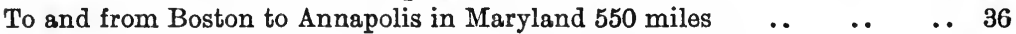

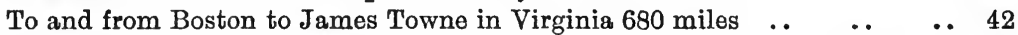

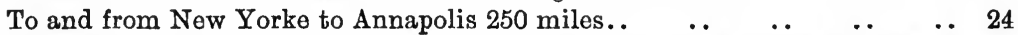
To and from New Yorke to James Towne 380 miles and many broad and

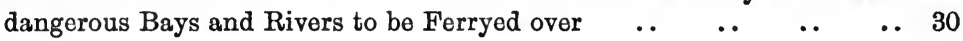

If it be objected $\mathrm{y}^{t}$. there is no reason to grant a postage upon forrensic letters where the Postmaster is at no charge of Conveyance,

It is answered first that it remidies the evills that letters are subject to by the present Method of Conveyance.

$2^{\text {dly }}$. It encreases the Revenue of the Post Office in England.

$3^{\text {dly }}$. That those Colonys having but little Correspondence with an other if the Reale Expence of Conveying letters from Coliny to Colony were charged upon Inland letters it would discourage all Correspondence.

Exa : The Charge of a letter from New Yorke to Boston at present is after $\mathrm{y}^{\bullet}$ rate of $12 \mathrm{~d}$. a letter and considering the fewness of $\mathrm{y}^{\mathrm{m}}$. and the extraordinary charge and trouble of keeping up the Post in time of Wintor taking it one Post with an other a single letter would not be Carryed for $5^{\mathrm{a}}$.

The Charges of settling a Post throughout Virginia and Maryland 
will cost at least $500^{\mathrm{d}}$. p. ann. \& 100 letters in a year will not come from those Collonys to the neighbouring Colonys their Correspondence being chiefly $w^{\text {th }}$. Europe. All which is humbly submitted by

May it please your Lordshipps

Your Lordpps most obedient servant

ANd : Hamilton.

I humbly beg leave of your Lordspps to add $\mathbf{y}^{\mathbf{t}} \cdot \mathbf{w}^{\mathbf{n}}$. his Majesty shall at any time be inclinable to take this Post Office under his Immediate direction I humbly make a proffer to make a Surrendor of $\mathrm{y}^{\mathrm{e}}$. pattent upon payment of $5000^{\mathrm{d}}$ or $1000^{\mathrm{d}}$. p. ann. for life for the remaining Tearme of $\mathrm{y}^{\mathrm{e}}$. Pattent.

Tho : Neale.

A Calculation what Charge will carry ye Post from Newcastle in Pensilvania to James City in Virginia about 400 Miles.

There being a great many broad \& dangerous rivers to be Crossed makes it difficult to procure men to Ryde ye Stages and will cost at least to carry ye Post from Newcastle through Maryland to James City in Virginia 300l. P Ann. I Reckon yt in 2 or 3 yeares \& may be less this Charge will be defrayed by what may Arise by Postage upon letters. The Post from Newcastle to New England now at last defraying att last its own Charge there will remain only ye Sallery to be allowed to ye Deputy Postmaster Generall which by ye Increase of ye Post will in 2 yeares more in probobility alsoe be defrayed.

As I have laid ye first foundation of ye American Post soe if ye King think fitt to continue me on this trust I will take upon me ye managem ${ }^{t}$ of ye whole from Piscatway 70 Miles eastward of Boston to James City in Virginia $\mathrm{w}^{\text {ch }}$ is 800 \& odd miles for $300 l$. p Annum and will keep exact Accts. of ye produce.

Soe yt $1200 l$. will in all probability be ye utmost Charge ye King will be att to bring ye American Post to support it Self vizt. 600l. for two yeares Carrying it through Maryland \& Virginia and 600l. more for 2 yeares salery to ye Manager or Deputy Postmaster Gen ${ }^{\text {ll }}$ and will thereafter bring in A Revenue All which is most humbly Submitted.

Aprill 26th 99

AND : Hamilton, Dep Postm of North America. 


\section{No. $1(c)$.}

Cock Pit Treasury Chambers.

The $\mathrm{L}^{\mathrm{ds}}$. Com ${ }^{\mathrm{rs}}$. of his Majties Treary are pleased to refer this petition and ye account annexed to $\mathrm{S}^{\mathrm{r}}$. Robt. Cotton $\mathrm{Kn}^{\mathrm{t}}$. \& $\mathrm{S}^{\mathrm{r}}$. Tho.

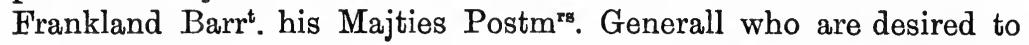
examine ye particulars and report to their Lopps a true state thereof together $\mathrm{w}^{\text {th }}$. their opinion what is fit to be done therein.

$\mathrm{W}^{\mathrm{m}}$ LOWNDES.

The account annex'd to $y^{e}$ petition makes $y^{e}$ charges of Erecting $\mathrm{y}^{\mathrm{e}}$ post in North America from May 1693 to May $97 \ldots 3817611 \frac{3}{4}$

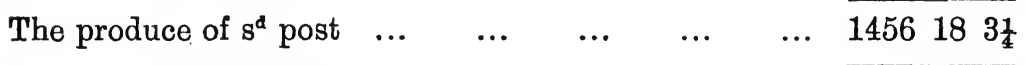

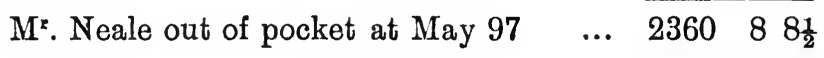

$3817611 \frac{3}{4}$

No. $1(d)$.

To the right Honble the Lords Com ${ }^{\mathrm{rs}}$. of his Maj ${ }^{\text {tys }}$. Treary.

May it please your Lordspps.

In obedience to $\mathrm{yo}^{*}$. Ld.spps. Order of Refference upon $\mathrm{y}^{\bullet}$ Memoriall of Thomas Neale and Andrew Hamilton Esq ${ }^{\text {rs. Wee }}$ have Considered the same and do find that the said A: Hamilton hath Established a regular Post to pass weekly from Boston to New Yorke in New England and from New York to Newcastle in Pensilvania which must undoubtedly be of great benefit and advantage to the People and tend to the encreasing of Trade in those Plantations; Wee have likewise examined the accounts given in by the said Hamilton of the Proffit and charge arising by this Post and do find that the Proffits have every yeare encreased, so as to defray all charges, excepting the sallary paid to the said Andrew Hamilton for his care in managing and settling the Posts in North America and it may be hoped that upon the severall Governors giving all reasonable encouragement to this usefull undertaking, and a due care in the management thereof, It may in some years bring in a Considerable proffit.

Wee have Consulted his Majestys Attorney and Solliciter Generall whether his Majesty can settle the rates and Postage between England and any of the Ports in America, and for the port of letters to and from New Yorke to or from any part of the said plantations ; and they are of opinion his Majesty May settle such rates in both respects as shall be thought reasonable (regard being had to the proportions and rates settled by the Act), for letters carried beyond 
sea, so $y^{\mathbf{1}}$ it doth not seeme necessary there should be any additionall Act of Parliam ${ }^{t}$. for the settling of rates upon all such letters.

To prevent any Collections of letters that may be made by any Masters of Ships or Seamen Wee are humbly of opinion it may be proper to appoint an Officer here whose business it should be to take Care of all letters directed to any of his Majestys Plantations, and upon going off of ships to those parts to put them up in severall and distinct bags, sealed with the Seale of the Office and sent to $\mathrm{y}^{\mathrm{e}} \mathrm{Ma}^{\mathrm{r}}$. of such Vessell who shall deliver $\mathrm{y}^{\mathrm{m}}$. to $\mathrm{y}^{\mathrm{e}}$ Deputy Postm ${ }^{\mathrm{x}}$. in the first Port where he shall arrive such Deputy paying him one penny for each letter Contained in $y^{\bullet}$ said bag as a recompence for his Care : and $y^{\circ}$ same method may likewise be observed in England for all such letters as shall come from America : and upon such Officers being Established it may be fit to give Publick Notice that no other person presume to make Collection of letters for those parts.

Wee have Considered of the severall rates mentioned in $\mathrm{Mr}$. Hamiltons Memoriall for the Inland Post of letters between one place \& an other in America and are humbly of opinion some of them are too high. It having been found by Experience in this Office That $\mathrm{y}^{\ominus}$ easy and cheap Corresponding doth encourage people to write letters and that this Revenue was but little in proportion to what it now is till the postage was reduced from sixpence to $3 d$.

Wee have advised with $\mathrm{Mr}$. Hamilton who hath settled and managed this Post under Mr. Neale and is recomended to Us by the Governor of Virginia to be well acquainted with that Country about enlarging the Post through Virginia \& Maryland and by his Competation hereunto annexed do find that it will require $1200^{\mathrm{d}}$. further Charge than $w^{\prime}$ has already been expended to Establish and bring the whole to perfection there.

Upon the whole it appears to Us that as the Establishing this American Post whereby the several Colonys have a regular way of Corresponding with each other is of great advantage to the Trade of his Majtys. Subjects in those parts so it may in few years bring in a cleare proffit over and above what may be required to defray $\mathrm{y}^{\circ}$ necessary Charges but it is to be apprehended that considering the same is in the hands of a private person the severall Governors will not give that encouragem ${ }^{6}$. to it they would do if the profit and advantage arrising thereby were to accrew to his Majty. All which is humbly submitted to your Lordsps. Consideration. Gen'. Post Office 27th April 1699.

$$
\text { R: Cotton Tho: Frankuand. }
$$


No. $1(e)$.

To the Right Honble \& $\mathrm{c}^{\mathrm{a}}$.

The humble Memoriall of Tho: Neale Esq'.

May it please your Lordsps.

Though after Strugling with many difficultys in the first settling the American Post I have now at last at a great Charge made it a regular Post and brought it to such a pass that where settled it supports it self and will in a very fow yeares bring in a fair Revenue, Yet since the Postm ${ }^{r}$. Gen ${ }^{1}$. in their Report to your Lordsps Conserning $\mathrm{y}^{t}$ Post have declared their opinion that it will not receive so due encouragement nor so soon attain to perfection in the hands of a private person for the good of the publick, as it would, were it in the hands of the King; I humbly offer to lay my Pattent of that Post office at his Majestys feet rather then an undertaking so usefull \& beneficiall to his Majestys subjects in America and to those that trade thither should want the least advantage for its support and to leave my selfe to his Maj'tys Justice and goodness for a Recompence of my risque and disbursments by a yearly Pention or otherwise.

And Whereas in $\mathrm{y}^{\theta}$ Memoriall annexed to the Report, the abuses hitherto practiced in Conveying letters to America and the method for preventing them for the future are set forth I humbly beseech yo Lordsps. $\mathrm{y}^{\mathrm{t}}$ the said Method if approved of by your Lordps. or such other as your Lordsps. shall think more proper may be put in Execusion for the benefit of the Publick and mine till his $\mathrm{Maj}^{\text {ty }}$. shall declare his pleasure conserning the surrender of my Patent.

All which is most humbly submitted to yo ${ }^{x}$. Lordsps.

Great Wisdom \& $c^{a}$. by

$$
\begin{aligned}
& \text { My Lords } \\
& \text { Your ever obedient }
\end{aligned}
$$

Tho: Neale.

April 28, 1699.

No. $1(f)$.

To the Kings most Excellent $\mathrm{Ma}^{\text {ty }}$.

The humble Petition of Andrew Hamilton, and Robert West.

\section{Sheweth}

That your Majtle. and the late Queen of Blessed Memory in the fourth Year of your Raigne, by Letters Patent granted to Thomas Neale Esq . full power and Authority to Erect a Post, and Post office in North America, To hold for one and Twenty yeares without any Account, And by the same Letters Patent directed the Post Master 
Generall of England to Issue Deputations from time to time to such Persons as Mr. Neale or his Assignes should Nominate, to Execute the same power.

In pursuance of which Grant, the Post Master Generall at Mr. Neales nomination, Deputed Your Peticoner Hamilton, who hath Setled a Post from New Yorke Southward as far as Virginia, and Eastward Seventy Miles beyond Boston in New England, which proves of great Advantage to the Trade of those Coloneys, and of no lesse Service to your Majtys. Governm ${ }^{t}$. there.

In the Setling and Supporting $w^{\text {ch }}$ Post, your Petr. West, above seven yeares agoe upon the request and Credit of Mr. Neale, advanced Two hundred pounds, and your Petitioner Hamilton hath since disbursed Eleven Hundred Pounds more, and brought it to such Perfection, that it allready defrays Its own Charge, and will in time be a Considerable Revenue.

That Mr. Neale being unable to pay your Petrs. or to give them other Satisfaction, in August 1699 Assigned all his Interest in the said Post to your Petitioner West for secureing all the Monys due to both your Petitioners and all such other sumes as your Petr. Hamilton should expend in further enlarging the said Post, with Common Interest for the whole Moneys.

That Mr. Neale Dying before payment of any part of the said Debts, and all persons declining to Act either as his Executor, or Administrator, Your Petrs. will be necessitated to dispose of the said Post for Satisfaction of their Debts, but being Sensible It is more for your Maj ${ }^{\text {ties }}$. Interest and Service, to have such Post Under the management and Controll of some Officer to be appointed by your $\mathrm{Ma}^{\text {tys }}$. than of any Private Person.

Your Petitioners humbly tender the same to your Majte. and if your Maj"te. shall not thinke fit to Accept It, They humbly pray that your Majtie. will Gratiously encourage the Continuance and Enlargement of the said Post, by granting them a further terme of years therein, and such additional Priviledges as are necessary for the Improvement of it.

And your Petitioners shall ever pray \& $c^{a}$.

At the Court.

No. 2.

SIR,

LoNDon Febr. 8th 1779.

My present disagreable Situation as an Officer under the Crown without Employment, and without a Salary, occasioned by the Rebellion in America, induces me to give you the Trouble of 
this Adress, and to request your advice and Assistance in procuring that Relief which my present Circumstances require.

You are not a Stranger to my Appointment to the Office of Deputy Postmaster of Philadelphia in the year 1776 by the Deputy postmasters General of North America, and that I continued to act in that Office, and as I trust to the entire Satisfaction of all concerned, until the Confusion and Sedition in that Country rendered it impossible for me to be of any kind of service.

In the Spring 1775 having good Reason to believe from a variety of Information that there was a Danger of breaking up the Post Office at Philadelphia under the Crown, and seizing upon all the Monies in my Custody, I immediately made up my Accounts, and remitted the Balance in my Hands to the Comptroller in New York up to the $5^{\text {th }}$ April of the same year.

About this time the disaffected Merchants in Philadelphia set up by Subscription a post Office in opposition to Government, appointed William Bradford Postmaster and compelled many of the well effected Merchants and others to send their Letters to it for Conveyance; and in May following the Mail was seized in New England under a public Avowel of the Rebels.

Under these Circumstances finding not only my person was in danger, but that I could be of no further service to the Crown by my continuing in Philadelphia, I left it and came into New York where my Conduct being approved, I procured leave of Absence, and returned to London in order to represent the true State of the Offices in America, which on my arrival I did. You will also recollect that as soon as possible after hearing that the City of Philadelphia was in possession of the Kings Troops I again embarked under an Expectation that the War would be settled by the Commissioners, and to take care of the post Office Affairs in that City. But on my arrival finding that All Letters by the packets \& $c^{2}$. were taken up by the Commander in Chief, and delivered not only to the Army and Navy but even to the Merchants, the City being evacuated soon after, I was obliged to return again to this place for safety. When in the Execution of my Office my Salary amounted to Two Hundred and Twenty five pounds Sterl's. p. Ann. out of which I paid Clerks Wages and Office Rent. This I received up to the 5 of April 1775. Since that time I have subsisted on my own means (except Two Hundred pounds at the Post Office by Warrant from the Treasury) without receiving any other part of my Salary from Government.

In these Circumstances it is with reluctance I find myself under the necessity of applying for the same Allowance from the Crown, 
which has been made to other persons in Office under it, in the like Situation.

I am Sir \&eas.

Anth. Todd, Esq".

Thos. Foxcroft.

Treasury authorized $£ 100$ a year from 5th April, 1775, " until he may be reinstated in the office or otherwise provided for."

No. 3.

General Post Office, February 15th, 1793.

SIR,

In your letter dated the 1st instant which we did not receive till the 8th, We have the honor to inform you that after much difficulty We have but lately obtained Mr. Finlay's accounts as Deputy Post Master General in America the first Statement of which was for the period between the 5th of April 1786 and the 10th of October 1790 and exhibited a balance due to the Office up to that date of $£ 1809.19 .4$ Sterling but the Account was inadmissible in point of form for reasons hereafter mentioned.

We are satisfied Sir that you will form no Opinion without having read the full state of the question on both sides and the proofs and documents by which Our Conduct towards Mr. Finlay may be judged and that you will form no hasty conclusion from his statement of his own case, which you will find to be greatly misrepresented.

In support of this assertion We have ordered Copies of the letters that We have lately written to Mr. Finlay upon the Subject of his Debt to be laid before you, And We shall if you will permit us Order our Deputy Accountant General and desire Mr. Callender to wait upon you and to explain the particulars of all that have passed.

Mr. Callender is Mr. Finlay's Agent without whose knowledge and concurrence, We have taken no one step of late in this business, nor sent out any dispatch to Mr. Finlay that Mr. Callender has not previously seen and approved.

$\mathrm{He}$ will be able to satisfy you Sir, whether our conduct towards Mr. Finlay has been grounded upon severity or upon forbearance, more than perhaps our duty strictly speaking, would justify.

In the mean time that we may do away any erroneous impression, which Mr. Finlay's letters may have made upon your mind, as well as upon Gov : Clarke's, We shall shortly put together the points which Our correspondence will prove, and We shall rely upon your justice to transmit copy of that correspondence to Gov : Clarke, that He may have full and correct information upon the subject. 
There is and has long been a considerable balance due from Mr. Finlay, to this Revenue, for the payment of which he has given no security, which balance We have repeatedly but in Vain called upon him to pay.

$\mathrm{He}$ is in possession from us not as He tells Governor Clarke, of a Salary of $£ 300$ per Annum, but of a Pension of $£ 150$ p. Annum, a Salary of $£ 150$ more, and a Commission of $£ 20$ per Cent on the net produce of letters within the province of Canada, which he assured us in May 1789 produced to Him a nett receipt of $£ 130$ p. Annum, but previous to his receiving any net produce, all charges, dead letters, under Deputies Salaries, and other allowances are by the Words of his Commission, to be first deducted.

Instead of this he has charged the Office $£ 20$ per Cent upon the Gross, the dead letters only deducted, and not upon the net produce and claimed to be allowed for sundry of those Articles of Management, which by His Commission on the Articles which are to be deducted before the Net Produce is paid to him.

He also charges his Pension for several quarters, which he must know, was paid to his Agent in this Country during a part of the time he claims it in Canada.

In an account amounting to several Thousand Pounds and for several Years, $\mathrm{He}$ has sent us home the particulars of no one Article of expenditure whatever, \& one Voucher only which is but for $£ 27$.

His accounts from the length of time and the manner in which they have at different periods been stated, are in a confused and contradictory state, and radically wrong, from his having taken considerable credit for Money received by his Agent here on Account of his Pension, and the whole of the Articles of his disbursements being destitute of Vouchers, up to the Period of the 10th of October 1792, without which they cannot pass this, or the Auditors' Office, together with his having taken a Credit for his $£ 20$ p. Cent on false principles, and contrary to the words of His Commission, which says it shall be on the Net and not on the Gross Produce. The Accountant General therefore thought it more adviseable, and Mr. Finlay's own Agent strongly recommended the measure, of Mr. Finlay's coming to England to adjust in person, the whole, and render an Account capable of being incorporated in the Annual Accounts of this Office, for the Auditors in which the true balance must be ascertained.

As far as depends upon us We have given him the option to come or not, just as He pleases, provided We have an intelligible Account and his Balance paid.

His letter to Governor Clarke of 28th October contains one misrepresentation which is too strong not to be observed upon; For $\mathrm{He}$ 
says We are about to reduce his Income from $£ 500$ a year to $£ 200$, though We have often told him that We would allow him, and our proposal for doing so is now before the Privy Council, an income of $£ 400$ p. Annum net, besides $£ 50$ per Annum for his Clerk. He will also receive $£ 100$ p. Year from the Province as Maitre des Postes, but which in fact is paid ultimately by this Country, being allowed in the Governor General's Accounts : however independent of that $£ 100$ p. Annum, he will then be in the receipt of $£ 400$ p. Annum from us net Money, free of all deductions for managing an Internal Revenue in America which will not produce to this Country at the end of the Year a single shilling after paying the expence of the Post between Halifax, through the King's Colonies, and Quebec, besides which this Office pays the expence of four Packet boats which cost upon the present Peace Establishment about $\$ 8000$ p. Annum, though the correspondence between Great Britain and America does not yield above $£ 3000$ per Annum.

The Commissioners of Enquiry recommend that Mr. Finlay's pension of $\$ 150$ a Year should cease, which however We have continued to Him, And that his Salary only of $£ 150$ p. Annum should remain and they do not appear to have known that exclusive of this Pension and Salary he enjoyed a former Commission from the Year 1774 of $£ 20$ per Cent upon the net postage of all Money received in Canada, for which however in our calculation We had allowed Him $£ 150$ per Annum though $\mathrm{He}$ in his own dispatches assured us it produced him only $£ 130$ per Annum.

We have shewn this letter to Mr. Church and Mr. Callender before it was copied out fair, they have altered and approved of it, So that We are now Sir communicating to you, not only our own sentiments, but those of the deputy Accountant General and $\mathrm{Mr}$. Finlay's own Agent.

$$
\begin{aligned}
& \text { We are, Sir, } \\
& \text { WaLsingham, } \\
& \text { Chesterfield. }
\end{aligned}
$$

The Right Hon ${ }^{\text {le }}$ Henry Dundass.

(viii) The Clerks of the Road and the Transmission of Newspapers. ${ }^{x}$

No. 1.

To the $\mathrm{R}^{\mathrm{t}}$. Hono ${ }^{\text {ble }}$. the Lord $\mathrm{Com}^{\mathrm{rs}}$. of his Majtle. Treasury.

May it please your Lordshipps

The Postmaster Generall Representation for Increasing the Clarks Salaries.

- From the British Official Records (undated). 
Wee humbly lay before your Lorpps that upon some Information given the last summer to the then Lords Justices as if his Majesties Revenue of the Post office was lessened by a practice which had been long used of the Clarks of the Roads sending great quantitys of Gazetts and other Prints free of postage. Their Excellancyes thought fitt to lay the same before his Majtie. who was thereupon pleased to signifie his pleasure to us by the Lord Keeper (now Lord Chancellor) in a Comittee of Councell that his Majes ${ }^{\text {tie }}$. did not think it reasonable that Practice should for the future be continued but we acquainting their Lordshipps that this having been a perquisite constantly allowed to the six Clarks of the Roades on consideration of the smalness of their Sallarys it would be reasonable upon the taking of it away to allow them a compensation for the same whereupon they told us wee should lay that matter before your Lordshipps of the Treasury as wee now doe and upon the strictest enquiry wee can make the Case appears to be as followes.

Upon the first Establishing of the Post office England was divided into six Roades and a Clark appointed to each Road and their Sallaryes being but small they were constantly allowed even by the farmers themselves the privilidge of sending Gazetts and some other prints free, as the business and Revenue of the office increased by setting up new posts soe likewise did their perquisites In soe much that complaint was made thereof to the late King James when Duke of York who upon a full examination into the matter thought it more adviseable to continue it as an Incouragement to them than to compensate them by an addition of Sallary and besides that the office hath considerably increased since wee came into it the present Juncture of affairs by the frequent and long sessions of Parliament and the War wherein the greatest part of this side of the world is engaged hath occationed peoples being more desirous of News then formerly soe as wee believe the postage of prints sent by the six Clarkes may now amount to about ..... tho att the same time the Clarkes does not receive soe great an advantage by them they paying the first cost for them and susteyne frequent losses by their Customers failing in their paym ${ }^{t}$. Now upon the takeing this perquisite from them wee are humbly of opinion it will be reasonable to give them such an equivolent as is conteyned in the skeme hereonto annexed for wee must observe to your Lordshipps that not only the improvement of the Revenue but all the letters being duely accounted for doth in a great measure depend upon those officers they being the persons who make the charges upon all the Postmasters of England and the very nature of the office requires such despatch that its scarce possible to contrive such Cheque but $y^{t}$ these officers being in combination with the Postmasters may defraud his 
Majestie and therefore it does not seem adviseable that men should be under such a temtation for want of a due Incouragement.

The attendance is alsoe soe great and at those unseasonable times and houres as renders them uncapable of applyeing themselves to any other business whereby to helpe to support themselves and familys though the Addition of Sallary which we have proposed doth not amount to halfe so much as the Postage of Prints now sent by the severall Clarkes yet we cannot say his Majesty will be a gainer thereby for it must be considered $\mathrm{y}^{\mathrm{t}}$ many persons who are now furnished with them from the Clarkes for Two pence a peice will scarce have them if they must pay a groat or six pence a peice beside the troubling some freind in Towne to send them and whether they may not find out some otherways of being furnished with them then by the Post as by Flyeing Coaches $\& c^{t}$. or whether those officers or persons who have the privelidge of franking their letters may not hereafter supply those with such Prints as they are now furnished with from this office.

Whereas the business of the office is soe much increased that for the regular and due dispatch of the letters wee have been forced to appoint a Sortor to each Clarke of the Road for an assistant whereby their trouble and attendance is very much greater then it was and being taken from sorting the burden and trouble of the rest is proportianably increased as there are fuer hands to perform it nether they or the assistant having any other advantage or perquisites besides theire bare sallary of forty pounds a yeare which is soe poor a subsistance that such as have dyed since wee came into the office have scarce left enough to bury them wee are humbly of opinion this may deserve your Lordshipps Consideration and soe upon the whole matter though we must acknowledge it an unseasonable time to propose an increase of Sallaryes which has made us defer it thus long we could not omit this oppertunity of doeing it and humbly hope if your Lordshipps shall think fitt to give these poor men the Incouragement proposed it will tend very much to his Majesty Service in this office.

No. 2.

The Right Honorable Lord Walsingham, and the Earl of Chesterfield, His Majesty's Post Master General.

The undersigned the Clerks of the Roads gratefully considering the Report made by your Lordships to Government which recommends for them a Salary of Three Hundred Pounds p. Annum with their present privilege of franking Newspapers unimpaired ask permission to submit to your Lordships Notice the following 
plan for increasing the circulation of Newspapers and in consequence the Revenue arising from the Stamp duty probably to the Amount of Eight thousand pounds p. Annum though attended by no additional expence to Government but entirely at their own risque and which they have determined immediately to execute should your Lordships arrangement take place.

They would first premise that when they were releived by your Lordships from the payment they formerly made to the officers in this Department and from the Office which was filled by Mr. Tamineau, they reduced their charge from forty Pounds per Centum to Twenty \& Twenty five Pounds per Centum on the prime cost of the papers which latter sum is the additional charge now made on the prime cost by all the Stationers Printers \& Dealers who serve the Country with papers, and if in some cases it be less, it is on account of payment being made in advance.

They now propose upon the Establishment of your Lordships Arrangement to reduce the general charge on the prime cost from twenty and twenty five per Centum to ten and fifteen pounds per Centum, and as all the circulators of Newspapers will now regulate their charge for Newspapers sold in the Country by that of the Clerks of the Roads, the charge fixed by the Clerks will be the general one in the course of Six Months from its commencement.

This reduction will cause a greater demand for Newspapers in the Country many who now take a Weekly paper will then take a three day paper \& many who now take a three day paper will then take a six day paper and two Persons who now join the expence of a Weekly or a three day paper may be induced by the reasonable charge to take each a paper or increase the number as above, and as the reduction becomes generally known which by the means of their Agents the Post Masters and other correspondents throughout Great Britain \& Ireland it can be in fourteen days, the Stationers Printers and Dealers must likewise lessen their charge or risk the loss of their Customers.

By abolishing the monopoly once enjoyed by the Clerks in the Offices of the Secretaries of State, and the Clerks of the Roads in this Office, permitting the Public to send and receive Newspapers free, the number increased as this circumstance became known from-20,967 to 78,217 weekly and it is by confirming this liberty to the Public and by a reduction in the charge that the circulation of Newspapers and consequently the increase of Revenue is intended to be promoted. The probable increase in the number of Newspapers circulated in the Country through the above reduced price may be stated at the lowest computation at one half penny each upon one hundred Newspapers each Clerk of the Road, one hundred 
each of the twenty principal Stationers \& Dealers and for the more inconsiderable Dealers which are very numerous fifty of whom are known Four hundred papers by every poste, which together will make the additional number circulated every Post three thousand.

By preserving the privelege of franking to the Clerks of the Roads a competition will be occasioned between them \& the other Dealers, the Public will be supplied on more moderate terms, and an increase of consumption will be promoted but should this competition be destroyed by the abolition of the privelege of the Clerks of the Roads, the principal Dealers purchasing the business carried on by less extensive circulation might thereby occasion a monopoly and then fix the price as it might suit their private interest and diminish the number of Newspapers circulated thereby greatly injuring the Revenue as formerly by the monopoly of the Clerks of the Secretaries of State and the Clerks of the Roads for it would be the interest of the Stationers and other Dealers as it was that of the Clerks under Government to sell a less number at an advanced price, the Capital employed would not be so large nor the trouble nor the risk so great.

The Clerks of the Roads here beg your Lordships attention to a proposal which there is no doubt will occasion a yet further increase of circulation of Newspapers, it has been before stated to your Lordships in the Report upon the Plan proposed by the Commissioners relative to a Tax on Newspapers that before the duty of one penny postage was laid on all Newspapers sent by Post to Ireland, the Weekly number remitted to that Kingdom was upon an Average 8,000 , and that the Weekly number now sent upon an average is only 1,380 , should Government consent to repeal this duty it is evident from the above statement that they would gain a considerable Sum the Clerks of the Roads will with pleasure make a considerable reduction in their charge to Ireland, as in the case of home consumption which will be a means of still further extending of circulation.

Number of Newspapers which passed through the General Post Office London between the 5th April 1764, and the 5th of April 1765, with the amount at two pence each Stamp duty,

1764 London Newspapers 1,090,289 $\quad \ldots \quad \ldots \quad$.. 10

and

1790 compared.

Number of Newspapers which passed through the General Post Office London between the 5th of January 1790 and the 5 th of January 1791, with the amount at two pence each Stamp duty, London Newspapers .. 3,944,093

Country ditto. .. 123,200

Total No. .. $\overline{4,067,293} \quad \ldots \quad \ldots £ 33,894$. 2 . 2 


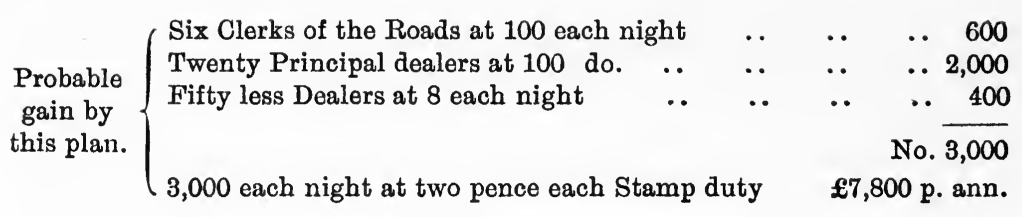

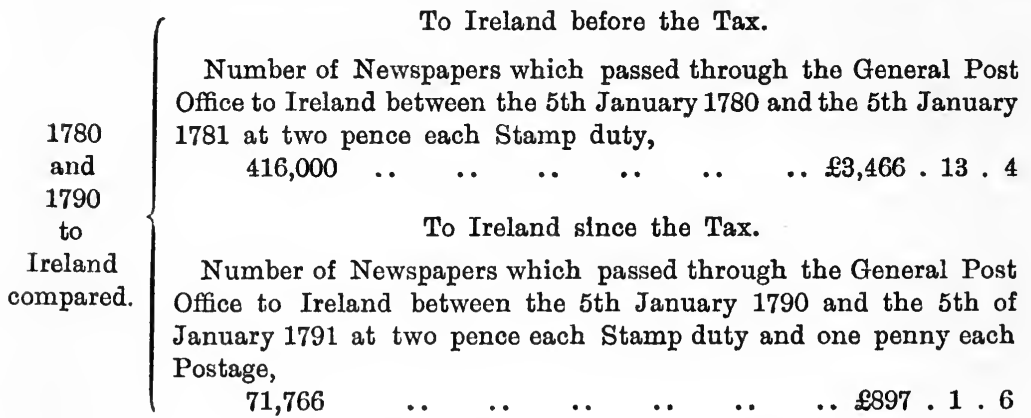

EDMund Barnes

IsaAc Henry Cabanes

William OgILvy
Charles Coltson

Samuel Ardron

Charles Evans.

No. 3.

To The Right Honorable Lord Walsingham and The Earl of Chesterfield, His Majesty's Post Master General.

The paper from the Post Master General relative to the Tax proposed by the Commissioners having been communicated to the Clerks of the Roads and the Inspector of Franks they beg permission to offer the subsequent observations.

That the proposal by the Commissioners for Government to receive a Tax of a penny for the postage of each Newspaper passing through the Post Office, however eligible it might appear at the time it was first proposed, will not they believe at this period, be productive of that expected advantage to the public the encrease of Revenue, as the reasons annexed among others may probably prove.

Because since the proposal was made to the Commissioners, and they made their Report an additional Stamp has been imposed of one halfpenny a paper, and another halfpenny on each has been added by the Printers, so that the Public now pay one penny more than they did at that time.

Because the proposed Tax would be a means of compelling the Stationers, Printers and Dealers to send their papers by Coach the same day at the customary charge of one farthing each paper 
instead of sending them by post on Government Account at a penny the second day. And it cannot be supposed that a number of persons many of them of considerable property would quietly submit to have the circulation of their papers confined to post conveyance at one penny each paper, without those serious efforts to oppose and prevent it which the prospect of certain and total ruin to their business and consequently to their Families must excite.

But allowing it were possible to confine the whole of the papers sold in the Country to post conveyance and a recompence made to those Stationers and Printers employed in the distribution at present would not the encreased price occasioned by this Tax very much diminish the Number of Newspapers now printed to the great injury of the Stamp duty? probably to a greater Amount than would be gained by the plan proposed. For were the Stage Coaches prohibited conveying Newspapers all the Morning Papers now conveyed by them to many parts of the Kingdom would be lost to the Stamp Revenue, and all the Morning Papers read at the Coffee Houses and other public Houses, would be collected by the Newsmen at a small sum each paper in the Afternoon and sent into the Country by the post in the Evening without the least trouble to themselves, it being their daily business to go round their London district, early in the Morning, and in the Afternoon before the dispatch of the Papers by the post.

Before the Penny postage was laid on all papers sent by post to Ireland the Weekly number remitted to that Kingdom was upon an Average 8,000: the Number now sent upon an Average is only 1,380 Weekly.

Because when the Tax was recommended by the Commissioners the first cost of a London Newspaper was threepence only, the first cost is now fourpence, to which add the Tax for postage it will be fivepence to any Post Town in England, which is one halfpenny more than the highest charge now made by any Dealer in the Country for a London Newspaper. But should this Tax take place the people who live at a distance from any Post Town must pay an additional halfpenny a Paper and some twopence on the receipt of each Paper which will bring the cost to fivepence halfpenny, some sixpence, and some as high as sevenpence each London Newspaper. This high price the Clerks of the Roads well know by experience would induce many people to take only a three day paper who now take a Six day paper and many who now take a three day paper only a weekly paper, and as the Salaries of the Clerks of the Roads employed in the business would be certain and no way answerable for any loss on the papers would there not be a great many people Customers no 
way able to pay for their Newspapers many of whom this mode of business would certainly introduce? consequently Government would be subject to several deficiencies in payment for Newspapers sent into the Country whether paid for half yearly, yearly, or each paper on delivery, the Receiver in the latter case would not feel himself obliged to give notice for his paper to be discontinued but would refuse it when offered, the cost of the paper would then be lost to Government. This latter mode of payment would give an opportunity to the Deputy Post Masters or their Clerks to Order more papers than actually required which after being read would be returned with the Quarterly Dead Letters to be allowed as refused or gone away.

Because the proposed Tax would cause a decided preference of Country Newspapers to those of London encrease the sale of the former and diminish that of the latter for as very few of the Country Newspapers pass through the Post Office, the Country Printers would be enabled to undersell the London Printers a penny a paper. The usual method with a Country Printer is immediately upon the arrival of his London paper to print his own with the London News and disperse them to Runners from ten to fifteen miles around the Town he resides in; these Runners not only disperse a considerable quantity of Newspapers but carry also letters which must materially injure the Revenue.

Because notwithstanding the Revenue to be raised by this Tax is very uncertain the conduct and management of it will be attended with much expence taken out of the hands of those deeply interested in its success the greater Burden will fall upon the Deputy Post Masters in the Country; the Country Newspapers when they arrive cannot be dispersed without a direction being numerous, the Deputies will no doubt expect an increase of Salary adequate to the business imposed on them; this it is conceived will bring a fresh expence upon Government. In most large Towns two additional Assistants to the Post Master will be necessary one at $£ 30$ and the other at $£ 20$ per Annum, it will also materially delay (in most of the Post Towns) the delivery of the letters by the time it will necessarily take in selecting folding and directing the Papers; allowing the same time to a Post Master and his Assistants as it takes herewith the same number of hands to dispatch them in the Post Office, the delay in many large Towns will be from one to two hours.

The Clerks of the Roads not having received any recompence whatever for the losses sustained by the Act of 1764 which abolished their then privelege of franking letters and gave to the Public liberty to send and receive Newspapers etc. free by a 


\section{APPENDIX C}

\section{LIST OF AUTHORITIES}

\section{UNITED KINGDOM}

Allen, Ralph. A Narrative of Mr. Allen's Transactions with the Government for the Better Management of the Bye, Way, and Cross Road Posts. 1761 (pub. London, 1897. Vide infra, Ogilvie, A. M. J.).

Andrews, Alexander. The History of British Journalism. London, 1859.

Baines, F. E. Forty Years at the Post Office. London, 1895.

Beadon, R. J. Uniform Imperial Postage. London, 1891.

Bennett, Edward. The Post Office and its Story. London, 1912. Bowie, A. G. The Romance of the British Post Office. London, 1897.

Bruce, Sir Robert, C.B. Postal Organisation, with special reference to the London Postal Service. London, 1912.

Cole, Sir Henry. Fifty Years of Public Work. London, 1884.

Collet, C. D. History of the Taxes on Knowledge. London, 1899. Corrie, John M. The Dumfries Post Office, 1642-1910. Dumfries, 1912.

D'Avenant, Winliam. Discourses on the Publick Revenues and on the Trade of England. London, 1698.

De-Laune, Tho. The Present State of London. London, 1681.

Harris, Stanley. Old Coaching Days. London, 1882.

Heaton, J. Henniker. Postal and Telegraphic Communications of the Empire. London, 1888.

Postal Reform. London, 1890.

Hemmeon, J. C., Ph.D. The History of the British Post Office. Harvard Economic Studies, vol. vii. Harvard University, Cambridge, Mass., 1912.

Hendy, J. G. The History of the Early Postmarks of the British Isles. London, 1905.

Hill, Frederick. An Autobiography of Fifty Years in Times of Reform. London, 1893. 
HinL, John. A Penny Post: or a Vindication of the Liberty and Birthright of every Englishman in Carrying Merchants and other Men's Letters, against any restraint of Farmers of such Employments. London, 1659.

Hill, Pearson. The Origin of Postage Stamps. London, 1890.

Hill, Sir Rowland. Post Office Reform: Its Importance and Practicability. London, 1837.

On the Collection of Postage by Means of Stamps. London, 1839.

The State and Prospects of Penny Postage. London, 1844.

Results of Postal Reform. London, 1864.

Life of Sir Rowland Hill, K.C.B., etc., and History of Penny Postage, by Sir Rowland Hill and his Nephew, George Birkbeck Hill, D.C.L. 2 vols. London, 1880.

Horne, L. T. Postal Communications of the Empire. British Empire Series, vol. v. London, 1902.

Hunt, F. KNIGHT. The Fourth Estate: Contributions towards a History of Newspapers and of the Liberty of the Press. London, 1850.

Hurcomb, C. W. The Posts under the Tudors. The Antiquary, 1914.

Hyde, J. W. The Royal Mail: Its Curiosities and Romance. London, 1889.

The Early History of the Post in Grant and Farm. London, 1894.

Joyce, Herbert, C.B. The History of the Post Office from its Establishment down to 1836. London, 1893.

Lang, T. B. Historical Summary of the Post Office in Scotland. Edinburgh, 1856.

Lewins, W. Her Majesty's Mails. London, 1864.

Macpherson, David. Annals of Commerce. London, 1805.

Murch, Jerom. Ralph Allen, John Palmer, and the English Post Office. London, 1880.

Nonway, A. H. The Post Office Packet Service. London, 1895.

Oginvie, A. M. J. Ralph Allen's Bye, Way, and Cross Road Posts. London, 1897.

Article on the "Post Office" in Dictionary of Political Economy. London, 1908.

Peach, R. E. M. The Life and Times of Ralph Allen. London, 1895.

Rarkes, H. St. J. Life and Letters of H. C. Raikes. London, 1898. Smyth, Eleanor C. Sir Rowland Hill: The Story of a Great Reform. London, 1907.

Stephen, Leshie. Life of Henry Fawcett. London, 1885. 
Stow; John. A Survey of the Cities of London and Westminster. London, 1720.

Swift, H. G. A History of Postal Agitation. London, 1900.

Symon, J. D. The Press and its Story. London, 1914.

Tega, William, F.R.H.S. Posts and Telegraphs. Past and

Present. London, 1878.

Tombs, R. C. The King's Post. Bristol, 1905.

The Bristol Royal Mail. Bristol (undated).

Webb, Sidney and Beatrice. The Story of the King's Highway. London, 1913.

Williams, J. B. A History of English Journalism. London, 1908. Wilson, John. History of the Birmingham Post Office. Birmingham Weekly Mercury, October, 1899.

The Practical Method of the Penny Post. London, 1681.

The Administration of the Post Office from the Introduction of

Mr. Rowland Hill's Plan of Penny Postage up to the

Present Time. London, 1844.

The Post Office of Fifty Years Ago. London, 1890.

Celebration of the Jubilee of Uniform Inland Penny Postage. London, 1891.

Records of the Life of S. A. Blackwood. London, 1896.

\section{Periodicals.}

Notes and Queries, 1st series, vol. iii ; 10th series, No. 141. Quarterly Review, 1839.

Edinburgh Review, 1840.

Chambers's Journal, vol. vii.

The Postmen's Gazette. London.

The Postal Clerks' Herald. Wolverhampton.

The Telegraph Chronicle. London.

The Postal and Telegraph Record. Manchester.

Telephone Journal. London.

St. Martin's-le-Grand Magazine. London.

\section{Parliamentary and Official Papers.}

Tenth Report of the Commissioners appointed by Act of Parliament to inquire into the Fees, Gratuities, Perquisites, and Emoluments, which are or have been lately received in the several Public Offices therein mentioned. 1788.

Report of the Committee on Mr. Palmer's Agreement. 1797. Twentieth and Twenty-first Reports of the Commissioners of 
Inquiry into the Collection and Management of the Revenue arising in Ireland and Great Britain. 1830.

The Ten Reports of the Commissioners for Inquiry into the Mode of Conducting the Business of the Post Office Department. 1834-38.

The Three Reports from the Select Committee on Postage. 1838. Report from Committee on the Conveyance of Mails by Railway. 1838.

Report from Select Committee on Postage. 1843.

Report from Secret Committee of House of Commons on the Post Office. 1844.

Report from Secret Committee of House of Lords on the Post Office. 1844.

Report from the Select Committee on Newspaper Stamps. 18th July, 1851.

Report of the Select Committee on Contract Packets, 1853.

Report of the Royal Commission on Railways, 7th May, 1867.

Report from Select Committee on Railway Amalgamations, etc. 1873.

Report of the Select Committee on Estimates of the Revenue Departments. 1888.

Post Office Wages. Report of Tweedmouth Committee, 1896.

Post Office Wages. Report of Bradford Committee, 1904.

Report of Select Committee on Post Office Servants (Hobhouse Committee), 1907.

The Post Office: An Historical Summary. London, 1911.

Report of Select Committee on Post Office Servants (Holt Committee), 1914.

Statement showing the Proposed Increases in Postal, Telegraph, and Telephone Charges, 1915 (Cd. 8,067).

First Report of the Committee on Retrenchment in the Public Expenditure, 1915 (Cd. 8,068).

Reports of the Postmaster-General on the Post Office. Annually (from 1854-5).

Official Records of the British Post Office.

Coвbetr, William. The Parliamentary History of England, from the Earliest Years to 1803.

Scobell, Henry. A Collection of Acts and Ordinances. London, 1658.

Calendars of State Papers.

Royal Commission on Historical Manuscripts.-Reports.

Hansard's Parliamentary Debates. 


\section{CANADA}

Report of the Special Committee of the House of Assembly on the Post Office Department of the Province of Lower Canada. February 11, 1832.

Lower Canada. Report of the Special Committee of the House of Assembly on the Present Condition of the Post Office Department. March 8, 1836.

Report of the Special Committee of the Legislative Council of Lower Canada on the Bill intitled "An Act to establish a Post Office in this Province, etc." March 15, 1836.

Report of a Select Committee of the Legislative Council of the Province of Upper Canada upon the Post Office. February 17, 1837.

Report on Affairs in British North America, by the Earl of Durham. 1840.

Report of the Commissioners appointed to Inquire into the Affairs of the Post Office in British North America. December 31, 1841.

Report of a Committee of the Executive Council of Canada on the Post Office. June 10, 1848.

Correspondence on the Subject of the Establishment of a General

Post Office System in the British Provinces of North America.

Montreal, February 27, 1849. (Appendix B.B.B., 8th volume of Journals of the Legislative Assembly of Canada.)

Report of the Railway Service Commissioners. Quebec, March 29, 1865.

Canada Official Postal Guide.

Debates and Proceedings in Dominion Parliament, reported in Ottawa Times.

Hansard. Official Reports of the Debates of the House of Commons and of the Senate of the Dominion of Canada.

Kingsford, William. The History of Canada. London, 1890. Hendy, J. G. Early Posts in Canada. Empire Review, London, 1903-4, vols. iv. and vi.

\section{UNITED STATES}

Bancroft, George. History of the United States of America. New York, 1883-5.

Burrows, Charles Williak. One-Cent Letter Postage, SecondClass Mail Rates, and Parcels Post. Cleveland, Ohio, 1911.

Frankin, Benjamin. Autobiography. London, 1908. 
Leavitt, Joshua (Corresponding Secretary, Cheap Postage Association). Cheap Postage. Boston, Mass., 1848.

Leech, D. D. T., and Nicholson, W. L. The Post Office Department of the United States of America; its History, Organization, and Working. Washington, D.C., 1879.

Newcomb, H. T. The Postal Deficit. Washington, D.C., 1900.

Nicholson, W. L. Vide Leech, D. D. T.

Norvell, S. Parcel Post. Address at Atlantic City, N.J., November 16, 1911.

Phelps, E. M. Selected Articles on the Parcels Post. Minneapolis, 1911.

Seitz, Don C. (Chairman, American Newspaper Publishers' Association). Statement before Commission on Second-Class Mail Matter. New York, 1911.

Slack, Stanley I. (Curator of the Postal Museum). A Brief History of the Postal Service. Omaha (undated).

Williams, Nathan B. The American Post Office. A Discussion of its History, Development, and Present-Day Relation to Express Companies. Washington, D.C., 1910.

Woolley, Mary E. The Early History of the Colonial Post Office. Providence, R.I., 1894.

History of the Railway Mail Service. Columbia Correspondence College. Washington, D.C., 1903.

International Parcels Post. Some Serious Errors Corrected, 1912. Document H.E. 6171.I.6, Library of Congress.

Report to Members of the American Weekly Publishers' Association of Proceedings before the Postal Commission on Second-Class Mail Matter. New York, 1906.

The Private Profit Railway versus The Public Service Post Office. Postal Progress League (1908).

An Argument on Second-Class Postal Rates from the Business Side Alone. Submitted to the Postal Commission on behalf of the Periodical Publishers' Association of America. New York, 1911.

An Answer to the Statement of the Post Office Department showing the estimates by which the cost of transporting and handling the several classes of Mail was obtained. The Periodical Publishers' Association of America. New York, 1911.

The Answer of the Magazines and their Demand. New York, 1911. Progress of the Contest for a Free, Untrammelled, Independent Public Press in the United States. Address delivered before the Periodical Publishers' Association of America (April 17, 1912). 
Mail-Carrying Railways Underpaid. A Statement by the Committee on Railway Mail Pay. New York, 1912.

\section{Congressional and Official Papers.}

Report of Committee on Rates of Pay for Carrying the Mails on Railroad Routes (1884).

Orders and Decisions relative to Railroad Mail Matter (1897).

A Brief Comparison of the Postal Facilities of Great Britain and the United States (1899).

Report of the Postal Committee of the National Board of Trade (1900).

Railway Mail Pay. Report of Joint Commission to Investigate the Postal Service (1901).

Record of Weight (July 1-December 31, 1906) of Second-Class Mail Matter (1907).

Report of Postal Commission on Second-Class Mail Matter (1907). Report of Special Weighings of the Mails of 1907 (1908).

Preliminary Report of Joint Commission on Business Method of

Post Office Department and Postal Service (1908).

Data relative to Proposed Extension of Parcel Post (1908).

Cost of Transporting and Handling the Several Classes of Mail Matter (1909).

Hearings before the Committee on the Post-Office and Post-Roads of the House of Representatives on Second-Class Mail (1910).

1911.

Instructions to Publishers in the Preparation of Second-Class Matter for Mailing and Dispatch (May 1).

Information issued by the Second Assistant Postmaster-General relative to the Transportation of Mails by Railroad.

Letter from Postmaster-General submitting a Report giving Results of the Inquiry as to the Operation Receipts and Expenditures of Railroad Companies Transporting the Mails, and recommending Legislation on the Subject (August 15).

Hearings of the Commission on Second-Class Mail Matter :-

Statements on behalf of the Post Office Department (August 1). Supplemental Statement on behalf of the Post Office Department (September 14).

Supplemental Statement on behalf of the Post Office Department (October 20 and 21).

Memorandum filed on behalf of the Publishers of Certain Magazines. 
Memorandum on behalf of the Post Office Department in Reply to "Memorandum filed on behalf of the Publishers of Certain Magazines" (October 28).

Supplemental Memorandum filed on behalf of the Publishers of Certain Magazines.

Memorandum on behalf of the Post Office Department in Reply to "Supplemental Memorandum filed on behalf of the Publishers of Certain Magazines" (November 27).

\section{2.}

Hearings before the Sub-Committee on Parcel Post of the Senate Committee on Post Offices and Post Roads.

Parcel Post in Foreign Countries (prepared under the direction of

Hon. Jonathan Bourne, Jun., Chairman of the Senate Committee on Post Offices and Post Roads).

Hearings before the Committee on Expenditure in the Post Office Department-Rural Delivery Service.

Parcel Post. Speech of Hon. David J. Lewis, of Maryland, in the House of Representatives (February 2).

Message of President transmitting Annual Report of the Postmaster-

General and Report of the Commission on Second-Class Mail Matter (February 22).

Postal Express as a Solution of the Parcel Post and High Cost of Living Problems, by Hon. David J. Lewis, Member of Congress (March 5).

The Parcel Post and Postal Express Situation in Congress. Letter to the People of the United States by Hon. Obadiah Gardner, United States Senator from the State of Maine (April 4).

Postal Express: Report from the Committee on Interstate and Foreign Commerce (April 25).

Alphabetical Scheme of New York for use of Publishers in the Distribution of Second-Class Mail (May).

Hearings before Senate Committee on Post Offices and Post Roads re Transportation of Periodical Second-Class Mail Matter by Freight (June 5-11).

Report on Post Office Appropriation Bill from Senate Committee on Post Offices and Post Roads (July 23).

Parcel Post Bill. Speech by Hon. David J. Lewis in House of Representatives (August 19).

Post Office Appropriations Act (containing authority for establishment of Inland Parcel Post).

The Postal Laws and Regulations pertaining to the Second Class of Mail Matter (October.) 
The Lewis Publishing Company $v$. The Post Office Department. Brief for the Post Office Department (November 19).

Parcel Post Regulations.

1913.

Interstate Commerce Commission: In the Matter of Express Rates, Practices, Accounts, and Revenues. Opinion No. 1967.

Reports of the Postmaster-General on the Post Office. Annually. Abstract of Laws passed between 1792 and 1910, fixing the Rates of Postage on Newspapers and other Periodical Publications when sent in the Domestic Mails.

Abstract of Laws passed between 1792 and 1910 fixing Rates of Postage on Domestic Mail Matter.

Journals of Congress. Philadelphia, 1781-2.

Journals of the Continental Congress. Philadelphia, 1774-89 (pub. Washington, D.C., 1904).

Gales and Seaton's Register of Debates in Congress. Washington, D.C., 1825.

The Debates and Proceedings in the Congress of the United States. Gales and Seaton, Washington, D.C., 1849.

Abridgement of 'Debates of Congress, from 1789 to 1856. New York, 1861.

Congressional Globe. Washington, D.C. Congressional Record. Washington, D.C.

The Postal Laws and Regulations of the United States of America. Washington, D.C., 1912.

\section{FRANCE}

Belloc, A. Les Postes françaises. Paris, 1886.

Bernede, Charles. Des Postes en générale, et particulièrement en France. Nantes, 1826.

Bonnet, Edgar. Importance des Postes et Télégraphes au point de vue social et économique. Paris, 1891.

Cazes, LÉon. Le Monopole postale. Paris, 1900.

Delmas, Albert. Les Agents des Postes et le Parlement Républicain. Paris, 1902.

Gallois, E. La Poste et les Moyens de Communication des Peuples à travers les Siècles. Paris, 1894.

Gouin, M. (Administrateur des Postes). Essai historique sur l'établissement des Postes en France. Paris, 1823.

Jaccottex, Paul (Professeur Adjoint à l'Ecole Professionnelle supérieure des Postes et des Télégraphes). Traité de Législation et d'Exploitation postales. Paris, 1891. 
Maurt, Lucien. Les Postes romaines. Paris, 1890.

Mercier, Renté. La Franchise postale. Librairie nouvelle de Droit et de Jurisprudence. Paris, 1904.

Paulhan, L. La Poste aux Lettres.

Rothschild, A. DE. Histoire de la Poste aux Lettres. Paris, 1879.

Les Services postaux français. Paris, 1905.

Répertoire du Droit administratif. Paris, 1905.

\section{Offictar Papers.}

Rapport au Président de la République sur les Conditions du Fonctionnement de l'Administration des Postes et des Télégraphes, par A. Millerand, le Ministre du Commerce, de

l'Industrie, des Postes, et des Télégraphes. May 12, 1900.

Proceedings in National Assembly. Reported in Moniteur Universel. Proceedings in Parliament. Reported in Journal Officiel.

Chambre des Députés. Rapport fait au nom de la Commission du Budget chargée d'examiner le projet de loi portant fixation du Budget général, Postes, Télégraphes, et Téléphones. (Annually.) Sénat. Rapport fait au nom de la Commission du Budget chargée d'examiner le projet de loi portant fixation du Budget général, Postes, Télégraphes, et Téléphones. (Annually.)

\section{GERMANY}

Crole, B. E. Geschichte der deutschen Post von ihren Anfängen bis zur Gegenwart. Eisenach, 1889.

Dambach, Otтo. Das Gesetz über das Postwesen des deutschen Reiches vom 28. Oktober 1871. Berlin, 1890.

Dieckmann, Cari. Postgeschichte deutscher Staaten seit einem halben Jahrtausend. Leipsic, 1896.

Faulhaber, B. Geschichte des Postwesens in Frankfurt am Main. Frankfurt a.M., 1883.

Grosse, Oskar. Die Beseitigung des Thurn und Taxis'schen Postwesens in Deutschland durch Heinrich Stephan. Minden in Westf., 1898.

Grunow, F. W. Zur Reform des Paketportos in Deutschland und Österreich-Ungarn. Leipsic, 1898.

HaAss, Friedrich. Die Post und der Charakter ihrer Einkünfte, mit einem Anhang über die Packetpost. Stuttgart, 1890.

Holzamer, J. Zur Geschichte der Briefportoreform in den Culturstaaten. Tübingen, 1879. 
Huls, C. H. "Die deutsche Reichs-Packetpost." Sammlung nationalökonomischer und statistischer Abhandlungen des staatswissenschaftlichen Seminars zu Halle (Saale) von Prof. Dr. Conrad. Jena, 1892.

Jung, J. Entwickelung des deutschen Post und Telegraphenwesen in den letzten 25 Jahren. Leipsic, 1893.

KönLer, B. Die Reichs-Post- und Telegraphentarife in ihren Rechtlichen Formen. Berlin, 1907.

Meyer, A. Die deutsche Post im Weltpostverein und im Wechselverkehr. Berlin, 1902.

Müller, C. F. Die Fürstlich Thurn und Taxis'schen Posten und Posttaxen. Jena, 1845.

Posten und Posttaxen. Freiburg im Breisgau, 1864.

NickaU, P. J. Wettbewerb in der Kleingewerbeförderung innerhalb des Reichspostgebiets. Würzburg, 1909.

Ohmann, F. Die Anfänge des Postwesens und die Taxis. Leipzig, 1909.

Perrot, F. Die Anwendung des Penny-Porto-Systems auf den Eisenbahntarif und das Packet-Porto. Rostock, 1872.

Portas, K. Deutsche Postzeitungsgebührentarif. Königsberg, 1914.

RüBsAM, Joseph. Francis von Taxis, the Founder of the Modern Post, and Johann Baptista von Taxis, his Nephew, 14911541. L'Union Postale, Berne,1892.

Schmid, K. A. H. Zur Geschichte der Briefporto-Reform in Deutschland. Jena, 1864.

Schmidt, Artur. Die Tarife der deutschen Reichs-Post- und Telegraphenverwaltung. Finanz-Archiv, Berlin, 1905-6.

von Stephan, Heinrich. Geschichte der preussischen Post. Berlin, 1859.

Ulurich, P. Die Finanzen der Reichs- Post- und Telegraphenverwaltung. Stettin, 1913.

Die Brieftaxe in Deutschland. Freiburg im Breisgau, 1862.

Die Uebernahme der Privat-Beförderungsbetriebe durch die Reichs-

Postrerwaltung. Deutsche Verkehrs-Zeitung, Berlin, March 1901.

Handwörterbuch der Staatswissenschaften. Jena, 1901 and 1910. Allgemeine Dienstanweisung für Post und Telegraphie. Berlin, 1901.

Archiv für Post und Telegraphie. Beihefte zum Amtsblatt des Reichs-Postamts. Fortnightly. Berlin.

Blätter für Post und Telegraphie. Zeitschrift der höheren Postund Telegraphen-Beamten. Berlin. 
Stenographische Berichte über die Verhandlungen des Reichstags. Berlin. (Cited Reichstag, Official Reports.)

\section{GENERAL}

Acworth, W. M. Elements of Railway Economics. Oxford, 1905. Adams, H. C. Science of Finance. New York, 1909.

Alexander, E. Porter. Railway Practice. New York, 1887.

Baines, F. E. Posts, Telegraphs, and Telephones, and their Relation to Trade. London, 1896.

Bastable, C. F. Public Finance. London", 1903.

Bennett, A. R. The Telephone Systems of the Continent of Europe. London, 1895.

Burritt, Eurhu. Ocean Penny Postage. London, 1849,

Coнn, G. The Science of Finance. Translated by T. B. Veblen. Chicago, 1895.

Corson, C. Railway Rates and Traffic. London, 1914.

Darwin, 'Leonard. Municipal Trade. London, 1903.

Eur, R. T. Taxation in American States and Cities. New York, 1888.

FARrer, Lord. The State in its Relation to Trade. London, 1902. Fischer, P. D. Post und Telegraphie im Weltverkehr. Berlin, 1879.

Giffen, Sir R. Essays in Finance. London, 1890.

Griekson, J. Railway Rates, English and Foreign. London, 1886. HaAss, Dr. Friedrich. Weltpostverein und Einheits-Porto (WeltPenny Porto). Heidenheim (Brenz), 1914.

Hadley, A. T. Railroad Transportation. Its History and its Laws. New York, 1886.

Hamiton, I. G. J. An Outline of Postal History and Practice, with a History of the Post Office in India. Calcutta, 1910.

Jevons, W. S. A State Parcel Post. Contemporary Review, January 1879.

Methods of Social Reform. London, 1883.

Jones, R. The Nature and First Principle of Taxation. London, 1914.

Jürgensohn, Arved. Weltportoreform. Berlin, 1910.

KNoop, D. Outlines of Railway Economics. London, 1913.

LEE, JoHn. Economics of Telegraphs and Telephones. London, 1913.

Leroy-Beaulieu, P. Traité de la Science des Finances. Paris, 1899.

McCuncoch, J. R. Taxation and the Funding System. London, 1863. 
Merritr, A. N. Scope of Government Functions. Journal of Political Economy, Chicago, July 1908.

Meyer, H. R. Public Ownership and the Telephone in Great Britain. New York, 1907.

Northcote, Stafford. Twenty Years of Financial Policy. London, 1862.

Parneli, Sir H. On Financial Reform. London, 1832.

Plenn, C. C. Introduction to Public Finance. New York, 1909.

Ripley, W. Z. Railway Problems. Boston, U.S.A., 1907.

SAY, L. Dictionnaire des Finances. Paris, 1889.

Seligman, E. R. A. Essays in Taxation. New York, 1913.

Spenoer, Herbert. The Man versus the State. London, 1884.

Stern, L. von. Lehrbuch der Finanzwissenschaft. Leipsic, 1885.

Terra, Otto De. Im Zeichen des Verkehrs. Berlin, 1899.

WaGNer, Adolph. Finanzwissenschaft. Leipsic, 1890.

Wilhelm, Julius. Frachtporto. Vienna, 1900.

Memoranda, chiefly relating to the Classification and Incidence of Imperial and Local Taxes. Bluebook C. 9528, 1899.

Rurfy, M. E. L'Union postale universelle. Sa fondation et son développement. Lausanne, 1900.

Official Documents of the International Postal Congresses. Published by the International Bureau, Berne.

Statistique générale des postes. (Annually.) Berne.

L'Union postale. (Monthly.) Berne.

Noтн.-The foregoing list includes particulars of the chief works consulted, but is not in any sense a complete bibliography. 


\section{INDEX}

Act of Union, 15

Acts, Post Office, see Post Office Acts Advertisement duty, 117, 119, 128

Agriculture, encouragement of, 190, 245

Aktentaxe, 225, 240

Allen, Ralph, 18

Armour, R., 138

Australia, parcel post in, 197

Bastiat, Frédéric, 86

Bath Road, 21

Binnenporto, 102

Blackwood, Sir Arthur, 234, 279

Blind, rate on printed matter for, 244 , 320

Bonaparte, Louis Napoleon, 167

Book Post, 32, 184, 220, 320

Books, rate for, see Rates of postage

Boten-Anstalten, 97, 209, 349, 350

Botenmeister, 97, 98

Botenpost, 98

Bourne, Jonathan, Senator, 196

Buildings, Post Oftice, cost of, 293, 309

Burlamachi, Philip, 10

Bye letters, 17

Canadian Magazine Post, 346

Cape Breton, posts in, 51

Carriers, common, and conveyance of

letters, 1, 250, 380, 381

Cartes de visite, 224

Catalogues, 170, 172, 225

Chesterfield, Lady, 112

Clanricarde, Lord, 53, 345
“ Class" newspapers, 124, 125

Classification of mail matter, see Mail matter; of postal revenue, see Revenue, net

Clerks of the Road, 114, 118, 403-11

Closed post, 222, 320 note

Colis encombrants, 280

Colonial letters, rates for, 345,346

Commercial papers, rate for, see Rates of postage

Commissioners of Inquiry into Fees and Emoluments, 1788, 115 note ; into Revenue Departments, 1829, 25, 114 note; of Post Office Inquiry, 1837, 248 note; 1838, 29

Commissioners on Post Office in British North America, Report of, 1840, 47, 48

Committee, Select, on Postage, 1838, 30 ; on Newspaper Stamps, 1851, 122,127

Commonwealth, The, 14

Confederation of British North American Colonies, 1867, 55, 141, 254

Conference, international postal, 1863, 265

Congress, Constitutional (United States), 70 ; Continental (United States), 66, 149

Congress, international postal, 1874, 266 ; 1876, 270; 1878, 277 ; 1880,278 ; 1886, 280 ; 1897, 272, 281 ; 1906, 274, 281

Convention, General Postal Union, 1874, 270; Parcel Post (international), 1880,279 
Conveyance of mails, cost of, 26,35 , $47,191,253,254,292,307,308$, 321,326

Conway Bridge, additional rate for, 339

Cost of handling (United Kingdom), 35, 311 ; for buildings, 293, 309; for conveyance of mails, $26,35,47$, $191,253,254,292,307,308,321$, 326 ; for staff, $289,301,306$; for second-class mail (United States), 156, 158; letters (France), 85; newspapers (Germany), 175 ; parcels (Germany), 219, (United States) 198i; postcards, 243

Council of State, 11, 12

Country newspapers (protected), see Newspapers (provincial)

Couriers, post, see Post-couriers

Crimean War, 125

Cromwell, Thomas, 3

Cross-posts, 14, 17, 22, 70, 388

Cumbersome parcels, additional charge for, 206, 215, 280; definition of, 206 note, 280 note

Cunard, Samuel, 347

Cunard Steamship Company, 348

Cursores, 1, 2, 377

Daily post, establishment of, in England, 19

Declaratory Act, 1778, 44, 45

Deficit, on newspapers, 133, 169, 176,

294 ; on parcels, 190, 219, 294 ; on second-class mail, 147, 155, 158,162

Delivery fees, 107, 110, 180, 206, 249, 258

Deputy Postmasters, see Postmasters

Deputy Postmaster-General (North America), 37, 48, 52, 64, 136, 140, 148

Dockwra, William, 183, 247

Double letter, definition of, 336

Dragonerpost, 98

Drop letter, 254

Duty (paper), 117, 119 note ; (advertisement), 117, 119, 128; (stamp), 117, 119, 121, 128
East India Company, 344

Elgin, Lord, 53

Evasion of postage, 16, 27, 48, 72, 254

Express companies, competition for second-class mail, 161; delivery of parcels, 193, 195

Farm (of the posts), 13, 14, 15, 70, 80, 380

Fee letter, see Letters

Finance, 35, 36

Finlay, Hugh, 37, 401

First-class mail matter, see Mail matter, classification of

Fittings (for sorting), 284 ; cost of, 293

Foot-messengers, 184, 221, 331, 378

Foreign letter office, 8, 12, 13

Foreign posts, see Posts

Fourth-class mail matter, see Mail matter, classification of

Foxcroft, Thomas, 66, 399

Frank, definition of, 27 note

Franking, 27, 49, 52, 114, 115, 116, $118,138,148,403-11$

Franklin, Benjamin, 39, 63, 64, 66, 148

Freeling, Sir Francis, 22, 137, 138

Freight trains, use of for second-class mail, 163

Gazette, London, 113, 114

Gazette, Oxford, 113, 114

General post, 248

General post delivery (London), 248

Germain, Lord George, 67

German-Austrian Postal Union, 1850, 213, 226, 236, 264

Geschäftspapiere, 240

Gladstone, W. E., 126, 130

Goddard, William, 65

Gratuitous transit (of foreign mails), 268, 273, 275

Halfpenny Packet Post, 222

Hamilton, Andrew, 60, 62, 392-9 
Hamilton, John, 64

Hand-stamping machines, 303

Handling, cost of, see Cost of handling; method of, 284

Hartington, Marquess of, 130

Heaton, Sir J. Henniker, 346

Heriot, John, 40

Hickes, James, 113

Hill, Matthew Davenport, 29

Hill, Sir Rowland, 23-30, 47, 72, 74, $84,127,220,312,323$

Horse-posts, see Posts

Howe, John, 43, 139

Illustrated London News, 129

Inland letter office, 10, 12

International Parcel Post, see Parcel post

Jaccottey, P., 171

Joyce, H., 17

King's messengers, 1, 4, 6, 377

Landbestellgeld, 110

Landkutschen, 97

Landporto, 102

Laurier, Sir Wilfred, 147

L'Estrange, Roger, 112, 113

Letter rate, see Rates of postage

Letters, definition of "single," " double," " treble," 336 ; bye, 17 ; cross-post, 17 ; drop, 254 ; fee, 51 ; way, 18,50 ; average weight of, $33,291,308$

Licences, issue of, by Post Office, 357

Licensing Act, 1662, 112, 117

Lichfield, Lord, 29

Local newspapers (protected), see Newspapers (provincial)

Local penny posts, 250

Local rates, see Rates of postage

London Gazette, 113, 114

London Penny Post, 183, 247, 342

London Threepenny Post, 252

London Twopenny Post, 252
Loss on certain branches of Post Office business, see Deficit

Maberley, Colonel, 29, 184

Magazine Post to Canada, 346

Magazines, transmission by post, 150, $152,154,155,159,346$

Mail-coach, introduction of, 21

Mail matter, classification of, 75,152 , 191,244

Mail order business, 196

Maîtres de poste, 37, 39

Manley, John, 13, 383

Maryland Journal, 65

Master of the Posts, 2, 12

Menai Bridge, additional rate for, 339

Merchant Adventurers, 8

Merchant Companies, 8

Mercurius Publicus, 112

Military post routes, $40,42,43$

Millerand, A., 92, 93

Monopoly, postal, 7, 9, 13, 60, 80, 255, $259,325,330,340,358,380-4$

Monsell, W., 133

Muddiman, Henry, 112, 113

Mulock, Sir William, 57, 146, 147

Murray, Robert, 247

Neale, Thomas, 60, 62, 391-8

Net revenue, see Revenue, net

New England colonies, 59

Newsbooks, 111, 112

Newsletters, 111

Newspaper rate, see Rates of postage

Newspaper Stamps, Select Committee on, 1851, 122, 127

Newspaper supplements, 171, 172, 181

Newspapers, average weight of, 132, 142,308 ; cost of transmission, 175,176 ; franking of, 148; free transmission of, $51,56,57,139$, $140,142,143,144$; "class," 124, 125 ; political, 167, 168; provincial (protected), 142, 146, 150, $151,166,169,177$; transient, 137, 152 
Nicholas, Sir Edward, 113

North German Union, 108, 213, 214, 228,257

Nuncii, 1, 2, 377

Old Age Pensions, payment of, 357 Open post, 222, 320 note

Oxenbridge, Clement, 13

Oxford Gazette, 113, 114

\section{Pacific mails, 75}

Packet post, see Post for the packet

Packet postage, 339

Page, W. J., 49, 52

Palmer, John, 20

Paper duty, 117, 119

Papiers d'affaires, 93, 239

Parcel Post, international, 185, 204, 206, 277; local, 207, 208; loss on, 190, 219, 295, 334

Parcel Post Act, 1882, 188, 288

Parcel rate, see Rates of postage

Parcels, cost of transportation, 188, $218,219,311,321,325,331$; average weight of, $33,190,216$, 325

Paris, University of, 78, 79

Parliamentary Intelligencer, 112

Parnell, Sir Henry, 24

Pattern Post, see Rates of postage (samples)

Penalty frank, 192

Penny Post (London), 183, 247, 342

Penny posts (local), 250

Penny postage, uniform, introduction of, 23

Penrose Overstreet Commission, 156, 157

Periodicals, transmission by post, 150 , $152,154,155,159$

Pitt, William, 21, 344

Political newspapers, 167, 168

Poor Man's Guardian, 120

Popish Plot, 14

Post Office Acts-

1657,13 ; 1660, 14, 337, 341 ; 1711, $15,229,248,337,343 ; 1730,249$, $251 ; 1763,17 ; 1764,115 ; 1765$,
$20,250,338$; 1784, 21, 338; 1794, $251 ; 1795,230 ; 1796,338 ; 1797$, 22 ; 1799, 344; 1801, 22, 230, 251, 338 ; 1802,116 ; 1805, 22, 230, 252, 338 ; 1812, 22, 230, 339 ; 1814, 344 ; 1815,345 ; 1836, 122 ; 1837, 339, 347 ; 1838, 288 ; 1839, 231 ; 1840, $231 ; 1853,128 ; 1855,128 ; 1870$, 131,221 ; 1882, 188 ; 1893, 288 ; 1908, 131

Post Office revenue, see Revenue, net Postage, origin of term, 2, 6 ; prepayment of, 27, 238, 251; rates of, see Rates of postage

Postage, uniform, see Uniform postage Postage stamps, introduction of, 27

Postal monopoly, see Monopoly

Postal traffic, growth of, in United Kingdom, 32

Postal Union Convention, 1874, 270

Post-boten, 97

Post-boys, 16, 20, 22

Postcards, 241 ; average weight of, 308

Post-couriers, 9, 39, 41, 49, 51, 52, $79,81,99,374,376$

Post for the packet, $5,8,378$

Post-horses, 2, 4, 5, 6, 20, 374-7, 381,385

Postmasters, 5, 7, 9, 18, 49, 51, 66, 71, $114,192,254,342,387,390,397$, $404,406,410$

Post-riders, 4, 5, 20, 22, 67

Post-roads, 14, 17

Post-stages, 2, 20, 38, 79, 99, 374-7

Posts, 2 ; cross-posts, 14, 17, 22, 70, 388 ; extraordinary, 3,6 ; foreign, 8,340 ; horse, $2,22,37,61,65$, 79, 99, 350 ; military, 40, 43, 98 ; ministerial, 67 ; municipal, 6 ; ordinary, 3 ; parliamentary, 67 ; regular, 2, 6; temporary, 3, 6; thorough, 4, 5 ; Thurn and Taxis, 108, 350; travelling, 3-6, 79 ; university, 6,78

Povey, Charles, 250

Power stamping machines, 303

Prepayment of postage, 27, 238, 251

Press, restrictions upon, 112, 117, 119, $122,126,166,167,180$

Prideaux, Edmund, 11 
Prince Edward Island, posts in, 52 Profit, Post Office, see Revenue, net Prospectuses, transmission by post, $170,172,225$

Provincial newspapers, see Newspapers Provost, Sir George, 42

De Quester, Matthew, 7, 340

Railway Clearing Committee, 189

Railway companies, remuneration of, for conveyance of mails, 186, 288 Railway rates, basis of, 321, 322, 323 Randolph, Thomas, 3 Rates of Postage-

\section{EngLand.}

Letters, 1635, 9; 1649, $11 ; 1657,13$, 336 ; $1660,14,337$; $1711,15,337$; $1765,20,338$; 1784, 21, 338; 1797, $1801,1805,22,338$; 1812, 22, 339 ; 1840, 23, 339 ; 1865, 31, 339 ; $1871,31,340 ; 1885,1897,32$, $340 ; 1915,36,340$

Newspapers, 1836, 122; 1853, 1855, $128 ; 1870,131 ; 1915,135$

Book Post, 1847, 220 ; 1853, 1866, 1870,221 ; 1897, 222 ; 1915, 223

Parcels, 1883, 187; 1915, 190

Samples, 1753, 1795, 1805, 1812, 230 ; 1837, 1863, 231 ; 1864, 1870, $232 ; 1887,1897,234 ; 1915,235$

Commercial Papers, 1660, 238; 1847, 239

Local Rates, 1680, 247 ; 1730, 249 ; 1794, 1801, 251; 1805, 252

\section{Canada.}

Letters (First-class Mail), 1765, 38; $1842,49-52$; 1851,$55 ; 1867,56$; $1889,1898,57$

Newspapers (Second-class Mail), 1840,136 ; 1844,$140 ; 1867,141$; 1882,$143 ; 1898,145 ; 1903,147$ Book Post (Third-class Mail), 245 Fourth-class Mail, 245

Parcels, 1914, 356
Local Rates, 1867, 1889, 254 ; 1898, 255

United States of America.

Letters (First-class Mail), 1693, 61 ; $1711,1765,63 ; 1775,66 ; 1777$, $68 ; 1780,1781,1782,69 ; 1792$, 1814,$71 ; 1845,73 ; 1851,1863$, $75 ; 1883,1885,76$

Newspapers (Second-class Mail), 1792,$149 ; 1794,1825,150 ; 1845$, $1847,1851,151$; 1863, 1872, 152 ; 1879, 153

Book Post (Third-class Mail), 76, 245

Fourth-class Mail, 76, 245

Parcels, 1913, 201 ; 1914, 202

\section{France.}

Letters, 1576, 1627, 1676, 80 ; 1703, 1759,$81 ; 1791,82 ; 1827,83$; 1849,$85 ; 1850,1854,1871,88$; $1876,1878,90 ; 1906,94 ; 1910$, 1917, 96

Newspapers, 1791, 1795, 1799, 165 ; $1827,1850,166$; 1856,167 ; 1878, $1895,1908,169$

Book Post, 1791, 1856, 223 ; 1878, $224 ; 1909,225$

Parcels, 1881, 205 ; 1897, 206

Samples, 1791, 1856, 235; 1871, 1873, 1875, 236

Papiers d'Affaires, 1856, 1871, 1875, 240

Local Rates, 1653, 255 ; 1759, 1878, 256

\section{Germany.}

Letters, 1712, 1762, 100; 1766, 1770 , 1822,$101 ; 1824,102 ; 1844,104$; 1848,$105 ; 1850,106 ; 1860,1861$, 107 ; 1868, 1871, 1900, 109

Newspapers, 1821, 1848, 174; 1899, 178

Book Post, 1712, 1821, 1824, 225 ; 1850,226 ; 1856, 227 ; 1871, 1874, $228 ; 1890,229$

Parcels, 1699, 1713, 210 ; 1762, 1766,$211 ; 1770,1805,1811,1824$, 212 ; 1842, 1850, 1857, 1867, 213; 1874, 214-15 
Samples, 1825, 1850, 236 ; 1860, 1863, 1871, 237; 1875, 1914, 238 Geschäftspapiere, 1900, 241

Local Rates, 1852, 256 ; 1860, 1865, 1867,$257 ; 1875,258 ; 1900,261$

\section{INTERNationaL.}

Letters, 1874, 270; 1906, 275

Parcels, 1880, 1886, 280 ; 1897, 281 ; 1906, 282

Rates, international transit, see Transit rates

Redirection (of letters, etc.), 283, note 2

Reform Act, 1832, 119

Revenue, net, $16,22,31,35,58,63$, $71,76,80,83,87,89,91,94,99$, 100, 104, 105, 109, 253, 314, 353, 355,358 ; theoretical character of, 362,363

Rice, Spring, 122

Richelieu, 80

Riders in post, 4, 5, 20, 22, 67

Rural delivery, 89, 110, 161, 314 note, 331,332 ; free, 161

Sample rate, see Rates of postage Savings Bank, Post Office, 33, 357 Schriftentaxe, 225, 240

Second-class Mail, see Mail matter, classification of ; Congressional Commission on, 1907, 156 ; 1912, 158; deficit, 147, 155, 158, 162; use of freight trains for, 163

Select Committee on Postage, Report of, 1838, 30; on Newspaper Stamps, 1851, 122, 127

Seven Years' War, 81, 100, 211

Ship Letter Office, 344

Ship letters, 339, 342

Single letter, definition of, 336

Smith, Adam, 329, 330

Sorting frames, 285

Stafetti, 8, 378

Staff, 33-5; cost of, 289, 301, 306

Stage coach, 20, 250 note, 385

Stamp duty (on newspapers), 117,119, 121,128

Stamping machines, 303
Stamps, postage, introduction of, 27

Stanhope, Lord, 7, 341, 380

State control of Post Office, 328

Stayner, T. A., 138

Stephan, H. von, 241, 266

Supplemental services, 33, 109, 357

Supplements (newspaper), 132, 171, 172,181

Surveyors (post office), 20, 21

Sutherland, Daniel, 43

Taxes on knowledge, 126, 142

Taxis, J. von, 350

Telegraphs, Post Office, 33, 358

Telephones, Post Office, 33, 358

Temporary uniform fourpenny rate, 30 note

Third-class Mail Matter, see Mail matter, classification of

Thirty Years' War, 209, 353

Thorough Post, 4, 5

Threepenny Post (London), 252

Thurn and Taxis Posts, 108, 350

Times newspaper, 121, 129

Trade journals, transmission by post, $132,147,159$

Transient newspapers, 137, 152

Transit, gratuitous, 268, 273, 275

Transit rates, international, 267, 270,

$271,273,275,279,281$

Travelling Post, 3-6, 79

Treble letter, definition of, 336

Tuke, Brian, 2, 3

Tupper, Sir Charles, 57

Twopenny Post (London), 252

Uniform postage, 23, 26, 28, 54, 72,

$75,85,108,312,323$

Union générale des Postes, 269

Union postale universelle, 269 , note 3

Universal penny postage, 276, 348

Universal Postal Union, 224, 229

University posts, 6,78

Urgent parcels, special fee for, 215

Wages (of postmasters), 3, 5

Wages, Post Office, 34, 297 
Walkley, A. B., 275 note

Wanamaker, J., 77, 154, 155, 192

Ward, Edmund, 137, 139

Ward, Sir J. G., 276

Warwick, Earl of, 11

Way letter, 18, 50

Way Office, 49, 50

Weighing of mails (United States), 156,157

Wells, H. G., 134
West, Robert, 398

Williamson, Joseph, 113

Witherings, Thomas, 8, 9, 12, 378, 381

Yearly express, 40

Zone rates, 177, 199, 201, 202, 215, 356 



\title{
LIST OF STUDIES IN ECONOMICS \& POLITICAL SCIENCE
}

\author{
A Series of Monographs by Lecturers and Students connected \\ with the London School of Economics and Political Science
}

\section{EDITED BY THE \\ DIRECTOR OF THE LONDON SCHOOL OF ECONOMICS AND POLITICAL SCIENCE}

1. The History of Local Rates in England. The substance of five lectures given at the School in November and December, 1895. By EDwiN Cansan, M.A., LL.D. I 896 ; second, enlarged edition, I9I2; Xv and 215 pp., crown 8vo, cloth. 3s. 6d. net.

P. S. King and Son.

2. Select Documents Illustrating the History of Trade Unionism. I.-The Talloring Trade. By F. W. Galton. With a Preface by SidNEY WeBB, LL.B. I $896 ; 242$ pp., crown 8vo, cloth. 5 s.

I. S. King and Son.

3. German Social Democracy. Six lectures delivered at the School in February and March, 1896 . By the Hon. BerTraxd Russell, B.A., late Fellow of Trinity College, Cambridge. With an Appendix on Social Democracy and the Woman Question in Germany by ALYS RUssell, B.A. I896; 204 pp., crown 8vo, cloth. 3s. 6 d.

P. S. King and Son.

4. The Referendum in Switzerland. By M. Simon Deploige, University of Louvain. With a Letter on the Referendum in Belgium by M. J. VAN DEN Heuvel, Professor of International Law in the University of Louvain. Translated by C. P. Trevelyas, M.A., Trinity College, Cambridge, and edited with Notes, Introduction, Bibliography, and Appendices, by LiLiaN Tons (Mrs. Knowles), of Girton College, Cambridge, Research Student at the School. I898; $\mathbf{x}$ and 334 pp., crown Svo, cloth. 7s. 6d. I'. S. King and Son.

5. The Economic Policy of Colbert. By A. J. Sargent, M.A., Senior Hulme Exhibitioner, Brasenose College, Oxford; and Whately Prizeman, 1897, Trinity College, Dublin. I899; viii and I38 pp., crown 8vo, cloth. 2s. 6 d. P. S. King and Son.

6. Local Variations in Wages. (The Adam Smith Prize, Cambridge University, I898.) By F. IV. LAwRence, M.A., Fellow of Trinity College, Cambridge. I899; viii and $90 \mathrm{pp}$., with Index and 18 Maps and Diagrams, 4 to, $\mathrm{II}$ in. by $8 \frac{1}{2}$ in., cloth. 8s. 6d. Longmans, Green and Co.

7. The Receipt Roll of the Exchequer for Michaelmas Term of the Thirty-first Year of Henry II (1185). A unique fragment transcribed and edited by the Class in Palseography and Diplomatic, under the supervision of the Lecturer, HUBERT HALL, F.S.A., of H.M. Public Record Office. With thirty-one Facsimile Plates in Collotype and Parallel readings from the contemporary Pipe Roll. I899; vii and 37 pp., folio, $15 \frac{1}{2}$ in. by $11 \frac{1}{2}$ in., in green cloth; 2 Copies left. Apply to the Director of the London School of Economics.

8. Elements of Statistics. By Arthur L. Bowley, M.A., Sc.D., F.S.S., Cobden and Adam Smith Prizeman, Cambridge ; Guy Silver Medallist of the Royal Statistical Society ; Newmarch Lecturer, 1897-8. 500 pp., and 40 Diagrams, demy 8vo, cloth. 1901; Third edition, 1907; viii and $336 \mathrm{pp}$. Ios. 6d. net.

P. S. King and Son.

9. The Place of Compensation in Temperance Reform. By C. P. SANger, M.A., late Fellow of Trinity College, Cambridge. Barrister-at-Law. I90I ; viii and 136 pp., crown 8 vo, cloth. 2s. 6d. net. P. S. King and Son.

10. A History of Factory Legislation. By B. L. Hurchins and A. Harrison (Mrs. Spencer), B.A., D.Sc. (Econ.), London. With a Preface by SIDNEY WEBB, LL.B. I903; new and revised edition, I9I I xvi and 298 pp., demy $8 v$ o, cloth. $6 \mathrm{~s}$. net.

P. S. King and Son, 

for the Fourth Year of the Episcopate of Peter Des Roches (1207). Transcribed and edited from the original Roll in the possession of the Ecclesiastical Commissioners by the Class in Palieography and Diplomatic, under the supervision of the Lecturer, HUBERT HALL, F.S.A., of H.M. Public Record Office. With a Frontispiece giving a Facsimile of the Roll. 1903; xlviii and $100 \mathrm{pp}$., folio, $13 \frac{1}{2}$ in. by $8 \frac{1}{2}$ in., green cloth. 15s. net.

P. S. King and Son.

12. Self-Government in Canada and How it was Achieved : The Story of Lord Durham's Report. By F. BRADShaw, B.A., D.Sc. (Econ.), London; Senior Hulme Exhibitioner, Brasenose College, Oxford. I903; 4 I4 pp., demy 8vo, cloth. 3s. $6 \mathrm{~d}$. net. $P$. S. King and Son.

13. History of the Commercial and Financial Relations between England and Ireland from the Period of the Restoration. By ALICE EFFIE MURRAY (Mrs. Radice), D.Sc. (Econ.), former Student at Girton College, Cambridge; Research Student of the London School of Economics and Political Science. I903; 486 pp., demy 8vo, cloth. 3s. 6d. net. P. S. King and Son.

14. The English Peasantry and the Enclosure of Common Fields. By Gilbert Slater, M.A., St. John's College, Cambridge; D.Sc. (Econ.), London. I906; 337 pp., demy 8vo, cloth. Ios. 6d. net. Constable and Co.

15. A History of the English Agricultural Labourer. By DR. IV. HASBACH, Professor of Economics in the University of Kiel. Translated from the Second Edition (1908) by Ruth Kenyon. Introduction by SidNEY WEBB, LL.B. I908; xvi and 470 pp., demy $8 \mathrm{vo}$, cloth. 7s. 6d. net.

\section{P. S. King and Son.}

16. A Colonial Autocracy : New South Wales under Governor Macquarie, 1810-1821. By Marion Phillips, B.A., Melbourne ; D.Sc. (Econ.), London. I909; xxiii and 336 pp., demy 8vo, cloth. Ios. 6d. net.

$$
\text { P. S. King and Son. }
$$

17. India and the Tariff Problem. By H. B. Lees Sirth, M.A., M.P. I909; I20 pp., crown 8vo, cloth. 35. 6d. net. Constable and Co.

18. Practical Notes on the Management of Elections. Three Lectures delivered at the School in November, I909, by ELLIS T. POwELL, LL.B., D.Sc. (Econ.), Fellow of the Royal Historical and Royal Economic Societies, of the Inner Temple, Barrister-at-Law. Igog; 52 pp., 8vo, paper. Is. 6d. net.

19. The Political Development of Japan. By G. E. UYEHARA, B.A., Washington, D.Sc. (Econ.), London. I9ro; xxiv and 296 pp., demy 8vo, cloth. 8s. 6d. net. Constable and Co.

20. National and Local Finance. By J. Watson Grice, D.Sc., (Econ.), London. Preface by Sidxey WebB, LL.B. I9Io; 428 pp., demy 8vo, cloth. Ios. 6d. net.

P. S. King and Son.

21. An Example of Communal Currency. Facts about the Guernsey Market-house. By J. THEODORE HARRIS, B.A. With an Introduction by SiDNEY WeBB, LL.B. I9I I xiv and 62 pp., crown $8 v o$, cloth. Is. 6d. net; paper, is. net.

P. S. King and Son.

22. Municipal Origins. History of Private Bill Legislation. By F. H. SPENCER, LL.B., D.Sc. (Econ.), London. With a Preface by Sir EDWARd Clarke, K.C. I9I I ; xi and 333 pp., demy 8vo, cloth. Ios. 6 d. net.

23. Seasonal Trades. By various Authors. With an Introduction by SIDNEY WeBb. Edited by SiDNEY WEBB, LL.B., and ARNOLD Freeman, M.A. I9I2; xi and 4 Io pp., demy 8vo, cloth. 7s. 6d. net.

Constable and Co.

24. Grants in Aid. A Criticism and a Proposal. By Sidney WEBB, LL.B. I9II ; vii and I35 pp., clemy 8vo, cloth. 5s. net.

25. The Panama Canal : A Study in International Law. By H. ARIAS, B.A., LL.D. I9rI ; xiv and I88 pp., 2 maps, bibliography, demy 8vo, cloth. IOs. 6d. net.

P. S. King and Son.

26. Combination Among Railway Companies. By W. A. Robertson, B.A. I9̨12; ro5 pp., demy 8vo, cloth. Is. 6d. net; paper Is. net. Constable and $\mathrm{Co}$. 
27. War and the Private Citizen : Studies in International Law. By A. PEARCE HigGixs, M.A., LL.D.; with Introcluctory Note by the Rt. Hon. Arthur Cohen, K.C. 1912 ; xvi and 200 pp., demy 8vo, cloth. 5s. net.

P. S. King and Son.

28. Life in an English Village : an Economic and Historical survey of the Parish of Corsley, in Wiltshire. By M. F. DAvirs. I90); xiii and 319 pp., illustrations, bibliography, demy $8 \mathrm{vo}$, cloth, Ios. ocl. net.

\section{T. Fisher l'nivin.}

29. English Apprenticeship and Child Labour: a History. By O. JOCELYN DunLOP, D.Sc. (Econ.), London; with a Supplementary Section on the Modern Problem of Juvenile Labour, by the Author and R. D. Denman, M.P. 1912 ; 390 pp., bibliography, demy 8vo, cloth. ros. 6 d. net.

$$
\text { T. Fisher Unwin. }
$$

30. Origin of Property and the Formation of the Village Community. By J. ST. Lewinski, D.Ec.Sc., Brussels. 1913; xi and 71 pp., demy 8 vo, cloth. 3 s. Gd. net.

Constable and Co.

31. The Tendency towards Industrial Combination (in some Spheres of British Industry). By G. R. CARTBR, M.A. I913; xxiii and 391 pp., clemy 8vo, cloth. Os. net.

Constable and $\mathrm{Co}$.

32. Tariffs at Work : an Outline of Practical Tariff Administration. By JoHn HEDley Higginson, B.Sc. (Econ.), Mitchell Student of the University of London; Cobden Prizeman and Silver Medallist. 1913 ; I50 pp., crown 8 vo, cloth. 2s. net.

P. S. King and Son.

33. English Taxation, 1640-1799. An Essay on Policy and Opinion. By William KenNedy, M.A., D.Sc. (Econ.), London; Shaw Research Student of the London School of Economics and Political Science. 1913; 200 pp., demy 8vo. 7s. 6d. net.

(i. Bell and Sons.

34. Emigration from the United Kingdom to North America, 1763-1912. By Stanley C. Johnson, M.A., Cambridge, D.Sc. (Econ.), London, 1913; xvi and 387 pp., clemy svo, cloth. 6s. net.

(i. Routlcdge and Sons.

35. The Financing of the Hundred Years' War, 1337-1360. By SchuYler B. Tekry. I913; xvi and $199 \mathrm{pp}$., demy $8 v^{\circ}$, cloth. 6s. net.

Coustable and Co.

36. Kinship and Social Organisation. By W. H. R. RIvErs, M.D., F.R.S., Fellow of St. John's College, Cambridge. 19 $+;$; 96 pp., demy Svo, cloth. 2s. $6 \mathrm{~d}$. net.

Constable and Co.

37. The Nature and First Principle of Taxation. By Rosert Jones, D.Sc. (Econ.), London. With a Preface by SidNey IVEBB, LL.B. 1914; xvii and $299 \mathrm{pp}$., denyy 8 vo, cloth. 7s. 6d, net. P. S. King and Son.

38. The Export of Capital. By C. K. Hobson, M.A., F.S.S., Shaw Research Student of the London School of Economics and Political Science. 1914; xxv and 264 pp., demy $8 \mathrm{vo}$, cloth. 7s. 6cl. net.

Constablc and Co.

39. Industrial Training. By Normax Burrell Dearle, M.A., D.Sc. (Econ.), London, Fellow of All Souls College, Oxford; Shaw Research Student of the London School of Economics and Political Science. 1914; 610 pp., demy 8 vo, cloth. Ios. 6 d. net.

P. S. King and Son.

40. Theory of Rates and Fares. From the French of Charles Colson's "Transports et tarifs" (3rd edition, 1907), by L. R. CHRistie, G. LEEDHAM, and C. TRAVIS. Edited and arranged by CHARLES TRAVIS, with an Introduction by W. M. AcivorTH, M.A. 1914 ; viii and 195 pp., demy 8 vo, cloth. 3s. 6d. net.

G. Bell and Sons, Ltd.

41. Advertising: a Study of a Modern Business Power. By G. W. Goodall, B.Sc. (Econ.), London. IVith an Introduction by SidNeY WEBB, LL.B. 1914; xviii and 91 pp., demy $8 v o$, cloth. 2s. 6d. net; paper Is. 6 d. net.

Constable and $\mathrm{Co}$.

\section{English Railways : their Development and their Relation} to the State. By Edward CaRnegie Cleveland-Stevens, M.A., Christ Church, Oxford; Shaw Research Student of the London School of Economics and Political Science. 1915; xvi and 325 pp., demy 8vo, cloth. 6s, net. G. Routledge and Sons. 
43. The Lands of the Scottish Kings in England. By Margaret F. MIOoRe, M.A. With an Introduction by P. Hume Brown, M.A., LL.D., D.D., Professor of Ancient Scottish History and Palaengraphy, University of Edinburgh. I9I 5 ; demy 8 vo, cloth. 5s. net.

44. The Colonisation of Australia, 1829-1842: the Wakefield Experiment in Empire Building. By RichaRd C. MILls, LL.M., Melbourne, D.Sc. (Econ.), London. With an Introduction by GrahaM WaLlas, M.A., Professor of Political Science in the University of London. I915; demy 8vo, cloth. Ios. 6d. net. Sidgwick and Jackson.

45. The Philosophy of Nietzsche. By A. Wolf, M.A., D.Lit., Fellow of University College, London; Reader in Logic and Ethics in the University of London. I9I5; I I4 pp., demy 8vo, cloth. 3s. 6d. net.

Constable and $\mathrm{Co}$.

46. Fnglish Public Health Administration. By B. G. Bannington. With a Preface by Graham Wallas, M.A., Professor of Political Science in the University of London. I9I5; 338 pp., demy 8vo, cloth. 7s. 6d. net.

P. S. King and Son.

47. British Incomes and Property. By J. C. STAmp, D.Sc. (Econ.), London. I()I6; xvi, 538 pp., demy Svo, cloth. I2s. 6 d. net.

48. Village Government in British India. By JонN MatтhaI. D.Sc. (Econ.), London. Sometine Tutor in History, Madras Christian College, "Vakil" of the Hisgh Court of Judicature, Madras. With a Preface by Professor Sidney Webb. 1915; xix, 2 I 1 pp., demy $8 v 0$, cloth. 4s. Gd. net. T. Fisher L'nwin.

\section{Monographs on Sociology.}

3. The Material Culture and Social Institutions of the Simpler Peoples. By L. T. HoBhouse, M.A., Martin White Professor of Sociology in the University of London, G. C. WheEler, B.A., and M. Ginsberg, B.A. I9I5; 300 pp., demy 8vo, paper. 2s. 6d. net. Chapman and Hall.

4. Village and Town Life in China. By TAo LI Kung, B.Sc. (Econ.), London, and LeONG YEW KoH, LL.B., B.Sc. (Econ.), London. Edited by L. T. Hobhouse, M.A. $1915 ; 153$ pp., demy 8vo, cloth. $5 \mathrm{~s}$. net.

(icorge Allen and Unwin.

Series of Bibliographies by Students of the School.

1. A Bibliography of Unemployment and the Unemployed. By F. ISABel TAYlor, B.Sc. (Econ.), London. Preface by Sidney WebB, LL.B. I909; xix and 7I pp., demy 8vo, cloth. 2s, net; paper, Is. 6d, net.

\section{P. S. King and Son.}

2. Two Select Bibliographies of Mediæval Historical Study. By Margaret F. Moore, M.A. With Preface and Appendix by Hubert Hall, F.S.A. I912 ; 85 pp., demy 8vo, cloth. 5s. net.

Constable and Co.

3. Bibliography of Roadmaking and Roads in the United Kingdom. By DOROTHY BALlen. An enlarged and revised edition of a similar work compiled by Mr. and Mrs. Sidney Webb in 1906. I9I4; xviii and 28I pp., demy 8 vo, cloth. I5s. net.

$P$. S. king and Son.

4. A Select Bibliography for the Study, Sources, and Literature of English Mediæval Economic History. Edited by Hubert HaLl, F.S.A. I9I4; xiii and 350 pp., demy 8vo, cloth. 5s. net. I. S. King and Son.

\section{Series of Geographical Studies.}

1. The Reigate Sheet of the One-inch Ordnance Survey. A Study in the Geography of the Surrey Hills. By ElLEx SMITH. Introduction by H. J. MACKINDER, M.A., M.P. I9Io ; xix and IIo pp., 6 maps, 23 illustrations, crown 8 vo, cloth. $5 \mathrm{~s}$. net.

A. and C. Black.

2. The Highlands of South-West Surrey. A Geographical Study in Sand and Clay. By E. C. MatThews. I9I I ; viii and I 24 pp., 7 maps, 8 illustrations, 8 vo, cloth. 5s. net. A. and C. Black.

\section{Series of Contour Maps of Critical Areas.}

1. The Hudson-Mohawk Gap. Prepared by the Diagram Company from a map by B. B. Dickinson. I9I 3 ; I sheet I $8^{\prime \prime}$ by $22 \frac{1}{2}$ ". Scale 20 miles to 1 inch. 6d. net; post free, folded $7 \mathrm{~d}$., rolled $9 \mathrm{~d}$. Sifton, Praed and Co. 

THIS BOOK IS DUE ON THE IAST DATE STAMPED BELOW

AN INITIAL FINE OF 25 CENTS WILL BE ASSESSED FOR FAILURE TO RETURN THIS BOOK ON THE DATE DUE. THE PENALTY WILL INCREASE TO $5 O$ CENTS ON THE FOURTH DAY AND TO \$1.00 ON THE SEVENTH DAY OVERDUE.

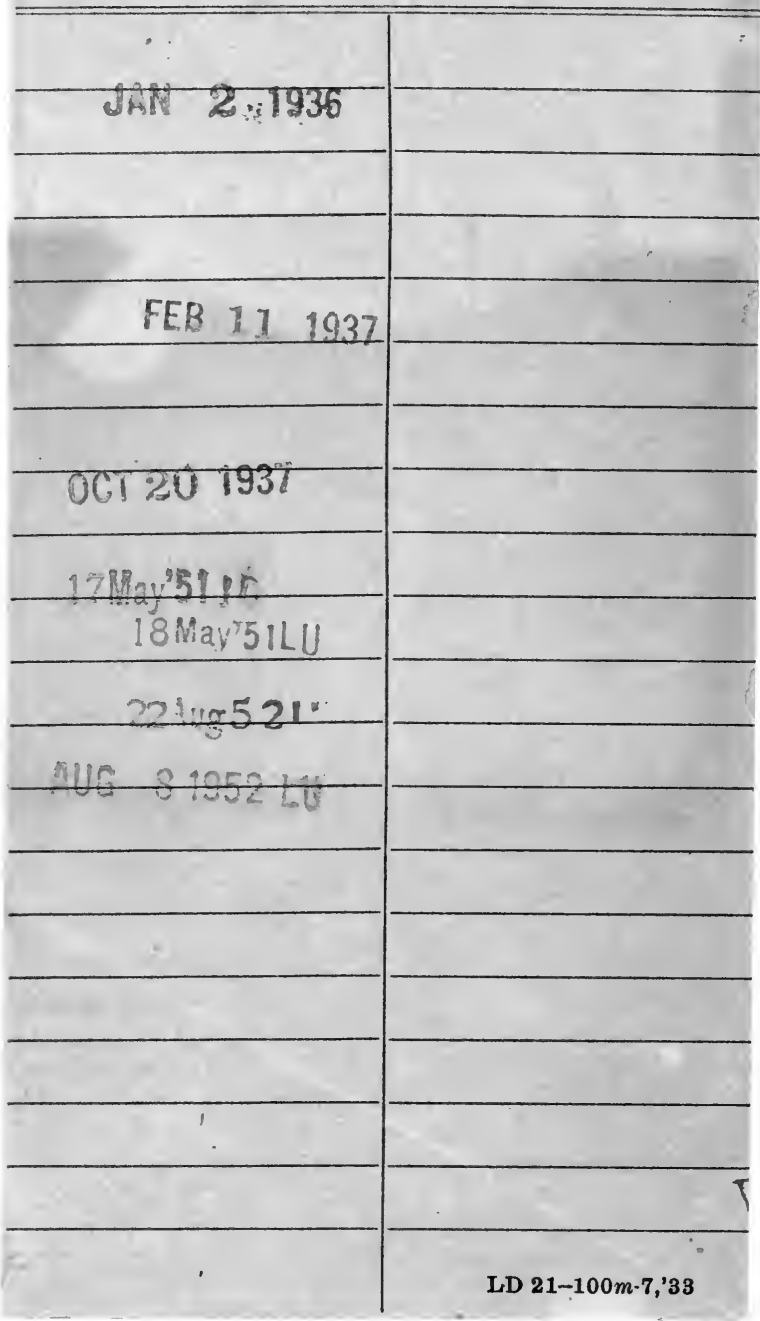


d

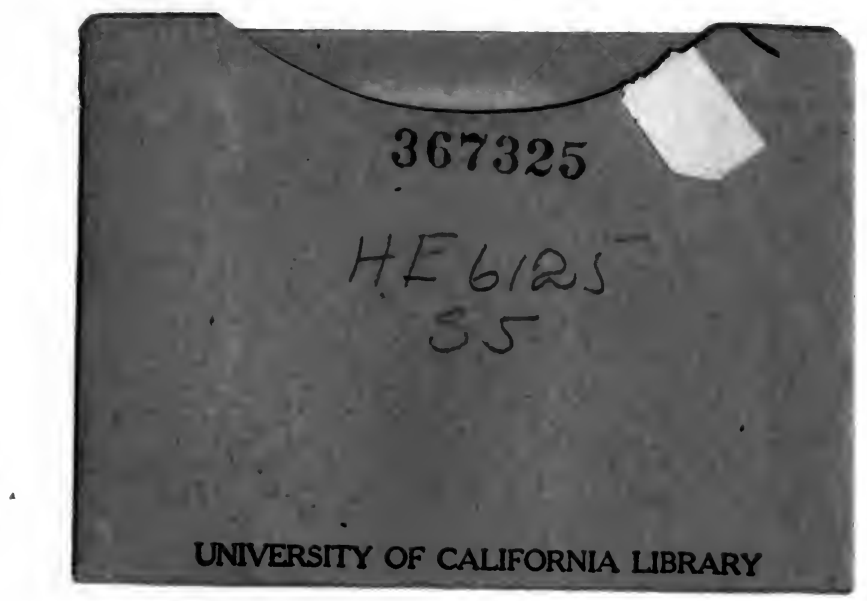


